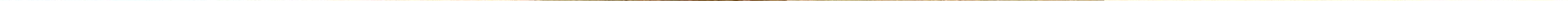




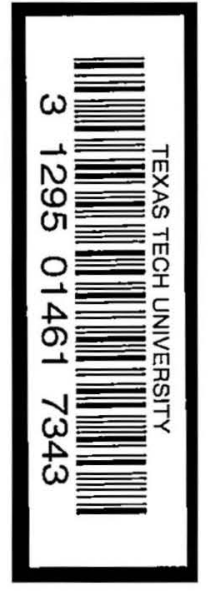

TEXAS TECH LERARY

DOCUMENT

* DATEDUE

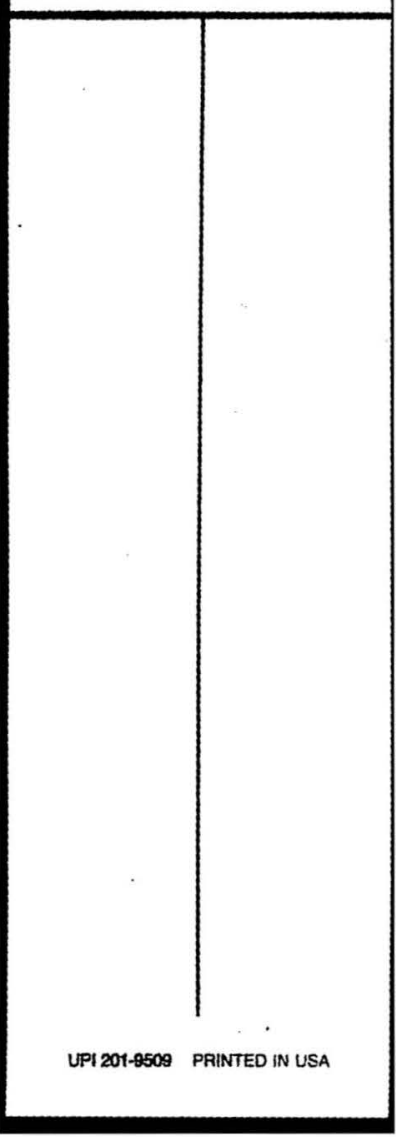


DEPARTMENT OF THE INTERIOR

UNITED STATES GEOLOGICAL SURVEY

GHARLES D. WALCOTT, DIRECTOR

$\mathrm{TH} \mathrm{E}$

\section{CLAYS OF THE UNITED STATES \\ EAST' OF T'HE MISSISSIPPI RIVER}

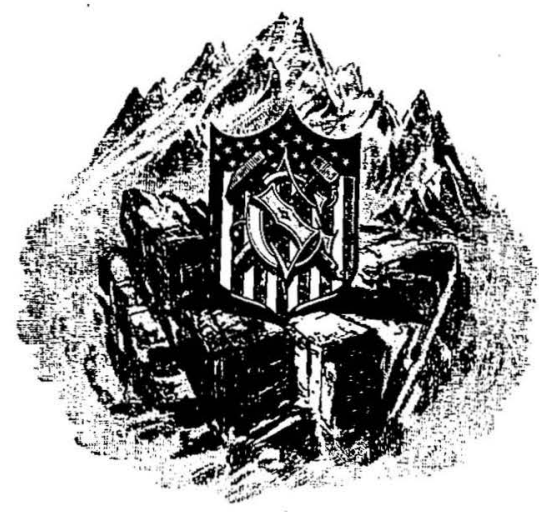

WASH IN GTON

GOVERNMENT PRINTING OFFICE

1903

WERARY

TEXAS TECHNOLOGICAL COLLEGE LUBBOCK, TEXAS 



\section{ONTENTS.}

Page.

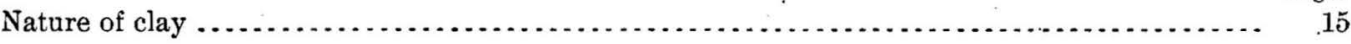

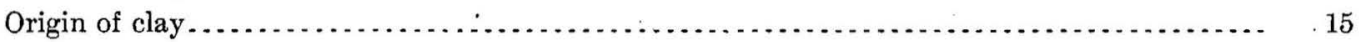

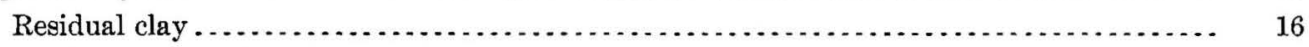

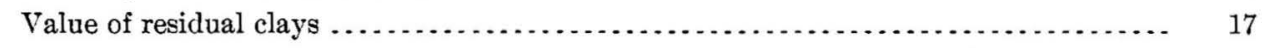

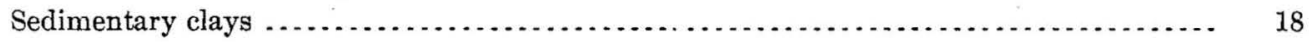

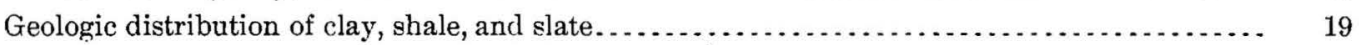

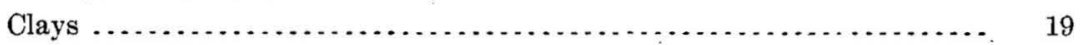

Shales.................................................. 20

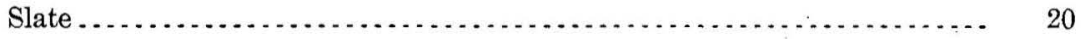

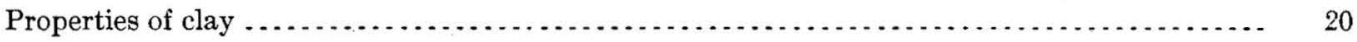

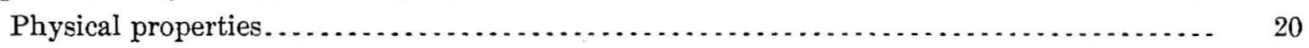

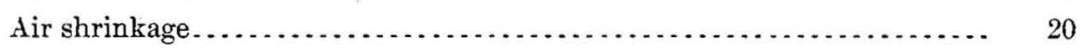

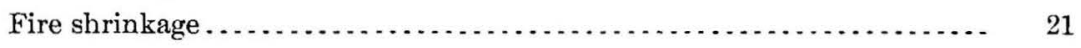

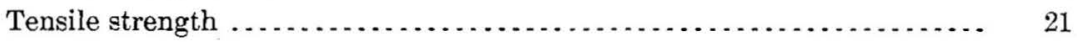

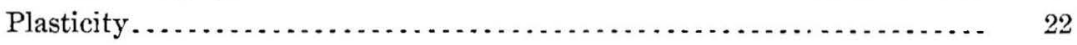

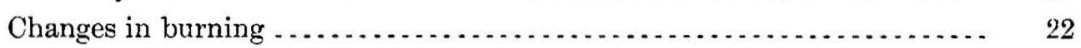

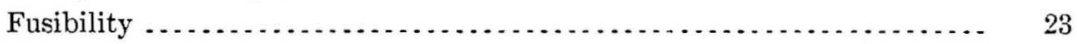

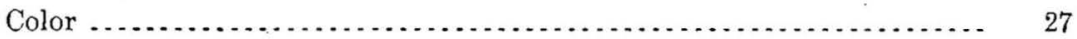

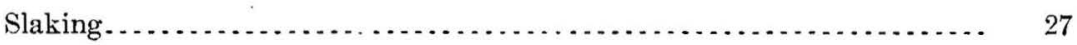

Chemical properties.................................................... 27

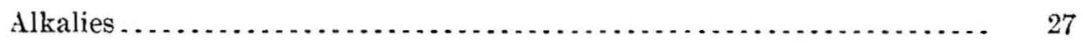

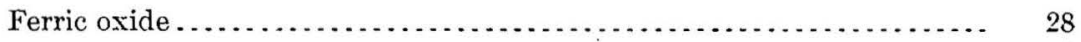

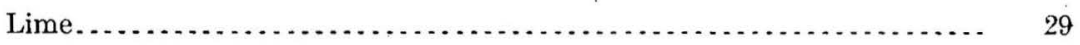

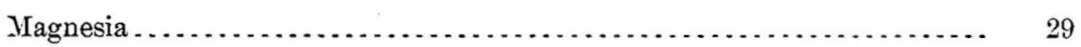

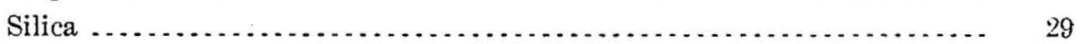

Titanic acid.............................................. 30

Organic matter.............................................. 30

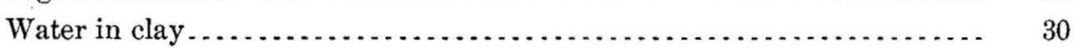

Methods of mining clays and shales . . . .

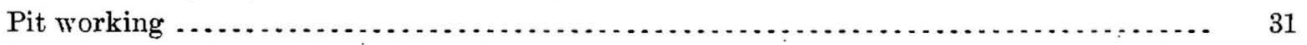

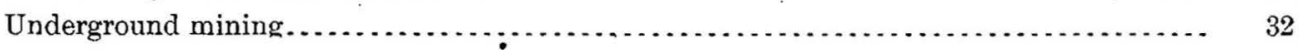

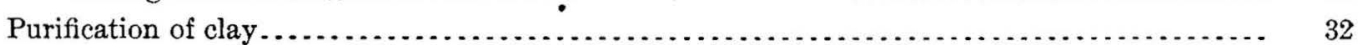

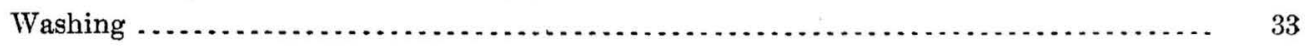

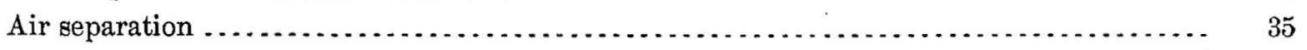

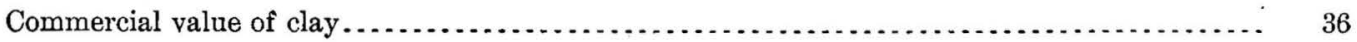


Page.

Clays employed for different wares and their characters $\ldots \ldots \ldots \ldots \ldots, \ldots \ldots \ldots \ldots \ldots \ldots, \quad 37$

China clays . . . . . . .

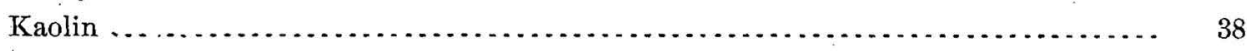

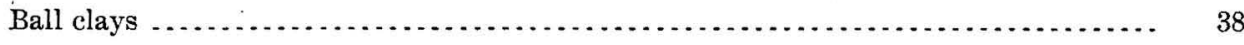

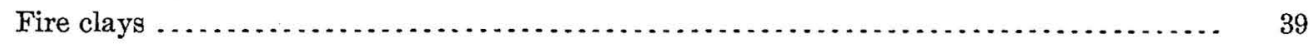

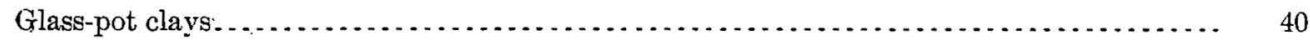

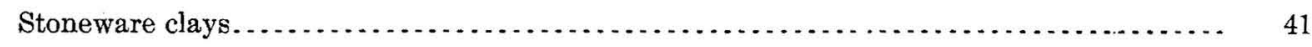

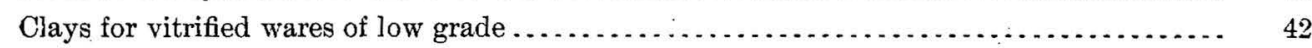

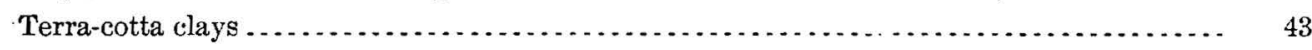

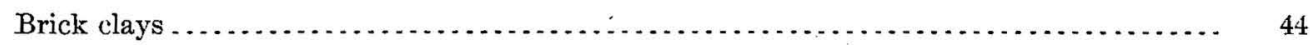

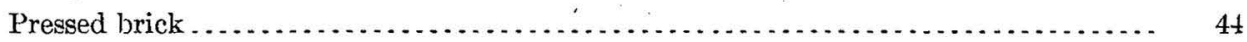

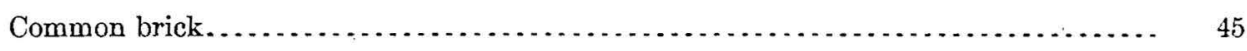

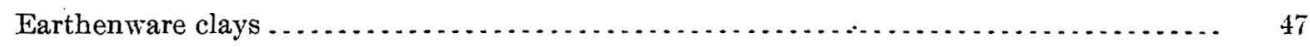

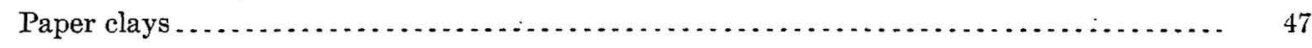

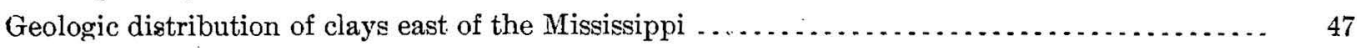

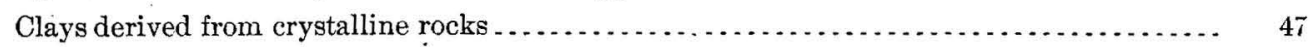

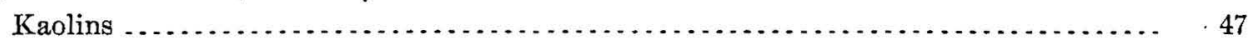

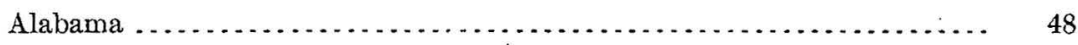

Connecticut................................................ 48

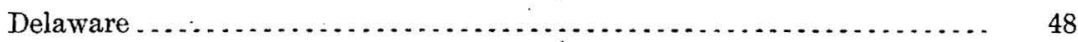

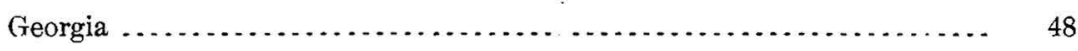

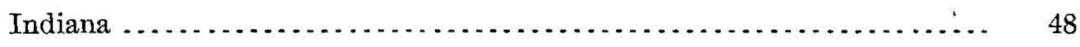

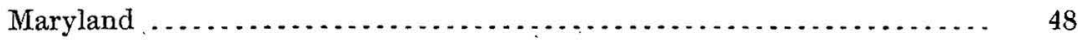

Massachusetts............................................ 49

North Carolina........................................... 49

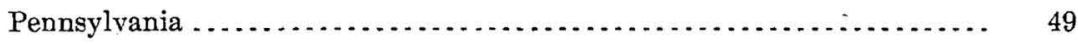

Virginia ................................................. 49

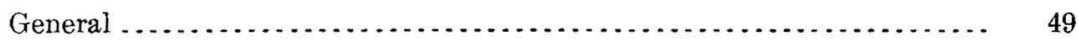

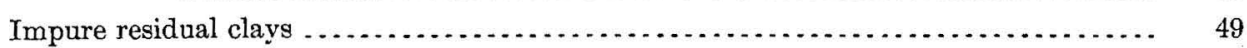

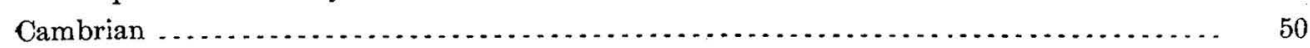

Impure residual clays ..................................... 50

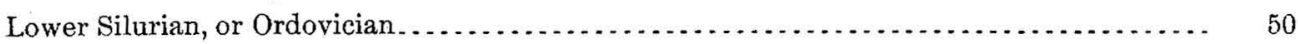

Hudson shales ......................................... 50

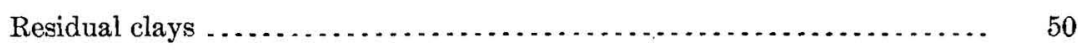

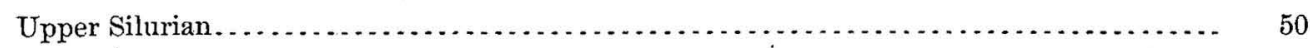

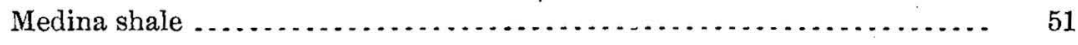

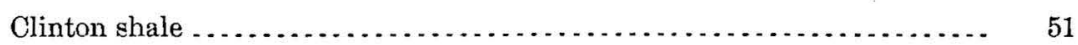

Shale of Niagara group . . . . . . . . . .

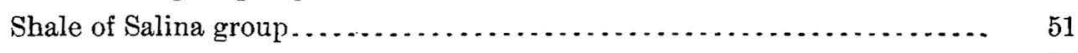

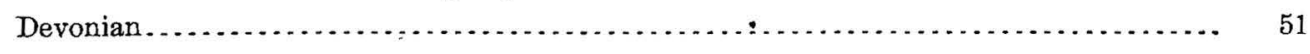

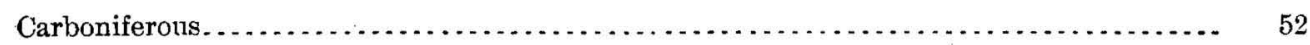

Pottsville conglomerate................................... 52

Lower Coal Measures........................................ $\quad{ }_{52}$

Lower Barren Measures...................................... 54 
Geologic distribution of clays east of the Mississippi-Continued.

Page.

Carboniferous-Continued.

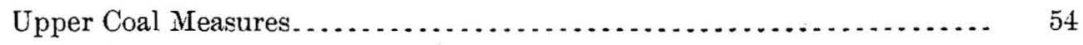

Upper Barren Measures ....................................... 55

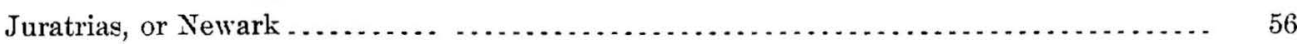

Cretaceous. . . . . . .

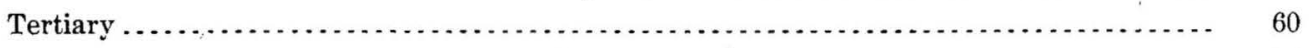

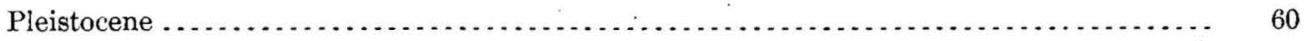

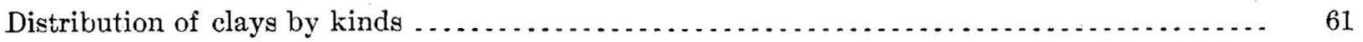

Brick clays . . . . . . . . . . . . .

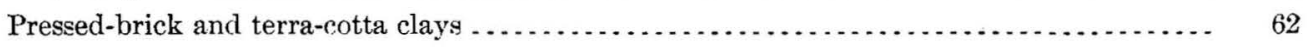

Stoneware clays. . . . . . . . . . . . . . . . . . . . .

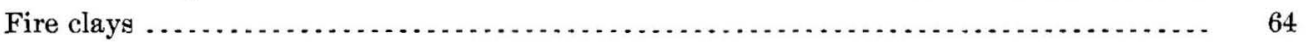

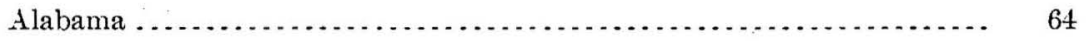

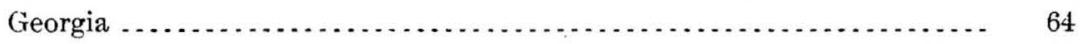

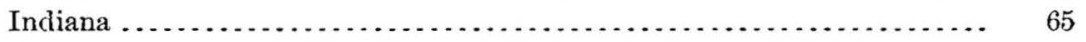

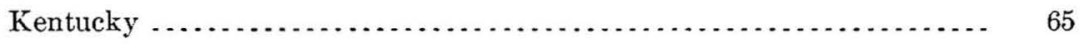

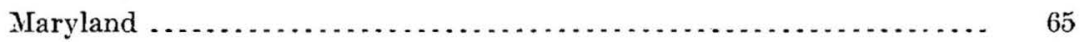

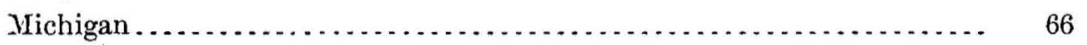

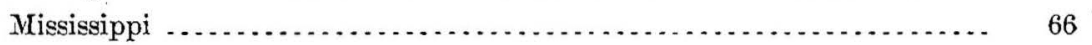

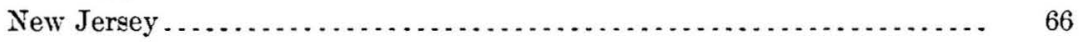

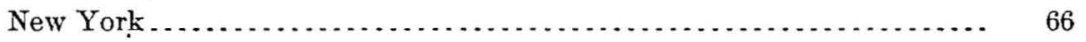

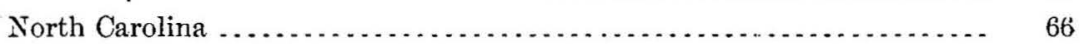

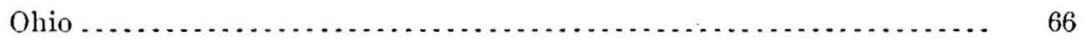

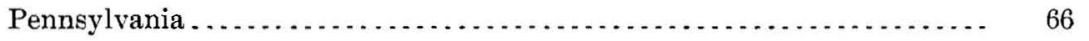

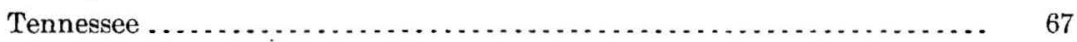

Virginia . . . . . .

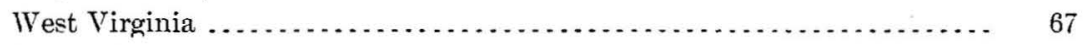

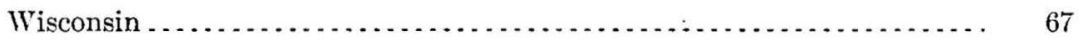

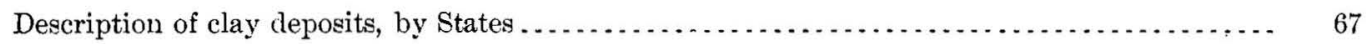

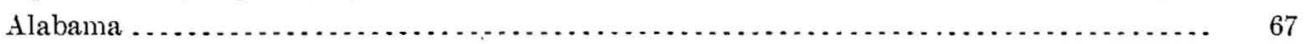

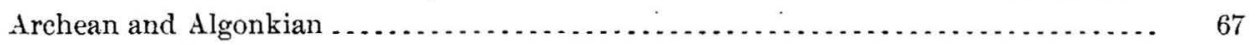

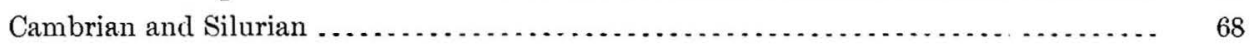

Lower Carboniferous . . . . . . . . . . . . . . . . . . . . . . . . . . . . . . . . . . . . . 69

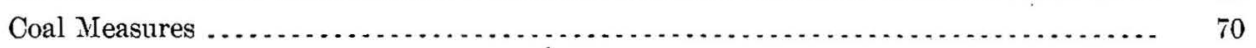

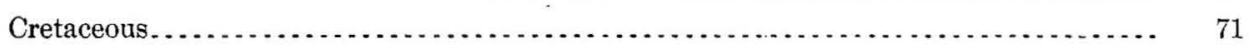

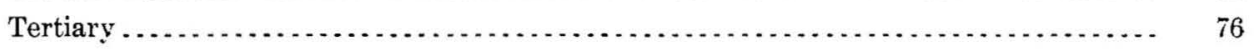

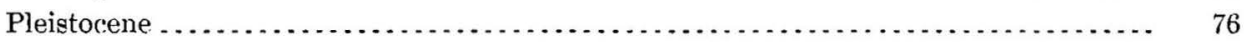

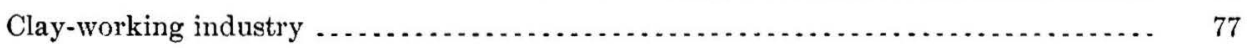

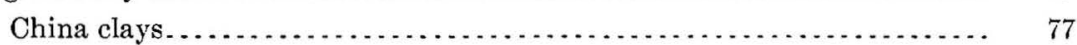

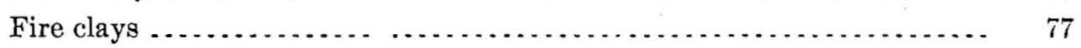

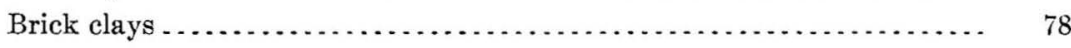

Clay products. . . . . . .

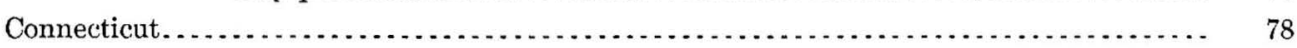

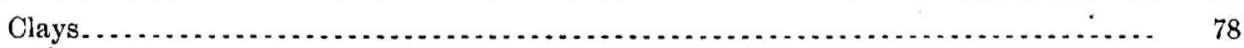

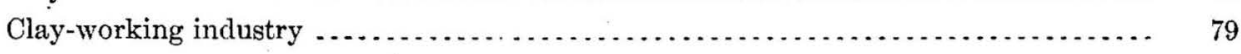


Description of clay deposits, by States-Continued. Page.

Delaware . . . . . . . $8{ }_{80}$

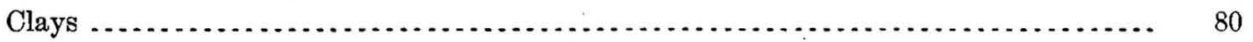

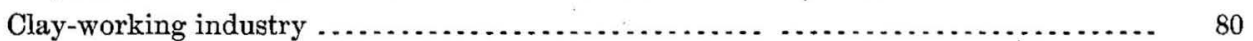

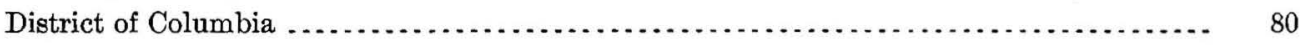

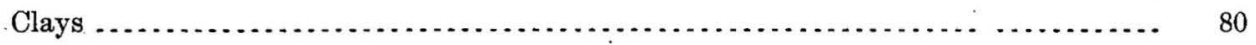

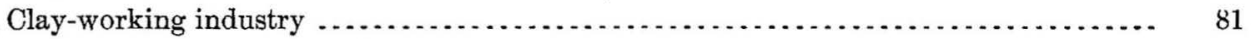

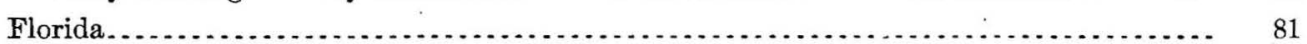

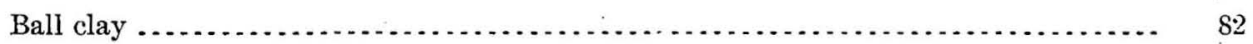

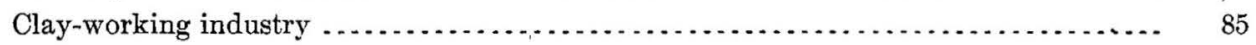

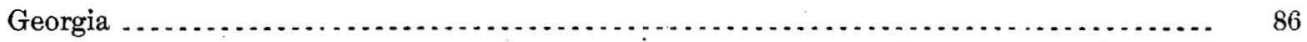

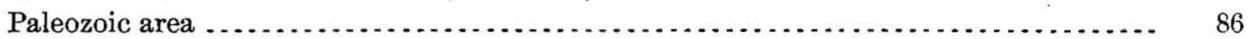

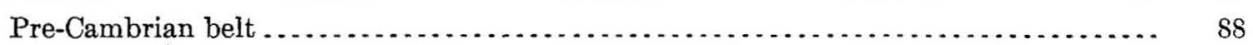

Coastal Plain region. . . . . . . .

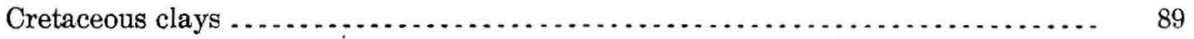

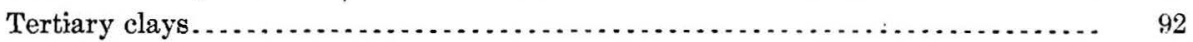

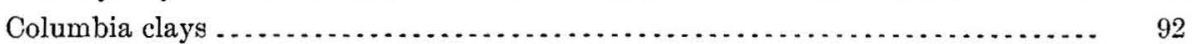

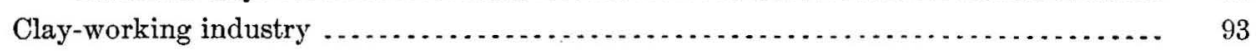

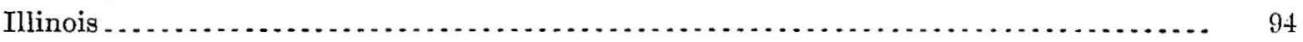

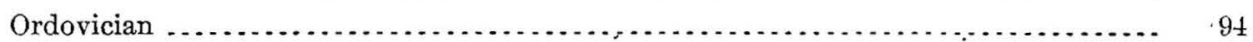

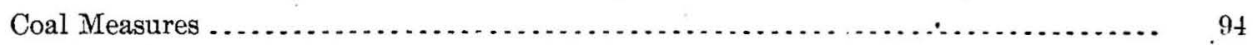

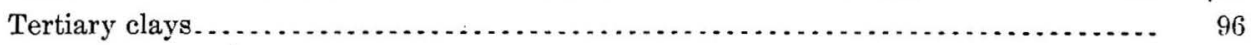

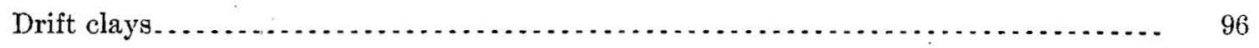

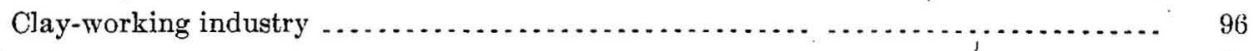

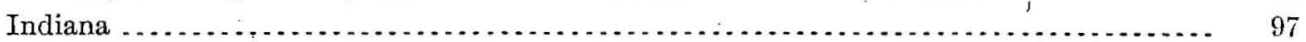

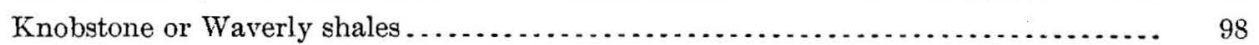

Coal Measures ....................................................... 98

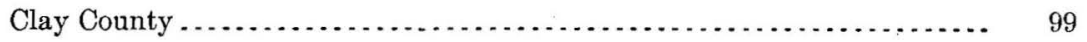

Dubois County ............................................ 100

Greene County ............................................. 101

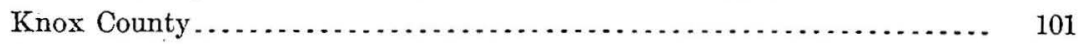

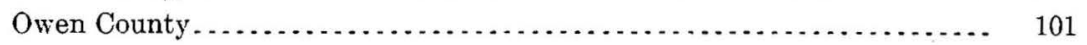

Perry County .............................................. 101

Pike County ................................................... 102

Gibson County ......................................... 102

Sullivan County ............................................ 102

Vanderburg County ........................................... 102

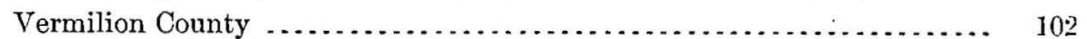

Vigo County ................................................ 102

Warrick County .............................................. 102

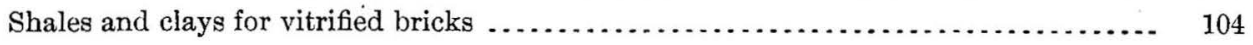

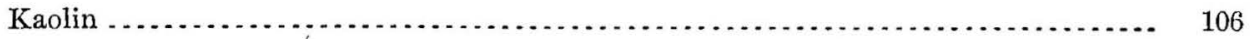

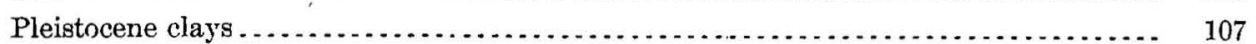

Benton County ....................................... 108

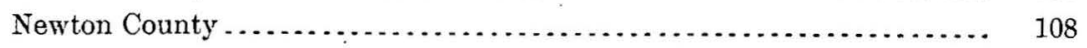

Jasper County ................................................... 109 
Description of clay deposits, by States-Continued.

Pleistocene clays-Continued.

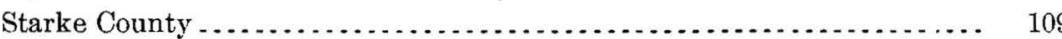

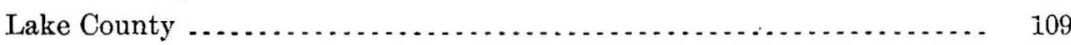

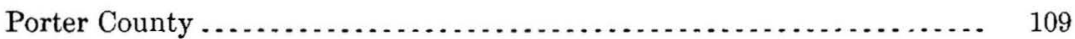

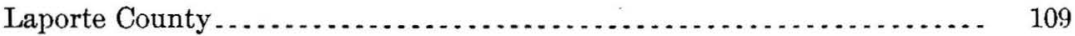

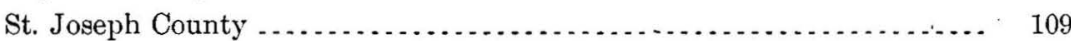

Miscellaneous occurrences .................................... 110

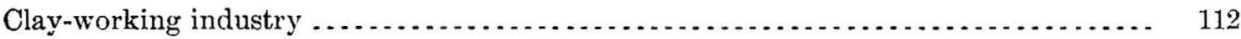

Common brick.................................................. 113

Pressed brick .................................................. 113

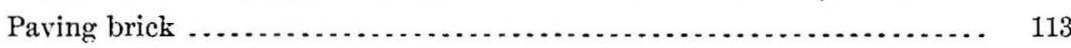

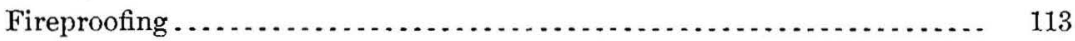

Sewer pipe ................................................... 113

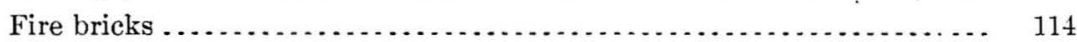

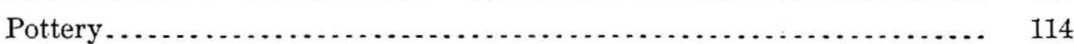

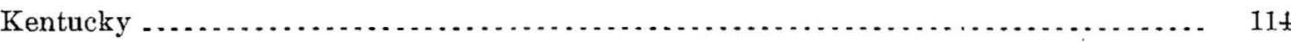

Lower Silurian, or Ordovician.......................................... 115

Upper Silurian . . . . .

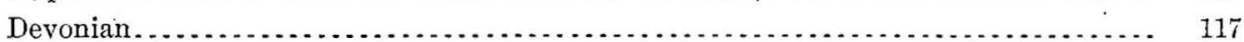

Lower Carboniferous................................................. 118

Upper Carboniferous, or Coal Measures................................. 118

Clays of Eastern coal field . ..................................... 118

Upper Ferriferous limestone ................................... 121

Analyses of clays from eastern Kentucky .......................... 122

Clays of Western coal field ................................... 123

Recent, or alluvial clays............................................... 124

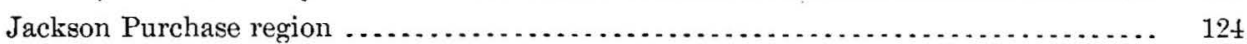

Ocherous clays............................................... 128

Fulton County ............................................... 129

Hickman County ........................................ 129

Ballard County .............................................. 129

McCracken County ........................................... 129

Marshall County ........................................... 130

Graves County .............................................. 130

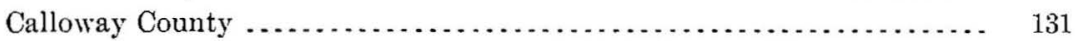

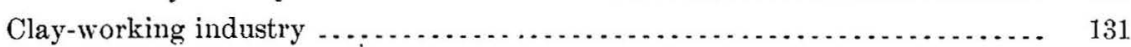

Maine, New Hampshire, Vermont........................................ 132

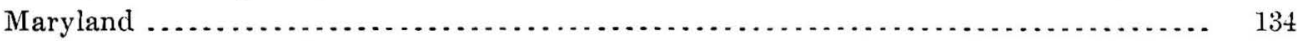

Algonkian residual clays............................................... 134

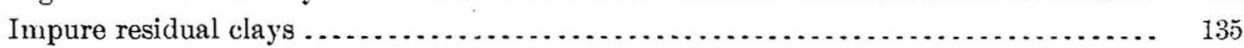

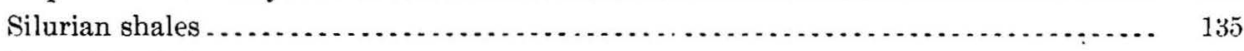

Devonian shales ..................................................... 136

Carboniferous shales ..................................................... 136

Mauch Chunt formation ................................... 136 
Description of clay deposits, by States-Continued. Page.

Maryland-Continued.

Carboniferous shales-Continued.

Pottsville formation ...................................... 137

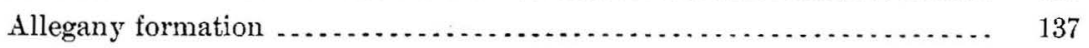

Conemangh formation ..................................... 138

Cretaceous and Juratrias cläys ........................................ 138

Patuxent formation ...................................... 139

Arundel formation ........................................ 139

Patapsco formation...................................... 141

Raritan formation.......................................... 141

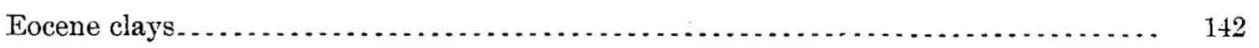

Neocene clays........................................................... 143

Pleistocene clays . . . . . . . . . . . . . . . .

Analyses and physical tests of Maryland clay ............................ 144

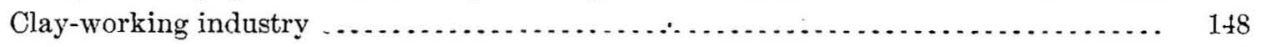

Massachusetts .............................................................. 149

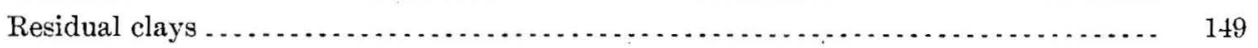

Mesozoic clays . . . . . . . . .

Pleistocene clays .................................................... 151

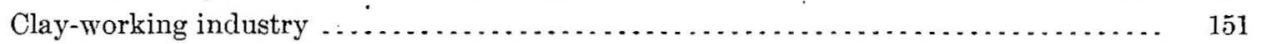

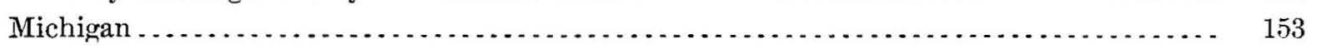

Paleozoic shales........................................................ 153

Coal Measure shales............................................ 153

Michigan shales . ............................................... 154

Coldwater shales .............................................. 154

Marshall shales ................................................ 155

Hamilton shales ................................................ 155

Analyses and physical tests of Paleozoic shales.......................... 155

Pleistocene clays .................................................. 156

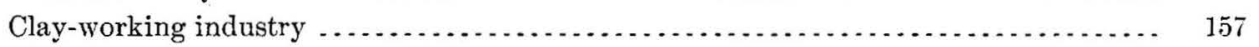

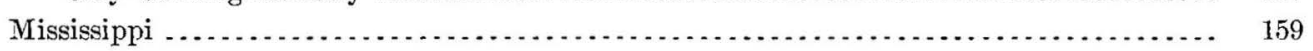

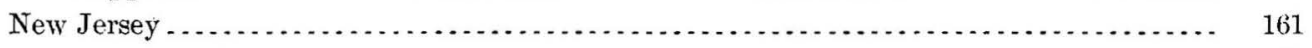

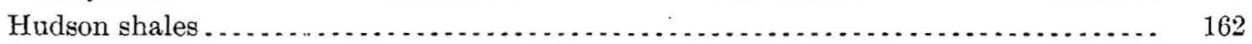

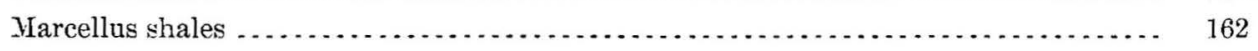

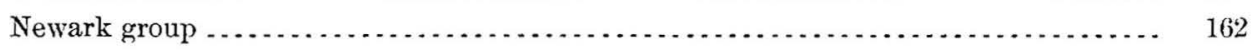

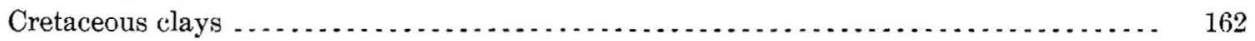

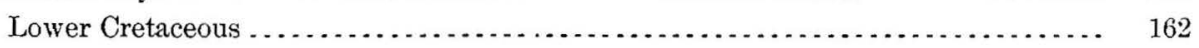

Upper Cretaceous ............................................... 165

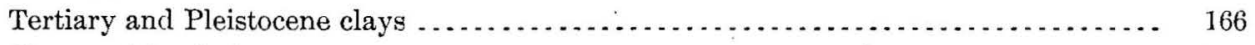

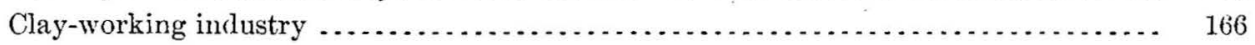

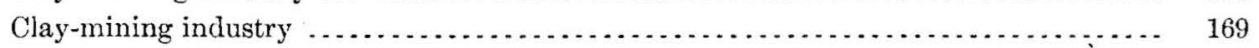

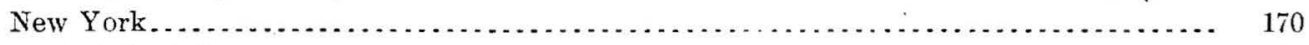

Residual clays ...................................................... 170

Paleozoic shales.................................................... 171

Cretaceous and Tertiary clays.......................................... 173

Pleistocene clays ...................................................... 175

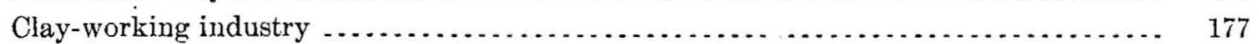


Description of clay deposits, by States-Continued. Page.

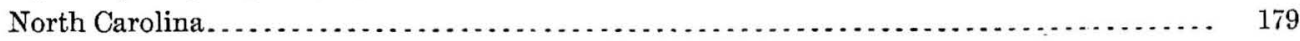

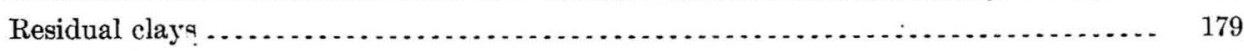

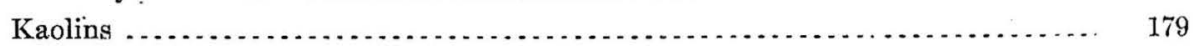

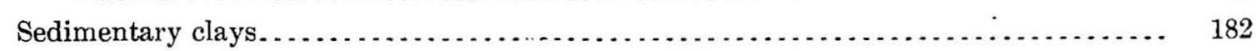

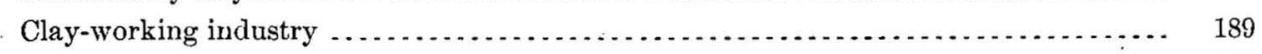

Ohio .

Lower Silurian, or Ordovician.

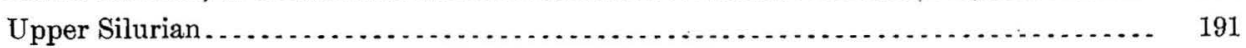

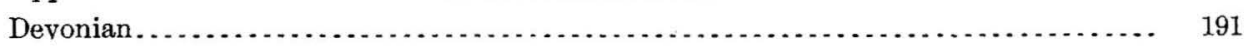

Lower Carboniferous .................................................. 192

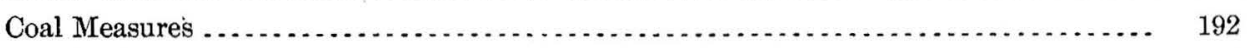

Conglomerate group . . . . . . . . 193

Sharon shales...................................................... 193

Quakertown clay and shale .................................... 193

Lower Mercer clay and shale ..................................... 194

Upper Mercer clay and shale ................................. 195

Tionesta clay ................................................... 195

Lower Coal Measures ................................................. 195

Putnam Hill or Brookville clay ................................. 195

Ferriferous limestone and clays ................................. 197

Lower Kittanning clay and shales............................. 197

Middle Kittanning clay ....................................... 197

Lower Freeport clay ........................................ 197

Upper Freeport clay and shale............................... 197

Lower Barren Measures ......................................... 197

Upper Productive Measures......................................... 200

Upper Barren Measures ............................................ 200

Pleistocene . . . . . .

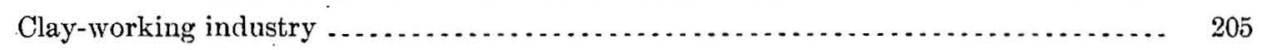

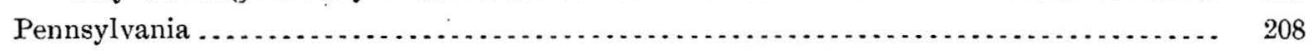

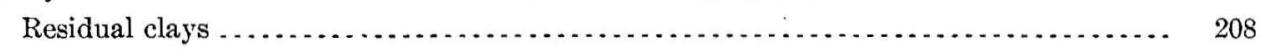

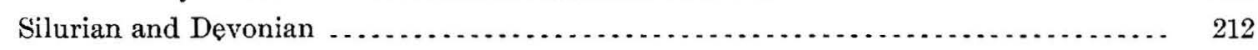

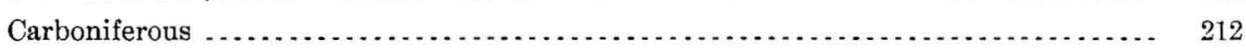

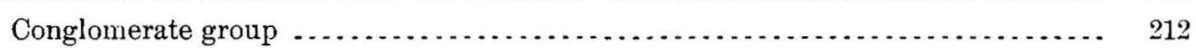

Mercer or Alton fire clays ..................................... 213

Sharon or Marshburg Upper Coal fire clay.......................... 214

Savage Mountain fire clay .................................... 215

Lower Productive Measures ...................................... 215

Brookville coal under clay ..................................... 218

Clarion coal under clay ...................................... 221

Ferriferous coal under clay ................................... 222

Lower Kittanning fire clay .................................... 222

Armstrong County ............................................. 224

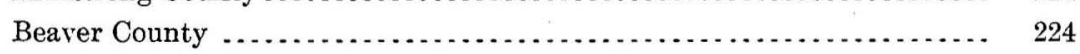

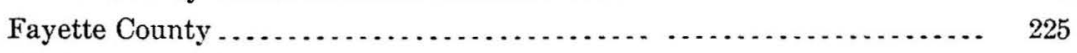

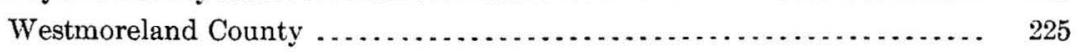


Pennsylvania-Continued.

Carboniferous-Continued.

Lower Productive Measures-Continued.

Middle Kittanning clay.

Upper Kittanning clay

Lower Freeport clay ..........................

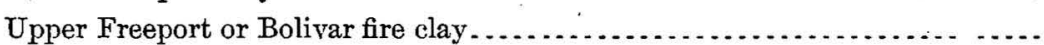

Allegheny County...

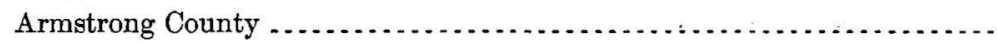

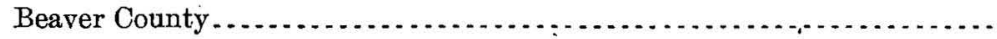

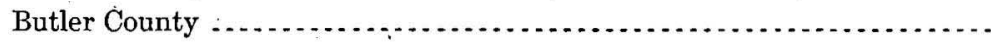

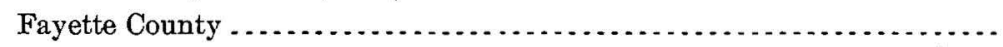

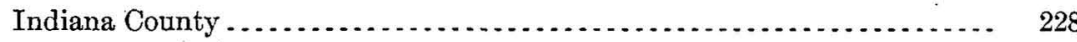

Westmoreland County .............................................. 228

Barren Measures or Elk River group ................................. 231

Upper Coal Measures or Monongahela River group ........................ 233

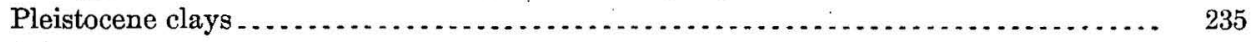

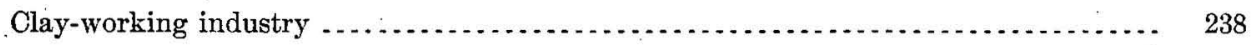

Common brick........................................... 238

Pressed brick ............................................. 239

Paving brick................................................. 239

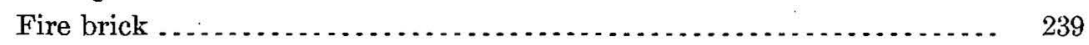

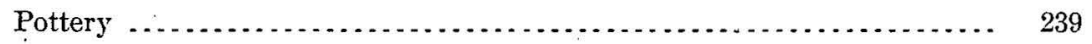

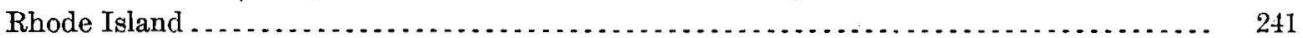

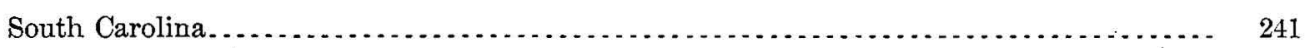

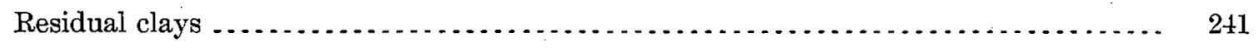

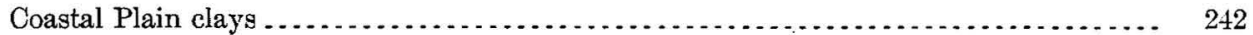

Clay-working industry . . . . .

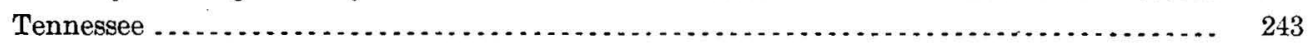

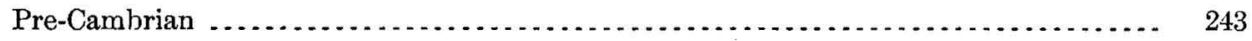

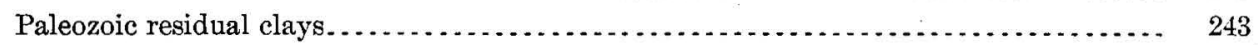

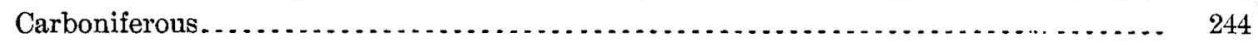

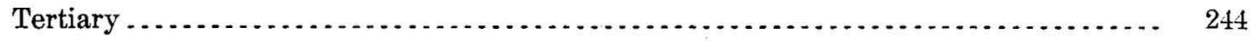

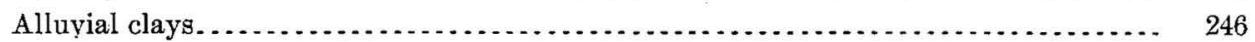

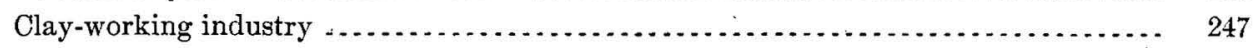

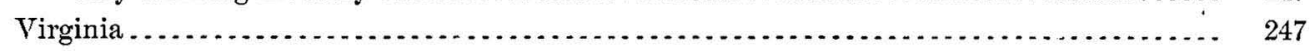

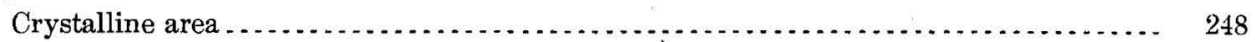

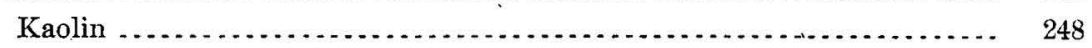

Cambro-Silurian clays ................................................... 249

Carboniferous........................................................... 249

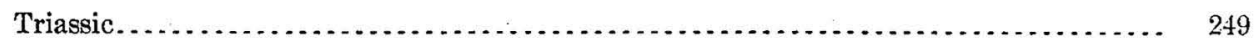

Coastal Plain formations. . ................................................ 250

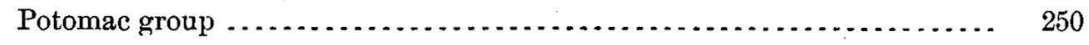

Pamunkey formation......................................... 250

Chesapeake formation........................................ 250

Lafayette formation ....................................... 250

Columbia formation............................................ 250 
Description of clay deposits, by States--Continued. Page.

Virginia-Continued.

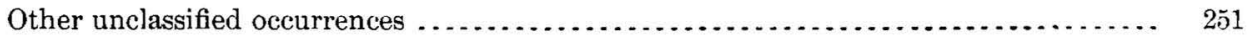

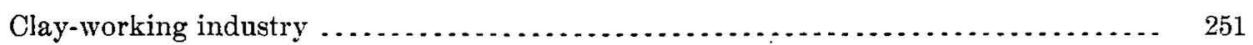

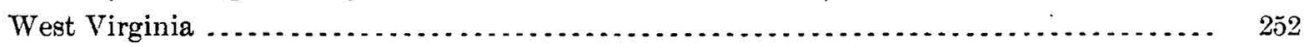

Carboniferous.......................................................... 252

Pottsville conglomerate.............................................. 252

Lower Coal Measures................................................... 253

Barren Measures .................................................... 258

Upper Coal Measures............................................... 259

Upper Barren Measures .......................................... 260

Pleistocene clays .......................................................... 260

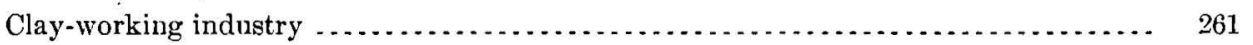

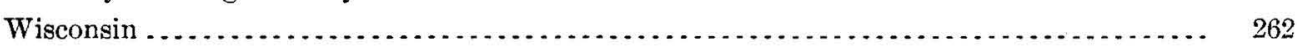

Residual clays ...................................................... 262

Plastic kaolins ........................................................ 262

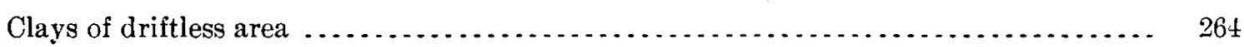

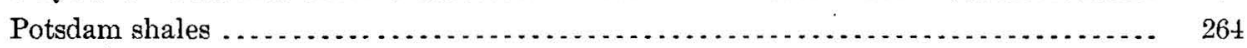

Hudson shale ....................................................... 265

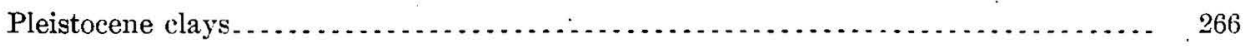

Lacustrine deposits . . . . . . . . . .

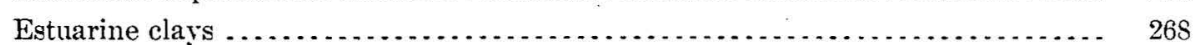

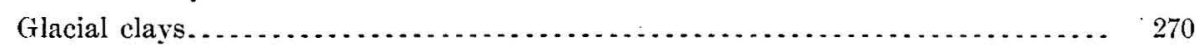

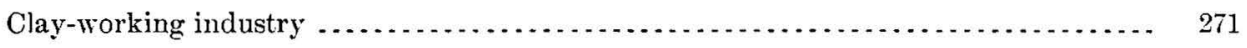

Résumé of clay-working industry east of Mississippi River ............................ 273

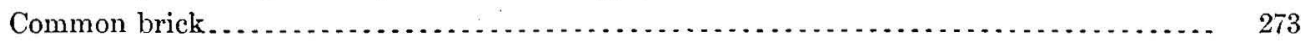

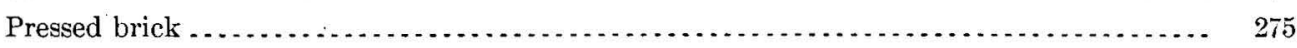

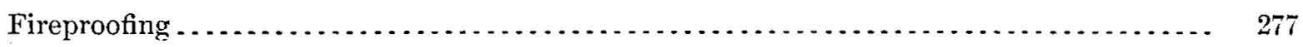

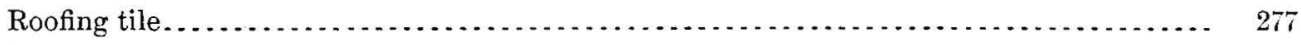

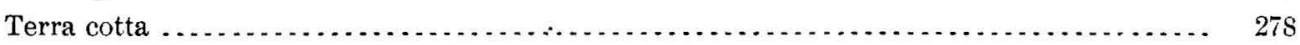

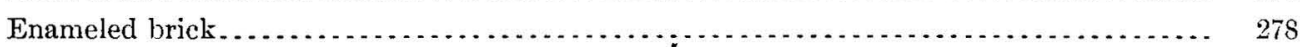

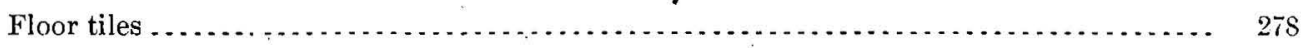

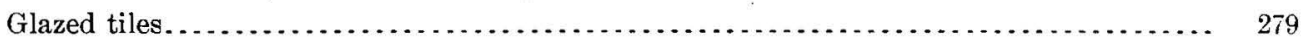

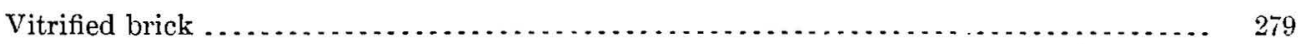

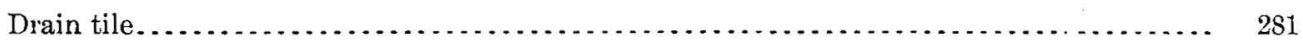

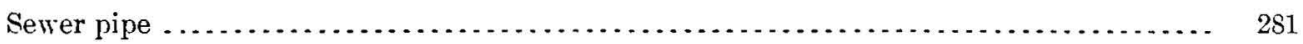

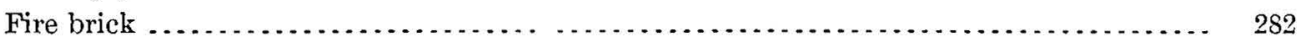

Pottery ...

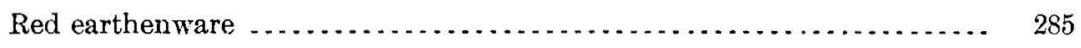

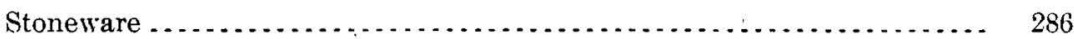

White earthenware and C. C. ware ............................. 286

Semivitreous porcelain .................................... 287

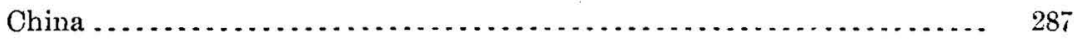

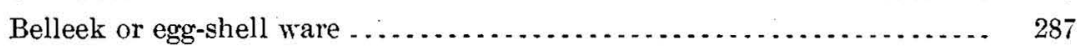

Electrical supplies....................................... $28 \pi$

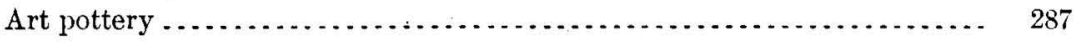

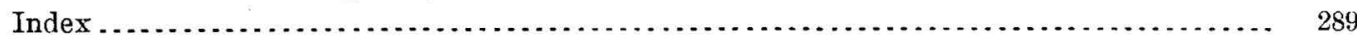





\section{ILIUSTRATIONS.}

Plate I. A, View of ball-clay mine at Edgar, Fla.; $B$, View of kaolin mine near Dillsboro, N. C.

, View of kaolin pit near Hockessin, Del., showing the drift over the kaolin and the starting of a circular shaft; $B$, View of kaolin-washing plant of J. T. Burgess, Hockessin, Del ...

III. Map showing distribution of clays in New York, New Jersey, Ohio, Pennsylrania, West Virginia, and parts of neighboring States.

IV. Map showing distribution of clays in Michigan, Wisconsin, Illinois, Indiana, Ken-

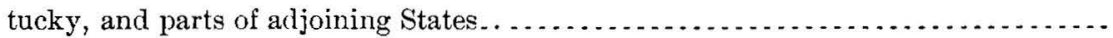

V. $A$, Shale pit near Belleville, Ill.; $B$, View of Cretaceous clay at Woodbridge, N. J....

VI. View of Pleistocene clays in Hudson River Valley . . ...........................

VII. Map showing distribution of clay in the Southern Atlantic States and westward to Mississippi

VIII. Map showing location of paving-brick and fire-brick works east of the Mississippi River ...

IX. Map showing location of potteries and of kaolin and ball-clay pits east of the Mississippi

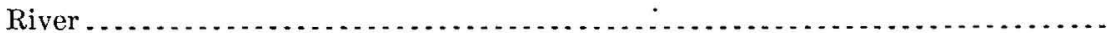

FIG. 1. Section illustrating the formation of residual clay

2. Section illustrating occurrence of sedimentary clay

3. Section showing lenticular character of clay deposits in Coastal Plain region ...........

4. Section of Barren Measures opposite Steubenville, Ohio . ........................

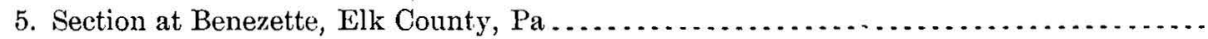

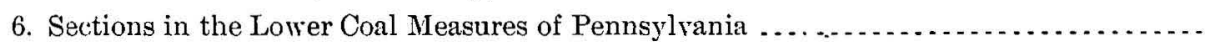

7. Section showing Lower Kittanning fire clay in western Pennsylvania ................

8. Section of Barren Measures in Pittsburg region, Pennsylvania .....................

9. Section of Upper Prodnctive Measures in Fayette and Westmoreland counties, Pa .....

10. Section of Barren Measures in.West Virginia ................................

11. Section of Upper Productive Measures on Robinsons Run, Monongalia County, Wr. Ya... 



\title{
THE CLAYS OF THE UNITED STATES EAST OF THE MISSISSIPPI RIVER.
}

\author{
By Heinrich Ries. \\ NATURE OF CLAY.
}

The term clay is applied to a natural substance or rock which, when finely ground and mixed with water, forms a pasty, moldable mass that preserves its shape when air dried, and when burned changes to a hard, rock-like substance by the coalescence of its particles, through softening under the action of heat.

A microscopic examination of clay shows that it is made up of a great number of small mineral fragments of many different kinds and of varying shape, ranging in size from those which are under $\frac{1}{10 \overline{0}} \mathrm{~mm}$. in diameter (known as clay) up to grains of sand which are sufficiently large to be easily visible to the naked eye. The smaller particles predominate.

Since clays vary mineralogically they vary also chemically, but the plasticity may remain the same through a wide range of chemical composition, and this property is evidently not dependent on the chemical composition alone, but is due rather to some physical cause. The plasticity may be destroyed by heating the clay to a sufficiently high temperature to drive off the chemically combined water.

Although varying in their mineral composition, most clays are supposed to contain more or less of the mineral kaolinite (a hydrated silicate of alumina), which is commonly referred to as the clay base or clay substance. The adoption of the latter term has probably arisen from the fact that many have considered this mineral to be the cause of plasticity, an idea now known to be somewhat incorrect, because some of the most plastic clays contain but small quantities of kaolinite, and vice versa.

\section{ORIGIN OF CLAY.}

Clay is usually formed directly or indirectly from the decomposition of rocks containing feldspar, this change being due either to weathering or to exposure to certain acid vapors. This mineral changes to kaolinite, but the latter may also be 
formed from quartz, ${ }^{a}$ and even amphiboles and pyroxenes may yield hydrous aluminum silicates. ${ }^{b}$

A mass of kaolinite is known as kaolin, the former being the mineralogical name, the latter the rock term though the two are unfortunately often mixed.

Feldspar alone yields by its decomposition a mass of pure white clay, and the presence of quartz or white mica will interfere but little with its color. The admixture, however, of any minerals containing iron at once affects the tint of the kaolin and strongly discolors it, iron in fact being the most common coloring material which clays contain.

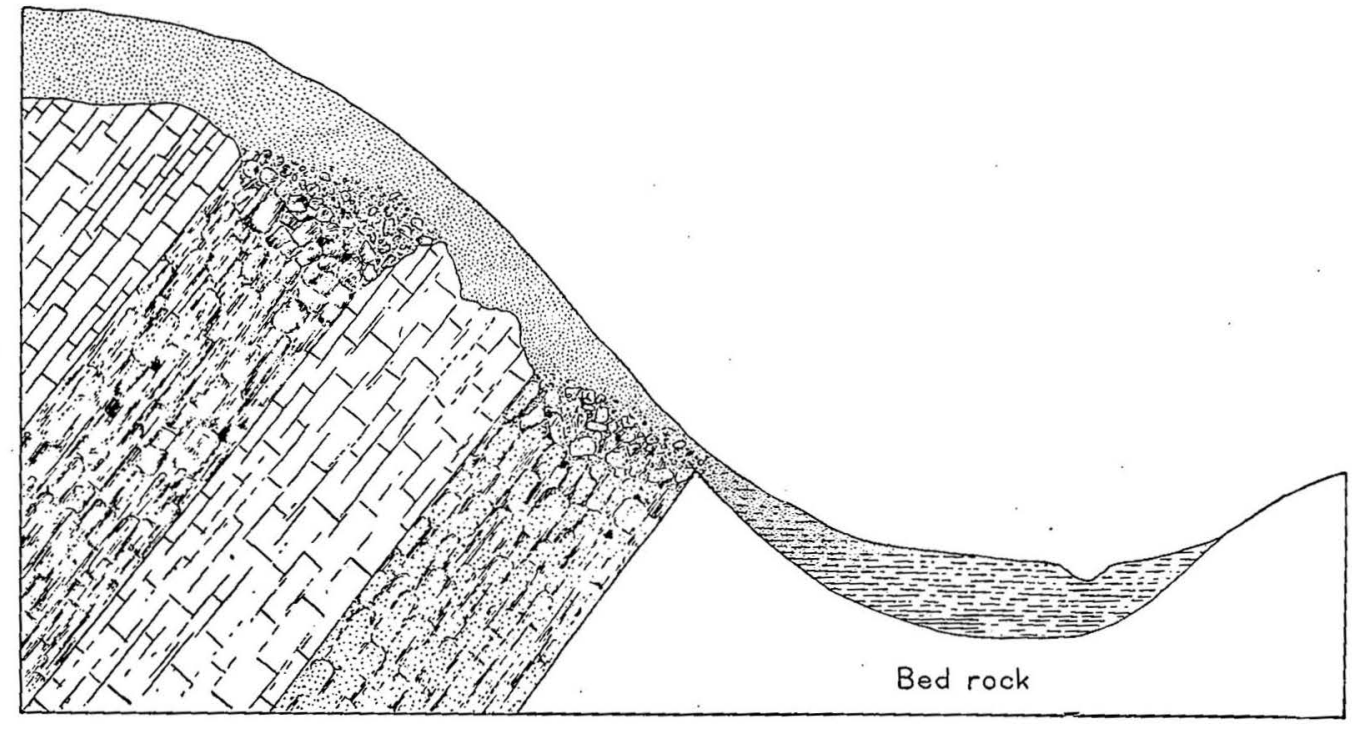

FIG. 1:-Section illustrating the formation of residual clay.

RESIDUAL CLAYS.

When a mass of feldspathic rock weathers down to clay and the latter remains at or close to the place of its origin the deposit is termed a residual one (fig. 1), since the clay thus formed represents the residuum of the rock decay, the soluble portions of the parent rock having been wholly or partly carried off. Residual clays are usually very impure and highly colored by iron, and since they are formed by weathering they show a gradual passage from the fully formed clay at the surface to the parent rock below, limestone residuals forming the only exception, the change from clay to rock in such cases being sudden. Residual clays often contain more or less angular fragments of undecomposed or partly decayed mineral matter, and these may

$a$ Trans. Am. Inst. Min. Eng., Vol. XXX, p. 614. $\quad b$ Merrill, G. P., Rocks, Rock Weathering, and Soils, p. 21. 
increase in number and size as the parent rock is approached. The depth of residual deposits varies with the depth to which the weathering has penetrated the parent rock and also with the surface slope on which the clay has been formed. On steep slopes residual clays seldom show great thickness, since they are easily washed. away, but in valleys and on flat surfaces their thickness may be great. In the Southern States, in fact in the entire area s.outh of the terminal moraine of the Glacial epoch (see p. 50), residual clays are abundant wherever the rock is weathered and the slope has been sufficiently gentle to permit them to remain. Along the line of the Appalachians the Cambrian and Silurian limestones are especially important sources of residual clays, because their decay has yielded a great mantle of this material. They are common in the Great Valley, notably at its southern end. The pre-Cambrian crystalline rocks have likewise formed an extensive residual deposit of similar character. These deposits will be referred to in more detail under headings relating to the different States and formations. ${ }^{a}$

VALUE OF RESIDUAL CLAYS.

Since residual clays are usually impure they are seldom of ralue for anything better than common brick or drain tile, although the finer parts are sometimes used for pottery. In rare instances they show great freedom from iron, notably in the case of the residual clays derived from the decomposition of pegmatite veins (western North Carolina) or highly feldspathic gneisses (Cecil County, Md). Those formed by the decay of some of the Cambro-Silurian schists in southeastern Pennsrylvania and portions of the Knox dolomite may also be nearly white in color.

Analyses of residual clays.

\begin{tabular}{|c|c|c|c|c|c|c|c|c|}
\hline & 1. & 2. & 3. & 4. & 5. & 6. & i. & 8. \\
\hline Alumina & 22.17 & 20.47 & 19.64 & 14. $7 t$ & 31.76 & 26.43 & 21. 764 & 18.98 \\
\hline Silica.... & 5อั. 42 & 58.63 & 61.66 & 76.78 & 52.03 & 54.54 & $72.16 t$ & 70.83 \\
\hline Water ......... & 9.86 & 7. 26 & ........ & 4. 894 & 15.55 & 9.87 & t. $75 \mathrm{~s}$ & 5.45 \\
\hline Ferric oxide ........... & 8. 3 & S. 58 & 7.54 & 1. $6 t$ & Tr. & 9.04 & .99 & 1.24 \\
\hline Lime ................ & .15 & Tr. & $\operatorname{Tr}$ & $\operatorname{Tr}$ & $\operatorname{Tr}$. & 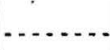 & $.22 t$ & .24 \\
\hline Magnesia ............. & 1. 45 & 1.42 & Tr. & .389 & .54 & & .698 & .02 \\
\hline Alkalies . . . . . . . . . . . & 2.49 & 4.00 & 2.32 & 1.557 & & & 5. 139 & 2.59 \\
\hline $\mathrm{CO}_{2} \ldots$ & & & & & & & & 1. $0 \%$ \\
\hline
\end{tabular}

1. From Knoxville limestone, Morrisville. Calhoun County, Ala.

2. Cartersville, Bartow County, Ga. (Georgia Geol. Surv., 1893).

a See also Russell, I. C., Subaerial decay of rocks and origin of the red color of certain formations: Bull. U. S. Geol. Survey No. 62.

9647 -No. $11-03-2$ 
3. Rockmart, Polk County, Ga. (Georgia Geol. Surv., 1893).

4. From chert, Graves County, Ky: (Kentucky Geol. Survey, Chem. Anal., Pt. III).

5. Blandford, Hampden County, Mass. (Tech. Quart., 1890).

6. Cary, Wake County, N. C.

7. From slate, Fogelsville, Lehigh County, Pa. (Pennsylvania Geol. Survey, Rept. D, p. 13).

8. Grand Rapids, Wood County, Wis. (Wisconsin Acad. Sci., 1870-1876).

\section{SEDIMENTARY CLAYS.}

Those plastic products of rock decay which do not remain over the parent rock are washed down into the brooks and rivers and carried on to the lakes or seas, where they are spread out over the bottom as bedded or stratified deposits of clay, to which the term sedimentary clay is given (fig. 2). The section of such a deposit

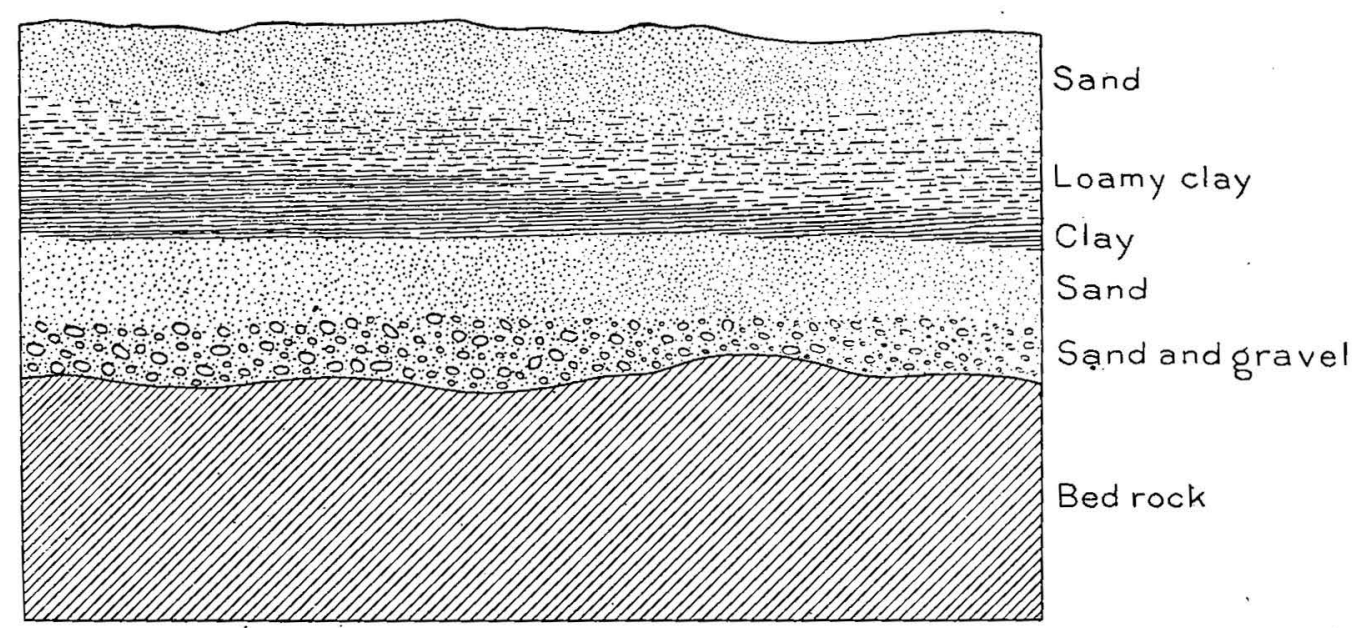

FIG. 2.-Section illustrating oceurrence of sedimentary clay.

shows a series of layers which bear no genetic relation to the underlying rock. They may represent a section of many beds of very similar character or of widely different nature, some being sandy, others quite fine. By the accumulation of many beds of sediment on top of the clay the latter may become consolidated to form a bed of shale. The shale when ground and mixed with water, however, often yields a mass as plastic as common surface clay. In many regions where the rocks have been folded and metamorphosed the shale has been changed to slate. This alteration, being the result of pressure, and perhaps heat, has been sufficient to destroy the inherent property of plasticity, for the slates when ground and mixed with water will not develop a plastic mass. The shales that occur in association with the coal beds are often erroneously termed slate by miners, probably for the reason that many of them are hard and brittle and thus somewhat resemble true slate. 


\section{GEOLOGIC DISTRIBUTION OF CLAY, SHALE, AND SLATE.}

Clays.-Sedimentary clays are commonly found in the younger geologic formations-that is, those ranging from the Cretaceous up to and including the Pleistocene. The Tertiary and Cretaceous clay beds of the eastern United States usually represent marine deposits, and may be of considerable extent, except where they were deposited in areas that were subject to shifting ocean currents, in which case they may be small and very irregular. This is true of many of our Coastal Plain clay deposits, for here beds of clay may pass horizontally into sand within a very short distance. The Pleistocene deposits also yield vast quantities of sedimentary clay which may have been formed under several different conditions, giving the following types:

(1) Lake clays; beds of clay laid down in the areas bordering the present Great Lakes during the time when the waters spread over a greater territory than they do now. This type may show great extent and thickness, but the clays are often calcareous. They are common in Wisconsin, Michigan, northern Indiana, and western New York.

(2) Estuarine clays, deposited in depressed valleys or estuaries of the sea or in lakes, and represented by certain Wisconsin types and those of the Hudson Valley, and by many Columbia clays along the Atlantic coast. These may also be of great thickness. They are usually impure and of widely different character at different localities.

(3) Pond clays, formed in small lakes or ponds scattered all over the Northern States north of the line of the terminal moraine. They are usually basin shaped and may or may not be extensive. They are found in many flat-bottomed valleys and are extensively worked for the manufacture of brick and tile.

(4) Moraine deposits, of irregular size and often lens shaped, occurring in moraines or glacial till. They are apt to be stony and very sandy, and are often calcareous. Very few of them are sufficiently extensive to support a large factory for a long period.

(5) River-terrace deposits, commonly sandy beds, representing mud and clay deposited by streams during perlods of overflow. They underlie the flat terraces bordering many of our larger rivers and sometimes the smaller ones. In some valleys several terraces are found at different levels, and of these the lowest one is frequently overflowed during periods of high flood and the clay deposit thus added to. Clays of this type are worked along the Ohio and Mississippi rivers, the Tennessee, the Potomac, the Mohawk, and other streams. These deposits are used mostly for the manufacture of common brick and tile-in rare instances for paving brick and terra cotta. They are sometimes sufficiently fine grained to be employed in the manufacture of pottery. 
Shates.-In the United States east of the Mississippi consolidated clays or shales are confined to the Paleozoic and Juratrias formations. They occur in unlimited quantities in rocks of Cambrian, Silurian, Devonian, Carboniferous, and Juratrias age. Considering them as a whole, those of the Carboniferous are the most important, and are extensively used in the manufacture of common brick, paving brick, pressed brick, terra cotta, firebrick, stoneware, etc. The Devonian shales are of less value, but where sufficiently free from grit to be plastic on grinding they are found to be a valuable source of clay. The Triassic shales have little commercial value.

Slate.-Slate is rarely used in the manufacture of clay products, although in a few regions it is ground up and mixed with some plastic clay for molding into brick. Such a mixture is usually made on account of some color-burning or refractory quality which the slate may possess.

\section{PROPERTIES OF CLAY.}

PHYSICAL PROPERTIES. $a$

Since these affect the commercial value of the clay to a very large extent, it may be well to mention them briefly. Under the physical properties of clay are included air and fire shrinkage, tensile strength, plasticity, fusibility, color, and slaking.

Air shrinkage.-This refers to the decrease in size which takes place during the air drying of the clay, and is due to the evaporation of the water which has been used to mix up the material. The amount of air shrinkage usually stands in direct relation to the quantity of water absorbed by the clay during the mixing or tempering. Since plastic clays absorb more water than lean or slightly plastic ones, they show a higher air shrirtkage. The air shrinkage ranges from 1 to 2 per cent in very lean or sandy clays up to 8 or 10 per cent or possibly even more in very plastic material. The air shrinkage is a matter of considerable importance to the clay worker, for the reason that the greater the decrease in size of the clay product during drying the greater the danger of its warping or cracking. Clays with a high air shrinkage usually have to be dried very slowly and carefully, and the aim of the manufacturer, therefore, is to find a clay or make a mixture of clays which will not only have a low air shrinkage but will also stand rapid drying. The air shrinkage begins as soon as the clay has been molded or is taken from the machine, and all of the moisture is not driven off until the brick is placed in the kiln. The last portions of it evaporate in the early stages of burning, during which period great quantities of steam can be seen issuing from the chimneys of the kiln; this is known as the water-smoking process. Some clays part readily with the water contained in their pores, especially if they are sandy.

a For a more detailed discussion of these properties than can be given here, see The clays of New York and their uses: Bull. New York State Museum No. 3, p. 538. 
Fire shrinkage.-All clays undergo a second diminution in volume during the firing, and this may range from 2 or 3 per cent up to 15 or 20 per cent or even more, showing just as much variation as the air shrinkage, but being due to different causes. The fire shrinkage does not really begin until the chemically combined water and carbonic-acid gas are driven out of the clay, consequently it commences at about dull redness. Although most clays shrink in burning, there are a few, such as those containing much quartz, which tend to expand at high temperatures.

Both the air shrinkage and the fire shrinkage may often be decreased by the addition of sand to the clay mixture.

Tensile strength.-The tensile strength of the clay is the resistance which it offers to rupture in its air-dried condition, and in most clays seems to stand more or less in relation to its plasticity - that is, very plastic clays often, but not always, have a high tensile strength. A high tensile strength in clay is desirable, since it helps the ware to resist cracking in drying and also permits it to stand handling better in its air-dried condition, but clays show a wide variation in respect to this property. The kaolins show the lowest tensile strength of all the clays, while the impure Gumbo clays of the Central and Western States show perhaps the highest cohesive power of any known. The following figures represent the usual range of tensile strength shown by different varieties of clay:

Tensile strength of different kinds of clay.

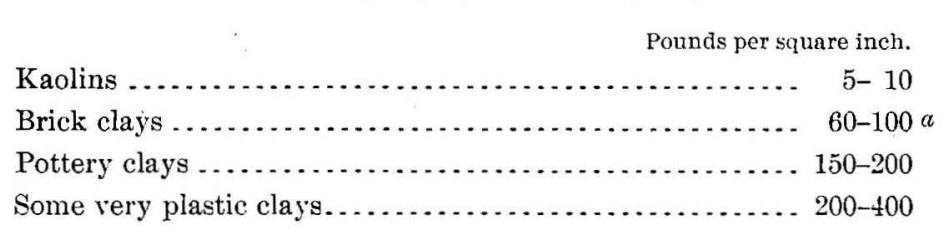

The work which has been done on the clays from different parts of the eastern United States indicates that the materials from any one formation may show a wide variation as regards cohesiveness. Thus among the Coastal Plain elays we find that those from New Jersey and Maryland, and even those from North Carolina, in many cases show but moderate tensile strength, while many of those obtained from the same formation in Alabama often show a very high tensile strength, as can be seen by an inspection of the tables of tests given on subsequent pages. Some of the residual clays of the Appalachian region show high strength; others show low

- strength, due to the presence of considerable sandy matter. The shales of the Pale. ozoic formations do not as a rule show great strength, running commonly from 60 to 80 pounds, or in some cases 100 pounds, per. square inch. 'The fire clays of the Carboniferous may also show a wide variation. The Pleistocene clays found in the drift regions of the Northeastern States often have great tensile power, and the

a Often more. 
same is true of many of the sedimentary clays found in river bottoms in various parts of the country.

The tensile strength of clays is usually tested by making them up into briquettes of the same size and shape as those made for testing the tensile strength of cement. They are then thoroughly air dried in a warm room and broken in the machine. Such tests should be made with great care in order to obtain uniform and accurate results, for if the experiments are improperly made the results obtained will be misleading and incorrect.

Plasticity. - This is the property of forming a pasty mass when mixed with water, so that the clay can be molded into any form, which it retains when dried and burned. The plasticity seems to depend more on the physical than on the chemical composition of the clay. The purest clays are by no means the most plastic ones, and the high-grade kaolins, such as those mined in North Carolina and Pennsylvania or those imported from England, are always very lean. The sedimentary clays are in many cases much more plastic than the residual clays, the natural washing process which they have undergone seeming to have increased their plasticity. ${ }^{a}$ Many shales, on being ground and mixed with water, will make a plastic mass, but they are on the whole not so plastic as soft surface sedimentary clays. This may be due to the fact that the grains are not always consolidated by mere pressure alone, but may be slightly cemented, so that the grinding does not thoroughly disintegrate the mass. If two samples of the same shale be disintegrated, the one by grinding and the other by exposure to the weather, the latter will usually show more plasticity when they are mixed with water.

Fineness of grain seems to have more or less to do with the plasticity of a clay, so that an increase in its sandiness decreases the plasticity, and consequently clays - that are too plastic or fat to work may often be made more easily workable by the addition of sand. Care should always be taken, however, not to add too mueh of this material to the clay, since an excess of it diminishes its density when burned, and produces a brick or other clay product which is porous and more or less unsound.

Changes in burning.- The shrinkage of the clay in firing has already been referred to. A second change which takes place in the burning of the clay is its densification, for as the clay shrinks in the kiln the particles draw closer and closer together, and the mass becomes more and more dense, reaching at last a condition of impermeability. This nonabsorbent condition is not attained, however, by a mere drawing together of the particles, but is aided by their softening under the action of heat, and by the weight of the clay pressing them together, so that they pack into a solid mass. When the clay has reached this condition in burning, it is

$a$ Prof. G. H. Cook found that the plasticity of many lean elays is increased when they are ground, by reason of the breaking up of bunches of minerals, especially kaolinite, that they contain. 
said to have been vitrified. Before this point is reached the clay particles soften sufficiently to stick together, but not to crush out of shape, and this stage is known as that of incipient fusion. Most common bricks are burned to this latter point, while paving bricks, sewer pipe, and stoneware are vitrified. If a clay is heated beyond the condition of vitrification, it becomes softer and softer until a temperature is reached at which the clay flows or becomes viscous.

The difference in temperature between the points of incipient fusion and viscosity varies in different clays. In calcareous clays the softening action takes place rapidly and the two extremes may not be more than $50^{\circ}$ or $100^{\circ} \mathrm{F}$. apart, but in noncalcareous clays the points of incipient fusion and vitrification may be separated by an interval of $400^{\circ} \mathrm{F}$. Though the above-named three stages in the burning of the clay are recognized, it is sometimes rather difficult to determine them exactly. The recognition of this difference between the temperatures of incipient fusion and viscosity has a practical value. It is necessary to vitrify many clay products, but when a kiln full is being burned it is not possible to stop the rising temperature within the space of a few degrees, consequently if the difference between the temperature of vitrification and that of viscosity is great it is safe to burn the kiln of ware up to the vitrified stage, and even a little beyond it, without danger of rendering the whole mass viscous.

Fusibility.-The fusibility of clay may depend on the amount of fluxes orfluxing elements, such as lime, magnesia, iron oxide, and alkalies, the size of the clay grain, and also the conditions of the firing, whether oxidizing or reducing. With other things equal the temperature of fusion will fall with an increase in the percentage of fluxing impurities which the clay contains. Fine-grained clays will, other things being equal, usually fuse at a lower temperature than coarse-grained ones. Common brick clays will often fuse at a temperature of. from $2,000^{\circ}$ to $2,300^{\circ} \mathrm{F}$. Stoneware clays can often be heated to a temperature of $2,600^{\circ}$ or $2,700^{\circ} \mathrm{F}$. before becoming viscous, while good fire clays do not become viscous until $3,200^{\circ}$ or $3,300^{\circ} \mathrm{F}$., or eren more, is reached. The temperature of fusion may be determined in several different ways. One method consists in using test pieces of known composition and consequently known fusibility. Such a set, which is much used by practical clay workers, is known as Seger cones. They are made up of a series of mixtures of clay and fluxes so compounded and graded as to represent a succession of fusion points, each being but a few degrees higher than the preceding. The ingredients of these cones are kaolin, feldspar, quartz, marble, and pure ferric oxide. The series consists of 58 members, the lowest one having a fusion point of $1,094^{\circ} \mathrm{F}$. $\left(590^{\circ} \mathrm{C}\right.$.), and the highest $3,362^{\circ} \mathrm{F} .\left(1,850^{\circ} \mathrm{C}\right.$.). In order to test the heat of a kiln these cones are placed in the fire at a point where the flame will not strike them. As the heat rises the cones begin to soften, and when the fusing point is reached each bends orer until 
its tip touches its base. The cones are placed in the kiln at a point where they can be watched through a peephole. Several cones of the several members are put in, for example, 05,1 , and 5 . If cones 05 and 1 are melted in the burning, but 5 is not affected, it indicates that the temperature was between 1 and 5 . In the next burning 2, 3, and 4 are put in; 2 and 3 may be fused but 4 remain unaffected, showing that the temperature of the kiln was the same as the fusing point of cone 3 .

Since these cones are being used very much and are rapidly increasing in favor, it seems desirable to give here the fusion points of the series and also their composition.

Composition and fusing points of Seger cones.

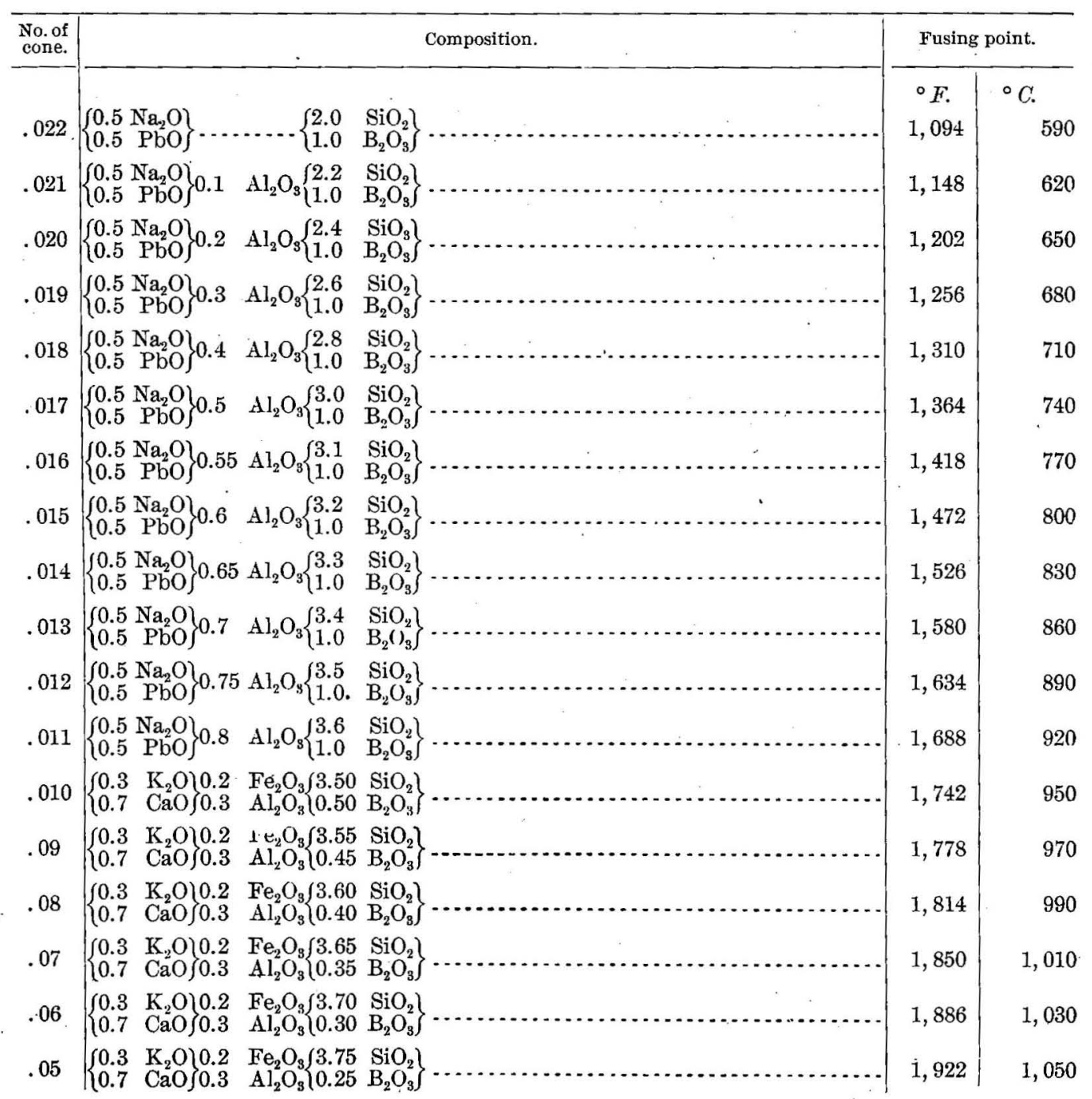


PHYSICAL PROPERTIES.

Composition and fusing points of Seger cones-Continued.

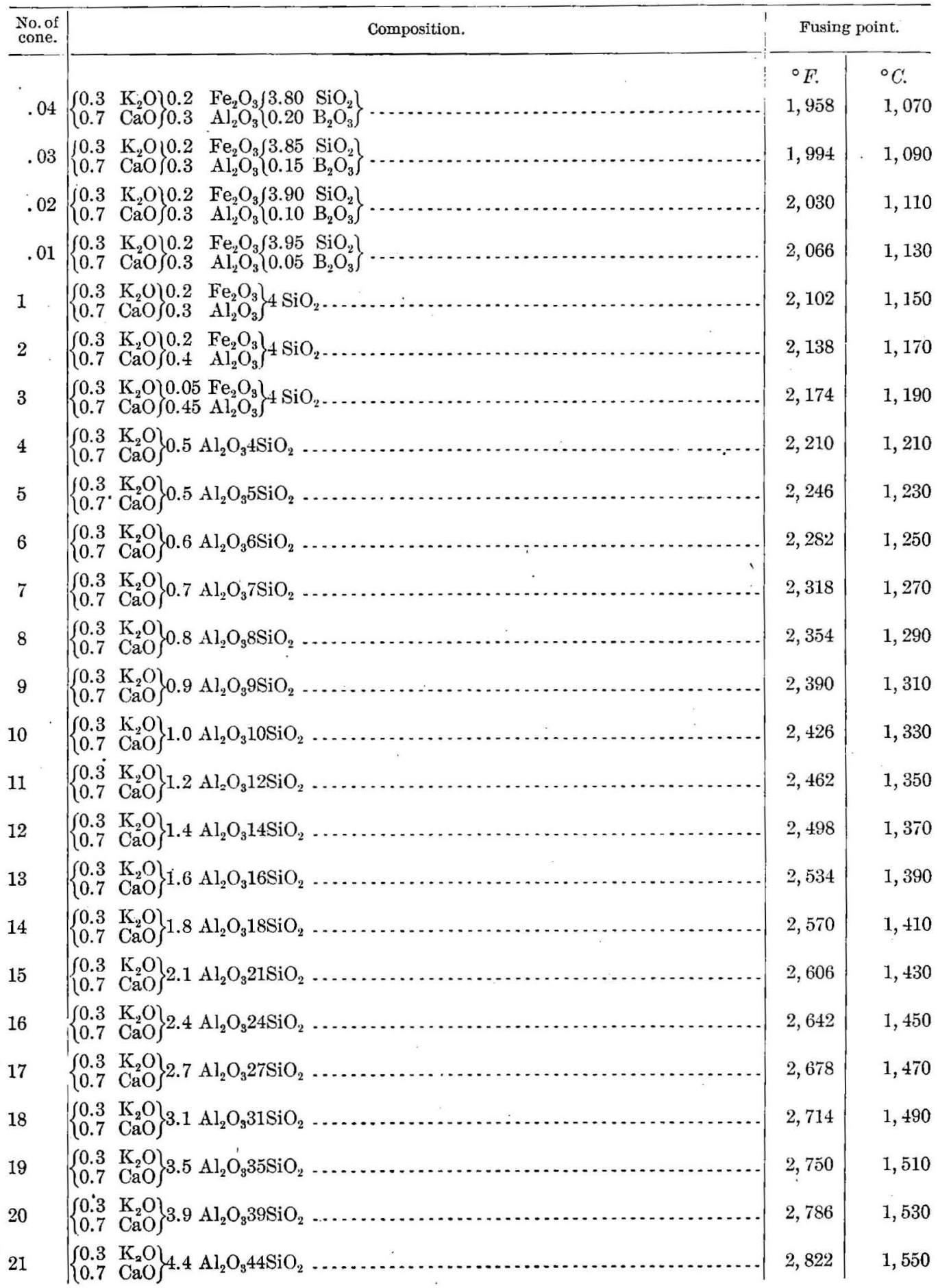


Composition and fusing points of Seger cones-Continued.

\begin{tabular}{|c|c|c|c|}
\hline $\begin{array}{l}\text { No. of } \\
\text { cone. }\end{array}$ & Composition. & Fusin & point. \\
\hline 22 & $\left\{\begin{array}{ll}0.3 & \mathrm{~K}_{2} \mathrm{O} \\
0.7 & \mathrm{CaO}\end{array}\right\} 4.9 \mathrm{Al}_{2} \mathrm{O}_{3} 49 \mathrm{SiO}_{2} \ldots \ldots$ & $\begin{array}{c}{ }^{\circ} F . \\
2,858\end{array}$ & $\begin{array}{l}{ }^{\circ} \mathrm{C} . \\
1,570\end{array}$ \\
\hline 23. & $\left\{\begin{array}{ll}0.3 & \mathrm{~K}_{2} \mathrm{O} \\
0.7 & \mathrm{CaO}\end{array}\right\} 5.4 \mathrm{Al}_{2} \mathrm{O}_{3}, 54 \mathrm{SiO}_{2} \ldots$ & 2,894 & 1,590 \\
\hline 24 & $\left\{\begin{array}{ll}0.3 & \mathrm{~K}_{2} \mathrm{O} \\
0.7 & \mathrm{CaO}\end{array}\right\} 6.0 \mathrm{Al}_{2} \mathrm{O}_{3} 60 \mathrm{SiO}_{2} \ldots$ & 2,930 & 1,610 \\
\hline 25 & $\left\{\begin{array}{ll}0.3 & \mathrm{~K}_{2} \mathrm{O} \\
0.7 & \mathrm{CaO}\end{array}\right\} 6.6 \mathrm{Al}_{2} \mathrm{O}_{3} 66 \mathrm{SiO}_{2} \ldots$ & 2,966 & 1,630 \\
\hline 26 & $\left\{\begin{array}{ll}0.3 & \mathrm{~K}_{2} \mathrm{O} \\
0.7 & \mathrm{CaO}^{\prime}\end{array} 7.2 \mathrm{Al}_{2} \mathrm{O}_{3} 72 \mathrm{SiO}_{2} \ldots\right.$ & 3,002 & 1,650 \\
\hline 27 & $\left\{\begin{array}{ll}0.3 & \mathrm{~K}_{2} \mathrm{O} \\
0.7 & \mathrm{CaO}\end{array}\right\} 20 \quad \mathrm{Al}_{2} \mathrm{O}_{3} 200 \mathrm{SiO}_{2} \ldots$ & 3,038 & 1,670 \\
\hline 28 & $\mathrm{Al}_{2} \mathrm{O}_{3} 10 \quad \mathrm{SiO}_{2} \ldots$ & 3,074 & 1,690 \\
\hline 29 & $\mathrm{Al}_{2} \mathrm{O}_{3} 8 \quad \mathrm{SiO}_{2} \ldots \ldots \ldots$ & 3,110 & 1,710 \\
\hline 30 & $\mathrm{Al}_{2} \dot{\mathrm{O}}_{3} \quad 6 \quad \mathrm{SiO}_{2} \ldots \ldots$ & 3,146 & 1,730 \\
\hline 31 & $\mathrm{Al}_{2} \mathrm{O}_{3} \quad 5 \quad \mathrm{SiO}_{2} \ldots \ldots \ldots$ & 3,182 & 1,750 \\
\hline 32 & $\mathrm{Al}_{2} \mathrm{O}_{3} 4 \quad \mathrm{SiO}_{2} \ldots \ldots \ldots$ & 3,218 & 1,770 \\
\hline 33 & $\mathrm{Al}_{2} \mathrm{O}_{3} \quad 3 \quad \mathrm{SiO}_{2} \ldots \ldots \ldots$ & 3,254 & 1,790 \\
\hline 34 & $\mathrm{Al}_{2} \mathrm{O}_{3} \quad 2.5 \mathrm{SiO}_{2} \ldots \ldots \ldots$ & 3,290 & 1,810 \\
\hline 35 & $\mathrm{Al}_{2} \mathrm{O}_{3} 2 \quad \mathrm{SiO}_{2} \ldots \ldots \ldots \ldots$ & 3,326 & 1,830 \\
\hline 36 & 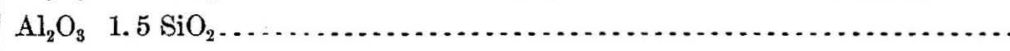 & 3,362 & 1,850 \\
\hline
\end{tabular}

For the burning of common bricks the temperatures reached will range from cone 05 to 01 ; for hollow ware 05 or 01 is probably reached in most cases. In burning paving brick the temperature may range from cone 1 to cone 3 ; for terra cotta most manufacturers burn from cone 5 to cone 7 , unless calcareous clays or impure shales are used, when the temperature would be much lower, ranging from perhaps cone 03 to 1 or 2 . In the manufacture of white earthenware the biscuit is commonly burned at from cone 6 to cone 8 . In fire-brick manufacture it ranges from cone 10 to cone 14 .

A second means of measuring the temperature of the kiln is the thermoelectric pyrometer: which measures a current generated by the heating of a thermopile. ${ }^{a}$ The latter consists of two wires, one of platinum and the other of rhodium and platinum, which are soldered together at one end, while they are isolated by being inserted in two fire-clay tubes. The two wires connect with a galvanometer, the declination of whose needle increases with the temperature at the end of the wires. In order to measure the temperature of the kiln, the tubes carrying the wires are put in the kiln either at the beginning of the burning or during the firing. Such a machine, while expensive, is very accurate and is used to a considerable extent by probably at least eighteen clay-working firms in the United States.

a Barus, Carl, On the thermo-electric measurement of high temperatures: Bull. U. S. Geol. Survey No. 54. 
Color.-The color of a clay is not always an indication of its quality. Many clays are so brilliantly colored with iron-for example, the residual clays of the south-that the color at once indicates their nonrefractory character. When the color, however, is due to carbonaceous or organic matter it is less easy to tell what the color-burning qualities of the clay in question are.

Many black clays burn pure white or cream white. On the other hand, some black clays may burn red, in which case the organic matter masks the presence of the iron. Aside from increasing the shrinkage of the clay, and probably also its absorptive capacity for water, the organic matter exerts little effect on the material. Clays which contain large quantities of it have to be burned rather slowly in order to get it out of the pores of the mass before the clay begins to shrink and vitrify.

Slaking.-The slaking quality of the clay refers to its property of falling apart or disintegrating when thrown into water. Clays which disintegrate rapidly can be mixed up readily, and can be easily washed in case they have to be freed from impurities by mechanical means. Clays which are dense slake very slowly. Many shales will not slake when thrown into water, but exposed to the slow disintegrating action of the weather they fall to pieces slowly but completely.

CHEMICAL PROPERTIES OF CLAY.

The ordinary quantitative analysis, as carried out on clays, shows the quantity of silica, alumina, iron oxide, lime, magnesia, potash, and soda which they contain. In addition to these, there may also be titanic acid, manganese oxide, phosphoric acid, and sulphuric acid, but these four are rarely determined in the ordinary chemical analysis, since they are usually present in but small amounts. The practical clay worker usually considers a physical test far more valuable than a chemical analysis, for the reason that the facts contained in the former are easily capable of interpretation, while those of the latter can not as a rule be utilized by him. While a chemical analysis is always valuable if capable of proper interpretation, it is more so in the case of high-grade than in low-grade clays.

All the constituents which are determined by ordinary chemical analysis influence the fusibility of clay, by either decreasing or increasing it, and consequently such constituents are sometimes grouped as fluxing and nonfluxing ones. Clay containing only kaolinite, the hydrated silicate of alumina, is rery refractory, but its fire-resisting qualities may be decreased by addition of any of the fluxes or fluxing impurities, such as iron, lime, magnesia, alkalies. It may therefore be well to refer briefly to the effect of the different elements individually, and also to their sources.

Alkalies.-These include potash and soda, which are present in nearly all clays. They have usually been derived from feldspar or mica, both of which are present in at least small quantity if not in larger amounts. Other minerals, such as garnet, 
hornblende, and pyroxene, may also yield these elements. The alkalies found in kaolins probably come from feldspar and white mica, while those found in the residual clays have been partly derived from the iron-beiring minerals, such as garnet, hornblende, and pyroxene. "If the alkalies are present in the clay as an ingredient of feldspar grains, they form a desirable fluxing material, and it is on this account that much feldspar is added to kaolin in the manufacture of porcelain, white earthenware, and other wares having a white, dense body. The alkalies probably do not exert any influence on the color of the burned ware.

Ferric oxide.-This may serve either as a flux or as a coloring agent. Its rôle as the latter is mentioned in another part of the paper. Very few clays are free from iron-indeed, it is present in large quantities in some, such as ocher. The residual clays of the Southern States owe their brilliant shades to this coloring material. It also gives the red or brownish colors to many of the shales which are used in the manufacture of paving brick. In fact, it may color a clay or shale red, yellow, brown, or even bluish gray, and sometimes green, according to the compound of iron which is present. Iron is a widespread ingredient of clays, partly because it can be derived from such a large number of minerals. As found in clays, it is present probably in the form of one of the oxides, such as limonite or hematite, or sometimes it may be present as a silicate or even a carbonate. In not a few cases it is found in the clay in the form of a sulphide, as in the mineral pyrite, but its presence is then easily recognized by the fact that it forms yellow metallic grains or bunches, which in black or bluish-black clays are often associated with the lumps of lignite that the deposits contain. Pyrite may cause considerable trouble in the treatment of the clay, for in burning it gives off sulphuric acid, which may make the ware poor, or if present in the clay in little lumps, and these are not extracted or crushed in the preparation of the clay, the lumps will tend to melt and swell up during the burning and split off pieces of the ware. When iron is present in the form of a carbonate or the mineral siderite, it often forms round, stony, or concretionary masses, which are sometimes known as carbonate ore. These are abundant in many of the Carboniferous shales of eastern Ohio and Kentucky, and are present in not a few of the Carboniferous shales of Michigan. They also occur in the Potomac clays in some States. ${ }^{a}$ In the mining of the clay these ironcarbonate concretions are usually thrown out. Some clays contain iron in the form of the phosphate, as the mineral vivianile, which is most easily recognized by the presence of blue specks or lumps which it forms.

Whatever iron compound is present in the green clay during the process of burning will be converted into the ferric condition, provided the atmosphere of the kiln is oxidizing-that is, clear and free from smoke; and later in the burning, when the

a Ries, H., The clays of Maryland: Maryland Geol. Survey, Vol IV, p. 224. 
clay softens or begins to melt, the iron unites with the silica and other elements in the clay and forms a complex silicate. In addition to affecting the fusibility of the clay the iron also colors the burned ware, a small quantity of iron yielding a buff color, a larger quantity a red tint; and the shade produced in any case deepens with higher firing. If lime is present in the clay in excess of the iron the red coloring of the latter will be destroyed and a buff color will be produced instead. It is for this reason that calcareous clays burn to a white or creamy tint.

Lime.-Most clays contain this compound, but certain types are peculiarly rich in it. These are the drift clays of the Nortinern States and the lake clays of the same region, as well as many of the Paleozoic shales, especially those of the Cambrian and Silurian formations. The residual clays of the Southern States and most of the clay deposits of the Coastal Plain region, with the exception of those of Tertiary age, are usually very low in lime. Calcareous shales may form residual clays low in lime, because during weathering the latter is usually leached out. Lime in clay is commonly derived from the minerals calcite and dolomite, and in rare cases from certain species of feldspar, hornblende, or garnet. Lime, whatever its form, serves as a flux in burning and, as has already been pointed out, tends to destroy the red iron coloration. It also increases the rate of softening of the clay under fire, and consequently, as explained on another page, calcareous clays are undesirable for the manufacture of vitrified ware. The presence of calcium carbonate in a clay can usually be detected by putting a few drops of muriatic acid on it. The effect of the presence of carbonate of lime depends somewhat on the manner of its occurrence or distribution in the clay. Where present in a very finely divided condition it is much less injurious than if it were scattered through the clay in the form of lumps or pebbles. In burning, carbonate of lime is apt to cause difficulty on account of the expulsion of the carbonic acid gas it contains, which forms blisters on the surface of the ware. If present in the form of lumps or pebbles, these may absorb moisture after the brick is burned, and slake, thereby splitting the product. Good bricks can be made from clays containing 20 per cent or more of carbonate of lime, provided it is in a finely divided condition. Calcareous clays are often used in the manufacture of common brick and also for making common earthen ware, drain tile, and, less oiten, terra cotta. They are not suitable for the manufacture of paving brick, stoneware, or sewer pipe. Many such clays are now being used for the manufacture of Portland cement. In addition to affecting the color and fusibility of the clay, lime may also decrease the fire shrinkage.

Magnesia.-With the exception of a variety known as fuller's earth, very few clays contain magnesia in large quantities. As far as known, its action seems to be similar to that of carbonate of lime.

Silica.-The silica present in clay may be of three different kinds, namely: (1) Quartz, (2) that which is combined with alumina and water in kaolinite, and 
(3) that which is combined with one or more bases in the silicate minerals, such as feldspar, hornblende, or 'garnet. In the ordinary chemical analysis the first and third are sometimes placed together under the head of sand, or often incorrectly termed free silica. The silica included under the term sand is practically insoluble in caustic soda and sulphuric acid. There are probably no clays which are perfectly free from quartz, although the amount which they contain may sometimes be very small. Quartz acts as a flux at high temperatures, but at low temperatures it acts as a refractory agent. ${ }^{a}$ It also serves to decrease the fire shrinkage and the plasticity of the clay. It may also increase the porosity of the burned ware.

Titanic acid.-This mineral is no doubt widely spread in clays, but is seldom determined in the ordinary chemical analysis. In small amounts it does not seem to exert any effect on the pyrometric characters of the material. Clay never contains enough of it to warrant its extraction. ${ }^{b}$

Organic matter.-This affects not only the color of the clay, but possibly its plasticity and no doubt its absorptive power. It is contained in the clay in the form of very finely divided plant tissue or larger portions of plants or leaves which have settled in the material during its deposition. The color of many of the Carboniferous shales and also of the Cretaceous clays is due to the organic matter which they contain.

Water in clay.-Clays contain two kinds of water, namely, hygroscopic moisture and chemically combined water. Moisture is the water mechanically mixed with the clay grains, and in clays freshly taken from the bank is often as high as 30 or 40 per cent. Shales contain but a small percentage of moisture. The air drying usually causes the evaporation of most of the mechanically combined water, and its expulsion is accompanied by a shrinkage of the mass. It ceases, however, before all the moisture has passed off, for the reason that the shrinkage stops when the particles have all come into contact with one another, but there still remain in the mass pores which hold a certain amount of moisture that is not driven off until the early stages of burning. Moisture may exert a very injurious effect on clays, in that it tends to dissolve the soluble salts which they sometimes contain and to bring them to the surface during air drying, thus forming a scum or efflorescence. If driven off too fast during the early stages of the burning a blistering of the ware may follow.

Combined water is present in every clay, there being nearly 14 per cent in pure kaolin and as low as 2 to 3 per cent in some impure or sandy clays. The sources of combined water in clays are dry kaolinite, limonite, or hydrated silicates. The combined water is driven off at a red heat, and when this occurs an additional shrinkage of the mass takes place.

a The Collected Writings of H. A. Seger, Vol. I, p. 537.

$b$ See analyses of fire clays given under Pennsylvania and New Jersey 
CLAYS OF UNITED STATES EAST OH MISSISSIPPI RIVER.

METHODS OF MINING CLAYS AND SHALES.

The methods employed for mining clay or shale are in most cases essentially the same. When the deposit is of great thickness and extent and the quality of the clay throughout the bank is the same the extraction of the material is very simple and can be accomplished more cheaply and more quickly than if the clay deposit is of small extent or contains a number of varieties of clay intermixed.

The methods commonly employed are two-(1) quarrying or open-pit work, and (2) underground working.

\section{PIT WORKING.}

If the deposit of clay or shale which immediately underlies the surface is of great extent and the material is to be extracted in large quantities it will be found economical to use a steam shovel for digging the clay. The capacity of such machines is great and their cost of operation is low, provided they can be kept steadily employed. Excavators of this type are much used in some of the large shale and clay banks of Ohio and Indiana and parts of Pennsylvania, but in other States their use is rather limited. In the States mentioned they are employed chiefly for digging Carboniferous shales, which often form beds of great thickness and horizontal extent. For smaller excavations a custom more commonly followed is to dig the clay by means of pick and shovel. This is done at those yards where the operations are not on a sufficiently large scale to warrant the installment of a steam shovel, and also in those deposits where the clays vary in character in different parts of the bank and can not be mixed in the mining, as would necessarily follow from the use of a steam shovel. This is the method of excavation employed at probably the majority of clay-working plants in the United States. It is employed in most of the Coastal Plain deposits and in the drift clays of the Nortkern States. Some surface clays are dug with a wheel scraper, a method which is advantageous provided the clay is not too tough.

A modification of the open-pit method is employed in the case of kaolin deposits, which commonly occur in the form of veins. In these deposits circular pits are often sunk to a depth of 50,60 , or more feet, and lined with a temporary crib work. When the kaolin is all worked out the pitis filled, the cribbing being taken out as the filling proceeds. When the entire pit is filled a second circular pit is sunk next to the first one, and the process is thus continued until the whole vein is worked out. The clay is hoisted from the pit in large buckets.

In cases where the clay has to be washed, and is of a very sandy and open character, it is sometimes possible to flood the pit with water, and with a combination scraper and pump to loosen up the clay and carry it up to the works through a pipe.

In not a few regions the clay is found forming banks or terraces along the sides of a valley, and the clay-working plant is often located at the base of the bank. At 
some of these localities the undermining system is adopted. In this method the clay is undermined at the base of the bank to a distance of several feet, and wedges are driven into the top of the bank several feet from its front edge, thus prying off large masses, which break in falling.

\section{UNDERGROUND MINING.}

Where the desposit of shale does not immediately underlie the surface, but is covered by many feet of other beds of rock, the stripping of the overlying layers would become too costly, and consequently underground methods of mining are adopted. If a bed of shale or clay outcrops at the surface, the usual method is to run a drift or slope in along the clay bed, while from this drift gangways radiate outward in different directions along the line of the deposit, the method of mining being somewhat similar to that followed in the case of coal. Where the clay does not outcrop at the surface it is usually necessary to sink a shaft to the bed, and to run levels from this shaft in different directions into different parts of the clay or shale stratum. In many cases the shaft sunk may encounter more than one bed of clay, so that several deposits can all be mined at the same time. Some of the Carboniferous clay or shale deposits often underlie coal seams, and in such cases the coal also is mined and not infrequently is used as fuel at the brickworks. In rare instances the shale beds have been so upfolded that their dip is nearly vertical, and it is then possible to mine out the shale without removing the rocks that are interbedded with it.

After it is mined the clay is loaded into barrows, carts, or tram cars and hauled to the works. Where the quantity extracted is comparatively small and the lead is very short, the most profitable method is to use wheelbarrows. Where the output is large, cars drawn by horses or tram cars run on a temporary track are found to be the most suitable. Where the scale of operations is large, steam haulage is preferable, and this is commonly employed where the factory is some distance from the bank and the quantity of the clay to be hauled is considerable. A very few factories in this country transport their clay from the bank to the plant by means of a wirerope tramway; this metbod of haulage is frequently employed abroad.

\section{PURIFICATION OF CLAY.}

Many clays, as they come from the bank or mines, contain mineral impurities which it is undersirable to retain in the clay, and means are therefore often taken to remove them. These methods of purification are not often applied to low-grade clay, for the reason that they would increase the expense of manufacture too much, and they are consequently confined chiefly to the better grades of raw material. The two methods commonly employed for cleansing clays are screening and washing. Clays are often screened to free them from limestone pebbles or lumps of pyrite or other stony 
matter whose presence is undesirable. As the injurious effect of these substances can often be greatly lessened by reducing them to a finely divided condition, it is not uncommon to crush the material rather than to screen it, for the screening process usually necessitates previous drying.

WASHING.

Clays employed for the manufacture of pottery are usually washed. The process of washing consists in disintegrating the clay, either in troughs by rotating knives or by slaking it in water and then exposing it to a current. This operation effects a mechanical separation of the material-the finer grains of clay, on account of their lightness, being carried off to settling tanks, while the coarse, sandy particles and pebbles, on account of their greater weight, fall to the bottom of the washing troughs.

Low-grade clays are rarely washed in the United States, but abroad the simple washing process is often used to free the clay from an excess of sand.

Following is a description of the washing process:"

"Clays are washed by one of two methods. With the first method, the clay is thrown into large circular tubs filled with water, in which it is stirred up by revolving arms, and the clay lumps are thereby disintegrated. By this treatment the fine kaolinite particles, as well as very fine grains of mica, feldspar, and quartz, remain suspended in the liquid, while the coarser grains settle in the bottom of the tank. The water with the suspended clay is then drawn off to the settling tanks.

"A modification of this consists in the use of a large cylinder, closed at both ends, which is set in a horizontal position, and contains an axis with iron arms, their revolution serving to break up the clay, which is charged through a hopper at the top. A current of water passes through the cylinder and carries the fine clay particles with it, while the coarse ones are left behind in the machine. The speed of the current has to be regulated by experiment, for if too much water is used coarse material will be washed out of the cylinder, and, conver'sely, if the current is too slow the clay will not yield a sufficient pereentage of washed product. One objection to this apparatus is that it has to be stopped from time to time to remove the coarse sand from the machine.

"The method most commonly used at the present day for washing kaolin is in its general detail as follows:

"As the kaolin comes from the mine it is generally discharged into a log washer, a semicylindric trough, in which rerolves a horizontal axis bearing short arms. The action of the arms breaks up the kaolin more or less thoroughly, according to its density, and facilitates the subsequent washing. The stream of water directed into the $\log$ washer sweeps the kaolin and most of the sand into the washing trough, which is about 15 inches wide and 12 inches deep, but should be wider and deeper if the kaolin is very sandy.

"The troughing has a slight pitch, commonly about 1 inch in 20 feet, but the amount depends on the kaolin and whether the contained sand is fine or coarse. If the

a Biull. New York State Museum No. 35, p. 799.

$96+7$-No. $11--03-3$ 
kaolin is very fine and settles slowly, the pitch need not be so great, and vice versa. A large quantity of very coarse sand in the kaolin is a nuisance, as it clogs up the $\log$ washer and the upper end of the trough more quickly, causing much labor to keep them clean. As it is, considerable sand settles there, and to keep the trough clear sand wheels are used. The wheels are wooden, bearing a number of iron scoops on their periphery. As the wheels revolve the scoops catch up a portion of the sand which has settled in the trough, and as each scoop reaches the upper limit of its turn on the wheel, by its inverted position, drops the sand outside the trough. These sand wheels are a help, but it is often necessary, in addition, to keep a man shoveling the sand from the trough.

"If the sand is finer it is not dropped so quickly and, distributed more evenly along the trough, does not clog it up so fast.

"The zigzag arrangement of the troughing has been objected to by some, as it produces irregularities in the current, causing the sand to bank up in the corners, at the bends, and at certain points along the sides of the troughing. ${ }^{a}$. The effect is to narrow the channel and consequently increase the velocity of the current, thereby causing the fine sand to be carried still farther toward the settling tank. This difficulty, which is not often serious, has been obviated either by having the troughing straight or by allowing the water and suspended clay as they come from the log washer to pass through a section of straight trough, and from this into another of the same depth, but five or six times the width, and divided by several longitudinal partitions. The water and the clay then pass into a third section, twice as wide as the second, and divided by twice the number of longitudinal divisions. By this means the water moves only in a straight course, but as it is being continually spread out over a wider space, it flows with an ever-decreasing velocity.

"By the time the water has reached the end of the troughing nearly all the coarse grains have been dropped and the water is ready to be led into the settling vats, but as a further and necessary precaution it is discharged on a screen of 100 meshes to the linear inch, with the object of removing any coarse particles that might remain, and also of eliminating sticks and other bits of floating dirt.

"Two kinds of screens can be used-the first stationary, the second revolving. The stationary screen is simply a frame covered with a copper cloth and set at a slight angle. The water and suspended kaolin fall on the screen and pass through, otherwise they run off and are lost. A slight improvement is to have two or three screens overlapping one another, so that whatever does not get through the first will fall on the second. If the vegetable matter and sticks are allowed to accumulate they clog the screen and prevent the kaolin from running through, consequently stationary screens must be closely watched.

"The revolving screens are far better, for they are self-cleansing. Such screens are barrel-shaped, and the water, with the kaolin in suspension, is discharged into the interior and passes outward through the screen cloth. As the screen revolves the dirt caught is carried upward and finally drops; but instead of falling down on the other side of the screen it falls on a board, which diverts it out to the ground.

"The settling tanks, into which the kaolin and the water are discharged, may be and often are about 8 feet wide by 4 feet deep and 50 or more feet long. As soon as 
one is filled the water is diverted into another. The larger a tank the longer it will take to fill it and allow the kaolin to settle. Clays obtained in this manner are expensive, particularly when the market takes the output of washed kaolin as soon as it is ready. Small tanks have the advantage of permitting the slip to dry more quickly, especially when the layer of clay is not very thick, furthermore a small pit takes less time to fill and empty. But one disadvantage urged against a number of small tanks is that a thoroughly average product is not obtained, owing to the thinness of the layer of settlings and the small amount in each. In addition, a series of small tanks requires considerable room. The advantages asserted in the case of large tanks are that the clay can be discharged into any one for a considerable period, and if the clay deposit varies in character the different grades get into one tank and a better average is thereby obtained.

"If the kaolin settles too slowly, alum is sometimes added to the water to hasten the deposition. When the kaolin has settled, most of the clear water is drawn off; the cream-like mass of kaolin and water in the bottom of the rat is drawn off by means of slip pumps and forced by these into the presses.

"The presses consist simply of flat iron or wooden frames, between which are flat canvas bags. These bags are connected by nipples with a supply tube from the slip pumps, and by means of the pressure from the pumps nearly all of the water is forced out of the kaolin and through the canvas. When as much water as possible is squeezed out, the press is opened and the sheets of semidry kaolin are taken out. It is then dried either on racks in the open air or in a steam-heated room.

"As for every ton of kaolin usually about two-fifths or one-quarter of a ton of washed kaolin is obtained, it is desirable to have the washing plant at the mines, to avoid the hauling of 60 or 70 per cent of useless sand which has to be washed out before the kaolin can be used or even placed on the market."

\section{AIR SEPARATION.}

This is a method of cleansing clays which has been rarely tried, yet in some of the cases where it has been used it is said to have met with success. It is especially applicable to those clays from which it is necessary to remove simply coarse or sandy particles. The process consists, in brief, in feeding the dry clay into a pulverizer which reduces it to the condition of a very fine powder. As the material is discharged from the pulverizer into a long box or tunnel, it is seized by a powerful current of air, which at once picks up the fine particles and carries them along to the end of the airway, where they are dropped into a bin. The coarser particles, which are too heavy to be picked up by the current, drop back and are carried through the pulverizer once more. Such a method would be especially applicable to kaolins that are free from iron, but probably would not be found adaptable to many of those containing ferruginous particles.

There are several forms of separators on the market. In the Raymond pulverizer and separator the material is pulverized in the lower part of the machine and then thrown upward, the finer particles being carried off by a fan to the discharge hopper, the coarser ones falling back into the hopper. 


\section{COMMERCLAL VALUE OF CLAY.}

Since most clays are manufactured into clay products by the firm mining them, but a small proportion of the total quantity of clay mined is sold. The grades which are sold are usually kaolins, ball clays, fire clays, paper clays, and some pottery and terra-cotta clays. Clays are commonly sold by the ton, the price being quoted either f. o. b. or at the market. Their value ranges from as low as 50 or 75 cents per ton for some pottery and terra-cotta clays up to as high as $\$ 10$ or $\$ 12$ per ton for washed kaolins.

The valuation of clay is based on its purity, physical characters, distance from market, size of deposit, and demand. Clays which might be valuable if near transportation lines are often valueless because of their remoteness from railways. Kaolins commonly bring from $\$ 10$ to $\$ 12$ per ton, delivered in Trenton, N. J., or East Liverpool, Ohio. Ball clays vary in price. The rate per ton delivered in Trenton would be somewhat as follows: Florida ball clay (washed), \$10 per short ton; English ball clay, $\$ 8$ to $\$ 10$ per long ton; New Jersey crude, $\$ 5$ to $\$ 6$ per long ton; New Jersey washed, $\$ 7$ to $\$ 8$; Kentucky and Tennessee clay (washed), slightly more than New Jersey:

Fire clays usually bring from $\$ 1$ to $\$ 2$ per ton f. o. b., the average value in 1900 being $\$ 1.70$ per ton. Many fire clays are sold for pottery and terra-cotta manufacture.

Paper clays vary from $\$ 7$ to $\$ 10$ per ton for domestic ones, the value being based on freedom from grit and whiteness of color.

The structure and mode of occurrence are potent factors which must enter into the valuation of any clay bed. Persons unfamiliar with clays are apt to look only at the character of the material itself, giving no attention to the extent and thickness of the deposit, amount of overburden, etc. Many clay deposits in the Cretaceous or Tertiary formations of the Southern States often show a variety of plastic material in the same section, but the different grades are so closely mixed that the amount of labor required to separate them in mining would be so great as to prohibit the sale of the clay.

\section{USES OF CTAY.}

The uses of clay can be best shown by the following table, compiled originally by R. T. Hill ${ }^{a}$ and amplified by the writer.

Domestic.-Porcelain, white earthenware, stoneware, yellow ware and Rockıngham ware for table service and cooking; majolica stoves; polishing brick, bath brick, fire kindlers.

Structural.-Brick, common, front, pressed, ornamental, hollow, glazed, adobe,

$a$ Mineral Resources U.S. 1891, p. 475. 
terra cotta; roofing tile; glazed and encaustic tile; drain tile; paving brick; chimney flues; chimney pots; doorknobs; fireproofing; terra-cotta lumber; copings; fence posts.

Hygienic.-Urinals, closet bowls, sinks, washtubs, bath tubs, pitchers, sewer pipe, ventilating flues, foundation blocks, vitrified bricks.

Decorative.-Ornamental pottery, terra cotta, majolica, garden furniture, tombstones.

Minor uses.-Food adulterant; paint fillers; paper filling; electric insulators; pumps; fulling cloth; scouring soap; packing for horses' feet; chemical apparatus; condensing worms; ink bottles; ultramarine manufacture; emery wheels; playing marbles; battery cups; pins, stilts and spurs for potter's use; shuttle eyes and thread guides; smoking pipes; umbrella stands; pedestals; filter tubes; caster wheels; pump wheels.

Refractory wares.-Crucibles and other assaying apparatus; gas retorts; fire bricks; glass pots; blocks for tank furnaces; saggers; stove and furnace bricks; blocks for fire boxes; tuyeres; cupola bricks.

Engineering works. - Puddle; Portland cement; railroad ballast; water conduits; turbine wheels.

\section{CLAYS EMPLOYED.}

Very few of the above materials are made from one grade of clay alone; in fact, probably 90 per cent of the articles mentioned in the above list are molded of a mixture of at least three clays, and many clays are used for several purposes.

The aim of the manufacturer in each case is to get a mixture of the proper plasticity, color-burning qualities, shrinkage, and refractoriness. This is a subject to which much consideration is given in the manufacture of the medium and higher grades of ware, for neglect of these points may cause much loss in burning.

The class of clays employed in the more important kinds of wares mentioned above is as followis:

\section{CHINA CLAYS. $a$}

Porcelain, white earthenware, and granite ware are made of a mixture of kaolin, ball clay, feldspar, and quartz, all rendered very fine grained by preliminary washing or grinding.

The clays used must be of the best quality, burning to a white color at the fusing point of cone 8 (about $2,350^{\circ} \mathrm{F}$.). This necessitates the selection of a clay of very low ferric-oxide content, preferably under 1 per cent. Good plasticity is also desired, and is supplied by the ball clay. The kaolins and ball clays employed are partly of domestic production and partly imported. The imported ball clays come from England, and vitrify at a much lower temperature. ${ }^{b}$

a For distribution see Pl. IX, p. 284.

$b$ For analyses and tests of kaolins and ball clays see Alabama, North Carolina, Florida, Pennsylvania, Delaware, and Tennessee. Also Ries, H., The pottery industry of the United States: Seventeenth Ann. Rept. U. S. Geol. Survey, Pt. III (continued), p. 842. 
The following physical tests will give some idea of the character of the materials used:

KAOLIN.

Harris Clay Company, Webster, N. C.-Works up with 42 per cent of water to a lean mass. Air shrinkage, 6 per cent; fire shrinkage, 4 per cent, making a total of 10 per cent. Average tensile strength, 20 pounds per square inch, with a maximum of 22 . Incipient fusion, $2,300^{\circ} \mathrm{F}$; ; vitrification at $2,500^{\circ}$; viscosity above 2,700 . Burns white. $^{a}$

Arnold land, Thayer, Davidson County, N. C.-Works up with 23 per cent water to a lean mass, whose air shrinkage is 3.2 per cent and fire shrinkage 3.3 per cent, giving a total of 6.5 per cent. Average tensile strength per square inch, 13 pounds; maximum, 14 pounds. Incipient fusion at $2,300^{\circ} \mathrm{F}$; ; complete fusion at $2,600^{\circ}$; viscosity at $2,700^{\circ}$. Total per cent of fluxes, $2.36 .^{a}$

Glen Allen, Mo.-Requires 23.2 per cent water to work it up to a lean paste, whose air shrinkage is 4 per cent and fire shrinkage 8.4 per cent, making a total shrinkage of 12.4 per cent. Average tensile strength per square inch, 12 pounds; maximum, 14 pounds. Incipient fusion at $2,200^{\circ} \mathrm{F}$; vitrification at $2,500^{\circ}$; viscosity not given.

\section{BALL CLAYS.}

Regina, Jefferson County, Mo.-With 22.7 per cent of water it worked up to a very plastic mass, whose air shrinkage was 7.7 per cent and fire shrinkage 12.2 per cent, giving a total of 19.9 per cent. Average tensile strength per square inch, 99 pounds; maximum, 108 pounds. Incipient fusion at $1,800^{\circ} \mathrm{F}$; vitrification at $2,100^{\circ}$, and viscosity at $2,400^{\circ}$. Total fluxes, 5.15 per cent. ${ }^{b}$

Edgar, Fla.-Very plastic and has an average tensile strength of about 65 pounds per square inch. Incipient fusion at $1,800^{\circ} \mathrm{F}$; ; vitrification at $2,100^{\circ}$, and viscosity at $2,400^{\circ}$. Total fluxes, 5.15 per cent. ${ }^{\circ}$

South Amboy district, New Jersey.-When burned at cones $\varepsilon$ and 9 is of a yellowish-white color, and shows a total shrinkage of 14 per cent. This is rather plastic, but has a low tensile strength.

$a$ Bull. North Carolina Geol. Survey No. 13, p. 59

$b$ Missouri Geol. Survey, Yol. XI, p. 578.

c Langenbeck, Chemistry of Pottery, p. 101. 
The following table gives the composition of several American ball clays and kaolins, as well as of the English clay, the latter being added for purposes of comparison:

Analyses of ball clays.

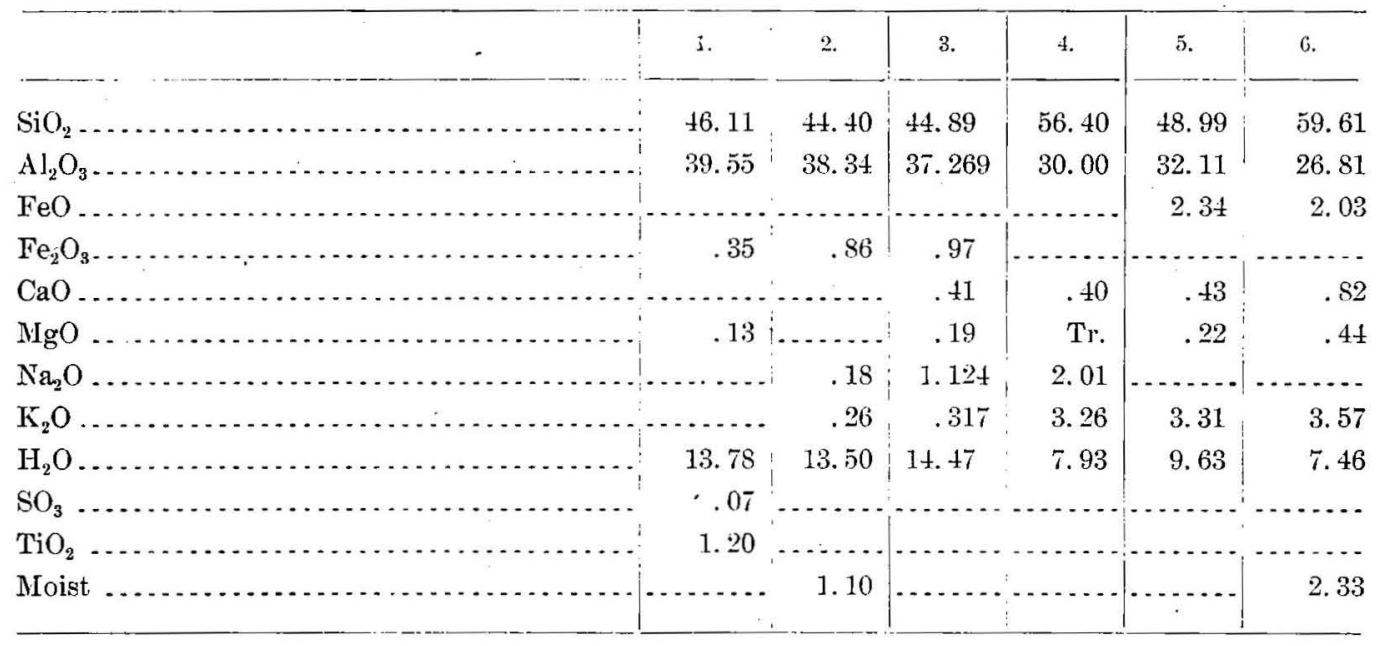

1, Edgar, Fla.; 2, Burts Creek, N. J.; 3, South Amboy, X.J.; 4, Mayfield, Ky.; 5 and 6, "Poole" clay from Wareham, kngland.

Analyses of mashed koolins.

\begin{tabular}{|c|c|c|c|c|c|c|c|c|}
\hline & 1. & 2. & 3. & 4. & 5. & 6. & 7. & 8. \\
\hline $\mathrm{SiO}_{2} \ldots$ & 46.278 & 45.70 & 46.50 & 50.96 & 48.26 & 47.71 & 46.87 & 59.42 \\
\hline $\mathrm{Al}_{2} \mathrm{O}_{3} \ldots \ldots$ & 36.25 & 40.61 & 37.40 & 33.30 & 37.64 & 36.78 & 38.00 & 27.15 \\
\hline $\mathrm{Fe}_{2} \mathrm{O}_{3} \ldots \ldots \ldots \ldots$ & 1. 644 & 1.39 & .80 & .82 & .46 & & .89 & 1. $\pi$ \\
\hline $\mathrm{CaO} \ldots$. & .192 & .45 & Tr. & $\cdots$ & .06 & & Tr. & \\
\hline $\mathrm{MgO} \ldots .$. & .321 & .09 & $\cdots$ & 2.42 & Tr. & & .35 & .52 \\
\hline Alkalies.. & 2.536 & 2.82 & 1.1 & $\cdots$ & 1.56 & 2.58 & 1.22 & $" 1.50$ \\
\hline $\mathrm{H}_{2} \mathrm{O}$ & 13.535 & 8. 98 & 12. 49 & 8.95 & 12.02 & 13.03 & 12.70 & 9.85 \\
\hline
\end{tabular}

1. Brandywine Summit, Pa.

2. Harris Clay Company, near Webster, N. C. 6. Coussac-Bonneval, Franes.

3. West Comwall, Conn.
5. Cornwall, England.
8. Pilsen, Bohemia.

4. Glen Loch, Pa.

FIRE CLAYS.

Fire bricks, crucibles, and similar wares are made from clays whose main requisite is refractoriness, although plasticity is also needed. Consequently mixtures of several different clays must be made for the best results. A clay to be considered 
refractory should not fuse under $3,000^{\circ} \mathrm{F}$. (cone 27). The following analyses show the composition of several standard American fire clays:

Analyses of fire clays.

\begin{tabular}{|c|c|c|c|c|c|c|c|c|c|}
\hline & 1. & 2. & 3. & 4. & 5. & 6. & 7. & 8. & 9. \\
\hline $\mathrm{SiO}_{2}$. & 74.25 & 63.00 & 52.52 & 59.92 & 57.80 & 61.75 & 51.92 & 46.90 & 44.20 \\
\hline $\mathrm{Al}_{2} \mathrm{O}_{3} \ldots$ & 17.25 & 23.57 & 31.84 & 27.56 & 25.54 & 23.66 & 31.64 & 35.90 & 38.66 \\
\hline $\mathrm{FeO}$. & . & .46 & & & $\cdots$ & 1.93 & 1.134 & & $\cdots$ \\
\hline $\mathrm{Fe}_{2} \mathrm{O}_{3}$ & 1.19 & 1.87 & .67 & 1.03 & 2.51 & $\cdots$ & $\cdots \cdots$ & 1.10 & .74 \\
\hline $\mathrm{CaO}$. & .40 & .44 & .50 & Tr. & .25 & .455 & .03 & & ...... \\
\hline $\mathrm{MgO}$ & Tr. & .89 & .19 & Tr. & .61 & .353 & .443 & & $\cdots$ \\
\hline Alkali & .52 & 2.69 & .59 & .67 & 2.69 & 2.418 & .402 & .44 & .46 \\
\hline $\mathrm{TiO}_{2}, \ldots \ldots$ & (....... & 1.10 & 1. 68 & . & …. & 1. 78 & 1.16 & 1.30 & 1. 20 \\
\hline $\mathrm{H}_{2} \mathrm{O} \ldots$ & 6.30 & 6.45 & $11.68^{\circ}$ & 9.70 & 8.35 & 7.20 & 13.49 & 12.80 & 13.55 \\
\hline
\end{tabular}

1. Bibbville, Ala.

2. Mecca, Parke County, Ind.

3. Mineral Point, Ohio (flint clay).

4. Salineville, Ohio (flint clay).

5. East Palestine, Ohio.
6. New Brighton, Pa.

7. Salina, $\mathrm{Pa}$.

8. Woodbridge, N. J.

9. Sayreville, N. J.

There are several special grades of fire clay whose value depends on other properties than refractoriness. These are glass-pot and zinc-retort clays.

\section{GLASS-POT CLAYS.}

The manufacture of glass pots calls for a clay which is not only refractory, but burns dense at a moderately low temperature, so that it will resist the fluxing action of the molten glass. It must possess good bonding power and burn without warping. Great care is necessary in the selection of the clay and the manufacture of the pot. ${ }^{a}$

Most of the glass-pot clay used in the United States is imported from Germany, but in recent years much clay from Missouri, and a smaller quantity from Pennsylvania, have been used to mix with the imported material. In the following table is the analysis of a Pennsylvania glass-pot clay:

a For discussion of manufacture see Orton, E., jr., Report on the clays of Ohio: Ohio Geol. Survey, Vol. VII, part 1; Ries, H., The clays of New York: Bull. New York State Museum No. 35, p. 786. 
Analysis of glass-pot clays from Layton station, $P a$.

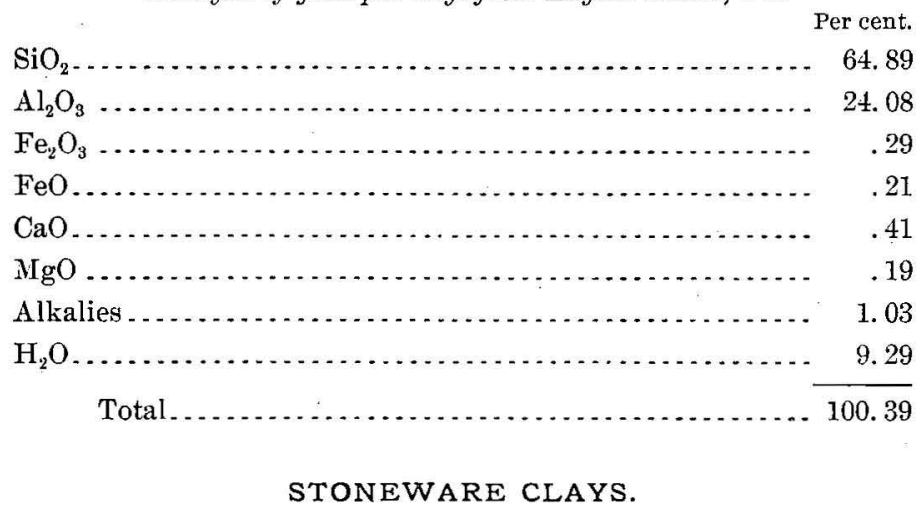

Stoneware is commonly made of a semirefractory clay, which burns dense and holds its form well in burning. The clays may often show high plasticity and tensile strength (often 150 to 200 pounds per square inch), and not uncommonly burn buff. This is the type employed in chemical and sanitary apparatus. The physical characters of several stoneware clays are here given:

Waltemer's, Barton County, MLo.-With 19.2 per cent of water this works up to a rather lean mass, whose air shrinkage is 5.5 per cent and fire shrinkage 6.1 per cent, giving a total of 11.6 per cent. Average tensile strength per square inch 87 pounds, maximum 98 pounds. Incipient fusion at $2,000^{\circ} \mathrm{F}$, vitrification at $2,200^{\circ},{ }^{a}$ viscosity at $2,400^{\circ}$. Total fluxes, 2.42 per cent.

Calhoun, Henry County, Mo. - A very plastic, buff-burning clay requiring 16.5 per cent of water to temper it. Air shrinkage 5.5 per cent, fire shrinkage 2.2 per cent, total 7.7 per cent. Average tensile strength per square inch 150 pounds, maximum 168 pounds. Incipient fusion at $2,100^{\circ} \mathrm{F}$, vitrification at $2,300^{\circ}$, viscosity at $2,500^{\circ}$. Total fluxes present, 5.04 per cent. $^{b}$

Sammis's pits, Little Nech, near' Northport, Long Island, N. Y.-A yellow, sandy clay requiring 25 per cent of water to work it up, and having fair plasticity. Average tensile strength per square inch 25 pounds, maximum 30 pounds. Air shrinkage 5.5 per cent, fire shrinkage 6.5 per cent, giving a total of 12 per cent. At $2,300^{\circ} \mathrm{F}$. nearly vitrified, and becoming viscous at cone 27 . Burns buff.c

Fernbank, Lamar County, Ala.-A very plastic clay which works up with 32.6 per cent of water. Air shrinkage 10 per cent, fire shrinkage 7 per cent, giving a total shrinkage of 17 per cent. Average tensile strength 152 pounds per square inch, maximum 185 pounds. Incipient fusion : at $1,900^{\circ} \mathrm{F}$., vitrification at $2,100^{\circ}$, viscosity at $2,300^{\circ}$. Clay burns red and has 6.65 per cent total fluxes. ${ }^{a}$

a Missouri Geol. Survey, Vol. XI, p. 575. 0 Ibid., p. 577. c Bull. New York State MIuseum No. 35, p. $\$ 21$. a Bull. Alubama Gcol. Survey No. 6, p. 174. 


\section{CLAYS FOR VITRIFIED WARES OF LOW GRADE.}

Sewer pipe, paving brick, and other vitrified wares of nonrefractory character are made from clays or shales of fine grain, ferruginous composition, and preferably good plasticity and tensile strength. They vitrify usually at a low temperature, cone 2 to 4 , have a low fire shrinkage, and burn to a dense red body. In Ohio a mixture of low-grade fire clay and shale is sometimes preferred. The following analyses give the average composition of a number of carefully selected clays used for paving brick:

Analyses of clays used for making paring bricks. t

\begin{tabular}{|c|c|c|c|}
\hline . & Minimum. & Maximum. & Average. \\
\hline Silica $\ldots \ldots \ldots \ldots \ldots \ldots \ldots$ & 49.00 & .75 .00 & 56.00 \\
\hline Alumina $\ldots \ldots \ldots \ldots$ & 11.00 & 25.00 & 22.50 \\
\hline Ferric oxide ....... & 2.00 & 9:00 & 6.70 \\
\hline Lime....... & $.20^{\circ}$ & 3.50 & 1. 20 \\
\hline Magnesia . . . . . . . . . . . . . . . & .10 & 3.00 & 1. 40 \\
\hline 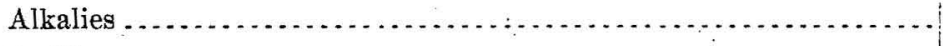 & 1.00 & 5.50 & 3.70 \\
\hline Ignition $\ldots \ldots \ldots \ldots \ldots \ldots$ & 3.00 & 13.00 & 7.00 \\
\hline
\end{tabular}

a Wheeler, Vitrified Paving Brick.

The analyses show that the iron oxide, lime, magnesia, and alkalies are usually rather high.

The following tests of clays and shales obtained from different localities will illustrate fairly well the physical character of the raw materials used in the manufacture of paving brick.

Carboniferous shate from the pit of the Saginaw Clay Manufacturing Company, 1 mile north of Flushing, Mich.-The lower shale layer, or so-called fire clay, requiring 20 per cent of water to work up into a moderately plastic mass with an air shrinkage of 5 per cent. Tensile strength of air-dried briquettes from 60 to 65 pounds per square inch. Incipient fusion at cone 1, with total shrinkage of 10 per cent; at cone 5 , shrinkage 11 per cent; vitrification at cone 7; viscosity at cone $11 .{ }^{a}$

Upper shale from the same bank, hard, and sandy in character.-With 20 per cent of water worked up into a lean mass having an air shrinkage of 3 per cent; total shrinkage up to cone 05,5 per cent, with incipient fusion occurring at cone 1 . At this latter point the color was red and the total shrinkage was 7 per cent. Vitrification at cone 6 ; total shrinkage 9 per cent; viscosity at cone 8 . Tensile strength from 35 to 40 pounds per square inch. A mixture of the two shales is used. ${ }^{a}$

Carboniferous shale from Galesburg, Ill.-This requires 28 per cent of water to work up. Air shrinkage, 4 per cent; total shrinkage at cone 03,10 per cent; vitrifi- 
cation at cone 2, and viscosity at cone 5 . Tensile strength, 60 to 70 pounds per square inch."

Pleistocene clay from Three Rivers, New York.-Requires 28 per cent of water to work it up into a very plastic mass. Air shrinkage, 5 per cent. Incipient fusion at cone 05 , with total shrinkage of 7 per cent; vitrification at cone 1, with 11 per cent total shrinkage. Viscosity at cone 3. Tensile strength of briquettes, 60 to 70 pounds per square inch. These figures are probably low. ${ }^{b}$

Paving-brick shale, Coaldale, Ala.-A yellowish-red shale with considerable grit. Mixes up to a lean mass with 22 per cent of water and 4 per cent air shrinkage. Total shrinkage up to vitrification, 9.5 per cent. Tensile strength, 25 to 35 pounds. Incipient fusion, $1,900^{\circ} \mathrm{F}$., and viscosity at $2,150^{\circ} \mathrm{F} \cdot{ }^{\circ}$

\section{TERRA-COTTA CLAYS.}

Terra cotta is made from a great number of different clays, but most manufacturers of this material are now using fire clays, for these give the best results at the temperatures (cone 6-8) attained in their kilns. The color of the body of the burned mixture is usually buff, the exterior or surface color being due to an application of slip to the outside of the ware. A few terra-cotta maker's use low-grade red-burning clays or shales. Since the clays that are used in the manufacture of terra cotta are often employed for the manufacture of other grades of clay products, it is not possible to give a table of analyses of what might be strictly called terra-cotta clays, and therefore only four are given in order to show what a wide range of materials is

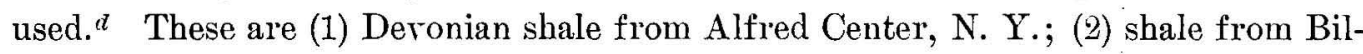
lings, Mo.; (3) Pleistocene clay from Glens Falls, N. Y.; and (4) Cretaceous clay from Woodbridge, N. J.

Analyses of clay used for the manufacture of terra cotta.

\begin{tabular}{|c|c|c|c|c|}
\hline & 1. & 2. & 3. & - 4. \\
\hline 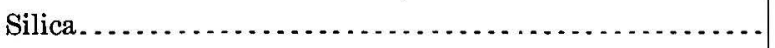 & 53.20 & 63.11 & 48.35 & 44. 20 \\
\hline 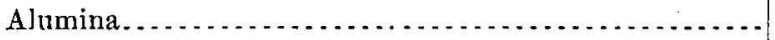 & 23.25 & 23.11 & 11.38 & 38.66 \\
\hline 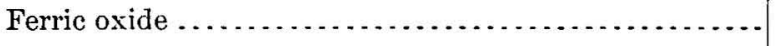 & 10.99 & 1. 79 & 4.02 & .74 \\
\hline Lime $\ldots . . . \ldots \ldots \ldots \ldots \ldots$ & 1.01 & .42 & 15.38 & $\ldots$. \\
\hline 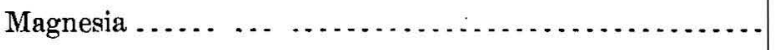 & .62 & .70 & 3.17 & - ..... \\
\hline Alkalies ... . . . . . . . . . . . . . . . . & 2.69 & 3.71 & 6.05 & .46 \\
\hline 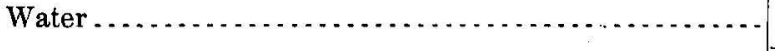 & 6.39 & 7.05 & (2.......... & 13.55 \\
\hline Total ............ & 98.15 & 99.89 & $\cdots$ & 97.61 \\
\hline
\end{tabular}

Clay for terra cotta should burn to a hard body at a moderately high temperature, say $2,300^{\circ} \mathrm{F}$., producing a nearly impervious product. While it is desirable to

a Bull. New York State Museum No. 35, p. 744 $b$ Ibid., p. $75 \pi$ c Bull. Alabana Geol. Survey No. 6, p. 187. a Mineral Industry, Vol. IX. 
have a vitrifiable clay, the burning of the body is seldom carried to this point for the reason that it is accompanied by too much risk of cracking by overshrinkage. Accordingly, it is customary to use a semirefractory clay which is burned to a hard body, but not an impervious one. ${ }^{a}$

\section{BRICK CLAYS.}

PRESSED BRICK.

Pressed or ornamental brick are often molded from refractory or semirefractory clays because the buff product thus obtained is very popular, and, furthermore, the buff color makes a good base with which artificial coloring material may be mixed for the production of many other shades. Red clays are still used to some extent, but the demand for them is not nearly as great as formerly.

Whatever the class of clay used for pressed brick, uniformity of shade and freedom from discoloration are essential features of the burned product. The discoloration is due to improper mixing or the presence of soluble compounds in the clay, which form a scum on the surface. ${ }^{b}$

The physical properties of the clay are of much importance. High refractoriness is not essential, but since straightness of outline is called for, clays of low shrinkage are preferred. Excessively plastic material is undesirable where the stiff mud process is employed, but for dry press brick the plastic qualities of the clay do not play so important a rôle.

Clays of streaky character are often avoided unless they mix readily in the machine. Many Coastal Plain clays contain layers of tough whitish-burning clay mixed with ferruginous sandy layers. Imperfect mixing of such a clay shows itself in the brick by the presence of white spots scattered through it.

In the following table are given analyses of pressed-brick clays, showing the range of materials now used:

Analyses of clays used for making pressed brick.

\begin{tabular}{|c|c|c|c|}
\hline & $\begin{array}{l}\text { Shale-Kan- } \\
\text { sas City, Mo. }\end{array}$ & $\begin{array}{l}\text { White clay- } \\
\text { Grover, N. C. }\end{array}$ & $\begin{array}{l}\text { Front brick } \\
\text { clay-Sayre- } \\
\text { ville, N.J. }\end{array}$ \\
\hline 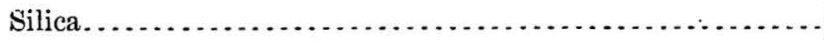 & 55.75 & 68.28 & 56.10 \\
\hline 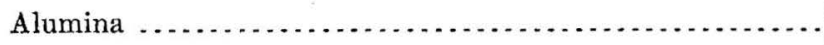 & 21.16 & 18.83 & 27.42 \\
\hline 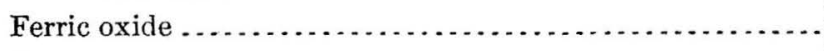 & 5.69 & 2.60 & 2.68 \\
\hline Lime $\ldots \ldots \ldots \ldots \ldots \ldots \ldots \ldots \ldots \ldots \ldots \ldots \ldots$ & 3.25 & .70 & (........... \\
\hline 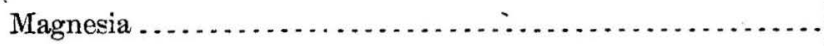 & 2.84 & .13 & .18 \\
\hline Alkalies & 3.02 & 2.29 & 2.71 \\
\hline 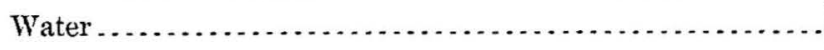 & 8.45 & 6.47 & 6 \\
\hline Moisture.................... & - $\ldots .$. & .76 & 2.90 \\
\hline Titanic acid $\ldots \ldots \ldots$ & ..... & .27 & 1 \\
\hline
\end{tabular}

a For manufacture of terra cotta see Bull. New York State Museum No. 35, p. 761. $\checkmark$ Bull. New York State Museum No. 35, p. 681. 
COMMON BRICK.

These are made from almost any kind of clay, ranging from the calcareous, pebbly clays found in the regions around the Great Lakes to the impure, ferruginous, residual clays found all over the South. Little care is taken, as a rule, in the manufacture of common brick, although when the clay at hand is too plastic or fat it is customary to lessen its pastiness by the addition of sand. The addition of too great a quantity, however, will make the brick porous and weak.

A clay to be used for the manufacture of common brick should burn red if possible, since there is then more possibility of its burning dense at a comparatively low temperature and thus avoiding the use of too much fuel. Most brick clays are burned to about cone 0.05 , and at this temperature the clay commonly shows incipient fusion. Good brick clays should burn hard at a temperature of not over $2,000^{\circ} \mathrm{F}$, namely, at cone 1, or preferably lower. This means the presence of sufficient fluxing material to bind the clay grains together into a hard body when burned. Large sand grains and pebbles are undesirable, for they tend to make the product porous and weak. The best results are commonly obtained with clays carrying from 5 to 7 per cent of ferric oxide. The residual limestone clays are often ferruginous, and those derired from gabbros or other dark-colored igneous rocks of the crystalline area are often highly so-too much so, in fact, for the production of really good brick.

The following figures give the maximum, minimum, and average percentage of the different constituents in brick clays, the figures being deduced from a number of analyses from different parts of the country: "

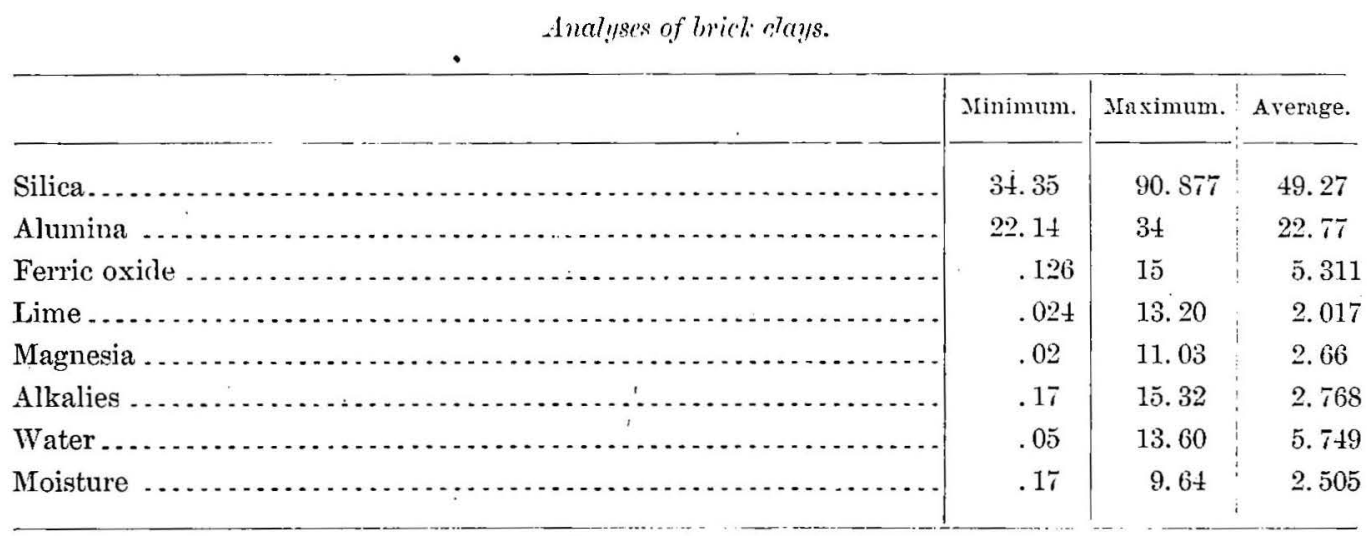

The following tests indicate the physical character of brick clays:

Pleistocene brick clay from the Hudson Valley at Roseton, N. I.-Air shrinkage, 5 per cent; incipient fusion at cone 0.05 ; vitrification at cone 0.04 , with a total shrinkage of 14 per cent; viscosity at cone 0.01 . Tensile strength, 75 to 93 pounds per square inch. ${ }^{b}$ 
Pleistocene clay from Canandaigua, N. Y., upper layer in bank.-Requires 22 per cent of water to work it up to a plastic mass; air shrinkage, 8 per cent; incipient fusion at cone 0.05 , with a total shrinkage of 15 per cent; vitrification at cone 0.03 , with total shrinkage of 16 per cent; viscosity at cone 8 . Burns red. ${ }^{a}$

Lower or buff-burning clay from same locality. -18.5 per cent water required to temper it. Air shrinkage, 6 per cent; vitrification at cone 1 , with 14 per cent shrinkage; viscosity at cone 2. Tensile strength 95 to 110 pounds per square inch.

Brick clay of glacial age, Southold, Suffolk County, N. Y.-A very plastic clay requiring 40 per cent of water. Air shrinkage, 8 per cent. Vitrification at cone 1 , with total shrinkage of 16 per cent. Viscosity at cone $4 .{ }^{b}$ Clay burns deep red. Tensile strength 133 to 140 pounds per square inch.

Brick clay from Clippert Brothers' yard, Detroit, Mich.-A calcareous clay. Twenty-four per cent of water required to work it up, the briquettes having an air shrinkage of 4 per cent. At cone 0.05 total shrinkage 6 per cent, clay burns red; at cone 0.01 incipient fusion occurs with a total shrinkage of 14 per cent, the bricklet being buff; vitrification occurs at cone 2 , and the clay becomes viscous at cone 4 . Its tensile strength is 150-190 pounds per square inch. ${ }^{c}$

Lover clay from the same locality.-A very plastic blue clay requiring 26 per cent of water. Incipient fusion occurs at cone 0.05 , with a total shrinkage of 9 per cent; vitrification at cone 1 , with a total shrinkage of 15 per cent; viscosity at cone 5. Tensile strength, 175 to 190 pounds per square inch. It is found difficult to work this clay alone.

Residual brick clay near Greensboro, N. C.-Twenty-eight per cent of water required to work it up. Air shrinkage, 9 per cent. Total shrinkage up to vitrification, 15 per cent. Average tensile strength, 85 pounds per square inch. Incipient fusion at $2,050^{\circ} \mathrm{F}$., vitrification at $2,250^{\circ}$, viscosity at $2,450^{\circ}$. Clay burns red. ${ }^{d}$

An alluvial brick clay from Kirkpatrick's yard, Greensboro, N. C.-Thirty per cent of water works it up into a very plastic mass. Air shrinkage, 11 per cent., Total shrinkage up to vitrification, 16 per cent. Average tensile strength, 220 pounds per square inch; maximum, 232 pounds. Incipient fusion at $1,900^{\circ} \mathrm{F}$, vitrification at $2,100^{\circ}$, and viscosity at $2,300^{\circ}$. It burns to a dense red body, but requires slow heating to prevent cracking. ${ }^{e}$

Brick clay, Jefferson City, Mo.-A lean clay, requiring 17.2 per cent of water to temper it. Air shrinkage, 5.7 per cent. Shrinkage in burning, 4.3 per cent. Incipient fusion $2,000^{\circ} \mathrm{F}$., vitritication at $2,000^{\circ}$, and viscosity at $2,300^{\circ}$. Average tensile strength, 151 pounds per square inch. $f$

Brick clay, Kansas City, Mo.-18.4 per cent of water required, giving a lean mass. Air shrinkage, 5.1 per cent. Total shrinkage in burning, 10.8 per cent.

$\alpha$ Bull. New York State Museum No. 35, p. 719 b Ibid., p. 737 .

c. Michigan Geol. Survey, Vol. VIII, Pt. I, p 50. d Bull. North Carolina Geol. Survey No. 13, p. 114.

Ibid., p. 115.

$f$ Missouri Geol. Survey, Vol. XI, p. 486. 
Incipient fusion at $2,000^{\circ} \mathrm{F}$., vitrification at $2,200^{\circ}$, and viscosity at $2,200^{\circ}$. Average tensile strength, 151 pounds per square inch. This is a loessoid clay. ${ }^{a}$

Brick clay (loess) from Denver, Colo.-A lean clay, taking 14.5 per cent of water to work it up. Air shrinkage, 6 per cent; total shrinkage in burning, 9 per cent; air-dried briquettes average tensile strength of 55 pounds per square inch. Incipient fusion at $2,000^{\circ} \mathrm{F}$, vitrification at $2,100^{\circ}$, viscosity at $2,200^{\circ}$. Clay burns red. ${ }^{b}$

EARTHENWARE CLAYS.

Many of the smoother surface clays employed in making common brick are also found satisfactory for the manufacture of earthenware. The materials needed are such as will form a mass of good plasticity with water, will turn readily on the potter's wheel, and will burn to a porous body without excessive shrinkage.

The clays used are commonly the less gritty sedimentary clays, for the low price of the ware seldom permits the expense of washing.

PAPER CLAYS.

These form a type of clay much used by paper manufacturer's and having special qualities. Since the clays are not to be molded or burned, plasticity and behavior under fire are of no importance. The great essentials are whiteness of color and freedom from grit. The former property must be originally possessed by the clay. The percentage of grit, however, can often be lowered if the color is good.

The best grades of paper clay are imported washed kaolins, but large quantities of good paper clay are also obtained from the Potomac formation of South Carolina and Georgia, the Algonkian kaolins of Maryland and Delaware, and the white residual clays of the Cambro-Silurian formations of southeastern Pennsylvania.

GEOLOGIC DISTRIBUTION OF CLAYS EAST OF THE MISSISSIPPI.

CLAYS DERIVED FROM CRYSTALLINE ROCKS.

KAOLINS.

These include the highest grades of clay found in this country, being those which are used in the manufacture of porcelain, white earthenware, and other objects requiring a white-burning material. They are usually formed from the weathering of pegmatite veins, granites, or feldspathic gneisses, which are free from ferruginous minerals and consequently are to be sought for chiefly in those regions of metamorphic or igneous rocks in which the products of rock decay still remain. In rarer instances talcose schists seem to have been the parent rock, as in the case of those white

a Missouri Geol. Survey, Vol. XI, p. 486.

$b$ Eighteenth Ann. Rept. U. S. Geol. Survey, Pt. V (continued), p. 1131. 
residual clays found in the great valley region of southeastern Pennsylvania. This would mean their possible occurrence in those areas of New England and the Appalachian region where igneous and metamorphic rocks of the types above mentioned are to be found, and also in similar areas in Wisconsin and Michigan. They will rarely be found in those portions of these areas lying north of the terminal moraine of the continental ice sheet, as the latter in its advaince across the country scraped up most of the residual clay that had formed up to that time. Since gneissic or granitic rocks are rarely free from iron-bearing minerals, such as biotite, hornblende, garnet, etc., over large areas, the feldspar veins must be looked to for most of our supply of kaolin.

Up to the present time true kaolins are known to occur in Alabama, Delaware, Connecticut, Maryland, Massachusetts, North Carolina, Pennsylvania, and Virginia. (See Pl. IX.)

Alabama.-Kaolins occur in the eastern part of the State, in the counties of Randolph and Cleburne (see detailed account of Alabama clays, p. 68). They are rather siliceous, yet are of excellent quality, but most of them lie too far from the railroad for present utilization, and are therefore still undeveloped.

In Alabama Cambrian kaolins also are said to occur, especially in Etowah, Talladega, Calhoun, and Blount counties.

Curiously enough, these masses of white clay may often be found in close association with or even surrounded by a very ferruginous clay that carries limonite. Many of the present white-clay pits are in abandoned limonite mines.

Connecticut.-Deposits of kaolin are not usually looked for north of the terminal moraine, for the reasons already given. One deposit is known to exist near West Cornwall, and a second one is found north of New Canaan, but the latter probably lies within the State of Massachusetts. Both of these have been derived from the decay of metamorphic rocks free from iron, but the former only has been found to burn white enough for making white earthenware.

Delaware.-Kaolin pits have been worked for a number of years at Hockessin and Newark. They are formed from pegmatite veins. (See Pl. II, $A$ and $B$.)

Georgia.-No mention is made in any publications of the occurrence of true kaolin in the crystalline area of this State, although the writer has seen specimens from Georgia that were undoubtedly white clay of residual character. It is very likely that veins of this material. will be found by prospecting in the proper regions. The Knox dolomite yiekds white residual clay, but does not burn pure white.

Indiana.-Indianaite is a white clay, found in pockets of Carboniferous limestone in Lawrence, Martin, and Owen counties, Ind.

Maryland.--The feldspathic gneisses underlying the Coastal Plain formations in Cecil County seem to have been extensively decomposed, and at Northeast the kaolin 


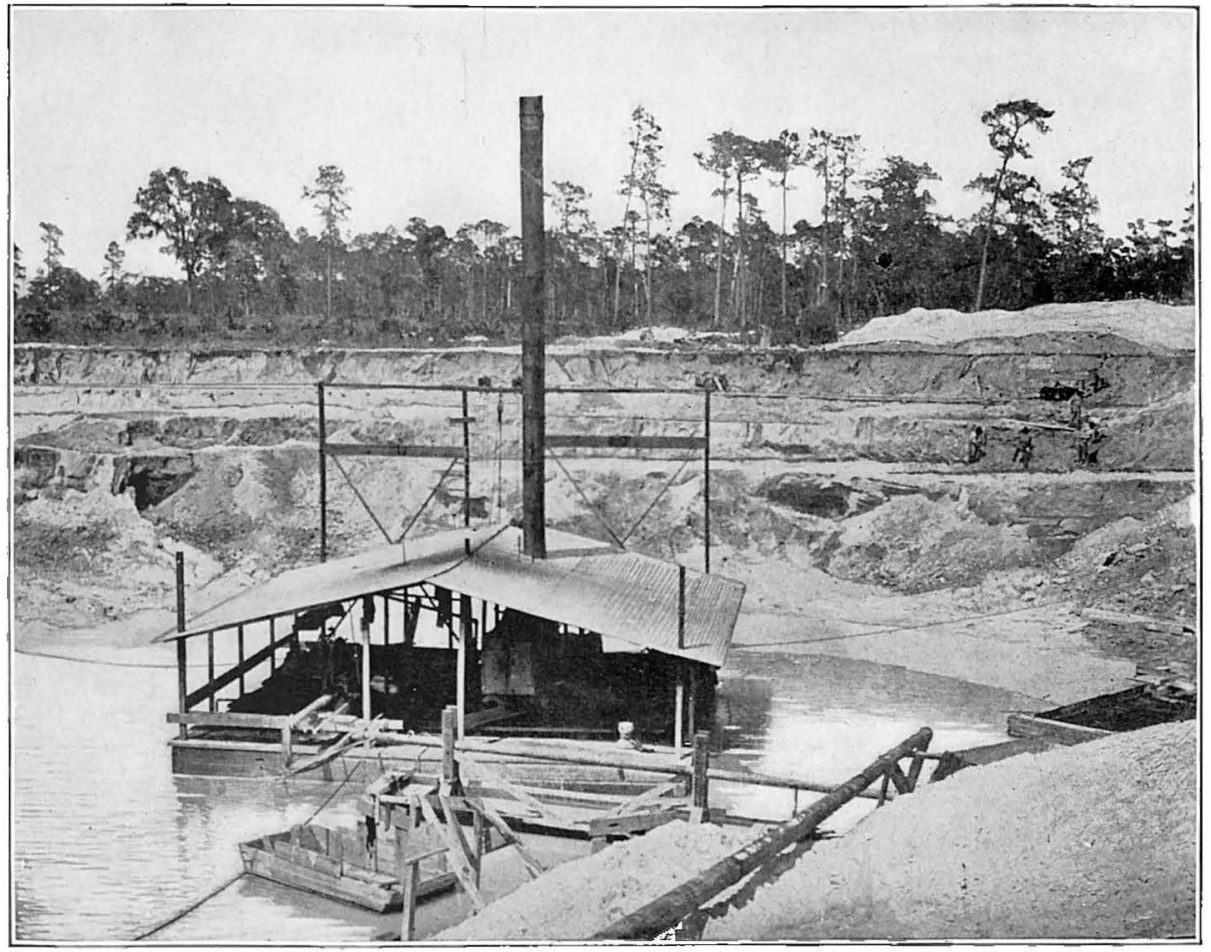

A. BALL-CLAY PIT AT EDGAR, FLA.

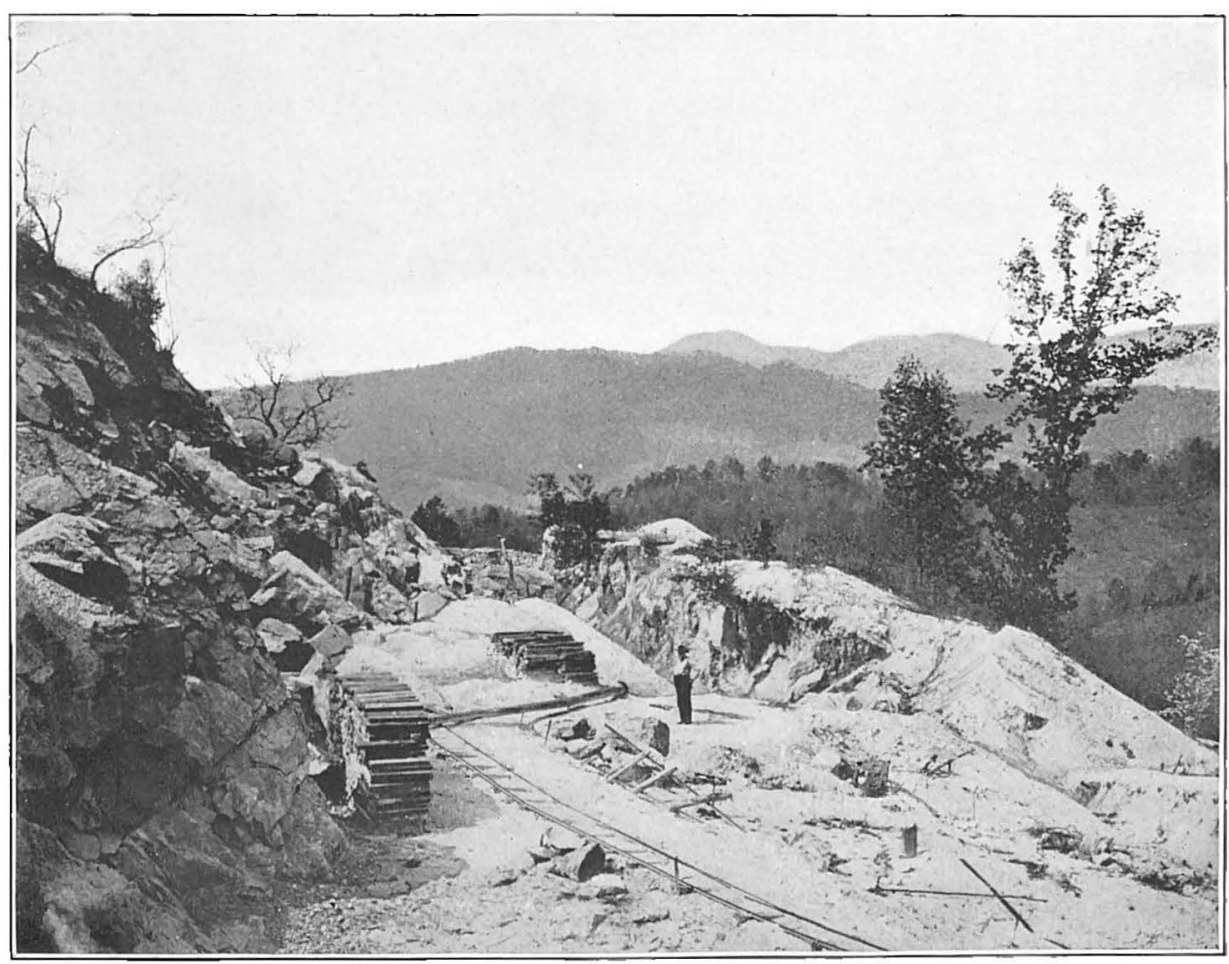

B. KAOLIN MINE NEAR DILLSBORO, N. C. 

is mined and washed for the market. The deposits have also been prospected in the surrounding area. The Maryland kaolins have been used chiefly in the manufacture of paper.

Massachusetts. - A deposit is found near Blandford. It was formed from pegmatite veins occurring in the schist of that region. It is used in the manufacture of white brick, but has not been made into higher grades of ware.

North Carolina. - This State contains some of the most important deposits of kaolin worked in the United States. They are mostly confined to the western counties of the State and were formed from pegmatite veins. (See Pl. I, B.)

Pennsylvania. ${ }^{a}$-The deposits near Brandy wine Summit contain some of the oldest mines in the country. Others occur at Kaolin and Columbia. The origin of these viens is similar to those of Delaware-indeed.they form part of the same group. In some cases the lower limit of the kaolin has been reached and the mine is now worked for feldspar instead of clay.

In southeastern Pennsylvania the decay of schistose or limestone rocks along the contact of the Cambrian and Silurian has yielded some white residual clays which, after washing, are suitable for white earthenware manufacture (see Pennsylvania). In the Southern States the decay of the Knox dolomite also yields them in some places (see Georgia and Tennessee), and though siliceous they are used for making fire bricks.

Virginia.-Kaolin is found in Henry and Patrick counties, and possibly elsewhere, but the deposits are just being developed. The writer has seen some rery white samples of kaolin which were said to come from a locality about 50 miles west of Richmond.

General.-All of the kaolins mentioned, with the exception of those from Massachusetts, New Canaan (Conn.), Maryland, and Alabama, are being used in the manufacture of white ware. The white-burning sedimentary ball clays found in Florida are sometimes. incorrectly spoken of as kaolin. The term is also incorrectly applied to certain micaceous feldspathic sands found in the Cretaceous formations of New Jersey.

The output of the American mines furnishing kaolins of proper quality is insufficient to supply the demand, and hence a large amount is imported annually from the Cornwall district of England.

\section{IMPURE RESIDUAL CLAYS.}

Many impure residual clays are found along the Appalachian belt, which have been derived from pre-Cambrian rocks. They are usually ferruginous, often gritty,

a Hopkins, T. C., Clays of the Great Valley and South Mountain areas: Ann Rept. Pennsylvania State College, 15991900; Clays of southeastern Pennsylvania (in part): Idem, 1898-99. $9647-$ No. $11-03-4$

\section{LIBRARY TEXAS TECHNOLOGICAL COLLEGE LUBBOCK, TEXAS}


and sometimes highly plastic. They are rarely used for anything better than common brick, but in Maryland are dug, near Dorsey, for fire brick, and at Catonsville for earthenware manufacture.

\section{CAMBRIAN.}

The Cambrian formations carry few shales which can be ground up to a plastic mass, but the residual deposits are of much commercial value.

Impure residucals. ${ }^{a-T h r o u g h o u t ~ t h a t ~ p a r t ~ o f ~ t h e ~ e a s t e r n ~ U n i t e d ~ S t a t e s ~ l y i n g ~}$ south of the terminal moraine where limestones, shales, or schists are exposed, there is an abundance of residual clays, usually of high plasticity and good tensile strength, and that commonly, burn red. In the upland regions of Tennessee, Kentucky, and neighboring States these Cambrian residuals are used for brick and tile, and sometimes for pottery.

In Wisconsin (see p. 262) the Cambrian shales supply residual clays, often of good quality.

LOWER SILURIAN, OR ORDOVICIAN.

The clays derived from the Ordovician or Lower Silurian formations are mostly residual, the shales being only occasionally used.

- Hudson shales.-Though a widespread formation, these shales vary greatly in character from one locality to another. They form a great area in New York, but are sometimes more or less metamorphosed, and hence derelop little or no plasticity on grinding. In other parts of the same State they are too siliceous, and hence have no commercial value. They are worked near Belvidere, and also near Washington, N. J., but south and west of Pennsylvania, although the shales are of common occurrence where the Ordovician is found, they are in most instances too calcareous to be used in their unweathered condition for the manufacture of clay products. The Cincinnati shales of northern Illinois have been used for pottery.

Residual clays. - These are abundantly developed in the Southern States, being derived from both the Hudson shales and the Ordovician limestones. The Trenton limestone yields the clay soils of the Blue Grass region of Kentucky, and is also found in neighboring States. These residual clays are mostly ferruginous, but are often well adapted to making brick and tile, and in some cases even pottery. Although these clays are derived from calcareous formations, the weathering leaches out most of the lime carbonate.

\section{UPPER SILURIAN.}

This system contains more shaly members than the preceding, but fewer than the Devonian, which succeeds it. The shaly members are found in the Medina, Clinton, Niagara, and Salina.

a See Bull. U. S. Geol. Survey No. 52. Also descriptions of clays in Alabama. Georgia, Maryland, Kentucky, and Tennessee, on later pages. 
Medina shale.--This shale is found in considerable quantity in Ohio, New York, and in the middle and southern Appalachian region. It is but little used for the manufacture of clay products, partly because it is often too siliceous, ferruginous, or calcareous, and also because better clay materials are usually obtainable in the areas where it occurs. Its weathered outcrop is employed in Canada for the manufacture of dry-pressed brick. The Medina shales have been worked in Ohio for tile manufacture, but no mention is made of their having been utilized in other localities.

Clinton shale.-This may have value for the clay worker, but no mention is made anywhere of its being used. In Pennsylvania there are considerable belts of it in the east-central part of the State. ${ }^{a}$ Outcrops also occur in western Maryland which give promising results in laboratory tests" (see Maryland, p. 135).

Shale of Niagara group.-This is usually highly calcareous or magnesian, and is not used in its fresh condition. It is common in New York, Pennsylvania, and Ohio.

Shate of Salina group.-This shale is especially well developed in New York State. It is soft, plastic, and molds readily when used for brick manufacture. Calcareous bands and gypsum streaks are not uncommon in it ${ }^{c}$ (see New York, p. 172.)

DEVONIAN.

In the upper part of this system are found several important shale-bearing formations-the Chemung, Portage, and Hamilton. Under the Hamilton is the Narcellus, but this is not utilized, and indeed gives little promise.

The Hamilton is of great thickness in New York and Pennsylvania, but much less important in Ohio. In New York it is worked in the western part of the State, in Erie County, but in the eastern portion it is too siliceous to be used without mixing in the surface clay. It will probably be found suitable at many localities in Pennsylvania where argillaceous beds occur. The Portage and Chemung both carry many shale beds in southern New York, and are there much used by clay workers. ${ }^{d}$ They are likely to b? found useful in Pennsylvania. In Ohio the Hamilton beds are followed by two formations, known as the Obio shale and the Bedford shale. The former, which is either a black or greenish shale, is siliceous, but has been used at Columbus for sewer pipe and common brick. The Bedford shale resembles the preceding somewhat, and has been used for pressed brick at Akron and also near Independence.

In the Southern States the Devonian gives good results at Cumberland, Allegany County, Md., where the formation known as the Jennings shale is employed for the manufacture of vitrified brick. The same formation when followed westward into the adjoining county of Garrett, however, shows little material of plastic character.

a See genlogical map of Pennsylvania, Final summary Report Pennsylvania Geol. survey, 1893. b. Marylund Geol. Survey, Vol. IV, p. 455.

c Bull. New York Strte Mruseum No. 35, p. 829.

a Ibid., pp. 834 and 836 . 
The Devonian shales are known in Tennessee, Kentucky, Georgia, and Alabama, but their extent is not comparable with that seen in the North.

In Michigan the Marshall shale series of the Devonian is well developed around Jordan, and its weathered outcrop yields some tough plastic clays. ${ }^{a}$ The Hamilton shales outcrop around Alpena.

In Indiana the Devonian underlies a great area in the central part of the State, but offers little promise to the clay worker.

\section{CARBONIFEROUS.}

This system contains the most widely distributed and perhaps the most important clay-bearing formations found in the eastern United States, being important in Pennsylvania, Ohio, West Virginia, Kentucky, Indiana, Illinois, and Michigan, and of less importance in Maryland, Virginia, Alabama, and Tennessee.

In the Appalachian area, especially of Pennsylvania, Ohio, West Virginia, Maryland, and Virginia, the Carboniferous section remains fairly uniform, and contains the following niembers, enumerated in order, from above downward:

$$
\text { Carboniferous formations in Appalachian region. }
$$

1. Upper Barren Measures, or Dunkard group.

2. Upper Productive Measures, or Monongahela group.

3. Lower Barren Measures, or Conemaugh group.

4. Lower Productive Measures, or Allegheny group.

5. Pottsville conglomerate, or New River group.

The Upper and Lower Productive Measures contain each several coal beds of well-marked stratigraphic position, which are often underlain by persistent beds of fire clay. The Pottsville conglomerate may also carry fire-clay deposits, while the Upper and Lower Barren Measures contain inexhaustible supplies of shale suitable for common, pressed, and vitrified brick and roofing tile.

Pottsville conglomerate. - This is made up largely of hard sandstones and conglomerates, but carries several beds of fire clay associated with the Mercer coals. The well-known Mount Savage clay, mined in Allegany County, Md., and also in Somerset County, Pa., is from this horizon. In Mercer County, Pa., fire clay underlies the Sharon coal, and in the Hanging Rock district of Scioto County, Ohio, fire clays are found under the Upper and Lower Mercer and Quakertown coals. The clay underlying the latter has furnished an important supply of pottery material. On the whole, however, the conglomerate series is not nearly so important to the clay worker as the higher-lying ones.

Lower Coal Measures.-These contain a number of valuable deposits of fire clay. The thickness of the series is 300 feet in western Pennsylvania, and rarely less than

$a$ Ries, H., The clays and shales of Michigan: Michigan Geol: Survey, Vol. VIIl, Pt. Y, p 45. 
250 feet in any other part of the State. In Ohio it is less than 200 feet, but it thickens southward, so that in the region of the Kanawha River it is 1,000 feet thick. $^{a}$ Beginning at the top, the following members are recognized:

Section of Lower Coal Measures.

1. Upper Freeport coal.

2. Upper Freeport limestone.

3. Lower Freeport coal.

4. Lower Freeport limestone.

5. Freeport sandstone.

6. Johnstown coal.

7. Johnstown cement.

8. Kittanning middle coal.

9. Kittanning lowèr coal.

10. Kittanning sandstone.

11. Buhrstone iron ore.

12. Ferriferous limestone.

13. Clarion coal.

14. Brookville coal.

Of this section fire clays are found under $1,3,6,8,9,12,13$, and 14 .

Wherever the Upper Freeport limestone is absent or thin, a fire clay known as the Bolivar clay comes in. It is a fine nonplastic or flint clay, found especially in Westmoreland, Fayette, and other counties of Pennsylvania. In Ohio it is said to be valuable at only one or two points, in Jefferson and Muskingum counties, while in West Virginia it is valuable only on Deckers Creek, in Preston and Monongalia counties. ${ }^{b}$ It has recently been found in Garrett County, Md. ${ }^{c}$

Another important bed of fire clay is found in many regions under the Lower Kittanning coal. In parts of West Virginia and at several places in Ohio it does not all immediately underlie the coal, but may reach down nearly to the top of the Ferriferons limestone. ${ }^{d}$ East of the Allegheny River it does not appear to be very important, but west of that river it is generally present and attains its maximum development along the Beaver and west of that stream, down the Ohio, the potteries of New Brighton, Rochester, East Liverpool, New Cumberland, and other points in these valleys all deriving their clay from this horizon. Prof. I. C. White makes the following statement concerning this bed : ${ }^{e}$

"In the Beaver County region the thickness is generally about $s$ to 10 feet, but occasionally runs up to 15 and down to 5 . It often consists of two portions-an upper soft clay and-a lower hard clay, the latter being used in the manufacture of fire brick, etc. In western Pennsylvania and eastern Ohio this clay bed is often a very valuable element in settling questions of stratigraphy which would otherwise be extremely difficult of solution; in fact, it is valuable for this purpose clear across $a$ White, I. C., Bull. U. S. Geol. Survey No.65, p. 99.
$b$ Ibid., p. 159-160.

c Maryland Geol. Survey, Vol. IV, p. 503. 
the Ohio coal field, since, according to Orton, although not entirely persistent, yet it furnishes valuable clay mines in every county of its outcrop from the Pennsylvania line across the Kentucky border.

"In West Virginia (except along the Upper Ohio River) the deposit is seldom of value, being too silicious, and it has been developed in only one region, viz, at Nuzums [now Hammond] on the Tygarts Valley River. Here, along the crown of the Chesnut Ridge anticlinal, the coal above disappears locally, and then a valuable bed of hard clay replaces it, just as it often does in Ohio, when the hard flinty clay is present."

A bed of good fire clay often underlies the Clarion coal in both Ohio and Pennsylvania, and may at times rest directly on the Pottsville conglomerate. ${ }^{\prime}$ A good fire clay is also seen under the Brookville coal in some parts of Pennsylvania, especially Jefferson and Clarion counties. It is mined in Clearfield County, at Blue Ball, Wallaceton, and other points along the line of the Tyrone and Clearfield road. ${ }^{b}$ A fire clay is found under the Middle Kittanning coal in Pennsylvania in the counties of Armstrong, Beaver, Allegheny, Blair, and Tioga, and another bed is known under the Upper Kittanning.

In Ohio the Lower Freeport clay has not been developed, although Prof. E. Orton, $\mathrm{jr}$., states that there is a good flint clay at this horizon southeast of Zanesville.

Lower Barren Measures or Conemangh group. - The upper part consists chiefly of shales, while the lower portion shows more massive sandstones. Among the former there are many red and marly shales, which make a broad band of red soil extending from Pennsylvania southward through central West Virginia and beyond the Kentucky line. Their outcrops then circle around through eastern Kentucky and southern Ohio and back to Pennsylvania. The group shows a maximum thickness of 800 feet near Charleston, W.Va., and a minimum of 300 feet along its northwest border in Ohio. It averages about 600 feet in Pennsylvania and northern West Virginia. The many beds of shale, though lacking in fire clays, should form an inexhaustible supply of material for making common, pressed, and paving brick, roofing tile, floor tile, terra cotta, etc. They are utilized in Allegheny County, Pa., and at Clarksburg, Fairmont, Charleston, and Huntington, W. Va. They are not wanting in Ohio, but have not thus far been used.

Upper Coal Measures or Monongahela group.- - This series begins at the base of the Pittsburg coal and extends to the Cassville shales. Its greatest development is along the Monongahela River in southwestern Pennsylvania and West Virginia. It contains six distinct coal seams. At the northern end of the basin interstratified rocks are mostly limsstones, ${ }^{c}$ but toward the south these disappear and red shales take their place. This change shows itself in the more subdued character of the topography. 
Up to the present time the rocks of this series have been little used outside of western Pennsylvania, but they offer, no doubt, an important field for exploitation by the clay worker.

Upper Barren Measures, Permo-Carboniferons or Dunkard group.-Concerning these, I. C. White makes the following statement: ${ }^{a}$

"These deposits occupy a rather limited area in the Appalachian field, being found in only two counties (Greene and Washington) of Pennsylvania, with the exception of small isolated patches in Fayette, Westmoreland, and Allegheny. In Ohio there is a larger area of them bordering the Ohio River through the counties of Belmont, Monroe, Washington, Meigs, and Gallia. But it is in West Virginia that we find the principal belt of these beds, for there they cover a wide region bordering the Ohio River between the Pennsylvania line at the north and the Great Kanawha River on the south.

"The character of the rocks varies greatly in different portions of this area. At the northeastern end of the field, in Washington County, Pa., limestones seem to predominate in thickness over the gray shales, sandstones, and thin coal beds with which they are there interstratified. But southwestward the limestones and coals gradually disappear, so that in Jackson County, W. Va., no regular coal beds are found, and only one limestone (the Nineveh) remains. The limestones continue in considerable number in Greene, Ohio, Marshall, and Monongalia counties and the southern part of Wetzel County, but southward from this line they rapidly disappear, with the single exception noted. The coal beds all die out with the disappearance of the limestone except one (the Washington), which seems to extend beyond the Little Kanawha River before it passes out of the series.

"As the limestones and thin coal beds gradually fade out to the southwest, red shale, a variety of rock almost unknown in Washington County, Pa., gradually comes into the section, in thin beds at first, but finally extends throughout the whole series and forms nearly one-half its thickness, thus making a broad band of red soil from the Pennsylvania line southwestward to the Great Kanawha River."

The series contains little fire clay and the shales have not been used except, perhaps, in Pennsylvania.

The Carboniferous section of the other States included in the area under discussion is not wanting in clays and shales. Alabama contains many Carboniferous shale deposits of commercial value, some of which are now utilized in the manufacture of paving brick. The Carboniferous coals of both Tennessee and Kentucky are often underlain by deposits of fire clay, a few of which have been worked, but there is still great opportunity for much profitable exploitation. Some of the more important clay seams of Ohio are traceable across the border into Kentucky. In Indiana many beds of fire clay, stoneware clay, and shale are found interbedded with the coal beds of the Coal Measures in the southwestern part of the State, and they have been sufficiently developed to demonstrate their value for many different purposes. Illi-

a White, I. C., Bull. U. S. Geol. Survey No. 65, p. 43. 
nois also contains many beds of clay, especially under the lower coal seams found in the Carboniferous section of that State. In addition to these there are also heavy beds of shale which have been extensively used in the manufacture of paving brick and other clay products.

Owing to the absence of folding in the Coal Measures of both Indiana and Illinois and to the fact that the country is flatter than that in the Appalachian States, the seams often have no outcrop, and consequently shaft mining has to be resorted to.

Many beds of shale are found in the Coal Measures and the Lower Carboniferous formations of Michigan, but up to the present time they have been but little developed. The work that has been done shows that the shales are adapted to the manu. facture of paving brick, pressed brick, and sewer pipe, but that fire clays are not likely to be found, for although many shafts have already been sunk in mining the coal of that State, not one bed of refractory clay has been encountered.

Considering the Carboniferous system as a whole, it is seen that it is a most valuable one to the clay worker, as it contains all grades of clay in inexhaustible quantities. These deposits are referred to in much greater detail under the various States.

\section{JURATRIAS, OR NEWARK.}

This formation is composed chiefly of red micaceous sandstones, and has up to the present time been of little value to the clay worker. It is found in the Connecticut Valley in Connecticut and Massachusetts, and in southeastern New York, and it extends in a belt across New Jersey and Pennsylvania and into Maryland. A narrow area of it is found in North Carolina and Virginia. Throughout this region it is composed chiefly of micaceous sandstones, but in places may also carry shale beds. Up to the present time these shale members have not been used by the clay worker, except in one locality in North Carolina. As a rule they are too micaceous or sandy, and develop little plasticity on being ground and mixed with water. Furthermore, on account of their high percentage of iron oxide, they fuse or sinter at a very low temperature. In North Carolina the weathered outcrops of the Triassic shales have been used as an ingredient in sewer-pipe mixtures. It is also possible that the shales associated with the Triassic coals in the Richmond field of Virginia and in the neighboring area of North Carolina may be found suitable for the uses of the clay worker, but up to the present time they remain untouched.

\section{CRETACEOUS.}

The Cretaceous system is an important source of plastic materials throughout the Coastal Plain region of the Atlantic and the Gulf States, since it carries clay deposits throughout its entire length from Marthas Vineyard to Mississippi. As it embraces the oldest of the formations underlying the Coastal Plain and as these dip 
southeastward, it is found outcropping along the western and northwestern edge of this area. The outcrop forms a belt of variable width, which reaches its maximum in the Southern States. The clays found in the Cretaceous formations represent nearly every class of plastic material known, ranging from those that are very impure or very sandy to others showing a high degree of purity or extreme fineness of grain. Consequently they furnish a supply of material that is suitable for the manufacture of many different kinds of ware. The general section of the formation varies somewhat from place to place and is referred to in the detailed descriptions under the different States.

The Cretaceous system is divisible into a lower group of sands, gravels, and clays and an upper or marme group of sandstones and marls. ${ }^{a}$

The nonmarine or lower division is the most important to the clay worker. It extends across New Jersey from Perth Amboy to Philadelphia, then across Maryland and beyond, passing by way of Alexandria, Fredericksburg, and Richmond to the vicinity of Petersburg. It is well exposed at many points along the Rappahannock and James rivers, but only to a small extent along the Appomattox. South of - Petersburg the exposures are few, most of the Cretaceous formation being covered by Tertiary deposits, so that the former appears only in river cuttings.

In the Gulf-border region the inland boundary of the Cretaceous extends from a point on the Mississippi River a few miles above its confluence with the Ohio to a point on the Savannah River near Augusta, Ga. From the point of beginning just mentioned it extends eastward to a point on the Ohio River a few miles above its confluence with the Tennessee River, and from there it may be followed along a strongly convex and not very irregular line to the eastern terminus. From its northerly point within western Kentucky the direction of this line is almost due south, through western Tennessee and northeastern Mississippi. There it takes a southeasterly direction and passes into northwestern Alabama. Thence by a broad curve it passes nearly centrally through Alabama, and through a part of Georgia, to the point near Augusta mentioned above.

The structural characters of the Cretaceous are very similar throughout the area under consideration, the deposits being made up of a series of alternating beds of sand, clay, and gravel. In some places the beds of clay are fairly persistent, as in New Jersey, but in most of the States where the Cretaceous is exposed the clay beds are usually of a lenticular character, interbedded with and surrounded by masses of sand. (Fig. 3.) This structural peculiarity is due to the ever-changing conditions under which the beds were deposited, the water over the same area being at one time quiet, when fine clay would be deposited, and at other times rough, owing to the shifting of the currents, when more sandy material would be laid down. This

a See Bull. U. S. Geol. Survey No. 82, Correlation papers--Cretaceous. 
fact indicates the necessity of carefully exploiting any deposit in this region before a factory is located near it. In the northeastern part of the area the Cretaceous clays occur on Marthas Vineyard, and are well exposed in the section at Gay Head. At this locality there are some small deposits of refractory material, but the clars are often corered by a large amount of orerburden and hare been much disturbed by ice action, resulting in the mixing up of pure and impure layers, thus rendering the working of them rather difficult. Farther southwest the Cretaceous beds outcrop at a few points on the northern shore of Long Island, where they are worked for obtaining a refractory or semirefractory siliceous clay, used chiefly in the manufacture of stoneware. Deposits of limited extent and similar nature are also known on Staten Island. The most important development of the Cretaceous clays occurs

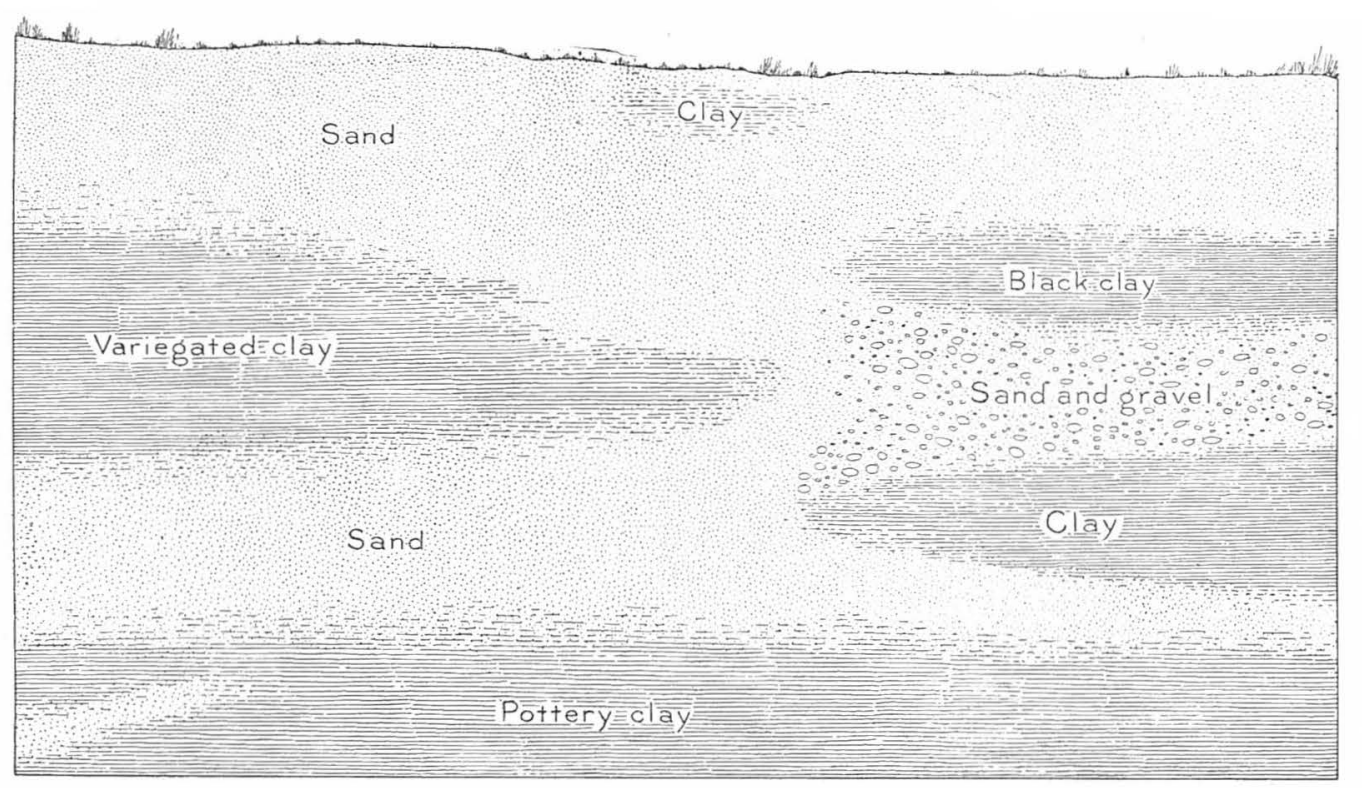

FIG. 3.-Section showing Ienticular character of clay deposits in Coustal Plain region.

in New Jersey, where Lower Cretaceous beds form a strip $t$ to 6 miles wide, extending in a northeast-southwest direction from the vicinity of South Amboy to a point opposite Philadelphia. In this section several well-marked members have been found, such as the Woodbridge fire-clay bed, the Amboy fire clay, and the Amboy stoneware clay. These have been worked for a number of years, as will be seen from the detailed description of them given under New Jersey. They supply a great variety of clays, ranging from the most refractory to the most fusible. In the seventies it was only the more refractory grades that were chiefly sought after, but since that time uses have been found for the poorer qualities of clay found in the New Jersey area. These are being much exploited at the present time, and are used 
especially for the manufacture of hollow brick and conduits. The Upper Cretaceous beds which outcrop to the southeast contain two important beds of clay marl, which are of much value for the manufacture of brick, tile, earthenware, and possibly other low- or medium-grade wares. They are well exposed near Matawan, Moorestown, and Camden.

In Maryland the Cretaceous beds extend across the State in a belt about 12 miles wide, through Cecil, Harford, Baltimore, Howard, Anne Arundel, and Prince George counties. Here these clay beds belong to the Potomac group of the Lower Cretaceous, which is also important. In Anne Arundel County its width of outcrop is great. As pointed out under Maryland (p. 139), the lower or Patuxent member is usually sandy, but may carry refractory clays.

The Arundel formation, which is especially dereloped in Anne Arundel County, carries large deposits of brick clays. The Patapsco yields the greatest variety of clays found in the Cretaceous within the boundaries of Maryland, embracing stoneware clays, fire clays, and brick clays. The Raritan, which overlies it, is little worked, although clay beds are well developed in it along the Magothy and Severn rivers.

The clays of the District of Columbia are similar to those of Maryland, but their continuation across Virginia is narrow and their commercial ralue is not in all cases well known.

In Georgia the Cretaceous outcrops form a triangular area haring its apex at Macon and following the fall line to the Chattahoorhee Rirer. The sections show many deposits of white clay of highly refractory character but of Iow plasticity and tensile strength.

In North Carolina the Cretaceous beds outcrop near the western border of the Coastal Plain, but carry little clay of value.

In South Carolina the Potomae group of the Cretaceous forms a belt $t$ or 5 miles wide, extending through Aiken, south of Lexington, and through Columbia to Camden and Cheraw. ${ }^{a}$ The finer clays occur near the top of the formation, or toward its southeastern edge.

The Cretaceous becomes of great importance in Alabama, especially in the Lower Cretaceous or Tuscaloosa formation, which carries clays of raried character, some being nearly pure or white, others dark gray and very plastic, and some ferruginous. So far as the writer's observations have gone the Cretaceous clays of Alabama rank next to those of New Jersey in general quality. The formation crosses Alabama in a general northwesterly direction, forming a curve that enters the State at Columbus, Ga., and leaves it in Colbert County, at the Mississippi border. It forms the northeast corner of Mississippi and small areas in Tennessee and Kentucky. 
TERTIARY.

The formations of this age have thus far proved to be of little value to the clay worker, although they are widely distributed throughout the Coastal Plain region and up the Mississippi Valley as far as Ohio, overlying the Cretaceous and, indeed, sometimes completely hiding it. They, in turn, may be covered by Pleistocene deposits.

Owing to the complexity of their relations to other formations it is often difficult to recognize the Tertiary beds, and detailed statements regarding them are given under the descriptions of the States rather than here. The formations consist of a series of sands, marls, and some clays. The latter are usually of local extent.

In New Jersey (see p. 166) the Miocene clays are worked for brick. In Maryland (see p. 143) a red clay of importance is found in the Eocene. Ter. tiary clays are worked in North Carolina and Georgia and are of importance. Many deposits are also said to exist in Alabama and are now being studied by the geological survey of that State.

The Tertiary clays of western Kentucky and Tennessee are perhaps as important as any in the eastern United States, and are actively worked at several points for fire brick and stoneware. In the former State they are restricted to the Jackson Purchase region.

The Lafayette formation, of Upper Tertiary age, is a prominent member of the Coastal Plain deposits, and consists of a series of loams, clays, sands, and gravels, usually of orange color. It extends from New Jersey southward to Florida and thence westward, its greatest width being on the Roanoke River. ${ }^{a}$ In central Georgia it stretches from the fall line to the inland margin of the coastal sands all the way from the Savannah to the Chattahoochee River. It expands greatly in Alabama, forming an almost continuous belt reaching from the fall line at Montgomery and Tuscaloosa to Mobile Bay, and it is even more extensive in Mississippi.

The Lafayette formation may contain a variety of clay deposits, ${ }^{b}$ especially in western Kentucky and Tennessee, but there is doubt whether these clays are really of Lafayette age.

In most regions the Lafayette forms an objectionable mantle of sands and gravels over the Cretaceous and early Tertiary clay-bearing beds under it.

PLEISTOCENE.

The Pleistocene formations serve as the chief source of brick- and tile-making materials in the United States east of the Mississippi, the deposits, which are often clays or loams, forming a great mantle over the pre-Pleistocene beds.

$a$ Twelfth Ann. Rept. U. S. Geol. Survey, Pt. I, p. 489.

$b$ Ibid., p. 505. 
In the area north of the terminal moraine the clays are found in ponded valleys in the glacial till, underlying terracés along rivers, or around the Great Lakes. They are well adapted to the manufacture of the lower grades of clayr products, such as common brick and earthenware, and less often paving brick, terra cotta, sewer pipe, and stoneware.

In the more Southern States the Pleistocene clays form plastic loams in the lower-lying districts, especially along the main river valleys and estuaries of the coastal region, and are known as the Columbia formation, the type locality of which is in the District of Columbia, where it is well developed along the Potomac River. There it consists of a sheet of brown loam, passing down into a bed of pebbles and bowlders. ${ }^{~ T h e ~ l o a m ~ r a n g e s ~ f r o m ~} 3$ or 4 to 20 or 30 feet in thickness.

To the north the formation grades into pebbly beds in southern New Jersey, while the sandy clays are well developed along some of the waterways, such as the Rappahannock, the James, the Appomattox, the Roanoke, and intermediate rivers, but farther south they increase greatly in sandiness.

In some of the Southern States, as Alabama, ${ }^{b}$ there are extensive stretches of fluvial or river deposits of Columbia loam, known as " second bottoms," which stretch from the coastal zone to the fall line and sometimes beyond. Typical exposures of second-bottom loam occur along the Chattahoochee River about Columbus, Ga., and on the Tuscaloosa River at Tuscaloosa, Ala. They are worked around Philadelphia, Baltimore, Washington, and other cities. The clays underlying the flood plains of the broader river valleys in the South may also be placed here.

\section{DISTRIBUTION OF CLAYS BY KINDS.}

BRICK CLAYS.

There is no grade of clay which is more widely distributed or found in larger quantities than common brick clay, hardly a township being without an available deposit. (For distribution see Pls. III, IV, and VII.)

In the northeastern or New England States practically all the brick clays are glacial deposits, in some places filling depressions, in others included in the drift, or elsewhere underlying terraces along river valleys.

In New York many kinds of brick cliays are obtained from the drift deposits, ${ }^{c}$ but the Silurian shales of central New York, the Devonian shales of southern New York, and the Cretaceous clays of Long Island may likewise be drawn upon.

In Pennsylvania the drift clays and river-terrace clays are still available and are used both in western Pennsylvania and around Philadelphia. In addition to these, however, there are the mellowed outcrops of the Carboniferous and Devonian shales,

\footnotetext{
a Twelfth Ann. Rept. U. S. Geol. Surv., Pt. I, p. $384 . \quad$ bIbid., p. $389 . \quad$ osee New York Pleistocene clays, p. 175.
} 
the former especially being extensively used around Pittsburg, the latter as yet at only a few isolated localities. In addition to these the residual clays of the Great Valley region are much employed.

Throughout the Southern States brick clays are dug from the Columbia loams and Cretaceous beds of the Coastal Plain region, and from residual deposits in the uplands. The wash from the latter may often be collected in the valley bottoms and serve to supply some local brickyard.

In Ohio, Indiana, Illinois, Michigan, and Wisconsin the drift clays are almost invariably drawn upon for common brick materials, for they lie on the surface and the clay is therefore easily obtained and worked. The same formations are often drawn upon for earthenware clays, except that it is usually the less sandy beds that are sought. If red earthenware is to be made the calcareous deposits are avoided. These are not very abundant, except in Indiana, Illinois, Wisconsin, and Michigan.

PRESSED-BRICK AND TERRA-COTTA CLAYS.

Since these two grades of ware are being made from very similar raw. materials at the present day, they can be discussed together. Two classes of clay are usedrefractory or buff-burning clays and red-burning ones. The refractory clay sought is commonly a No. 2 fire clay, and must be obtained mostly from either the Cretaceous or the Carboniferous formations, and hence its distribution is limited. Since pressed brick and terra cotta both command a good price, the manufacturer can afford to transport the product some distance to the market.

In Massachusetts; at Blandford and south of Clayton, there are residual clays which have been used for light-colored wares, but the clay had to be mixed with more plastic material brought from other States. New York has limited quantities of the proper clay on Staten Island and Long Island. In New Jersey much buff-burning material can be dug from the Cretaceous deposits, and the same is known to be true of Maryland and Alabama. The Tertiary deposits may also yield some light-burning clays in New Jersey.

In Ohio, Pennsylvania, and Indiana great supplies are obtainable from the clay underlying the coal. Illinois, Kentucky, and Tennessee may prove to have similar supplies, but the two last-named States are still far from the markets consuming the greatest quantities of terra cotta. The Tertiary and Pleistocene formations of the Atlantic and Gulf coast contain at times beds of buff-burning, semirefractory clays." Calcareous clays might also be used for buff wares, but they are not preferred, owing to their low fusibility.

Red terra-cotta and brick clays are obtainable from the same formations as common brick clays, but there is little demand for them at the present time. Many

$a$ See New Jersey, p. 166. 
of the Carboniferous shales, and even Devonian ones, have been found to yield a rich red color. Such are used near Pittsburg, Pa., and Corning, N. Y.

STONEWARE CLAYS.

Under this title may be included those semirefractory clays that are used for many other kinds of material than stoneware, all of which, however, call for a dense burning clay of moderate fire-resisting quality. Their distribution is rather restricted (see Pls. III, IV, and VII). Most important are the deposits of Carboniferous age, especially those of the Lower Coal Measures, for in these rocks considerable deposits of plastic clay are often found underlying the coal seams. They are worked to an enormous extent in Ohio to supply the stoneware industry of that State, and among these clays the Lower Kittanning is especially important. The same beds are worked in the eastern extension of these rocks in western Pennsylvania, but they are not utilized in Kentucky or West Virginia, though they may occur. In New Jersey good stoneware clays are found in the Cretaceous belt, especially in Middlesex County, and in rocks of the same age in Maryland, especially in Cecil County, but in no State are they as valuable as the Ohio materials.

Beds of good quality are found underlying many of the coals in southwestern Indiana and probably Illinois, but little is known of the occurrence of any in Michigan or Wisconsin. Stoneware clays occur in the Cretaceous of Alabama, especially in the counties of Autauga, Perry, Bibb, Tuscaloosa, Pickens, Fayette, Lamar, and Franklin. ${ }^{a}$ They may be looked for in the Cretaceous area of Jones, Baldwin, Twiggs, and Wilkinson counties, Ga., in the Jackson Purchase of western Kentucky, and especially in the Tertiary formations and beds of similar age in western Tennessee.

FIRE CLAYS.

These are widely distributed, both geologically and geographically, being found in 21 States out of the 24 lying east of the Mississippi, and in three of these, viz, Ohio, Pennsylvania, and New Jersey, they are of vast importance (see Pls. III, IV, and VII). Refractory clays are commonly used in the State in which they are mined, but in some States much of the supply is shipped. Thus fire clay from New Jersey is sent to Ohio, Pennsylvania, West Virginia, New York, Massachusetts, Connecticut, Maryland, and Maine. Indiau clay is sent in small quantities to Kentucky and Georgia, and Alabama clay is sent to Tennessee.

The uses of fire clay have been already referred to under another head. ${ }^{b}$ Attention should once more be drawn to the fact, however, that the term "fire clay" is very loosely used, so that clays' are termed "fire clays" which have no claim to the title. Bricks that are used for boiler settings are called "fire brick," but experiment shows that they melt completely at cone 27 or lower.

a See Alabama, p. $₫ 1$.

bSee "Üses of clay," p. 37. 
The following table shows the refractoriness of some of our better American fire clays, the figures being the result of tests made by H. O. Hofman and the writer:

\begin{tabular}{|c|c|}
\hline Locality. & $\begin{array}{l}\text { Fusion } \\
\text { point. }\end{array}$ \\
\hline & Cone. \\
\hline Kreischerville, N. Y., No. 1 white.............. & $35+$ \\
\hline St. Louis, Mo., Christy raw clay ................ & $31-30$ \\
\hline Golden, Colo $\ldots \ldots \ldots \ldots \ldots \ldots \ldots \ldots \ldots$ & $32-31$ \\
\hline Mineral Point, Ohio & 33 \\
\hline Mount Savage, Md $\ldots \ldots \ldots \ldots \ldots \ldots \ldots \ldots$ & 33 \\
\hline 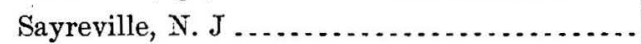 & 35 \\
\hline Woodbridge, $\mathrm{x} . \mathrm{J}$ & 34 \\
\hline
\end{tabular}

Most of the fire clay mined goes into fire brick, but large quantities are used as one of the clays in mixtures for saggers, terra cotta, zinc retorts, gas retorts, stoneware, etc.

As the refractory clays are of much value their distribution is here given in some detail.

Alabama. - The residual clays or kaolins of Randolph and Cleburne counties are very refractory, although they lack plasticity. Their most important use will probably be for china manufacture rather than fire brick. Similar white clays are found at times in the residual clays of the Cambro-Silurian areas, as in Calhoun and Cherokee counties. White refractory clays are found in the Lower Carboniferous clays of the Wills Valley region and are worked for shipment to fire-brick factories at Chattanooga, Tenn. No fire-clay deposits have been discovered in the Coal Measures up to the present time.

Refractory clays are most commonly found in the Tuscaloosa formation (Lower Cretaceous), being worked at Woodstock, Bibbville, and other places. They usually possess high plasticity and often burn dense at a comparatively low temperature. Other important occurrences are at Hull station and Tuscaloosa, in Tuscaloosa County; Potters Mills, Marion County; and Pegram, Colbert County.

The Tertiary may contain fire clays, but they have not thus far been exploited. A peculiar flint-like clay is found in Choctaw, Conecuh County.

Georgia.-The fire clays of this State are derived chiefly from the Cretaceous and Paleozoic formations. The best fire clays are those found in the Potomac group of the Cretaceous, in the southeastern part of the State. They form lenses of white clay, having very high refractoriness but low plasticity. Important areas are located around Griswoldville, Lewiston, Butler, and Macon.

Many residual clays bave come from the decomposition of the Cambrian and 



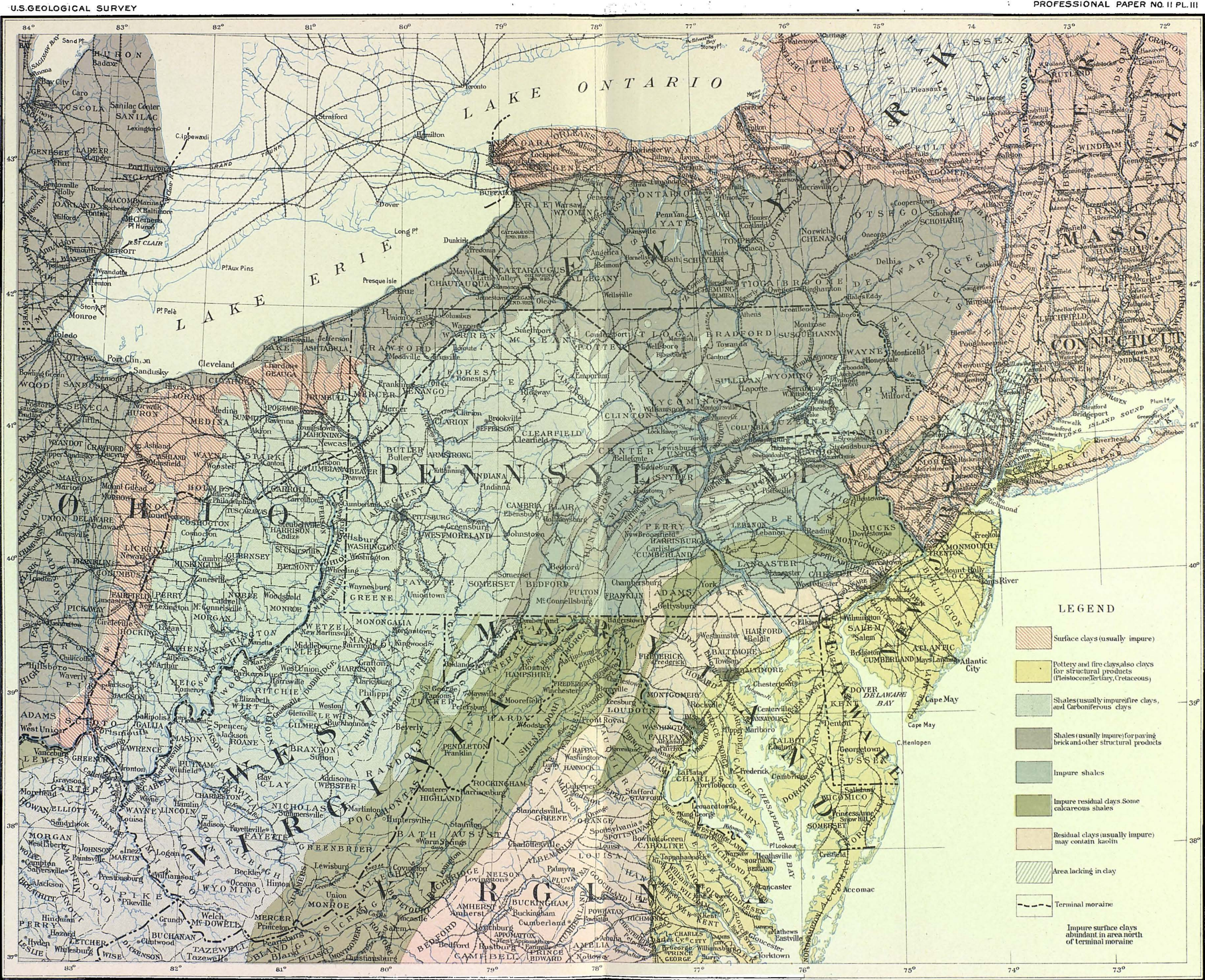

MAP SHOWING DISTRIBUTION OF CLAYS IN THE NOR'LHERN APPALACHIAN REGION

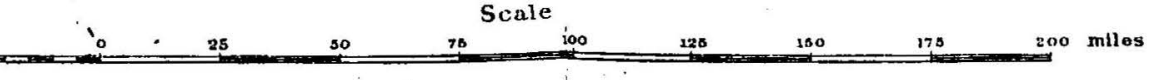




Ordovician limestones, and these, though commonly ferruginous, often contain white siliceous clays of good fire-resisting qualities.

Indiana. - The only rocks' in Indiana carrying fire clays are of Carboniferous age, found in the southwest corner of the State. They usually underlie the coal seams, and several of them are persistent. They vary in thickness, but are often 3 to 4 feet thick. They are commonly mined by means of shafts, from which coal also is extracted. Actual fire tests are lacking, but the Indiana clays are probably not so refractory as those found in Pennsylvania and New Jersey or in Ohio.

Kentrucky.-Analyses published by the Kentucky geological survey ${ }^{a}$ show the presence of many fire clays in the Carboniferous. The beds of clay often underlie the coal, but their degree of persistence is not known, nor do many of them seem to have been developed. In Greenup, Boyd, Carter, and Lawrence counties one bed of fire clay is known near the base of the Subconglomerate, and another under coal No. 6 . The former is a flint clay and is said to resemble that found at Sciotoville, Ohio. Fire clays are also known under seams $2,3,4,5,6,7,8$ in the eastern field, ${ }^{b}$ but are not always present, and in some cases may be thin enough to require mining with the coal. Fire clay is sometimes found in the Upper Ferriferous limestone in Greenup, Carter, and Boyd counties and has been used in the manufacture of fire brick. Refractory clays occur, no doubt, in the western coal field, but little has been published concerning them.

Many fire clays occur in the Tertiary and also in the Cretaceous of the Jackson Purchase region, but they have been used more for the manufacture of stoneware than for fire brick.

Maryland.-Refractory clays exist in the Algonkian, Cretaceous, and Carboniferous. The Algonkian refractories are residual in character and are found along the western border of the Coastal Plain area, especially at Dorsey and Northeast. Those of the Potomac formation are found chiefly in the Patuxent and Raritan members, but also show in the Patapsco. They do not occupy any definite stratigraphic position, and form more or less lenticular masses. Many of them are decidedly refractory and of low shrinkage, but are rather low in bonding power. Their chief use is for the manufacture of stove brick, fire brick, and gas retorts.

The Carboniferous fire clays are the basis of an important local industry in Allegany County and are found in the Conglomerate series belonging under the Mount Savage coal. Both the flint and the plastic varieties occur. They are known at several points on Savage Mountain, also at Swallows Falls and Blaine, Garrett County. More recently the Bolivar fire clay has been found on the Castleman River in Garrett County. The Carboniferous fire clays are much used for fire brick and also for enameled brick.

a See Kentucky Geol. Survey, Chem. Anal., Pts. I, II, III. b See detailed account of Kentucky clays, p. 112 this paper. $9647-$ No. $11-03-5$ 
Michigan.-No fire clays have thus far been discovered in this State.

Mississippi.-Fire clays are found in the Cretaceous and Tertiary beds of the northeastern portion of the State; but they are not extensively worked.

New Jersey.-Few States contain a more important series of refractory clays than does this one, and although they are confined almost exclusively to the Lower Cretaceous beds, they have been worked for many years not only to support a local industry but also to supply factories in other States. Curiously enough, this same member of the Cretaceous carries much less refractory clay in the States farther south. In New Jersey several well-marked members are recognized in the series of Middlesex County, including the Woodbridge fire clay, Amboy bed, and Raritan bed. The materials are all plastic, soft, and range in refractoriness from low-grade fire clays up to others of high heat-resisting power.

New York.-The fire clays occur in small quantity on Staten Island and at several points on the north shore of Long Island. Few of them are highly refractory. They are usually sandy and plastic.

North Carolina. - The only highly refractory clays that have been found in this State are the kaolins resulting from the decay of pegmatite veins. They are of more value for making white ware than for the manufacture of 'fire bricks.

Ohio.-This State is one of the two most important producers of refractory clay products. The fire clays are obtained entirely from the Carboniferous, especially the Coal Measures. In the Lower Carboniferous an important flint clay is worked at Sciotoville and Portsmouth. In the Conglomerate measures the Tionesta, Upper and Lower Mercer, Sharon, and Quakertown coals are underlain by a seam of fire clay, which is worked at Massillon, the Lower Mercer being worked in Stark, Tuscarawas, Hocking, and Muskingum counties. In the Lower Coal Measures, clay underlies the Upper and Lower Freeport, Middle and Lower Kittanning, and Brookville coals. That from the Kittanning far exceeds all the others in value and is extensively worked.

Pennsylvania.-Refractory clays are found in the Cambro-Silurian and Carboniferous formations. The former occur mainly in southeastern Pennsylvania, and result from the decomposition of talcose schists, slates, and limestones. The latter are found in western and central Pennsylvania and serve as the basis of a large industry. They are referred to in some detail under Pennsylvania, but their distribution may be summarized as follows:

Distribution of Carboniferous formations in Pennsylvania. CONGLOMERATE GROUP.

Alton fire clay; Elk County.

Mercer clay; North Butte, Beaver, Lawrence, and Mercer counties.

Sharon clay; Elk and Mercer counties. 
Distribution of Carboniferents formations in Pennsylvania-Continued.

LOWER PRODUCTIVE MEASURES.

Brookville clay ; Clearfield, Elk, and Jefferson counties.

Clarion clay; Indiana and Beaver counties.

Ferriferous; Armstrong County; hard and also semiplastic.

Kittanning fire clay; a valuable refractory plastic clay, sometimes termed the New Brighton. Known in several counties, including Armstrong, Beaver, Tioga, Blair, Fayette, and Westmoreland.

Upper Freeport or Bolivar; the important flint clay deposit of Pennsylvania. Widely distributed, but not always refractory, for its place may be taken by shale. It has been noted in Allegheny, Armstrong, Beaver, Butler, Fayette, Indiana, Somerset, and Westmoreland counties.

UPPER COAL MEASURES.

These often carry a thin seam of fire clay, which forms a parting in the Pittsburg coal seam.

Tennessee.-The fire clays occurring in the Tertiary formations of western Tennessee are worked locally for making fire brick, notably at Grand Junction and Pinson. The Carboniferous rocks contain many fire-clay beds, but most of them are undeveloped. The residual clay from the Knox dolomite is at times refractory and has been utilized for fire brick.

Virginia.-Fire clays are, no doubt, to be found in the Coastal Plain formations, and kaolins occur in the crystalline area. No fire clays have been reported from the Carboniferous rocks.

West Virginia.-Fire clays are known in the Pottsville conglomerate of the Coal Measures, as at Piedmont. Refractory clays are also found under the Upper Freeport and Kittanning coals, but they are not nearly so abundant as those of Pennsylvania or Ohio.

Wisconsin.-The elays derived from pre-Cambrian schists and Potsdam sandstones may be refractory, but they are not dereloped.

DESCRIPTION OF CLAY DEPOSITS, BY STATES.

ALABAMA.

Alabama is the only one of the Gulf States whose clay resources have been investigated in a systematic manner, and the investigations macle show the presence of a great variety of materials that are of value in the fictile arts. The geologic map of the State shows a wide range of formations, nearly all of which carry valuable clay deposits.

ARCHEAN AND ALGONKIAN:

Archean and Algonkian rocks underlie a roughly triangular area in the eastern part of the State, the base of the triangle extending from near the northern border of Cleburne County southward to Russell County, and the apex being at Clanton, Chilton County. The rocks of this area are granites, gneisses, and schists, all of which may, by surface decay, furnish residual clay. The schist areas are, however, of additional importance, for they carry many pegmatite veins which have been 
changed to kaolin in their upper part. A belt of mica-schists extends from Cleburne and adjacent parts of Randolph through Clay and Coosa into Chilton County.

The deposits, according to Dr. E. A. Smith, State geologist, lie near Milner, Pinetucky, and Micaville, in Randolph County, and Stone Hill, in Cleburne County." At the present time these kaolins are undeveloped, as railroad facilities are lacking in that region.

The Alabama kaolins are rather siliceous, highly refractory, and burn to a very white color.

CAMBRIAN AND SILURIAN.

The clays obtained from these formations are either residual deposits or are concentrates from these, which have been carried by surface waters down into sinks and other depressions. ${ }^{b}$ While the Silurian rocks contain some shaly members, these are not, so far as known; used for the manufacture of brick, but the residual clays are extensively employed for this purpose. These clays are usually rather impure, but in places may be quite free from impurities, as are those found near Gadsden, Etowah County; Kymulga, Talladega County; Peaceburg and Oaxanna, Calhoun County, and in Blount County. Indeed, these white clays sometimes form masses in the residual limonites, as in T. 15 N., R. 8 E., secs. 21 and 23. Another such deposit, a residual limestone clay, is in T. $1 \pm$ N., R. 8 E., in Calhoun County.

In Cherokee County, north of the line of the Southern Railway, in secs. 1 and 2 of T. 12 N., R. $1 \mathrm{E}$, are many beds of limonite with horses of white clay. These have been tried at Chattanooga for fire-brick manufacture.

Accumulations of good clay are not uncommon in the depressions or sinks of the Cambro-Silurian limestone region. They are utilized at Oxford, Calhoun County, for pottery manufacture, and at De Armanville, in the Choccolocco Valley, for brick.

In the following table are given the physical and chemical characteristics of Alabama clays.

Physical and chemical characters of clays from Alabama.

\begin{tabular}{|c|c|c|c|c|c|c|c|c|c|c|c|}
\hline \multirow{2}{*}{$\begin{array}{c}\text { Num- } \\
\text { ber. }\end{array}$} & \multirow{2}{*}{$\begin{array}{l}\text { Percent } \\
\text { water re- } \\
\text { quired. }\end{array}$} & \multicolumn{2}{|c|}{$\begin{array}{c}\text { Tensile } \\
\text { strength. }\end{array}$} & \multirow{2}{*}{$\begin{array}{l}\text { Air } \\
\text { shrink. } \\
\text { age. }\end{array}$} & \multirow{2}{*}{$\begin{array}{l}\text { Fire } \\
\text { shrink- } \\
\text { age. }\end{array}$} & \multirow{2}{*}{$\begin{array}{l}\text { Ircipient } \\
\text { fusion. }\end{array}$} & \multirow{2}{*}{$\begin{array}{l}\text { Titrifica- } \\
\text { t tion. }\end{array}$} & \multirow{2}{*}{ Viscosity: } & \multirow{2}{*}{$\begin{array}{l}\text { Color when } \\
\text { burned. }\end{array}$} & \multirow{2}{*}{ Variety. } & \multirow{2}{*}{$\begin{array}{c}\text { Page of } \\
\text { Bull. 6, } \\
\text { All. } \\
\text { Geol. } \\
\text { Surv. }\end{array}$} \\
\hline & & $\begin{array}{l}\text { Aver- } \\
\text { age. }\end{array}$ & $\begin{array}{l}\text { Maxi- } \\
\text { mum. }\end{array}$ & & & & & & & & \\
\hline & & & & & & & Come. & Come. & & & \\
\hline 1 & 37.5 & 143 & 154 & 8 & 7 & 2,250 & & $2 i$ & $\left\{\begin{array}{l}\text { Cream } \\
\text { white }\end{array}\right\}$ & China clay.. & 121 \\
\hline 2 & 25 & 20 & 25 & 5 & 8 & 2,250 & 30 & & 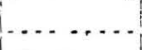 & Fire clay ... & 135 \\
\hline 3 & 16 & 9 & 10 & 2 & 2 & $+2,500$ & $\ldots \ldots$ & $\cdots$ & Buff .... & ....do. ..... & 136 \\
\hline 4 & 28 & 45 & $5 \tilde{5}$ & 5 & 15 & 2,200 & 2,350 & $2 \bar{t}$ & ... do ... & Stoneware. & .... \\
\hline 5 & 26.75 & 130 & $1 \pm 4$ & 10 & 8 & 2,200 & 2,400 & 2,600 & ....do... & $\cdots$ & 189 \\
\hline
\end{tabular}




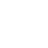



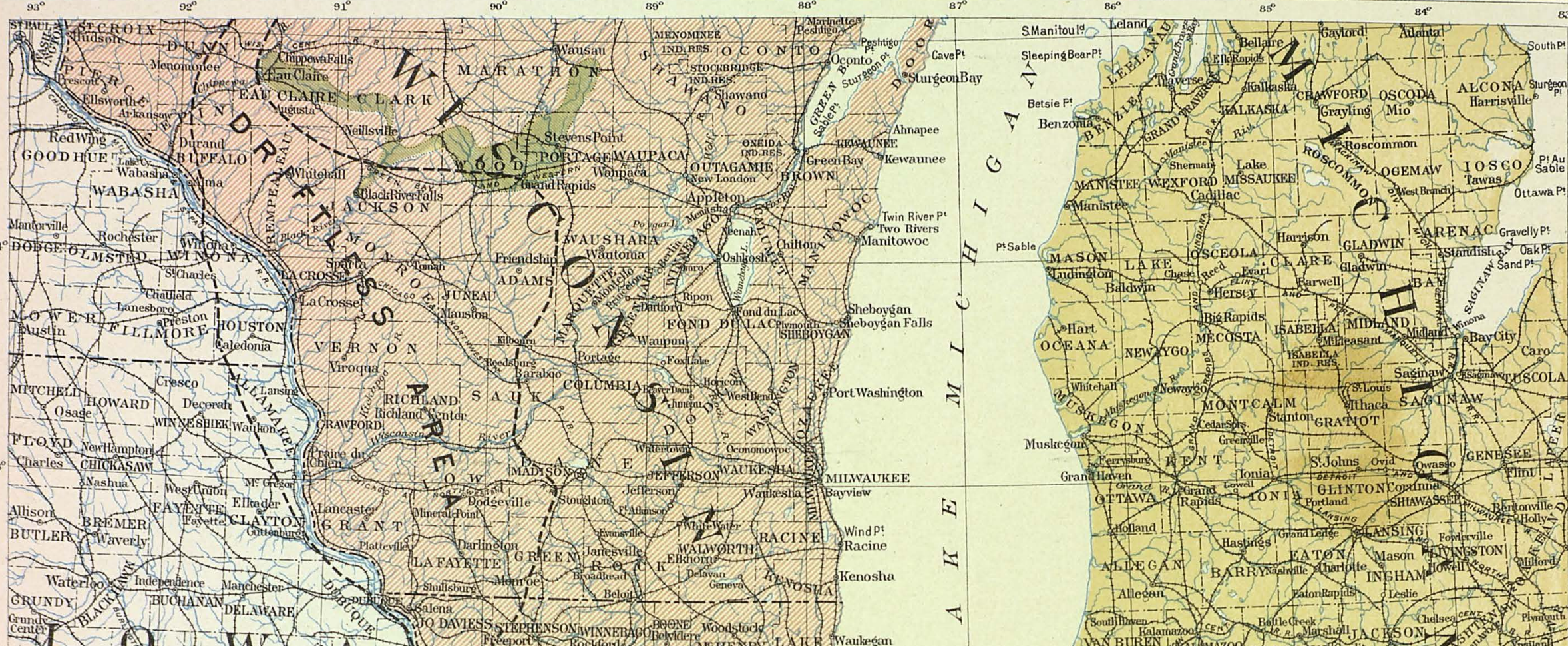

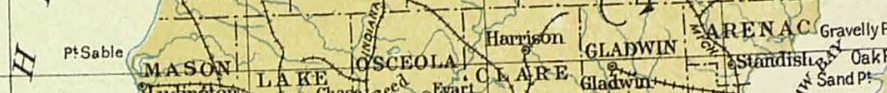
20.

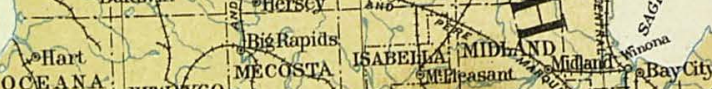

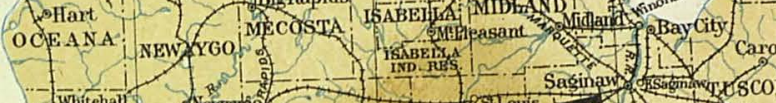

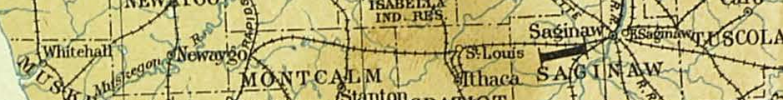

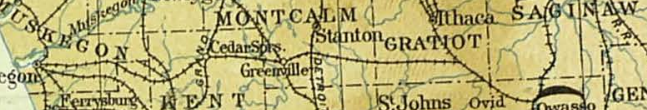

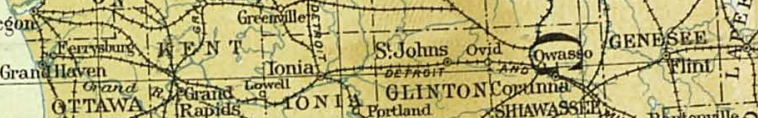

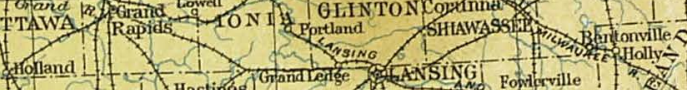

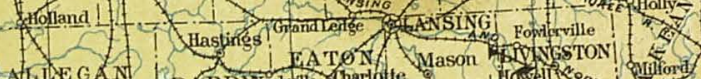

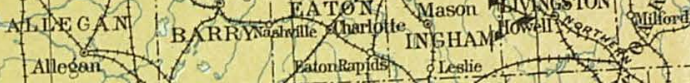

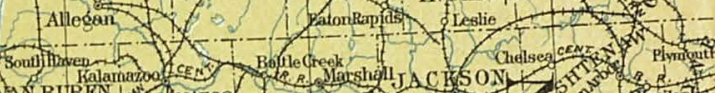

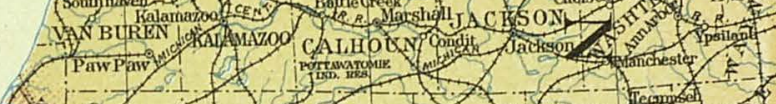

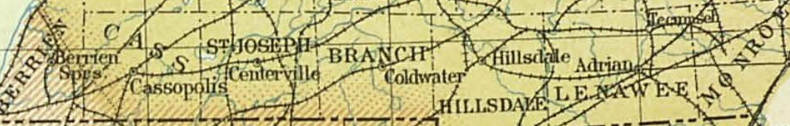

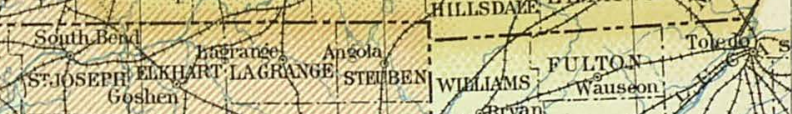

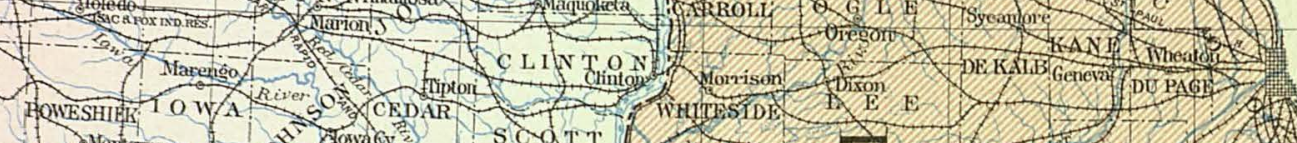

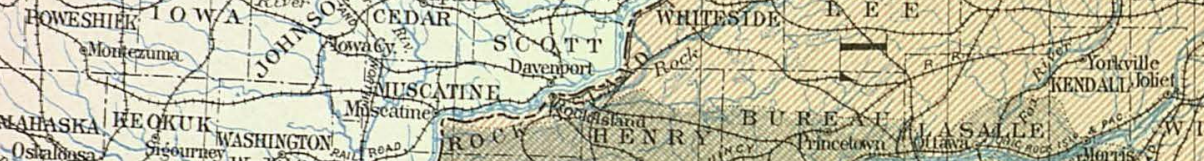

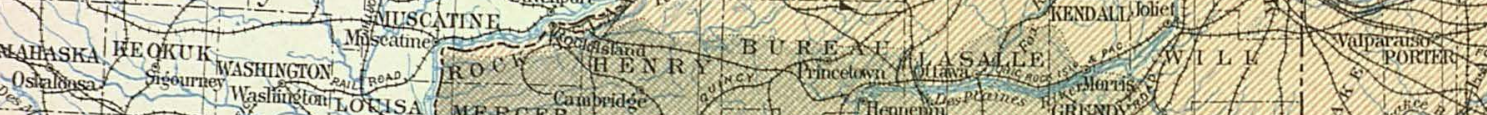

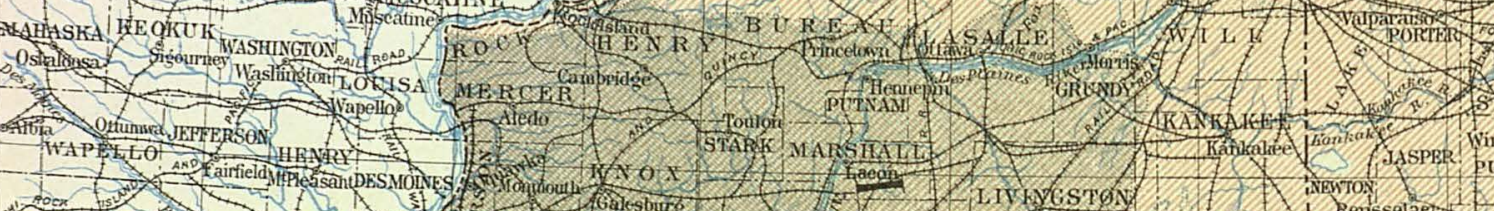

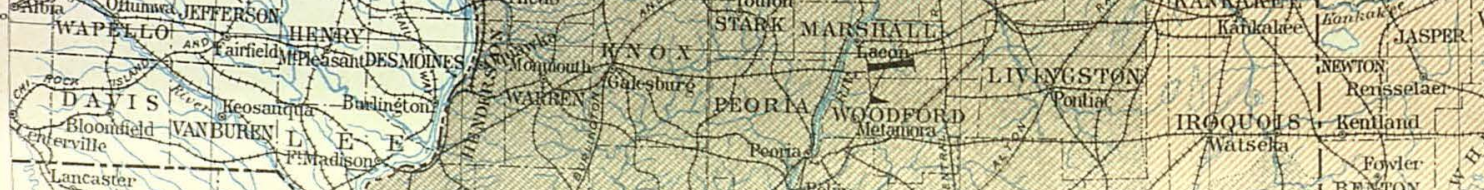

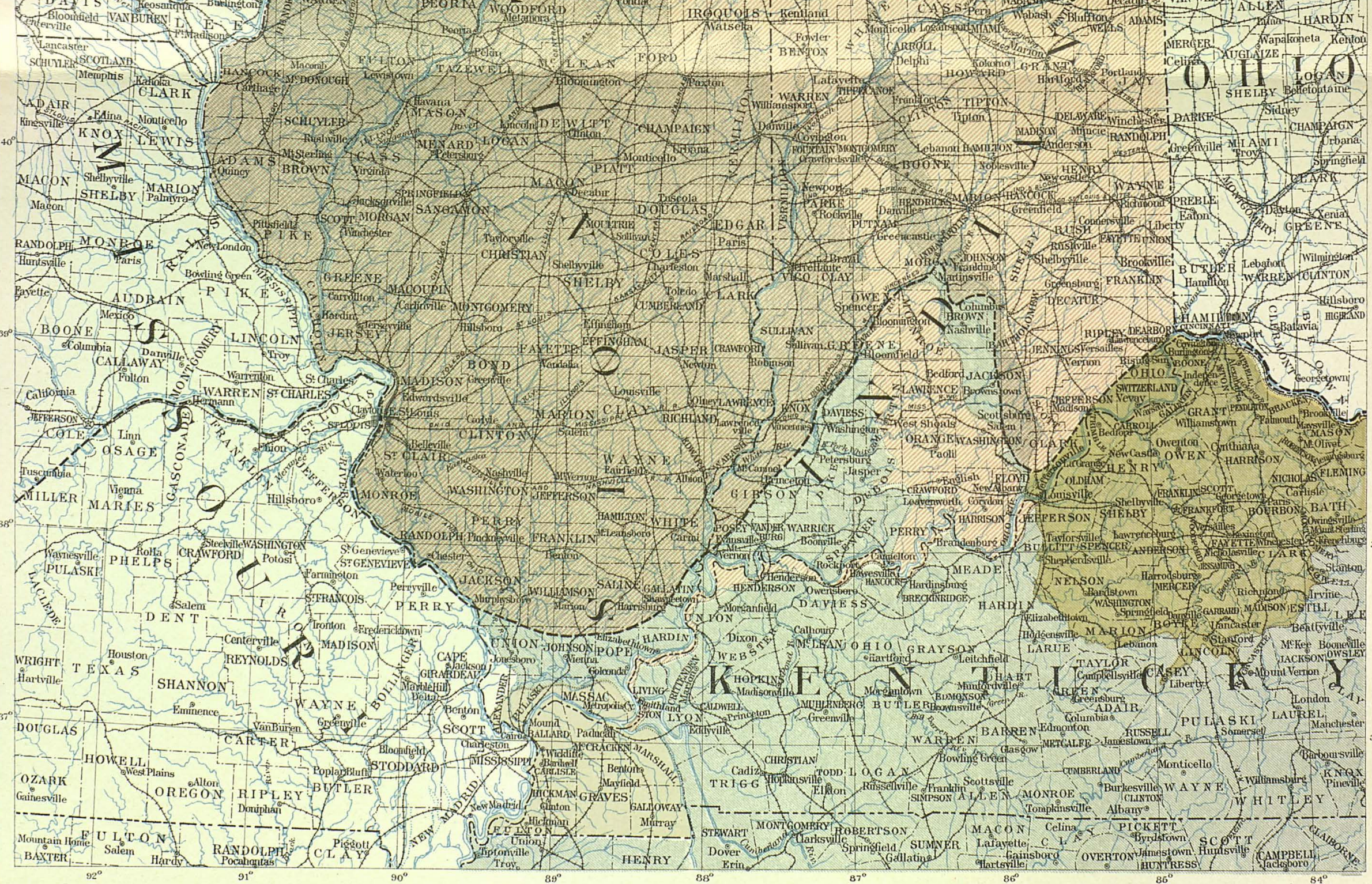

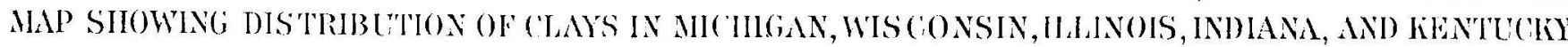

LEGEND

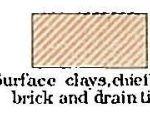

civelly for.
ain ilie
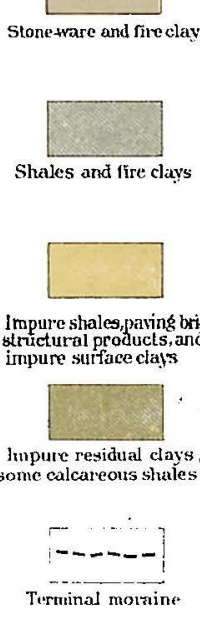


Physical and chemical characters of clays from Alabama-Continued.

\begin{tabular}{|c|c|c|c|c|c|}
\hline ! & 1. & 2. & 3. & 4. & 5. \\
\hline Silica.$\ldots \ldots \ldots \ldots \ldots \ldots \ldots \ldots \ldots \ldots \ldots \ldots \ldots$ & 67.95 & 51. 90 & 84.21 & 61.50 & 71.30 \\
\hline Alumina. .... & 20.15 & 35.00 & 9.75 & 26. 20 & 17.16 \\
\hline 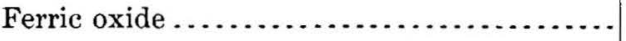 & 1.00 & .99 & .69 & 2. 10 & 1.94 \\
\hline Lime ................ & 1.00 & .23 & .70 & .50 & .60 \\
\hline Magnesia $\ldots \ldots \ldots \ldots \ldots \ldots \ldots \ldots \ldots$ & Trace. & .10 & .14 & .43 & .43 \\
\hline Alkalies..........$\ldots \ldots \ldots$ & 1.87 & .55 & $\cdots$ & .70 & .95 \\
\hline Ignition $\ldots \ldots \ldots \ldots \ldots \ldots$ & 8.00 & 11. 30 & 4. 10 & 7.29 & 7. 60 \\
\hline Total & 99.97 & 100.07 & 99.59 & 98.72 & 99.98 \\
\hline
\end{tabular}

1. J. R. Hughes, Gadsden, Etowah County.

2. Peaceburg, Calhoun County.

3. Oaxanna, Calhoun County.

4. F. S. White, Blount County.

5. Oxford, Calhoun County.

LOWER CARBONIFEROUS.

This series underlies small areas in the northern portion of the State, but no mention is anywhere made of clays belonging to it. In Wills Valley, however, it contains one of the best-known deposits of white clay. It occurs in the lower strata of the series, close above the black Devonian shale. The deposits are found in the upper or northeastern end of the valley, and on both sides of it, although the most important is on the east side. ${ }^{a}$

The Red Mountain regions are made up of Clinton and Devonian rocks, and the elay occurs in the lower strata of the Lower Carboniferous, not far above the black shale, and is found to be present on both sides of the valley for 10 or 12 miles from the State line southward.

In the northwest corner of sec. 3, T. 6 N., R. 9 E., on the west side of the valley, the following section is exposed in a test pit:

Section in test pit in northuest corner of sec. $3, T .6$ N., R. 9 E., Alabama.

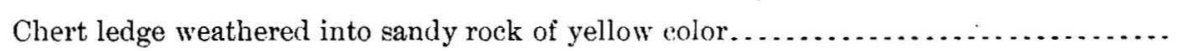

Strata hidden by débris

Feet. Inches.

White clay without grit, in places like halloysite..

$2-3 \quad 0$

Hidden

Deronian shale .

30

30

a McCalley, H., Alabama Geol. Survey, Valley Regions, Pt. II, pp. 175-182, from which the description quoted is taken. 
The white clay is locally known as chalk. Near the State line about Eureka station and thence southward for 2 miles the clay is worked in many places, having an aggregate thickness of about 40 feet, but thickens occasionally to 180-200 feet, of which as much as 60 feet are white clay. The clay is often mined by tunnels, and one of these mines is operated by the Montague Company of ('hattanooga. The clays are refractory, as is shown by analyses and tests. Some beds of potter's clay have also been found in this formation.

Analyses and tests of Lower Carboniferous clays of Alabama.

\begin{tabular}{|c|c|c|c|}
\hline . & 1. & 2. & 3. \\
\hline Silica. . & 82.04 & 79. 80 & 66.25 \\
\hline Alumina ............ & 12.17 & 11.75 & 22. 90 \\
\hline Ferric oxide $\ldots \ldots \ldots \ldots \ldots \ldots \ldots$ & Trace. & 1.75 & 1. 60 \\
\hline Lime . . . . . . . . . . . & Trace. & .75 & Trace. \\
\hline Magnesia..................... & .327 & Trace. & Trace. \\
\hline Alkalies ......... & .60 & 1.50 & .75 \\
\hline 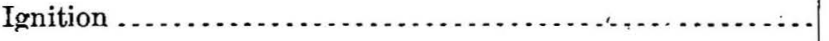 & 4. 325 & 4. 11 & 9.05 \\
\hline 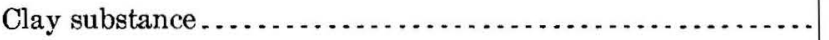 & 31.10 & $\therefore$. & 40. 70 \\
\hline 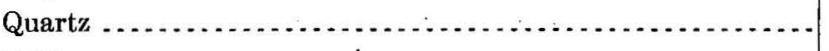 & 64.80 & $\therefore-$ & 47.90 \\
\hline Feldspar $\ldots \ldots \ldots \ldots \ldots \ldots \ldots \ldots$ & 3.90 & . . . & 11. 20 \\
\hline 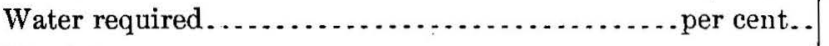 & 35 & 39 & 40 \\
\hline Plasticity $\ldots \ldots \ldots \ldots \ldots \ldots \ldots \ldots \ldots$ & Lean. & Lean. & Lean. \\
\hline Air shrinkage.................. & ............ & 8 & $\cdots$ \\
\hline Fire shrinkage $\ldots \ldots \ldots \ldots . . . . . . . . . .$. & 2 & 9 & ............ \\
\hline Incipient fusion $\ldots \ldots \ldots \ldots \ldots \ldots$ & $2,400^{\circ} \mathrm{F}$ & $2,350^{\circ} \mathrm{F}$. & $2,300^{\circ} \mathrm{F}$. \\
\hline 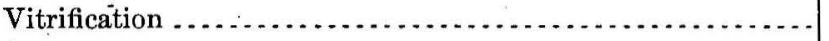 & Cone 27 & 2,700 & Cone $2 \overline{7}$ \\
\hline 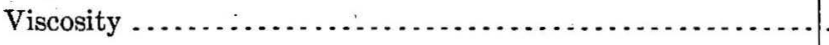 & $\ldots \ldots \ldots$. & Cone 27 & ............... \\
\hline 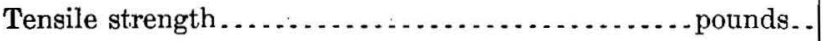 & $5-6$ & 20 & ........... \\
\hline 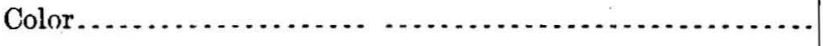 & Yellow. & Yellow. & Yellow. \\
\hline
\end{tabular}

1. Montague mines.

2. Valley Head.

3. Fort Payne, Dekalb County.

COAL MEASCRES.

The Coal Measures occupy a large triangular area in the northern part of the State, and should prove to be of importance to the clay worker. The following counties are largely covered by them: Lawrence, Morgan, Jackson, Marshall, Dekalb, Cullman, Winston, Walker, Blount, Jefferson, Shelby. Unfortunately a large portion of this area lies remote from the railways, although it is traversed by the Northern Alabama and the Louisville and Nashville railroads.

The under clays in some parts of the conl fields have been employed for making 
pottery, as at Jugtown, near Sterrit, in St. Clair County, and also at Fort Payne and Rodentown, in Dekalb County; Advance station, in Tuscaloosa County; Summit, in Blount County, and Arab, in Marshall County.

The shales are used in some parts of the State for making vitrified brick, especially at Coaldale. At the Graves coal mine, near Birmingham, there are two bodies of shale which are promising. Good exposures of Carboniferous shale also outcrop near Pearces Mills, in Marion County, and are probably well adapted for pressed brick or even terra cotta. No fire clays have been found in the Coal Measures."

The following tests indicate the characters of some of these materials:

Analyses and tests of Carboniferous shales of Alabama.

\begin{tabular}{|c|c|c|c|c|}
\hline & 1. & 2. & 3. & 4. \\
\hline Silica ... . . . . . . . . & 57.80 & 61.55 & & \\
\hline Alumina........... & 25.00 & 20.25 & & \\
\hline Ferric oxide ........ & 4.00 & 7.23 & &. \\
\hline lime............ & 2. 10 & Trace. & & \\
\hline Magnesia ..... & .80 & .986 & & \\
\hline 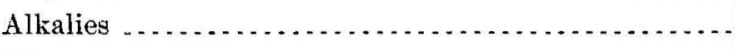 & 1.80 & 2.25 & & - . \\
\hline Water .......... & 7.50 & 6.19 & & - \\
\hline Water required ......................... per cent. . & 25 & 20 & 22 & 40 \\
\hline 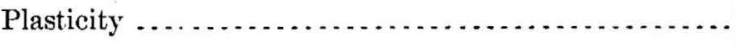 & Good. & Moderate. & Lean. & \\
\hline Tensile strength ............ & 105 & 40 & 25 & -..... \\
\hline 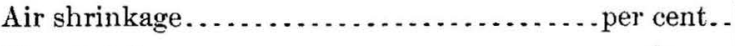 & 2 & $1 \frac{1}{2}$ & 4 & 4 \\
\hline 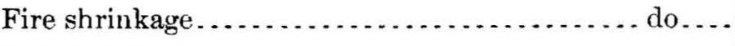 & 10 & 5 & 5.5 & 5 \\
\hline Incipient fusion $\ldots \ldots \ldots \ldots \ldots \ldots$ & 2,000 & 2,000 & 1,900 & 2,100 \\
\hline Vitrified ........... & 2,200 & 2,250 & 2,150 & 2,300 \\
\hline Color ... & Red. & Red. & Red. & Red. \\
\hline
\end{tabular}

1. Gray shale, Birmingham. Alabama Geol. Survey, Bull. No. 6, p. 186.

2. Yellow shale, Birmingham. Ibid.

3. Shale, Coaldale. Ibid., p. 187.

4. Shale, Pearces Mills, Marion County. Ibid., p. 188.

CRETACEOUS. ${ }^{b}$

The Cretaceous formations are no doubt the most important clay-bearing beds in the State, and most of the deposits have thus far been found in one member of the Cretaceous, namely the Tuscaloosa. This consists usually of yellow and grayish sands, with smaller beds of pink and light-purple sands thinly laminated, dark-gray clays holding many leaf impressions, and gray lenses of massive clay which vary in color from yellow to almost pure white. This formation occupies a belt of country 
extending from the northwest corner of the State around the edges of the Paleozoic formations to the Georgia State line at Columbus. Its greatest width is at the northwest boundary of the State, where it is 30 or 40 miles wide in Alabama and about the same width in Mississippi. From here the belt gradually diminishes in breadth toward the southwest, until at Wetumka and thence eastward to the State line it forms the surface along a belt only a few miles wide. East of the Alabama River the proportion of clay to the rest of the strata is less than in any other section, and at the same time the clays in this region are more sandy. From the Alabama River northwestward, in the gullies, ravines, and railroad cuts, there are many exposures of these belts exhibiting sections of clay beds from 6 to 50 feet thick and of varying degrees of purity. The purer clays have as yet been found in only the northern part of this area, in Fayette, Marion, Franklin, and Colbert counties, and in the adjoining parts of Mississippi. ${ }^{a}$

Some of the more important occurrences may be mentioned, beginning with the counties in the southeastern end of the Lower Cretaceous belt.

In Russell and Macon counties clays are exposed along the river flowing through Girard, in the hills west of the town, and mottled clays outcrop near Marvyn; Crawford, and Society Hill.

In Elmore and Autauga counties pottery clays are worked around Edgewood, the section at Chalk Bluff, EImore County, being as follows:

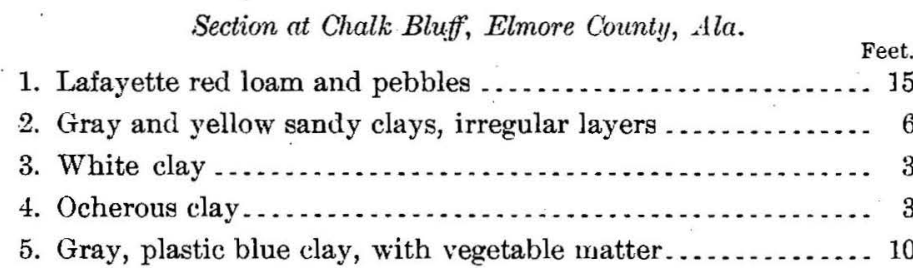

North and northwest from Plattville there are many exposures, but they are rather sandy.

In Bibb County good exposures of massive clays are found between Randolph and Centerville, and again southwest of Centerville, in Ts. 21 and 22 , Rs. 7 and 8. ${ }^{b}$

Additional good exposures occur along the Alabama Great Southern Railroad, as at Bibbville, where the clays have been used for fire brick, much clay being shipped to Bessemer from this locality. Other pits are at Woodstock, which lies to the north.

In Tuscaloosa many good exposures occur within the city limits, and some of them have been worked for pottery. The clays are exposed in ravines and along the Alabama Great Southern Railroad east of Tuscaloosa.

a Local details of the Tuscaloosa formation in the counties of Pickens, Fuyette, Marion, Franklin, Colbert, Lee, Russell, Macon, Lamar, Autauga. Cherokee, Perry, Bibb, and Tuscaloosa are given in the Alabama Geol. Survey, Coastal Plain, pp. 307-349, 531, 532, 536, 541, 549, 554, 556, 559.

$b$ Ibid., p. 345. 
The following section, 10 to 12 miles east of 'Tuscaloosa, illustrates the character of the formation:
Section 10 to 12 miles east of Tuscaloosa, Ala. Feet. Inches.
1. Purple, massive clays................................ 50
2. Ferruginous sandstone crusts....................... $6-8 \quad 0$
3. Variegated clayey sands, holding small pieces of purple clay . $\begin{array}{ll}10 & 0\end{array}$
4. Purple clays with partings of sand..................... $10 \quad 0$
5. Ferruginous crust ................................ 10
6. Laminated gray and yellow, sandy clay ...............6-8 0
7. Lignite with pyrite nodules .......................... $2 \quad{ }_{2} \quad 6$
8. Dark-gray, somewhat massive clays.................... $6 \quad 6$
9. Strata obscured by débris from above ................... 18
10. Purple clay at base of hill, thickness undetermined.

In Pickens County clays are seen near the line of the Mobile and Ohio Railroad from the Tuscaloosa County line to near Columbus. Lamar County contains many deposits of clay underlying the surface red loam of the Lafayette formation, especially at Millport, Fernbank, between Fayette Court-House and Vernon, also at Buttahatchie Creek above Hunnels Bluff, and on Wilson Creek near Friendship Church. The clays show considerable variety.

Pottery clays have been worked one-half mile east of Sulligent and 6 miles north of Millville. The products from these compete with those made at Holly Springs, Miss.

Fayette County contains many beds of purple, gray, and white clay. The lastmentioned occur around the court-house.

The following section, 1 mile east of Concord Church, shows several beds of promising character: ${ }^{a}$

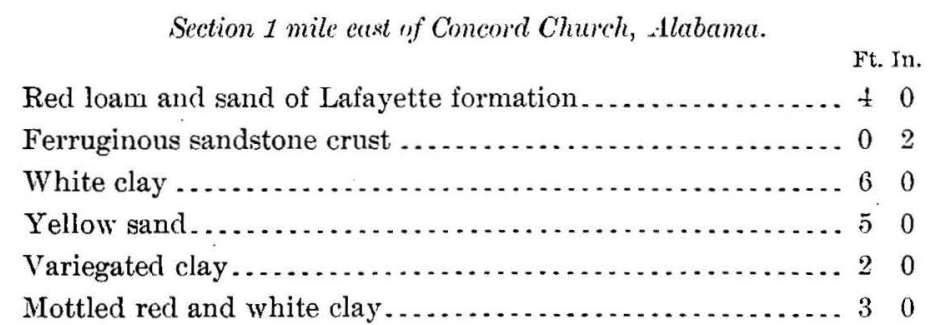

Marion County ${ }^{b}$ shows much Tuscaloosa clay, the materials being exposed in the cuts from Eldridge to Guin along the Kansas City, Memphis and Birmingham Railroad. Thick beds also outcrop around Glen Allen, ${ }^{c}$ and white siliceous clays occur around Chalk Bluff and Pearces Mill, Marion County. (See No. 6 of the analyses.) Much clay also occur's near Bexar, and this closely resembles that used for pottery across the border in Mississippi.

a Bull. Alabrma Geol. Surver No. 6, p. 103.

bAlabama Geol. Survey, Bull. No. 6, p. 104, and Coastal Plain, pp. 331, 332, 333.

c Bull, Alabama Geol. Survey No. 6, pp. 104 and 105. 
Colbert County contains fire clays, which have been worked near Pegram, on the Southern Railroad. The clay is obtained from the following section, exposed in the NW. $\frac{1}{4}$ sec. 34 , T. 3 N., R. 15 W.

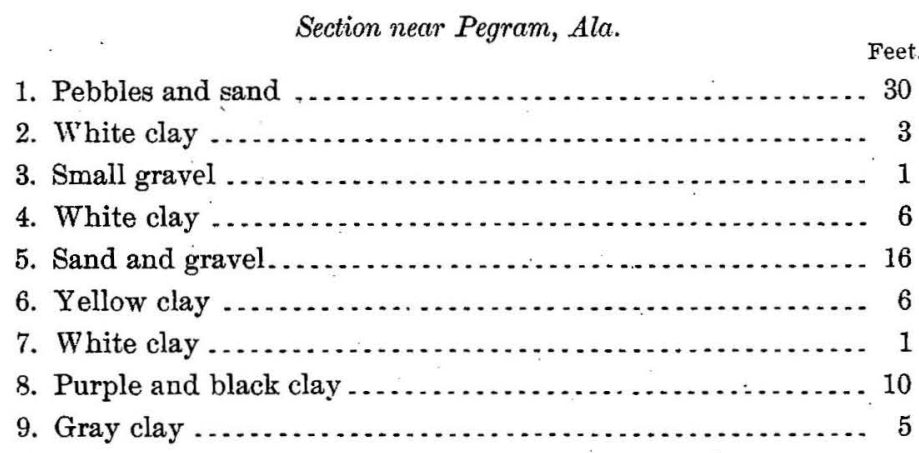

Tests are given below of $4,6,8$, and $9 .^{a}$

Lauderdale County contains a bed of paint clay 10 feet thick, near the county line.

In the following table are given the physical tests and chemical analyses of a . number of Lower Cretaceous clays, taken from Bulletin 6 of the Alabama Geological Survey. In each case the page on which the tests appear is given.

Analyses and tests of Lower Cretaceous clays of Alabama.

\begin{tabular}{|c|c|c|c|c|c|c|c|}
\hline & 1. & 2. & 3. & 4. & 5. & 6. & 7. \\
\hline Silica. & 60.50 & 56.28 & $74.25^{\circ}$ & 65.82 & 58.13 & 52.95 & 80.55 \\
\hline Alumina ....... & 26.55 & 32.50 & 17.25 & 24.58 & 24.68 & 35.10 & 10.50 \\
\hline Ferric oxide. & .30 & .20 & 1.19 & 1.25 & 3.85 & .80 & 1.53 \\
\hline Lime........ & .90 & Trace. & .40 & $\ldots \ldots$. & .15 & Trace. & .34 \\
\hline Magnesia ........ & .65 & Trace. & Trace. & Trace. & .32 & Trace. & Trace. \\
\hline Alkalies......... & 2.70 & Trace. & .52 . & .60 & 1.78 & .93 & $\ldots$. \\
\hline Water............... & 7.20 & 11.05 & 6.30 . & 8.165 & 11.78 & 11.40 & 5.85 \\
\hline Moisture ... & .70 & .20 & & & & & 1. 70 \\
\hline Plasticity ............. & Lean. & Lean. & Good. & Moderate. & Good. & Lean. & Lean. \\
\hline Per cent $\mathrm{H}_{2} \mathrm{O}$ required. & 30 & 25 & 22.6 & 23 & 36 & 37 & 28.6 \\
\hline Tensile strength..... & 9 & 14 & 102 & 105 & & & 46 \\
\hline Air shrinkage ....... & 4 & 3 & $6 \frac{1}{2}$ & 7 & 12 & 4 & 10 \\
\hline Fire shrinkage ... & 12 & 12 & $3 \frac{1}{2}$ & 11 & 6 & & 3 \\
\hline Incipient fusion ... & 2,000 & 2,300 & 2,300 & $2,150^{\circ} \mathrm{F}$. & 2,200 & Cone 27 & 2,150 \\
\hline Vitrification ...... & $\cdots$ & 2,500 & Cone 27 & $2,350^{\circ} \mathrm{F}$. & Cone 27 & Cone 30 & 2,350 \\
\hline Viscosity :........ & ............ & $2,700+$ & ….. & $2,900^{\circ} \mathrm{F}$ & & Cone 33 & 2,500 \\
\hline Color when burned.... & Whitish. & White. & Buff. & Buff. & Reddish. & Whitish. & $\begin{array}{r}\text { Yellowish } \\
\text { white. }\end{array}$ \\
\hline
\end{tabular}

aBull. Alabamr Geol. Survey No. 6, pp. 110, 130,158; and Valley Regions, Pt. I., p. 180 
Analyses and tests of Lower Cretaceous clays of Alabama-Continued.

\begin{tabular}{|c|c|c|c|c|c|c|c|c|}
\hline & 8. & 9. & 10. & 11. & 12. & 13. & 14. & 15. \\
\hline Silica................. & 60.38 & . & 60.03 & 68.23 & 60.9 & 69.50 & 65.58 & 67.10 \\
\hline Alumina .............. & 20.21 & & 24.66 & 20.35 & 18.98 & 13 & 19.23 & 19.37 \\
\hline Ferric oxide ......... & 6.16 & - & 3.69 & 3.20 & 7.68 & 6.40 & 4.48 & 2.88 \\
\hline Lime. . . . . . . . . . . & .09 & $\cdots$ & .13 & .34 & Trace. & .25 & Trace. & Trace. \\
\hline Magnesia .............. & .72 & $\ldots \ldots \ldots$ & .38 & Trace. & Traice. & Trace. & Trace. & .725 \\
\hline Alkalies.......... & 1.80 & & Trace. & .74 & Trace. & Trace. & Trace. & .672 \\
\hline Water............ & 10.21 & $\ldots \ldots \ldots$ & 11. 342 & 6.10 & 12.46 & 6.70 & 5.50 & 6.08 \\
\hline Moisture ... & - & & . & ........ & .90 & 3.40 & 1. 40 & 1. 71 \\
\hline Plasticity .............. & $\cdots$. & Fair. & .... & Good. & Fat. & Good. & Good. & ........ \\
\hline Per cent $\mathrm{H}_{2} \mathrm{O}$ required. & 38 & 36 & 31.5 & 21.8 & 45 & 32.6 & $34: 3$ & 25 \\
\hline Tensile strength.... & $300-384$ & 100 & 85 & 117 & 100 & 152 & 116 & $\begin{array}{r}a 95 \\
b 111\end{array}$ \\
\hline Air shrinkage. .... . & 6 & 11 & 9 & 4 & 12.5 & 10 & 7 & 6.2 \\
\hline Fire shrinkage .... & 7 & 7 & 8 & 8 & 6.5 & 7 & 6 & 5.8 \\
\hline Incipient fusion. . . . . & 2,100 & 2,100 & 2,100 & 2,000 & 1,900 & 1,900 & 2,000 & 2,000 \\
\hline Vitrification ...... & 2,200 & 2,300 & 2,200 & 2,200 & 2,100 & 2,100 & 2,200 & - $\ldots \ldots$ \\
\hline Viscosity ... & 2,600 & Cone 27 & 2,500 & 2,400 & 2,300 & 2,300 & 2,400 & 2,400 \\
\hline \multirow[t]{2}{*}{ Color when burned.... } & 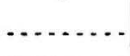 & Red. & Buff. & Buff. & Red. & Red. & Red. & Red. \\
\hline & 16. & 17. & 18. & 19. & 20. & 21. & 22. & 23. \\
\hline Silica & 72.20 & 67.50 & 66.45 & 71.32 & & 75.70 & 71.33 & 72.40 \\
\hline Alumina ..... & 17. 42 & 19.84 & 18.53 & 20.10 & & 14.36 & 21.88 & 14.86 \\
\hline Ferric oxide .......... & 2.40 & 6.15 & 2. 40 & 1.05 & & 4.64 & .32 & 7.64 \\
\hline Lime.......... & Trace. & .12 & 1. $\check{0}$ & Trace. & & Trace. & .234 & .20 \\
\hline Magnesia ... & Trace. & .10 & 1.25 & .316 & & Trace. & .305 & .40 \\
\hline Alkalies... & .56 & 1.50 & Trace. & Trace. & & - & 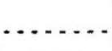 & $\ldots$ \\
\hline Water..... & 7.40 & 6.15 & S. 68 & 7.505 & & 4.45 & 5.54 & 5.05 \\
\hline Moisture ......... & .12 & $\ldots \ldots$ & .78 & $\cdots .$. & $\ldots$ & 1.24 & 1.05 & .65 \\
\hline Plasticity ... & .... & & $\ldots$ & & & 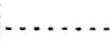 & 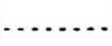 & $\cdots$ \\
\hline Per cent $\mathrm{H}_{2} \mathrm{O}$ required. & 33 & 20 & 26 & 33 & 40 & 28 & 26 & 39 \\
\hline \multirow{2}{*}{ Tensile strength. } & a 106 & a 102 & a 30 & - & & $a 45$ & a 66 & $a 55$ \\
\hline & $b 123$ & $b 127$ & $b 35$ & & - & $b 53$ & $b 68$ & $b 80$ \\
\hline Air shrinkage.... & 10 & 10 & 5 & 6 & 6 & 6 & 6 & 6 \\
\hline Fire shrinkage ........ & 4 & 4 & 10 & 10 & 14 & 3 & 3 & 11 \\
\hline Incipient fusion....... & 2,000 & 1,900 & 2,150 & 2,100 & 2,100 & 2,100 & 2,000 & 2,000 \\
\hline Vitrification ...... & 2,200 & 2,100 & 2,300 & 2,200 & 2,250 & 2,250 & 2,160 & 2,150 \\
\hline Viscosity . & 2,400 & 2,300 & 2,500 & Cone 27 & Cone 2 & 2,400 & 2,300 & 2,300 \\
\hline Color when burned.... & Buff. & Red. & $\begin{array}{c}\text { Yellowish } \\
\text { white. }\end{array}$ & Cream. & Brown. & Buff. & Buff. & Red. \\
\hline
\end{tabular}


1. Rock Run; Cherokee County. Alabama Geol. Survey, Bull. No. 6, p. 119.

2. Pearces Mills, Marion County. Ibid., p. 130.

3. Bibbville, Bibb County; fire clay. Ibid.; p. 151.

4. Elgin property, near Woodstock, Bibb County. Ibid., p. 153.

5. J. C. Bean, Tuscaloosa County; fire clay. Ibid., p. 154.

6. Pearces Mills, Marion County; fire clay. Ibid., p. 157.

7. J. W. Williams, Pegram, Colbert County. Ibid., p. 158.

8. Chalk Bluff, Elmore County; stoneware clay.

9. J. C. Bean, Tuscaloosa, Tuscaloosa County. Alabama Geol. Survey, Bull. No. 6, p. 170.

10. J. C. Bean, Tuscaloosa, Tuscaloosa County. Ibid., p. ' $>$ 1.

11. Roberts Mill, Coal Fire Creek, Pickens County. Ibid.

12. Cribbs's place, Bedford, Lamar County; pottery clay. Ibid., p. 173.

13. J. B、 Green, Fernbank, Lamar County. Ibid., p. 174.

14. W. Doty, Fayette County; pottery clay. Ibid., p. 175.

15. W. Doty, Fayette County; pottery clay. Ibid., p. 176.

16. Shirleys Mills, Fayette County; pottery clay. Ibid., p. 178.

17. T. Rollins, Franklin County; pottery clay. Ibid., p. 181.

18. J. W. Williams, Pegram, Colbert County; pottery clay.' Ibid., p. 182.

- 19. Shirleys Mills, Fayette County. Ibid., p. 190.

20. Chalk Bluff, Elmore County. Ibid., p. 191.

21. W. D. Bagwells, 7 miles north of Fayette Court-House, Fayette County. Ibid., p. 195.

22. H. Palmer, Bexar, Marion County. Ibid.

23. Bexar, Marion County; mottled clay. Ibid., p. 197.

TERTIARY.

The Tertiary formations underlie the southern third of Alabama. While it is known that they contain extensive deposits of clay, they have not been investigated.

A siliceous clay, resembling flint clay in appearance, is found in abundance in the counties of Choctaw, Clarke, Conecuh, etc., in the Lower Claiborne or Buhrstone division of the Tertiary. The composition of this flint is as follows:

Analyses of fire clay from Choctaw County, Ala.

\begin{tabular}{|c|c|c|}
\hline & 1. & 2. \\
\hline Silica $\ldots . . . \ldots$. & 86.30 & 85.70 \\
\hline Alumina ....... & 5.12 & 6.15 \\
\hline Ferric oxide ............... & 1. 60 & 1.80 \\
\hline Lime................. & .46 & Trace. \\
\hline Water $\ldots \ldots \ldots$ & 6.60 & 7.00 \\
\hline Total & 100.08 & 100.65 \\
\hline
\end{tabular}

PLEISTOCENE.

Over much of the Coastal Plain in the second bottoms of the rivers there is a great extent of yellow loam suitable for brick making. It corresponds in age to the 
Columbia loams of the Northern States. No laboratory examination of it has been made.

CLAY-WORKING INDUSTRY.

Alabama ranked number 26 among the clay-producing States in 1900, and number 23 in 1901. In view of the variety of clays available this indicates a small development of the industry, due no doubt partly to lack of knowledge of the available raw materials and partly to absence of market. For the former reason it may be well, therefore, to group together the occurrences of the more important kinds of clay thus far described.

China clays. - The kaolins have already been collectively described on a previous page and need not be discussed again here.

Fire clays.-The fire clays of Alabama come from four geologic horizons, namely: (1) The Cambrian and Silurian limestone formations of the Coosa Valley region, seen at Peaceburg, Calhoun County, Oxanna, Calhoun County, and Rock Run, Cherokee County; (2) the cherty limestone of the Lower Carboniferous formations of Wills Valley, seen at Wills Valley and Valley Head, Dekalb County; (3) the Tuscaloosa formation of the Lower Cretaceous, occurrences being known at Bibbville and Woodstock, in Bibb County, Hull station and Tuscaloosa, in Tuscaloosa County, Potters Mills, in Marion County, and Pegram in Colbert County; (4) the Lower Tertiary formation, Choctaw County.

Very few of these deposits have been worked, but a number of them have been tested for the Alabama geological survey, as previously mentioned.

The refractory character of some of these Alabama fire clays can be judged from the following tests made on them in the Deville furnace:

Refractoriness of tlabama five clays.

\begin{tabular}{|c|c|}
\hline Locality. & Refractoriness. \\
\hline Peaceburg, near Anniston. . . . . . . . & Vitrified at cone 30 and still retained its shape. \\
\hline Rock Run, Cherokee County ............... & $\begin{array}{l}\text { Some bauxites vitrified at cone } 30 \text {, while others } \\
\text { showed only incipient fusion. }\end{array}$ \\
\hline 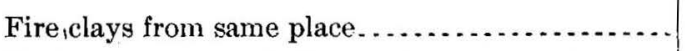 & Usually vitrified at cone 30. \\
\hline Valley Head, Dekalb County, Montague mines.... & Incipiently fused at cone $2 \pi$. \\
\hline Second grade of fire clay, same mines....... & Viscous at cone $2 \pi$. \\
\hline Bibbville, Bibb County............. & Incipiently fused at cone $2 \bar{\tau}$. \\
\hline J. C. Bean, Tuscaloosa County ....... . & Vitrified at cone $2 \pi$ \\
\hline Pearces Mills, Marion County ........ & Vitrified at 30 ; became viscous at 33 . \\
\hline
\end{tabular}

Clays suitable for the manufacture of pottery and stoneware are found at a number of places, among which are the following: Property of F. S. White, Blount County; C. C. Davenport, Rọck Run, Dekalb County; McLean Pottery Company, 
Coosada, Bedford, Fernbank, Lamar County; Cribb's pottery, Tuscaloosa, and J. C. Bean, Tuscaloosa County; Coal Fire Creek, Pickens County; Shirleys Mill, Fayette County; Pegram, Colbert County.

Brick clays.-Many deposits occur in the State, in several formations, among them the Carboniferous shales, Cambro-Silurian limestone residuals, and the second bottoms of the Coastal Plain.

Clay products.-Brick works are located at a great many places, chief among which may be mentioned Anniston, Bessemer, East Birmingham, Geneva, Mobile, Montgomery, North Birmingham, and Talledega. Fire brick are made in the vicinity of Birmingham, and at Anniston, Ashby, and Pegram. There are no fewer than 30 potteries scattered over the State, the products consisting of earthenware and stoneware. No white ware is manufactured in Alabama. The value of the clay products of Alabama has been as follows:

Value of clay products of Alabama in 1901.

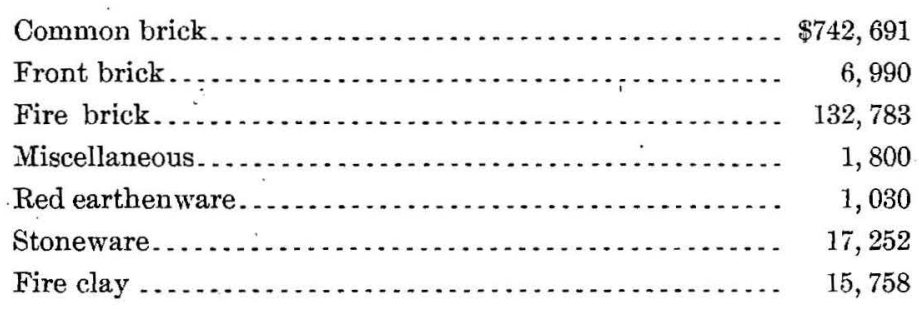

Value of clay products of Alabama from 1895 to 1901.

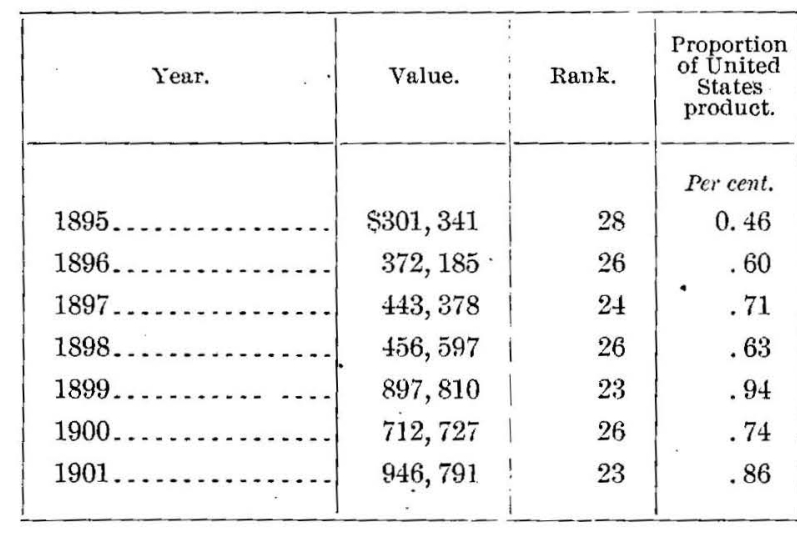

CONNECTICUT.

CLAYS.

The clays of Connecticut are nearly all surface deposits of Pleistocene age, and hence are suitable only for the manufacture of structural products, drain tile, or the lower grade of pottery. 
A deposit of kaolin, formed from the decomposition of feldspathic gneiss, occurs about 4 miles west of West Cornwall. It is washed and shipped to white-ware potteries. Indications seem to warrant the assumption that the deposit is very large. An analysis of the washed product is given below:

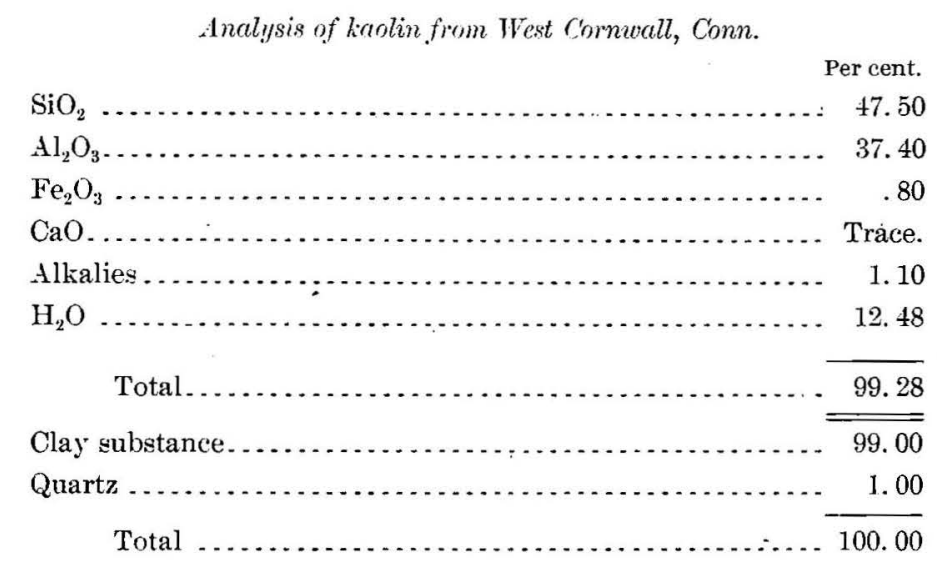

The material is very refractory, its fusing point lying above cone 27 .

\section{CLAY-WORKING INDUSTRY.}

Many common brick are made in Connecticut from surface clays; especially around Berlin, Hartford, New Haven, and Middletown. Fire brick are produced at New Haven from New Jersey clays. Some pottery is also manufactured.

The total value of the clay products of Connecticut and Rhode Island ${ }^{a}$ from 1895 to 1901 was as follows:

Total ralue of clay products of Connerticut and Rhode Island from 1895 to 1901.

\begin{tabular}{|c|c|c|c|c|}
\hline Year. & vilue. & ; & Runk. & $\begin{array}{l}\text { Proportion } \\
\text { of United } \\
\text { States } \\
\text { product. }\end{array}$ \\
\hline & & 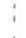 & & Per cent. \\
\hline 1895. & 8831,925 & 1 & 20 & 1.27 \\
\hline 1896 & $1,151,598$ & & 11 & 1. 85 \\
\hline 1897. & $1,336,670$ & ; & 10 & 2.13 \\
\hline 1898 & 952,180 & : & 16 & 1.32 \\
\hline 1899. & $1,074,202$ & $\vdots$ & 20 & 1. 12 \\
\hline $1900 \ldots . .$. & $1,099,972$ & 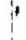 & 20 & 1. 14 \\
\hline $1901 \ldots \ldots \ldots \ldots$ & $1,130,909$ & & 21 & 1.03 \\
\hline
\end{tabular}

a Rhode Islund is included in the Geolngienl survey statistics after 1897 , and henee it is necessary to give the two together. 


\section{DELAWARE.}

CLAYS.

Little has been published regarding the clay resources of this State. In its northwestern part, along the Pennsylvania boundary, deposits of kaolin similar to those found in southeastern Pennsylvania have been worked for a number of years at Hockessin and Newark, Del. The product is washed before shipment.

The Potomac beds of the Coastal Plain area are said to contain stoneware and fire clays, and have been worked at one or two localities not far from Wilmington to supply the chemical stoneware works at Philadelphia.

J. C. Booth, in his Memoir of the Geological Survey of Delaware (1841), refers to a red-clay formation which shows well in the borders of Christiana Creek, where it forms hills rising to 60 or 80 feet above tide. It is mostly red, but contains occasional veins of white clay. It is stated to be of value at one locality on the Delaware shore below Newcastle.

\section{CLAY-WORKING INDUSTRY.}

Delaware is of little importance as a producer of clay products. The total value between 1895 and 1901 is given below:

Value of clay products of Delaware from 1895 to 1901.

\begin{tabular}{|c|c|c|c|}
\hline Year. & Value. & Rank. & $\begin{array}{c}\text { Proportion } \\
\text { of United } \\
\text { States } \\
\text { product. }\end{array}$ \\
\hline & & & Per cent. \\
\hline 1895. & $\$ 58,615$ & 41 & 0.09 \\
\hline $1896 \ldots$ & 61,003 & 41 & .10 \\
\hline $1897 \ldots$ & - 68,458 & 40 & .11 \\
\hline $1898 \ldots$ & 90,555 & 39 & .13 \\
\hline $1899 \ldots \ldots$ & 168,485 & 38 & .18 \\
\hline $1900 \ldots$ & 156,274 & 39 & .16 \\
\hline $1901 \ldots$ & 131,164 & 40 & .12 \\
\hline
\end{tabular}

DISTRICT OF COLUMBIA.

CLAYS.

A small but energetic local industry is based on clays derived from the Coastal Plain formations of this area. According to Darton, ${ }^{a}$ there is an abundance of brick clay in the vicinity of Washington, and much of it is used. The clays worked are 
chiefly of later: Columbia age, but at the intersection of Bladensburg road and Florida avenue extensive excavations have been made in sandy Potomac clays.

The chief workings in Columbia loams are on the west side of the Potomac River, between Washington and Alexandria, and just south of Alexandria.

In the eastern part of Washington wide areas have been stripped of a thin layer of loam for brickmaking. The upper loam is suitable for brick over the greater part of the wide later Columbia terraces adjoining the Potomac River. On the smaller areas along creeks and on the terraces adjoining the greater part of the Anacostia River the deposit is usually too sandy for working.

The sandy clays of the Potomac are often suitable for brickmaking, and have been used to some extent. On the wider terraces of earlier Columbia and Lafayette formations are many local areas of loam which are available. Other sources of supply are detrital clays and alluvium from crystalline rocks.

The Potomac clays are worked for tiles at Terra Cotta, University station, and Lamond, on the Metropolitan Branch of the Baltimore and Ohio Railroad. Many masses of these clays occur, especially east of the Anacostia River.

\section{CLAY-WORKING INDUSTRY.}

The value of the clay products of the District of Columbia each vear since 1895 is as follows:

Value of clay products of District of Columbia from 1S:5 to 1901.

\begin{tabular}{|c|c|c|c|}
\hline Year. & Value. & Rank. & $\begin{array}{l}\text { Proportion } \\
\text { of Lnited } \\
\text { States } \\
\text { product. }\end{array}$ \\
\hline & & & Per cent. \\
\hline $1895 \ldots \ldots \ldots . . . . . .$. & $\$ 373,304$ & 27 & $0 . \overline{7}$ \\
\hline $1896 \ldots$ & 353,565 & 28 & .57 \\
\hline $1897 \ldots \ldots \ldots \ldots$ & 288,981 & 30 & .46 \\
\hline $1898 \ldots$ & 320,320 & 30 & .45 \\
\hline 1899. & 481,145 & 33 & .50 \\
\hline $1900 \ldots$ & 288,933 & 35 & .30 \\
\hline $1901 \ldots \ldots \ldots . . . . .$. & 324,008 & 35 & .29 \\
\hline
\end{tabular}

\section{FLORIDA.}

The clays of Florida are mostly surface deposits of Tertiary or Pleistocene age, and occur chiefly in the northern part of the State. Very little has been published regarding them. The following facts are taken mostly from published notes made by the writer several years ago. ${ }^{a}$

a Seventeenth Ann. Rept. U. S. Geol. Survey, Pt. III (continued), p. 87o.

$9647-$ No. $11-03-6$ 
Brick clays are of common occurrence in Florida, especially in the northern balf of the State, but they are often sandy and are worked on only a small scale at many localities. A large pit has been opened at Jacksonville for brickmaking. Other plants are at Ocklocknee, west of Tallahassee, Bartow, Leesburg, etc.

BAII, CLAY.

Florida is one of the few States producing this material. It occurs at several points in the north-central portion of Florida (PI. IX), and the different areas may represent portions of a formerly continuous bed. It is undoubtedly of sedimentary origin, and the occurrence of such an extensive deposit so free in most places from impurities is remarkable. The mass is made up of a mixture of white clay and quartz pebbles, the latter forming 65 to 75 per cent of the entire mass, so that for every ton of washed clay about four tons of the crude material have to be mined. The quartz pebbles vary in size from that of a pin head to a diameter of three-quarters of an inch. The largest ones seem to occur chiefly at the northern end of the area in which the kaolin is found. If the deposits were nearer to the pottery centers, or if freight rates were lower, the pebbles could no doubt be ground for potter's use. The largest pit which was being worked at the time of the writer's visit was that at Edgar, Fla., (Pl. I, A), which is about 50 miles southwest of Jacksonville. The section in the pit at this locality was as follows:

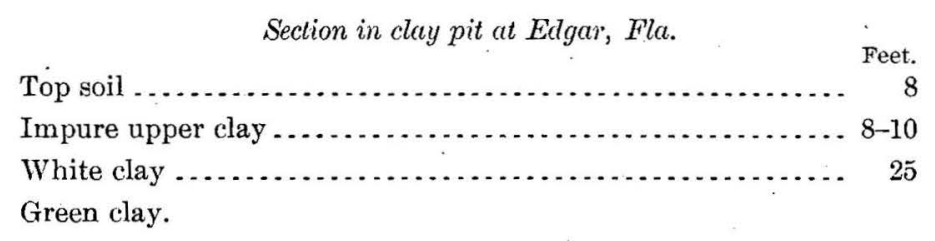

The thickness of the green clay is not exactly known, but at other localities it is seen to rest on limestone.

Another but more extensive area of this clay occurs along the Palatlakaha River, south of Leesburg, Lake County. This large clay tract begins 1 mile south of Lake Harris, into which the Palatlakaba River flows, and extends along both sides of the river nearly to Villa City. Throughout this belt there is an overburden of about 3 feet of loose sand, under which lies the white ball clay, of a depth varying from 10 to 30 feet. It is frequently well exposed in the bluffs along the river. This deposit has been opened up at a point about $t$ miles south of Leesburg, where it is said to be 25 to 30 feet thick.

Another area of this same clay occurs at Bartow Junction, Polk County, about 45 miles northeast of Tampa.

The sandy character of the raw clay permits its being worked by a method somewhat different from that usually practiced at most kaolin mines. At Edgar 
the pit is filled with water, and on this there is a float carrying a scraper and pump. The former loosens up the clay in the bottom of the pit and the latter draws it up to the surface and discharges the water, with suspended clay and sand, into the washing troughs.

Owing to the fact that this Florida clay is very plastic it is put on the market under the name of ball clay. It is very refractory and burns white. In the table below are given chemical analyses of the clay from different points. It differs from the English ball clay chiefly in its greater refractoriness, and also somewhat in its plasticity. The shrinkage of it at cone 8 is stated by Langenbeck to be 15 per cent. ${ }^{t}$

Analyses of Florida ball clay.

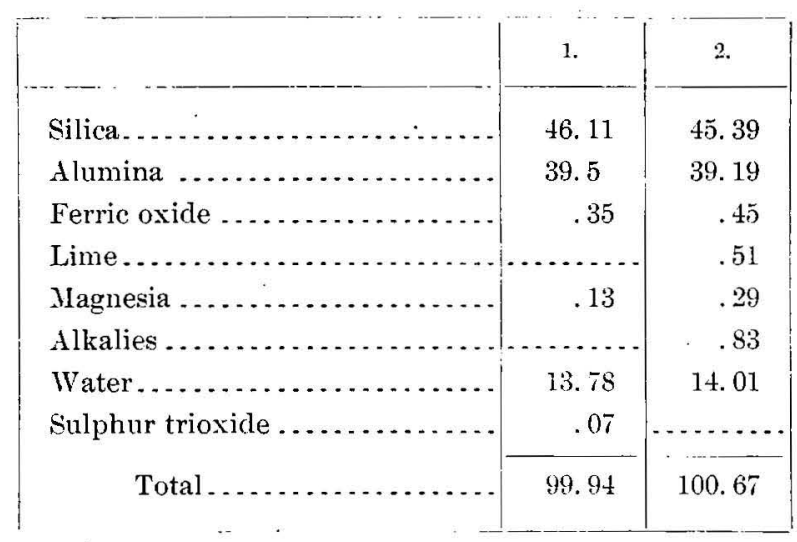

1. Washed clay from Palatlakaha River.

2. Washed clay from Edgar.

According to Mr. T. W. Vaughan, of the United States Geological Survey, who has been doing field work on the Tertiary formations of northern Florida and southwestern Georgia, another deposit of ball clay occurs on the land of $\mathrm{Mr}$. Augustus Munroe, sec. 32, T. 10 S., R. 23 E. Mr. Vaughan states that-

"The material is very sandy, but its thickness could not be ascertained from observation. Several auger holes had been sunk, and these indicate a thickness of about 10 feet. The bed is said to be thicker near the summit of the hill. The overburden varies from 4 to 10 feet, and the deposit can be economically worked over an area of several acres. The transportation facilities are good, as the Plant System railway is only a half mile distant."

Mr. Vaughan bas supplied a number of data regarding the clays in that region, which are given below.

White calcareous clay outcrops on the land of W. B. Stoutamire, 18 miles southwest of 'Tallahassee, Leon County, and three-quarters of a mile north of his house. The outcrop is on a hillside in sec. 1, T. 1 S., R. 4 W. 
The chemical composition of the clay is indicated by the following analysis:

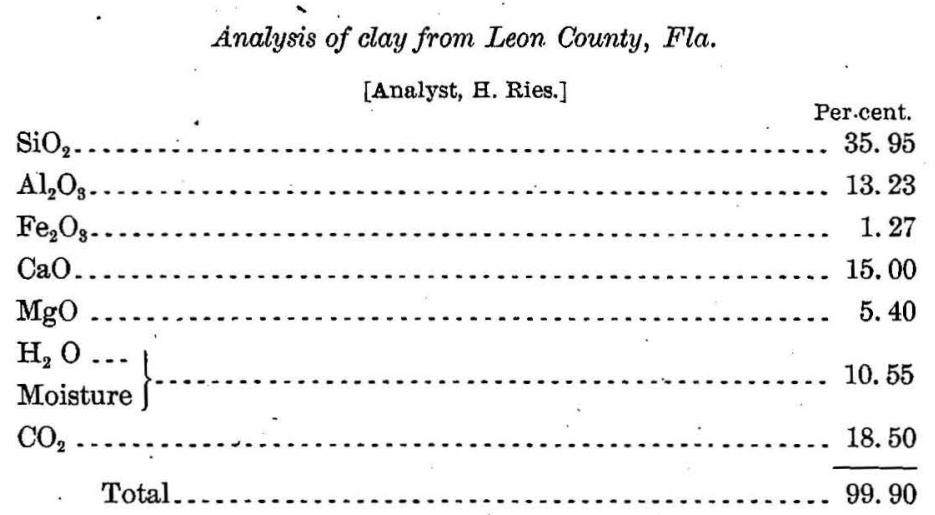

Brick clay crops out on the property of J. D. Stoutamire, in sec. 15, T. 1 S., R. 4 W. A physical examination of this clay shows it to be very plastic and to absorb 40 per cent of water in being worked up. It has a large air shrinkage-17 per cent-and when being burned up to cone 05 its fire shrinkage is 4 per cent, and up to cone 2 its fire shrinkage is 5 per cent. Its tensile strength is very good, ranging from 175 to 210 pounds per square inch. The clay is peculiar in that it burns to a very light-buff product, due apparently to a low percentage of iron oxide, and not to the presence of carbonate of lime. Incipient fusion occurs at 05 , and the clay burns to a hard, dense product at cone 2 . If mixed with sufficient sand to prevent its shrinking so much in burning, it could, very probably, be utilized in the manufacture of light-colored front brick. , It does not show the same tendency to crack in drying that the sample from Climax, Ga., does. Owing to its light color, the soluble salts, if present, did not tend to show themselves.

Another locality at which calcareous clay was found is on the land of $\mathrm{Mr}$. W. W. Williams, about one-half mile southeast of Jackson Bluff, on the Ochlockonee River, in sec. 21, T. 1 S., R. 4 W. The outcrop occurs in the bed and along the sides of a small creek. The material is overlain by about 6 feet of sandy alluvium, and $2 \frac{1}{2}$ feet of clay is exposed. The chemical composition is given below:

Analysis of calcareous clay from the land of Mr. W. W. Williams, near Jackson Bluff, Ochlockmee River, Fla. [Analyst, H. Ries.]

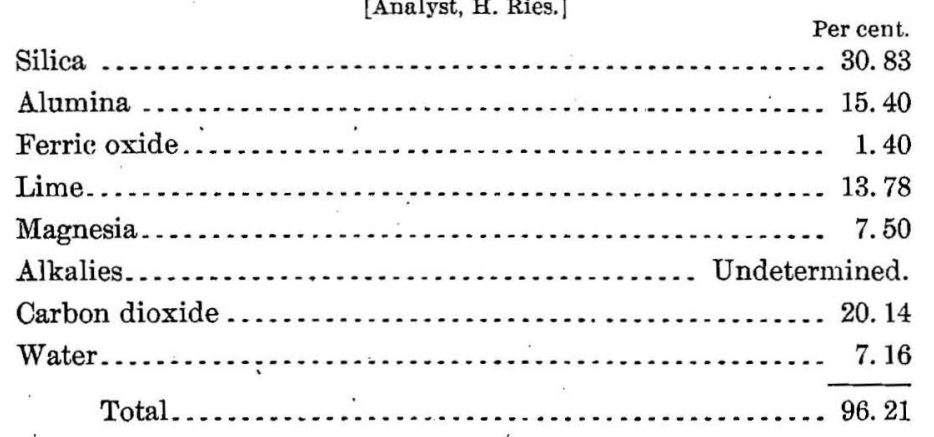


This clay behaves very differently from most calcareous clays and may possibly contain some silica in the hydrous form, which perhaps accounts for its great shrinkage in burning. The bricklets made from it took 45 per cent of water to work them up, and the mixture had an air shrinkage of 16 per cent. Although this was not of very plastic feel, yet its tensile strength was very high, averaging 338 pounds per square inch, with a minimum of 300 and a maximum of 388 . When burned to cone 05 the fire shrinkage was 5 per cent. 'The bricklet was still scratched with a knife and was very absorbent. At cone 01 the fire shrinkage was 7 per cent, the bricklet still absorbent and barely scratched with the knife. At cone 1 the fire shrinkage remained the same, the hardness about the same, and the color was creamy. At cone 3 the fire shrinkage was 7 per cent, the color light buff, and the bricklet was very absorbent. At cone 5 the fire shrinkage was 12 per cent, the color reddish buff; the bricklet could not be scratched by a knife, but it had not yet vitrified. It seemed to vitrify at about cone 6 . Up to this point it held its form, but when heated up to cone 8 it rapidly became viscous and went to a slaggy mass of yellowish color. The clay behaves peculiarly for a calcareous one, and the writer expects, therefore, to examine it a little further and to report more fully on its peculiarities. It could not be used alone in the manufacture of clay products on account of its high shrinkage, but no doubt it would make excellent binding material if mixed in with another clay.

CLAY-WORKING INDUSTRY.

The total value of the clay products of Florida for each year from 1895 to 1901 was as follows:

Value of clay products of Florida from 1895 to 1901.

\begin{tabular}{|c|c|c|c|}
\hline Year. & Value. & Rank. & $\begin{array}{l}\text { Proportion } \\
\text { of United } \\
\text { States pro- } \\
\text { duct. }\end{array}$ \\
\hline $1895 \ldots$ & 114,015 & 39 & $\begin{array}{c}\text { Per cent. } \\
0.17\end{array}$ \\
\hline $1896 \ldots$ & $122,1+4$ & 39 & .20 \\
\hline $1897 \ldots$ & $89, \pm 35$ & 38 & .14 \\
\hline 1898. & 130,987 & 38 & .17 \\
\hline $1899 \ldots \ldots$. & 138,808 & 41 & .14 \\
\hline $1900 \ldots \ldots \ldots \ldots$ & 140,604 & 40 & .15 \\
\hline $1901 \ldots \ldots \ldots \ldots \ldots$ & $190,67 t$ & 39 & .17 \\
\hline
\end{tabular}


Value of clay products in Florida in 1901.

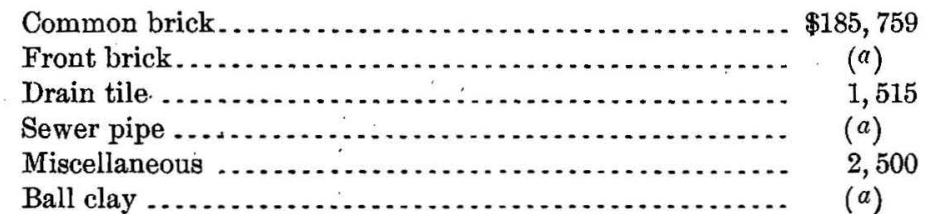

GEORGIA.

Georgia is divisible, geologically, into three areas, viz: (1) A northwestern area, underlain by rocks of Paleozoic age, consisting of shales, limestones, and sandstones; (2) a central broad belt of pre-Cambrian rocks, such as granites and gneisses; (3) a southeastern belt, in the Coastal Plain region, composed of unconsolidated sedimentary rocks of recent geologic age-Cretaceous, Tertiary, and Pleistocene.

\section{PALEOZOIC AREA. ${ }^{b}$}

This belt includes the counties of Polk, Floyd, Barton, Gordon, Murray, Whitfield, Catoosa, Chattooga, Walker, and Dade. In this area the rocks range from the Cambrian to the Carboniferous, inclusive, with the exception of the Lower Cambrian ${ }^{c}$ and Upper Ordovician beds.

The general section involves the following formations:

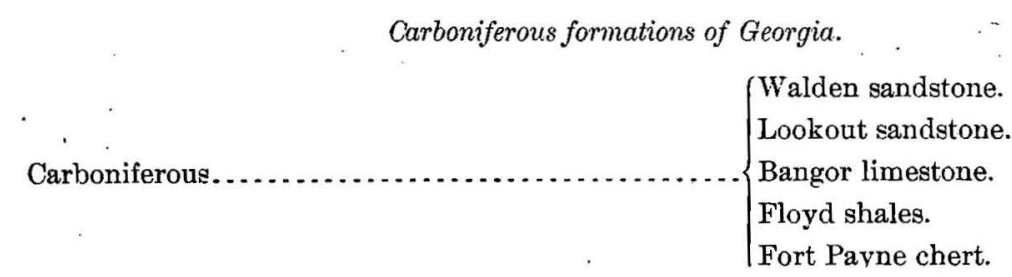

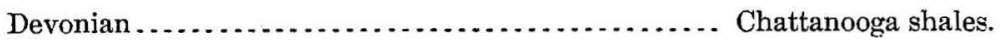

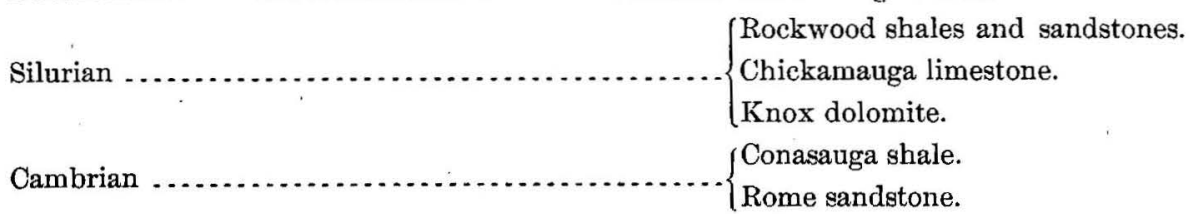

The thickness of this section is considerable, but is difficult to determine accurately because the strata have been much folded and have also been displaced by extended faulting. It can be said, however, that the different formations extend across the northwestern part of the State in a northeast-southwest direction, and that within the area occupied by them they furnish both residual clays and shales. The residual clays have been derived by decomposition from various types of rocks, including sandstones, shales, and limestones, and the general product of weathering

$a$ Less than three producers.

$b$ Spencer, J. W., The Paleozoic group: Georgia Geol. Survey, 1893. Also Geologic Atlas UT. S., folio 2, Ringgold c spencer, J. W., ibid., pp. 28-29. 
is a ferruginous clay, which may vary in siliceousness and plasticity, the degree of these depending on the character of the parent rock, etc.

The impure residuals ${ }^{a}$ may be derived from calcareous Paleozoic shales.

In places the limestones may be decayed to a depth of 22 feet. $^{b}$

The residual earths from the limestones run as follows in composition: ${ }^{c}$

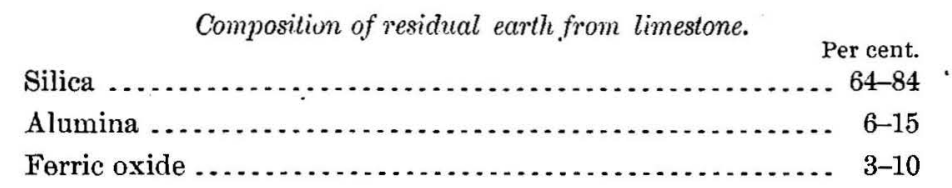

The Knox dolomite and Chickamauga and Bangor limestones are important sources of residual clays, and while these are commonly rather impure, pockets of white material may occur which may yield clay suitable for fire brick. The clay deposits are often large. In the cherty remains of other portions of the Knox dolomite the siliceous nodules are embedded in white, siliceous, chalky clay, as near Cave Spring, or in the Lookout Valley in Fort Payne chert. The siliceous matter could probably be separated by washing. At Woodlands a fine quality of clay is said to exist.

The following two analyses show the composition of these residuals:

Analyses of white residual clays from northwest Georgia.

\begin{tabular}{|c|c|c|}
\hline & 1. & 2. \\
\hline Silica (combined)...... & 40.40 & 20.10 \\
\hline Silica (free sand) .......... & .80 & 46.10 \\
\hline Alumina ........... & 38.60 & 15.41 \\
\hline Ferric oxide ......... & 1.45 & 6.06 \\
\hline Lime ............... & … & .... \\
\hline Magnesia .................... & .30 & 1. 29 \\
\hline Potash $\ldots \ldots \ldots \ldots \ldots$ & .09 & 4.55 \\
\hline Soda $\ldots \ldots \ldots \ldots \ldots \ldots$ & .02 & .34 \\
\hline Titanic acid............... & 1.95 & 1.35 \\
\hline Water ................ & 16.35 & 4.75 \\
\hline Moisture ............ & .35 & .20 \\
\hline Total... & 100.31 & 100.15 \\
\hline
\end{tabular}

1. Clay from bauxite beds on Flowery Branch, Floyd County.

2. Clay from a "horse" in the iron-ore beds at Grady.

These clays are probably refractory, judging from the character of the bauxite at Rock Run, in adjacent territory in Alabama.

a Spencer. J. W., The Puleozoic group: Georgia Geol Survey, 1893, p. 282. $\quad$ bIbid., p. $22 . \quad c$ Ibid., p. 23. 
The following analyses of Paleozoic shales, given by. J. W. Spencer, will show their composition:

Analyses of Paleozoic shales and clays from Georgia.

\begin{tabular}{|c|c|c|c|c|}
\hline . & 1. & 2. & 3. & 4. \\
\hline Silica (combined) ........... & 9.30 & 19.40 & & \\
\hline Silica (free) ... & 62.30 & 39.20 & 02.02 & 0.000 \\
\hline Alumina $\ldots \ldots \ldots \ldots$ & 11.50 & 18.05 & 26.17 & 19.01 \\
\hline Ferric oxide...$\ldots \ldots \ldots$ & 5.59 & 8.31 & 9.46 & 2.02 \\
\hline Lime..... . & $\ldots .$. & $\ldots \ldots$ & Trace. & Trace. \\
\hline Magnesia . . . . . . . . . . & 1. 30 & 1.55 & 1.08 & .87 \\
\hline 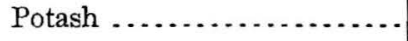 & 4.20 & 4. 63 & 2. 71 & 2.10 \\
\hline Soda $\ldots . . . . . . .$. & .35 & .33 & .20 & $.18^{-}$ \\
\hline Manganese dioxide .......... & .60 & & & \\
\hline Titanic acid.... & 1.10 & .68 & (a) & (a) \\
\hline Water ............................. & 3.80 & 7.60 & 7.00 & 6.88 \\
\hline Moisture ................. & .15 & .40 & .23 & .26 \\
\hline Total . . & 100.19 & 100.15 & 99.67 & 100.65 \\
\hline
\end{tabular}

1. Light-colored hydromica shale in ridge above Etowah iron bridge south of Cartersville.

2. Light-red shale, 1 mile southwest of Cartersville, of Oostanaula series.

3. Less calcareous clay of same series 2 miles northwest of Cartersville.

4. Light-colored plastic clay, from near head of McLamore's cove, of Lower Carboniferous age.

\section{PRE-CAMBRIAN BELT.}

This covers an area of about 12,000 square miles, and consists of granites, gneisses, schists, and marbles, and in places pegmatite veins. The latter should afford kaolin, and throughout the region residual clays are abundant. The wash from them may form secondary deposits in the valleys.

\section{COASTAL PLAIN REGION.}

The Coastal Plain district of Georgia includes that portion of the State lying southeast of a line drawn through Augusta, Macon, and Columbus, these towns being along the "fall line" which represents the boundary between the older and younger" formations of the State. In this area the formations range from Cretaceous to Pleistocene, and contain many clay deposits of varying character, ranging from the impure, easily fusible clays to snowy white clays of high refractoriness. The general character of most of the deposits is that of a lens-shaped mass surrounded by sand or sandy clay.

The Cretaceous occupies the smallest area at the surface, consisting of a triangle, of which the base is on the Chattahoochee River, the apex is at Macon, and the northwest side coincides approximately with the fall line. It includes, however, 
the most important clays found along the fall line in Georgia, representing the Potomac series. The Cretaceous section shows considerable thickness, for in following down the Chattahoochee River from Columbus about 1,640 feet of Cretaceous beds are seen, aftording an excellent opportunity for studying their character. A belt of clays occurs near the base of the Georgia Cretaceous section, and these have been traced across the State into South Carolina. ${ }^{\prime}$

The Eocene and Miocene beds of the Tertiary overlap the Cretaceous beds to the south and east and extend to the coast. Both the Cretaceous and the Tertiary, however, are covered by a mantle of Lafayette and Columbia sands, gravels, and clays, which may at times so effectively conceal the older beds that they are seen only in railroad cuts, ravines, or hillsides.

CRETACEOUS.

Within the triangular area mentioned above the Cretaceous is well exposed in cuts along the Central Railroad of Georgia, especially between Columbus and Macon; and for a number of miles east of Macon along the railroad there are many exposures of white clays and sands. The region around Griswoldville, 10 miles east of Macon, contains the best Potomac clays along the fall line. It includes the southern half of Jones and Baldwin counties and the northern half of Twiggs and Wilkinson. According to Ladd, clay is exposed at many points on the property of J. R. Van Buren \& Co., especially in the railroad cuts and gullies along the terrace followed by the Central Railroad. The clays of this region are from 6 to 10 feet thick, often white in.color, free from grit, and have a soapy feel, for they contain many muscovite scales of microscopic size. Some of these clays have been shipped to Chattanooga for use in the manufacture of fire brick.

Thick beds of white clay also occur at Lewiston, east of Griswoldville, and are mined for wali paper and encaustic tiling. The product, after mining, is separated into three grades-white, yellow, and spotted. The following section, exposed in the eastern pit at this locality, may be regarded as fairly typical:

Section in pit at. Leviston, (it.

1. Red and yellow clayey sand, with seams of laminated clay; also thin seams of brown iron ore

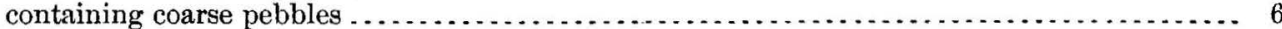

£. Irregular siliceous beds resembling quartzite, and containing drusy quartz cavities and many

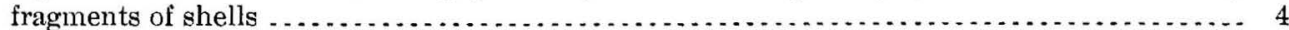

3. White sand, free from iron stain, cross bedded in places, containing mica and kaolin, and also nodules and fragments of white clay, in the upper surfaces of which are sharply outlined pear-shaped cavities, each filled with a yellowish clay. These cavities vary in diameter from

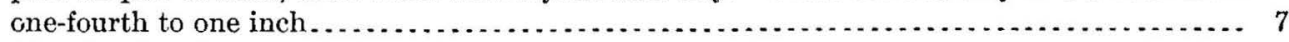

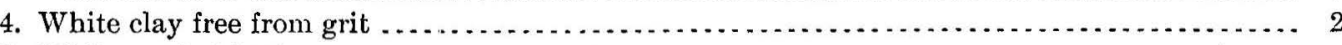
5. White sand at bottom.

Another deposit occurs $1 \frac{1}{2}$ miles east of Lewiston, on the property of J. J. Whitehurst, the clay there being 8 to 10 feet thick, with 6 to 8 feet of stripping.

a Ladd, G. E., The clays of Georgia: Bull. Georgia Geol. Survey No. 6, p. 80. 
There are many pits of Potomae clay $2 \frac{1}{2}$ miles south of Gordon, on the E. J. Massey estate, along the northern base of the ridge, but in most places they are overlain by a great thickness of Tertiary clay and Orange sands. . Outcrops of Potomac clays also occur around McIntyre, and at a point $1 \frac{1}{2}$ miles south of Dry Branch, a station on the Macon, Dublin and Savannah Railroad in Twiggs County. Here the slay, which is similar to that at Lerviston, is 15 feet thick, and mostly white. West of Fitzpatrick and between there and Bullards station are similar occurrences of Potomac clay. Potomac clays are also found west of the city of Augusta; around Grovetown, Columbia County, and 3 miles south of the same locality. They are also traceable eastward from Columbus, and range from mottled to pure white. They are overlain by Lafayette and Columbia. At Butler the clay is from 20 to 25 feet thick and is mined for paper. In Crawford County the Potomac clays are used in the manufacture of common pottery, while around Macon they crop out on both sides of the river.

From the following table, giving the chemical and physical properties of some of these clays, it will be seen that they run low, usually, in fluxing impurities, and hence are highly refractory. Their tensile strength in most cases is rather low. They are used for paper manufacture, pottery, and encaustic tiling. The paper clays have to be washed for shipment.

Analyses and physical characters of Coastal Plain clays in Georgia.

\begin{tabular}{|c|c|c|c|c|c|c|c|}
\hline & 1. & 2. & 3. & 4. & 5. & 6. & $\pi$. \\
\hline Moisture ...... & 0.57 . & 0.99 & 0.21 & 1.91 & 8.7 & 0.72 & 3.64 \\
\hline Ignition & 13.08 & 12.98 & 14.52 & 13.39 & 11. 24 & 13. 64 & 19.41 \\
\hline Combined $\mathrm{SiO}_{2} \ldots \ldots$ & 44.94 & 44.92 & $4 \bar{z} .79$ & 43.08 & 54.39 & 43.85 & 13.62 \\
\hline $\mathrm{Al}_{2} \mathrm{O}_{3} \ldots \ldots \ldots \ldots \ldots$ & 39.13 & 39.13 & 40.42 & 40.63 & 14.64 & 38.28 & 11.56 \\
\hline Free $\mathrm{SiO}_{2} \ldots \ldots \ldots$ & 1.23 & 1.55 & .82 & 1.94 & 1.89 & 2.77 & 36. 80 \\
\hline $\mathrm{Fe}_{2} \mathrm{O}_{3} \ldots \ldots$ & .45 & 1.05 & .70 & 1.01 & .28 & 1.02 & 2.2 \\
\hline $\mathrm{CaO} \ldots \ldots . .$. & .18 & .40 & .37 & .16 & 7.08 & .18 & 13. 89 \\
\hline MgO.................... & .11 & .17 & $\cdots \cdot$ & .00 & 1.71 & ..... & 1.73 \\
\hline $\mathrm{K}_{2} \mathrm{O} \ldots \ldots \ldots$ & .51 & Tr. & $\operatorname{Tr}$. & .27 & 4 & .05 & $\operatorname{Tr}$. \\
\hline $\mathrm{Na}_{2} \mathrm{O}$ & .63 & $\operatorname{Tr}$. & .83 & Tr. & 23 & .08 & 1.36 \\
\hline Absorption ........... & 112 & $\cdots$ & 80 & & 200 & 100 & 98 \\
\hline Air shrinkage & .8 &.$\dot{9}$ & 8 & 8 & 25 & 8 & $18-20$ \\
\hline Tensile strength . & 25 & 19 & Under 10 & $12-15$ & 213 & 24 & $\begin{array}{l}143 \\
304 \\
255\end{array}$ \\
\hline Cone of fusion ..... & 36 & 36 & 36 & $35-36$ & 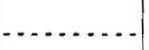 & 35 & ...... \\
\hline Specific gravity & 1.76 & $\begin{array}{l}1.5 \\
1.9\end{array}$ & $\begin{array}{l}1.89 \\
1.94\end{array}$ & $\begin{array}{l}1.72 \\
1.89\end{array}$ & $\begin{array}{r}.9 \\
1.2\end{array}$ & $\begin{array}{l}1.69 \\
1.75\end{array}$ & $\frac{1.8}{2}$ \\
\hline Color when burn & & White. & & $\begin{array}{l}\text { White and } \\
\text { pinkish. }\end{array}$ & $\begin{array}{c}\text { Buff to } \\
\text { pale yel- } \\
\text { low. }\end{array}$ & & \\
\hline ge. & & & 4 & 0 & 6 & 2 & 2 \\
\hline
\end{tabular}


1. J. R. Van Buren \& Co., Griswoldville. Bull. Georgia Geol. Survey No. 6, p. 108.

2. Lewiston Clay Works. Ibid., p. 115.

3. Z. T. Miller property. Ibid., p. 126.

4. Payne and Nelson pit near Macon, Twiggs County. Ibid., p. 133.

5. Tertiary clay, 1 mile east of Fitzpatrick. Ibid., p. 135.

6. Fire clay, Stevens Pottery, Georgia. Ibid., p. 139.

7. Summit.

Clays $1-6$ are Potomac clays (Cretaceous); clay 7 is Tertiary.

The following notes on Cretaceous clays of Georgia have been supplied by $\mathrm{Mr}$. T. Wayland Vaughan, of the United States Geological Survey:

Clay is well exposed on the Plant System Railway 1 mile west of Climax, Ga. The bottom of the section is about 23 feet below the level of the railroad, and the top of it is 30 feet above. The section is as follows:

Section 1 mile west of Climax, Ga.

15. Soil and humus. From a few inches to a foot or more. Feet. Inches

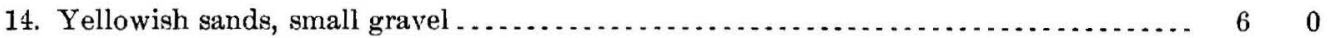

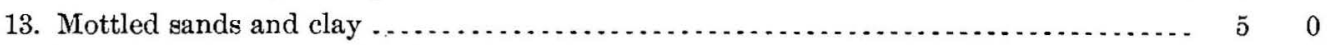

12. Sands and some clay, showing distinct stratification, whitish, yellowish, and reddish.. $25 \quad 0$

(The upper 20 feet cross bedded. There is some ferruginous sandstone.)

11. Clays, blotched reddish . . . . . . . . . . . . . . . . .

(About 2 feet below the level of the railroad.)

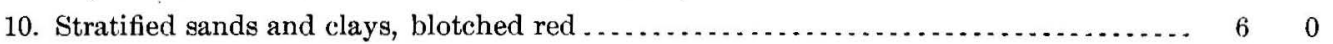

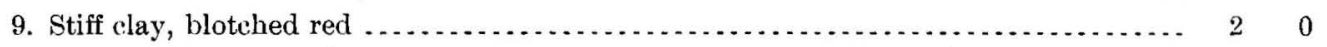

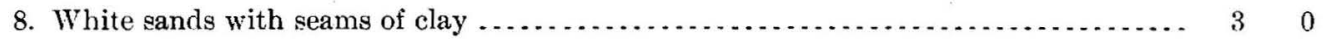

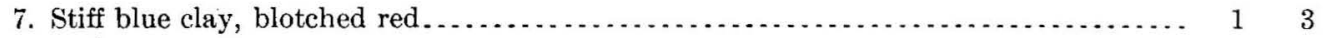

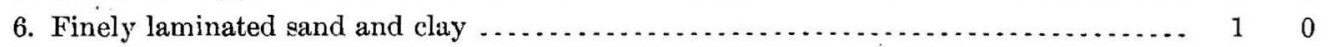

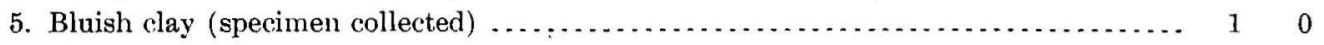

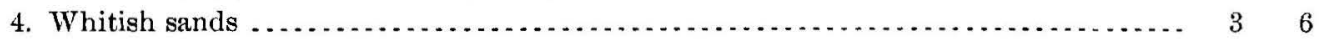

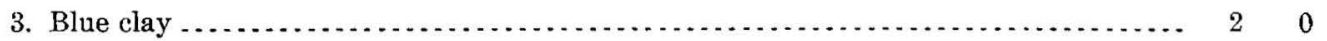

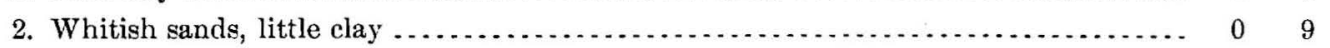

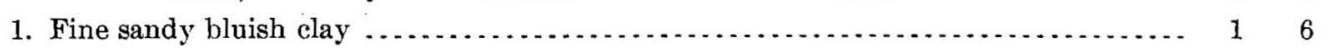

The clay from this point is reddish, and is doubtless suitable for the manufacture of brick. It is exceedingly fine grained and on this account takes up considerable water in mixing, the amount being 40 per cent. A number of bricklets and briquets were made from this mixture, and the former in drying showed a total shrinkage of 17 per cent, which was sufficient to induce cracking in the clay. On this account it would have to be more or less thoroughly mixed with sand. The clay contains a large proportion of soluble salts, and in the process of air drying these form a white scum on those surfaces and edges of the bricklet from which the water evaporates most rapidly. The tensile strength of air-dried briquets ranged from 140 to 180 pounds per square inch, but in most cases they probably broke before the actual limit of strength was reached, by reason of the formation of incipient cracks in drying. 
The clay burns to a red color at a very low temperature-cone 05-and at this point is dense and hard, showing a total shrinkage of 18 per cent. Most common brick clays would not show a shrinkage of more than 10 per cent up to this point.

Clay from Cohn tobacco plantation. - The clay used on the Cohn \& Co. tobacco plantation in the manufacture of brick for use in buildings, etc., on the plantation took the same quantity of water as the clay just described to mix it up, and its air shrinkage was 15 per cent, but it showed less scum on the surface, due to soluble materials in the clay. At cone 05 the clay burns to a good red color, with a fire shrinkage of 2 per cent, which is less than that of the other two samples. There were a few small cracks.

When burned to cone 2 the color was a much deeper red, and the fire shrinkage

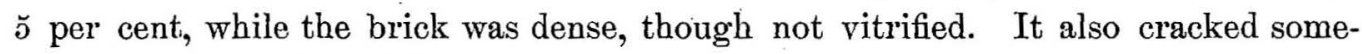
what, due to the high shrinkage.

The tensile strength of the air-dried briquets made from the clay was high, ranging from 260 to 300 pounds per square inch, with an average of 270 pounds.

This clay would also need to have sand mixed with it in molding, but owing to its high tensile strength could no doubt take considerable of this material.

$$
\text { TERTIARY CLAYS. }
$$

The Tertiary clays, though probably more extensive than those of the Cretaceous, are not so well known.

Ladd $^{a}$ mentions their occurrence around Fitzpatrick and 1 mile east of that place. A Tertiary outlier occurs 6 miles northwest of Griswoldville, and is well exposed in the railroad cut at Summit. It is a bluish or greenish, more or less laminated clay, of calcareous character, melting at $1,100^{\curvearrowright} \mathrm{C}$. It is used with Potomac clays, and Ladd suggests that it may be used for the manufacture of paving brick. Beds probably of Tertiary age are also known in the railroad cut east of Grovetown station.

COLUMBIA CLAYS.

These are widespread in the Coastal Plain region. They are worked around Hudson, and also in the terraces around Macon, where they are employed for making brick and sewer pipe.

Additional beds are worked for brick around Augusta, and at Milledgeville. This latter deposit is at least 10 feet thick.

According to Spencer ${ }^{b}$ most of the bricks manufactured in northwestern Georgia are made from alluvial clays. Good material for this purpose is found along the Etowah River at Cartersville. This is less fusible than the same class of material 
worked at Rome, but the latter is said to make a better brick. The following analyses indicate the composition:

Anclyses of Columbia brick clays from Georgia.

\begin{tabular}{|c|c|c|c|}
\hline & 1. & 2. & 3. \\
\hline Silica (combined) $\ldots \ldots \ldots \ldots \ldots \ldots \ldots$ & 69.18 & 17 & 14. 30 \\
\hline Silica (free) $\ldots \ldots \ldots \ldots \ldots \ldots \ldots \ldots$ & - $\therefore . .$. & 50.80 & 63.30 \\
\hline 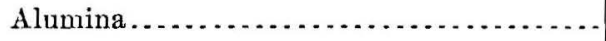 & 15.43 & 13.82 & 10.90 \\
\hline Ferric oxide $\ldots \ldots \ldots \ldots$ & 5.83 & 5. 74 & 2.25 \\
\hline 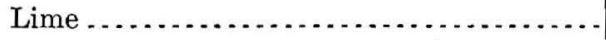 & $\ldots .$. & .......... & $\ldots$ \\
\hline Magnesia $\ldots \ldots \ldots \ldots \ldots \ldots$ & .71 & .81 & .63 \\
\hline 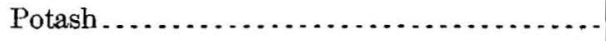 & 1. 83 & 2 & 1.83 \\
\hline 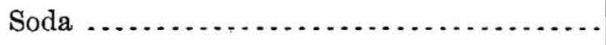 & .15 & .55 & .32 \\
\hline Titanic acid .... & ....... & $\cdot 1.67$ & 1. 98 \\
\hline 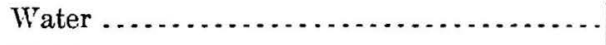 & 6.61 & 7.35 & 4. 70 \\
\hline Moisture................... & .22 & .25 & .20 \\
\hline Total ................ & 99.96 & 99.99 & 100. 41 \\
\hline
\end{tabular}

1. Brick clay from Cartersville, on Etowah River.

2. Surface clay at Rome.

3. Lower clay at Rome, 10 feet below surface.

CLAY-WORKING INDUSTRY.

Georgia in 1901 ranked sixteenth among the clay-producing States, haring gained considerably in the last six years. The value of the clay products has been as follows:

Value of clay products of Georgia from 1895101901.

\begin{tabular}{|c|c|c|c|}
\hline Year. & Value. & Rank. & $\begin{array}{l}\text { Proportion } \\
\text { of Cnited } \\
\text { States } \\
\text { product. }\end{array}$ \\
\hline & & & Per cent. \\
\hline $1895 \ldots . . .$. & $\$ 867,355$ & 15 & 1.33 \\
\hline $1896 \ldots \ldots \ldots \ldots$ & 904,813 & 15 & 1.46 \\
\hline $1897 \ldots \ldots \ldots \ldots$ & 962,513 & 14 & 1.54 \\
\hline $1898 \ldots \ldots \ldots \ldots$ & 857,258 & 18 & 1.20 \\
\hline $1899 \ldots \ldots \ldots \ldots \ldots \ldots$ & $1,263,995$ & $1 \check{\sigma}$ & 1.32 \\
\hline $1900 \ldots \ldots \ldots \ldots \ldots \ldots$ & $1,193,218$ & 17 & 1.24 \\
\hline $1901 \ldots \ldots \ldots+1 . \ldots$ & $1,545,083$ & 16 & 1.40 \\
\hline
\end{tabular}


The values of the various clay products in 1900 and 1901 were as follows:

Value of clay products of Georgia in 1900 and 1901.

\begin{tabular}{|c|c|c|}
\hline$\cdot$ & 1900. & 1901. \\
\hline Common brick $\ldots \ldots \ldots \ldots \ldots \ldots$ & $\$ 982,083$ & $\$ 1,182,533$ \\
\hline Front brick ... & 49,800 & 55,700 \\
\hline Terra cotta..... & 66,000 & 71,800 \\
\hline Fireproofing ... & $\cdot$ & $(a)$ \\
\hline Sewer pipe........... & 25450 & 151,500 \\
\hline Vitrified brick.. & 30,400 & $(a)$ \\
\hline Drain tile. . & & $(a)$ \\
\hline Fire brick... & 35,502 & 35,000 \\
\hline Pottery . . . . . . . . . . & 21,033 & 17,230 \\
\hline Clay $\ldots \ldots \ldots \ldots \ldots \ldots \ldots$ & 32,645 & . $\quad 44,315$ \\
\hline
\end{tabular}

$a$ Less than three producers; henee not given.

Common brick are made from the residuals of the Bangor and Chickamauga limestones in the northwestern corner of the State, much clay having been dug near Blowing Springs. The calcareous Cambrian shales have been worked for the same purpose at a point 4 miles south of Lafayette. ${ }^{a}$ Common brick, and even pressed and paving brick, are made from alluvial clays found in the valleys at Rome, Macon, and elsewhere, and the Coastal Plain clays are likewise worked for structural products. Fire brick, sewer pipe, and pottery are produced in limited quantities from the Potomac clays along the fall line. Stephens Pottery, at Stephens Pottery post-office, is the chief factory. Some of these clays are suitable for paper manufacture and are shipped to factories in other States. A valuable deposit of clay has recently been exploited in the southeastern portion of the State for use in roofing-tile manufacture.

\section{ILLINOIS. $b$}

The clay materials of this State come from the Ordovician, the Coal Measures, and the drift.

ORDOVICIAN.

This is probably of little importance, but the Cincinnati shales are recommended for pottery or brickmaking, ${ }^{c}$ where they outcrop in Daviess and Boone counties.

\section{COAL MEASURES.}

The' Coal Measures underlie a large area in the central, eastern, and southern portions of the State, within a line passing from Hampton, in Rock Island County, to the

a Geologic Atlas U. S., folio 2, Ringgold.

$b$ See Worthen, A. H., reports on Economic Geology of Illinois, Vols. I, II, III; also Illinois Geol. Survey, Vol. VII

cIllinois Geol. Survey, Vol. III, pp. 37, 101. 


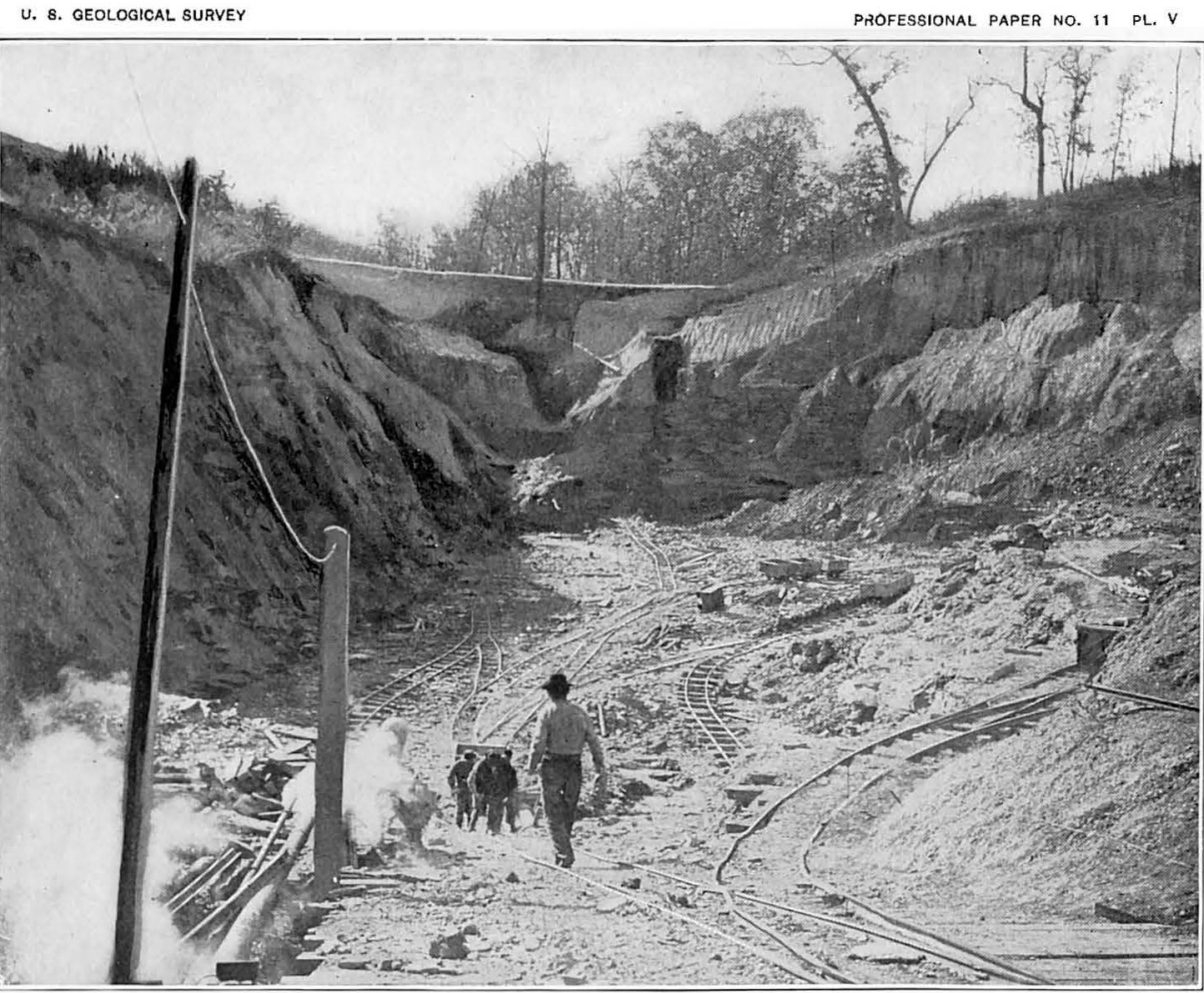

A. SHALE PIT NEAR BELLEVILLE, ILL,

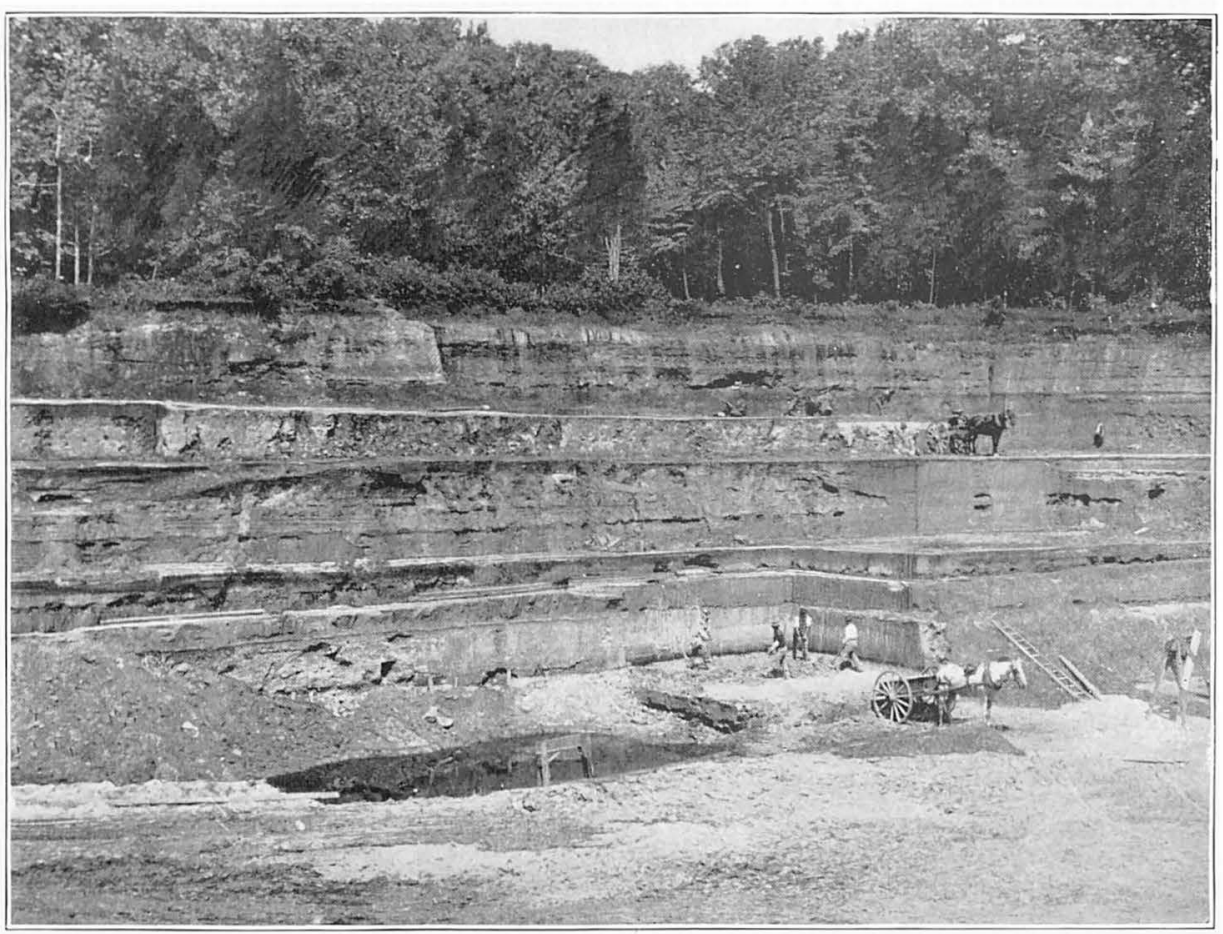

B. CRETACEOUS CLAY AT WOOdBRIDGE, N. J. 

junction of the Kankakee and Iroquois rivers, and extending thence southward to near Chatsworth, in Livingston County, and westward to the Indiana boundary.

The Coal Measure section embraces sixteen seams of coal, No. 1 being the lowest, which are interbedded with a great series of shales, clays, and sandstones. The under clays are often of a refractory character. Owing to the nearly horizontal position of the beds, mining is usually carried on by shaft, although at several localities, as Galesburg and Belleville (Pl. V, $A$ ), great outerops of shales occur. The best beds of potter's and fire clays in the State are associated with the lower or No. 1 coal seam. Many excellent sections are given in the reports of the Illinois Geological Survey. Unfortunately little has been published regarding the economic value of the clays and shales of this State, although they form the basis of an active clay-working industry. The Carboniferous shales are employed, however, in the manufacture of paving brick, terra cotta, pressed brick, roofing tile; and other clay products, the results produced being excellent. ${ }^{a}$

Many references are given by Mr. Worthen ${ }^{b}$ to individual occurrences of clay in Illinois, among which the following may be specially mentioned:

Beds of fire clay in Illinois.

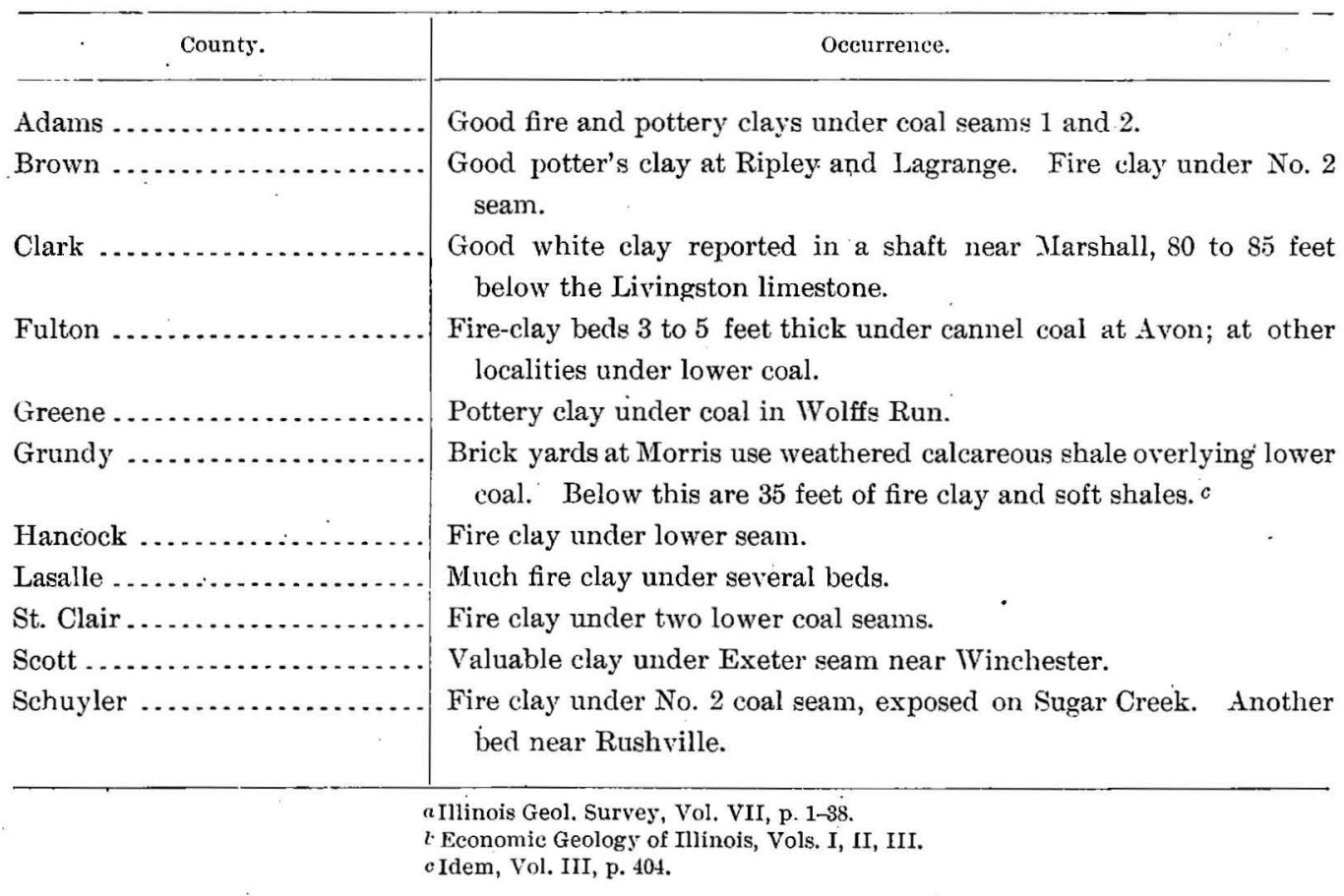




\section{TERTIARY CLAYS.}

In Pulaski and Alexander counties the Tertiary contains beds of potter's clay, as. at Mound City on the Ohio River and near Santa Fe. The clays at both these points are said to have been used for pottery manufacture.

\section{DRIFT CLAYS. ${ }^{a}$}

These form an abundant supply of surface material all over the State. Around Chicago these clays are lake deposits of considerable extent, but they are very calcareous and contain many pebbles. They are extensively worked for making common brick and roofing tile. In other portions of the State the clays are found in the drift or underlying terraces along the broader rivers, especially the Illinois. At Fielden, Jersey County, the clay at the base of the drift is used for pottery. ${ }^{b}$ Many loess and drift clays occur in Pike, Ripley, Fulton, McHenry, Lake, Morgan, Bureau, Will, Salina, and Rudolph counties.

\section{CLAY-WORKING INDUSTRY.}

Illinois is the fourth State in importance as a clay producer, having over 560 clay-working plants. Common brick are manufactured at many places in all parts of the State, Chicago being the most important. . Considerable quantities are also made at Bloomington, Danville, Peoria, Quincy, and Streator. Surface clays are commonly employed.

Pressed brick are also an important item of production. Illinois is a large producer of paving brick, factories being located at Utica, Streator, Springfield, Galesburg, Alton, etc. Two roofing-tile works are located in the State, the one at Ottawa using Carboniferous shales, the other, at Chicago Heights, employing calcareous lake clays. Fire brick are manufactured to some extent from the under clays of the coal seams to supply a local demand, but many fire clays are also sent from Ohio. Stoneware and earthenware are produced in considerable quantities, and some white ware is made at Peoria, but the clays used are obtained from other States. Terra cotta is made near Chicago from a mixture of Illinois and Indiana materials. 
The value of the clay products made in 1900 and 1901 was as follows:

Value of clay products of Illinois in 1900 and 1901.

\begin{tabular}{|c|c|c|}
\hline & 1900. & 1901. \\
\hline Common brick.... & $\$ 3,981,577$ & $\$ 5,188,654$ \\
\hline Front brick $\ldots \ldots \ldots \ldots$ & 240,989 & 204,980 \\
\hline Paving brick........ & 720,089 & 899,454 \\
\hline Fancy brick .... & 15,705 & 13,105 \\
\hline Firé brick ........................... & 175,259 & 212,510 \\
\hline Drain tile............ & 734,249 & 696,588 \\
\hline Sewer pipe ........... & 271,035 & 348,716 \\
\hline Terra cotta ..... & …..... & 812,015 \\
\hline Fireproofing $\ldots \ldots \ldots \ldots \ldots$ & 76,347 & 263,276 \\
\hline Other tile......................... & 229,729 & 229,746 \\
\hline Miscellaneous ........................ & 25,237 & 28,121 \\
\hline Red earthenware............. & 57,068 & 6,600 \\
\hline Stoneware ................... & 578,405 & 585,649 \\
\hline C. C. ware ....................... & & \\
\hline White granite $\ldots \ldots \ldots \ldots \ldots \ldots$ & 68,000 & 83,900 \\
\hline 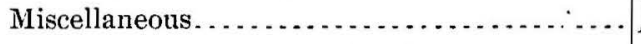 & & \\
\hline Clays (pipes, terra cotta, firestone ware) ....... & 52,872 & 63,131 \\
\hline
\end{tabular}

Value of clay products of Illinois from 1895 to 1901.

\begin{tabular}{|c|c|c|c|}
\hline Year. & Value. & Rank. & $\begin{array}{c}\text { Proportion } \\
\text { of } \mathrm{U} . \mathrm{S} \text {. } \\
\text { product. }\end{array}$ \\
\hline $1895 \ldots \ldots$ & $\$ 7,619,884$ & 3 & $\begin{array}{c}\text { Per cent. } \\
11.67\end{array}$ \\
\hline $1896 \ldots \ldots$ & $5,398,247$ & 4 & 9.44 \\
\hline $1897 \ldots$ & $5,398,574$ & 5 & 8. 86 \\
\hline $1898 \ldots \ldots \ldots \ldots$ & $6,866,715$ & 4 & 9.37 \\
\hline $1899 \ldots$ & $7,259,825$ & 5 & 7.58 \\
\hline 1900. & $7,708,859$ & 4 & 8.01 \\
\hline $1901 \ldots \ldots \ldots$ & $9,6 \pm 2,490$ & 4 & 8.75 \\
\hline
\end{tabular}

INDIANA.

The geologic map of Indiana shows a series of Paleozoic formations, ranging from the Hudson formation to the Coal Measures (see Pl. IV). Outcrops are scarce, however, owing to the heavy covering of drift, and are to be sought chiefly in the valleys. Of these Paleozoic rocks, the Carboniferous are the only ones of importance to the clay worker, for they contain many beds of shale and clay of considerable $9647-$ No. $11-03-7$ 
value, while neither the Devonian nor Silurian contains plastic materials that offer promise. The Carboniferous rocks are confined to the southwestern corner of Indiana, and contain the most valuable clay deposits found within the State. The drift covers nearly the entire State, and contains many brick and other clays.

\section{KNOBSTONE OR WAVERLY SHALES.}

These are found in the western part of Clark and Scott counties, northwestern Washington, most of Jackson and Brown, western Bartholomew, and most of Morgan and Hendricks counties.

In Jackson County there are important outcrops along the White River southwest of Seymour, and also west of Surprise station. The shale is locally known as soapstone. It also outcrops south of Freetown. The best deposits are at a place called Blue Lick on the south side of the Baltimore and Ohio Southwestern Railroad.

The following is the composition of an average sample of Knobstone shale from "Blue Lick," Jackson County, Ind., suitable for paving brick, sewer pipe, roofing tile, and other vitrified products.

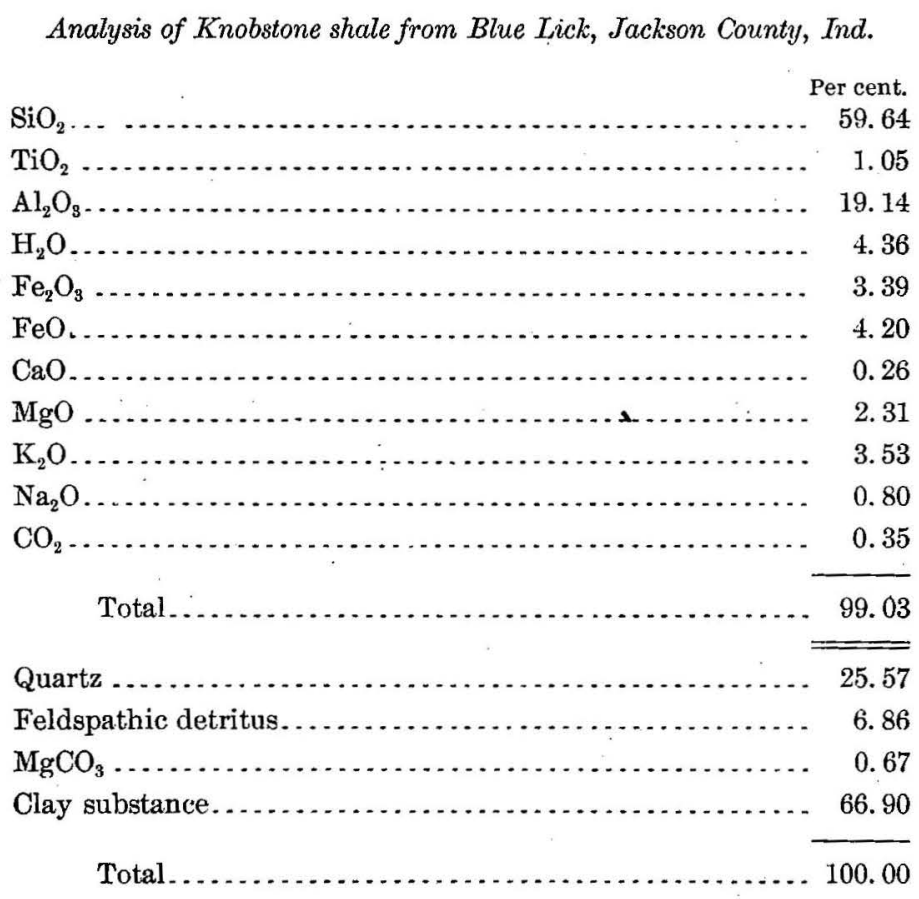

COAL MEASURES.

The Coal Measure clays underlie the surface of the southwestern part of the State, as shown on the map (Pl. IV). From this it is seen that Carboniferous clays 
and shales are to be found in the counties of Fountain, Vermilion, Parke, Vigo, Clay, Owen, Sullivan, Greene, Knox, Daviess, Martin; Dubois, Pike, Gibson, Vanderburg, Warrick, Spencer, and Perry. ${ }^{a}$ Posey County, in the southwestern corner, is entirely covered by the Upper or Barren Coal Measures, and since little coal is mined there, little is known about the clays. The following section shows the arrangement of the clay deposits in this part of the State: ${ }^{b}$

\section{Typical section of Coal Measure strata and interbedded rocks.}

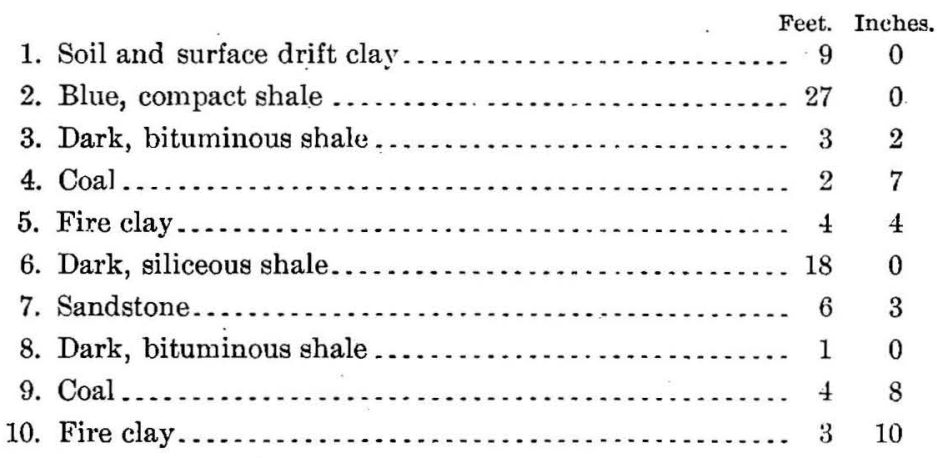

The fire clays 5 and 10 in the section are almost invariably found with the coal seams which they underlie. The dark, bitumınous shales 3 and 8 of the above section are usually found on top of most of the seams of coal and are known to the miners as "black slate." The klue and drab shales 2 and 6 "comprise the greater part of the Coal Measure rocks of Indiana and, taken as a whole, are the most valuable clay deposits appearing in the State. They are not closely related to the strata found above and below them and their thickness and composition vary excessively."

The relations of the shales, clays, and coal are such that the three can often be mined by one shaft. Since the accompanying coal seams are often referred to, it may be well to state that 14 seams are recognized in the Indiana Coal Measures and aie lettered from $A$ to $\mathrm{N}$.

For detailed information the report above referred to should be consulted. The more important occurrences are mentioned below.

Clay County.-This is probably the most important clay-producing county in the State, Brazii, the county seat, being an important clay-manufacturing center. This development dates largely from 1890, and the clays now used supply several branches ог the industry.

a Platchley, W. S., Preliminary report on the clays and clay industries of the coal-bearing counties of Indiana: Twentieth Ann. Rept. Ind. Dept. Geol. and Nat, Res., p. 42 .

$b$ Ibid, p. 43. 
A section at the sewer-pipe works, 1 mile northwest of Brazil, in SE. 1 sec. 25 , T. 13 N., R. 7 W., shows the following beds:

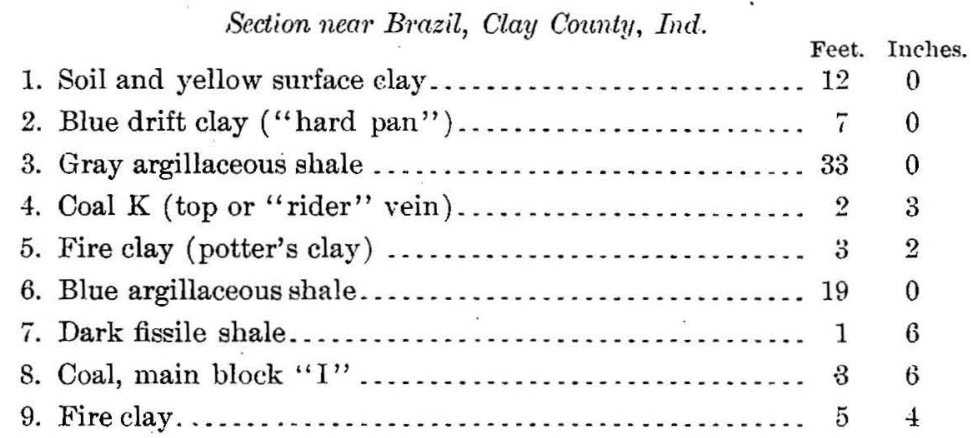

The fire clay 9 is said to make a strong, durable sewer pipe. The potter's clay beneath the coal $\mathrm{K}$ has been used since 1859 in the pottery at Brazil, and the gray shale 3 is utilized by the Indiana Paving Brick Company, the bed being 30 feet thick. The Chicago Sewer Pipe Company, 1 mile southwest of Brazii, makes sewer pipe from the clay shale 3. This is found at present on all sides of Brazil to a distance of 2 miles, except to the southeast, where it seems to be largely replaced by the sandstone. The blue shale 6 overlies the middle vein of the block coal I wherever the latter is found. One mile northwest of Clay City the under clay of the main block coal is mined and shipped for use in the manufacture of ornamental brick, fire brick, and terra cotta. It is similar to the under clay found at the same horizon at Brazil, but not so refractory as the clays at Montezuma. A stoneware pottery has been in operation at Clay City since 1846 .

Dubois Connty. "-The most important clay deposits of Dubois County are in the vicinity of Jasper and Huntingburg, where there are outcrops of soft, light-gray shales. There are three veins of coal here, under each of which is fire clay 3 to 5 feet thick and good for pottery or fire brick. A potter's clay is obtained here which is used at Huntingburg and Evansville. ${ }^{b}$ A section at the mines of the Huntingburg Pressed Brick Company in Beelers Hill is as follows:

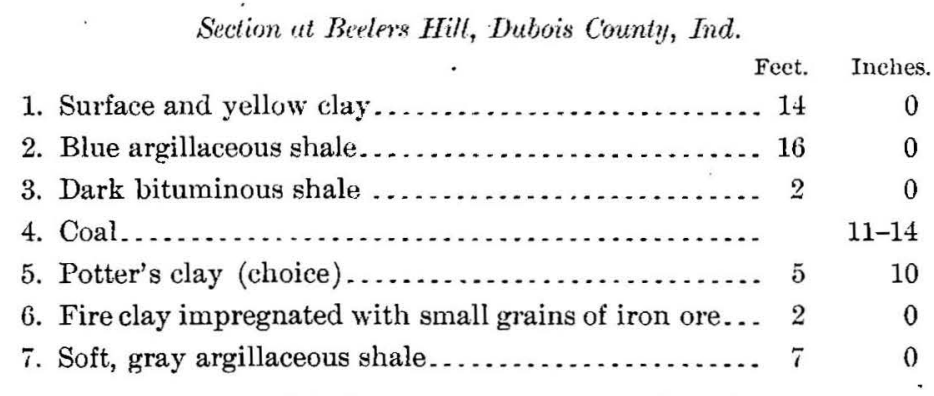

No. 5 has been shipped and brings 85 cents a ton f. o. b. 
Greene County. ${ }^{a-B e d s}$ of shale of commercial value are rarely found above coai A, wnich outcrops in the eastern half of the county, but the fire clay under it is often of excellent quality.

Inox County. ${ }^{b}$-The Upper or Barren Coal Measures form the surface rocks of most of the county, the Lower or Productive Measures outcropping only on the eastern border, especially in the bluffs of White River. The clays have been but little used, although several beds of fire clay occur under coal seams $\mathrm{L}, \mathrm{K}$, and $\mathrm{M}$.

Owen Conty. ${ }^{c}$-The more valuable deposits of clay and shales are found in Ts. 9 and $10 \mathrm{~N}$, and Rs. 5 and $6 \mathrm{~W}$., in which region also are located the upper coal veins. The fire clay is again found under block coal I. The deposit of shale over the coal is one of the best in the State. It belongs to the same horizon and is similar to that worked at Brazil for sewer pipe and other products. The fire clay under the coal is inferior because it contains much pyrites. The fire clay is also found in the mines north of Patricksburg and southwest of the same town. The shale overlying coal I comes to the surface at many places.

Near the town of Freedom, in Owen County, there is a large deposit of pinkish and red clay lying near the surface. It underlies a considerable area and has been shipped to the Encaustic Tile and Terra Cotta Company works at Indianapolis, the Encaustic Tile Works at Anderson, Ind., and to Newark, N. J. It is one of the most important clays of Indiana. Although appearing to be a surface clay it really is a decomposed shale, and when mixed with the less refractory clay from Carbon, Ind., makes a red floor tile.

Perry Connty.-Potter's and fire clays are exposed in the shaft at the coal mines one-half mile above Troy. Sewer pipes are niade from a shale obtained near Cannelton, and the same material is also found to be suitable for the manufacture of stoneware, supplying one of the largest factories of its kind in Indiana. The clay used at both factories is the under clay of the top coal found extensively in the vicinity of Cannelton. The following section is seen on the land of the American Cannel Coal Company, $1 \frac{1}{\frac{1}{m}}$ miles cast of Cannelton:

Section near Cannelton, Perry County, Ind.

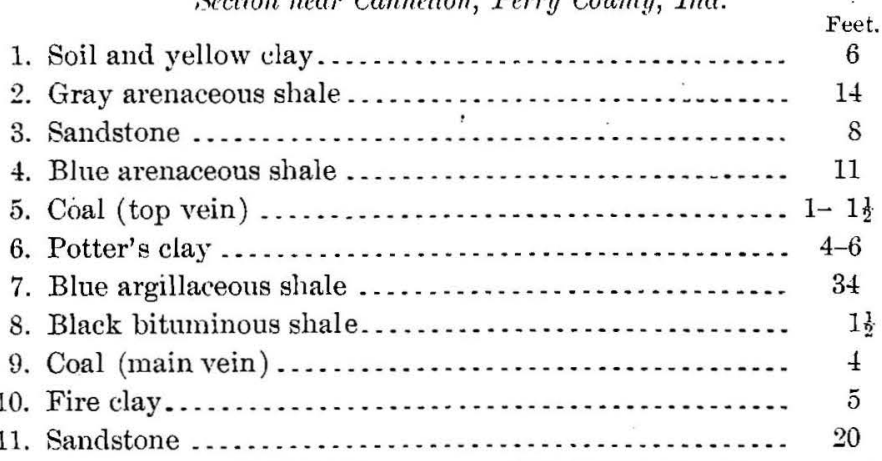

"Twentieth Ann. Rept. Ind. Dept. Geol, and Nat. Res., p. 87. $b$ Ibid., p. 94. c Ibid., p. 85. 
Fire clay 10 burns to a buff color and is not highly refractory. Large quantities of both 7 and 10 in the section have to be handled each year in the mining of the coal, and at present are not being used.

Pike County. ${ }^{a}$-Fire clays are found in the sections under the coal at Sand Hill 2 miles north of Petersburg; also at Blackburn and again at Plainfield.

Gibson County. ${ }^{b}$-Large deposits of shale occur near Princeton.

Sullivan County.c-Fire clays underlie the coal, but only one deposit of pottery clay is known, and that is near Pleasantville.

Vinderburg County. ${ }^{d}$-There are several large clay works at Evansville, amorg them the Evansville Pressed Brick Company, which uses shales. Fire clay occurs in this county beneath coal $\mathrm{N}$, and is of much better quality than that below vein M.

At the Pressed Brick Company's works, the shale section on Pigeon Creek shows the following beds:

Section on Pigeon Creek, Vanderburg County, Ind.

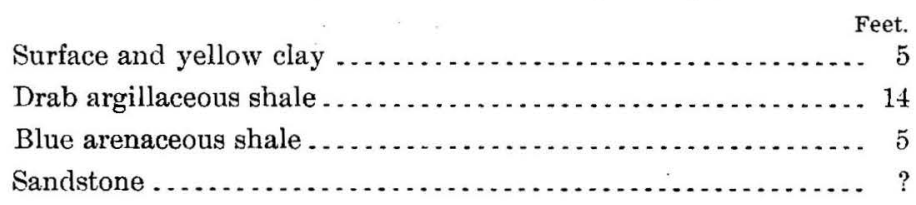

This shale, which is both drab and blue, is said to cover a large area north and northwest of Evansville, and outcrops in a number of places along Pigeon Creek and its tributaries. ${ }^{e}$

The shale outerops are also used near Babytown, in this county, for brick manufacture.

Vermition County. $f$-The entire area of this county is included in the Coal Measure formations, but about one-third is taken up by the terraces and lowland bottoms of the Wabash and its tributaries. The remainder is upland, along the eastern border of which are high bluffs rising above the level of the river. Along these bluffs large and arailable deposits of under clays and shales are exposed. They are used near Clinton by a brick and pipe company, and also for paving brick, but some of these shales require the admixture of drift clay to the extent of about 25 per cent to prevent warping and cracking in burning. There are many outcrops of shale farther north, between Clinton and Hillsdale, and also north of the latter place. The following rather complete section is found in a ravine in the SW. $\frac{1}{4}$ sec. 26 , T. 16 N., R. 9 W., a short distance from West Montezuma station:

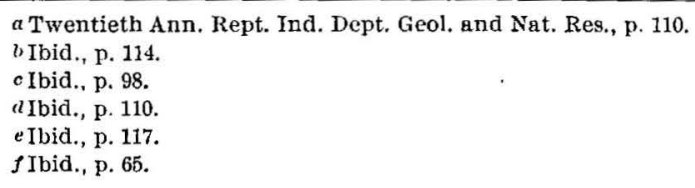


Section near West Montezuma, Termilion County, Ind.

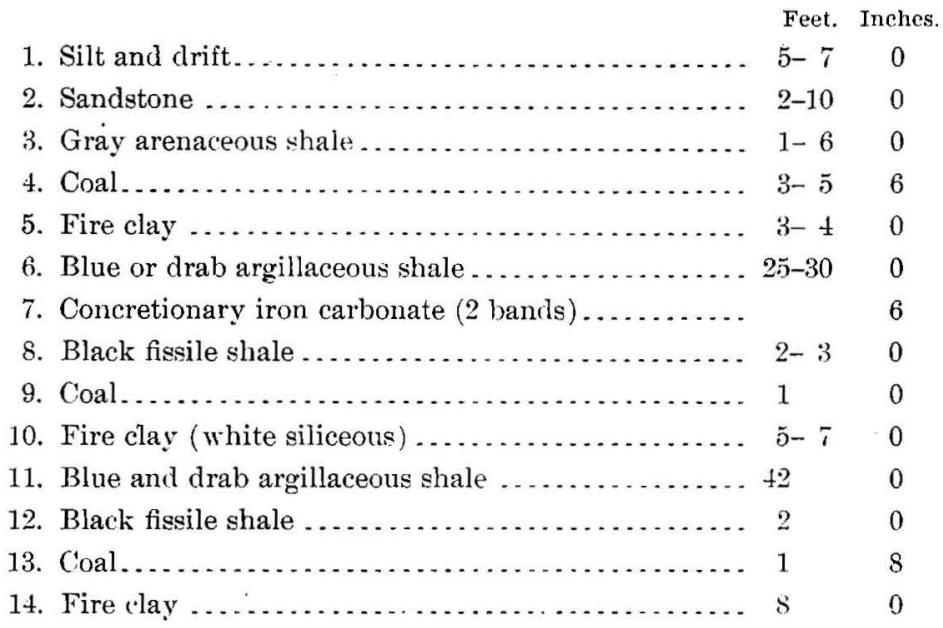

Fire clay 10 of the section is the most refractory under clay that has been found in the State, the bricks made from it being sent to Georgia and Alabama. Many good clay outcrops are found west of Newport along the Little Vermilion River. The largest pressed-brick plant in the State is located $1 \frac{1}{2}$ miles southwest of Cayuga, in this county, and utilizes the shales outcropping northwest of Newport."

Vigo County.-The largest and most valuable shale and clay deposits are found on the west side of the Wabash River and north of the old National road. The following section is given from Broadhurst's mine, 1 mile west of Maxville, and can be taken as illustrative of the general section in this county:

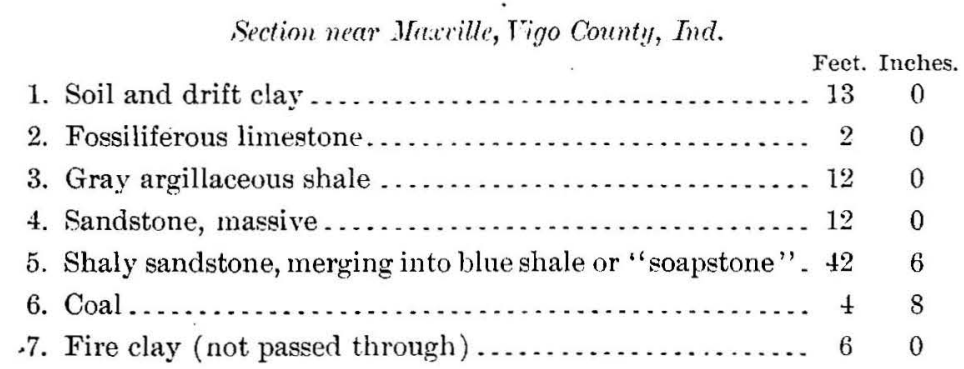

Near Terre Haute a brick and pipe company is working a shale for hollow brick, which is similar to 5 of the above section.

Warrick County.-Coal seams and the accompanying clay and shale beds are known to occur in the county, but on account of lack of railway facilities they have been little developed.

a Twentieth Amn. Rept. Ind. Dept. Geol, and Nat. Res., p. 70. 


\section{SHALES AND CLAYS FOR VITRIFIED BRICKS. ${ }^{a}$}

The best deposits of unworked shales and clays for making vitrified bricks lie just east of Mecca, Parke County; west of Montezuma, Parke County; west of Terre Haute and near Riley, Vigo County.

Other large deposits of shale of good quality are located 1 mile southeast of Veedershurg; on Cold Creek; on Brouillets Creek; south of Clinton, Vermilion County; section 6, Pierson Township, Vigo County; near Patricksburg and Woodside, Owen County; and near Farnsworth, Sullivan County.

In the tables given below there will be found a number of analyses of Carboniferous shales and clays of Indiana.

Analyses of under clays of Indiana Coal Measures.

\begin{tabular}{|c|c|c|c|c|c|c|}
\hline & 1. & 2. & 3. & 4. & 5. & 6. \\
\hline $\mathrm{SiO}_{2}$. & 69.23 & 57.57 & 54.46 & 63.00 & 83.44 & 68.13 \\
\hline $\mathrm{TiO}_{2} \ldots \ldots$ & 1.50 & 1.10 & 1.20 & 1. 10 & 1.29 & $\cdots$ \\
\hline $\mathrm{Al}_{2} \mathrm{O}_{3} \ldots \ldots$ & 18.97 & 21.70 & 25.71 & 23.57 & 10.36 & 20.80 \\
\hline Combined $\mathrm{H}_{2} \mathrm{O} \quad \ldots \ldots \ldots \ldots$ & 5.46 & 6. 78 & 8.50 & 6.45 & 3.15 & 5.72 \\
\hline $\mathrm{Fe}_{2} \mathrm{O}_{3} \ldots \ldots$ & 1.57 & 2.26 & 5.51 & 1.87 & 0.27 & 1.20 \\
\hline $\mathrm{FeO} \ldots \ldots \ldots \ldots$ & 0.55 & 4.11 & 0.91 & 0.46 & 0.28 & ..... \\
\hline $\mathrm{CaO} \ldots \ldots \ldots \ldots \ldots$ & 0.12 & 0.32 & 0.24 & 0.44 & 0.36 & 0.42 \\
\hline $\mathrm{MgO} \ldots \ldots$ & 0.36 & 1.12 & 0.83 & 0.89 & 0.14 & 0.37 \\
\hline $\mathrm{K}_{2} \mathrm{O} \ldots \ldots \ldots \ldots \ldots \ldots \ldots$ & 2.27 & 2. 16 & 2.68 & 2.40 & 0.03 & 2.28 \\
\hline $\mathrm{Na}_{2} \mathrm{O} \ldots \ldots \ldots$ & 0.33 & 0.33 & 0.33 & 0.29 & 0.71 & 0.27 \\
\hline $\mathrm{CO}_{2} \ldots \ldots$ & & 1.73 & & $\cdots \cdot$ & ..... & .... \\
\hline Total...... & 100.36 & 99.18 & 100.37 & 100.47 & 100.03 & 99.19 \\
\hline Quartz ........ & 39.36 & 27.95 & 19.69 & 26.31 & 46.33 & - \\
\hline Feldspathic detritus ........... & 1. 67 & 1.95 & 0.83 & 1.00 & 39.28 & \\
\hline $\mathrm{FeCO}_{3} \ldots \ldots \ldots$ & ….... & 3.65 & $\cdots$ & $\cdots \cdots$ & $\ldots$ & \\
\hline Clay substance $\ldots \ldots \ldots \ldots \ldots$ & 58.37 & 66.81 & 79.48 & 72.69 & 14.39 & \\
\hline
\end{tabular}

1. Under clay No. 5, from mine owned by Bockting Bros., Huntingburg, Dubois County. Used for stoneware at Huntingburg and Evansville.

2. Under clay from beneath the vein of coal worked by the American Cannel Coal Company, Cannelton, Perry County.

3. Under clay No. 8, from the land of S. L. McCune, Mecca, Parke County.

4. Under clay 16, from the land of S. L. McCune, Mecca, Parke County.

5. Under clay No. 10, from the land of Joseph Burns, West Montezuma, Vermilion County. Used for fire bricks.

6. Average of stoneware clays selected from the ground clays used in several of the large Akron, Ohio, stoneware factories, and then mixed. (Inserter for comparison.) 
INDIANA.

Analyses of Carboniferous shales of Indiana.

\begin{tabular}{|c|c|c|c|c|c|c|c|c|c|c|}
\hline & 1. & 2. & 3. & 4. & 5. & \multicolumn{2}{|l|}{6.} & 7. & 8. & 9. \\
\hline $\mathrm{O}_{2}$ & 56.62 & 59.55 & 61.46 & 65.87 & 65.78 & 55.09 & 09 & $9.7 \pi$ & 59.02 & 58.83 \\
\hline $\mathrm{TiO}_{2}$ & $\ldots$ & 1.00 & 1.20 & 1. 10 & 1.00 & & 20 & .80 & 1.10 & .70 \\
\hline $\mathrm{Al}_{2} \mathrm{O}_{3}$. & 21.63 & 16.21 & 16.54 & 14. 66 & 14.79 & 20.76 & 76 & 0.60 & 20.93 & 22.34 \\
\hline (Combined) $\mathrm{H}_{2} \mathrm{O}$ & 6.53 & 5.62 & 5.09 & 4. 59 & 4.98 & 7.01 & 01 & 4.53 & 7.59 & 5.22 \\
\hline $\mathrm{Fe}_{2} \mathrm{O}_{3}$ & 7.08 & 2.18 & 3.77 & 6.23 & 8.03 & & 00 & 2.22 & 4.45 & 5.13 \\
\hline $\mathrm{FeO}$. & $\cdots$. & 7. 13 & 3.71 & 1.37 & - & 4. 01 & 01 & 3. 70 & 1.56 & 1.44 \\
\hline $\mathrm{aO}$. & 1.11 & .75 & .66 & .39 & .54 & 1.51 & 51 & .64 & .51 & .49 \\
\hline $\mathrm{MgO}$ & 1.41 & 1.58 & 1.81 & 1. 54 & 1. 42 & & 18 & 1.98 & 1. 66 & 1.56 \\
\hline $\mathrm{K}_{2} \mathrm{O}$ & 3. 14 & 2.81 & 3.28 & 2. 66 & 2.82 & & 36 & 3.10 & 2.92 & 4. 18 \\
\hline $\mathrm{Na}_{2} \mathrm{O}$ & .48 & .28 & 1.09 & 1. 31 & .97 & & 34 & .85 &. \pm 1 & .63 \\
\hline $\mathrm{CO}_{2}$. & 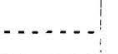 & 3.15 & 1. 45 & 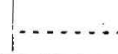 & .26 & & 04 & .90 & & $\ldots$ \\
\hline Tota & 98.00 & 100.26 & 100.06 & 99.72 & 100.59 & \multirow{2}{*}{\multicolumn{2}{|c|}{$\begin{array}{l}99.50 \\
20.90\end{array}$}} & 99.09 & 100.15 & 100.52 \\
\hline Quartz .... &. & 34.61 & 27.94 & 36.87 & 34.34 & & & 3.04 & 23.82 & 22.81 \\
\hline Feldspathic detritus &. & 1.81 & 8.56 & 13.07 & 12.58 & \multicolumn{2}{|c|}{2.03} & 3.37 & 3.28 & 8.30 \\
\hline Fer & - & 8.61 & 3.82 & & $\ldots$ & \multicolumn{2}{|c|}{6.46} & 2. 37 & & \\
\hline $\mathrm{MgC}$ & & & & & .50 & & 13 & & & $\cdots$ \\
\hline Clay : & 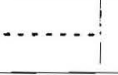 & 54.97 & 59.68 & 50.06 & 52.58 & 69.48 & 48 & $3.22: 7$ & 72.90 & 68.89 \\
\hline & 10. & 11. & 12. & 13. & 14. & 15. & 16. & 17. & 18. & 19. \\
\hline $\mathrm{SiO}_{2}$. & 61.05 & $5: 56.68$ & 53.26 & 64.05 & 46.07 & 56.32 & 55.31 & 62.04 & t $\quad 67.82$ & 68.46 \\
\hline $\mathrm{TiO}_{2}$ & 1. 20 & .90 & 1.05 & 1.00 & 1.19 & 1.07 & 1.15 & 1.30 & 1.10 & 1. 49 \\
\hline $\mathrm{Al}_{2} \mathrm{O}_{3}$. & 21.46 & 320.33 & 25.77 & 16.00 & 24.22 & 24.34 & 22.46 & 18.49 & \begin{tabular}{l|l}
9 & 13.60
\end{tabular} & 16.08 \\
\hline (Combined) $\mathrm{H}_{2} \mathrm{O}$ & 6. 94 & 6.54 & 7.00 & 3.79 & 9.76 & 6.33 & 7.48 & 6.50 & 9.72 & 7.04 \\
\hline $\mathrm{Fe}_{2} \mathrm{O}_{3}$. & 5.57 & 4.35 & 3.32 & .89 & 9.65 & 5.60 & 7.18 & 7.54 & 4.04 & 1.92 \\
\hline $\mathrm{FeO} \ldots$ & .71 & 3.69 & 3.82 & $5.85^{\circ}$ & .34 & .24 & .23 & .06 & .45 & .06 \\
\hline $\mathrm{CaO} \ldots$ & .25 & .57 & .32 &.+2 & .19 & .31 & .66 & .16 & .57 & .99 \\
\hline $\mathrm{MgO} \ldots$ & .70 & 2.04 & 1.90 & 2.00 & 1.31 & .54 & .93 & .91 & .44 & .05 \\
\hline $\mathrm{K}_{2} \mathrm{O} \ldots \ldots$ & 2.34 & 3.15 & 2.54 & 2.59 & 1.66 & 2.85 & 2.05 & .93 & 1. 68 & 1.31 \\
\hline $\mathrm{Na}_{2} \mathrm{O} \ldots \ldots \ldots$ & .30 & .63 & .44 & 1.19 & 2.76 & 2.34 & 2.06 & 2.04 & 1.18 & 2. 40 \\
\hline $\mathrm{CO}_{2} \ldots \ldots$ & - & .47 & 1. 10 & 2.68 & 2.87 & $\cdots \cdots \cdots$ & 1.24 & 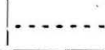 & 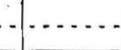 & 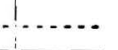 \\
\hline Tota & 100.52 & \begin{tabular}{l|l}
2 & 99.35.
\end{tabular} & 100.52 & 100.46 & 100.02 & 99.94 & 100.75 & 99.97 & 100.60 & 99.80 \\
\hline Quartz & 25.87 & \begin{tabular}{l|l}
7 & 29.85
\end{tabular} & 28.66 & & 15. 91 & 13.19 & 11.91 & 30.60 & 38.70 & 37.58 \\
\hline Feldspathic det & 1. 62 & 8.24 & 2.32 & & 13.39 & 13.21 & 25.38 & 16. 68 & 317.90 & 16.87 \\
\hline Ferrous carbc & . & 1.23 & 2.90 & & .54 & & .37 & & & \\
\hline $\mathrm{Mg}$ & .. & & ì & & $\ldots$ & & 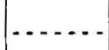 & & & $\cdots$ \\
\hline Clay substance. & 72.51 & 160.68 & 66.12 & & 70.72 & 73.54 & 63.46 & 52.69 & 44.00 & 45.35 \\
\hline
\end{tabular}

1. Average of ten analyses of shales used in the manufacture of paving brick and sewer pipe in the State of Ohio. Adopted as the standard for this report. (Inserted for comparison.)

2. Mixture of shales and surface clay as used by the Wabash Clay Company, Veedersburg, Fountain County, in the making of paving blocks. 
3. Mixture of shales and small amount of surface clay as used by the Clinton Paving Brick Company, Clinton, Vermilion County, for the making of paving brick. A verage sample.

4. Mixtures of shales and surface clay as used by the Evansville Pressed Brick Company, Evansville, Vanderburg County, in the making of paving and dry-pressed brick. Average sample.

5. Mixture of shales 3 and 4, from the clay pit of the Cayuga Pressed Brick Company, Vermilion County. Used for making red dry-pressed brick. Average sample.

6. Bastard shale 5, from the pit of the Cayuga Pressed Brick Company, Vermilion County. Used in the making of buff dry-pressed brick. Average sample.

7. Shale 2, from the land of S. L. McCune, Mecca, Parke County.

8. Shale 9 , from the land of S. L. McCune, Mecca, Parke County.

9. Shale 5, from the land of S. L. McCune, Mecca, Parke County.

10. Shale from the land of H. T. Thorp, near Terre Haute, Vigo County.

11. Mixture of shales from railway cut near Lincoln City, Spencer County.

12. Shale 7, from above the main vein of coal worked by the American Cannel Coal Company, Cannelton, Perry County.

13. Shale from above the worked vein of coal, Prospect Hill mine, Vincennes, Knox County.

14. Shale 6, from the land of Joseph Burns, West Montezuma, Vermilion County.

15. Shale 11, from the land of Joseph Burns, West Montezuma, Vermilion County.

16. Shale 8 , from above the worked vein of coal, shaft No. 1, Island Coal Company, Linton, Greene County.

17. Shale from near "Air-line" shops, Princeton, Gibson County.

18. Shale from the land of Frank Landers, near Stonebluff, Fountain County.

19. Shale from the land of J. W. Shuster, near Stonebluff, Fountain County.

KAOLIN.

At several localities in Lawrence, Martin, and Owen counties are found deposits of white clay known as indianaite, the best-known occurrence being near Huron, Lawrence County.

These deposits were first mentioned by E. T. Cox, in the report for 1874, and the kaolin was locally known as mineral tallow. It was at one time used at Cincinnati for making white ware, and later it was used by the Pennsylvania Salt Company. It varies from 4 to 11 feet in thickness, with an average of $5 \frac{1}{2}$ to 6 feet, forming a horizontal stratum overlain by sandstone, and in places contains a light green mineral known as allophane. The upper half of the kaolin stratum is chiefly composed of massive snow-white clay, associated with which, near its upper part, are occasional concretionary masses, some of them a foot or more in diameter. They disintegrate on exposure to air, but the kaolin is nonplastic. The lower half of the kaolin ranges from pale buff to rich, deep brown in color. An analysis of this kaolin is as follows: 


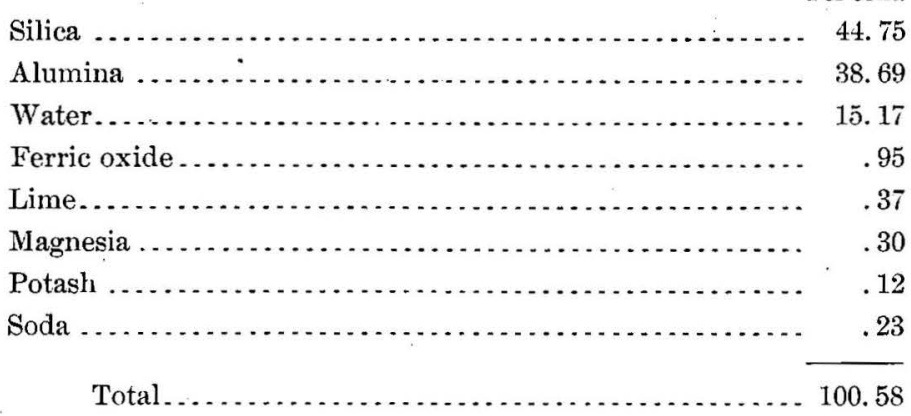

Kaolin outcrops at several places in the eastern half of Martin County, and beds have been worked on small scale." One mine is on the south side of White River in NW. $\frac{1}{4}$ sec. 27 , T. 3 N., R. 4 W., $2 \frac{1}{2}$ miles west of Shoals. Here the kaolin is $4 \frac{1}{2}$ to 5 feet thick, but is not uniform in character. The uppermost layer is a hard, semitransparent, milk-colored clay. Under this is a soft, chalk-white to cream-colored clay. The third layer is hard, dark amber brown to black, with much iron oxide. Kaolin is also found near Willow Valley and Pleasant Valley. A number of outcrops are seen north of White River, one of these being near the town of Dover Hill. Another deposit is three-fourtbs of a mile south of the Indiana Springs Hotel. The kaolin is considered to underlie the greater part of the eastern half of Martin County, at the lower horizon of the Conglomerate sandstone of the Carboniferous.

In Owen County ${ }^{b}$ kaolin is known to occur 5 miles southeast of Spencer. It probably underlies the greater part of T. 9 N., R. $3 \mathrm{~W}$.

In Greene County ${ }^{c}$ kaolin similar to that found in Lawrence and Martin counties is found in Beech Creek Township and near Newark.

\section{PLEISTOCENE CLAYS.}

These are soft, plastic clays, found at the surface or at no great distance below it, and while occurring over a large part of the State, they are especially important in the northwestern part of Indiana, and on this account have been made the subject of a special report. ${ }^{d}$

In this region three classes are distinguishable, viz, drift clays or "hard pans," alluvial clays, and silty or marly clays.

The drift clays are the most common type, forming a large percentage of the unstratified morainic material, but they are usually too impure for making anything but common brick and tile. They are often calcareous.

a Twentieth Annurl Rept. Ind. Dept. Geol. and Nat. Res., 1895, p. 101.

$b$ Ibid., p. 86.

$c$ Ibid., p. 88.

d Blatchley, W. S., The clays of northwestern Indiuna: Twenty-second Ann, Rept. Ind. Dept. Geol. and Nat. Res., 1897. 
The alluvial clays form larger deposits along the lowlands and second bottoms of the larger streams of northwestern Indiana. They have been formed during periods of overflow, and in some places show a thickness of 30 to 90 feet. They are free from pebbles or coarse particles, and usually possess high plasticity.

The silty or marly clay resembles the preceding class very closely, but differs in having been deposited in bays, lakes, or harbors in quiet water. These clays are usually finer grained than the alluvial ones, are thinly laminated, and often highly calcareous, so that they produce a buff product: The occurrence of these clays in Benton, Newton, Jasper, Starke, Lake, Porter, Laporte, and St. Joseph counties has been discussed in a report of the Indiana geological survey. ${ }^{a}$ Their general character can be judged from the facts given below.

Benton County.-This county lies on the western border of the State, and the clays found in it are all of glacial origin, many of them lying immediately under the black prairie loam. Their thickness ranges from 5 to 20 feet, and the best deposit, which is at Earl Park has been worked since 1891. Its section is as follows:

Section at Earl Park, Benton County, Ind.

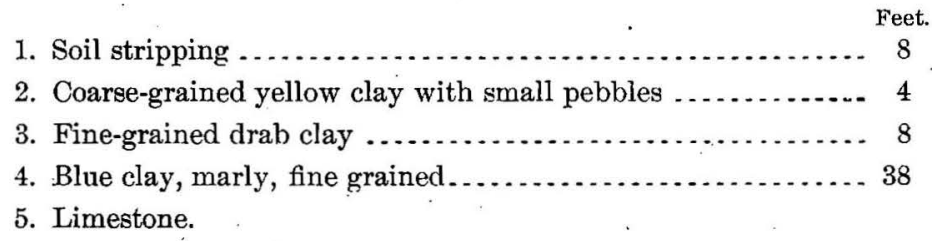

2 has little lime; 3 and 4 are similar, often contain pebbles, and are calcareous. At Lochiel the clay resembles the upper stratum of the Earl Park section and is used for making hollow brick. Drain tile and ordinary brick are made from the drift clays at Fowler, and tile factories are located at other places in the county.

Newton County.-Much of the surface of this county is covered with loose sand, and the clays are all drift or marly ones, being either deposits from the melting ice or laid down just after the close of the Glacial epoch. In places their thickness is 120 to 140 feet, but in others it is less than 10 feet. A sand cover in the northern part of the county conceals much of the clay. The most extensive workings are around Brook, where the following section was taken:

Section at Brook, Neuton County, Ind.

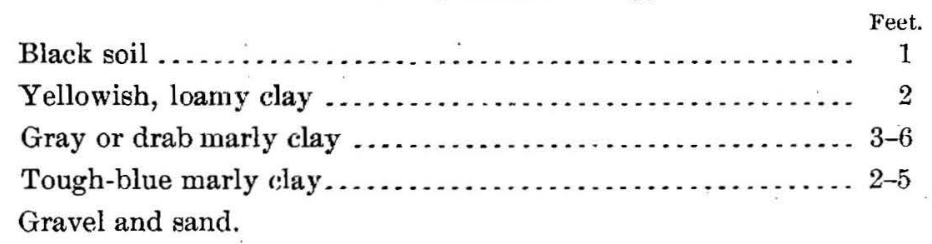
p. 112

a The clays and elay industries of northwestern Indiana, Twenty-second Ann. Rept. Ind. Dept. Geol. and Nat. Res., 
The clay is used in the manufacture of terra-cotta lumber and hollow brick.

Jasper County. - Clays occur at several points, the best being $1 \frac{1}{2}$ miles north of Rensselaer, where the deposits are 13 to 15 feet thick.

Starke County. - There is much marshy land in this county which has been drained, and at other places there are sandy and prairie soils; but beneath these throughout northwestern Indiana there is a vein of fine-grained ash-blue bowlder clay. At times this appears at the surface.

Lake County.-Two kinds of clays are found in this county, viz, the drift clays and the silty or marly clays. The former are used at Lowell and Crown Point for brick and tile, the latter on large scale at Hobart for terra-cotta lumber, flue lining, fireproofing, and common and pressed brick. The pit at Owen, north of Hobart, has an area of 4 acres and is 25 feet deep, showing the following section:

Section at Owen, Lake County, Ind.

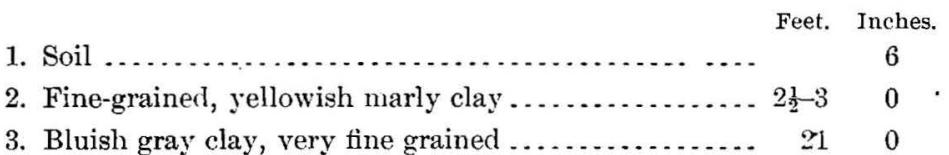

These clays are evidently lacustrine deposits formed during the highest stage of the glacial Lake Chicago. ${ }^{a}$

Porter County.-Here again the drift clays and the marly ones occur. The former are used for common brick and common tile at Hebron and Valparaiso. The marly clays are used in the manufacture of pressed-brick at Porter and of common brick at Granite City and Chester. ${ }^{b}$ At the junction of the Michigan Central and Lake Shore railroads at Porter, Ind., is the largest pressed-brick factory in the State, operated by the Chicago Hydranlic Pressed Brick Company. The clay underlies an area of 45 acres to a depth of 6 feet.

Laporte Connty. - This includes Michigan City, northeast of which, along Treaty Creek, are large deposits of bluish-gray marly clay. ${ }^{c}$

St. Joseph Connty. - The best deposits are in the immediate vicinity of South Bend, and along the St. Joseph River, consisting of thick beds of pearl-gray marly clay which is very fine-grained and plastic. Blush clay here is in places 50 feet thick.

a Twenty-second Ann. Rept. Ind. Dept. Geol. and Nat. Res., p. 33.

$b$ See table of analyses below.

c Analysis No. 4 of following table. 
The following analyses indicate the character of these surface clays:

Analyses of clays of northwestern Indiana.

\begin{tabular}{|c|c|c|c|c|}
\hline . & 1. & 2. & 3. & 4. \\
\hline $\mathrm{SiO}_{2} \ldots \ldots$ & 50.56 & 50.37 & 53.02 & 50.47 \\
\hline $\mathrm{TiO}_{2} \ldots \ldots$ & 1.00 & .65 & 1. 30 & 1.45 \\
\hline $\mathrm{Al}_{2} \mathrm{O}_{3} \ldots \ldots \ldots$ & 13.11 & 9.93 & 10. 72 & 12. 77 \\
\hline Combined water ................ & 2. 76 & 1.50 & 2.21 & 3.14 \\
\hline $\mathrm{Fe}_{2} \mathrm{O}_{3} \ldots \ldots \ldots \ldots \ldots$ & 2.98 & 2.10 & 2.54 & 2. 44 \\
\hline $\mathrm{FeO} \ldots \ldots$ & 2.34 & 2.05 & 2. 22 & 2. 52 \\
\hline $\mathrm{CaO} \ldots \ldots$ & 7.87 & 10.26 & 8. 38 & 8.17 \\
\hline $\mathrm{MgO} \ldots \ldots \ldots \ldots$ & 5.06 & 6.26 & 5.28 & 5.22 \\
\hline $\mathrm{K}_{2} \mathrm{O} \ldots \ldots$ & 3. 74 & 3.04 & 3.25 & 3. 70 \\
\hline $\mathrm{Na}_{2} \mathrm{O} \ldots \ldots \ldots \ldots$ & 0.70 & 0.79 & 086 & 0.73 \\
\hline $\mathrm{CO}_{2} \ldots \ldots \ldots \ldots$ & 9.62 & 12.50 & 10.48 & 9.80 \\
\hline Total.... & 99.72 & 99.45 & 100.26 & 100.41 \\
\hline Quartz . . . . & 23.61 & 28.78 & 24.89 & 21.39 \\
\hline Feldspathic detritus. ....... & 15.94 & 11. 14 & 14. 91 & 12.70 \\
\hline $\mathrm{CaCO}_{3} \ldots \ldots \ldots$ & 14.05 & 18.32 & 14.86 & 14.59 \\
\hline $\mathrm{MgCO}_{3} \ldots \ldots \ldots \ldots$ & 6.54 & 8.48 & 7. 60 & 6.42 \\
\hline Clay substance $\ldots \ldots \ldots$ & 39.86 & 33.28 & 37.74 & 44.90 \\
\hline
\end{tabular}

1. Average of the material used in making terra-cotta lumber at Hobart, Lake County, Ind.

2. Average sample of the upper portion of the bed of bluish-gray marly clay at Garden City, Porter County, Ind.

3. Average sample of the bluish-gray marly clay from the pit of P. E. Anderson \& Sons, Chesterton, Porter County, Ind.

4. Average sample of the bluish-gray marly clay from the pit of Roeske Bros., Michigan City, Laporte County, Ind.

Miscellaneous occurrences.-Prof. W. S. Blatchley, State geologist of Indiana, informed the writer that the majority of the surface clays of the northern portion of the State are similar to those that occur around South Bend. The following analysis is somewhat typical of the drift clays of northern Indiana: ${ }^{a}$

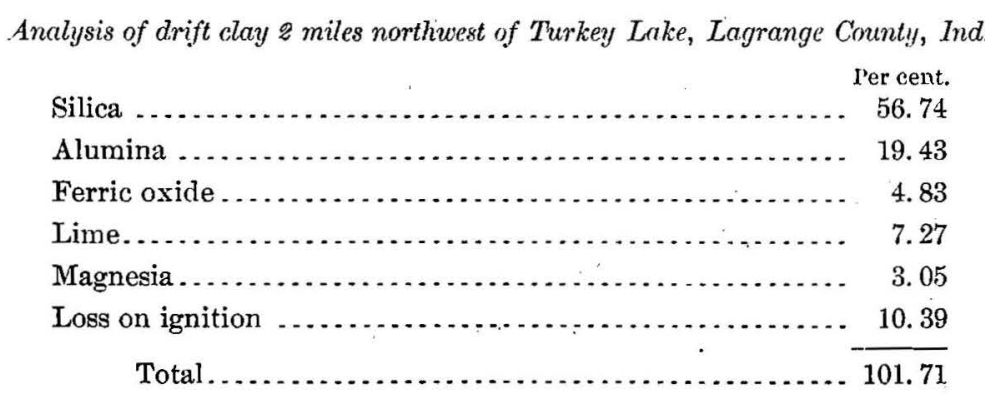

a Twenty-fifth Ann. Rept. ind. Dept. Geol. and Nat. Res., p. 112. 
The section of the deposit is as follows:

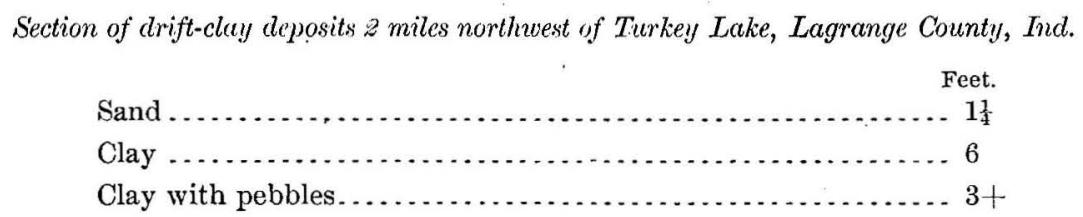

At Coal City, in Owen County, is one of the largest ordinary brickyards in western Indiana. ${ }^{a}$ The clay used is a yellow surface clay, free from lime.

A yellow surface clay near Huntingburg makes a fine red-front brick and closely resembles that worked at Washington, Ind. ${ }^{b}$

A surface clay occurs near Princeton, resembling those so characteristic of the southern counties of Indiana. Fine pressed brick are made from it at Huntingburg, Dubois County. It burns to a good red color. Its analysis is as follows: ${ }^{c}$

Analysis of surface clay near Princeton, Gibson County, Ind.

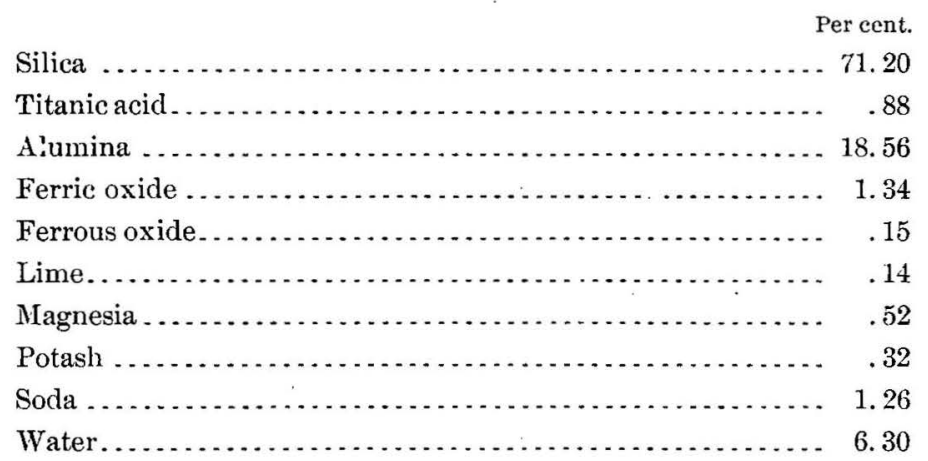

Many deposits of good surface clays also occur in the vicinity of Gosport, Owen County. They are abundant in Spencer County, around Rockport. ${ }^{\prime}$

At Switz, drift clay is found 3 feet below the surface; and also a thick stratum of tough, blue drift clay, making excellent drain tile. ${ }^{e}$

In the vicinity of Washington, Daviess County, there is found a good grade of yellow surface clay, averaging 15 to 18 feet in thickness, which can be made into a fine, dry-pressed, front brick. Fire clays for mixing with it are obtainable not far off.

The river bottoms of Vigo County are bordered by river terraces which vary in width from 3 to 8 miles and contain considerable quantities of recent sedimentary clays. A good grade of dry-pressed brick is made from a bed of such clay over 20 feet thick found in the lowlands of the Wabash River, near Terre Haute, in this

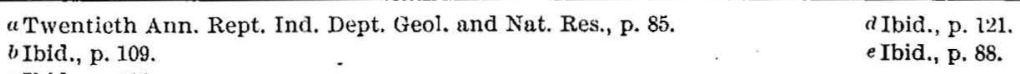


county. The clay is of even texture and free from pebbles, but an objection to it is the lack of uniformity in the shade of the burned clay.

The following is an analysis of the Terre Haute sedimentary clay:

$$
\text { Analysis of Terre Haute sedimentary clay. }
$$

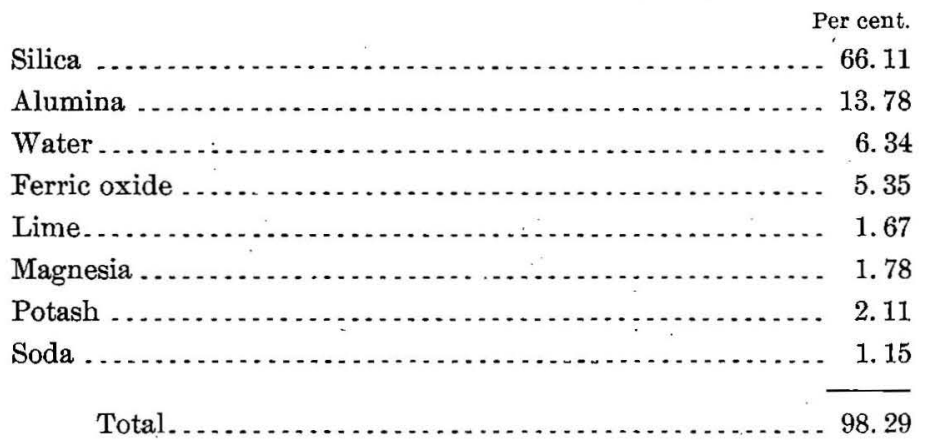

Drift clays are said to occur over most of Miami County. ${ }^{a}$ They occur either at the surface or interbedded with sand and gravel. Pottery clays are known at Denver. In Allen County brick and tile clays are common in the surface formations, ${ }^{b}$ and the same is true of Marshall County. ${ }^{c}$

\section{CLAY-WORKING INDUSTRY.}

Indiana ranks seventh among the clay-producing States. This is due partly to the presence of many clays well suited to the manufacture of brick and other clay products, and also the proximity of several large cities, such as Indianapolis and Chicago.

The value of the clay products of Indiana is shown by the following figures.

Value of clay products in Indiana from 1895 to 1901.

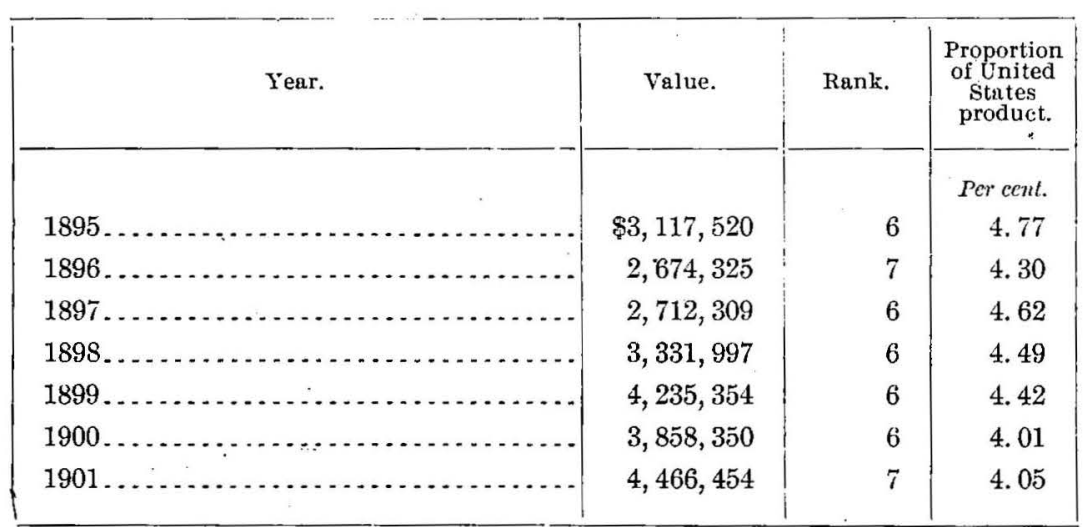

a Sixteenth Ann. Rept. Ind. Dept. Geol and Nat. Res., p. 176.

$b$ Ibid, p. 127.

$c$ Fifteenth Ann. Rept. Ind. Dept, Geol. and Nat. Res., p. 180. 
Value of clay products of Indiana in 1900 and 1901.

\begin{tabular}{|c|c|c|}
\hline$\theta^{-}$ & 1900. & 1901. \\
\hline Common brick.......... & $\$ 1,391,873$ & $\$ 1,624,133$ \\
\hline Front brick:... & 172,752 & 234,775 \\
\hline Vitrified brick . . . . . . . . & 331,276 & 320,221 \\
\hline Fancy or ornamental.... & 7,310 & 8,160 \\
\hline Fire brick $\ldots \ldots \ldots \ldots$ & 40,976 & 51,526 \\
\hline Stove linings. . . . . . . . . & $(a)$ & $(a)$ \\
\hline Drain tile..... & 674,602 & 772,241 \\
\hline Sewer pipe....... & 279,719 & 253,626 \\
\hline Ornamental terra cotta... & $(a)$ & $(a)$ \\
\hline Fireproofing .... & 116,581 & 91,081 \\
\hline Tile ........... & 343,985 & 478,130 \\
\hline Red earthenware.... . & 4,337 & 6,650 \\
\hline Stoneware .... & 44,207 & 47,712 \\
\hline Other pottery wares. & 229,830 & 413,000 \\
\hline Clay mined..... & 21,145 & 25,705 \\
\hline Miscellaneous... & 112,576 & 50,790 \\
\hline
\end{tabular}

$a$ Less than three firms reporting.

Common brick.-Common brick are manufactured at a great many localities, usually from drift clays.

Pressed brick.-Pressed brick are produced at Cayuga, Vermilion County; Hillsboro, Fountain County; Terre Haute, Vigo County; Huntingburg, Dubois County; Evansville, Vanderburg County; and Montezuma, Parke County. They are made in part from semifire clays, but also from alluvial ones. At Porter, Porter County, the drift clays are used.

Paving brick.-Paving brick are manufactured at several places in Indiana, among them Clinton, Vermilion County; Veedersburg, Fountain County; Brazil, Clay County; Evansville, Vanderburg County; and New Albany, Floyd County.

Fireproofing.-This is made in large quantities near Hobart, in northwestern Indiana. The material used is calcareous glacial clay.

Sewer pipe. ${ }^{a-T h e}$ clays used for making these are the same as those employed for paving brick, namely, the under clays and shales. Shale is used at Brazil, but most of the works at other places prefer the under clay. Pumps are made from semirefractory clay at Brazil, Ind., and sewer pipes are manufactured also at Mecca, Parke County; Cannelton, Perry County; and Terre Haute, Vigo County.

a Twentietl Ann. Rept. Dept. Ind. Geol. and Nat. Res., p. 164.

$9647-$ No. $11-03-8$ 
Fire bricks.-These are made but at four factories in Indiana, which get their clay from the stratum underlying a large area in Parke and Vermilion counties. It is a white semiplastic under clay. The factories are located at Hillsdale and Montezuma.

Pottery.-Both earthenware and stoneware are made by many small works in the coal-bearing counties, there being 11 factories making stoneware, 3 of which are of considerable size. One factory at Evansville makes white graniteware. Stoneware clays are especially mentioned by Blatchley, ${ }^{a}$ from the vicinity of Annapolis, Parke County; Brazil, Clay County; Shoals, Martin County; Huntingburg, Dubois County; and Cannelton, Perry County. Stoneware is made at Annapolis, Bloomingdale and Rockville, Parke County; Brazil and Clay City, Clay County; Worthington, Greene County; Shoals, Martin County; Huntingburg, Dubois County; Cannelton, Perry County; and Evansville, Vanderburg County.

\section{KENTUCKY.}

No systematic report has ever been issued on the clays and shales of the State, and except as to the Jackson Purchase region the information published is mostly of a scattered character, although many samples, collected from time to time by the geologists of the Kentucky geological survey, have been analyzed and the results are published in the State geological reports. ${ }^{b}$

Within the State there are found a series of geologic formations ranging from the Ordovician to the Pleistocene. Some of these contain deposits of soft, plastic clays or shales, while others yield clays only as a result of surface weathering. A section across the State from east to west shows that the formations are not highly tilted, as they are farther eastward, but that they are rather flat, having a comparatively gentle dip, so that in any one area where two formations are exposed the older of the two may have been laid bare as a result of erosion.

Beginning with the oldest or Ordovician, we find that this occupies an irregularly shaped area in the northern part of the State. The Trenton limestone of this series forms a large portion of the surface in the counties of Jessamine, Woodford, Mercer, Boyle, and portions of Scott, Franklin, Bourbon, and Fayette. Surrounding this is a much larger area where the upper portion of the Ordovician is exposed in the counties of Boone, Kenton, Campbell, Gallatin, Carroll, Grant, Pendleton, Bracken, Mason, Robertson, Harrison, Henry, Wayne, Nichols, Scott, Shelby, Spencer, Anderson, Washington, Garrard, Madison, Clark, Montgomery, and Bath. Outcropping on the eastern and western sides of this area is a strip of Upper Silurian which on the western side passes through the counties of Trimble, Oldham, Jefferson, Bullet, Nelson, and on the eastern side through Lewis, Fleming, and Bath counties.

$a$ Twentieth Ann. Rept. Ind. Dept. Geol. and Nat. Res., 1895, p. 171. $b$ See Kentucky Geol. Surv., Chem. Anal., Pts. I, II, III. 
Devonian rocks surround the Silurian areas on the east, west, and south, forming a narrow, irregular patch, whose exact distribution can best be seen from an examination of a geologic map of the State. The Lower Carboniferous is found in both the eastern and western half of the State. It forms an irregular band extending southwestward from opposite Portsmouth, Ohio, through Lewis, Rowan, Menifee, Powell, and Rockcastle counties, and then broadening considerably, it is exposed through the central part of the State as far eastward as the western boundary of Howard County. The area then splits, one portion spreading northwestward into Hardin, Breckinridge, and Meade counties, the other fork extending through the southern part of the State in Warren, Logan, Todd, and Christian counties, as far west as the Tennessee River and north to the Ohio. The Upper Carboniferous rocks underlie two large areas of more or less solid outline. One of these areas is in the eastern part of the State and extends from the West Virginia and Virginia borders northwest and west to the Lower Carboniferous boundary. The second area forms a large more or less rectangular patch in the western part of the State, reaching along the Ohio River from Skillman, in Hancock County, to Blackburn, in Union County. South of these points this area extends approximately as far as the northern boundary of Christian, Todd, Logan, and Warren counties. From the southeastern corner of it a branch extends eastward, covering most of Edmonson and Grayson counties. The Tertiary area occupies that portion of the State between the southern boundary and the Tennessee and Ohio rivers. In this area there are some small strips of Cretaceous in Marshall and Calloway counties and some broad patches of Pleistocene along the Ohio River.

LOWER SILURIAN, OR ORDOVICIAN.

The Ordovician rocks may yield two types of plastic material, viz, residual clays and shales.

The residual clays are derived chiefly from the limestones of this formation - and form a tough red clay, the dominant soil type of the Blue Grass region. They are probably well adapted to the manufacture of red brick and perhaps earthenware.

The Ordovician shales occur in both the Cincinnati and the Hudson groups, but in most places they are probably calcareous, so that they are better adapted to the manufacture of Portland cement than bricks. Calcareous clay is derived from the upper Hudson shales in Oldham County; ${ }^{a}$ from the Cincinnati group, on the Lexington turnpike, 2 miles south of Covington; ${ }^{b}$ in Jefferson County; ${ }^{c}$ and in Campbell County, one-fourth mile from Newport. ${ }^{d}$ Shales obtained from the Cincinnati group near Bridgeport have been used for making paint. ${ }^{e}$ \begin{tabular}{ll}
\hline$a$ Kentucky Geol. Survey, Report on Oldham County, p. 19. & $d$ Idem, Chem. Anal., Pt. I, 1884, p. 34. \\
$b$ Idem, Report on Kenton County, p. 133. & $e$ Ibid., p. 76.
\end{tabular} c Idem, Report on Jefferson County, p. 50 . 
The following are analyses of some of these shales:

Analyses of Lower Silurian shales from Kentucky.

\begin{tabular}{|c|c|c|c|c|c|}
\hline . & 1. & 2. & 3. & 4. & 5. \\
\hline Silica...... & 56.40 & 43.461 & 47.16 & 47.32 & 47.96 \\
\hline Alumina... & & & & & 21.34 \\
\hline Ferric oxide ...................... & 29.971 & 21.000 & 22.85 & 28.05 & 6.60 \\
\hline $\begin{array}{l}\text { Manganese dioxide } \ldots \ldots \ldots \ldots \ldots \\
\text { Lime carbonate } \ldots \ldots \ldots \ldots \ldots \ldots \ldots \ldots\end{array}$ & 760 & 27.040 & 20.14 & 13.49 & \\
\hline Lime........... & ........ & ….... & ........ & $\cdots \cdots$ & 5.824 \\
\hline Magnesia .... . & 1.514 & .680 & .84 & 1. 135 & 3.524 \\
\hline Phosphoric acid.. & .166 & .607 & .128 & 3. 254 & $\ldots$ \\
\hline Potash & 3.538 & 2.447 & 2. 301 & .64 & 5.264 \\
\hline Soda $\ldots . . . . .$. & .551 & .915 & 1.590 & .345 & .250 \\
\hline Ignition & 7.100 & 3.85 & 5.200 & 4.80 & 9.238 \\
\hline
\end{tabular}

1. Clay from Cincinnati group, 2 miles south of Covington. Kentucky Geol. Survey, Chem. Anal., Pt. I, p. 133.

2. Marly shale, Cincinnati group, junction of Ohio and Licking rivers, 12 feet above low-watermark. Ibid., p. 134.

3. Marly shale, between impure limestone, 5 feet above low-water mark, Whitehall. Ibid.

4. Marly shale from Cincinnati group, one-fourth mile from New port, upper blue clay. Ibid., p. 36 .

5. Clay shale from Cincinnati group, Jeffersontown, Jefferson County. Idem, Pt. II, p. 50.

\section{UPPER SILURIAN.}

The Upper Silurian rocks yield clays and shales similar to the Ordovician as far as known. Some good clays are said to exist in the lower beds of the series. ${ }^{a}$ In Madison County ${ }^{b}$ a good quality of clay is mentioned from Waco, 9 miles east of Richmond, while marly shales occur in Henry, ${ }^{c}$ Fulton, ${ }^{d}$ Campbell, and Franklin counties. In Fleming County ${ }^{e}$ the shale of the Niagara group yields a stiff, blue clay. Other clays are found in Madison and Clark counties. ${ }^{f}$

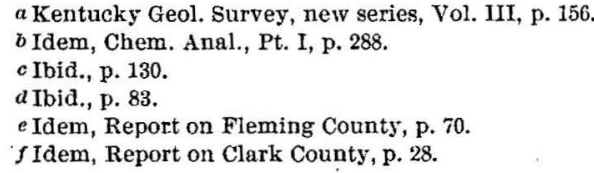


The following analyses indicate the composition of some of these Silurian shales: Analyses of Cpper Silurian shales from Kentucky.

\begin{tabular}{|c|c|c|c|c|c|c|}
\hline . & 1. & 2. & 3. & 4. & 5. & 6. \\
\hline Silica $\ldots \ldots \ldots \ldots \ldots \ldots \ldots \ldots \ldots \ldots \ldots \ldots \ldots$ & 42.3 & 48.78 & 59.976 & 56.96 & 59.000 & 42.56 \\
\hline Alumina ................. & 20.84 & 17.32 & & $\mid \ldots \ldots$ & 20.68 & 900 \\
\hline Ferric oxid $\ldots \ldots \ldots \ldots \ldots \ldots \ldots$ & 4. 12 & 3.24 & 27.64 & $\{28.74$ & 4.96 & 20.98 \\
\hline $\mathrm{MnO}$ and $\mathrm{P}_{2} \mathrm{O}_{5} \ldots \ldots \ldots \ldots$ & & 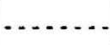 & & & & \\
\hline $\mathrm{CaSO}_{4} \ldots \ldots \ldots \ldots \ldots \ldots$ & $\cdots$ & 19.285 & & & & ........ \\
\hline Lime $\ldots . . . \ldots \ldots \ldots \ldots \ldots \ldots$ & 13.32 & $\cdots .$. & .......... & $\ldots \ldots$ & 1. 456 & 8.680 \\
\hline Lime carbonate ......... & $\ldots$ & $\ldots$ & .280 & .20 & $\ldots . . .$. & $\ldots$ \\
\hline Magnesia . . . . . . . . . & .461. & .496 & .606 & .752 & 1.096 & 7. 247 \\
\hline Potash...... & 2.387 & 4.768 & 3. 931 & 2.502 & 5.500 & 4.819 \\
\hline Soda................. & .351 & .24 & .547 & .315 & .217 & .166 \\
\hline Loss on ignition, etc .......... & 16. 221 & 5.871 & 7.02 & 10.531 & 8.091 & 15.548 \\
\hline
\end{tabular}

1 and 2. Analyses of shale of Niagara group from Madison County.

3. Potter's clay, Waco, Ky., first grade. Kentucky Geol. Survey, Chem. Anal., Pt. I, p. 288.

4. Potter's clay, Waco, Ky., second grade. Ibid., p. 288.

5. Shaly clay from land of F. W. Lewis, 2 miles south of Bobtown, in Madison County; sample of upper 10 inches. Ibid., p. 296.

6. Shaly clay from same locality, from 10 to 20 inches below the surface. Ibid.

\section{DEVONIAN}

Little is known regarding the value of the Devonian for clay working. As stated above, it occupies a rather limited area.

The following analysis is given of the "Ohio" shale: ${ }^{a}$

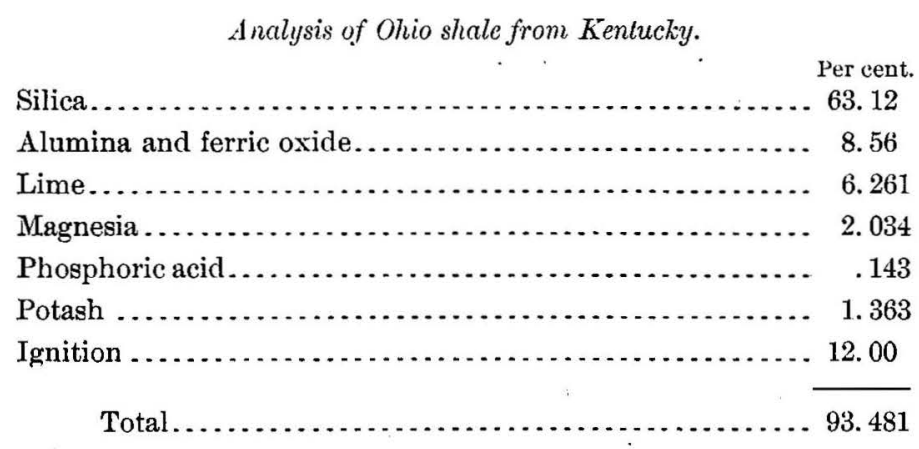

An excellent grade of pottery is made at Waco from the residual elay of the Panola shale. 


\section{LOWER CARBONIFEROUS.}

The Lower Carboniferous contains several deposits of shales and clay, whose character must be mostly judged from the chemical analyses given below. In Montgomery County the Lower Carboniferous shales yield heavy clays. ${ }^{a}$

Analyses of Lower Carboniferous clays and shales.

\begin{tabular}{|c|c|c|c|c|c|c|c|c|}
\hline & 1. & 2. & 3. & 4. & 5. & 6. & 7. & 8. \\
\hline Silica...... & 66.96 & 80.16 & 77.66 & 74.46 & 71.56 & 67.56 & 49.689 & 61.10 \\
\hline Alumina $\ldots . . . . . . . . . . .$. & 15.626 & 11.60 & 16. 80 & 20.44 & 22.86 & 22.54 & $\{19.026$ & 18.20 \\
\hline Ferric oxid ...................... & 8.38 & & & & & & 3.932 & 6.00 \\
\hline Lime........... & 0.493 & a. 76 & .48 & .64 & .68 & .98 & .927 & 4.904 \\
\hline Magnesia .... & .677 & .56 & Undet. & Undet. & Undet. & .671 & 1. 96 & 1. 542 \\
\hline Phosphoric acid.. & .154 & Undet. & ... do .. & $\ldots$ do ... & ... do ... & .025 & -.. & $\cdots$ \\
\hline Potash .... & 3.295 & 3.854 & 1.002 & ... do .. & $\ldots$ do .. & 2.47 & 3.827 . & 4. 101 \\
\hline Soda ............ & .628 & .583 & .484 & $\ldots$ do .. & ... do .. & .058 & .288 & .821 \\
\hline Ignition ..... & 3.787 & 2. 483 & 4.34 & 4. 46 & 4.90 & 5. 696 & 17.41 & 3. 332 \\
\hline
\end{tabular}

a Carbonate.

1. Marly clay shale, Tar Creek Hill, near Cloverport, Breckinridge County. Kentucky Geological Survey, Chem. Anal., Pt. I, p. 374.

2. Siliceous clay, Souder's farm, near Green River, Chester group; 4 to 6 feet thick. Ibid., p. 242.

3. Same farm, on Caney Branch, 1 mile from Green River, 7 to 8 feet thick. Upper layer. Ibid.

4. Same, second layer.

5. Same, third layer.

6. Same, lowest layer.

Last four $(3,4,5,6)$, suggested for common pottery.

7. Plastic clay, Waverly group, land of G. Glasgow, 3 miles south of Beréa, Madison County. Idem, Pt. II, p. 297.

9. Marly clay, Keokuk group, Nelson County. Recommended for terra cotta. Ibid., p. '67.

UPPER CARBONIFEROUS, OR COAL MEASURES.

The Upper Carboniferous of Kentucky occupies, as already stated, two distinct areas, one in the eastern part of the State, the other in the western.

CLAYS OF EASTERN COAL FIELD.

The eastern area covers about 11,000 square miles, and is a continuation of the Ohio, West Virginia, and Virginia areas. Attempts to correlate the Kentucky seams, however, with those of the States mentioned, have met with difficulty, and it is not always possible; indeed, the sections at opposite ends of the Kentucky area are hard to correlate. 
The following comparative sections are given by MacFarland: ${ }^{a}$

Section showing correlative beds in Kentucky, Ohio, and Pennsylrania.

\begin{tabular}{|c|c|c|}
\hline Kentucky. & Ohio. & Pennsylvania. \\
\hline Coal No. 1. & Jackson Shaft. & Sharon. \\
\hline Coal No. $3 \ldots$. . & No. $3 \ldots \ldots \ldots \ldots \ldots$ & Lower or Upper Mercer. \\
\hline Elkhorn... & 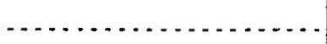 & \\
\hline Jellico........... & $\cdots$ & \\
\hline Peach Orchard.. & $\cdots$ & \\
\hline Coal No. $4 \ldots . .$. & No. $4 \ldots . .$. & \\
\hline Coal No. $5 .$. & No. $6 \ldots \ldots . .$. & Brookville. \\
\hline Coal No. 7 ...... & Sheridan ........ & \\
\hline Ashland........ & Hocking No. $10 \ldots$ & \\
\hline Coal No. $8 \ldots$ & No. $11 \ldots . . .$. & Lower Kittanning. \\
\hline
\end{tabular}

The general section given for Greenup, Boyd, Carter, and part of Lawrence counties, ${ }^{b}$ shows a bed of fine clay near the base of the subconglomerate, and a second one under coal No. 6.

That in the subconglomerate bed is a fire clay. ${ }^{c}$ Like the coal with which it is often closely associated, it may sometimes be entirely wanting, as at points where the conglomerate sandstone follows the limestone without an intervening bed of shales of considerable thickness. This fire clay is said to correspond to that used at Sciotoville, Ohio, and is of good quality and inexhaustible quantity. Following is an analysis of average sample from the upper part of the bed at Boone Furnace:

Analysis of fire clay from Boone Furnace, Ky.

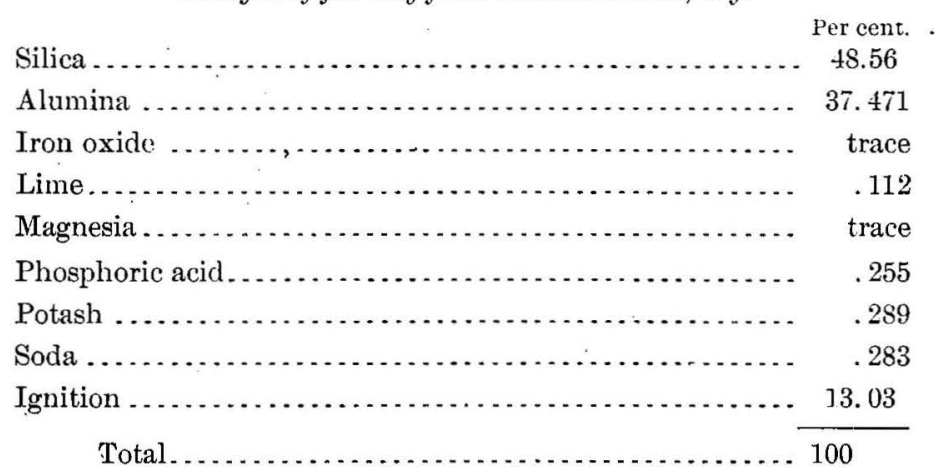

Other analyses show more silica. The bed is from 4 to 6 feet thick. On Mr. Ratcliffe's place, near the lime kilns, it shows a thickness of 8 feet, but is not all of good quality.

aTrans. Am. Inst. Min. Eng., Vol. XXV, p. 520

$b$ Kentucky Geol. Survey, Eastern coal field, Pl.

c Ibid., section 2, Pl. XXIX, and section 28, Pl. VIII. 
The bed occurs in nearly all of that portion of Greenup and Carter counties which presents the rocks of this horizon above drainage. ${ }^{a}$ It has also been noted further southward along the western outcrops of the Coal Measures, and has been mined and shipped in large quantities to Cincinnati from the head of Indian Run, in Greenup County.

In the valley of Schultz Creek and on Plumb Creek, at the place of Judge Fullerton, ${ }^{b}$ the section shows sbale underlying the block iron ore and overlying the Conglomerate sandstone. Fire clay is wanting on the south side of the valley, where the Conglomerate sandstone has great development, but on the opposite side the conglomerate is not so prominent and fire clay is said to be present. The fire clay would probably be found all along the ridge. An interesting section is seen at Thomson's bank, ${ }^{c}$ where the coal is underlain by 20 feet of shales, including fire clay.

West of Boone Furnace, ${ }^{d}$ at the old orchard drift on Overmans Creek, ${ }^{e}$ the section shows a bed of nonplastic fire clay underlying the double coal seam. $f$ The subconglomerate shales are also present, as is shown by the occurrence of the fireclay bed exposed above forks of the creek on the middle branch, where there are 6 feet of nonplastic clay of fine quality. The general section in this region, known as the Stewart section, is given below $f^{\text {: }}$

General section of Coal Measures in Rockcastle County, Ky.

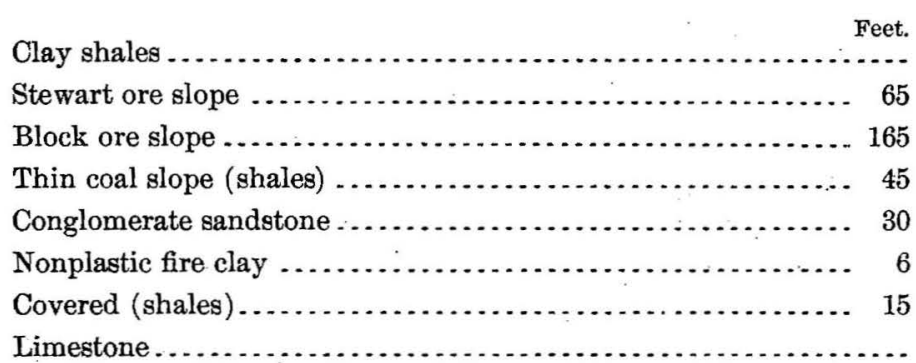

The sections given in the report referred to abovie ${ }^{g}$ indicate the presence of fire clay at several points. Thus under coal 2 it is seen at the McHenry coal property, at Beach Orchard, and under Bogg's coal, all in Lawrence County. On Irish Creek shale underlies the coal. Fire clay is shown under coal 3, at Raccoon Furnace, Pennsylvania Furnace and Bellefont Furnace, Hunnewell Furnace, head of Dry Fork, and also in the Holbrook Bank, Brushy Creek. ${ }^{h}$ Under coal 4 it is indicated

a See Kentucky Geol. Survey, Eastern coal field, 1884, sections 1 and 4, Pl. II; 5, 7, and 8, PI. III; 9, Pl. IV; 19, PI. VI; 25, P1. VIII.

$b$ Ibid., p. 30.

c Ibid., p. 32.

dIbi'd., p. 33.

e Ibid., p. 43.

$f$ Ibid., sec. 7, Pl. B.

o Ibid., p. 43.

$h$ Ibid. 
at Indian Run and Hunnewell, both in Greenup County. Coal 5 shows under shale at Willard. Coal 6 has an under fire clay at Willard, Keyes Creek, and Turkey Pen Creek, Boyd County, also at Horse Branch, near Catlettsburg, Boyd County. . Under coal 7 fire clay occurs at Fourmile Creek, Boyd County; clay or shale underlie it at Star Furnace, East Coalton, and Willard, Boyd County. Coal 8 carries an under clay at Blaine Falls, Lawrence County, and at Willard. The thickness of these beds seems to range in most cases from 2 to 3 feet.

In Menifee County ${ }^{a}$ the Coal Measures in the western part of the county are represented by shale series and by the Conglomerate sandstone. In Greenup and Carter counties these shales are present, though they are not always separated from the shales'above the conglomerate, the Conglomerate sandstone being entirely wanting near the Obio River in places, but becoming prominent to the southwest. In that region the section includes a thick bed of nonplastic fire clay associated with limestone, ore, and coal. The fire-clay bed seems to fall off in importance in proportion as the Subconglomerate shales become more prominent, and few traces of it are found in this region.

Fire clay accompanies many. of the coal seams in parts of Jackson, Pulaski, Laurel, and Rockcastle counties, but is not worked. ${ }^{b}$

UPPER FERRIFEROUS LIMESTONE. $c$

This carries a bed of ore which in Greenup, Carter, and Boyd counties is usually overlain by a heavy bed of white marl or fire clay which sometimes directly overlies the ore, especially where the limestone is absent. At Amanda Furnace ${ }^{d}$ the ore is overlain by two or three beds of fire clay of different quality, from 10 to 15 feet thick in all. This clay is largely used for the manufacture of fire brick at the Bellefonte works and for potters' use in Cincinnati. The following section is given from one of the beds back of Amanda.

Section near Amanda, Ky.

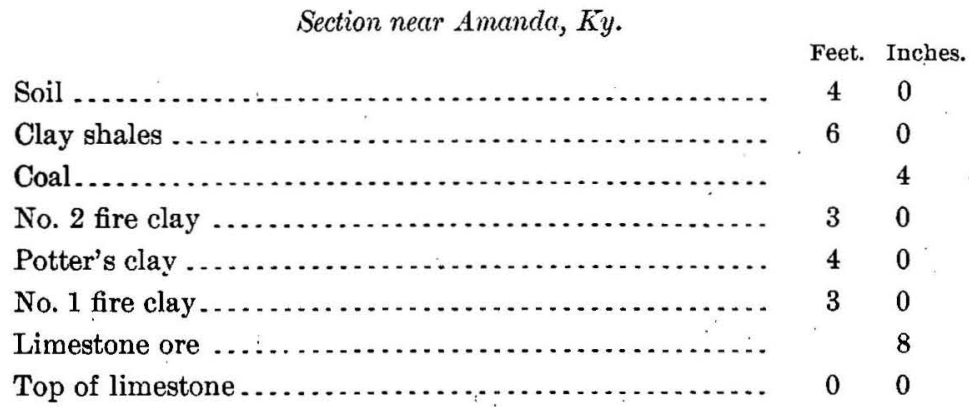

Kentucky Geol. Survey, Eastern coal field, 1884, p. 20

$b$ Geologic Atlas U. S., folio 47 , London.

c Kentucky Geol. Survey, Eastern coal field, 1884, p. 140.

$d$ Ibid., p. 141. 
ANALYSES OF EASTERN KENTUCKY CLAYS.

The following analyses are of clays from eastern Kentucky:

Analyses of clays from eastern Kentucky.

\begin{tabular}{|c|c|c|c|c|c|c|c|c|c|c|}
\hline & 1. & 2. & 3. & & 4. & 5. & 6. & 7. & 8. & 9. \\
\hline $\mathrm{SiO}_{2} \ldots$ & 48.56 & 45.96 & 54.62 & & .46 & 45.56 & 64.26 & 66.06 & 62.68 & 43.58 \\
\hline $\mathrm{Al}_{2} \mathrm{O}_{3}$ & 37.471 & 38.531 & 32.46 & 6627. & $7.203 \quad 43$ & $43.775 \quad 2$ & 24.604 & 23.726 & 14.803 & 40.86 \\
\hline $\mathrm{Fe}_{2} \mathrm{O}_{3}$ & $\operatorname{Tr}$. & Tr. & $\mathrm{T}$ & r. & $\operatorname{Tr}$. & Tr. $\mathrm{U}$ & Undet. & Undet. & 6.16 & .76 \\
\hline $\mathrm{CaO} \ldots$ & .112 & .145 & $\mathrm{~T}$ & r. & Tr. & .145 & .538 & a. 30 & a 8.28 & .29 \\
\hline $\mathrm{MgO} \ldots . .$. & Tr. & Tr. & $\mathrm{T}$ & r. & Tr. & Tr. & .209 & a. 121 & $a 1.65$ & .14 \\
\hline $\mathrm{P}_{2} \mathrm{O}_{5} \ldots \ldots$ & .255 & .563 & .24 & & .147 & .307 & .946 & .127 & .217 & ... \\
\hline $\mathrm{SO}_{3}$ & Undet. & Undet. & Unde & & \begin{tabular}{l|l} 
ndet. & $\mathrm{U}_{\mathrm{x}}$
\end{tabular} & Jndet. &. $\mathrm{I} 57$ & Undet. & & ... \\
\hline $\mathrm{K}_{2} \mathrm{O} \ldots \ldots$ & $.289^{\circ}$ & .25 & .21 & & .85 & .963 & .751 & 2.093 & 3. 108 & .19 \\
\hline $\mathrm{Na}_{2} \mathrm{O} \ldots$. & .283 & .341 & .67 & & .584 & .728 & .515 & 2.273 & .149 & .05 \\
\hline Ignition .. & 13.03 & 14.21 & 11. 78 & & .756 & .8 .522 & 8.30 & 5.30 & 2.953 & 14.43 \\
\hline 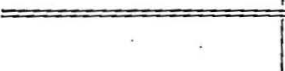 & 10. & 11. & 12. & & 13. & 14. & 15. & 16. & 17. & 18. \\
\hline $\mathrm{O}_{2}$. & 44.84 & 41.28 & 41.5 & & 68 & 32.92 & 66.56 & 47.06 & 67.70 & 55.56 \\
\hline $\mathrm{Al}_{2} \mathrm{O}_{3} \ldots \ldots$ & 40.18 & 40.56 & 38.3 & & \begin{tabular}{l|l}
.281 & 20
\end{tabular} & $0.735 \quad 2$ & 22.679 & 36.62 & 22.092 & 31.027 \\
\hline $\mathrm{Fe}_{2} \mathrm{O}_{3}$ & 1. 76 & 4.42 & 4.0 & & Tr. & 3.82 & Tr. & Tr. & $\operatorname{Tr}$. & $\operatorname{Tr}$. \\
\hline $\mathrm{aO} \ldots \ldots . . .$. & .21 & .60 & .2 & 21 & .213 & .213 & .157 & .615 & .101 & .325 \\
\hline $\mathrm{MgO}$. & .13 & .17 & .1 & 10 & .136 & 2. 281 & .605 & .389 & .285 & .403 \\
\hline${ }_{2} \mathrm{O}_{5}$ & $\cdots$ & $\cdots$ & & & .626 & .371 & .563 & .626 & .498 & .358 \\
\hline $\mathrm{O}_{3}$. & .... & … & $\cdots$ & $\ldots$ Un & adet. $\mathrm{Un}$ & Indet. U & Undet. 0 & Undet. & Undet. & Undet. \\
\hline $\mathrm{K}_{2} \mathrm{O} \ldots \ldots$ & .17 & .11 & $\mathrm{~T}$ & r. & .193 & 2.601 & 1. 946 & 1. 156 & 1. 156 & 1. 167 \\
\hline $\mathrm{Na}_{2} \mathrm{O} \ldots \ldots \ldots$ & .06 & Tr. & $\mathrm{T}$ & r. & .211 & .659 & .69 & .234 & .268 & .56 \\
\hline \multirow[t]{2}{*}{ Ignition .......... } & 12.65 & 12.86 & 15.6 & & 66 & 6. 40 & 6.80 & 13.30 & 7.90 & 10.60 \\
\hline & 19. & 20. & 21. & 22. & 23. & 24. & 25. & 26. & 27. & 28. \\
\hline $\mathrm{SiO}_{2}$ & 47.56 & 59.10 & 84.76 & 54.18 & 51.66 & 69.26 & 70.86 & 62.76 & 40.14 & 56.44 \\
\hline $\mathrm{Al}_{2} \mathrm{O}_{3}$. & 40.661 & & & 25.36 & 15.56 & 16.64 & 19.24 & 26.42 & 43.72 & 60 \\
\hline $\mathrm{Fe}_{2} \mathrm{O}_{3}$ & Tr. & & $\pm \mid$ & 4.82 & 7.68 & 4.52 & 3. 12 & 1.58 & 1.98 & U \\
\hline $\mathrm{CaO} \ldots .$. & .28 & Tr. & $\operatorname{Tr}$. & .549 & 7.269 & Tr. & Tr. & .325 & \multirow{2}{*}{1.60} & \multirow{2}{*}{ 1. 30} \\
\hline $\mathrm{MgO}$. & .497 & .72 & .65 & 1.614 & .817 & .893 & .425 & Tr. & & \\
\hline $\mathrm{P}_{2} \mathrm{O}_{5}$ - & .249 & & & & Undet. & Tr. & Tr. & Undet. & \multirow{5}{*}{12.56} & \multirow{5}{*}{14.30} \\
\hline $\mathrm{SO}_{3}$ & Tr. & & & & & ....... & $\cdots$ & & & \\
\hline $\mathrm{K}_{2} \mathrm{O} \ldots$ & .308 & 3.86 & 1.58 & 4. 286 & 3. 276 & 6. 3.102 & 2.351 & .916 & & \\
\hline $\mathrm{Na}_{2} \mathrm{O}$ & .409 & Tr. & .05 & .348 & .293 & .210 & .253 & .268 & & \\
\hline Ignition ............. & 10.036 & 6.56 & 1.56 & 9.80 & 13.445 & 5.375 & 3.751 & 7.731 & & \\
\hline
\end{tabular}

1. Ridge between Grassy and Three Prong creeks; Boone Furnace property, Carter County, 8' to 10 feet. Kentucky Geol. Survey, Chem. Anal., Pt. I, p. 43.

2. Same locality, lower bed.

3. Same locality, rougher part of upper layer. 
4. Fire clay under coal, Old Orchard diggings, Boone Furnace property. Ibid., p. 44

5. Same bed as 1. Ibid., p. 44.

6. Fire clay under 12-inch coal, G.. Osenton's land, near Grayson, Carter County. Ibid., p. 44.

7. Clay shale, railroad cut, one-hali mile south of station, Grayson, Carter County. Ibid., p. 44.

8. Washed sample ferruginous marly clay, Limestone station, Carter County. Idem, Pt. II, 1885 , p. 181.

9. Fire clay, Perry's branch of Tygarts Creek, near mouth, and near E. L. \& B. S. R. R.; bed 9 feet thick. Ibid., p. 276.

10, 11, 12. Same locality.

13. Fire clay, Louder's land, near Kenton Furnace, Greenup County. Idem, Pt. I, 1884, p. 100.

14. Fire clay, 2 feet above limestone ore, head of Powdermill Hollow, 2 miles from Kenton Furnace. Ibid.

15. Clay, fourth above limestone and limestone ore, on Pea Ridge, $2 \frac{1}{2}$ feet thick. Ibid.

16. Clay resting on limestone ore, Pea Ridge, near Hunnewell. Ibid.

17. Clay, $2 \frac{1}{2}$ feet, second above limestone ore, Pea Ridge. Ibid.

18. Clay, 14 inches thick, third bed above limestone ore, Pea Ridge. Ibid., p. 101.

19. Fire clay, Thomas bank, headwaters of Wings Branch of Shultz Creek. Average sample of upper layer; 5 feet above the cherty limestone. Ibid.

20. Clay, 5 feet thick, on Indian Creek, Whitley County. Idem, Pt. III, 1888, p. 204.

21. Jellico clay, Whitley County. Ibid.

22. Bituminous shale, 5 feet thick, on Knoxville branch of Louisville and Nashville Railroad near Brummitts station. Idem, Pt. II, 1885, p. 309. Burns buff, gray.

23. Shale, below coal at Mud Creek mines, Butler County.

24. Shale, below coal F, mouth of Brush Kun on Rough Creek, Ohio County. Idem, Pt. I, 1884 , p. 418.

25. Clay from Elm Lick, R. B. Thompson's land. Ibid.

26. Clay from Bald Knob Church, Caney precinct, on Pinchico road, 2 feet below a coal bed. Burns salmon.

27. Upper layer of fire clay used at Ashland.

28. Lower layer of fire clay used at Ashland.

\section{CLAYS OF WESTERT COAL FIELD.}

Very little information has been published regarding the clays of the Western coal field. A bed is mentioned near Bald Knob Church, Ohio County, where ${ }^{a}$ on B. F. Jenkins's farm the following section is seen:

Section near Bald Knob Church, Orio County, Ky.

Covered space, red clay $\cdot$ on surface

$\begin{array}{cc}\text { Feet. } & \text { Inches. } \\ 5 & 0 \\ 0 & 9 \\ 3 & 0 \\ 1 & 0 \\ 28 & 0 \\ 8 & 0 \\ 35 & 0\end{array}$

Coal F. .

Under clay

Mottled linestone-

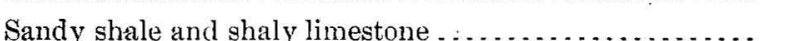

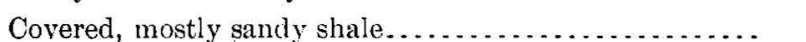

Soft, disintegrating sandstone .................... 350

a Kentucky Geol. Survey, Western coal field, 1884, p. 163 
In Ohio County ${ }^{a}$ a hard clay occurs below coal $\mathrm{F}$ at the mouth of Brush Run in Rough Creek; also near Elm Creek on R. B. Thompson's land. This is much used at Louisville. Again clay is seen at Bald Knob, on the Pinchico road.

Clay suitable for making vitrified brick has been worked at Cloverport in Grayson County, near Millwood station, on the Illinois Central Railroad. An 11-foot bed is worked for making sewer pipe, and is overlain by 18 inches of coal. The vitrified brick now made at Louisville are a mixture of this clay with a shale obtained 2 miles west of New Albany, Ind.

\section{RECENT, OR ALLUVIAL CLAYS.}

Leaving those of the Jackson Purchase region out of consideration, alluvial clays may be looked for in many river valleys where terraces have been formed. They are found in the terraces along the existing streams and are usually very sandy, although often of excellent quality, especially along the Ohio. Shaler states that in various sections along the Ohio he has failed to find any fine-grained clays in the belt of land below the top of the highest water, while the next level, rising, say, 10 feet above this high-water mark, contains very generally, in the district near Covington, at least, a blue-gray clay that is of fair quality. ${ }^{b}$ In Clinton County ${ }^{c}$ small areas are found along the Columbia River and its tributaries, and are underlain by dark clays. In Henry County ${ }^{d}$ deposits valuable for brick making are found along the Kentucky River.

Clay deposits are found in many sink holes of the limestone region, and while the clays may be suitable for pottery, still, owing to their origin, the deposits can never be extensive.

\section{JACKSON PURCHASE REGION.}

The clays of this area are so distinct from those found in other parts of the State that they can best be treated by themselves. They have furthermore been dealt with quite fully in a report on the Jackson Purchase region issued by the Kentucky geological survey, from which most of the following facts have been taken.

The Jackson Purchase includes the country embraced between the Mississippi, Ohio, and Tennessee rivers and the Tennessee State line. The geologic section beginning at the top is as follows: ${ }^{e}$

Section in Jackson Purchase region, Kentucky.

Alluvium (of river and creek bottoms).

Pletstocene.

Brown lóam; surface loam of uplands.

Loess; gray silt of Mississippi bluffs.

Port Hudson (Hilgard's Louisiana); stiff dark and bluish clays with calcareous concretions under the river alluvium.

Stratified drift.

a Geol. Atlas U. S., folio 46, Richmond.

$b$ Kentucky Geol. Survey, new series, Vol. III, p. 405.

c Idem, Report on Clinton County, p. 25.
dIdem, Report on Henry County, p. 12. $e$ Idem, Report on Jackson Purchase region, p. 17. 
Section in Jackson Purchase region, Kentucky-Continued.

Tertiary.

Lagrange; stiff plastic clays, variegated in color and interstratified with whitish sand, and carrying leaf impressions.

Lignitic; black arenaceous clay and claystone.

Porters Creek; massive and jointed clays, locally called soapstone.

Hickman; siliceous claystone over a thick bed of buff-colored clays.

Cretaceous.

Ripley; black clay in very thin laminæ, separated by fine white and yellow micaceous sands. Lower Carboniferous.

Lower; heavy limestone beds interpolated with dark flint layers.

Devonian.

Massive quartzose sand rocks.

Most of the clays in this part of the State, which we found in all the counties, appear highly refractory before the blowpipe. The classes recognized are:

1. Drab clays of Hickman Bluffs. ${ }^{a}$

2. Siliceous clays from Columbus Bluffs, which face the Mississippi River at Columbus and at the chalk banks below. These rise more than 100 feet above the town. The upper portion is made of 30 feet each of gray silt or loess and gravel. Under the gravel is variegated colored plastic clay 15 feet thick; under this 85 feet siliceous clays. These clays burn hard to a light-creamy color. They are finely siliceous. The clay beds are exposed in the bluffs east of the town. The siliceous clays show in the deep ravine by the Clinton road and the plastic clays in the face of the bluff south of the railroad cut. ${ }^{b}$ The siliceous fire clays in places have been cut away, as at the chalk banks, and their places are taken by interstratified beds of fine clay and white sand. The same is true in the bluffs north of Columbus to a short distance beyond Laketon. These were supposed to belong to the Lignitic (Tertiary) group, and are found farther east associated with the belt of dark clay in McCracken and Graves counties. ${ }^{c}$

3. White or light-colored plastic clays. These form beds of greater or less size in each of the counties and are put in what is known as the Lagrange group of the Tertiary. The clay has been deposited since the deposition of the black clays. It usually is white or light purple in color, fine grained, and varies in thickness from a few inches to many feet.

4. Black and bluish-black clays. These are confined to the Cretaceous and the Lignitic or Lower Tertiary belt that passes through Calloway, Marshall, McCracken, and Ballard counties, and to the Port Hudson group of the Pleistocene, which occurs in the valley and bottom land of the three bordering rivers. The dark color is due to vegetable matter. These clays are said to be refractory.

a Section given on p. 38 of Report on Jackson Purchase region.

bIbid., p. 101

cIbid. 
Analyses of white and siliceous refractory clays of Hickman County, Ky. a

\begin{tabular}{|c|c|c|c|}
\hline . & 1. . & 2. & 3. \\
\hline Silica. . . . & 85.18 & 84.918 & 76. 360 \\
\hline Alumina $\ldots \ldots \ldots \ldots . . . . . .$. & 10. 26 & 10.56 & 14. 951 \\
\hline Ferric oxide $\ldots . . . \ldots \ldots \ldots \ldots . . . . . .$. & 1. 12 & 1. 102 & 2. 109 \\
\hline Lime $\ldots \ldots \ldots$ & Trace. & 0.572 & 0.325 \\
\hline Magnesia . . . . . . . . . . . . . & 0.064 & 0.108 & 0.173 \\
\hline Potash $\ldots \ldots \ldots \ldots \ldots \ldots$ & 0.954 & 0.651 & 1. 171 \\
\hline Soda $\ldots . . . . . . . . . . . . . . . . . .$. & 0.146 & Not est. & 0.125 \\
\hline Water, etc $\ldots \ldots \ldots \ldots \ldots$ & 2.276 & 2.089 & 4. 786 \\
\hline Total.... & 100.000 & 100.000 & 100.000 \\
\hline
\end{tabular}

a Kentucky Geol. Survey, Report on Jackson Purchase region, 188s, p. 102.

1. Fire clay, bluff above Columbus, Hickman County. Plastic.

2. Clay from bluffs in upper part of town of Columbus, Hickman County. Same bed as 1.' Light gray, burns to hard body and light-cream color.

3. Clay from "Chalk banks," 2 miles below Columbus. Burns hard.

Analyses of clays from Hickman Bluffs, Fulton County, Ky.a

\begin{tabular}{|c|c|c|c|c|c|c|c|c|}
\hline & 1. & 2. & 3. & 4. & 5. & 6. & 7. & 8. \\
\hline Silica... & 71.340 & 83.38 & 71.08 & 74.10 & 83.50 & 77.96 & 76.86 & 64.80 \\
\hline Alumina & 17. 190 & 9.80 & 19.05 & 16.46 & 9.94 & 13.97 & 14.60 & 21.07 \\
\hline Ferric oxide ...... & 2. 770 & 2.12 & 2.81 & 2.70 & 2.50 & 2.39 & 3.02 & 5.27 \\
\hline Lime ... . . . . & 1. 612 & .963 & .627 & .358 & .358 & .134 & .425 & 1.40 \\
\hline Magnesia ............. & .209 & .187 & .403 & .187 & .173 & .163 & .308 & .05 \\
\hline Potash ............... & .925 & .617 & .578 & .559 & .539 & .797 & .736 & .646 \\
\hline Soda .............. & .232 & .118 & .225 . & .135 & .109 & .124 & .257 & .202 \\
\hline Water, etc ...... & 5. 722 & 2.815 & 5. 227 & 5. 501 & 2. 881 & 4.462 & 3.794 & 6.562 \\
\hline Total.: & 100.000 & 100.000 & 100.000 & 100.000 & 100.000 & 100.000 & 100.000 & 100.000 \\
\hline
\end{tabular}

1. Greenish or bluish sandy refractory clay, 1.mile north of Hickman, Fulton County. Burns light gray buff.

'2. Greenish to bluish sandy refractory clay, under gravel beds in bluffs in upper part of Hickman, Fulton County, 6 feet thick. Burns light brick color.

3. Refractory clay stone. Burns light gray buff.

4. Slate-colored or bluish refractory joint clay from Hickman Bluffs and under preceding. Burns to hard body of light brown color.

5. Greenish claystone and green refractory clay from Hickman Bluffs. Underlies No. 4. Rather plastic, burns to light brick color. Bed, 10 feet thick.

6. Greenish indurated and refractory joint elay, lower part of Hickman Bluffs. Burns brownish buff. Bed, 50 feet thick. 
7. Greenish refractory clay, Hickman Bluffs; 95 feet above low water. Same bed as No. 6 . Rather plastic and burns red buff.

8. Indurated clay, Hickman Bluffs, 45 feet above low water. Plastic." Burns light buff and is easily fusible.

Analyses of refractory, white, and light-colored clays from Jackson Purchase region, Kentucky."

\begin{tabular}{|c|c|c|c|c|c|c|c|c|c|c|}
\hline Locality. & : & 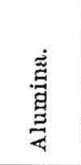 & 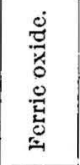 & 䆑 & 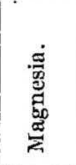 & . & 离 & 离 & 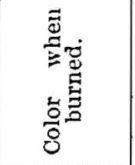 & 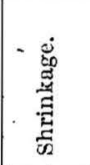 \\
\hline & & & & & & & & & & ret. \\
\hline $\begin{array}{l}\text { White pipe clay, } 3 \text { miles east of New Prov- } \\
\text { idence, Calloway County. }\end{array}$ & 61.680 & 28.500 & 1.680 & 0.101 & 0.136 & 1.158 & 0.822 & 5.923 & $\begin{array}{l}\text { White, un- } \\
\text { glazed. }\end{array}$ & \\
\hline $\begin{array}{l}\text { White plastic clay, } 6 \text { miles northeast of } \\
\text { Nurray, Calloway County. }\end{array}$ & 57.810 & 30.340 & 1.180 & .011 & .050 & .618 & .519 & 9.442 & Cream ..... & \\
\hline $\begin{array}{l}\text { White clay, } 1 \text { mile east of Wyatt's sehool- } \\
\text { house, Calloway County. }\end{array}$ & 46.020 & 38.980 & Tr. & .773 & .136 & .303 & .172 & 13.610 & $\begin{array}{c}\text { B rown, } \\
\text { white } \\
\text { when } \\
\text { glazed. }\end{array}$ & \\
\hline $\begin{array}{l}\text { Howard's pottery, Bell City, Graves } \\
\text { County; } 6-10 \text { feet. }\end{array}$ & 56.980 & 32. 160 & 2.160 & Tr. & .209 & $.838 !$ & .111 & 7.542 & Cream.... & \\
\hline Stiff plastic clay, $10-15$ feet.. & 62.680 & 25.880 & 2.900 & Tr. & .319 & 1.147 & .928 & 6.146 & $\begin{array}{c}\text { White, un- } \\
\text { glazed. }\end{array}$ & 10 \\
\hline $\begin{array}{l}\text { Panther Creek, } 6 \text { miles east of Masfield, } \\
\text { Graves County; plastic. }\end{array}$ & 75.550 & 16. 751 & 1.198 & Tr. & $\therefore 14$ & 1.094 & .216 & 5.047 & Salmon... & \\
\hline $\begin{array}{l}\text { Fire clay, Wickliffe, Ballard County; 10- } \\
12 \text { feet. }\end{array}$ & 73.240 & 15.760 & 1.920 & $.325 \vdots$ & .519 & $1.467 !$ & .147 & 6.622 & Buff & \\
\hline $\begin{array}{l}\text { Refractory white clay, one-half mile } \\
\text { northwest of Blandville: bluish white. }\end{array}$ & 74.840 & 16.580 & 1.400 & .269 & .209 & $1.293 i$ & .283 & 5.126 & Whit & \\
\hline $\begin{array}{l}\text { White plastic clay, Cane Creek. 2 miles } \\
\text { north of Wickliffe, Ballard County. }\end{array}$ & 63.840 & 26.040 & .740 & Tr. & .137 & .714 & .207 & 8. 822 & & \\
\hline $\begin{array}{l}\text { Clay, T. D. Campbell, Laketon, Ballard } \\
\text { County: purplish gray. }\end{array}$ & 67.501 & 23.051 & 2. 109 . & .257 & .065 & .412 & .020 & 6. 585 & & \\
\hline $\begin{array}{l}\text { Samuel farm, } 4 \text { miles south of Blandville, } \\
\text { Ballard County. }\end{array}$ & 71.940 & 20.700 & Tr. & .370 & .350 & .630 & 0.0 & 6.200 & Whit & \\
\hline $\begin{array}{l}\text { Plastic clay, G. Ryan, } 4 \text { miles northeast of } \\
\text { Milburn, Bullurd County, } 4 \text { feet. }\end{array}$ & 76.540 & $1: 320$ & .960 & $\mathrm{Tr}$. & .331 & .926 & .229 & 6.194 & Light gray & \\
\hline $\begin{array}{l}\text { Bluish plastic clay, } 3 \text { miles enst of Bland- } \\
\text { ville, Ballard County; } 3 \text { feet. }\end{array}$ & 71.180 & 20.800 & 1. 780 & Tr. ' & .101 & .247 & .291 & 5.601 & & \\
\hline $\begin{array}{l}\text { Micaceous clay, } 5 \text { miles north of Benton, } \\
\text { Marshall County. }\end{array}$ & 84.580 & 10. 6.50 & $.330 !$ & .13i & .101 & .954 & .292 & 2. 956 & $\begin{array}{l}\text { D } \underset{\text { cream, }}{\mathbf{k}} \\
\text { glazed. }\end{array}$ & 10 \\
\hline $\begin{array}{l}\text { Micaceous clay, } 2 \text { miles east of Palma, } \\
\text { Marshall County; plastic. }\end{array}$ & 62.920 & 29.880 & Tr. & Tr. & .209 & 1.564 & .172 & 5.255 & ...do... & 15 \\
\hline $\begin{array}{l}\text { Five miles south of Paducah, MeCracken } \\
\text { County; bluish, plastic. }\end{array}$ & 64.480 & 24.691 & 1. 869 & .448 & $.13 \pi$ & 1.457 & .083 & 6.835 & & \\
\hline $\begin{array}{l}\text { Refractory, Moore's Mill, } 1 \text { mile southwest } \\
\text { of Blandville. }\end{array}$ & 74.460 & 15.070 & 1. 633 & .314 & .245 & .940 & .021 & 4.317 & Dark buff. & 15 \\
\hline
\end{tabular}

« Kentucky Geol. Survey, Report on Jackson Purchase region, p. 103 et seq

Clays which are easily fusible are found in a number of the counties, but are said to be confined chiefly to those on the eastern side of the Jackson Purchase region, namely, in McCracken, Graves, Marshall, and Calloway counties. They vary in color from nearly white to black. Some are highly gypseous, while others are sprinkled with vivianite. They are pre-Pleistocene, and are overlain by gravel, sand, and brown loam of that period. They include some of the white varieties belonging to the period intermediate between the Tertiary and Pleistocene and the black clays of the next higher or Port Hudson group. 


\begin{tabular}{|c|c|c|c|c|c|c|c|c|c|c|}
\hline Locality. & Silica. & Alumi- & $\begin{array}{l}\text { Ferric } \\
\text { oxide. }\end{array}$ & Lime. & $\begin{array}{c}\text { Magne- } \\
\text { sia. }\end{array}$ & Potash. & Soda. & Water. & $\begin{array}{l}\text { Color when } \\
\text { burned. }\end{array}$ & $\begin{array}{l}\text { Shrink:- } \\
\text { age. }\end{array}$ \\
\hline . & & & & & & & & & & Per ct. \\
\hline $\begin{array}{l}\text { Stiff clay, } 4 \text { miles south of Padu- } \\
\text { cah. }\end{array}$ & 59.50 & 24.96 & .72 & .325 & .396 & 1.934 & .286 & 11.879 & Buff ..... & 15 \\
\hline $\begin{array}{l}\text { Gypseous clay, } 4 \text { miles southwest } \\
\text { of Paducah. }\end{array}$ & 67.58 & 20.04 & .54 & $b 1.743$ & .158 & 1.34 & .075 & 8.524 & Dark cream ... & $12 \frac{1}{8}$ \\
\hline $\begin{array}{l}\text { Purplish plastic clay, } 3 \text { miles } \\
\text { east of Lovelaceville, Mc- } \\
\text { Cracken County, } 3 \text { feet thick. }\end{array}$ & 66.32 & 22.93 & 1.19 & .437 & .209 & 1.107 & .470 & 7.377 & & \\
\hline $\begin{array}{l}\text { Stiff plastic clay, railroad cut } \\
\text { south of Guili Hill and } 3 \\
\text { miles south of Wingo, Graves } \\
\text { County. }\end{array}$ & 75.12 & 15.96 & 1.42 & Tr. & .317 & 1.351 & .245 & 5.587 & Brown.. & $7 \frac{1}{8}$ \\
\hline $\begin{array}{l}\text { Plastic clay, north uf Boaz sta- } \\
\text { tion, Graves County. }\end{array}$ & 61.92 & 30.060 & .30 & Tr. & .064 & 1.602 & .239 & 5.815 & $\begin{array}{l}\text { Milk white, un- } \\
\text { glazed. }\end{array}$ & \\
\hline $\begin{array}{l}\text { Plastic clay, just south of Scale, } \\
\text { Marshall County. }\end{array}$ & 52.58 & 31.07 & .1 .51 & .137 & .245 & 1.775 & .318 & 12.365 & $\begin{array}{l}\text { Buff, w h e n } \\
\text { glazed. }\end{array}$ & \\
\hline $\begin{array}{l}\text { Dark clay, Tennessee River } \\
\text { landing, Highland, Marshall, } \\
\text { County. }\end{array}$ & 60.98 & 18.48 & 7.50 & .78 & 1.128 & 2.664 & .627 & 7.841 & Dark red.. & \\
\hline $\begin{array}{l}\text { Blue micaceous clas, west } \\
\text { edge of Paducah, McCracken } \\
\text { County. }\end{array}$ & 73.192 & 16.54 & 1.84 & .369 & .461 & 1.969 & .541 & 5.088 & & \\
\hline $\begin{array}{l}\text { Micaceous clay, } \text { mile enst of } \\
\text { Baring's ford, Clark River, or } \\
7 \text { miles southeast of Padueah, } \\
\text { MeCracken County. }\end{array}$ & 69.22 & 17.54 & 1.44 & .437 & .858 & 2.452 & .472 & 7.581 & Brick red. & 12 \\
\hline
\end{tabular}

a Kentucky Geol. Survey, Report on Jackson Purchase region, 1888, p. 113 et seq. b As gypsum.

Ocherous clays. - Yellow ocherous clays occur at many points in the Jackson Purchase counties and have been used locally for paint. On burning they oxidize to a bright red. In addition there are certain bluish clays which burn to a good red. One of these beds outcrops in the banks of the Tennessee River at Highland Landing, Marshall County. In Ballard County they are prominent near Wycliffe and Laketon, being exposed in ravines. Another bed of ocher is known in McCracken County, one-half mile east of the boring on Clarks River, 7 miles from-Paducah. It burns a deep red. Still another lies at Wadesboro in Calloway County.

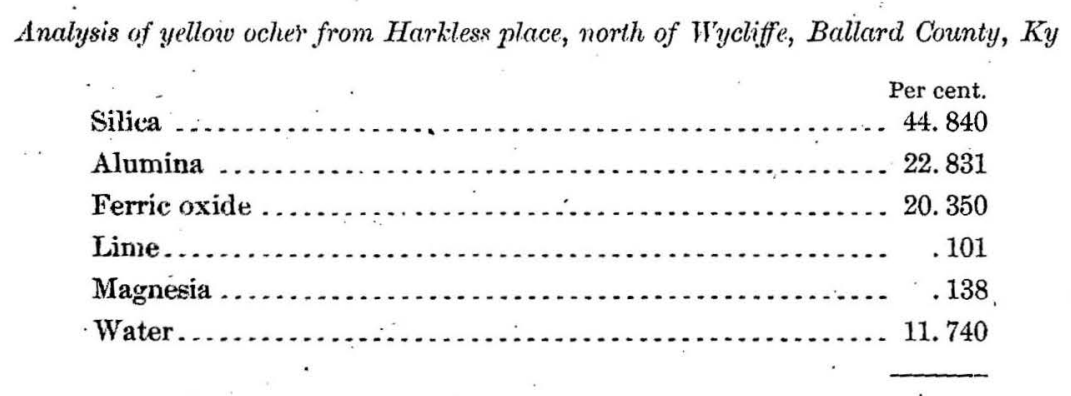

100.000

Since the clays of this area are so important commercially, it seems desirable to mention them in some detail. 
Fulton County. ${ }^{a}$-The bluffs at Hickman and southward to the Tennessee line contain much pure clay free from coarse sand and iron pyrites which, it is claimed could be used for the manufacture of tile, terra cotta, and pottery. White and bluish pipe clay occur between the sands of the Lagrange group in the eastern part of the county, but are covered too deeply by Pleistocene sands and loams to render their working profitable, unless worked by drifts.

Hickman County. ${ }^{b}$-Pottery clay is prominent in the bluffs at Columbus and other points bordering the Mississippi. The clays belong to the Tertiary beds proper, while those of the Lagrange group, which have been analyzed, appear as white plastic strata in heavy beds of white sand. Less plastic clays occur in the bluff east of Columbus. Two potteries at Columbus have used the blue clay from the base of the sand and clay from the bluff just north of the chalk banks.

Baillard Conty. ${ }^{-}$-Many exposures of white and variegated clays occur in the central and southern portions of the county, some of these being refractory. No exposures have been observed north of Cain Creek and Hinkelville. The clays which may be considered most valuable are those in the western part of the county, exposed in the bluffs along the Mississippi and in the banks and river bottoms tributary to - that stream. They vary from dark-gray or black clays of the Lignitic group to whitish and more plastic varieties of the more recent or Lagrange group. The former are exposed at the base of the bluffs along the Mississippi bottom from Laketon to Wycliffe, along. Mayfield Creek to and beyond Blandville, along Cain Creek north of as well as in the creek bottom in the flats to the eastward of Wycliffe and in an isolated bed 2 miles west of Milburn. For the most part they are covered deeply by Pleistocene gravel and soil. In the neighborhood of $\mathrm{W}^{\mathrm{T}} \mathrm{y}$ cliffe there is less covering. These dark lignitic clays are several feet thick and are siliceous and refractory, thus resembling those of the Columbus Blufts. (See analyses, p. 127.) Their use for fireproofing is suggested.

Second clays, or whiter and more plastic clays, are not extensively found in this county, their beds being mostly thin. They are seen in the high bluffs from Laketon southward and at a few points in the eastern part of the county. An outerop is 1 mile north of Blandville, and a few miles south of the same town. They have no great value.

McCracken Connty." -The clays in the county vary from black to white, and are usually distributed according to geologic formations. The black clays are found in the Cretaceous and also in the Tertiary (Eocene) belts in the eastern and middle parts of the county. Those of the former outcrop in the banks of Clarks River

a Kentucky Geol. Survey, Report on Jackson Purchase region, 1885, p. 214.

bIbid, p. 225.

r Ibid, p. 241

a Ibid., p. 256.

9647 -No. $11-03-9$ 
above the railroad bridge and are highly micaceous in character. They have no value. The Tertiary black clays, overlying these, also occur in the Clarks River bluffs, with an exposure of about 15 feet, and again at the foot of the hills south of Paducah. Although only 12 feet thick here, to the northwest or west of Paducah the thickness is as much as 90 feet. An analysis of some clay taken out of the same belt near Murray, Calloway County, is given in the table on p. 127. This same clay is found 5 miles south of Paducah, and at Florence station. Also on the east side of Clarks River.

The whitish clays belong almost entirely to formations later than the Lignitic (Lower Tertiary), and in this county are exclusively found in the central and western portion. The Lagrange group comprises most of the beds. This would include the clay 4 miles southwest of Paducah, on the Hough place, and farther southwest on the place of Dr. Roof, and of Mrs. Annie Grief, 10 miles from Paducah. Also in the north bluff of Mayfield Creek.

Marshall County. ${ }^{a}$-The clays comprise grayish-black joint clay of Tertiary age, and more recent, plastic, lighter-colored and more or less refractory pipe clays, together with a thinly laminated, dark, and micaceous Cretaceous clay, which is exposed in the beds on the sand hill north of Benton. This same clay outcrops also below the foot of the belts bordering Clarks River bottom near Sharps post-office. Black joint clay is found west of Benton, forming a part of that belt which reaches from Murray, Calloway County, on the south, into McCracken County, on the northwest.

The plastic clays of variegated white to purple color are found chiefly east of the belt of black clay just mentioned. The blue clays referred to as occurring in the valley of the Tennessee River are well exposed at Highland Landing. A section of the river bank, beginning at the top, shows:

$$
\text { Section of bank of Tennessee River-at Highland Landing, Ky. }
$$

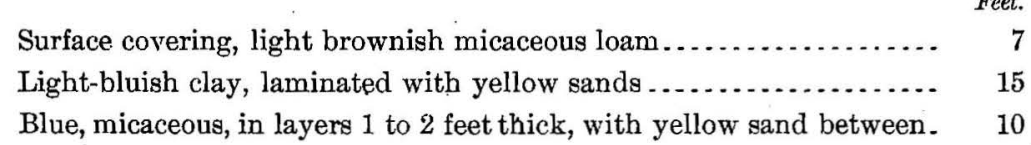

Graves County. ${ }^{b}$ - White pipe clay is abundant throughout the county, and is penetrated by almost all wells that reach below the gravel beds. It outcrops frequently in the damp ravines. Along the line of railroad from northern part of county southward many good clays are exposed in the cuts, especially north of Boaz, but no thick clays are exposed until within $2 \frac{1}{2}$ miles south of Wingo. The clays in the next or "big" cut are of white, purple, and yellow colors and somewhat sandy. 
They are again exposed 3 miles north of Water Valley, and outcrop to that station and Fulton on the State line.

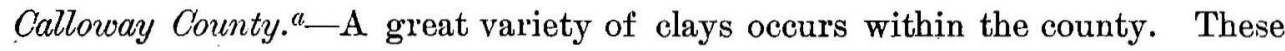
are both refractory and nonrefractory, and many are well situated for workings. The black joint clays occupy a belt from the Tennessee line northward through Murray and Wadesboro, into Marshall County, being exposed at a number of points along the west side of Clarks River. They are exposed in the southern part of the county west of New Providence. A prominent exposure is at the Paris bridge 1 mile south of Murray. Other exposures are seen in the bluffs of creeks north of Murray, and in the ravines that border the road north to Wadesboro. They are from 10 to 20 feet thick.

White pipe clays are abundant and found chiefly on the east and west of the black joint clay belt. A highly plastic white variety is found near Mayfield, in sec. 4, T. 3, R. $3 \mathrm{E}$. The same clay appears in the branch south of this place and also in the bluffs east of the river, at Backusburg, to the east of Murray. On a line passing through it north and south are several beds of white clays, notably at Russell's pottery. They burn to a good color, but difficulty was experienced with the crazing. Another locality of white clay is in the river east of New Providence.

CLAY-WORKING INDUSTRY.

The value of the industry of this State in 1900 and 1901 was as follows:

\begin{tabular}{|c|c|c|}
\hline . & 1900. & 1901. \\
\hline Common brick . . . . . . . . . . . . . & $\$ 608,334$ & $\$ 621,756^{\circ}$ \\
\hline Front brick. . . . . . . . . . . . . . . & 21,098 & 16,535 \\
\hline Vitrified brick ............... & $(b)$ & $(b)$ \\
\hline Fancy brick ...................... & $(b)$ & $(b)$ \\
\hline Fire brick .... & 393,220 & 377,741 \\
\hline Stove linings........... & $(b)$ & $(b)$ \\
\hline Draintile............ & 26,727 & 29,498 \\
\hline Sewer pipe.... & $(b)$ & $(b)$ \\
\hline 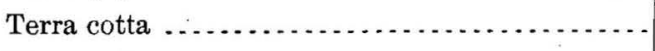 & $(b)$ & $(b)$ \\
\hline Fireproofing $\ldots \ldots \ldots \ldots$. & $(b)$ & $(b)$ \\
\hline Red earthenware $\ldots \ldots \ldots \ldots \ldots \ldots \ldots$ & 21,202 & 139697 \\
\hline Stoneware $\ldots \ldots \ldots \ldots \ldots \ldots$ & 110,295 & 159,091 \\
\hline
\end{tabular}

" Kentucky Geol. Survey, Report on Jackson Purchase region, 1888, p. 312. $b$ Product included in other States. 
Value of clay products of Kentucky from 1895 to 1901.

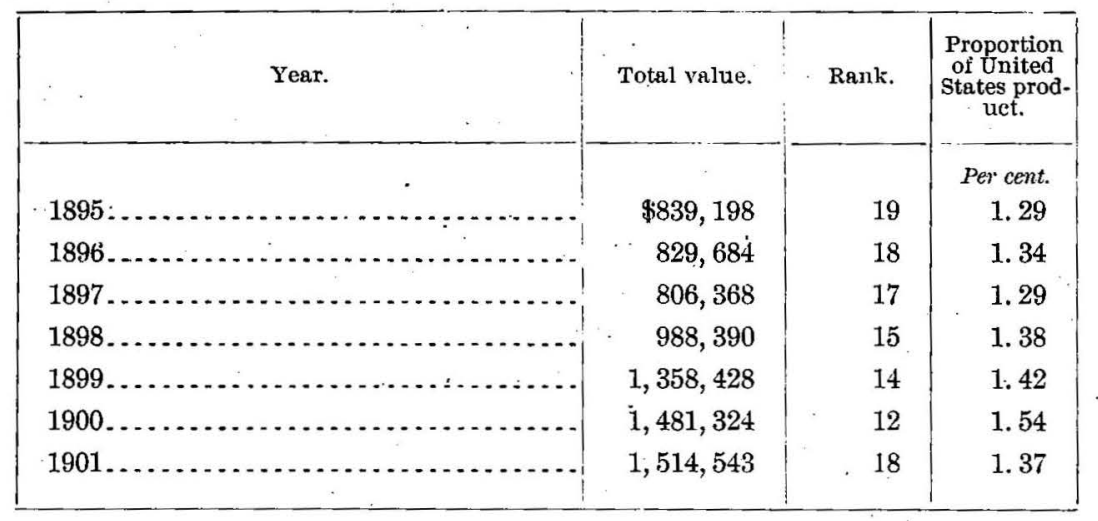

Common brick, fire brick, and stoneware are the most important clay products manufactured by the State. Brickyards are located at many localities, especially Ashland, Covington, Louisville, and Paducah. Wall tile are made at Covington, chiefly from clays obtained in other States. Paving brick are made at Louisville from a mixture of Indiana shale and low grade Kentucky fire clay. Fire brick are produced at several places from local clays. About 12 potteries are in operation, most of them located in the western part of the State. They obtain their material chiefly from Tertiary clays.

There is, no doubt, an abundance and variety of raw clay and shale in Kèntucky, but distance from the more important markets, together with the fact that neighboring States on the north and northeast also contain a wealth of clay, and are therefore dangerous competitors, will interfere with the rapid development of her clay resources. With the increasing industrial development of the region to the south and west of Kentucky, good -markets should be found for the disposal of her clay wares.

- MAINE, NEW HAMPSHIRE, AND VERMONT.

The larger portion of these three States is underlain by either pre-Cambrian crystalline rocks or metamorphosed Paleozoic formations, consequently little clay is to be looked for in such areas. Covering the entire surface of these States, however, is a mantle of Pleistocene deposits, mostly glacial drift, which is employed at many places for the manufacture of bricks, as it often contains clayey members. None of the deposits are refractory, and indeed, they may often be quite calcareous. The glacial clays are found in the till or have accumulated in hollows, but in addition to these there are to be found a series of estuarine deposits, represented by the clay beds that have been formed in the larger valleys during a sinking of the land, and consequent drowning of these valleys, in post-Glacial time. The deposits of this character are usually more persistent and thicker than the preceding type of drift 
clays. They are found especially in the larger valleys. They also underlie the terraces along the eastern shore of Lake Champlain, where they reach a height of several hundred feet above sea level.

A rather important series of residual clays is found in Vermont in connection with the deposits of manganese and iron ore. These materials are of residual character, and are said to occur ${ }^{a}$ at Brandon, Monkton, and Bennington, as well as in Shaftsbury, Wallingford, Plymouth, and Chittenden. They have been worked in past years for the manufacture of porcelain, stoneware, fire brick, and paper, but now are dug chiefly for the paper trade. Some of them are very white in color, others are often ferruginous. The following is an analysis of clay from the mines at Forestdale, Vt., which are worked by the Brandon and Montreal China Clay Company:

\begin{tabular}{|c|c|}
\hline Silica & $\begin{array}{r}\text { Per cent. } \\
53.70\end{array}$ \\
\hline 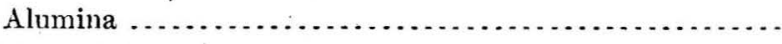 & 35.12 \\
\hline Iron oxide......... & .06 \\
\hline Lime............. & Trace. \\
\hline 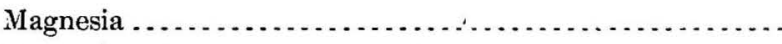 & Trace. \\
\hline Loss on ignition .............. & 10.55 \\
\hline Alkalies, by difference $\ldots \ldots \ldots \ldots \ldots \ldots \ldots$ & .57 \\
\hline
\end{tabular}

The products manufactured in these three States consist chiefly of common brick and earthenware. Where higher grades of ware are manufactured the raw materials used are obtained entirely or in large part from other. States. The following tables give the production for the year 1900:

Value of clay products of Maine, New Frampshire, and Vermont in 1901.

\begin{tabular}{|c|c|c|c|}
\hline & Maine. & $\begin{array}{l}\text { New Hamp- } \\
\text { shire. }\end{array}$ & Vermont. \\
\hline Common brick....... & $\$ 407,354$ & $\$ 741,589$ & $\$ 61,554$ \\
\hline Front brick .......... & 22,350 & $\left({ }^{b}\right)$ & \\
\hline Vitrified brick ...... & $(b)$ & ........ & \\
\hline Fire brick .......... & $\left({ }^{b}\right)$ & $(b)$ & \\
\hline 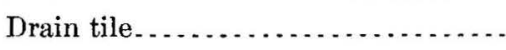 & 3,830 & & $(b)$ \\
\hline Sewer pipe ..... & $(b)$ & & \\
\hline Fireproofing ......... & $\cdots \cdot$ & - & $\cdots \cdots$ \\
\hline Miscellaneous.. & & & 16,000 \\
\hline Pottery ........... & $(b)$ & $\left({ }^{b}\right)$ & \\
\hline Total & 734,678 & 765,964 & 77,554 \\
\hline
\end{tabular}

a Geol. of Vermont, Vol. II, p. 802

${ }^{b}$ Product obtained from less than three firms, and hence can not be given. 


\section{MARYLAND, $a$}

The clay deposits of Maryland are found in formations ranging from the Algonkian to the Pleistocene, and the several formations are each more or less limited to one of the three topographic provinces into which the State is divisiblethe Coastal Plain, the Piedmont Plateau, and the Appalachian region.

The Coastal Plain area contains the Pleistocene, Neocene, Eocene, Cretaceous, Juratrias, and some of the Algonkian formations, and forms a tract extending across the State from northeast to southwest, being bounded on the southeast by the Atlantic Ocean and on the northwest by a line passing from Wilmington through Baltimore to Washington. Although rather flat, still the numerous small streams which dissect it afford many good exposures of the underlying formations.

The Piedmont Plateau region, which extends from the western boundary of the Coastal Plain to the Appalachian Mountains, is characterized by broken, hilly country with undulating surface, and is crossed by numerous rivers which cut into the underlying formations. Within this area the clays are obtained partly from the Paleozoic and to a less extent from the Mesozoic and pre-Cambrian formations. The first two yield shales, while the third gives a series of residual clays which may at times be of value. Where the Paleozoic rocks have been metamorphosed, however, into slates and schists, they are seldom of any value to the clay worker in their unweathered condition. In the eastern part of the Piedmont Plateau region we find considerable areas of metamorphic rocks, such as gneisses, and also of igneous rocks, such as granites and gabbros, which yield residual clays, often of a ferruginous character. ${ }^{b}$. In the western portion of the Piedmont Plateau the , Cambrian and Silurian rockss cover considerable areas in Frederick and Carroll counties, and by their decomposition yield residual clays.

The Appalachian region consists of a series of parallel mountain ridges composed of upturned Paleozoic strata. Here the shales are contained partly in the Devonian and partly in the Carboniferous rocks, which are abundant in Allegany and Garrett counties.

\section{ALGONKIAN RESIDUAL CLAYS.}

The residual Algonkian clays have attracted considerable attention, especially in Cecil County (Pl. IX), for the reason that they have been derived from feldspathic gneiss that contains but little iron, so that the plastic product is of white color and burns to a similar tint. While there are many prospect holes in the kaolin deposits around Northeast and at other points in Cecil County, still there is only one clay-washing plant in operation. Field tests show that the amount of overburden varies, as does also the depth of the kaolin deposit, but that there is no doubt a large

$a$ Ries, Fi., The clays of Maryland: Maryland Geol. Survey, Vol. IV.

$b$ For map showing distribution of these, see Maryland Geol. Survey, Vol. IV, PI, LVIII. 
quantity of the material awaiting exploitation and development. The material always requires washing, and where washed the product amounts to about 30 per cent of the quantity mined. In the Maryland clay report already referred to a number of occurrences of kaolin are mentioned." Farther south an important deposit of residual clay has been opened up along the Baltimore and Ohio Railroad, 1 mile northeast of Dorsey station, Howard County. It contains too much iron to permit its being used in the manufacture of whiteware, and is consequently sold in its crude condition for making a refractory brick.

IMPURE RESIDUAL CLAYS.

In addition to the kaolins, there are a number of residual clays found within the State which have been derived from various geologic formations, and occur at many localities in the Piedmont Plateau. They are usually ferruginous, and hence burn red, and even in their natural condition often show brilliant tints of yellow, brown, or red. These residual clays may have been derived from the granites, gabbros, serpentines, gneisses, shales, limestones, and schists. They vary in thickness, and, except in the case of the limestone residuals invariably pass by slow gradation into the parent rock below. The clay obtained from the gabbros and other dark-colored igneous rocks is usually extremely plastic and may show a very high tensile strength. The areas in which these are found are: (1) The Stony Forest area in Harford and Cecil counties; (2) a belt extending from Conowingo on the Susquehanna, in a southsouthwest direction to Baltimore; (3) an irregular area beginning west of Baltimore and extending as far south as Laurel. These dark ferruginous clays are used for brick making at several points, and in some cases also for pottery. The granites which also yield ferruginous clays form extensive areas around Port Deposit, Woodstock, Ellicott City, and Guilford.

There are a number of crystalline limestones in Baltimore and Harford counties, but owing to the fact that they are magnesian in character they form a sand on weathering rather than a plastic clay. To the west, however, in Washington County, there is a broad belt of Shenandoah limestone about 16 miles wide, extending across the State in a northeast-southwest direction, which gives an abundance of brick clay when weathered.

\section{SILURIAN SHALES.}

These with few exceptions have no value in Maryland for the manufacture of clay products, unless they have weathered to residual clays. The reason for this is that in most cases the beds have been too much altered by folding. One of the few exceptions is the Clinton shale, which outcrops on the hill above the cement works at Pinto. 
These are represented in Allegany and Garrett counties by a great series of shales, sandy shales, and shaly sandstones. In some cases the shales have been so altered by folding that they develop little or no plasticity when ground and mixed with water, while at other times they are of excellent value for the manufacturer of clay products. Of the several subdivisions the Hampshire, or uppermost one, while of considerable thickness, is of little value, for the reason that the shales are in most cases too siliceous to make a good product. In the Jennings formation, however, the shales are in many places capable of utilization. They are well exposed east of Cumberland, and have there been used for the manufacture of paving brick, for on grinding and mixing with water they form a plastic mass that has a body of a good density aud burns to a good red color.

\section{CARBONIFEROUS SHALES.}

These are found in the western part of the State in Garrett County and western Allegany County, and are divisible into a number of different formations. The shales are sometimes refractory, but more often are not so. None of the beds except the fire clays are being used at the present time. The Dunkirk formation, which overlies the Waynesburg coal, contains a number of shales, some of which outcrop near Frostburg, but none of them seem to mellow down rapidly to a clay. In the Monongahela formation, whose limits are marked by the Waynesburg coal above and the Pittsburg coal below, there are a number of beds of sandstone and shales, the latter being both sandy and clayey. It is doubtful whether they would be suited to the manufacture of brick without being weathered.

Mauch Chunk formation. - This is perhaps the richest formation in the State in shales, and is consequently of the greatest interest to the clay worker. It flanks the ridges of western Allegany and eastern Garrett counties, and grades gradually downward into the Greenbrier deposits. The formation is composed chiefly of red shales, which are interbedded with reddish-brown sandstones. In places these shales are mellowed down to a plastic clay of red color. Both the Greenbrier and the Pocono formations, which lie under the Mauch Chunk, are of little value to the clay worker.

The Mount Savage fire clay, which occupies a well-marked stratigraphic position, is a deposit of great value, for it possesses high refractory qualities. It is fortunate that its stratigraphic position is known, for, owing to the heavy covering in the region of Allegany and Garrett counties, outcrops of it are very scarce. It has already been opened up at two points on Savage Mountain, which are west of Frostburg and Mount Savage, and also on the Little Allegheny Mountains west of Ellerslie. The deposit is also found outcropping near Blaine and at Swallows Falls, 
Garrett County. The bed sometimes contains flint clay and sometimes plastic shale clay. The analyses and tests of the material are given in the table on pages 145-147.

Pottsville formation. - The Pottsville formation is the only one of the Carboniferous formations which has been commercially exploited for clay in Maryland, for it contains valuable deposits of fire clay whose position is indicated by the following section, measured in Pennsylvania just north of the Maryland line.

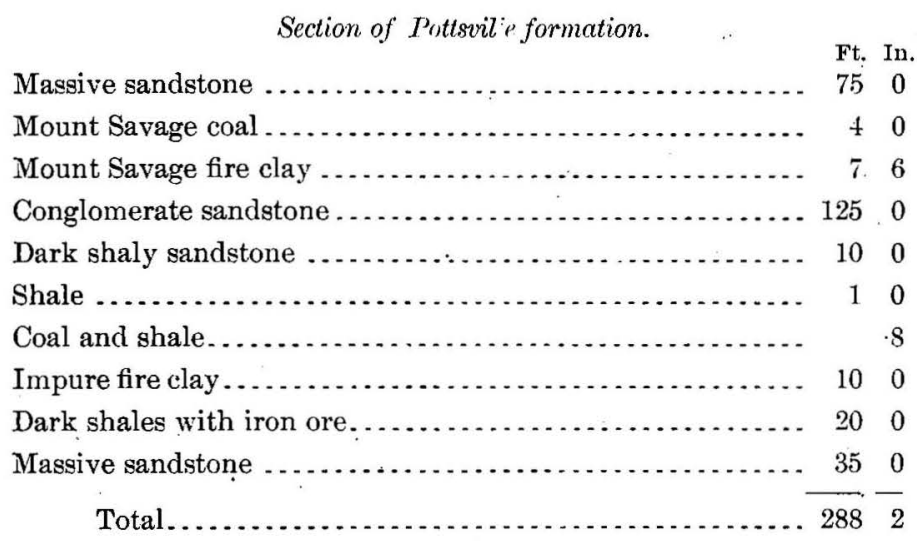

Allegany formation.--The Allegany formation underlies the Conemaugh and outcrops on the eastern side of the Georges Creek coal basin, high up on the western slope of Dans and Little Allegheny mountains. It contains many beds of shale, as can be seen from the following section:

Section at Franklin village', A'legany County, Md.

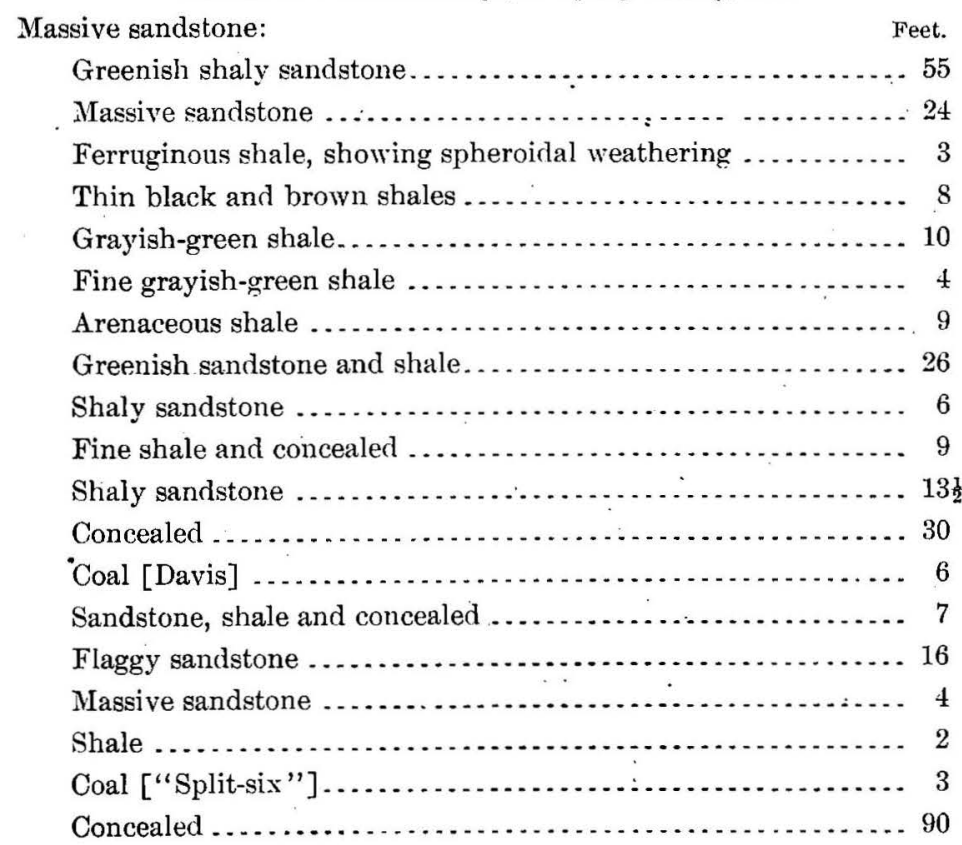


None of these shales are at the present time being used, but some of them appear promising. Even though they might not be used for bricks, they could perhaps be used in the manufacture of Portland cement.

Conemaugh formation. - This formation, formerly called the Barren Measures, contains many shale deposits, with the Mahoning sandstone at the base. The shales are usually argillaceous and are sometimes associated with coal. The following section from the upper part of the formation is found along the Potomac gravity plane, in Allegany County, and illustrates the general sequence of the beds.

Section at the Potomac plane, Allegany County, Md.

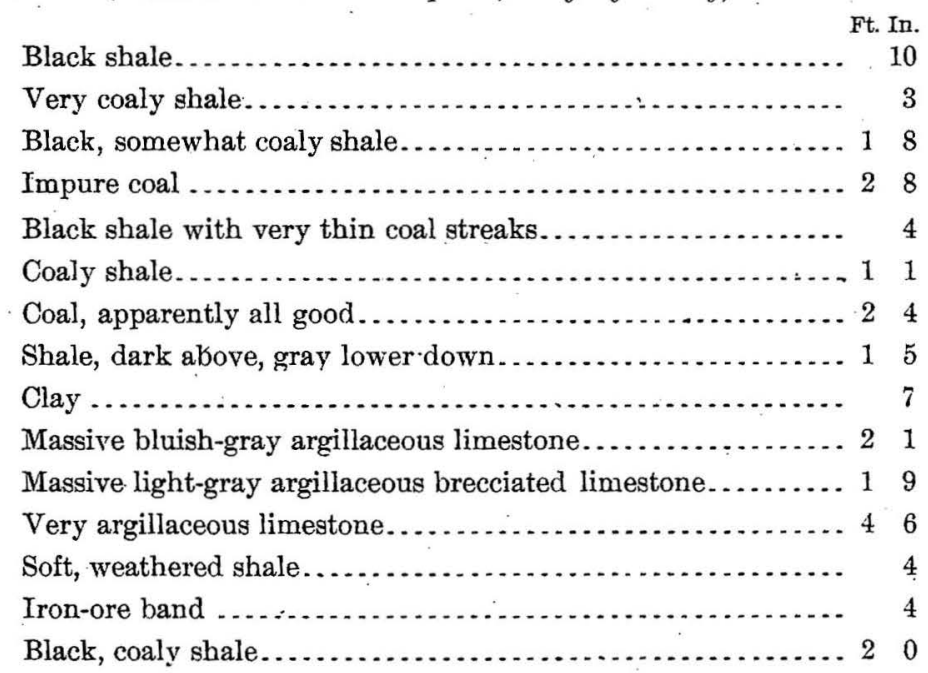

Some of the shales which were tested developed fair plasticity. None of them showed refractory characters.

CRETACEOUS AND JURATRIAS CLAYS.

The deposits of Cretaceous and Juratrias age underlie large areas in Maryland and are perhaps the most important series of clays in the State. The subdivisions of the Cretaceous are as follows:

Cretaceous and Juratrias formations of Maryland.

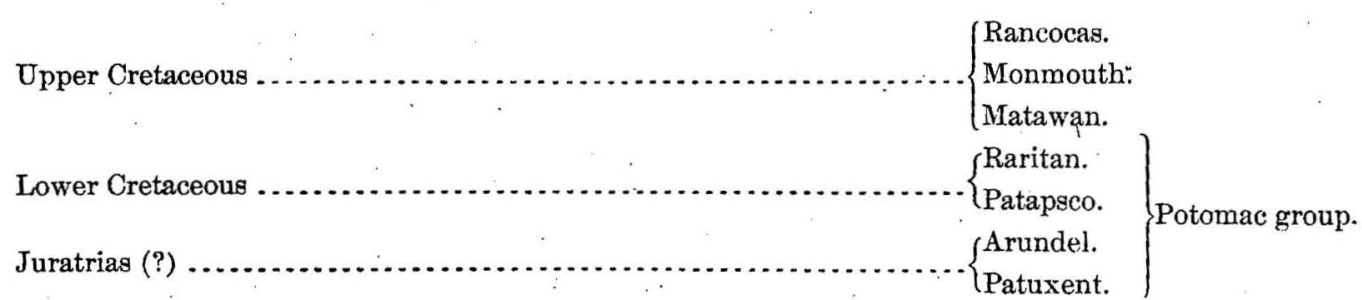


The Upper Cretaceous deposits of Maryland, which are a continuation of similar lárge beds in Delaware and New Jersey, cross the State from northeast to southwest, being developed in Cecil, Kent, Anne Arundel, and Prince George counties. They bear little clay and at the present time no pits have been opened in them. Those of the Potomac group, or Lower Cretaceous, are highly important, however. This group consists of a series of sands, sandy clays, and gravels which have been deposited at different periods and under varying conditions, the result being that the most unlike materials passed into each other horizontally. In vertical sections the most contrasted materials may overlie one another. The general dip of the beds is slight and ranges from 30 to 50 feet per mile to the southeast. Although the dip is fairly uniform, still the different members of the Potomac group have no welldefined upper and lower limits, or even top. On the contrary, the upper surface of any one member may be very uneven, owing to the fact that it has been much eroded or worn down by water action before the next member above it was deposited, while, therefore, if traced horizontally along the line of strike, any one member might be found at different levels, still the regularity of succession of the different members can be recognized if we follow across the surface at right angles to the line of strike, and thereby encounter successively the outcrops from the lowest to the highest division.

Patuxent formation.-This shows its type development in the upper valleys of the Big Patuxent and Little Patuxent rivers. As it is the basal member of the Potomac group it is naturally found near the landward margin of the Coastal Plain and rests on the crystalline rocks of the Picdmont Plateau. The Patuxent formation can be traced as a narrow, irregular, and sometimes broken belt from Cecil County on the northeast across Harford, Baltimore, Anne Arundel, and Prince George counties to the borders of the District of Columbia on the southwest. While the deposits of the Patuxent are mostly sand, often of high purity, still beds of sandy clay sufficiently plastic for the clay workers' use are occasionally found. Stoneware clays are also at times met with in this formation. The thickness of the Patuxent is estimated at about 150 feet, and it is less important than the Patapsco, Arundel, or even the Raritan. In Cecil County it contains little clay of commercial value, but around Baltimore and in Harford County refractory clays have been found in it near Sewall on the Baltimore and Obio Railroad. Owing to the sandy character of these Patuxent clays they are usually low in tensile strength, but also show a low shrinkage in drying and burning. Some of them even have been used with much success in the manufacture of terra cotta, being mixed with more plastic Arundel clays.

Arundel formation.-This receives its name from its occurrence in Anne Arundel County, where the deposits of this horizon are well developed. Like the Patapsco, it can be traced as a broken belt the entire distance from Cecil 
County to the District of Columbia; or more properly, it may be said to occur as a series of long, narrow belts that extend in a general northwest-southeast direction, forming a low angle with the border of the Piedmont Plateau. The deposits consist of a series of great and small lenses of clays bearing iron ore, which have commonly been deposited in old depressions in the surface of the Patuxent formation. These clays, which are commonly spoken of by the miners as blue charcoal clay, are usually dark colored and very tough, and at times are bighly carbonaceous. These lens-shaped deposits of the Arundel formation vary considerably in size and may range in thickness from a few feet up to 125 feet. The following two sections give an idea of the character of the Arundel:

Section at Reynold's mine, Piney Run, Anne Amundel County, MI.

RARITAN:

White and light-brown sand, gravel containing crusts of iron stone.............. 10

PatapsCo:

White and variegated argillaceous sands ("fuller's earth"), etc., "paint rock," at base.. 10 ARUNDEL:

Drab-colored, compact, laminated clays containing nodules of ore and also plant impres-

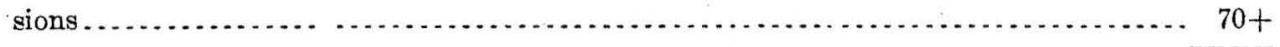

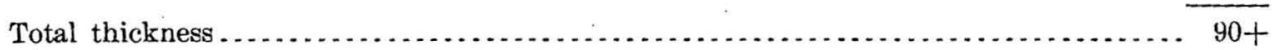

Section of Old Blue Bank, Muirkirk, Prince.George County, Md.

Pleistocene:

Feet.

Patapsco:

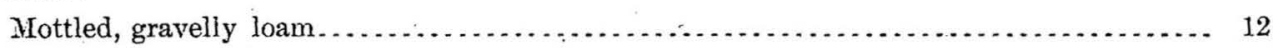

ARUNDEL:

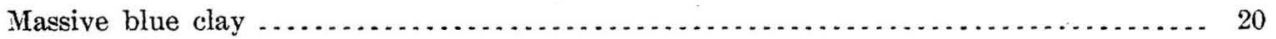

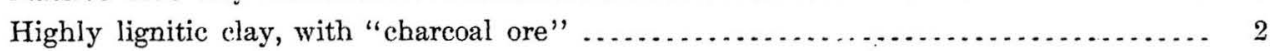

Tough, dry, blue clay, with "white ore" .................................. 15

Patuxent:

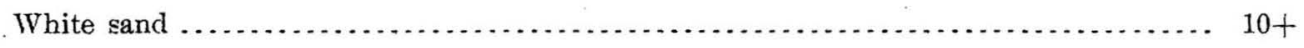

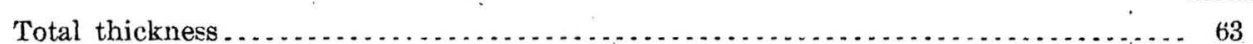

These lenses of Arundel clay are weli seen near Piney Run, Anne Arundel County; at Sewall and Joppa, Harford County; on Stemmers Run, Baltimore County; and at Locust Point, Baltimore. The Arundel clays are usually blue in color, often siliceous and of good plasticity, but as a rule do not have high tensile strength. They are used in large quantities for the manufacture of common and pressed brick, terra cotta, roofing tile, and common pottery. On account of the great abundance of iron ore in them it is sometimes necessary to adopt some special means to free the clay from the lumps of this material. Arundel clays are found in the counties of 
Cecil, Harford, Anne Arundel, Howard, Prince George, and Baltimore. In the City of Baltimore they are used in the manufacture of sewer pipe, and at Spring Gardens (Middle Branch of Patapsco River), near the same city, the clay has been dug for pottery, being used even in the manufaçture of yellow ware. Some refractory clay is obtained from the Arundel formation at Locust Point, near Fort McHenry, and brick clay is dug at Curtis Bay Junction. In fact many of the brickyards around Baltimore use Arundel clay. The clay from this same formation has been dug for terra-cotta manufacture south of Baltimore, and at this point is underlain by a layer of red clay that is used in the manufacture of paint. Aside from these uses the Arundel clays háve also been found suitable for the manufacture of Portland cement. Physical tests of these clays are to be found in the annexed table (p. 146). The Arundel formation does not contain any deposits of white refractory clay, such as are found in the Raritan, Patapsco, or the Patuxent.

Patapse formation.-The typical exposures of this formation are on the shores of the Patapsco River. It is very abundant and extends entirely across the State from the Delaware line to the Potomac River. The Patapsco deposits are chiefly bright-colored and mottled clays, which sometimes occur in much lighter-colored sands and clays. At times they may be ore bearing, and again they are often more or less dark colored and lignitic. The strike of the formation is practically the same as that of the Raritan, and its total thickness is at least 200 feet. A prominent feature of the Patapsco formation are the great banks of red and white variegated clays which outcrop at many points and are known as terra-cotta clays. The Patapsco clays are perhaps more worked than any of the other members of the Potomac group. Thus, bluish stoneware clays are dug from near the base of the Patapsco in Cecil County. The Patapsco also contains a number of deposits of refractory clay, which are usually whitish and sandy in character. These are found in Cecil, Harford, Baltimore, Anne Arundel, and Prince George counties.

The variegated clays occur at so many points that it would be impossible to mention them all in detail, but they are very prominent in Cecil County, northeast of Havre de Grace, being exposed in the cuts along the Pennsylvania Railroad.

Raritan formation.-The deposits of the Raritan consist of sands and clays, the former largely predominating in the upper portion of the formation; in other words, in the eastern and southern portions of the belt in which it outcrops. The clays are usually light colored, and may become variegated, red, or even black. The thickness of the Raritan in central Maryland is estimated as not far from 200 feet, but it lessens in thickness greatly to the south, nearly disappearing in the District of Columbia. The following section of the Raritan on the west shore of Elk Neck, at the Lower White Banks, indicates its character. 
Massive, variegated, and drab clays, mostly covered by talus, to tide level.

This section does not show much clay, and yet there are localities in which the Raritan may contain an abundance of it. The counties in which the Raritan clays are found are Cecil, Harford, Baltimore, Anne Arundel, Prince George, Howard, and Montgomery. In most of these, especially the eastern ones, there are often beds of white, sandy, fairly refractory clay, known as fuller's earth. Among the important exposures of the Raritan may be mentioned those occurring along the Magothy and the Severn rivers, around the glass pits at the head of the latter river. Up to the present time the Raritan clays have been but little worked.

EOCENE CLAYS.

The Eocene deposits extend across the State in a northeast-southwest direction, forming a belt of varying width, which is greatest in the region of Upper Marlboro, Prince George County. They are composed of several members, as follows:

Eocene deposits of Maryland.a

\begin{tabular}{|c|c|c|}
\hline . Group. & Formation or stage. & Member or substage. \\
\hline Pamunkey & $\left\{\begin{array}{l}\text { Nanjemoy ... } \\
\text { Aquia ....... }\end{array}\right.$ & $\begin{array}{l}\left\{\begin{array}{l}\text { Woodstock. } \\
\text { Potapaco. }\end{array}\right. \\
\left\{\begin{array}{l}\text { Paspotansa. } \\
\text { Piscataway. }\end{array}\right.\end{array}$ \\
\hline
\end{tabular}

These different members involve beds of sand, clayey sand, greensand or marl, but only one containing clay deposits of any importance is the Potapaco. This contains a clay deposit near its base, the material being very characteristic in appearance. It is not found north of South Kiver, but extends from that stream southwestward, showing many good outcrops, among which the following are especially prominent: In the valleys of the Western and Charles branches of the 
Patuxent; on the road from Davidsonville to Annapolis; halfway between the former locality and South River; at Upper Malboro; also at many points south of Hardesty. It also occur's on the west side of the Patuxent River, in every little cove between Hardesty and Hills Bridge. This red clay is also exposed in the Potomac Valley in Prince George County, and even across the Potomac in Virginia.

It is a fine-grained red material with more or. less fine sand and has a thickness of at least 20 feet. It is not worked at present, but could probably be used for pressed brick, but is insufficiently plastic for pottery.

NEOCENE CLAYS.

These underlie a broad area in the eastern portion of the State, and form deposits of considerable thickness. The deposits of this age have been divided into the Lafayette and the Chesapeake formations, respectively the upper and lower members of the series.

The Lafayette consists of gravel, sands, and clays, which are irregularly stratified and often change rapidly within narrow limits, seldom exceeding 25 feet in thickness, rarely being of much value to the clay worker. On the divides in Charles County the Lafayette formation contains a buff-colored loamy clay, resembling somewhat the Philadelphia brick clay in appearance.

The Chesapeake formation contains sands and marls, with only local developments of clay or diatomaceous earth. It is of little economic value to the clay worker.

PLEISTOCENE CLAYS.

These overlie the earlier formations of the Coastal Plain, and in some cases extend up on the rocks of the Piedmont Plateau. They form a mantle of sandy clay, loam, and gravel of various thickness. The loams, which belong to the Columbia group, are very extensive and rarely wanting, so that they form an abundant source of brick-making material which is not overlooked. In most cases the Pleistocene clays underlie terraces at no great elevation above sea level, but up to the present time the Pleistocene clays have been used for nothing except common brick and earthenware. Columbia clays are well developed at a number of points, as in the cut north of Perryville, Cecil County; at the base of Bull Mountain, Cecil County; and at many points around the city of Baltimore not more than 30 feet ahove sea level. At the last-named locality they are extensively used for the manufacture of common brick, for they are moderately plastic and have sufficient iron to burn to a good red color. In Anne Arundel County they are well exposed in brick-clay pits near Curtis Bay. An important series of Pleistocene clays of higher grade is found outcropping along the shore of Chesapeake Bay from Bodkin Point southward. 
Many of these outcrops have been found to be well suited to the manufacture of stoneware, for they burn to a dense body of creamy color, and are often of very fair refractoriness. ${ }^{a}$ Other deposits are found in Howard County, north of Savage station; and along the west side of the Anacostia River, especially within the District of Columbia. In the counties of southern Maryland there are considerable deposits of clay of Pleistocene age which could no doubt be used for the manufacture of brick and tile. The deposits are often-lens-shaped, some of them similar in appearance to those of Bodkin Point. Important lenses of these clay are found one-half mile northeast of Drum Point, one-fourth mile west of Drum Point, one-half mile south of St. Leonard Creek, 1 mile west of Cedar Point, 5 miles south of Cedai Point, and at other places. Along the eastern shore of southern Chesapeake Bay are scattered clay deposits of Pleistocene age, which are often rather loamy in their character. Pits have been opened near several of the larger towns, especially Centerville, Queen Anne County; Greenshoro and Ridgely, Caroline County; Cambridge and Vienna, Dorchester County; St. Michảels and Tilghman, Talbot County; Salisbury, Wicomico County; Crisfield, Somerset County; Berlin and Pocomoke, Worcester County.

$$
\text { ANALYSES AND PHYSICAL TESTS OF MARYLAND CLAYS. }
$$

The following tables show the physical properties and ehemical analyses of a number of Maryland clay and shale samples: ${ }^{b}$

$a$ See table of tests of Maryland clays, pp. 146 and 147. $b$ From Maryland Geol. Survey, Vol. IV, pp. 494-496. 
Analyses of Maryland clays.

\begin{tabular}{|c|c|c|c|c|c|c|c|c|c|c|c|}
\hline Localits. & Character. & Age. & $\mathrm{SiO}_{2}$. & $\mathrm{Al}_{2} \mathrm{O}_{3}$ & $\mathrm{Fe}_{2} \mathrm{O}_{3}$ & CaO. & MgO. & $\begin{array}{l}\text { Alka- } \\
\text { lies. }\end{array}$ & $\begin{array}{l}\text { Igni- } \\
\text { tion. }\end{array}$ & Total. & \begin{tabular}{|l} 
Total \\
fluxes.
\end{tabular} \\
\hline $\begin{array}{l}\text { Allegany County: } \\
\text { Cumberland... }\end{array}$ & Buttom shole for noving brick & Jennings & & & & & 0.40 & & & & \\
\hline $\begin{array}{l}\text { mberls } \\
\text { Do... }\end{array}$ & $\begin{array}{l}\text { Bottom snale for paving brie } \\
\text { Top shale for paving brick.. }\end{array}$ & $\begin{array}{l}\text { Jennings } \\
\text {..... do .... }\end{array}$ & $\begin{array}{l}70.23 \\
68.30\end{array}$ & $\begin{array}{l}17.71 \\
17.50\end{array}$ & $\begin{array}{l}4.10 \\
4.00\end{array}$ & $\begin{array}{r}0.70 \\
.80\end{array}$ & $\begin{array}{r}0.40 \\
.6 \overline{5}\end{array}$ & $\begin{array}{l}1.76 \\
3.10\end{array}$ & $\begin{array}{l}4.80 \\
5.10\end{array}$ & $\begin{array}{l}99.72 \\
99.45\end{array}$ & $\begin{array}{l}6.96 \\
8.55\end{array}$ \\
\hline Frostburg .... & Not worked. & Conemaugh : & 51.05 & 28.60 & 3.75 & 3. 80 & 1.24 & .50 & 10.85 & 99.79 & 9.29 \\
\hline North of Westernport & ...... do .... & Allegheny & 56.50 & 22.90 & 6.37 & 1.60 & 1.58 & 1.60 & 10.00 & 99.55 & 11.15 \\
\hline Mount: & Flint clay .... & Pottsville.... & 56.15 & 33.295 & .59 & .17 & .115 & & 9.68 & 100.00 & .875 \\
\hline Anne Arundel County: & & & & & & & & & & & \\
\hline Severn River & Baldwin's sandpit, not worked.... & Raritan...... & 75.40 & 16.73 & 1.27 & .35 & .90 & .50 & 5.30 & 100.45 & 3.02 \\
\hline Bo & Not worked ...... & Pleistocene... & 69.40 & 19.70 & 2.00 & .20 & .60 & .62 & 7.85 & 100.37 & 3.42 \\
\hline Dorse & ..... do & Raritan....... & 70.08 & 23.00 & .96 & & & & .5 .96 & 100.00 & .96 \\
\hline Sw & .....do $\ldots$.............. & ..... do ...... & 58.00 & 19.10 & 2.80 & .93 & .08 & .80 & 18.20 & $a 99.91$ & 4.61 \\
\hline Shore below B & Vivianite clay, not worked..... & Pleistocene... & 58.10 & 26.00 & 3.90 & .90 & .35 & .60 & 2.40 & 99.25 & 5.75 \\
\hline Baltims & Sewer-pipe clay .. & Arundel .... & 59.70 & 27.00 & 2.10 & .60 & .52 & 1.96 & 8.20 & 100.08 & 5.18 \\
\hline Baltimc & & & & & & & & & & & \\
\hline & $\mathrm{B}$ & ......do. & 71.55 & 17.70 & 2.25 & .60 & .86 & .42 & 6.50 & 99.88 & 4.13 \\
\hline F. $\mathrm{L}$ & ta clay ............ & ..... do ... & 68.30 & 21.27 & 1.43 & .52 & .80 & .20 & 7.55 & 100.07 & 2.95 \\
\hline $\begin{array}{l}\text { Cromwell Bros.' briekyard east of } \\
\text { Baltimore. }\end{array}$ & Sandy red clay, 8 feet from tor & & 77.62 & 12.46 & 4.10 & .52 & .46 & & 4.58 & 100.74 & 5.08 \\
\hline Do... & Less st & & 72.02 & 16.66 & 1.38 & .12 & .85 & & 6.35 & 97.38 & 2.35 \\
\hline & Clean blue clay, 38 feet from & & 71.66 & 16.92 & 1.82 & & .93 & & 6.14 & 97.47 & 2.75 \\
\hline Cecil Cor & & & & & & & & & & & \\
\hline & Grosh & Patapsco & 65.70 & 20.30 & 1.00 & 3.50 & 1.44 & .62 & 7.60 & 100.16 & $6.5 \dot{6}$ \\
\hline & Stone & .....do. & 72.50 & 17.00 & 1. 50 & .35 & .60 & 1.10 & 6.50 & 99.45 & 3.55 \\
\hline B & Not worked .. & Pleistocenc... & 76.80 & 15.00 & 2.50 & .20 & .41 & .62 & 5.15 & 100.68 & 3.73 \\
\hline & Krolin . & Algonkian.... & 55.65 & 30.53 & .97 & .75 & .60 & .20 & 12.30 & 100.35 & 2.52 \\
\hline Garrett $\mathrm{Co}$ & & & & & & & & & & & \\
\hline & work & Pottsville. & 45.40 & 38.90 & 1.01 . & .31 & Trace. & Trace. & 15. 20 & 100.82 & 1.32 \\
\hline Swallow Falls. & Flint clay ........ & ...... do .......... & 61.00 & 26.36 & .83 & .21 & .10 & Trace. & 11.60 & $100: 04$ & 1.14 \\
\hline & Shale fire clay.. & ...... do .......... & 46.10 & 38.05 & 1.05 & .39 & .60 & $\cdots$ & 12.95 & 99.14 & 2.04 \\
\hline Prince Ge & & & & & & & & & & & \\
\hline & Not worked. & Encene ............ & 58.60 & 28.71 & 3.22 & .40 & .35 & .63 & .8 .90 & 100.81 & 4. 60 \\
\hline Washing & & & & & & & & & & & \\
\hline $\begin{array}{l}\text { WilliumsI } \\
\text { Do... }\end{array}$ & $\begin{array}{l}\text { Dark-red brick clay .. } \\
\text { Light-gray brick clay }\end{array}$ & $\begin{array}{l}\text { Pleistoc } \\
\text { …do. }\end{array}$ & $\begin{array}{l}67.50 \\
61.30\end{array}$ & $\begin{array}{l}17.20 \\
22.30\end{array}$ & $\begin{array}{l}6.70 \\
3.80\end{array}$ & .70 & & $\begin{array}{l}1.76 \\
2.10\end{array}$ & $\begin{array}{l}5.90 \\
8.00\end{array}$ & $\begin{array}{c}99.51 \\
98.20\end{array}$ & $\begin{array}{l}8.91 \\
\text { 6i. } 610\end{array}$ \\
\hline & & & & & & & & & & & \\
\hline
\end{tabular}

a $\mathrm{P}_{2} \mathrm{O}_{5}$ undetermineri. 
Table showing results of physical tests on Maryland clays.

\begin{tabular}{|c|c|c|c|c|c|c|c|c|c|c|c|c|}
\hline \multirow{2}{*}{ Locality. } & \multirow[b]{2}{*}{$\begin{array}{l}\text { U. S. Geological survey } \\
\text { atlas sheet. }\end{array}$} & \multirow[b]{2}{*}{ Age. } & \multirow[b]{2}{*}{ Rate of slaking. } & \multirow{2}{*}{ 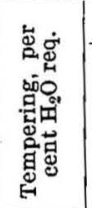 } & \multicolumn{3}{|c|}{ Shrinkage. } & \multirow{2}{*}{ 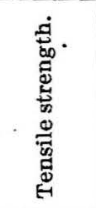 } & \multirow{2}{*}{ 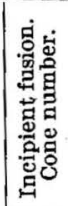 } & \multirow[b]{2}{*}{ 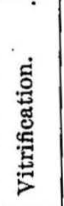 } & \multirow[b]{2}{*}{$\begin{array}{l}\text { 惫 } \\
\text { 总 } \\
\text {; }\end{array}$} & \multirow[b]{2}{*}{ Plasticity. } \\
\hline & & & & & 室 & 蜜 & ङ્ّ & & & & & \\
\hline $\begin{array}{l}\text { Allegany County: } \\
\text { Savage Mountain }\end{array}$ & Frostburg . & Mauch Chunk... & Slow.. & $\begin{array}{r}\text { Per ct. } \\
19\end{array}$ & 4 & 5 & 9 & 55 & 01 & 4 & 7 & Lean. \\
\hline Near Franklin...... & ...... do ........... & Allegheny ..... & ...... do ........ & 16 & 3 & 5 & 8 & 40 & 1 & $5-6$ & $\because$ & Do. \\
\hline $\begin{array}{l}\text { Anne Arundel County: } \\
\text { Bodkin Point....... }\end{array}$ & North Poin & Pleistocene & ......do & & & 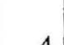 & $19 \mathrm{C}$ & . & 8 & $97+1$ & & \\
\hline $\begin{array}{l}\text { Bodkin Point............... } \\
1 \text { mile south of Bodkin Point }\end{array}$ & $\begin{array}{l}\text { North Poin } \\
\text {..... do .... }\end{array}$ & $\begin{array}{l}\text { Pleistocene. } \\
\text {...... do ....... }\end{array}$ & -............ & $\begin{array}{l}30 \\
35\end{array}$ & $\begin{array}{l}6 \\
8\end{array}$ & $\begin{array}{r}4 \\
10\end{array}$ & $\begin{array}{l}10 \\
18\end{array}$ & $160-130$ & 1 & 4 & $7-8$ & $\begin{array}{l}\text { Good. } \\
\text { Do. }\end{array}$ \\
\hline 2 miles south of Bodkin Point & .....do .............. & ...... do .......... & Moderately fast... & 40 & 11 & 9 & 20 & $223-250$ & 05 & 2 & 7 & Very good. \\
\hline Harman, $\frac{1}{\text { mile south. }}$. & Relay............. & Raritan... & ....... do ...... & 19 & 4 & 6 & 10 & $60-70$ & 3 & $8+$ & & Morlerate. \\
\hline F. Link's pit....... & Baltimore .......... & Arundel ....... & $\ldots$. do ............. & $22 \frac{1}{\mathbf{a}}$ & 6 & 9 & 15 & 77 & 1 & 6 & 10 & Good. \\
\hline Severn River, Brown's. & Relay............. & Raritan........ & Slow............... & 24 & 6 & 10 & 16 & Low. & $1-2$ & 10 & 27 & Moderate. \\
\hline Glass-sand pits... & Relay................... & ......do ............. & Fast .............. & 17 & 5 & 11 & 16 & 90 & 3 & 8 & $10+$ & Good. \\
\hline Baltimore ........... & Baltimore .......... & Arundel ........... & Slow.............. & 30 & 7 & 11 & 18 & 134 & 1 & 6 & $8+$ & Do. \\
\hline Bultimore County: & & & & & & & & & & & & \\
\hline Rittenhouse, Baltir & Baltimore. & Patapsco.. & Moderately fast. & 31 & 9 & 11 & 20 & 111 & 05 & 4 & $7-8$ & Do. \\
\hline Curtis Bay Junction & ....... do .......... & Arundel .... & ..... do .............. & $26 \frac{1}{4}$ & 5 & 7 & 12 & 75 & 2 & 8 & $10+$ & Do. \\
\hline Locust Point... & ......do .... & ......do ....... & Slow............... & 22 & 5 & 7 & 12 & $65-70$ & 6 & 10 & $27-$ & Very good. \\
\hline Cecil County: & & & & & & & & & & & & \\
\hline Bull Mountain . & Elkton.... & Pleistocene. & ......do ..... & 25 & 5 & 5 & 10 & $123-134$ & 01 & 5 & $7+$ & Good. \\
\hline Carpenter Point ........ & Havre de Grace . & Patapsco .. & ...... do .......... & 33 & 6 & 6 & 12 & $110-125$ & 1 & 8 & 25 & Very good. \\
\hline Eder................. & Elkton..... & ....... do $\ldots$ & ..... do ... & 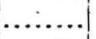 & 6 & 8 & 14 & $68-75$ & 4 & $10+$ & $27+$ & Do. \\
\hline Grosh stoneware clay ....... & Elkton.... & ......do .... & ....... do ............. & 23 & 6 & 10 & 16 & $110-125$ & 01 & 8 & $12-14$ & Do. \\
\hline 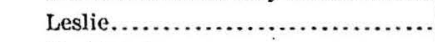 & Elkton......... & Residual .. & Fast ....... & 20 & 2 & 2 & 4 & 10 & 27 & & & Lean. \\
\hline Northeast ...... & & ..... do $\ldots$... & ..... do ........... & 18 & $1 \frac{1}{0}$ & $12 \frac{1}{2}$ & $a 14$ & 20 & 10 & 27 & & Do. \\
\hline Northeast River. & Elkton... & Patapsco .. & Slow ................ & 30 & 6 & 4 & 10 & 40 & 8 & $27+$ & & Moderate. \\
\hline Shannon Hill.... & Elkton ... & ..... do ........ & Moderately fast... & 20 & 5 & $3 \frac{1}{2}$ & $8 \frac{1}{2}$ & 100 & 3 & 8 & $10+$ & Fair. \\
\hline Howard County: & & & & & & & & & & & & \\
\hline Dorsey. & Relay . & Residual ... & Fast .... & 25 & 4 & $b_{5}$ & .... & 15 & $27+$ & & & Lean. \\
\hline Do......... & Relay..... & Arundel .. & ..... do ... & 22 & 5 & 7 & 12. & 60 & ... $>>>$ & 12 & 27 & Good. \\
\hline $\begin{array}{l}\text { Prince George County: } \\
\text { Upper Marlboro .... }\end{array}$ & E. Washington & Eocene... & ......do .. & 35 & 9 & 11 & 20 & 132 & $0 \Sigma$ & 6 & 10 & Fair. \\
\hline
\end{tabular}


Table showing the behavior of a number of Maryland clays heated to cone 27.

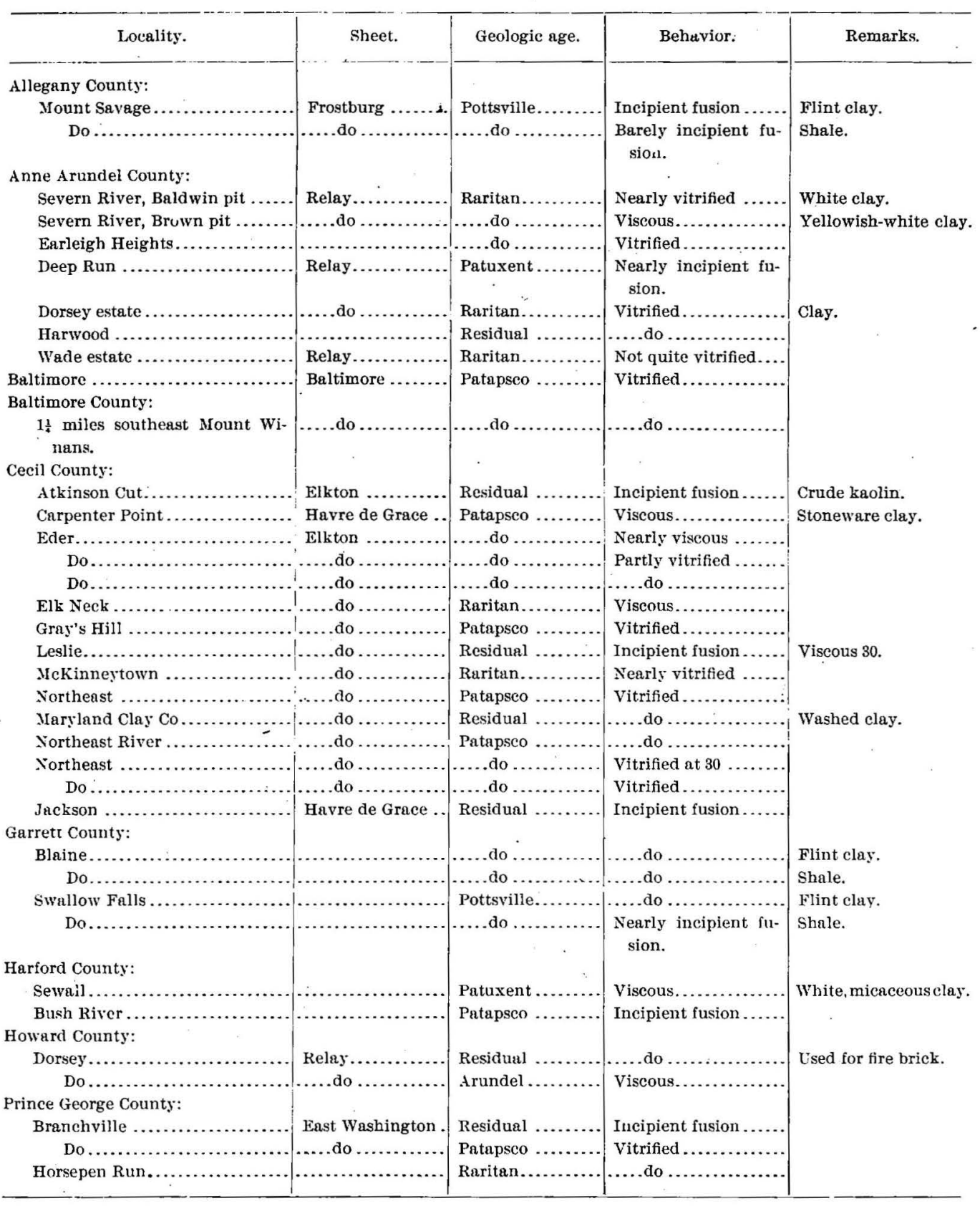


CLAY'-WORKING INDUSTRY.

The chief product manufactured in Maryland is common brick, as clays suitable for brick making are found at many localities, being obtained from the Coastal Plain sedimentary clays, the residual clays of the Piedmont Plateau, and the shale deposits of the Paleozoic area. In the Coastal Plain regịon the Columbia loams are most sought. Comparatively few pressed brick are manufactured within the State, although dry-pressed ones have been made at Baltimore, and re-pressed soft ones are made at Williamstown and several other localities. Paving brick are manufactured from the Devonian shales east of Cumberland, with good success.

The terra-cotta industry of Maryland is comparatively little developed, and yet the results thus far produced are very promising. Buff-colored terra cotta and roofing tile are manufactured in the vicinity of Baltimore from mixtures of the Arundel and Patuxent clays. The variegated Patapsco clay has not been used for this purpose, although beds containing material very similar to it are being made into terra cotta in the vicinity of Washington, D. C. Sewer pipe is manufactured at but one locality, and it is made from a mixture of Arundel clays. The fire-brick industry is of considerable importance within the State of Maryland, the refractory clays being obtained from the Coastal Plains formation, or from the Carboniferous deposits of the Appalachian region. The Carboniferous fire clays of Maryland have been worked since 1841, and the mines on Savage Mountain supply the fire-brick works at Mount Savage, Frostburg, and Ellerslie. Around the city of Baltimore there are fire-brick works which obtain their raw material in part from Pleistocene clays and in part from residual Algonkian deposits. There is an abundance of refractory material, however, in both the Patapsco and the Patuxent. Around Northeast, in Cecil County, there is a considerable development of the stove-brick industry, the raw materials being obtained at no great distance from the works.

Maryland possesses one of the few enameled-brick works in the United States. The factory is at Mount Savage, and the product is made from a mixture of flint and plastic fire clays, which are also used for the manufacture of fire brick at that locality. There are several important white-ware potteries at Baltimore, which have been in operation for a number of years, but, curiously enough, they draw their entire supply of clays from other States. Red earthenware, Rockingham ware, and even stoneware, are made from local clays at several localities near Baltimore, as well as at places in other parts of the State. The relative importance of the Maryland clay-working industry can be seen from the following figures, which give the value of the clay products of Maryland in 1900 and 1901, and also the total production since 1895: 
MARYLAND-MASSACEUSETTS.

Value of clay products of Maryland in 1900 and 1901.

\begin{tabular}{|c|c|c|}
\hline & 1900. & 1901. \\
\hline Common brick. $\ldots \ldots \ldots \ldots$ & $\$ 724,013$ & $\$ 676,708$ \\
\hline 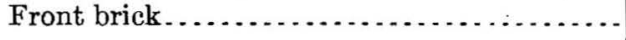 & 60,729 & 76,792 \\
\hline Vitrified brick $\ldots . . . . \ldots \ldots \ldots . .$. & 595 & (a) \\
\hline Fancy brick .................. & 9,886 & 11,000 \\
\hline Fire brick ............ & 321,666 & 342,055 \\
\hline 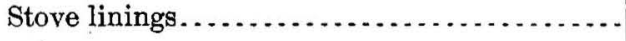 & 36,049 & 40,237 \\
\hline 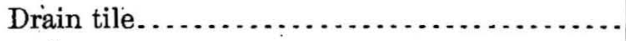 & 2,363 & 2,402 \\
\hline Sewer pipe . . . . . & $(a)$ & $(a)$ \\
\hline Terra cotta .......... & 119,938 & (a) \\
\hline Tile............ & & 16,586 \\
\hline Pottery $\ldots \ldots \ldots \ldots$ & 436,617 & 333,480 \\
\hline Miscellaneous. $\ldots \ldots \ldots \ldots$ & 26,193 & 12,586 \\
\hline
\end{tabular}

$a$ Less than three producers.

Value of clay products of Maryland from 1895 to 1901.

\begin{tabular}{|r|r|r|r|r|}
\hline & &
\end{tabular}$\ldots$

MASSACHUSETTS.

The workable beds of clay, with very few exceptions, are confined to the Cretaceous, Tertiary, and Pleistocene formations. The first timo occur on Marthas Vineyard and Nantucket, and belong to the same series as those found on northern Long Island and in New Jersey, while the latter are scattered all over the State.

Residual clays are rare.

\section{RESIDUAL CLAYS.}

Two remarkable deposits of white residual clay or kaolin are found in Massachusetts. One of these is at Blandford, Hampden County; the other is + miles south of Clayton, Berkshire County. 
The Blandford kaolin has been formed from the decomposition of a pegmatite vein cutting through mica-schist, having at one point a width of nearly 100 feet. ${ }^{a}$ The material has been used at East Russell, 5. miles from Blandford, for the manufacture of white brick and terra cotta, being mixed with New Jersey clays for this purpose. Its composition is as follows:

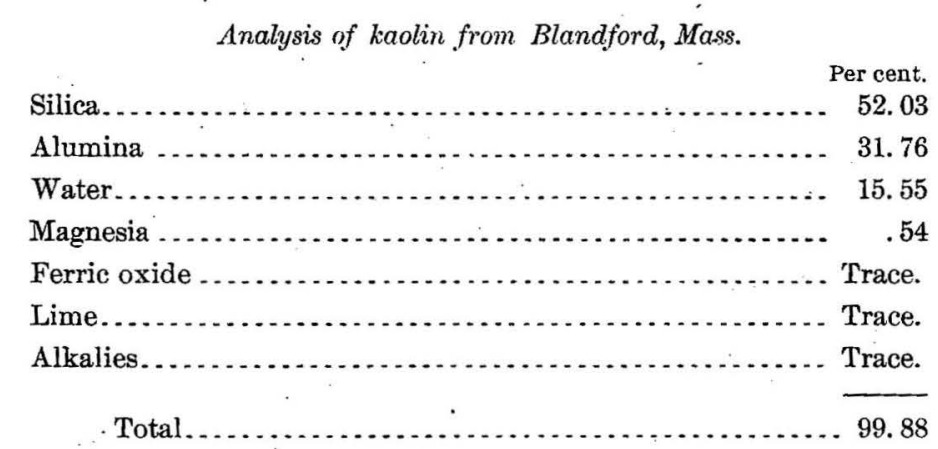

The kaolin deposit south of Clayton is large, but has not been described. It no doubt has been derived from the decomposition of quartzite or feldspathic gneiss, and has been worked since 1893 for the manufacture of terra cotta.

Its composition is given below.

Analysis of kaolin from deposit south of Clayton, Mass.

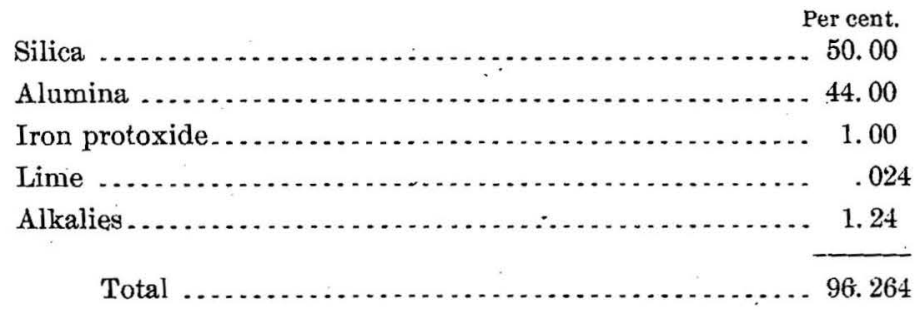

MESOZOIC CLAYS.

The Cretaceous and Tertiary beds form a thick series of clays and sands which are well exposed in the cliffs at Gay Head. Although originally deposited horizontally, they have since been much folded and broken by the continental glacier which advanced against them, so that between their disturbed condition and their rapid variation in character the beds are of little commercial value. Where they are least disturbed, as on Gay Head, the shipping facilities are poor. Here and there in the deposits white or buff clays have heen found in pockety form, and these have been dug at several points. These clays have found a limited application for pottery manufacture.

$a$ Crosby, W. O., The kaolin in Blandford, Mass.: Tech. Quar., Vol. III, No. 3. Aug. 1890. 


\section{PLEISTOCENE CLAYS.}

Above the Cretaceous and Tertiary deposits is another series of beds, known as the Weyquosque series, which aggregate 200 .feet on the southern side of the island.

The Pleistocene beds are extensive on the islands of Marthas Vineyard, Nantucket, and in southeastern Massachusetts on Cape Cod, but most of these are not well adapted to brick manufacture, as they warp too much in burning. The latter or true glacial clays are found and worked at many points. Some of these were formed in estuaries, others in pools, under or in front of the ice, while still others occur in the morainal drift and represent ground-up rock flour. In the region south and east of a line from the mouth of the Merrimac River to Stonington, Conn., they are not found above an elevation of 100 feet. Around Boston these glacial clays are well developed in the estuaries of the Charles, Mystic, and Saugas rivers north and west of Boston. The clay is bluish, plastic, and very fine, and may at times contain bowlders or scattered pebbles. Around North Cambridge the clays are 82 to 85 feet thick, and are underlain by gravel. These clays are also extensively worked along the Mystic River at Medford; at Cambridge and Belmont, on the Charles River; at Holyoke and South Hadley, on the Connecticut; and at Taunton, on the Taunton River. $^{a}$

Very few analyses have been published of Massachusetts clay, and no physical tests. Such analyses as have been obtainable are given below.

Analyses of Massachusetts clays.

\begin{tabular}{|c|c|c|}
\hline . & 1. & 2. \\
\hline 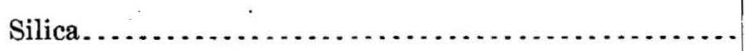 & 48.99 & 57.50 \\
\hline 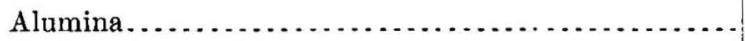 & 28.90 & 31.21 \\
\hline Ferric oxide $\ldots \ldots \ldots \ldots \ldots \ldots \ldots \ldots$ & 3.89 & $\ldots$. \\
\hline Lime . . . . . . . . . . . . . . . & 7.1 & .19 \\
\hline 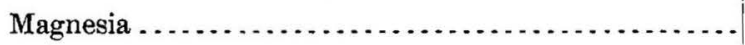 & 3. $66^{\prime}$ & .20 \\
\hline Alkalies . . . . . . . . . . . . . . . & 4.73 & .40 \\
\hline 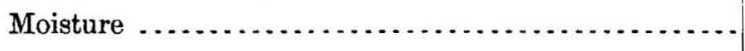 & 3.31 & 9.83 \\
\hline Total ................. & 100.58 & 99.33 \\
\hline
\end{tabular}

1. Glacial clay, West Cambridge, Middlesex County; J. Card, analyst.

2. Red clay, south end Gay Head section, Dukes County, Seventh Annual Rept. U. S. Geol. Survey, p. 359.

$$
\text { CLAY-WORKING INDUSTRY. }
$$

Considering the lack of clay resources in Massachusetts, the State possesses a remarkably varied clay industry. This consequently necessitates the shipping in of 
many clays from other States, chiefly New Jersey, and to a lesser extent New York. Since these raw materials can be sent to the consumer by boat usually, the cost of manufacture is not necessarily great.

Brick are made from local surface clays at a great many localities, notably around Boston, in the towns of Medford, Revere, Cambridge, Belmont, and Everett, as well as at several places in southeastern Massachusetts near Taunton and Bridgewater. In the northeastern part of the State common brick are also made at Newburyport and Danvers. There are also many firms scattered over other parts of the State, most of them supplying a local demand. Pressed brick are made at but few localities outside of Boston. Fancy brick are manufactured at South Boston from a mixture of New Jersey and Gay Head clays. Some glazed brick are also produced.

Many stove linings are made at Taunton from New Jersey materials, while at Chelsea a high grade of art tile is manufactured from a mixture of Pennsylvania kaolin, New Jersey clay, and Massachusetts quartz. Fireproofing is produced from common clay at Revere, and terra cotta at Clayton in part from a residual clay.

Potteries are located at about 18 localities. The product is chiefly earthenware, but some stoneware is also turned out. The Grueby fayence made at Boston is a unique type of pottery which has won considerable reputation.

The value of clay products in 1900 and 1901 in Massachusetts was as follows:

Value of clay products of Massachusetts in 1900 and 1901.

\begin{tabular}{|c|c|c|}
\hline & 1900. & 1901. \\
\hline Common brick.......... & $\$ 1,123,586$ & $\$ 1,060,493$ \\
\hline Front brick... . & $.87,575$ & 98,892 \\
\hline Fancy brick $\ldots \ldots \ldots \ldots \ldots$ & $(a)$ & $(a)$ \\
\hline 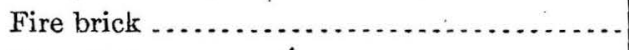 & 69,400 & 57,945 \\
\hline Stove linings................................. & 144,044 & 135,570 \\
\hline Terra cotta $\ldots \ldots \ldots \ldots \ldots \ldots \ldots \ldots \ldots \ldots \ldots \ldots \ldots$ & (a) & (a) \\
\hline Fireproofing ........ & (a) & $(a)$ \\
\hline Tile (not drain) ............... & (a) & (a) \\
\hline 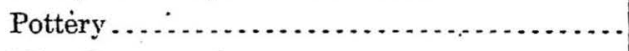 & 238,724 & 281,368 \\
\hline Miscellaneous . . . . . . . & 11,791 & 13,301 \\
\hline Total.......... & $1,833,101$ & $1,870,837$ \\
\hline
\end{tabular}

$a$ Less than three producers. 
The total value of the clay products produced from 1895 to 1901 was as follows:

Value of clay products of Massachusetts from 1895 to 1901.

\begin{tabular}{|c|c|c|c|c|}
\hline Year. & $\cdot$ & Rank. & Value. & $\begin{array}{c}\text { Proportion } \\
\text { of United } \\
\text { States } \\
\text { product. }\end{array}$ \\
\hline \multicolumn{2}{|l|}{100} & & & Per cent. \\
\hline $1895 \ldots \ldots \ldots \ldots$ & $\ldots \ldots$ & 8 & $\$ 2,221,590$ & 3.40 \\
\hline $1896 \ldots$ & & 8 & $2,264,974$ & 3.63 \\
\hline $1897 \ldots \ldots \ldots$ & …, & 8 & $2,179,396$ & 3.50 \\
\hline $1898 \ldots \ldots \ldots$. & $\ldots \ldots$ & 9 & $1,809,070$ & 2. 48 \\
\hline 1899. & - & 9 & $2,181,710$ & 2.28 \\
\hline $1900 \ldots . .$. & - & 10 & $1,833,101$ & 1.91 \\
\hline $1901 \ldots \ldots$ & . & 10 & $i, 870,837$ & 1. 70 \\
\hline
\end{tabular}

MICHIGAN. $a$

The clays of Michigan are derived from two types of deposits, (1) Paleozoic shales (Pl. IV), and (2) Pleistocene clays.

\section{PALEOZOYC SHALES.}

The formations yielding shales suitable for the manufacture of brick are those of the Coal Measures, the Michigan series, the Coldwater series, the Marshall shales, and the Hamilton or Traverse shales. The last two belong to the Devonian. The Hudson group also contains shales, but most of these are too calcareous to be used, although they could perhaps find application for the manufacture of Portland cement.

COAL MEASURE SHALES.

These occur interbedded with the coal seams and sandstones and are of three types, namely, a light-gray shale, often underlying the coal and erroneously called fire clay; a black fine-grained brittle shale; and a dark grayish-black shale. These last two usually overlie the coal seam. These shales are found associated with the coals in the different mines around Saginaw, Owosso, Corunna, St. Charles, Verne, Bay City, and Sebewaing. The sections at any two mines, although often but a short distance apart, may be quite different; but the following, taken from the shaft of the Standard Mining Company at Saginaw, ${ }^{b}$ will illustrate the usual character of the Coal Measure sections.

a Most of the information regarding the clay industry in this State has been taken from the Report on the clays and shales of Michigan, by H. Ries: Michigan Geol. Survey, Vol. VIII, Pt. I.

b Ibịd., p. 33 . 


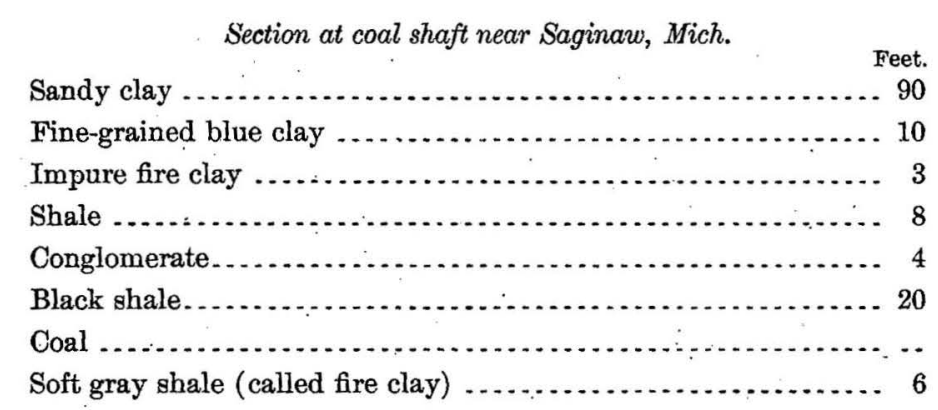

When ground up and mixed with water all of these shales give a plastic mass, but one whose tensile strength is usually low, as can be seen from the appended table (p: 156). Nevertheless they have in several places been found sufficiently plastic to be molded in stiff-mud brick machines for the mixing of paving brick or sewer pipe. They usually vitrify around cone 3 or 4 and become viscous anywhere from cone 5 to 11 .

The Coal Measure shales form a basin lying southeast of Saginaw and having a diameter of about 50 miles. The outcrops are found chiefly around the edges of the basin, and in the center the shales are not only at a considerable depth below the surface, but there is usually a heavy covering of glacial drift or lake deposits at many points.

MICHIGAN SHALES. $a$

Rocks of this series form a belt from 10 to 20 miles wide surrounding the Coal Measure rocks in the Lower Peninsula. They are best exposed at Grand Rapids, where they form a bed from 6 to 10 feet thick, overlying the gypsum deposits. They are also seen in Huron and Arenac Counties, and along the Cass River in Tuscola County. From laboratory tests it is found that the Michigan shales are usually more fusible than those of the Coal Measures and that they burn to a good red color, although they may, in some cases, contain an abundance of soluble salts. Samples of them taken from weathered outcrops show considerable plasticity. These shales have been worked for the manufacture of brick at Grand Rapids.

COLDWATER SHALES.

The deposits of this series are very extensive and have been opened up in quarries at Bronson, Union City, and Coldwater. On the northeast side of the Coal Measures area they are well exposed near Forestville, on Lake Huron. Although hitherto used chiefly for the manufacture of Portland cement, the Coldwater shales will no doubt be found to be well suited for the manufacture of clay products. Samples tested show that they vitrify at about cone 2 and becomes viscous at cone 5 .

a A geologic map showing distribution of the different formations is given in Water-Supply and Irrigation Paper No. 30, U. S. Geol. Survey. 
MARSHALL SHALES.

The shales of the Marshall series of the Devonian are very extensive and are well developed around East Jordan, while the mellowed outcrops form a very tenacious clay and are used in the manufacture of brick. Like the Coldwater shales, they contain considerable soluble salts.

HAMILTON SHALES.

These outcrop around Alpena, but have not been used in the manufacture of clay products. Their chemical composition seems to show that they may be promising.

The search for shale outcrops in Michigan is often attended with difficulty, owing to the heavy covering of drift. In the central part of the Michigan coal basin the drift is very thick, so that prospecting is best carried on around its edges.

The coal shafts at Saginaw, Bay City, and other localities all afford an excellent opportunity for examining the shale beds.

ANALYSES AND PHYSICAL TESTS OF PALEOZOIC SHALES.

In the two following tables there are given the physical tests and chemical composition of a number of Michigan shale samples:

Analyses of Michigan shales.

\begin{tabular}{|c|c|c|c|c|c|c|c|c|c|c|c|c|c|}
\hline . & 1. & 2. & 3. & 4. & 5. & 6. & 7. & 8. & 9. & 10. & 11. & 12. & 13. \\
\hline $\mathrm{SiO}_{2}$ & 55.30 & 57.10 & 52.45 & 44.30 & 57.20 & 58.70 . & 56.50 & 62.10 & 53.44 & 58.70 & 55.95 & 58.60 & 61.09 \\
\hline $\mathrm{Al}_{2} \mathrm{O}_{3} \ldots \ldots \ldots \ldots$ & 14.20 & 20.02 & 23.27 & 23. 72 & 18. 95 & 25.95 & 19. 31 & 20.09 & 24.80 & 18. 31 & 17.43 & 17.66 & 19.19 \\
\hline $\mathrm{Fe}_{2} \mathrm{O}_{3} \ldots \ldots \ldots \ldots$ & 3.62 & 8.18 & 7.93 & 7. 68 & 8.31 & $\ldots \ldots .$. & 5.89 & 7.81 & $\cdots$ & 7.19 & 7.67 & 7.44 & 6.78 \\
\hline $\mathrm{CaCO}_{3} \ldots \ldots \ldots$ & .30 & .71 & 1.82 & 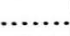 & 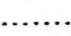 & ....... & 1.00 & & $\cdots$ & 1.80 & 2.14 & 2.14 & ..... \\
\hline $\mathrm{CaO} \ldots$ & $\ldots .$. & $\cdots$ & ...... & 1.11 & .83 & 1.00 & ....... & .65 & .76 & & $\cdots$ & ....... & 2.51 \\
\hline $\mathrm{MgCO}_{3} \ldots \ldots \ldots \ldots$ & 2.61 & 1.47 & 1.06 & ....... & $\ldots \ldots$ & ....... & 1.85 & & & .98 & 1.55 & 2.19 & ...... \\
\hline Mgo.......... & ........ & ........ & ........ & 1.50 & 1.83 & .74 & $\ldots . .$. & .96 & .25 & 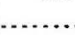 & 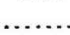 & $\therefore$ & .65 \\
\hline Alk................. & 2.15 & 2.76 & 4.37 & 2.00 & 2.70 & 5.54 & 5.98 & & & 3.67 & 2.86 & .. & 3.16 \\
\hline $\begin{array}{l}\mathrm{H}_{2} \mathrm{O} \ldots \\
\text { Org } \ldots\end{array}$ & 21.82 & 9.76 & 9.10 & 17.64 & 9.00 & 8.07 & 9.47 & 7.90 & 20.75 & 9.35 & 12.40 & 11.97 & 5.13 \\
\hline $\mathrm{CO}_{2} \ldots \ldots \ldots$ & & & & 2.36 & 1.32 & & & & & & & & $\ldots$. \\
\hline $\mathrm{O}_{3} \ldots \ldots \ldots$ & & & & & .12 & & & .49 & & & & & 1.42 \\
\hline
\end{tabular}

1. Coal Measures clay under coal, Standard Mining Company, Saginaw. Michigan Geol. Survey, Vol. VIII, Pt. I, p. 26.

2. Upper layer of shale, underlying coal, Michigan Coal and Mining Company's shaft, Bay City. Ibid., p. 36 .

3. Shale over coal, Wenona Coal Company, Bay City. Ibid.

4. Gray shale, Grand Ledge. Ibid., p. 38.

5. Black shale, same locality. Ibid.

6. Shale, Michigan series, Grand Rapids. Ibid., p. 40.

7. Shale, Michigan series, Alabastine quarry, Grand Rapids. Ibid., p. 41.

8. Coldwater series, Bronson. Ibid.

9. Coldwater series, Coldwater. Ibid., p. 43.

10. Same, Forestville. Ibid., p. 46.

11. Devonian shale, East Jordan. Ibid.

12. Devonian shale, East Jordan. Ibid.

13. Hamilton shale, Alpena. Ibid., p. 48. 
Physical characters of Michigan shales.

\begin{tabular}{|c|c|c|c|c|c|c|c|c|c|c|}
\hline Locality. & $\begin{array}{l}\text { Per } \\
\text { cent of } \\
\text { water } \\
\text { requir- } \\
\text { ed for } \\
\text { mixing. }\end{array}$ & $\begin{array}{c}\text { Tensile } \\
\text { strength. }\end{array}$ & Plasticity. & $\begin{array}{l}\text { Air } \\
\text { shrink- } \\
\text { age. }\end{array}$ & $\begin{array}{l}\text { Fire } \\
\text { shrink- } \\
\text { age. }\end{array}$ & $\begin{array}{l}\text { Incip- } \\
\text { ient } \\
\text { fusion. }\end{array}$ & $\begin{array}{l}\text { Vitrifi- } \\
\text { cation. } \\
\text {. }\end{array}$ & $\begin{array}{l}\text { Viscos- } \\
\text { ity. }\end{array}$ & Color. & $\begin{array}{l}\text { Michi- } \\
\text { gan } \\
\text { Geol. } \\
\text { Survey, } \\
\text { Vol. } \\
\text { VIII, } \\
\text { Pt.I. }\end{array}$ \\
\hline Dwosso, under clay.. & 19 & $35-40$ & Low . & 4 & 5 & $\begin{array}{r}\text { Cone. } \\
02\end{array}$ & $\begin{array}{r}\text { Cone. } \\
4\end{array}$ & $\begin{array}{r}\text { Cone. } \\
9\end{array}$ & Red & $\begin{array}{l}\text { Page. } \\
\qquad 27\end{array}$ \\
\hline t. Charles.... & 18 & ..... & .....do. & 4 & 8 & 1 & 5 & 8 & Gray, buff. & 28 \\
\hline pDark-gray shale.. & 20 & $35-40$ & ......do & 3 & 6 & 1 & 6 & 8 & Deep red. & 32 \\
\hline Flushing... \{ Light-gray clay.. & 20 & $60-65$ & Fair ....... & 5 & 7 & 1 & 7 & 11 & Gray, buff. & 31 \\
\hline $\begin{array}{l}\text { Saginaw, Standard Mining } \\
\text { Co., under clay. }\end{array}$ & 20 & $55-65$ & $\ldots . . d o$ do... & 4 & 6 & 1 & 4 & 9 & Red .... & 33 \\
\hline $\begin{array}{l}\text { Bay City, Central Coal Mining } \\
\text { Co., under clay. }\end{array}$ & 20 & $50-60$ & ds & 5 & & 1 & 5 & 11 & Buff .. & 35 \\
\hline $\begin{array}{l}\text { Sebewaing, Michigan Stand- } \\
\text { ard CoalCo. }\end{array}$ & 17 & 90 & Goo & 5 & 8 & 1 & 5 & 9 & .....do. & 37 \\
\hline $\begin{array}{l}\text { Grand Rapids, Alabastine Co., } \\
\text { quarny. }\end{array}$ & 32 & 105 & $\ldots . . d$ & 6 & 10 & 05 & 01 & 3 & Red & 40 \\
\hline $\begin{array}{l}\text { Coldwater, somewhat weath- } \\
\text { ered. }\end{array}$ & 21 & $125-139$ & do & 7 & 9 & 03 & 2 & 5 & dr & 42 \\
\hline Quincy, fresh shale.... & is & $75-80$ & Fair & 4 & 8 & 03 & 3 & 6 & Deep red. & 42 \\
\hline White Rock ...................... & 19 & $36-42$ & Low ....... & 4 & .7 & 03 & 3 & 6 & .....do.... & 44 \\
\hline Norwood .......................... & 24 & $135-150$ & Good ...... & 6 & 8 & 02 & 1 & 3 & (a) & 46 \\
\hline
\end{tabular}

PLEISTOCENE CLAYS.

These are divisible into three groups, namely, lake deposits, river deposits, and moraine deposits. All of these deposits are very calcareous except the river clays, which are least so, and these are rather gritty. In many cases the lake clays have been leached in their upper portions, and being thus freed from lime these beds nearer the surface tend to burn red. The lake clays are extensively developed around Detroit, Port Huron, South Haven, Marquette, Saginaw, and Escanaba. They are found often at a height as much as 50 or 60 feet above the present lake level. They are usually fine-grained, nearly always calcareous and fuse at a low temperature. Their tensile strength commonly ranges from 150 to 170 pounds per square inch. The moraine clays form irregular masses in the terminal moraine, and are worked at Ionia and at Lansing. Their physical properties are similar to those of the lake deposits. The river clays are less extensive. They are being. worked to the north of Sebewaing.

No clays of a refractory nature have thus far been found in the State. At Rowlee, in Ontonagon County, there is found a very fine-grained calcareous clay which can be used for slip and pottery. 
Analyses of Michigan surface clays.

\begin{tabular}{|c|c|c|c|c|c|c|c|c|c|c|c|c|}
\hline & 1. & 2. & 3. & 4. & 5. & 6. & 7. & 8. & 9. & 10. & 11. & 12. \\
\hline $\mathrm{SiO}_{2}$ & 58.50 & 52.35 & 54.62 & 55.35 & 44.15 & 40.15 & 42.85 & 47.75 & 41.86 & 52.26 & 52.92 & 57.75 \\
\hline $\mathrm{Al}_{2} \mathrm{O}_{3} \ldots$. & 1860 & f 14.90 & 12.82 & 17.89 & 10.00 & 11.25 & 9.87 & 17.60 & 10.70 & 22.95 & 12.25 & 14.39 \\
\hline $\mathrm{Fe}_{2} \mathrm{O}_{3} \ldots \ldots \ldots \ldots \ldots$ & 18.69 & $\{5.60\}$ & 2.00 & 6.86 & 4.08 & 4.88 & 3.43 & 9.13 & 5.02 & 8.15 & 6.45 & 4.41 \\
\hline $\mathrm{CaCO}_{3} \ldots \ldots \ldots$ & $\ldots \ldots \ldots$ & 15.10 & $\ldots \ldots \ldots$ & 7.25 & 24.64 & 21.43 & 25.55 & 2.60 & 14.33 & …... & 13.84 & ..... \\
\hline $\mathrm{CaO} \ldots \ldots \ldots \ldots \ldots . . . . .$. & 11.46 & ......... & 13. 68 & $\ldots$. & ......... & & & & $\ldots \ldots$ & 4.48 & & 7.18 \\
\hline $\mathrm{MgCO}_{3} \ldots$ & ........ & 5.75 & ......... & $2.6 \overline{5}$ & 1.50 & 8.93 & 13.23 & .70 & 2.81 & $\ldots$ & 3.55 & ...... \\
\hline MgO..... & 1.75 & $\ldots \ldots \ldots$ & 4.25 & .. & $\cdots$ & $\cdots$ & & & ....... & 1.32 & & 2.36 \\
\hline Alkalies....... & $\cdots$ & 1. 61 & & . & 1.55 & 2.06 & & 2.21 & 2.80 & ........ & 3.35 & 4.87 \\
\hline $\mathrm{H}_{2} \mathrm{O} \ldots \ldots$. & .... & 3.95 & & & 12.13 & 9.25 & 5.07 & 22.01 & 8.00 & 10.56 & 7.14 & \\
\hline $\operatorname{Org} \ldots \ldots \ldots \ldots \ldots$ & $\ldots \ldots$ & ....... & 12.01 & 5.00 & 1.95 & 2.05 & & & & & & 9.60 \\
\hline $\mathrm{CO}_{2} \ldots \ldots \ldots \ldots$ & 10.93 & $\ldots$ & & & & & & & 14.50 & & & 80 \\
\hline $\mathrm{SO}_{3} \ldots$ & & .34 & & .86 & & & & & & & & \\
\hline
\end{tabular}

1. Prairie Farm, junction of Flint and Shiawassee rivers. Michigan Geol. Surv., Vol. VIII, Pt. I, p. 49.

2. Grayling, Crawford County. Ibid.

3. Marquette, Marquette County. Ibid.

4. Middle Lake. Ibid.

5. Detroit, Wayne County, brick clay. Ibid., p. 53.

6. Detroit, Wayne County, pottery clay. Ibid.

7. Harrietta, Wexford. Ibid., p. 54 .

8. Saginaw, at shaft of Standard Mining County. Ibid., p. 55.

9. Lansing, Ingham. Ibid., p. 59.

10. Jackson, Jackson County. Ibid., p. 60.

11. Rockland, Ontonagon, slip clay. Ibid., p. 61.

12. Rockland, Ontonagon, slip clay.

Physical tests of Michigan surface clays.

\begin{tabular}{|c|c|c|c|c|c|c|c|c|c|c|}
\hline $\begin{array}{l}\text { Locality. } \\
\text {. }\end{array}$ & 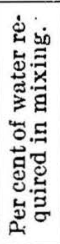 & 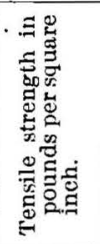 & 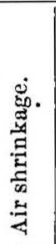 & 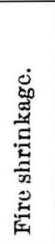 & 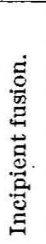 & 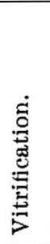 & $\begin{array}{l}\stackrel{3}{0} \\
\stackrel{0}{0} \\
\stackrel{0}{\circ}\end{array}$ & Color. & 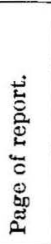 & Plasticity. \\
\hline Detroit, Clippert Bros., upper clay .... & 24 & $150-190$ & 4 & 11 & 01 & 2 & 4 & Buff . & 50 & \multirow{6}{*}{$\begin{array}{c}\text { Excellent. } \\
\text { Do. }\end{array}$} \\
\hline Detroit, Clippert Bros., lower clay .. & 26 & $175-190$ & ... & 15 & 05 & 1 & 5 & Gray, red & 50 & \\
\hline Ionia Pottery clay $\ldots \ldots \ldots \ldots \ldots \ldots$ & 28 & $150-170$ & $8 \frac{1}{3}$ & .... & 05 & 2 & & Cream.... & 51 & \\
\hline Brick clay, Ionia ............................ & 18 & ........... & 6 & ...... & 05 & 2 & 4 & Red buff.. & 52 & \\
\hline Saginaw, over Standard Mining Co. section . & 33 & $105-110$ & 7 & 11 & 05 & 01 & 3 & ............ & 55 & \\
\hline Kalamazoo, 6 miles from $. . . \ldots \ldots \ldots \ldots \ldots . . . . . .$. & 23 & $135-150$ & 6 & 11 & 04 & . 2 & 4 & Red. & 56 & \\
\hline
\end{tabular}

\section{CLAY-WORKING INDUSTRY.}

The clay-working industry of Michigan is confined chiefly to the lower grades of clay products. Common brick are made in considerable quantities from the calcareous surface clays at many localities, éspecially around Detroit, Port Huron, Lansing, etc. They are often of a buff color, but are sometimes red, especially when the 
leached surface beds are used. In most cases the market for the product is chiefly local. Paving brick are manufactured from the Carboniferous shales in the vicinity of Saginaw and Bay City, and sewer pipe are made at Grand Ledge, from shales of the same age. Though there is a considerable quantity of shale in the State which is available for the manufacture of clay products, such as paving brick, still the development of these branches of industry will probably be slow, owing to the conditions that exist in that region. Located as Michigan is, right next to the State of Ohio, which has enormous deposits of shale and clay that can be worked with the greatest ease and economy, it would be difficult for Michigan manufacturers to compete, even within the boundaries of their own State, with the Ohio products. The glacial clays at Ionia are used in the manufacture of earthenware, especially flowerpots and jugs.

The value of the clay products in Michigan in 1900 and 1901 was as follows:

Value of clay products of Michigan in 1900 and 1901.

\begin{tabular}{|c|c|c|}
\hline 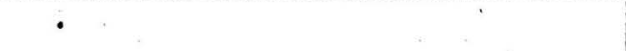 & 1900. & 1901. \\
\hline Common brick $\ldots \ldots \ldots$ & $\$ 863,250$ & $\$ 1,095,254$ \\
\hline Pressed brick $\ldots \ldots \ldots \ldots \ldots \ldots \ldots$ & 48,411 & 64,031 \\
\hline Vitrified brick . . . . . . . . . & (a) & $(a)$ \\
\hline Fancy brick .................. & 4,500 & $(a)$ \\
\hline Drain tile & 114,747 & 98,972 \\
\hline Sewer pipe $\ldots \ldots \ldots$ & 57,916 & $(a)$ \\
\hline Fireproofing $\ldots \ldots \ldots \ldots \ldots \ldots$ & 2,350 & 1,880 \\
\hline 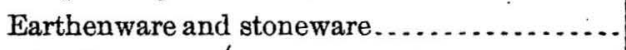 & 34,317 & 42,465 \\
\hline Miscellaneous............................ & 406 & 637 \\
\hline Total & $1,181,695$ & $1,542,034$ \\
\hline
\end{tabular}

The total value of the clay products of Michigan for several years past has been as follows:

Value of clay products of Michigan from $189 \dot{5}$ to 1901.

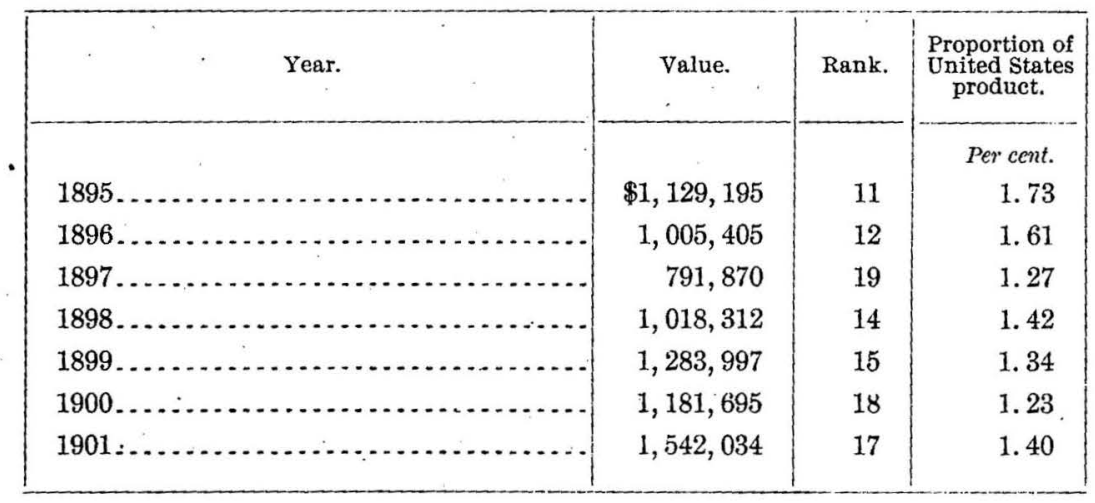




\section{MISSISSIPPI.}

The clay. deposits of this State are all obtained from recent formations. The Cretaceous beds occupy the northeastern corner of the State, being a continuation of the Alabama area.

The following notes are given by Dr. Hilgard in his Report on the Agriculture and Geology of the State of Mississippi, 1860, regarding the clays in townships 4, 5 , and 6 , in Tishomingo County: ${ }^{a}$

"A large deposit of white pipe clay of great purity . . . occurs in Tishomingo County, chiefly in the southern portion of the territory of the Carboniferous formation, following very nearly its western outline. It there forms a regular stratum of considerable extent, which, in one locality at least, was found to be more than 30 feet in thickness. The bed attains its best development, so far as the quality of the material is concerned, in the northern portion of township 5, and in T. 4, R. $11 \mathrm{E}$., where it is about 30 feet underground in the uplands, though at times appearing in limited outcrops on banks of the streams. Northeastward and southwestward from the region mentioned the bed also occurs, but changed in character, at least near the surface, to a white, gritty hardpan, or clays of various colors and of much less purity. It forms the lowest visible portion of the Orange Sand formation, and is almost invariably overlaid by strata of pebbles and puddingstone, which in their turn are sometimes overlaid by common orange-colored sand.

"The most southerly exposure of these beds known to me occurs on a small branch of McDouglas Mill Creek, on secs. 4 and 9, T. 6, R. 10 E., near Mr. Pannel's place. For more than a mile along this branch there are exposures in which about 20 feet of a whitish mass, varying from fine, clayey sand to a white, plastic clay, appears overlaid by thick beds (20 to 40 feet) of ferruginous pebble conglomerate, the latter in its turn being overlaid by the common ferruginous sand and brown sandstone on the hilltops.

"Similar outcrops appear in the neighborhood of Mr. Aleck Peden's place on secs. 3 and 27, T. 5, R. 10 E., northeast of Pannel's. Here also a white stratum, of which only a few feet are exhibited, is overlaid by pebble conglomerate, and this by the common Orange Sand. The white mass varies from white, plastic clay to fine-grained aluminous sandstone. Its upper layers are sometimes composed of a singular conglomeratic mass, consisting of small, white, quartz pebbles imbedded in pure white pipe clay. In both localities copious springs of pure water are shed by the impervious clay strata. At Mr. Peden's there is a fine, bold, chalybeate spring, which seems, however, to derive its mineral ingredients (sulphates of iron and magnesia and common salt) from the adjacent Carboniferous strata rather than from those of the Orange Sand. In either of the localities mentioned, materials suited for fine pottery, or queensware, might be obtained.

"Thence northward the stratum is not often found outcropping, but [lies], as has been stated, 20 to 30 feet below the surface of the uplands, the country being but slightly undulating. At Mr. Clingscale's, sec. 8, T. 5, R. 11 E., the clay stratum was struck at the depth of about 30 feet beneath sand and pebbles; it was dug into 
without being passed through, for nearly 30 feet more, no water being obtained from below, but dripping in above from the base of the pervious strata. The whiteness and plasticity of the material seemed to increase with the depth. The best portions of what was dug out of the well had already been removed at the time of my visit, having been used for various economical purposes, as 'chalk,' whitewash, and 'Lily White.' The specimens examined 'were, therefore, rather below the average quality, and on long exposure to the air their surface shows some yellowish spots. I found, nevertheless, that in baking at a high heat they yielded a biscuit of greater whiteness than their natural color when fresh, and that fine splinters exposed for ten minutes to the highest heat of the mouth blowpipe retained their shape perfectly while reduced to a semitransparent grit. A quantitative analysis of the clay from Clingscale's well gave the following results:

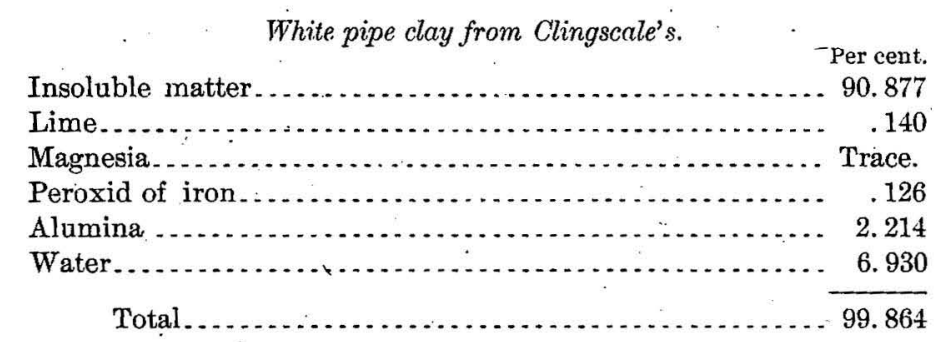

"This analysis (which was made solely for the purpose of ascertaining the ingredients foreign to the clay proper) proves the singular fact that this clay, though occurring in a formation characterized by the large amount of iron it commonly bears, contains a remarkably small amount of that substance, which, together with minute proportions of lime and magnesia, explains its infusibility."

The usual section seen in the clay pits involves Lafayette red sands which seem to overlie unconformably the beds of stoneware clay and white sands.

Sereral potteries are located at Holly Springs, at which locality two different clay pits are extensively worked. The section, according to E. C. Eckel, is as follows:

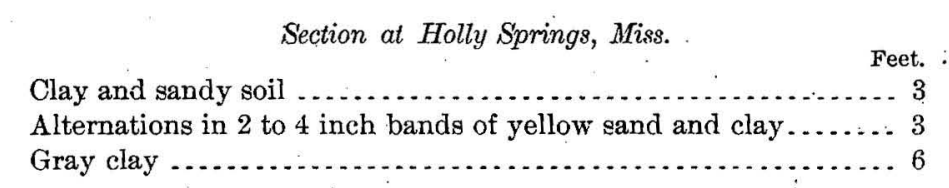

The eastern pits of this company show about 20 feet of clay, with much interbedding of white and yellow sands.

Harper, in his report on the Geology and Agriculture of the State of Mississippi (1857), refers to white clay ${ }^{a}$ occurring in sec. 14, T. T, R. 6 W., in Wayne County. . Pottery clay is mentioned from near Woodville, sec. 28, T. 2, R. 2 W., and also in Tippah County, sec. 17, T. 2, R. 3 E. All of these are plastic. Clays similar to those found at Holly Springs are said to occur in Panola County; sec. 18, T. 8, R. $8,{ }^{b}$

a Op. cit., p. 169.


and in Yazoo County, at the base of the hills crossing the county from north to south, and again in Calhoun County, near Hartford.

Potteiy clay is also noted ${ }^{a}$ in the bluff at Natchez, and at White Cliffs.

The value of the clay products produced in Mississippi in 1901 was as follows:

I'alue of clay products of Mississippi in 1901.

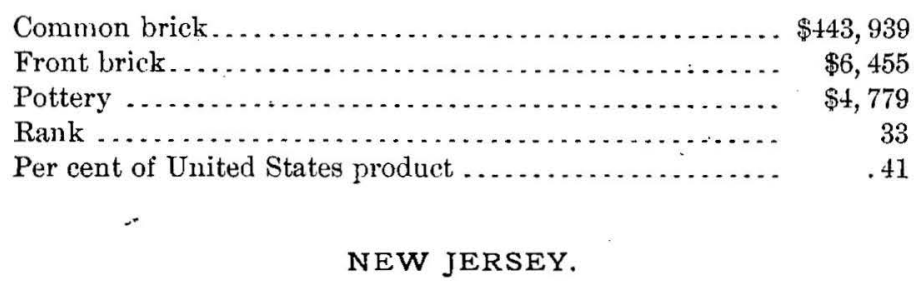

The various geologic formations extend across the State in a general northeastsouthwest direction, their areas being somewhat as follows:

A band of pre-Cambrian gneisses, limestones, and schists enters the State on the northern border, having a width of about 20 miles and covering eastern Sussex, western Passaic, portions of Morris, Hunterdon, and Warren counties. It narrows considerably southward, and is interbelted with areas of limestone, leaving the State at Riegelsville and Easton. Northwest of this area, in western Sussex and Warren counties, are strips of Hudson shales and Trenton limestones, while along the west border of the State, from the Water Gap to Por' Jervis, are narrow belts of Medina sandstone, Onondaga (Corniferous) limestone, and Marcellus shale.

The Triassic or Newark group forms a belt lying sontheast of the preCambrian rocks, its southeastern limit being the Hudson River, Arthur Kill, and thence southwestward through Bonhaintown, Milltown, Monmouth, Port Mercer, and Trenton, where it leaves the State. Its western edge extends from west of Mahwah, Bergen County, to Morristown, then through Bernardsville, Peapack, Lebanon, Juttland, Pattenburg, and Holland. The Triassic consists of sandstones and shales with intrusions of diabase.

The Lower Cretaceous forms a straight and even belt, 7 miles wide at South Amboy and 5 at Trenton, and then continues as a narrow irregular band from Kinkora to opposite Philadelphia, and beyond that as isolated patches. The Upper Cretaceous forms a broader belt, whose border passes through Long Branch, Prospectown, New Egypt, New Lisbon, Clementon, Hurffiville, East Lake, and Salem. Between this line and the coast the surface is underlain by Tertiary and later deposits, but the latter may also cover the Cretaceous in places.

The terminal moraine marking the southern limit of the glacial drift extends from Perth Amboy in an irregular line to Danville, and then westward to Belvidere.

a Wailes, B. L. C., Agriculture and Geology of Mississippi, 18:4, p. 228.

$9647-$ No. $11-03-11$ 
The character and qualities of the clay-bearing formations are summarized below.

HUDSON SHALES.

This is probably the only formation of the Paleozoic series which is likely to prove of value to the clay worker. The Hudson shales are found in a broad belt in Wantage, Frankford, Hampton, and Stillwater townships of Sussex County, and Hardwick, Blairstown, Knowlton, and Frelinghuysen townships of Warren County. In this area they are worked near Port Murray for the manufacture of fireproofing and bricks.

MARCELlUS SHALES. ,

The Marcellus shales form a narrow strip along the northwestern border from Tristates to Egypt Mills. They are of no value to the clay worker, for they contain too much sand and ferric oxide.

NEWARK GROUP.

The rocks of this group underlie a large area in the counties of Passaic, Union, Somerset, Hunterdon, and Mercer, and consist of sandstones, conglomerates, and shales, pierced by sheets and dikes of trap rock. The shales are found throughout the area, but predominate in the southwestern portion. Attempts have been made from time to time to develop the shaly beds, but with little success, as they lack plasticity and are of very low fusibility. It is of course possible to work them into bricks, but with the abundance of other and better clays in the State they are not likely to be utilized for some time at least.

CRETACEOUS.

This, the most important clay-bearing series found in New Jersey, forms a broad belt extending across the State from Raritan Bay and Sandy Hook to the Delaware River, Trenton marking its northwestern edge and Salem, in Salem County, its southeastern edge.

In New Jersey the Cretaceous is divisible into an upper and lower portion, and since the Cretaceous dips gently to the southeast, the Lower Cretaceous outcrops on the northwestern side of the Cretaceous belt.

LOWER CRETACEOUS.

The outcrops of these beds form a belt 4 to 5 miles wide, extending from Perth Amboy to Trenton, and thence farther southwestward along the Delaware River as a narrow irregular band. These beds formed the basis of a large report on the clays of New Jersey ${ }^{a}$ by the late Professor Cook, and up to the present time this volume is practically the only published information concerning them. ${ }^{b}$

$a$ New Jersey Geol. Survey, 1878.

$b$ A new report covering the entire State is now in preparation by the New Jersey Geol. Survey. 
From the study of the beds Professor Cook made the following sections:

Section of Lower Crelaceous rocks of New Jersey.

1. Dark-colored clay, with beds and laminze of lignite ..... Feet.

2. Sandy clay with sand, in alternate layers.............. to

3. Stoneware clay bed ............................. 30

4. Sand and sandy clay, with lignite near bottom .......... 50

5. South Amboy fire-clay bed....................... $\quad 20$

6. Sandy clay, generally red or yellow .................. 3

7. Sand and "kaolin" ............................ 10

8. Feldspar bed. . . . . . . . . .

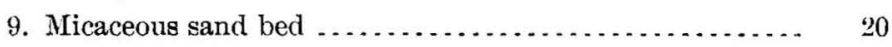

10. Laminated clay and sand ......................... 30

11. Pipe clay, top white .......................... 10

12. Sandy clay, including leaf bed.................... 5

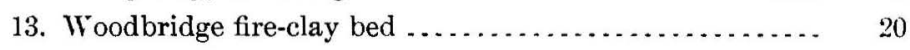

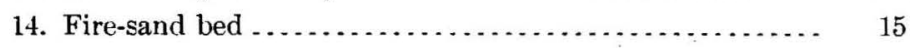

15. Raritan clay beds. $\left\{\begin{array}{l}\text { Fire clay } \ldots \ldots \ldots \ldots \ldots \ldots \ldots \ldots \ldots \ldots \ldots \ldots \\ \text { Sandy clay } \ldots \ldots \ldots \ldots \ldots \ldots \ldots \ldots\end{array}\right.$

Of this series several are very important and weli marked, viz, the Stoneware clay 3, the "Kaolin" bed 7 , the Woodbridge fire clay 13, and the Raritan clay 15. The beds all dip to the southeast, that of the Woodbridge being 51 feet per mile, of the South Amboy bed 48 feet, and the Stoneware 28 feet. While the section is fairly well differentiable, and the individual members are often traceable for considerable distances, still the subdivisions vary in thickness, a bed being sometimes 6 feet thick in one pit and 3 feet in an adjoining one but a few feet distant.

Among such a series of deposits a variety of clays is naturally to be looked for, and there are those which are used for fire brick, saggers, pressed brick, hollow brick, flue linings, white earthenware, terra cotta, gas retorts, floor tile, ete. The Raritan potter's clay, found at the base of the series, is often very plastic, but not refractory. The Raritan fire-clay bed contains much fine sand, but has greater fireresisting power. The fire-sand bed is seen in numerous pits about Woodbridge and the Raritan River. It is a white sand with some gravel, and occasional bits of lignite. The Woodbridge fire clay is named from its occurrence around the town of that name, having been extensively worked here and also at other points from Eagleswood to Bonhamtown. It ranges from a few feet up to 40 in thickness, averaging 20, but in places has been eroded. ${ }^{a}$ A good exposure is shown in Pl. V, $B$. Its character is that of a bluish-white refractory clay, the different layers varying in siliceousness, and therefore being separated in mining. 
The laminated clays and sands are well developed about Woodbridge, but especially along the Raritan River. These were formerly looked on as useless overburden in the mining of fire clay, but they are now extensively used in the manufacture of hollow brick, conduits, and common brick-indeed the quarrying work is done on such a scale that steam shovels are employed. 'They consist of alternating layers of sand and sandy clay, with lignite, pyrite, and mica. Of the feldspar and kaolin beds, the former represent a decayed feldspathic gravel with quartz pebbles, while the so-called kaolin is a micaceous sand, containing white quartz and mica, and is therefore incorrectly named.

The South Amboy fire-clay bed is best developed on the south side of the Raritan River, and is similar to the Woodbridge clay in importance. Its average thickness is 8 feet.

The stoneware clay outcrops southeast of the Amboy fire-clay bed and averages 15 feet.

These Lower Cretaceous beds are the most important found in New Jersey. They are extensively worked around Woodbridge, Perth Amboy, South River, South Amboy, and Bonhamtown, while farther southward newer developments are found along the Delaware River. While the clays form the basis of an important local industry, large qua ntities of them are also shipped to neighboring States, including New York, Connecticut, Massachusetts, Pennsylvania, Maryland, and Ohio.

The following table gives the composition of the different Lower Cretaceous clays:

Analyses of Neu Jersey five clays.

RARITAN FIRE-CLAY BED.

\begin{tabular}{|c|c|c|c|c|c|c|c|c|c|c|c|c|}
\hline Locality. & $\begin{array}{c}\text { Silica } \\
\text { com- } \\
\text { bined. }\end{array}$ & $\begin{array}{l}\text { Silica } \\
\text { free. }\end{array}$ & $\mathrm{AI}_{2} \mathrm{O}_{33}$. & $\mathrm{Fe}_{2} \mathrm{O}_{3}$. & $\mathrm{CaO}$ & $\mathrm{MgO}$. & $\mathrm{K}_{2} \mathrm{O}$. & $\mathrm{Na}_{2} \mathrm{O}$ & $\mathrm{TiO}_{2}$. & $\mathrm{H}_{2} \mathrm{O}$. & $\begin{array}{l}\text { Mois- } \\
\text { ture. }\end{array}$ & $\begin{array}{l}\text { Refer- } \\
\text { ence.it }\end{array}$ \\
\hline W. B. Dixon, Wood & 31.12 & 28.81 & 26.95 & 1.24 & & $0.0 \bar{t}$ & Tr. & Tr. & 1.90 & 9. 63 & $0.5 \overline{1}$ & 78 \\
\hline $\begin{array}{l}\text { B. Ellison, south-southwest of } \\
\text { Bonhamtown } \ldots \ldots \ldots \ldots \ldots\end{array}$ & 17.90 & 57.35 & 15.50 & 1.20 & & & 0.17 & & 1.60 & 4. 90 & 1.30 & 165 \\
\hline
\end{tabular}

WOODBRIDGE FIRE-CLAY BED.

\begin{tabular}{|c|c|c|c|c|c|c|c|c|c|c|c|c|}
\hline W. H. Berry, Woodbridge ......... & 40.50 & 6.40 & 35.90 & 1.10 & & & 0.28 & 0.16 & 1.30 & 12.80 & 1.50 & $82-84$ \\
\hline 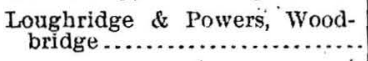 & 42.23 & . ธ็ & 39.53 & .50 & 0.10 & & .41 & .08 & 1. 40 & 13.59 & 1.21 & $90-92$ \\
\hline Same, extrn sandy, Woodbridge. & 20.00 & 51.80 & 18.92 & .88 & & & .48 & & $\left\{\begin{array}{l}\text { with } \\
\mathrm{Al}_{2} \mathrm{O}_{3}\end{array}\right.$ & 6.70 & .50 & 93 \\
\hline A. Hall \& Son, Woodbridge...... & 42.05 & 5.70 & 35.83 & .77 & & 0.11 & .44 & & 1.10 & 12.20 & 1.50 & $94-96$ \\
\hline Sons, Woor & 43.90 & 1.10 & 38.24 & .96 & Tr. & .11 & .15 & & 1.30 & 14.10 & .70 & $105-169$ \\
\hline W. H. P. Benton, Woodbridge.... & 42.00 & 1.40 & 36.56 & 1.04 & & & .35 & .37 & 1.40 & 14. 60 & .80 & $114-115$ \\
\hline 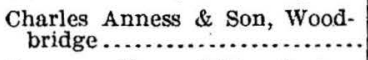 & 34.30 & 20.60 & 31.66 & .74 & & & 1.53 & & $\left\{\begin{array}{l}\text { with } \\
\mathrm{Al}_{2} \mathrm{O}_{3}\end{array}\right.$ & 10.50 & .60 & $115-116$ \\
\hline $\begin{array}{l}\text { n Clay and Manufactur- } \\
\text {, Raritan River ......... }\end{array}$ & 37.85 & 10.50 & 35.75 & .95 & & & 37 & & 1.60 & 12.30 & 1.00 & $144-146$ \\
\hline R. N. \& H. Valentine, San & 39.80 & 8.10 & 36.34 & 1.01 & & .04 & .15 & & $\left\{\begin{array}{l}\{\text { with } \\
\mathrm{Al}_{2} \mathrm{O}_{3}\end{array}\right.$ & 12.90 & 1.20 & 153 \\
\hline $\begin{array}{l}\text { C. A. Campbell \& Co., Sa } \\
\text { white fire clay....... }\end{array}$ & 36.20 & 12.20 & 35.94 & .96 & & & .08 & & 1.50 & 12.10 & 1.10 & 150 \\
\hline
\end{tabular}

a Figures given are pages for reference in Rept. New Jersey Geol. Survey on Clays, 1878. 
Analyses of New Jersey fre clays - Continued.

SOUTH AMBOY FIRE-CLAY BED.

\begin{tabular}{|c|c|c|c|c|c|c|c|c|c|c|c|c|}
\hline Locality. & $\begin{array}{c}\text { Silica } \\
\text { com- } \\
\text { bined. }\end{array}$ & $\begin{array}{l}\text { Silica } \\
\text { free. }\end{array}$ & $\mathrm{Al}_{2} \mathrm{O}_{3}$. & $\mathrm{Fe}_{2} \mathrm{O}_{3}$. & $\mathrm{CrO}$. & MgO. & $\mathrm{K}_{2} \mathrm{O}$. & $\mathrm{Na}_{2} \mathrm{O}$. & $\mathrm{TiO}_{2}$. & $\mathrm{H}_{2} \mathrm{O}$ & $\begin{array}{l}\text { Mois- } \\
\text { ture. }\end{array}$ & $\begin{array}{l}\text { Refer- } \\
\text { ence. } a\end{array}$ \\
\hline 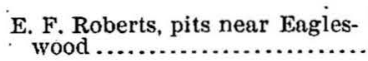 & 40.40 & 5.20 & 38.40 & 1.20 & 0.22 & 0.25 & 0.59 & & $\left\{\begin{array}{l}\text { with } \\
\mathrm{Al}_{2} \mathrm{O}_{3}\end{array}\right.$ & 12.50 & 1.30 & 135 \\
\hline 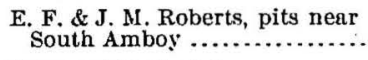 & 42.71 & .70 & 39.24 & .46 & .20 & & .47 & 0.42 & 1.60 & 13.32 & 1.58 & 200 \\
\hline Same, selected clay ............ & 44.20 & .20 & 39.14 & .45 & & & .25 & 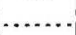 & 1.05 & 14.05 & .90 & 203 \\
\hline 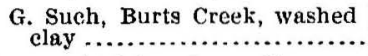 & 42.90 & 1.50 & 38.34 & .86 & & & .26 & .18 & 1.20 & 13.50 & 1.10 & 197 \\
\hline Sayre \& Fisher, Sayreville. & 41.10 & 3.10 & 38.66 & .74 & & & .28 & .18 & 1.20 & 13. 55 & 1.00 & 188 \\
\hline
\end{tabular}

FELDSPAR BED

\begin{tabular}{|c|c|c|c|c|c|c|c|c|c|c|c|c|}
\hline $\begin{array}{l}\text { W. M. Weidner, Forbes farm, } \\
\text { Perth Amboy township......... }\end{array}$ & \multirow[b]{2}{*}{16.50} & \multirow{2}{*}{$\begin{array}{l}58.40 \\
57.10\end{array}$} & \multirow{2}{*}{$\begin{array}{l}18.80 \\
17.46\end{array}$} & \multirow{2}{*}{$\begin{array}{r}0.49 \\
.54\end{array}$} & & & 0.15 & \multirow{2}{*}{$\begin{array}{r}0.21 \\
.21\end{array}$} & \multirow{2}{*}{$\begin{array}{c}\left\{\begin{array}{c}\text { with } \\
\mathrm{Al}_{2} \mathrm{O}_{3}\end{array}\right. \\
.90 \\
.90\end{array}$} & \multirow{2}{*}{$\begin{array}{r}4.90 \\
\text { 6. } 30\end{array}$} & \multirow{2}{*}{$\begin{array}{r}0.80 \\
.50\end{array}$} & \multirow{2}{*}{$\begin{array}{l}119 \\
137\end{array}$} \\
\hline 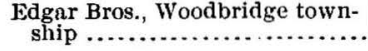 & & & & & & & .12 & & & & & \\
\hline $\begin{array}{l}\text { Knickerbocker Life Insurance } \\
\text { farm, Perth Amboy township. }\end{array}$ & & & 16.07 & .53 & & 0.25 & .15 & & & 4.30 & & 125 \\
\hline \multicolumn{13}{|c|}{ "KAOLIN" BED. } \\
\hline 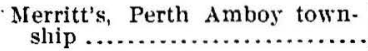 & 77. & & 17.10 & & & & 1.30 & & & 4. & & 129 \\
\hline Whitehead estate, Washington.. & 89. & & 7.80 & & & & & & & 2. & & 178 \\
\hline
\end{tabular}

FIRE SANDS.

A. Hall \& Sons

A. Hall \& Sons

II. Compton's, SE of Bonham

C. Compton

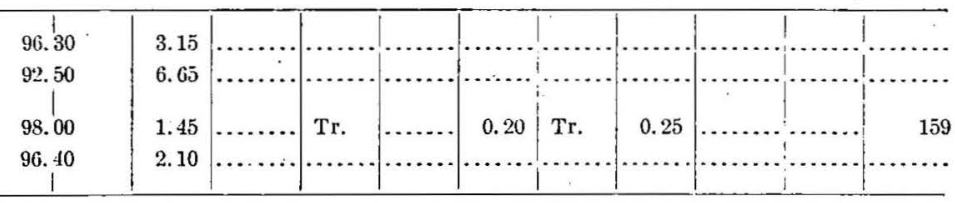

a Figures given are pages for reference in Rept. New Jersey Geol. Survey on Clays, 1878.

UPPER CRETACEOUS.

The Upper Cretaceous is of less importance than the Lower Cretaceous. It is composed of a series of sands, clays, and greensand marls, forming a belt lying to the southeast of the Lower Cretaceous zone of outcrop. The following classification is made by. W. B. Clark: ${ }^{a}$

$$
\left\{\begin{array}{l}
\text { Manasquan formation. } \\
\text { Rancocas formation. } \\
\text { Monmouth formation. } \\
\text { Matawan formation. }
\end{array}\right.
$$

The lower of these, the Matawan, is the only one of importance to the clay worker. It containis beds of sand and clay, the latter being generally black or drab and sometimes calcareous.

This formation occurs typically on Matawan Creek, in Monmouth County. In its lower part are a series of clays, known as the Crosswick clays from their occurrence at Crosswick village, on Crosswick Creek, Burlington County. The clays are 
plastic and in their lower beds many carry pyrite. They are well exposed on the shores of Raritan Bay ${ }^{a}$ and in the valleys of Matchaponix Creek, Crosswick Creek, Black Creek, and other tributaries of the Delaware River. To the south these clays pass into sands.

The Crosswick clays have been extensively used for brickmaking along Matawan Creek, Monmouth County; on Crosswick Creek and near Bordentown and Kinkora, in northern Burlington County; on Pensauken Creek near Senola, east of Camden, Camden County; and at Woodbury, in Gloncester County. ${ }^{b}$

TERTIARY AND PLEISTOCENE CLAYS.

These form scattered areas lying southeast of the Lower Cretaceous belt. They do not form continuous beds, but are irregular in form, with a tendency toward a basin-shaped structure. Their exact vertical or horizontal distribution has not yet been worked out. The formations recognized are the Bridgeton (Lafayette), Pensauken (Columbia), and Cape May. They contain many beds of clay, often of high plasticity and tensile strength. Some of the deposits are buff burning and semirefractory, and will no doubt serve as an important basis for the future development of New Jersey's already extensive clay-working industry.

North of the terminal moraine are many small deposits of glacial clay, which are found chiefly in the valleys and often afford an excellent brick-making material. These clays may also be found in the terminal moraine as well. To the south of the latter alluvial clays are not lacking in the valleys, but here they are usually the wash from the residual clays formed on the neighboring hillsides.

\section{CLAY-WORKING INDUSTRY.}

New Jersey now ranks fifth among the clay-producing States, as may be seen from the following table:

Value of clay products of New Jersey from 1895 to 1901.

\begin{tabular}{|c|c|c|c|}
\hline Year. & Value. & Rank. & $\begin{array}{c}\text { Proportion } \\
\text { of United } \\
\text { States prod- } \\
\text { uet. }\end{array}$ \\
\hline . & & & Per cent. \\
\hline $1895 \ldots \ldots \ldots$ & $\$ 4,899,120$ & 5 & 7.50 \\
\hline $1896 \ldots \ldots \ldots \ldots \ldots \ldots \ldots \ldots \ldots \ldots \ldots \ldots$ & $4,728,003$ & 5 & 7.58 \\
\hline $1897 \ldots \ldots \ldots$ & $6,180,847$ & 3 & 9.91 \\
\hline $1898 \ldots \ldots \ldots$ & $8,706,357$ & 3 & 12.01 \\
\hline $1899 \ldots \ldots \ldots$. & $10,787,273$ & 3 & 11. 26 \\
\hline $1900 \ldots \ldots$ & $10,928,423$ & 3 & 11.36 \\
\hline $1901 \ldots \ldots . . . . .$. & $11,681,878$ & 3 & 10.60 \\
\hline
\end{tabular}

a Ann. Rept. New Jersey Geol. Survey, 1897, p. 178.

b Ibia., p. 208. 
This position of importance among the States supporting a clay-working industry is due partly to the presence of many good clays and partly to the proximity to the important eastern markets, viz, New York, Philadelphia, and Boston. Furthermore, the location of many of the factories along tide water permits of the cheap shipment of the product. This applies to all grades of ware.

The value of the different grades of clay products made in New Jersey in 1900 and 1901 was as follows:

Value of clay products of New Jersey in 1900 and 1901.

\begin{tabular}{|c|c|c|}
\hline & 1900. & 1901. \\
\hline Common brick... & $\$ 1,809,906$ & $\$ 1,675,406$ \\
\hline Pressed brick ..... & 426,692 & 473,138 \\
\hline Vitrified brick .... & $(a)$ & (a) \\
\hline Fire brick ............ & $1,072,535$ & 780,327 \\
\hline Drain tile.............. & 55,655 & 22,612 \\
\hline Sewer pipe ....... & 154,481 & $(a)$ \\
\hline Terra cotta $\ldots \ldots \ldots \ldots$ & 647,884 & $920,6 \pm 4$ \\
\hline Fireproofing...... & 873,706 & 610,864 \\
\hline Fancy brick .......... & 4,112 & 11,514 \\
\hline Stove linings . . . . . . . . . . & (a) & (a) \\
\hline Tile (not drain) ....... & 508,392 & 486,122 \\
\hline Miscellaneous................... & 286,424 & 458,316 \\
\hline Plain red earthenware..... & 28,600 & 21,489 \\
\hline Plain stoneware .......... & 46,650 & 60,000 \\
\hline Yellow ware .................. & (a) & $(a)$ \\
\hline 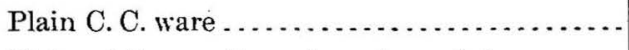 & 345,249 & 293,455 \\
\hline Plain white granite and semiporcelain .... & 494,282 & 718,613 \\
\hline Semivitreous, incl. N. H ... & 96,447 & 60,321 \\
\hline Total plain....................... & $3,820,948$ & $4,361,127$ \\
\hline Decorated C. C. ware .............. & 199,000 & 150,000 \\
\hline Decorated white granite........ & 645,338 & 767,650 \\
\hline Decorated semivitreous .......... & 292,479 & (a) \\
\hline Total decorated ......... & $1,431,703$ & $1,538,946$ \\
\hline China (plain) $\ldots \ldots \ldots \ldots \ldots$ & 345,112 & 344,224 \\
\hline China (decorated) $\ldots \ldots \ldots \ldots \ldots \ldots \ldots$ & (a) & 321,724 \\
\hline Bone, delft, and belleek (plain)......... & 38,800 & 237,835 \\
\hline Bone, delft, and belleek (decorated)...... & (a) & (n........ \\
\hline Sanitary (plain) ............ & $1,807,953$ & $2,194,354$ \\
\hline Sanitary (decorated) $\ldots \ldots \ldots \ldots \ldots \ldots$ & $(a)$ & (n........... \\
\hline Porcelain electrical supplies... & 285,466 & 342,479 \\
\hline Miscellaneous.......... & 325,389 & 88,357 \\
\hline
\end{tabular}

$a$ Less than three producers. 
Common brick are made at many points, especially in the vicinity of the larger. towns; but the region around Hackensack is the most important, for the extensive beds of Columbia clays found there are actively worked, supplying the market of New York City. Many common brick are also made from the Cretaceous clays around South River. In 1900 New Jersey ranked third as a producer of pressed brick, being outranked by Pennsylvania and Ohio. Large quantities of this product are made from the buff-burning tire clays of the Cretaceous belt near Perth Amboy, Sayreville, Trenton, etc. Hydraulic pressed brick are produced from Pleistocene clays at Winslow Junction and Mays Landing. Very few vitrified brick are made in New Jersey, chiefly because the raw materials are absent.

Terra cotta forms one of the important clay products of the State. In fact, New Jersey has been the leading producer of terra cotta for several years until 1900, when she fell slightly behind New York. Still, most of the terra cotta manufactured in the latter State is made from New Jersey clays. The terra-cotta factories are located chiefly in the Cretaceous clay belt, especially around Perth Amboy, the raw materials being drawn from various clay mines in that region.

Fireproofing is manufactured in encrmous quantities, the production of New Jersey far exceeding that of other States, and forming about 47 per cent of the United States production in 1900. The ware finds a ready market in the Eastern cities. The industry is based chiefly on the impure sandy clays outcropping along the Raritan River, near Perth Amboy, and also on the Hudson shales at Belvidere. In the former district conduit pipes are also manufactured in large amounts from similar clays.

Sewer pipe were made in considerable quantities in New Jersey in former years, but the industry has declined, for the clays available are much less suitable for this purpose than those found in other States.

Glazed tile for interior decoration and floor tile of different solid colors are manufactured at Trenton and also Perth Amboy, but the raw materials are mostly imported from other States.

Fire brick and pottery are the two most important branches of the New Jersey clay-working industry. The fire brick of New Jersey have long held a high reputation, and the clays around Woodbridge are extensively wrought for this purpose. The shapes include ordinary brick, cupola brick, locomotive blocks, tuyere nozzles, and many special shapes. Most of these are made from a mixture of several clays, and the product not uncommonly shows a high percentage of silica. The following analyses were made some years ago by the Pennsylvania geological survey: 
Analyses of fire brick made at Woodbridge, N. J.

\begin{tabular}{|c|c|c|}
\hline . & 1. & 2. \\
\hline $\mathrm{SiO}_{2}-\ldots \ldots \ldots \ldots$ & 71.55 & 58.75 \\
\hline $\mathrm{Al}_{2} \mathrm{O}_{3} \ldots \ldots \ldots \ldots \ldots \ldots \ldots \ldots$ & 25.090 & 36.79 \\
\hline $\mathrm{Fe}_{2} \mathrm{O}_{3} \ldots \ldots \ldots \ldots \ldots \ldots$ & 1. 280 & 1.39 \\
\hline $\mathrm{TiO}_{2} \ldots \ldots \ldots \ldots \ldots \ldots$ & 1.05 & 1.75 \\
\hline $\mathrm{CaO} \ldots \ldots \ldots \ldots$ & .65 & .11 \\
\hline $\mathrm{MgO} \ldots$ & .364 & .301 \\
\hline Alkalies ................ & .384 & .913 \\
\hline
\end{tabular}

1. Hall \& Sons, No. 1 fire brick. Second Pennsylvania Geol. Survey, Rept. MM, p. 269.

2. Hyzer \& Lewellen. Made from Woodbridge clay. Ibid.

A series of fire tests carried out by Prof. J. C. Smock showed that the bricks compared very favorably in refractoriness with those from other States.

Trenton is one of the two great pottery centers of the United States, the other being East Liverpool, Ohio. The location of factories at this point is due rather to its being a central point for shipment than to proximity of raw materials. The chief product is C. C. waresand white granite ware, but belleek, electrical supplies, vitreous china, and delft are made in smaller quantities. In recent years the manufacture of sanitary ware has been developed to an enormous extent. Fire brick, saggar clay, wad clay, and some ball clay are practically all that the white-ware manufacturer at Trenton draws from New Jersey. Most of the ball clay, and all of the kaolin, feldspar, and quartz are brought from other States, and even from England.

In addition to the factories located at Trenton, there are several others, situated at various points, as can be seen by reference to the map, PI. IX.

Common earthenware, stoneware, and yellow ware are produced at Trenton and other localities.

\section{CLAY-MINING INDUSTRY.}

Much of the clay mined in New Jersey is shipped to other States, to be there worked up into refractory and other products. 
The production of clay in 1900 and 1901 was as follows:

Production of clay in New Jersey in 1900 and 1901.

\begin{tabular}{|c|c|c|c|c|}
\hline \multirow{2}{*}{ Material. } & \multicolumn{2}{|c|}{1900.} & \multicolumn{2}{|c|}{1901.} \\
\hline & $\begin{array}{c}\text { Quantity } \\
\text { (short tons). }\end{array}$ & Value. & $\begin{array}{c}\text { Quantity } \\
\text { (short tons). }\end{array}$ & Value. \\
\hline Kaolin (so-called) ... & 2,986 & $\$ 2,456$ & 3,541 & $\$ 4,040$ \\
\hline Ball clay (raw) .... & (a) & .......... & $(a)$ & $\cdots$ \\
\hline Ball clay (washed). & (a) & . . . . . . & $(a)$ & $\ldots$. \\
\hline Fire clay (raw) ...... & 210,635 & 272,707 & 225,424 & 328,370 \\
\hline Fire clay (washed) & (a) & $(a)$ & 16,023 & 63,579 \\
\hline 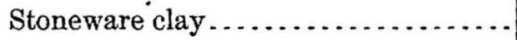 & 16,621 & 29,189 & 26,538 & 46,290 \\
\hline Pipe clay ...... & 8,705 & 6,812 & . . . . . & ......... \\
\hline Terra-cotta clay ..... & 38,123 & 43,687 & $\ldots \ldots \ldots$ & $\ldots$ \\
\hline Miscellaneous... & 25,704 & 41,562 & 116,170 & 135,418 \\
\hline Total. & 321,219 & 467,881 & 392,946 & 594,894 \\
\hline
\end{tabular}

$a$ Less than three producers.

NEW YORK.

The greater portion of New York State is underlain by sedimentary rocks of Paleozoic age, ranging from the Cambrian to the Carboniferous, inclusive. These consist in very large part of shales, but sandstones and limestones are at times prominent. In the northeastern and southeastern portions of the State are two great areas of crystalline rocks, forming the Adirondacks and Highlands. The rocks composing them are anorthosites, granites, gneisses, and schists, which would yield clays only by their decomposition. The Cretaceous and Tertiary formations, so abundant in States farther south, are found in New York only on Staten Island, Long Island, and Fishers Island.

Overlying all of the above are deposits of Pleistocene age, composed of either glacial drift or of sediments deposited by streams flowing from the ice sheet during its retreat across the State.

The clay deposits of the State may be grouped as follows: (1) Residual clays, (2) Paleozoic shales, (3) Cretaceous and Tertiary clays, (4) Pleistocene clays.

RESIDUAL CLAYS.

Owing to the location of New York State north of the southern limit reached. by the continental ice sheet during the Glacial epocb, very little of the residual clay which was formed by the surface decay of the rocks in pre-Glacial time has been left.

Some small deposits of kaolin are known to occur southeast of Sharon station and southeast of Fishkill Village, near Shenandoah Corners. Residual clay of more 
or less ferruginous character is found in the limonite deposits at Amenia, Dutchess County, and small deposits have also been noted near Morrisania, where they have resulted from the decay of the dolomitic limestone. ${ }^{a}$ None of these deposits have, however, proved of much commercial value. It is possible, though, that some kaolin beds of workable size may be found east or southeast of Sharon station, for a large one has been developed just east of the boundary line in Connecticut. If the material exists, it is to be looked for in the gneissic or schistose rocks.'

The mellowed outcrops of some of the Paleozoic shales can perhaps be classed as residual deposits, but they differ from those mentioned above in being the results of disintegration and not of decomposition.

\section{PALEOZOIC SHALES.}

These may be developed into one of the most important clay resources of the State. Those found in New York State belong to the following formations: Chemung, Portage, Hamilton, Salina, Niagara, Medina, Clinton, and Hudson. All of these shale formations, with the exception of the Hudson, form bands of variable width extending across the State in an east-west direction. Their distribution can best be seen by reference to the geologic map of New York, from which it will appear that the oldest formations outcrop toward the north, in belts running parallel to Lake Ontario. The formations have a gentle southward dip of 40 to 60 feet per mile, and in passing across the State from the lake shore southward the outcrops traversed will be successively younger.

Of the shale formations mentioned above, the Hudson has no economic value for the manufacture of clay products, for it lacks plasticity and is very siliceous. The Niagara also is both calcareous and siliceous.

The Medina shale is well developed at Lewiston, on the Niagara River, ${ }^{b}$ and along the Genesee River. It is not utilized in this State, but gives good results for dry-pressed brick in Ontario.

The Clinton shales are about 30 feet thick in places, notably in eastern Wayne County, and 24 feet thick at Rochester, Monroe County, and Wolcott Furnace. They have not been used and are probably often calcareous. ${ }^{c}$

The Salina forms a belt extending from Syracuse westward. The shale is soft, weathers easily, and possesses good plasticity, but may be quite calcareous, although good wares are made from it. Good exposures occur at Warner, Onondaga county.

The Hamilton, though extending from the Hudson River to Lake Erie, shows considerable lithologic variation, ranging from a sandstone to a clay shale. The latter phase is more common in the western part of the area underlain by it. It is

$a$ Martin, D. S., and Merrill. F. J. H.: Trans. New York Acad. Sei., Vol. IX, 1889, p. 45.

$b$ Bull New York State Museum No. 35, p. 827.

c Ibid., p. 828. 
worked at Cairo, Greene County, and Jewettville, Erie County, in one place for paving brick, in the other for dry-pressed brick.

Overlying the Hamilton is the Portage, which consists of a lower shaly member, the Cashaqua, a middle member of shales and sandstones, and an upper sandstone. The shale occurs along Cashaqua Creek, also along Seneca Lake and at Penn Yan, but becomes gritty east of this point. It is 33 feet thick along Lake Erie at Eighteenmile Creek, and 150 feet thick along the Genessee River. The shale is worked at Angola.

The Chemung includes the most southern shale formation of New York State, but it is interbedded with sandstones which become very prominent toward the east.

The section given by Professor Hall, beginning at the top, is as follows:

Section of Chemung formation in New York.

Sandstone and conglomerate.

Red sandstone.

Black, slaty shale.

Green shale with gray sandstones.

Gray and olive shales and shaly sandstones.

Olive shaly sandstones.

Specially good exposures occur on the Genesee River, and much shale is found westward from this point.

The following tables, compiled from Bull. New York State Museum No. 35, show the physical character and chemical composition of some of these shales.

Analyses of New York shales.

\begin{tabular}{|c|c|c|c|c|c|c|c|c|c|c|c|}
\hline Locality. & Geologic age. & Uses. : ' & $\mathrm{SiO}_{2}$. & $\mathrm{Al}_{2} \mathrm{O}_{3}$ & $\mathrm{Fe}_{2} \mathrm{O}_{3}$. & $\mathrm{CaO}$ & MgO. & Alkalies. & $\mathrm{H}_{2} \mathrm{O}$ & $\mathrm{CO}_{3}$ & $\begin{array}{l}\text { Miscel- } \\
\text { laneous. }\end{array}$ \\
\hline Lewiston. & Medina....... & Not worked ...... & 59.50 & 20.60 & 8.00 & 0.80 & 0.35 & 3.60 & 5.50 & & \\
\hline Rochester.... & Niagara ...... & .....do................ & 28.35 & 10.47 & 1.90 & 21.47 & 8.24 & 5.73 & . $\cdots \cdots$. & & \\
\hline Warner........ & $\begin{array}{l}\text { Salina (cal- } \\
\text { care ou } \\
\text { a ayer in } \\
\text { bank). }\end{array}$ & $\begin{array}{l}\text { Paving, common, } \\
\text { and hollow } \\
\text { brick. }\end{array}$ & 25.40 & 9.46 & 2.24 & 22.81 & 10.39 & .95 & $a 7.60$ & 20.96 & \\
\hline Do.. & $\begin{array}{l}\text { Salina red } \\
\text { shale. }\end{array}$ & ...... तo ................ & 52.30 & 18.85 & 6.55 & 3.36 & 4.49 . & $\begin{cases}\mathrm{K}_{2} \mathrm{O} & 4.65 \\
\mathrm{Na}_{2} \mathrm{O} & 1.35\end{cases}$ & a5.30 & 3.04 & \\
\hline Do. & $\begin{array}{c}\text { Salina blue } \\
\text { shrle. }\end{array}$ & ......do... & 57.79 & 16.15 & 5.20 & 2.73 & 4.67 & $\begin{cases}\mathrm{~K}_{2} \mathrm{O} & 4.11 \\
\mathrm{~N}_{2} \mathrm{a}_{2} \mathrm{O} & 1.22\end{cases}$ & 44.50 & 3.42 & \\
\hline Windom. & Hamilton .... & Not worked ....... & 57.30 & 21.61 & 6.50 & 2.52 & 1.50 & & 7.80 & & \\
\hline Do... & ..... do do.......... & .....do............... & 61.15 & 14.57 & 7.20 & 3.06 & .20 & . $\quad 1.90$ & 5.95 & & \\
\hline Angola ......... & Portage ...... & Flue linings...... & 65.15 & 15.29 & 6.16 & 3.50 & 1.57 & 5.71 & & & \\
\hline Alfred Center.. & Chemung .... & Roofing tile .... & 63.20 & 23.25 & 10.90 & 1.01 & .62 & 2.69 & 6. 39 & & $\begin{cases}\mathrm{MnO}_{2} & . \mathrm{.22} \\
\mathrm{TiO}_{2} & .91 \\
\mathrm{SO}_{3} & .41\end{cases}$ \\
\hline Hornellsville.. & .....do.. & Paving bricks ... & 64.45 & 17.77 & 7.04 & .58 & 1.85 & $\begin{cases}\mathrm{~K}_{2} \mathrm{O} & 2.52 \\
\mathrm{~N}_{2} \mathrm{O} & 1.95\end{cases}$ & & & \\
\hline Corning .. & ......do... & Terra cotta.. & 58.10 & 17.50 & 6.00 & 4.50 & 2.88 & 4.15 & 5.90 & & \\
\hline
\end{tabular}


Physical tests of New York shales.

\begin{tabular}{|c|c|c|c|c|c|c|c|c|c|c|c|}
\hline Locality. & $\begin{array}{l}\text { Geologic } \\
\text { age. }\end{array}$ & Uses. & 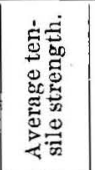 & 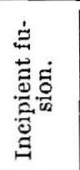 & 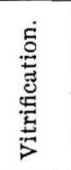 & 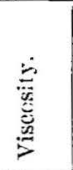 & $\frac{\dot{0}}{8}$ & 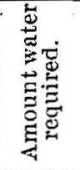 & 岂 & 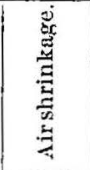 & 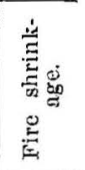 \\
\hline Lewiston.. & Medina..... & Notworked. & $\mid \begin{array}{c}\text { Lbs. per } \\
8 q . \mathrm{nll} \\
15\end{array}$ & $\begin{array}{c}\text { Cone. } \\
.04\end{array}$ & 1 & 4 & Red .. & $\begin{array}{l}\text { Per ct. } \\
16\end{array}$ & Lean & $\begin{array}{c}\text { Per ct. } \\
3\end{array}$ & ${ }_{6}^{\text {Per ct. }}$ \\
\hline Windom .. & Hamilton . & No. $2 \ldots \ldots$ & 40 & .03 & 1 & 4 & Red .. & 22 & Fair ...... & $4 \frac{1}{2}$ & $9 \frac{1}{2}$ \\
\hline Do ..... & ..... do ...... & No. $3 \ldots \ldots$ & ......... & .06 & 1 & 4 & Red .. & 20 & Fair ..... & 2 & 6. \\
\hline Do $\ldots \ldots$ & ......do ....... & No. $4 \ldots \ldots$. & ......... & .06 & 1 & & & 21. & …..... & 3 & 4 \\
\hline Do ... & ..... do ...... & No. $5 .$. & 35 & .03 & 1 & 5 & & 19 & ..... & 3 & $\ldots$. \\
\hline Angola...... & Portage.... & 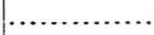 & 92 & .06 & 01 & 4 & & 21.4 & Fair ...... & 4 & 10 \\
\hline Jamestown .. & Chemung.. & ............... & $a 45-69$ & .06 & 01 & 2 & ….... & 17. & Lean ..... & 3 & 7 \\
\hline Alfred Center & .....do...... & & 61 & .06 & 01 & 3 & & 20 & Moderate. & 4 & 9 \\
\hline Hornellsville & ..... do ..... & $\ldots$. & a 34-39 & .06 & 01 & 4 & & 20 & Lean ..... & $2: 7$ & 5.3 \\
\hline Corning....... & ......do do.... & & ........ & .05 & 1 & $3-4$ & & 18 & Lean ..... & 2 & …..... \\
\hline
\end{tabular}

These include the Cretaceous clays of the Constal Plain region of Long, Staten, and Fishers islands, and some of possible Tertiary age in the same area. The clays of this region are of variable character, ranging from ferruginous ones to others that are low in impurities and are hence of refractory character. They are frequently siliceous, owing to the ever-changing conditions of deposition, and do not form beds of great extent, but on the contrary are often pockety or lens-shaped, the deposits of clay being surrounded by beds of sand, and the latter may thus often necessitate considerable stripping. Some of the deposits, as those at Glencove and Northport, have been worked for a number of years.

The Cretaceous age of many of these beds has been settled, "but those of supposed Tertiary age are still in doubt. On Long Island and Fishers Island the upper layers of the clay beds have been crumpled and shored by the ice as it adranced southward from Connecticut.

The more important localities at which these clays are exposed are at Kreischerville, Staten Island; Glencove, West Neck, Oyster Bay, Little Neck near Northport, Wyandance, and Farmingdale, Long Island. Most of the Long Island localities are along the north shore, the clays outcropping in the bluffs. In the central portion and along the south shore of the island clays are rarely seen. The poorer grades are worked locally but the better ones are shipped. 
The following table gives the composition of the clay of a number of the deposits:

Analyses of Cretaceous and Tertiary clays in New York State.

\begin{tabular}{|c|c|c|c|c|c|c|c|c|c|c|c|c|c|}
\hline Locality. & Geologic age. & Uses. & SiO.2 & $\mathrm{Al}_{2} \mathrm{O}_{3}$ & $\mathrm{Fe}_{2} \mathrm{O}_{3}$ & $\mathrm{CaO}$ & $\mathrm{MgO}$. & $\mathrm{K}_{2} \mathrm{O}$ & $\mathrm{Na}_{2} \mathrm{O}$. & $\begin{array}{l}\text { Mois- } \\
\text { ture. }\end{array}$ & $\mathrm{H}_{2} \mathrm{O}$. & $\mid \begin{array}{c}\text { Mis- } \\
\text { cella- } \\
\text { neous. }\end{array}$ & $\begin{array}{l}\text { Refer- } \\
\text { ence. } a\end{array}$ \\
\hline $\begin{array}{l}\text { Ejm Point, } \\
\text { Long Island. }\end{array}$ & Cretaceous & $\begin{array}{l}\text { Terra cotta } \\
\text { stoneware. }\end{array}$ & 76.50 & 15.17 & a 1.34 & .59 & .11 & .127 & .81 & .12 & 4.27 & $b .07$ & 818 \\
\hline $\begin{array}{l}\text { Glencove (Mrs. } \\
\text { McKenzie). }\end{array}$ & ...do & Stoneware.. & 55.30 & 29.90 & 1.10 & Trace. & .65 & \multicolumn{2}{|c|}{2.50} & & 9.75 & & 820 \\
\hline $\begin{array}{l}\text { Glencove (Car- } \\
\text { penter's pit). }\end{array}$ & ..do & ...do & 70.45 & 21.74 & 1. 72 & .24 & .30 & \multicolumn{2}{|c|}{5.00} & & & & 820 \\
\hline $\begin{array}{l}\text { White clay, Lit- } \\
\text { tleNeck, near } \\
\text { Northport. }\end{array}$ & ...do & .....do. & 68.34 & 19.89 & a. 90 & .35 & Trace. & 3.55 & .84 & & 6.03 & & 821 \\
\hline $\begin{array}{l}\text { Black clay, } \\
\text { same locality. }\end{array}$ & .....do & ....do. & .58 .84 & 23.40 & $a 1.18$ & & & 5.04 & .34 & & 9.20 & $c 1.03$ & 821 \\
\hline $\begin{array}{l}\text { White clay, Sea } \\
\text { Cliff. }\end{array}$ & $d$ & $\mathrm{de}$ & 62.35 & 23.14 & $a 1.12$ & & & 3.17 & 1. 76 & & 6.77 & $c 1.09$ & 821 \\
\hline $\begin{array}{r}\text { Kreischerville } \\
\text { (white clay). }\end{array}$ & ..... do. & Firebrick... & 47.40 & 39.01 & .15 & Trace. & Trace. & Trace. & Trace. & & 14.10 & & 789 \\
\hline $\begin{array}{l}\text { East Williston, } \\
\text { Long Island. }\end{array}$ & Pleistocene & $\begin{array}{c}\text { C omm on on } \\
\text { brisck. }\end{array}$ & 69.73 & 16.42 & 2.58 & 1.66 & .69 & & 27 & & & & 733 \\
\hline $\begin{array}{l}\text { West Neck, } \\
\text { Long Island. }\end{array}$ & (?) & .....do........ & 61. 11 & 19.23 & 5.43 & .96 & 1.88 & & 60 & & & & 735 \\
\hline Fishers Island.. & (?) & .... do ........ & 53.77 & 20.49 & 9.23 & 2.04 & 4.22 & & 60 & & & & 738 \\
\hline Farmingdale... & (?) & ..... do ........ & 62.39 & 23.60 & 3.39 & .70 & .10 & & 89 & & & & 739 \\
\hline Wyandance.... & . (?) & $\begin{array}{l}\text { Pressed } \\
\text { briek. }\end{array}$ & 60.20 & 23.07 & 1.45 & 1.20 & Trace & & 05 & 10. & 10 & & 742 \\
\hline
\end{tabular}

These clays show as wide a variation physically as well as chemically, varying from easily fusible brick clays to semirefractory or even highly refractory ones. The physical characters of a few samples are summarized below. ${ }^{a}$

Physical tests of Long Island and Staten Island clays.

\begin{tabular}{|c|c|c|c|c|c|c|c|c|c|}
\hline No. & $\begin{array}{c}\text { Amount } \\
\text { of water } \\
\text { required } \\
\text { to work } \\
\text { up. }\end{array}$ & Plasticity. & $\begin{array}{c}\text { Tensile } \\
\text { strength. }\end{array}$ & $\begin{array}{l}\text { Air } \\
\text { shrink- } \\
\text { age. }\end{array}$ & $\begin{array}{c}\text { Fire } \\
\text { shrink- } \\
\text { age. }\end{array}$ & $\begin{array}{l}\text { Incipient } \\
\text { fusion. }\end{array}$ & $\begin{array}{l}\text { Vitrifica- } \\
\text { tion. }\end{array}$ & Viscosity. & $\begin{array}{l}\text { Color when } \\
\text { burned. }\end{array}$ \\
\hline & Per cent. & & Lbs.per sq.in. & Per cent. & Per cent. & Cone. & & & \\
\hline $1 \ldots \ldots \ldots$ & 34.7 & Fair... & $20-25$ & 6 & 8 & .05 & 1 & 4 & Red. \\
\hline $2 \ldots$ & 28 & Good... & $30-40$ & 8 & 7 & .04 & 1 & 5 & Do. \\
\hline $3 \ldots$ & 31 & Fair.... & $50-60$ & 5 & 9 & .03 & 2 & 5 & Do. \\
\hline $4 \ldots$ & 33 & ..... do & $40-50$ & 6 & 10 & .04 & 1 & 5 & Do. \\
\hline 5. & 32.40 & ..... do & $22-50$ & 8 & 5 & 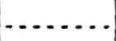 & 8 & 27 & Buff. \\
\hline $6 \ldots$ & 25 & .....do. & $25-30$ & 5.5 & 6.5 & 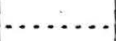 & 7 & 27 & Do. \\
\hline$\cdots$ & 38 & .....do. & 11-14 & 10 & 8.7 & 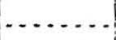 & $\ldots$ & $35+$ & White. \\
\hline 8. & 31 & ..... do & 20 & 6.5 & 8.5 & .09 & 9 & $34+$ & Buff. \\
\hline
\end{tabular}

1. Upper clay, Meyer's brickyard, 2 miles north of Farmingdale, Long Island. 2. Lower clay, same locality. 
3. Top sandy clay, Garden City Brick Company, Farmingdale, Long Island.

4. Mixture of middle and bottom clay, same locality.

5. Stoneware clay, Mrs. H. McKenzie's property, on north side of Mosquito Inlet at Glen cove, Long Island.

6. Yellow stoneware clay, Sammis pits, Little Neck, near Northport, Long Island.

7. White Cretaceous clay, Kreischerville, Staten Island.

8. Buff fire clay, Kreischerville, Staten Island.

\section{PLEISTOCENE CLAYS.}

They are divisible into four groups, viz, (1) morainal clays; (2) lacustrine clays, (3) local deposits formed in lakes; (4) estuary deposits.

The terminal moraine of the Glacial epoch crosse's New York State in an irregular line, forming a series of irregular, hummocky hills, which often contain considerable clay. In most cases, however, the clay is either too stony or too sandy to be of economic value. In places, as at Newfield and other points in Tompkins County, these clays are comparatively free from stones, and can be worked for brickmaking. They are rather calcareous.

The lacustrine clays were laid down during post-Glacial time, when the waters of Lakes Erie and Ontario were dammed up to the north by the retreating continental glacier, and spread over the land in the western and northwestern part of the State, much clay being deposited during this time. These clays underlie the flats around Buffalo, Lancaster, Tonawanda, and other places in the northwestern portion of the State, and are used locally for brickmaking. They often contain lime pebbles and concretions, although the clays themselves are not very calcareous.

The lake deposits represent the most widely distributed source of brick clays found in New York State, since they occur in many of the flat-bottomed valleys, which have been filled up by fine clayey sediment deposited in local lakes. They may be calcareous, often contain beds of sand, and are of variable depth, being commonly underlain by hardpan. The extremes of depth are shown by the two following sections:

Section of Pleistocene clay at Rochester.

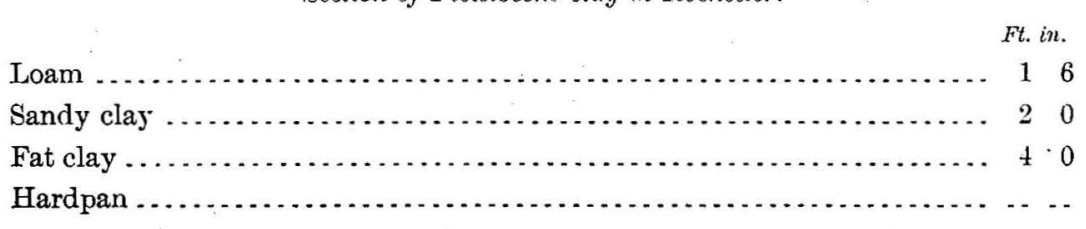


Section of Pleistocene clay at Jamestown.

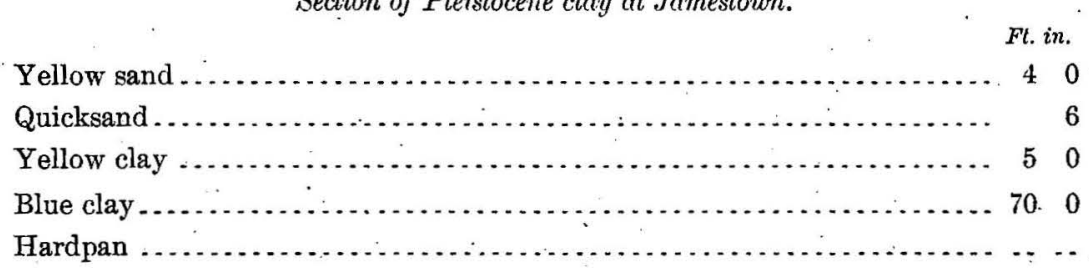

Most of these lake clays burn red and are used for common brick and fireproofing, though pressed brick and drain tile are sometimes made. Their areal extent may also vary. They are worked at a number of points, among which may be mentioned Rochester, Syracuse, Rome, Jamestown, Utica, Binghamton, Elmira, etc.

The estuarine clays are confined to the valleys of the Hudson River and Lake Champlain, and were formed during post-Glacial time, when the lind stood at a lower level. There was then deposited a great mass of impure clays. Subsequent to this the land was elevated and still later these beds were cut down by streams, so that the remnants now form terraces along the sides of the valley. The deposits are of variable thickness, due to the irregular surface of the underlying bed rock and glacial drift. The section involves three members, viz, an upper sand, a yellow clay, and a blue clay. The clay bed is made of many thin layers separated by very thin laminæ of sand, and the deposit often shows a thickness of not less than 60 feet and in some instances over 200 feet. (Pl. VI:) The clays are easily fusible, redburning materials, very constant in character from place to place. The physical test of one from Roseton illustrates well the physical nature.

Tests of clay from Roseton, $N . Y$.

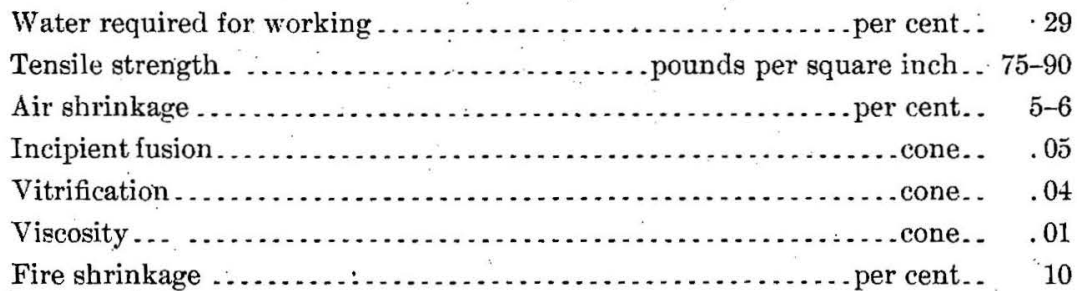

Though abundant in both the Hudson and Champlain valleys, those in the former are more extensively worked, but it is unfortunate that with the abundance and location of this material it is not adapted to the manufacture of other grades of product than common brick, drain tile, and common red earthenware. One exception is the deposit at Glens Falls, which is employed for terra cotta. 


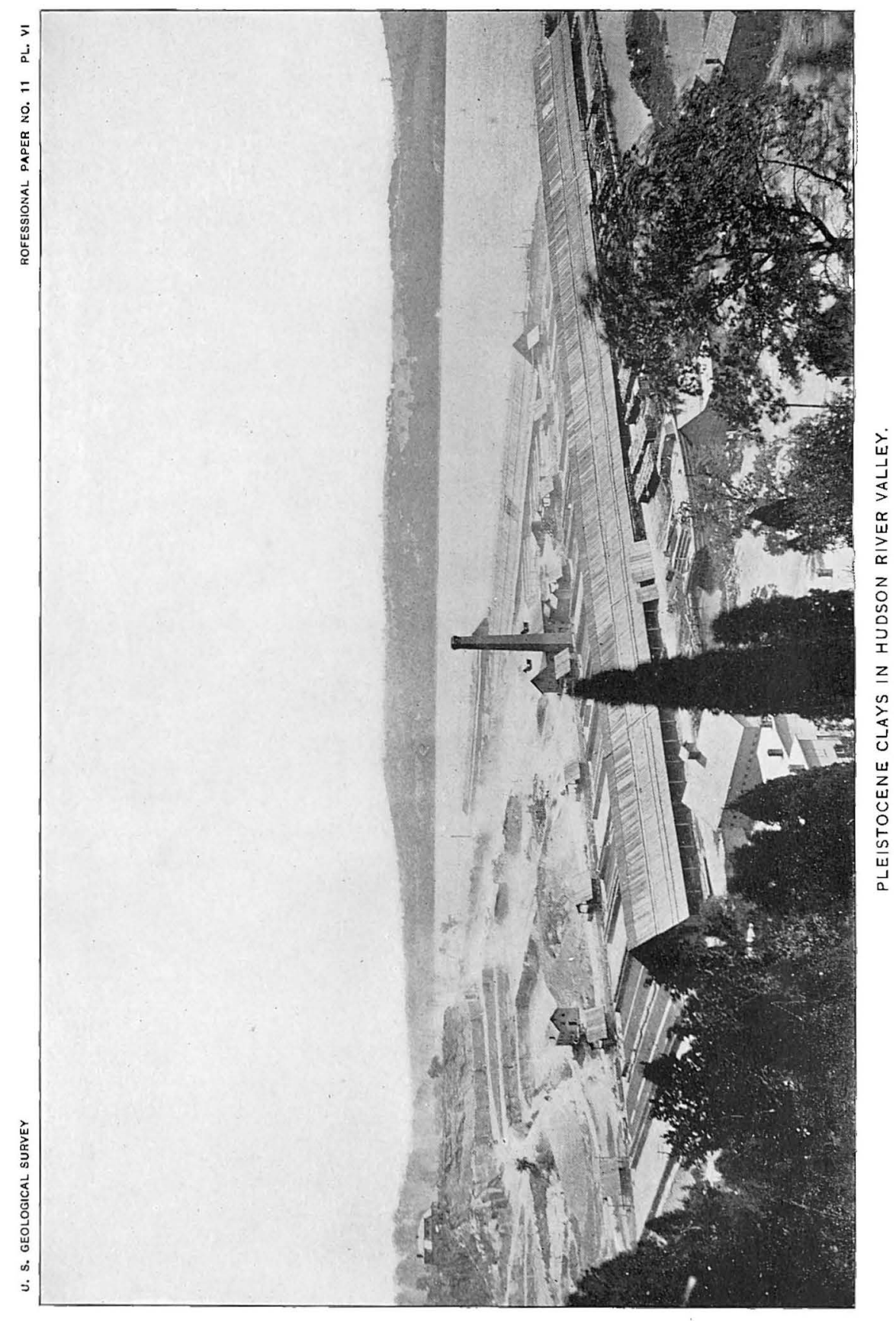



Analyses of Pleistocene or surface clays from New York State.

\begin{tabular}{|c|c|c|c|c|c|c|c|c|c|c|c|c|}
\hline Locality. & Origin. & Uses. & $\mathrm{SiO}_{2}$. & $\mathrm{Al}_{2} \mathrm{O}_{3}$. & $\mathrm{Fe}_{2} \mathrm{O}_{3}$. & $\mathrm{CaO}$. & $\mathrm{MgO}$ & $\mathrm{K}_{2} \mathrm{O} . \mathrm{Na} \mathrm{O}$ & $\mathrm{H}_{2} \mathrm{O}$. & $\begin{array}{l}\text { Mois- } \\
\text { ture. }\end{array}$ & $\begin{array}{c}\text { Mis- } \\
\text { cella- } \\
\text { ne- } \\
\text { ous. }\end{array}$ & $\begin{array}{l}\text { Refer } \\
\text { ence. }\end{array}$ \\
\hline Southold. & Drift clay..... & Common brick. & 59.05 & 22.11 & 6.54 & 2.19 & 2.64 & 6.22 & & & & 737 \\
\hline Roseton ........ & Estuary clay.. & .....do.................... & 55.00 & & 1.54 & 5.33 & 3.43 & .48 & & 22 & & 890 \\
\hline Rondout ....... & .... do......... & .....do................. & 57.80 & & .600 & 4.85 & 2.07 & & 12.68 & & & 699 \\
\hline Plattsburg... & .....do... & .....do................... & 65.14 & 13.38 & 7.65 & 2.18 & 2.36 & 8.51 & & & & 710 \\
\hline Newfield ...... & Drift... & $\begin{array}{l}\text { Common and pav- } \\
\text { ing brick. }\end{array}$ & 51.30 & 12.21 & 3.32 & 11.63 & 4.73 & 4. 33 & & & $b 1.50$ & 728 \\
\hline Rochester & & $\begin{array}{l}\text { Common brick and } \\
\text { fireproofing. }\end{array}$ & 50.55 & 15.46 & 4.38 & 10.95 & 3.35 & 6.3 & & & & 720 \\
\hline Buffalo... & $\begin{array}{l}\text { Lacustrine } \\
\text { clay. }\end{array}$ & Common brick..... & 57.36 & 16.20 & 4.55 & 5.34 & 3.90 & $\begin{array}{l}6.98 \\
\cdot\end{array}$ & & & & 723 \\
\hline Canandaigua.. & Upper clay ... & Pressed brick & 62.23 & 16.01 & 6.96 & 1.24 & 2.21 & 5.08 & 5.30 & & & 719 \\
\hline Watertown .... & ................... & Common brick..... & 64.39 & 14.40 & 5.00 & 3.60 & 1.31 & 4. 66 & $c 6.64$ & & & 711 \\
\hline Ogdensburg ... & Lake ......... & ...................... & 49.2 & 17.47 & 6.23 & 7.86 & 4.87 & 9.82 & & & $\cdots .$. & 712 \\
\hline Glens Falls .... & Estuarine..... & $\begin{array}{l}\text { Pressed brick and } \\
\text { terra cotta. }\end{array}$ & 4835 & 11.33 & 4.02 & 15.38 & 3.17 & 6.05 & & & $b 1.18$ & 760 \\
\hline & ..... do & ....do.......... & 57.46 & 21.15 & 5.52 & 3.65 & 1.5 & 4. 72 & & & & 760 \\
\hline Croton Point .. & Blue clay.... & Common brick.... & 51.61 & 19.2 & 8.19 & 7.6 & 1.25 & 5.32 & $d 7,25$ & & & 890 \\
\hline Do......... & Yellow clay .. & .....do................ & 56.75 & 20.15 & 8.82 & 3.14 & 1.20 & 4.5 & $d 5.52$ & & .. & 892 \\
\hline East Kingston. & Estuarine .... & .....do................ & 55.45 & 18.91 & 7. 39 & 5.40 & 3. 39 & & 7.80 & 5.58 & e. 74 & 892 \\
\hline
\end{tabular}

$a$ Figures given are pages f $\lrcorner$ r reference in Bull. New York State Mruseum No. 35.

$b$ Organic matter.

$c$ And organic.

$d \mathrm{CO}_{2}$

$e \mathrm{SO}_{3}$.

THE CLAY-WORKING INDUSTRY.

The rank of New York State among those making clay products is due rather to her location with respect to the Eastern markets than to the occurrence of proper raw materials within her boundaries.

The following table gives the total value of New York clay products during the last eight years:

Value of clay products of New York from 1894 to 1901.

\begin{tabular}{|c|c|c|c|}
\hline . Year. & Rank. & Total value. & $\begin{array}{l}\text { Proportion } \\
\text { United } \\
\text { States } \\
\text { product. }\end{array}$ \\
\hline & & & Per cent. \\
\hline $1894 \ldots \ldots \ldots \ldots$ & 4 & $\$ 5,164,022$ & 8.00 \\
\hline $1895 \ldots . . . \ldots .$. & 4 & $5,889,496$ & 9.02 \\
\hline $1896 \ldots \ldots \ldots$ & 3 & $6,414,206$ & 10.29 \\
\hline $1897 \ldots \ldots \ldots .$. & 4 & $5,615,504$ & 9.91 \\
\hline $1898 \ldots \ldots \ldots$ & 5 & $6,448,989$ & 9.01 \\
\hline $1899, \ldots \ldots \ldots \ldots \ldots$ & 4 & $8,076,412$ & 8.43 \\
\hline $1900 \ldots \ldots \ldots \ldots \ldots \ldots$ & 5 & $7,660,606$ & 7. 96 \\
\hline $1901 \ldots \ldots \ldots$ & 5 & $8,291,718$ & 7.52 \\
\hline
\end{tabular}

$9647-$ No. $11-03--12$ 
The clay products manufactured within the State include common brick, paving brick, front brick, fireproofing, drain tile, sewer pipe, fire brick, stove linings, terra cotta, red earthenware, white earthenware, stoneware, and porcelain.

The first five of these are, except at few places, made entirely from clays dug within the State. The rest, with the exception of red earthenware, are molded almost entirely from clays brought in from neighhoring States.

The value of the different grades of clay products made in New York in 1900 and 1901 was as follows:

Value of clay products of New York in 1900 and 1901.

\begin{tabular}{|c|c|c|}
\hline$"$ & 1900 & 1901. \\
\hline 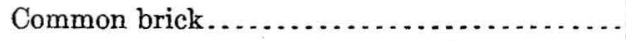 & $\$ 4,266,715$ & $\$ 4,947,599$ \\
\hline Front brick. . . . . . . . . . . . . & 249,078 & 254,696 \\
\hline Vitrified brick .............. & 347,671 & 343,343 \\
\hline Fancy or ornamental brick .... & (a) & (a) \\
\hline Fire brick ..................... & 360,933 & 293,944 \\
\hline Stove linings. ......... & 93,188 & 115,054 \\
\hline Drain tile........................ & 89,019 & 73,554 \\
\hline Sewer pipe ............. & 94,293 & 96,770 \\
\hline Terra cotta $\ldots . . . .$. & 676,408 & 754,911 \\
\hline Fireproofing ............... & 93,994 & 98,947 \\
\hline Tile, not drain . . . . . . . . . . . & 105,519 & 140,890 \\
\hline Red earthenware $. . . \ldots \ldots \ldots . . . . . . . . .$. & 25,207 & 27,472 \\
\hline Stoneware ...................... & 37,008 & 48,596 \\
\hline C. C. ware $\ldots \ldots \ldots$ & $(a)$ & $(a)$ \\
\hline 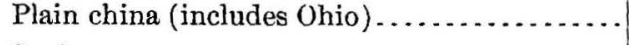 & 395,774 & 242,868 \\
\hline 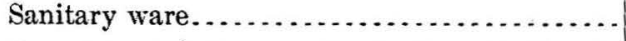 & (a) & (a) \\
\hline Porcelain electrical supplies (includes Indiana) - & 382,832 & 810,214 \\
\hline 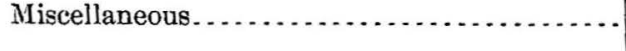 & 107,136 & 94,532 \\
\hline Total clay products. - & $7,660,606$ & $8,291,718$ \\
\hline
\end{tabular}

a Less than three producers.

Common brick are made from the Pleistocene clays, the Hudson Valley being one of the greatest brickmaking regions of the United States and well located for the New York market, but active competition and large output keeps the price of brick lower than in most regions. Other groups of brick plants using surface clays are to be found near the larger cities, as Rochester, Sy racuse, and Buffalo. While a number

of common-brick yards are located on Long Island, still the manufacturer in this region has to contend with heavy stripping, but here the product goes mostly to New England and commands a higher price. In recent years the Devonian shales of southern New York have been utilized with much success for common-brick manufacture. Pressed brick are made in small quantities on Long Island, Staten Island, and at Canandaigua. Paving brick are made at several localities from a wide 
variety of materials. Thus at Catskill from clay and Devonian shales; at Syracuse from surface clays; at Newfield from calcareous morainal clays, and at Hornellsville, Corning, and Jamestown from Devonian shales. The product in many cases stands the usual tests well.

'There are several terra-cotta works in New York, but the largest draws nearly all of its clays from New Jersey. Local clays are employed at Glens Falls and shales at Corning, while similar material is also used at Alfred Center for making red roofing tile.

For the manufacture of higher grades of ware, such as white earthenware, porcelain, and refractory goods, the factories around New York City obtain their clays from other States. There are a few potteries and refractory-ware factories scattered over other parts of the State (Pls. VIII and IX). Porcelain electrical goods are made at Syracuse, Victor, and Brooklyn.

\section{NORTH CAROLINA.}

The clay deposits of North Carolina are of two types, (1) residual clays and (2) sedimentary clays.

\section{RESIDUAL CLAYS.}

These may occur in any portion of the State west of the Coastal Plain region, especially that part underlain by granitic, gneissic, or schistose rocks. The eastern border of this area passes through Halifax, Franklin, Wake, Chatham, Moore, Richmond, and Anson (see Pl. VII). West of a line passing through Weldon, Raleigh, and Rockingham, the thickness of the clay beds varies from 2 feet to 20 or more, depending on the slope and character of the rocks. These clays are usually impure, gritty, and suited for little else than the manufacture of common brick. In rarer instances, as at Pomona and Grover, they may be semirefractory in their character.

$$
\text { KAOLINS. }
$$

In western North Carolina, in the Smoky Mountain region, there are many veins of pegmatite carrying coarsely crystalling quartz, feldspar, and mica (generally muscovite), with some garnet. These are usually decomposed to a depth of 60 to 100 feet, or sometimes more, yielding a mass of kaolin which, when washed, is of much value for the manufacture of white earthenware. These veins vary in width from a few inches to several hundred feet, and may be many hundred feet long, running sometimes parallel with the foliation of the metamorphic rocks in which they occur, at other times cutting across the strike. They may also branch or curve.

The most important of these deposits is near Webster, where a vein, which in places is 300 feet thick, has been worked for a number of years. This vein is split 
in two parts by a large horse of quartz. The analysis and physical characters are given in the table below.

In addition to this deposit there are others known-and in some cases workedat Sylva, Jackson County; Bosticks Mills, Richmond County; Troy, Montgomery County; and Wests Mills, Macon County. Others, according to Dr. J. H. Pratt, are located 2 miles a little west of north of Bryson City, Swain County; another between this and Bryson City and 1 mile from the town; also 2 miles south of Hall station, Jackson County; and $2 \frac{1}{2}$ miles southwest at Canton, Haywood County.

The chemical and physical properties of a number of residual clays from North Carolina are given herewith.

Chemical analyses of residual clays of North Carolina. a

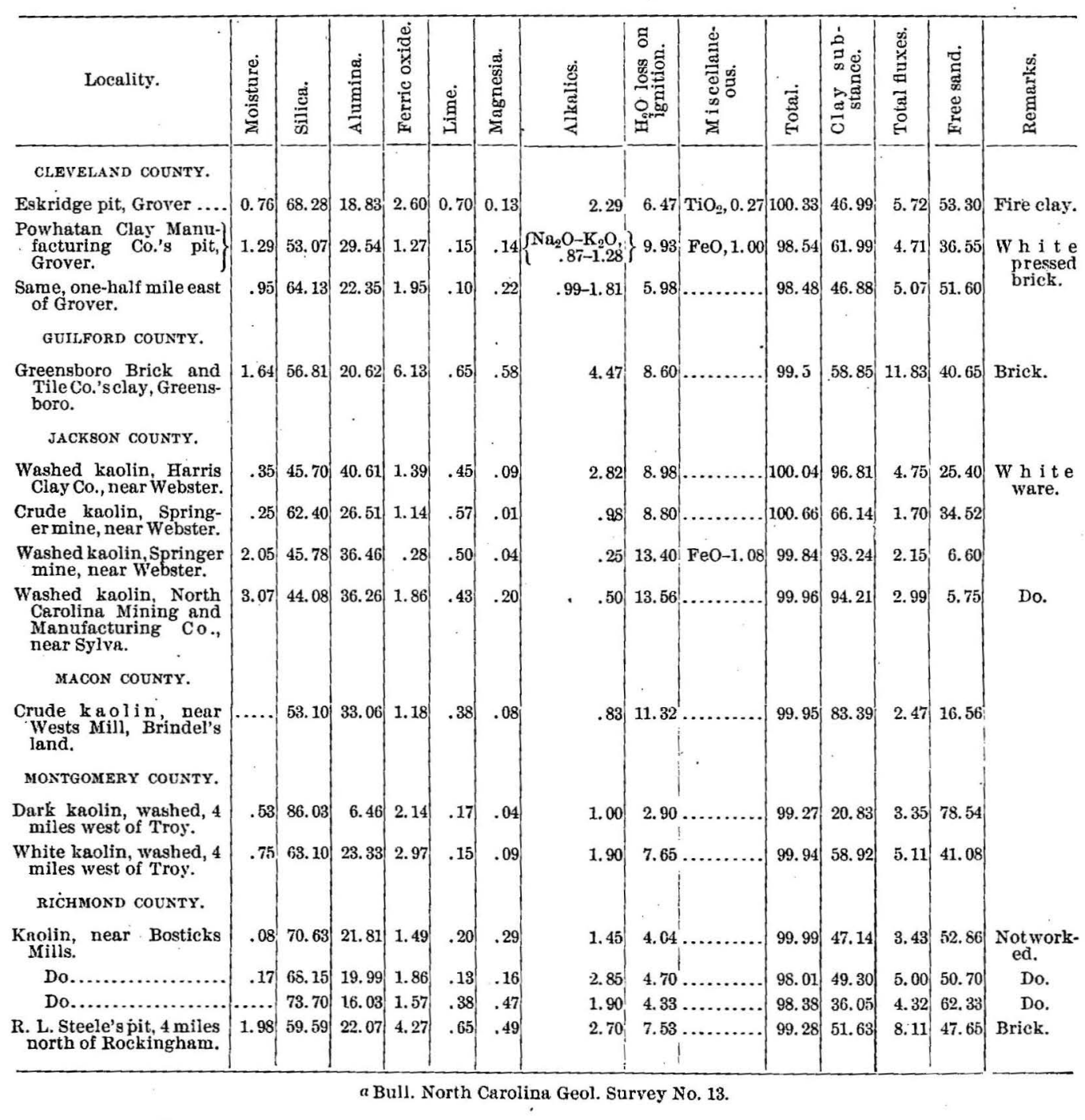






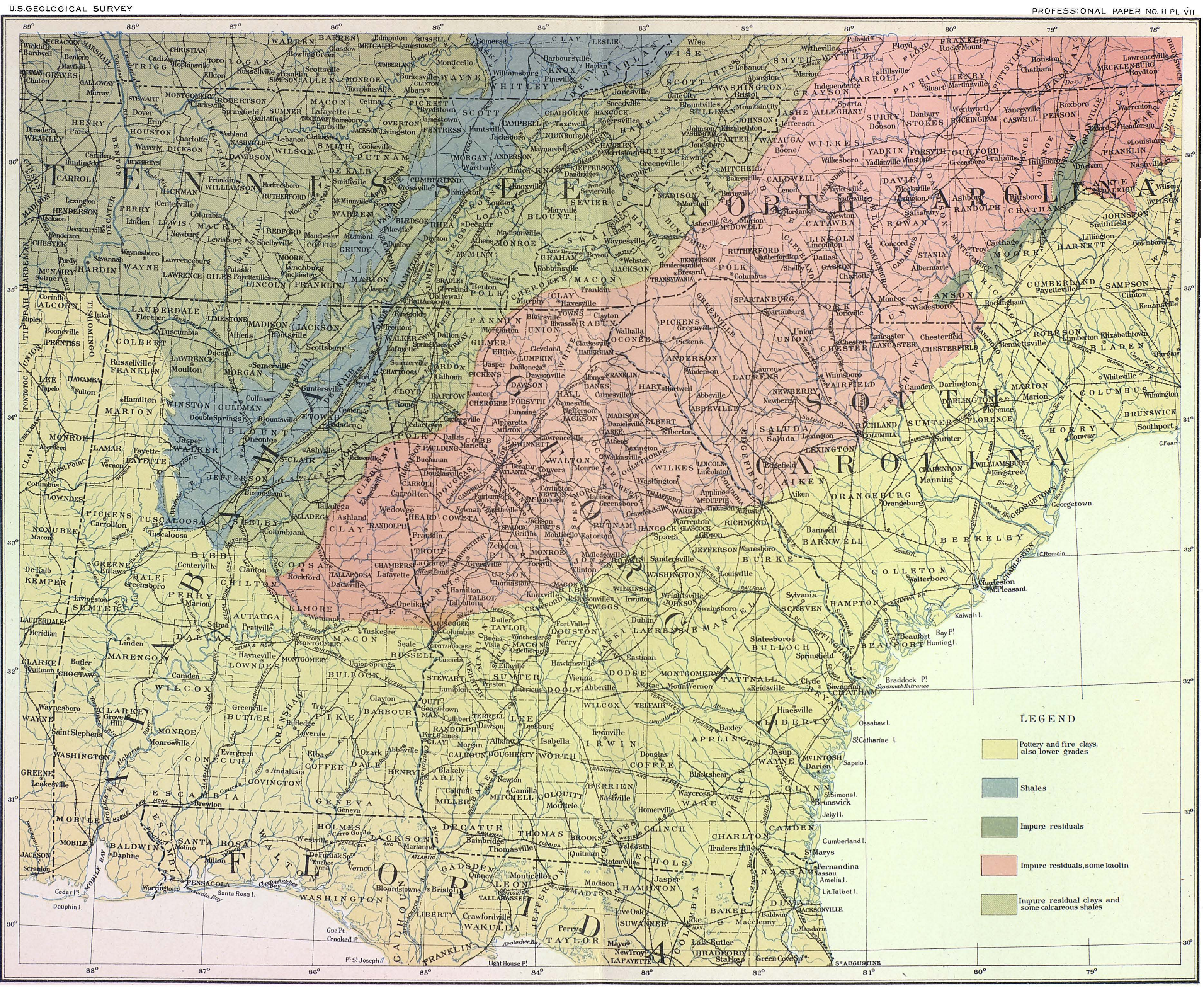

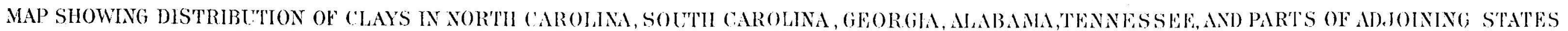



Physical tests of residual clays from North Carolina.

\begin{tabular}{|c|c|c|c|c|c|c|c|c|c|c|c|c|c|c|c|}
\hline Locality. & 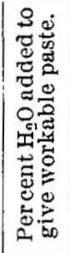 & 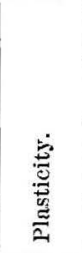 & 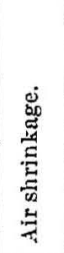 & 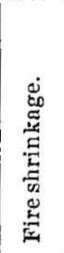 & 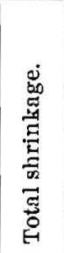 & 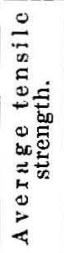 & 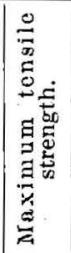 & 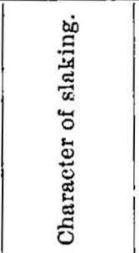 & 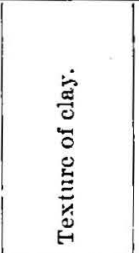 & 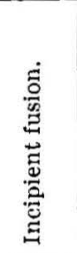 & 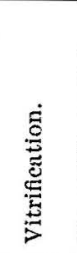 & 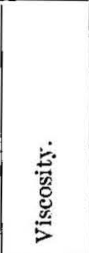 & 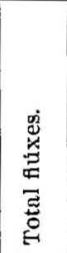 & 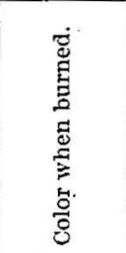 & 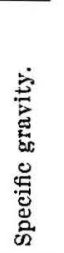 \\
\hline CLEVELAND COUNTY. & & & $\begin{array}{l}\text { Per } \\
\text { cent. }\end{array}$ & $\begin{array}{l}\text { Per } \\
\text { cent. }\end{array}$ & $\begin{array}{l}\text { Per } \\
\text { cent. }\end{array}$ & $\begin{array}{l}\text { Lbs. } \\
\text { per } \\
s q \text { in. }\end{array}$ & $\mid \begin{array}{c}L b s . \\
\text { per } \\
s y \text { in }\end{array}$ & & & ${ }^{\circ} F$. & ${ }^{\circ} F$. & ${ }^{\circ} \mathrm{F}$. & & & \\
\hline Eskridge pit, Grover .. & 32 & Lean. & 10.6 & 6 & 16.6 & 38 & 42 & Slow...... & $\begin{array}{c}\text { Coarse to } \\
\text { fine. }\end{array}$ & 2,100 & 2,300 & 2,500 & 5. 72 & $\begin{array}{l}\text { White to } \\
\text { red. }\end{array}$ & 2.57 \\
\hline $\begin{array}{l}\text { Powhatan Clay Manufacturing Co. pit, southwest of Grover. } \\
\text { Same, one-half mile east of Grover............................. }\end{array}$ & 28 & $\begin{array}{l}\text { Good. } \\
\text { Lean. }\end{array}$ & $\begin{array}{l}8 \\
4\end{array}$ & $\begin{array}{l}5 \\
4.5\end{array}$ & $\begin{array}{l}13 \\
8.5\end{array}$ & $\begin{array}{l}39 \\
31\end{array}$ & $\begin{array}{l}45 \\
35\end{array}$ & $\mid \begin{array}{cc}0 . \text { do } \\
\text { Verv slow }\end{array}$ & $\begin{array}{l}\text { Fine....... } \\
\text { Coarse .... }\end{array}$ & $\begin{array}{l}2,100 \\
2,150\end{array}$ & $\begin{array}{l}2,300 \\
2,350\end{array}$ & $\begin{array}{l}2,500 \\
2,550\end{array}$ & 4.71 & Whitish .. & 2.24 \\
\hline JACKSON COUNTY. & & & & & & & & & & & & & & & \\
\hline Washed knolin, Harris Clay Có., near Webs & 42 & Lean . & 6 & 4 & 10 & 20 & 22 & Slow. & Very fine. & 2,300 & 2,500 & $2,700+$ & 4.75 & White.. & 2.43 \\
\hline Crude kaolin, Springer mine, & 32 & ...do.. & 2 & $t$ & 6 & 6 & 7 & Fast .. & $\begin{array}{l}\text { Coarse to } \\
\text { fine. }\end{array}$ & 2,300 & 2,500 & $2,700+$ & 2.7 & .....do .... & 2.58 \\
\hline Washed krolin, Springer mine, near V & 38 & ....do . & 8 & 4.5 & 12.5 & 23 & 24 & Slow...... & Very fine. & 2,350 & 2,550 & $2,700+$ & 2.15 & ....do ...... & 2.27 \\
\hline $\begin{array}{l}\text { Washed kaolin, North Carolina Mining and Manufactur- } \\
\text { ing Co., near Sylva. } \\
\qquad \text { MACON Covstr. }\end{array}$ & 40 & ...do.. & 8 & 4 & 12 & 15 & & .... do ..... & ....do ...... & 2,200 & 2,450 & $2,700+$ & 2.99 & .....do ...... & 2.31 \\
\hline $\begin{array}{l}\text { Crude kaolin, near Wests Mill, Brindel's laLd ..... } \\
\text { MONTgoMery Cousty. }\end{array}$ & 31 & Lean. & 6 & 6 & 12 & 15 & 18 & Slow..... & Very fine. & 2,300 & 2,600 & $2,700+$ & 2.47 & White .... & 2.31 \\
\hline $\begin{array}{l}\text { Dark kaolin, washed, } 4 \text { miles west of Troy .... } \\
\text { Crude white kaolin, } 4 \text { miles west of Troy ..... }\end{array}$ & $\begin{array}{l}30 \\
28\end{array}$ & $\begin{array}{l}\text { Lean } \\
\ldots \text { do } .\end{array}$ & $\begin{array}{l}3 \\
3 \\
3\end{array}$ & $\begin{array}{r}10 \\
9\end{array}$ & $\begin{array}{l}13 \\
12\end{array}$ & $\begin{array}{r}9 \\
10\end{array}$ & $\begin{array}{l}12 \\
12\end{array}$ & 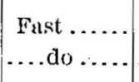 & Fine $\ldots . . .$. & $\begin{array}{l}2,100 \\
2,100\end{array}$ & $\begin{array}{l}2,300 \\
2,300\end{array}$ & $\begin{array}{l}2,500 \\
2,500\end{array}$ & $\begin{array}{l}3.35 \\
5.11\end{array}$ & $\begin{array}{l}\text { Pale buff . } \\
\text { Yellowish }\end{array}$ & $\begin{array}{l}2.32 \\
2.34\end{array}$ \\
\hline $\begin{array}{l}\text { White kaolin, washed, } 4 \text { miles west of Troy...... } \\
\text { RICHMOND countr. }\end{array}$ & 31 & ...do . & 3 & 6 & 9 & 11 & 14 & ..do & ....do .... & 2,100 & 2,300 & 2,550 & & ....do ....... & \\
\hline Kaolin, near Bostwicks Mills.. & 27.7 & Lean . & 4 & 9 & 13 & 10 & 14 & Slow & Fine.... & 2,250 & 2,500 & $2,700+$ & 3.43 & $\begin{array}{c}\text { Yellowish } \\
\text { white. }\end{array}$ & 2.41 \\
\hline 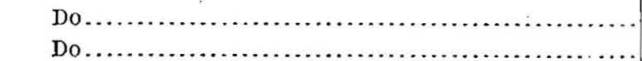 & \begin{tabular}{|l|}
26 \\
27.7
\end{tabular} & $\begin{array}{l}\text {...do... } \\
\text {...do... }\end{array}$ & $\begin{array}{l}3.5 \\
4\end{array}$ & $\begin{array}{l}8 \\
8\end{array}$ & $\begin{array}{l}11.5 \\
12\end{array}$ & $\begin{array}{l}13 \\
15\end{array}$ & $\begin{array}{l}16 \\
16\end{array}$ & $\begin{array}{ll}\text {....do } . . \\
\text {....do... }\end{array}$ & ....do .... & $\begin{array}{l}2,300 \\
2,250\end{array}$ & 2,500 & $2,700+$ & 5 & ....do ...... & 2.52 \\
\hline Washed kaolin, near Bostwicks Mills... & 26 & ....do... & 3 & 9 & 12 & 10 & 12 & .... do... & .... do ... & $\begin{array}{l}2,200 \\
2,250\end{array}$ & $\begin{array}{l}2,400 \\
2,450\end{array}$ & $\begin{array}{l}2,100+ \\
2,700+\end{array}$ & 4.32 & Y...do.... & 2.45 \\
\hline Do. & 29 & ...do .. & 4 & 7 & 11 & 8 & 11 & .....do . & ....do ...... & 2,250 & 2,450 & $2,700+$ & & Light yel- & . \\
\hline R. S. Steele, 4 miles north of Rockingliam. & 26 & Good. & 6 & 8 & 14 & 133 & 154 & .... do ... & Medium.. & 2,000 & 2,200 & 2,400 & 8.11 & Red ....... & 2.54 \\
\hline
\end{tabular}


SEDIMENTARY CLAYS.

These are very extensive, being found throughout the Coastal Plain area and in the broader upland valleys of the State. In the former region there are found many extensive beds of laminated clay, which are often well exposed in the river bank traversing that region. Along the Cape Fear River, 50 miles below Fayetteville, there are extensive beds of dark-colored clays, which burn red, but in places have much pyrite. . On the western border of the Coastal Plain, especially in Moore and Harnett counties, there are occasional exposures of clays of Eocene age which range in thickness from 5 to 15 feet. $^{a}$. The Miocene deposits may carry beds of a calcareous blue clay, such as are seen along the bluffs on the Roanoke and Tar rivers. The Lafayette formation, though a common surface deposit in the Coastal Plain region, commonly contains much gravel and sand and but little clay.

Most of the clay deposits found in the Coastal Plain area of North Carolina are rather lenticular in their character and hence lack great horizontal dimensions, passing within a short distance into beds of sand, not only vertically but also horizontally. The best deposits of sedimentary clay thus far developed in the State are those found in the valley bottoms, as around Fayetteville, Goldsboro, Weldon, Greensboro, etc. These are sediments which often show considerable plasticity.

In many valleys of the uplands the rivers are bordered by terraces of Columbia age. These clays are sometimes gritty and adapted to brickmaking; at other times are very plastic, free from grit, and suited to pottery manufacture. Terrace clays are abundant along the Catawba River near Morgantown and Mount Holly, on the Clarks River at Lincolnton, along the French Broad River at Asheville, and at Wilkesboro on the Yadkin River. The depth of these terrace clays commonly ranges from 5 to 10 feet, and they are in most instances covered by from 6 inches to a foot or more of sand or loam.

The Triassic shales form a narrow belt in Granville, Durham, Chatham, Moore, southeastern Montgomery, and Anson counties, but their value for making clay products is said to have been but little tested. At Pomona a weathered shale outcrop has been used in the manufacture of sewer pipe. Shales are also associated with the coal beds, but no information is available concerning them.

The following tables contain the physical tests and chemica analyses of a number of North Carolina sedimentary clays:

$a$ Holmes, J. A., The kaolin and clay deposits of North Carolina: Trans. Am. Inst. Min. Eng., Vol. XXV, p. 929. 
Chemical analyses of sedimentary clays of North Carolina.

\begin{tabular}{|c|c|c|c|c|c|c|c|c|c|c|c|c|c|c|}
\hline Locality. & $\begin{array}{l}\text { Moís- } \\
\text { ture. }\end{array}$ & Silica. & $\begin{array}{c}\text { Alu- } \\
\text { mina. }\end{array}$ & $\begin{array}{c}\text { Ferric } \\
\text { oxide. }\end{array}$ & Lime. & $\underset{\text { sia. }}{\operatorname{Magne}}$ & Alkalis. ${ }^{1}$ & $\mid \begin{array}{c}\mathrm{H}_{2} \mathrm{O} \\
\mathrm{Loss} \text { on } \\
\text { igni- } \\
\text { tion. }\end{array}$ & $\mid \begin{array}{c}\text { Miscel- } \\
\text { lane- } \\
\text { ous. }\end{array}$ & Total. & $\begin{array}{c}\text { Clay } \\
\text { sub- } \\
\text { stance. }\end{array} \mid$ & $\begin{array}{c}\text { Total } \\
\text { fluxes. }\end{array}$ & \begin{tabular}{c|c} 
Free \\
sand.
\end{tabular} & Remarks. \\
\hline BLADEN COUNTY. & \multirow{5}{*}{$\begin{array}{l}4.50 \\
2.80 \\
4.26\end{array}$} & \multirow[b]{2}{*}{56.13} & \multirow[b]{2}{*}{17.80} & \multirow[b]{2}{*}{5.85} & \multirow[b]{2}{*}{0.10} & \multirow[b]{2}{*}{0.79} & \multirow[b]{2}{*}{2.45} & \multirow[b]{2}{*}{11.60} & & \multirow{3}{*}{99.22} & \multirow{3}{*}{ a...... } & \multirow{2}{*}{7.29} & \multirow[b]{2}{*}{27.18} & \multirow{4}{*}{$\begin{array}{l}\text { Not worked. } \\
\text { Do. }\end{array}$} \\
\hline Upper brick clay, middle of bluff, Prospect Hall & & & & & & & & & & & & & & \\
\hline Middle brick clay, bluff at Prospect Hall ............ & & 63.30 & 15.87 & 5.48 & .27 & .21 & 2.40 & 8.25 & $a 1.78$ & & & 10.14 & 57.30 & \\
\hline Bottom brick clay, bluff at Prospect Hall ......... & & 55.65 & 20.86 & 5.11 & .30 & .64 & 2.13 & 9.94 & a1.18 & 100.07 & 85.03 & 9.36 & 15.05 & \\
\hline \multicolumn{14}{|l|}{ BUNCOMBE COUNTY. } & \\
\hline Upper clay, Penniman's, Emma ....... & 1.15 & 66.27 & 19.95 & 3.16 & .20 & .32 & 1.85 & 6.17 & $b 0.67$ & 99.74 & 49.34 & 6.20 & 50.40 & Brick. \\
\hline Lower clay, Penniman's, Emma .. & .80 & 70.66 & 17.21 & 3. 44 & .10 & .07 & 2.45 & 5.00 & & 99.73 & 41.71 & 7.16 & & \\
\hline Clay, Fletcher...................................... & 1.10 & 75.08 & 13. 73 & 3.47 & .30 & .17 & 1.48 & 4.65 & & 99.98 & 45.18 & 5.42 & & \\
\hline \multicolumn{15}{|l|}{ BURKE COUNTY. } \\
\hline Pottery clay, McDowell's, Morgantown......... & 1.68 & 69.58 & 14.03 & 6.41 & .40 & .27 & 1.65 & 5.73 & & 99. 75 & 45.47 & 8. 73 & 54.28 & Not worked. \\
\hline Brick clay..$\ldots \ldots \ldots \ldots \ldots \ldots$ & 1.80 & 67.03 & 16.88 & 6.50 & 1.00 & 1.10 & .90 & 4.78 & 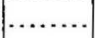 & 100.05 & 39.90 & 9.56 & 60.05 & \\
\hline \multicolumn{15}{|l|}{ CATAWBA COUNTY. } \\
\hline Pottery clay, northwest of Blackburn... & 2.08 & 50.17 & 28.77 & 2.88 & .05 & .22 & 1.04 & 14.03 & & 99.24 & 73.19 & 4.19 & 26.05 & Stoneware. \\
\hline \multicolumn{15}{|l|}{ CLEVELAND COUNTY. } \\
\hline Under elay, Cleveland Briek Co., south of Grover .... & 1.18 & 61.75 & 23.30 & 3.34 & .27 & .25 & 1.31 & 7.75 & $u .50$ & 99. 65 & 60.62 & 5.67 & 39.05 & Red brick. \\
\hline \multicolumn{15}{|l|}{ CUMBERLAND COUNTY. } \\
\hline $\begin{array}{l}\text { E. A. Poe's pit, one-half mile south of Fayetteville; } \\
\text { average clay. }\end{array}$ & 2.48 & 64.93 & 17.08 & 5.57 & .43 & .59 & 3.85 & 6.58 & & 101.51 & 53.13 & 10.44 & 45.90 & Bricks. \\
\hline $\begin{array}{l}\text { E. A. Poe's pit, one-half mile south oi Fayetteville; } \\
\text { "tough" clay. }\end{array}$ & 3.23 & 58.17 & 20.10 & 7.43 & .60 & .77 & 2.60 & 7.34 & & 100.24 & 48.09 & 11.40 & 52.15 & Not worked. \\
\hline \multicolumn{15}{|l|}{ FORSYTH COUNTY. } \\
\hline Lower clay, Bethania ................. & .90 & 64.39 & 19.11 & 5.39 & 80 & .22 & 1.72 & 7.75 & & 100.28 & $53: 18$ & 8.13 & 46.60 & Brick and tile. \\
\hline \multirow{2}{*}{\multicolumn{15}{|c|}{$\begin{array}{c}\text { Upper clay, Bethania } . . . \ldots \ldots \ldots \ldots \\
-\quad \text { GASTON CoUNTY. }\end{array}$}} \\
\hline & & & & & & & & & & & & & & \\
\hline Mount Holly, one-fourth mile south . & 1.43 & 61.28 & 20.83 & 5.51 & .49 & .14 & .84 & 8.75 & & 99.27 & 50.99 & 6.98 & 49.05 & Not worked. \\
\hline \multicolumn{15}{|l|}{ GUILFORD COUNTY. } \\
\hline Dean's clay, Greensboro................ & 1.90 & 59.27 & 22.31 & 6.69 & .25 & .13 & 90 & 9.00 & & 100.45 & 67.20 & 7.97 & 33.25 & Brick. \\
\hline Kirkpatrick's clay pit, Greensboro.............. & 1.50 & 69.70 & 12.87 & 6.13 & 2.55 & .57 & 2.79 & 4.08 & & 100.19 & 35.27 & 12.04 & 64.92 & Do. \\
\hline Fire clay, first pit, Pomona Terra Cotta Co......... & .98 & 70.45 & 17.34 & 3.16 & .25 & .22 & .70 & 6.63 & 60.33 & 100.06 & 48.26 & 4.66 & 51.501 & \\
\hline $\mathrm{aSO}_{3}$ & & & & & & & & & $b$ FeO. & & & & & \\
\hline
\end{tabular}


Chemical analyses of sedimentary clays of North Carolina-Continued.

\begin{tabular}{|c|c|c|c|c|c|c|c|c|c|c|c|c|c|c|}
\hline Locality. & $\begin{array}{l}\text { Mois- } \\
\text { ture. }\end{array}$ & Silica. & $\begin{array}{l}\text { Alu- } \\
\text { mina. }\end{array}$ & $\begin{array}{c}\text { Ferric } \\
\text { oxide. }\end{array}$ & Lime. & $\underset{\text { sia. }}{\text { Magne- }}$ & Alkalis. & $\begin{array}{c}\mathrm{H}_{2} \mathrm{O} \\
\text { Losson } \\
\text { igni- } \\
\text { tion. }\end{array}$ & $\begin{array}{c}\text { Miscel- } \\
\text { lann- } \\
\text { ous. }\end{array}$ & Total. & $\begin{array}{c}\text { Clay } \\
\text { sub- } \\
\text { stance. }\end{array}$ & $\begin{array}{l}\text { Total } \\
\text { fluxes. }\end{array}$ & $\begin{array}{r}\text { Free } \\
\text { sand. }\end{array}$ & Remarks. \\
\hline \multicolumn{15}{|l|}{ GUILFORD COUNTY-continued. } \\
\hline Under pipe-clay, first pit, Pomona Terra Cotta Co .. & 1.53 & 58.73 & 23:94 & 3.71 & .05 & .09 & 1.25 & 9.80 & 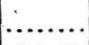 & 99.10 & 65.70 & 5.10 & 33.40 & Sewer pipe. \\
\hline Upper pipe-clay, first pit, Pomona Terra Cotta Co . & 2.05 & 54.28 & 22.27 & 8.45 & .45 & .18 & .60 & 10.50 & 61.33 & 100.11 & 67.57 & 11.01 & 32.51 & Do. \\
\hline Pipe clay, second pit, Pomona Terra Cotta Co. & 2.20 & 70.75 & 13.87 & 5.01 & .82 & .29 & 1.15 & $5: 00$ & & 99.09 & 39.40 & 7.27 & 59.70 & Do. \\
\hline Under fire-clay; Pomona Terra Cotta Co ........... & 1.17 & 70.15 & 15.51 & 3.34 & .83 & .07 & 3.75 & 5.14 & & 99.96 & 39.46 & 7.99 & 60.50 & \\
\hline Woodruff's fire-clay, 1 mile north of Pomona... & 1.43 & 71.60 & 15.27 & 3. 33 & .17 & .21 . & 2.12 & 5.40 & & 99,53 & 42,83 & 5.83 & 56.70 & Fire brick. \\
\hline \multicolumn{15}{|l|}{ HALIFAX COUNTY. } \\
\hline Upper sandy clay, Roanoke Rapids ................. & 1.63 & 67.55 & $13.16 \mathrm{j}$ & 8. 54 & .17 & .28 & 2.65 & 5. 08 & & 99.06 & 41.98 & 11.64 & 57.08 & Brick. \\
\hline Middle clay, Ronnoke Rapids... & 2.45 & 65.58 & 17.04 & 5.76 & .72 & .28 & 2.30 & 5. 58 & & 99.71 & 56.70 & 9.06 & 31.50 & Do. \\
\hline Under clay, Roanoke Rapids................... & 2.05 & 59.68 & 16.09 & 8.91 & 1.35 & .14 & 3.24 & 6.33 & & 97.79 & 42.28 & 13.24 & 39.82 & Do. \\
\hline \multicolumn{15}{|l|}{ HARNETT COUNTY. } \\
\hline $\begin{array}{l}\text { Clay, C. F. \& Y. Y. R. R. 92-93-mile post, southenst of } \\
\text { Spout «prings. }\end{array}$ & 1.42 & 6.4. 16 & 21.71 & 1.58 & .23 & .15 & .77 & 8.30 & $b 1.08$ & 99.40 & 58.55 & 3.81 & 40.90 & Not worked. \\
\hline $\begin{array}{l}\text { Clay, C. F. \& Y. V. R. R. 100-mile post, southeust of } \\
\text { Spout Springs. }\end{array}$ & 1.35 & 50.68 & 32.51 & 3.06 & .30 & .02 & .58 & 11.08 & & 99.58 & 83.43 & 3.96 & 16.15 & Do. \\
\hline Clay, west of Spout Springs station.................... & 1.05 & 53.65 & 28.66 & 4. 50 & .10 & 1.35 & .29 & 10.79 & & 100.39 & 73.77 & 6.24 & 26.65 & Do. \\
\hline \multicolumn{15}{|l|}{ JACKSON COUNTY. } \\
\hline Brick clay, three-fourths mile south of Sylva .. & $.4 \overline{5}$ & 66.70 & 19.75 & 3.25 & .45 & .16 & 2.12 & 6.65 & & 99.53 & 47.28 & 6.08 & 52.25 & Do. \\
\hline \multicolumn{15}{|l|}{ LINCOLN COUNTY. } \\
\hline $\begin{array}{l}\text { Pottery clay, T. Rhodes's place, } 2 \text { miles northwest of } \\
\text { Lincolntown. }\end{array}$ & 2.10 & 57.20 & 24. 82 & 3.25 & .73 & .13 & .93 & 8.25 & $b 1.42$ & 98.83 & 62.27 & 6.46 & 36.57 & Stoneware. \\
\hline Same, $2 \frac{1}{4}$ mile, northwest of Lincolntown....... & .69 & 57.08 & 26.11 & 4.64 & .20 & .16 & 1.42 & 8.52 & & 98.82 & 62.76 & 6. 42 & 35.96 & Do. \\
\hline \multicolumn{15}{|l|}{ MECKLENBURG COUNTY. } \\
\hline I. K. Cecil's yard, Charlotte.............. & 1.35 & 68.35 & 13.13 & 6.87 & 2.10 & .32 & 2.82 & 5.20 & & 100.18 & 38.73 & $\cdot 12.15$ & 61.45 & Brick. \\
\hline F. W. Shuman's yard, Charlotte ................. & 7.10 & 59.15 & 18.36 & 6.04 & .20 & .34 & 1. 72 & 7.47 & & 100.38 & & 8.30 & 39.50 & Do. \\
\hline F. M. Sassamon's yard, Charlotte ................... & 1.27 & 65.95 & 14.67 & 7.61 & 2.57 & .25 & 2.55 & 5.52 & & 100.39 & 43.84 & 12.98 & 56.45 & Do. \\
\hline Upper clay, S. Asbury's yard, Charlotte.... & .63 & 60.33 & 18.57 & 10.03 & .20 & .14 & .55 & 7.83 & & 98.28 & 56.23 & 10.92 & 42.05 & Do. \\
\hline \multicolumn{15}{|l|}{ ROWAN COUNTY. } \\
\hline D. G. Cecil's pit, Salisbury .............. & 1.91 & 69.89 & 15.31 & 4.39 & .55 & .16 & .70 & 6.37 & & 99.23 & 47.38 & 5.80 & 51.90 & Brick. \\
\hline \multicolumn{15}{|l|}{ ROBESON COUNTY. } \\
\hline $\mathrm{s}, \ldots \ldots \ldots \ldots \ldots \ldots \ldots$ & 1.09 & 78.16 & 8.26 & 4.09 & .40 & .22 & 2. 91 & 4.14 & & 99.27 & 15,22 & 7.62 & 74.05 & Brick. \\
\hline Pomona Sewer Pipe Co.'s pit, 1 mile west of Elkins & . & 59.48 & 19.24 & 8.26 & .60 & 1 & 3.76 & 6.41 & & 99.66 & 21 & 13.53 & 50.35 & Not worked \\
\hline
\end{tabular}




\begin{tabular}{|c|c|c|c|c|c|c|c|c|c|c|c|c|c|c|}
\hline $\begin{array}{r}\text { J. T. Shute's pit, Monroe.............. } \\
\text { WAKE COUNTY. }\end{array}$ & 1.65 & 76.60 & 9.98 & 4.46 & .30 & .27 & 2.25 & 4.30 & & 99.81 & 34.26 & 7.28 & .65 .55 & Brick. \\
\hline $\begin{array}{l}\text { Brick elay, penitentiary pits, Raleigh................... } \\
\text { WAYNE CoUNTY. }\end{array}$ & 1.60 & 70.03 & 15.64 & 2.88 & .80 & .57 & 1.47 & 6. 37 & & 99.36 & 14.81 & 5.72 & 54.55 & Brick. \\
\hline Brick clay, H. L. Grant's pit, Goldsboro . & 1.58 & 66.05 & 17.81 & 6. 69 & .30 & .25 & 1.04 & 6. 32 & & 100.04 & 51.47 & 7.76 & 48.05 & Briek. \\
\hline $\begin{array}{l}\text { Clay, Weil's pit, Goldsboro ....................... } \\
\text { Fire clay, H. L. Grant's pit, Goldsboro........... }\end{array}$ & $\begin{array}{l}1.85 \\
1.12\end{array}$ & $\begin{array}{l}67.90 \\
65.95\end{array}$ & $\begin{array}{l}18.74 \\
13.51\end{array}$ & $\begin{array}{l}3.16 \\
4.64\end{array}$ & $\begin{array}{l}.40 \\
.35\end{array}$ & $\begin{array}{l}.45 \\
.36\end{array}$ & $\begin{array}{l}1.85 \\
2.82\end{array}$ & $\begin{array}{r}6.03 \\
11.58\end{array}$ & & 100.38 & 46.23 & $\begin{array}{l}\mathbf{5 . 8 6} \\
8.17\end{array}$ & 54.15 & Do. \\
\hline WILKES COUNTY. & & & & & & & & & & & 13.00 & 0.16 & & Nor Worked. \\
\hline Pottery clay, just west of Wilkesboro ............... & 1.28 & 54.38 & 27.27 & 5.48 & .45 & .41 & .68 & 9.78 & & 99.73 & 75.73 & 7.02 & 24.00 & Stoneware. \\
\hline Pottery clay, C. Cowles's pit, Wilkesboro............ & 2.20 & 54.24 & 24.97 & 4.83 & .57 & .70 & 2.52 & 9.40 & & 99.43 & 67.08 & 8.62 & 32.3 .5 & Not worked. \\
\hline Brick clay, D. Smoak's pit, wilkesboro ............. & 1.03 & 53.75 & 24.91 & 7.99 & .70 & 1.12 & 2.94 & 7.60 & & 100.04 & 34.04 & 12.75 & 46.00 & Brick. \\
\hline $\begin{array}{l}\text { Bottom clay, D. Smoak's pit, Wilkesboro ............... } \\
\text { wiLsox coustry. }\end{array}$ & 2.10 & 52.25 & 20.66 & 11.14 & .60 & 1.08 & 4. 62 & 7.45 & & 99.90 & 57.45 & 17.44 & 42.45 & Do, \\
\hline Redtop clay, Luens's south pit, northeast of Wilson... & 2.31 & 62.99 & 13.56 & 11.52 & .10 & .29 & $2.07:$ & 6.03 & ${ }^{b} 0.33$ & 99.20 & 55.90 & 14.31 & 43.25 & Brick. \\
\hline Blue clay, Lucas's north pit, northeast of Wilson. & 1. 70 & 68.90 & 14.36 & 6.04 & .03 & .31 & 2.30 & 5.83 & & 99.47 & $\$ 6.72$ & 8. 6 is & 51.75 & Do. \\
\hline Clay, Lucas's bank, east of Wilson... & 1.68 & 68.28 & 13.59 & 5. 66 & .15 & .47 & 1.41 & 6.00 & & 97.24 & $\$ 3.69$ & 7.69 & 53.05 & \\
\hline
\end{tabular}


Physical tests of sedimentary clays from North Carolina.

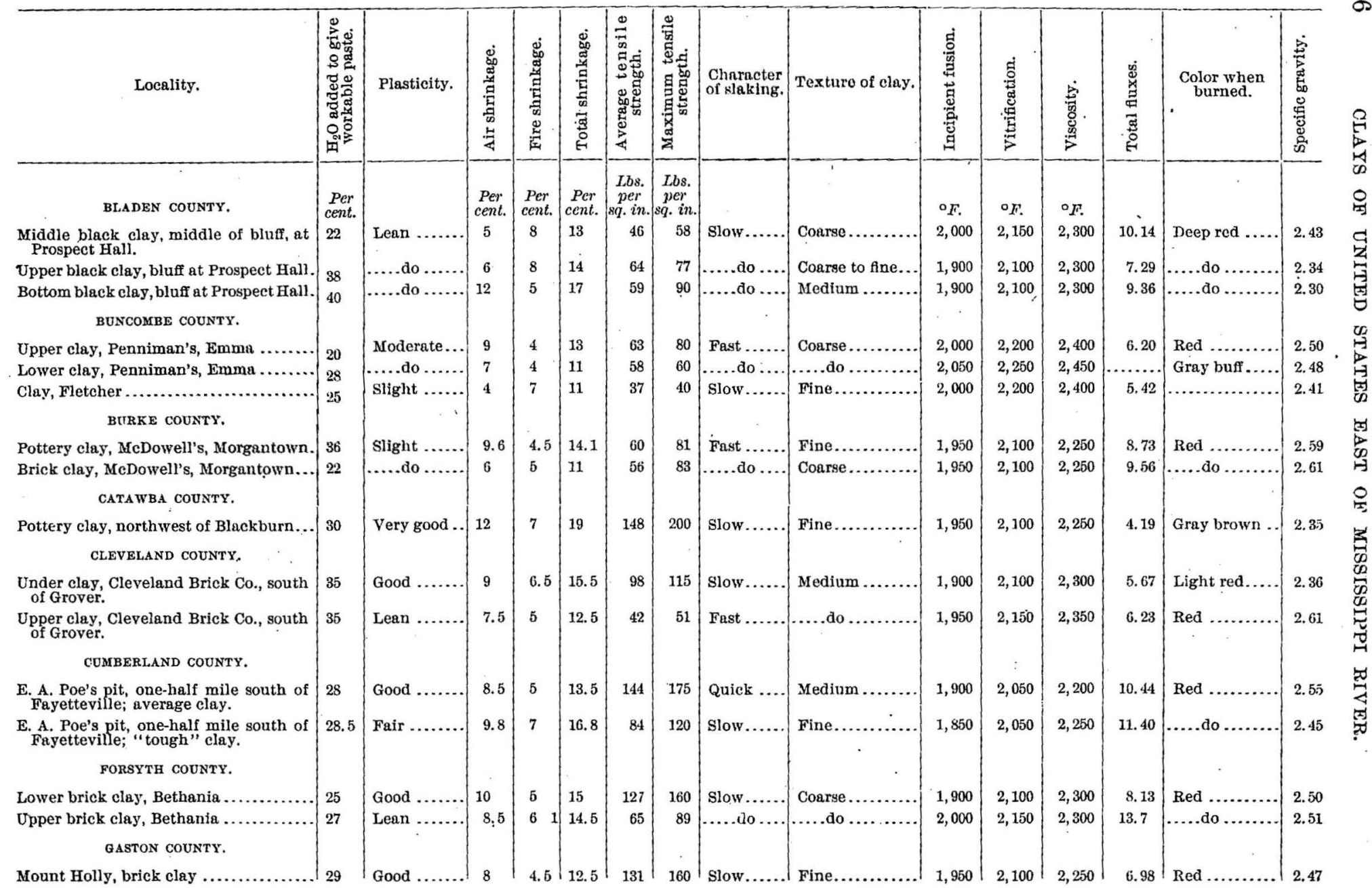




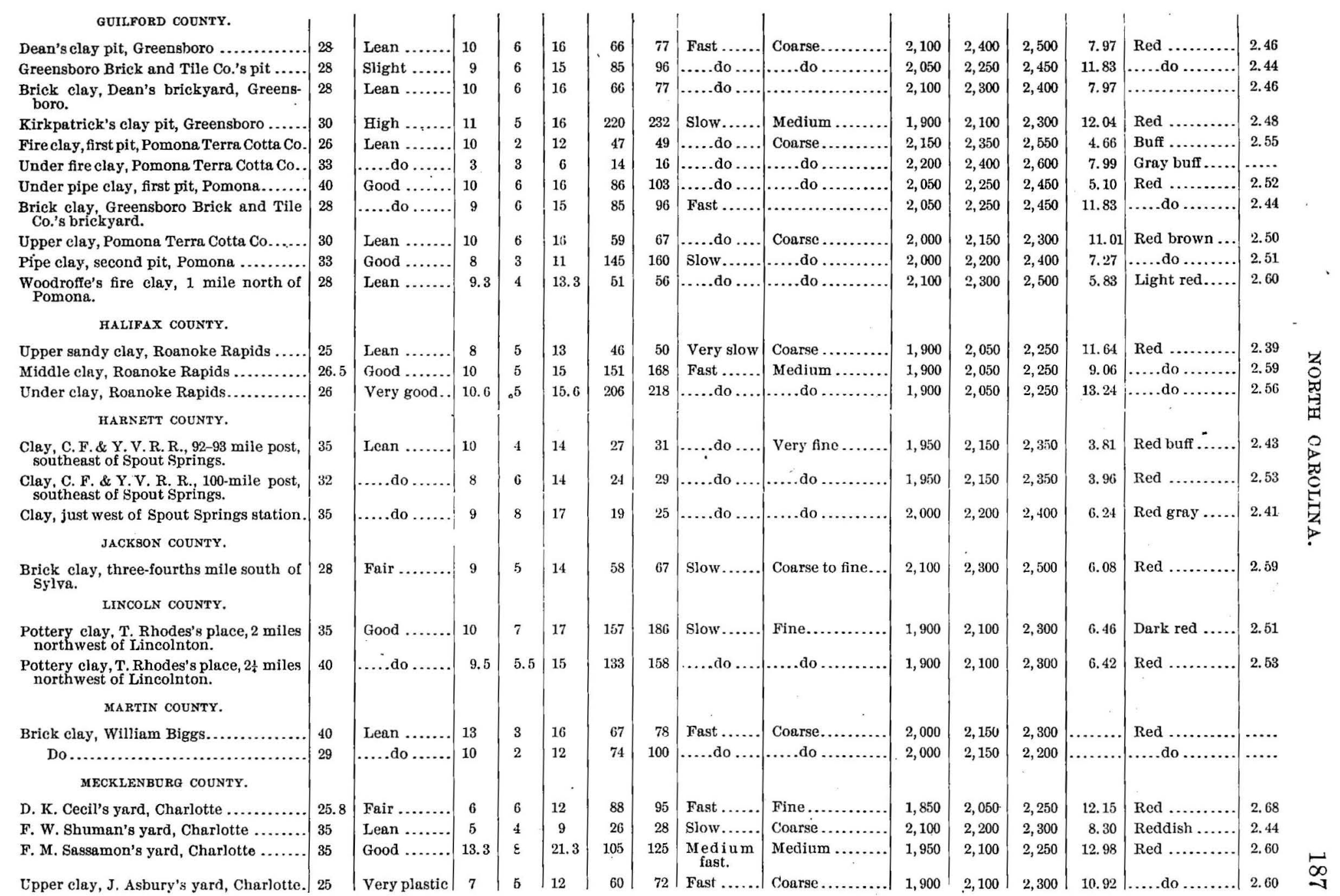


Physical tests of sedimentary clays from North Carolina-Continued.

\begin{tabular}{|c|c|c|c|c|c|c|c|c|c|c|c|c|c|c|c|}
\hline Locality. & 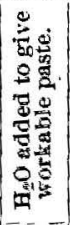 & Plastielty: & 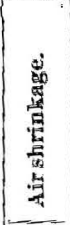 & 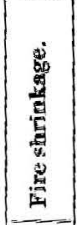 & 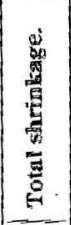 & 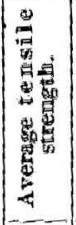 & 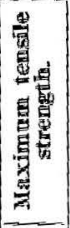 & $\begin{array}{l}\text { Chnincter } \\
\text { of aluking. }\end{array}$ & Texture of clay. & 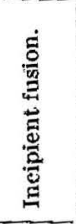 & 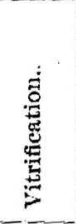 & 蒫 & 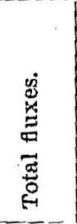 & $\begin{array}{l}\text { Color when } \\
\text { burned. }\end{array}$ & 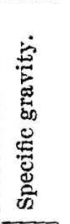 \\
\hline $\begin{array}{l}\text { RoBeson COUN's. } \\
\text { Brick elay, Red Springs........ }\end{array}$ & $\begin{array}{l}\text { Fer } \\
\text { cent. } \\
17\end{array}$ & Lean .... & $\begin{array}{r}\text { Per } \\
\text { cent. } \\
8.8\end{array}$ & $\left|\begin{array}{c}P e r \\
\text { cent. } \\
4\end{array}\right|$ & $\begin{array}{c}\text { Per } \\
\text { ccnt. } \\
12.8\end{array}$ & $\left|\begin{array}{c}\text { Lbs. } \\
\text { per } \\
\text { pq. in. } \\
-41\end{array}\right|$ & $\begin{array}{c}\text { Lbs. } \\
p e r \\
\text { pe. in. } \\
51\end{array}$ & Fast ...... & Coarse ......... & $\begin{array}{l}{ }^{\circ} \mathrm{F} . \\
2,100\end{array}$ & $\begin{array}{l}\circ F \\
2,250\end{array}$ & $\begin{array}{l}\circ, 4 \\
2,400\end{array}$ & 7.62 & Red .......... & 2.60 \\
\hline ROWAN COUNTY. & & & & & & & & & & & & & & & \\
\hline $\begin{array}{l}\text { Brick elay, D. K. Cecil, Salisbury ....... } \\
\text { SURRY coustr. }\end{array}$ & 28 & Good .... & 8.5 & 5.5 & 14 & 129 & 144 & Slow..... & Fine............. & 1,850 & 2,050 & 2,250 & 5.80 & Red ........ & ..... \\
\hline $\begin{array}{l}\text { Ponona Sewer Pipe Co.'s pit, } 1 \text { mile } \\
\text { northwest of Elkin. } \\
\text { Unron CounTy. }\end{array}$ & 16 & Lean ..... & 7 & 9 & 16 & 69 & 73 & Slow .... & Medium fine ... & 1,900 & 2,100 & 2,300 & 13.53 & Red .. & 2.59 \\
\hline $\begin{array}{c}\text { J. T. Shute's pit, Monroe ...................... } \\
\text { WAKE CounTY. }\end{array}$ & 23 & Good ...... & 6 & 3 & 9 & 124 & 148 & Slow... & Medium ......... & 1,950 & 2,150 & 2,350 & 7.28 & Red ........ & $\cdots \cdot$ \\
\hline $\begin{array}{l}\text { Brick clay, penitentiary pits, Raleigh ... } \\
\text { WAYNE CODNTY. }\end{array}$ & $2 \overline{5}$ & Good ..... & 9.3 & .4 & 13.3 & 123 & $144^{\circ}$ & $\begin{array}{c}\text { Medium } \\
\text { fast. }\end{array}$ & Medium ......... & 2,000 & 2,150 & 2,300 & 5.72 & Red :. & 2.54 \\
\hline Brick clay, H. L. Grant's pit, Goldsboro. . & 33 & Fair ...... & 8 & 6 & 11 & 65 & 74 & $\begin{array}{c}\text { Nedium } \\
\text { fast. }\end{array}$ & Coarse to fine.. & 1,900 & 2,100 & 2,300 & 7.76 & $\operatorname{Red} .$. & 2.53 \\
\hline Clay, Weil's pits, Goldsboro ..... & 25 & Good ....... & 8.3 & 3 & 11.3 & 85 & 102 & Slow...... & Fine... & 1,900 & 2,100 & 2,300 & 5.86 & Light red...... & 2.57 \\
\hline $\begin{array}{c}\text { Fire clay, H. L. Grant's pit, Goldsboro ... } \\
\text { WILKES COUNTY. }\end{array}$ & 25 & ......do ....... & 8.5 & 5 & 13.5 & 107 & 125 & $\begin{array}{c}\text { Moderate } \\
\text { fust. }\end{array}$ & .....do ............ & 1,950 & 2,150 & 2,300 & 8.17 & Deep red ...... & 2.55 \\
\hline Pottery clay, just & 40 & Moderate... & 7.5 & 12 & 19.5 & 51 & 63 & Slow..... & Fine............ & 1,900 & 2,050 & 2,200 & 7.02 & Red .... & 2.37 \\
\hline $\begin{array}{l}\text { Pottery clay, Calvin Cowles's property, } \\
\text { on-half mile north of Wilkesboro. }\end{array}$ & 35 & Good ....... & 10 & 5 & 15 & 169 & 192 & .....do... & .....do do.......... & 1,800 & 2,000 & 2,200 & 8. 62 & Gray brown.. & 2.46 \\
\hline Brick clay, D. Smoak, Wilkesboro ......... & 25 & Lean ........ & 5 & 10 & $1 \overline{5}$ & 74 & 76 & Fast ... & ..... do ......... & 1,900 & 2,100 & 2,300 & 12.75 & Deep red ...... & 2.63 \\
\hline Do....................................... & 24 & .....do $\ldots$.... & 6 & 9 & 15 & 71 & 84 & .....do .... & Medium fine.... & 1,900 & 2,100 & 2,300 & 17.44 & ......do .......... & 2.44 \\
\hline $\begin{array}{l}\text { WILsoN counTY. } \\
\text { Red-top clay, Lucas's S. pit, northeast of } \\
\text { Wilson. }\end{array}$ & 32 & Lean & 10 & 5 & 15 & 84 & 98 & Fast & Medium & 1,800 & 1,950 & 2,100 & 14.31 & Red & 2.62 \\
\hline $\begin{array}{l}\text { Blue-top clay, Lucas's } N \text {. pit, northenst } \\
\text { of Wilson. }\end{array}$ & 30 & Goce & 8 & 5.5 & 13.5 & 107 & 129 & Slo & ......do $\ldots$ & 1,900 & 2,050 & 2,200 & 8.68 & .....do. & 2.45 \\
\hline $\begin{array}{l}\text { Blue-top clay, Lucas's bank, east of Wil- } \\
\text { son. }\end{array}$ & 33 & ....do ..... & 11 & 4 & 15 & 138 & 155 & ....do... & ..... do ..... & 1,950 & 2,100 & 2,250 & 7.69 & ......do.. & 2.52 \\
\hline
\end{tabular}


CLAY-WORKING INDUSTRY.

The most important product of North Carolina is washed kaolin, which is shipped to many potteries in the Northern and Central States. The most numerous class of clay works is that engaged in the manufacture of common brick, many yards being scattered over the eastern half of the State. Local centers are at Goldsboro, Fayetteville, Greensboro, Wilkesboro, Charlotte, and Raleigh. The clays used are mostly surface sediments, and in some instances residual.

Sewer pipe are made at Pomona from a mixture of clays dug in the valley of Buffalo Creek, and fire-brick factories are located at Emma, Buncombe County; Grover, Cleveland County; and Pomona, Guilford County. The elays used in each case are semirefractory and siliceous.

Stoneware is made at several small potteries in Catawba and Lincoln counties. Others are scattered over the State, as at Wilkesboro, Wilkes County, and 2 miles north of Morgantown, Burke County.

The potteries in Lincoln and Catawba counties obtain most of their clay from the lowlands along the Clarke River, north of Lincolnton, some of them having to haul it 15 miles. They pay 50 cents a ton for it. The methods of manufacture are very crude, and the glazes are usually a ground mixture of ashes and glass.

The following figures give the production of the different grades of ware for 1900 and 1901, and also the total production for the past several years:

Value of clay products in North Carolina in 1900 and 1901.

\begin{tabular}{|c|c|c|}
\hline & 1900. & 1901. \\
\hline Common brick........................... & $\$ 737,577$ & $\$ 682,469$ \\
\hline Front brick........ & 4,025 & 8,070 \\
\hline Paving brick $\ldots \ldots \ldots \ldots \ldots \ldots \ldots \ldots \ldots$ & $(a)$ & .......... \\
\hline Fire brick $\ldots \ldots \ldots \ldots \ldots \ldots \ldots \ldots \ldots \ldots \ldots \ldots$ & 714 & 3,720 \\
\hline 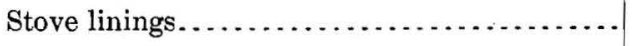 & $(a)$ & .......... \\
\hline Drain tile............. & 7,186 & 5,042 \\
\hline Sewer pipe............. & $(a)$ & .......... \\
\hline Miscellaneous......... & 5,000 & 5,000 \\
\hline 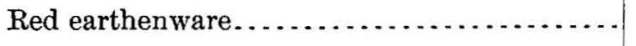 & 1,937 & 2,015 \\
\hline 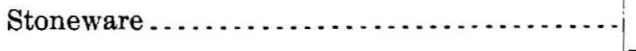 & 16,498 & 17,470 \\
\hline Total. . & $815,-975$ & 771,338 \\
\hline
\end{tabular}

$a$ Product mide by less than three firms, and hence output not given. 
Value of clay products of North Carolina from 1895 to 1901.

\begin{tabular}{|c|c|c|c|}
\hline . & Value. & Rank. & $\begin{array}{c}\text { Proportion } \\
\text { of United } \\
\text { States } \\
\text { product. }\end{array}$ \\
\hline & & & Per cent. \\
\hline 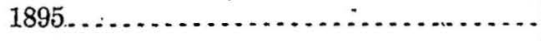 & $\$ 400,983$ & 26 & 0.61 \\
\hline $1896 \ldots \ldots \ldots$ & 420,899 & 24 & .68 \\
\hline 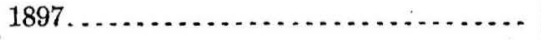 & 368,194 & 27 & .59 \\
\hline $1898 \ldots \ldots \ldots \ldots \ldots \ldots \ldots \ldots \ldots \ldots \ldots \ldots \ldots \ldots$ & 419,782 & 29 & .59 \\
\hline $1899 \ldots$ & 774,202 & 26 & .81 \\
\hline $1900 \ldots \ldots \ldots$ & 815,975 & 24 & .85 \\
\hline $1901 \ldots \ldots \ldots \ldots$ & 771,338 & 27 & .70 \\
\hline
\end{tabular}

OHIO.

The geologic scale of Ohio ${ }^{a}$ includes strata ranging from the Trenton limestone up to the glacial drift. This is shown in the following table:

\section{Geologic formations of Ohio.}

18. Glacit.

17. Upper Barren Coal Measures ............................... 500

16. Üper Productive Coal Measures ............................ 200

15. Lower Barren Coal Measures ........................... 500

14. Lower Productive Coal Measures .......................... 250

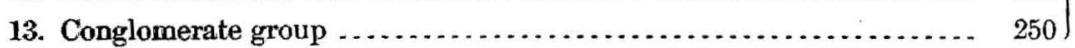

12. Iower Carboniferous limestone, Maxville, Newtonville, etc..........

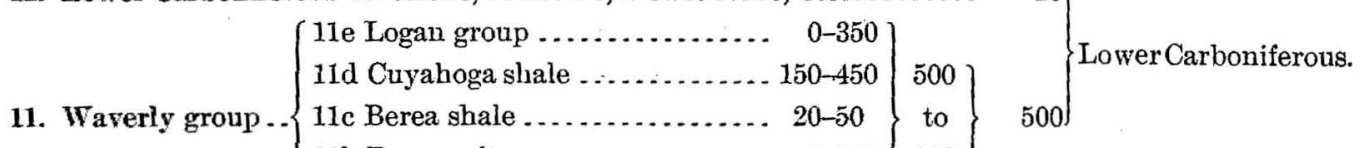

11. Waverly group.. $\left\{\begin{array}{lc}11 \mathrm{c} \text { Berea shale } \ldots \ldots \ldots \ldots \ldots \ldots \ldots & 20-50 \\ 11 \mathrm{~b} \text { Berea grit } \ldots \ldots \ldots \ldots \ldots \ldots \ldots & 5-160 \\ 11 \mathrm{a} \text { Bedo } & 800\end{array}\right\}$

Carboniferous.

11a Bedford shale .............. 50-150

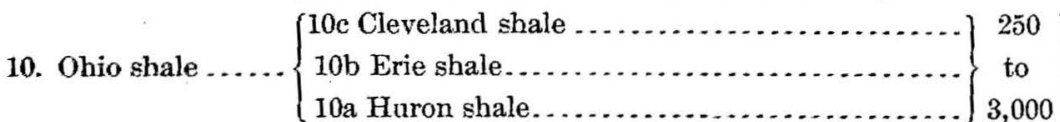

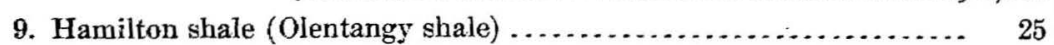

8. Deronian limestone, Upper Helderberg or Onondaga (Corniferous), including West Jefferson sandstone ............................

7. Lower Helderberg limestone or water lime, including Sylvania sand-

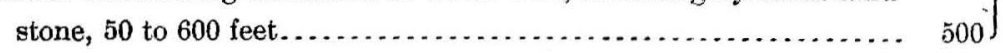

a Clays of Ohio, their origin, composition, and varieties. Vol. VII, Pt. I, Geology of Ohio, pp. 4-68. Norwalk, Ohio, 1893. 
Geologic formations of Ohio-Continued.

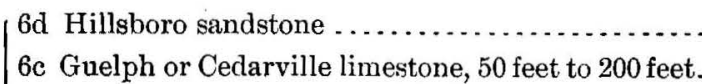
6. Niagara group.
6a Niagara shale, including Dayton limestone, 5 feet to 100 feet

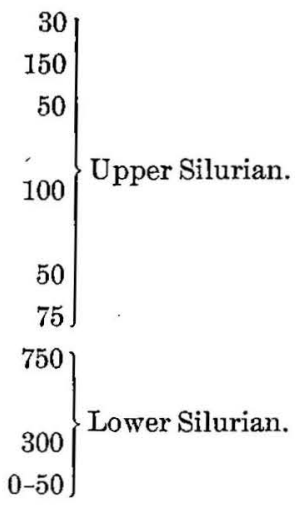
5. Clinton group, in outcrop, 20 feet to 75 feet; under cover, 75 feet to 150 feet ..
4. Medina shale, in outerop, 25 feet; under cover, 50 feet to 150 feet....
3. Hudson formation, 300 feet to 750 feet........................
2. Utica shale, not seen in outcrop, but 300 feet thick under cover in northern Ohio
1. Trenton limestone, seen only in Point Pleasant quarries, if at all ....

LOWER SILURIAN, OR ORDOVICIAN.

The rocks of this formation form a triangular area in southwestern Ohio, in Brown, Clermont, Hamilton, Highland, Clinton, Warren, Butler, Montgomery, Greene, Clark, Preble, and Miami counties. The shales are too calcareous for most uses aside from Portland cement, and are not worked.

UPPER SILURIAN.

The Silurian rocks underlie a forked area in the western third of Ohio, which extends from Lake Erie between Toledo and Sandusky Bay southward, increasing in width. Its eastern boundary runs nearly north and south, from Sandusky Bay to Washington Court-House, Fayette County, while the western border extends from Toledo to the western boundary of the State at a point south of the northwestern border of Mercer County. These formations contain two shales, the Medina and the Niagara. The lowest argillaceous bed known to have been worked is the Medina sandstone (No. 4), which is confined to southwestern Ohio. It is a reddish, whitish, yellowish, or bluish shale, and probably contains considerable lime or magnesia. The outcrops are very similar. It was used at one time for drain tile, but it is not now worked. The Hudson formation, which directly underlies the Medina shale, is no doubt similar, but it is rather calcareous, and no attempts have been made to use it. The Niagara shale ${ }^{a}$ forms an extensive calcareo-argillaceous deposit, and is to be classed as a marl shale. Its maximum thickness in Adams County is 100 feet.

DETONIAN.

The Devonian rocks form two separate areas in Obio. The one occupies the northwestern corner in the counties of Williams, Fulton, Defiance, Henry, Paulding, and Van Wert, and parts of Wood, Putnam, and Lucas counties; the other 
extends across the State in a belt from Lake Erie to the Ohio River, through Erie, Huron, Seneca, Crawford, Wyandot, Marion, Morrow, Delaware, Franklin, Pickaway, Ross, Pike, and Adams counties. The beds dip eastward, so that the shale formations occur in the eastern half of the belt.

The shale formations are the Hamilton and the Ohio. The Hamilton has not been worked for clay products and does not seem likely to be, for there are few outcrops and its thickness is only from 15 to 20 feet. The Ohio shale, however, is said to have possibilities, being a great formation with many outcrops, and ranging between 250 and 400 feet in thickness. If followed eastward its thickness is found to increase to more than 2,500 feet, and its outcrops occupy a belt 10 to 25 miles wide that reaches entirely across the State from north to south. It is not a homogeneous formation, the beds varying considerably, but two leading types noticeable are a black shale and a greenish-blue shale. They are all highly siliceous, but the black shale has 8 to 10 per cent organic matter, and the greenish-blue variety owes its color to the silicate of iron which it contains. Columbus is practically the only point in the State where this series has been used. Here both sewer pipe and common brick are made of it. It was the greenish phase that was used in every case.

\section{LOWER CARBONIFEROUS.}

The Bedford shale is not always distinguishable from the preceding, and sometimes resembles it closely in color. In most places it is a red shale, and hence where it has this color can be easily identified. It is a very persistent bed, ranging from 20 to 80 feet thick. The Akron Vitrified Brick Company uses the red shale in making pressed brick, and it has also been mined and worked at or near Independence.

The Cuyahoga shale is a great bed, 150 to 450 feet thick, of light gray or blue color, but, according to Prof. E. Orton, is not being worked.

The Lower Carboniferous limestone horizon holds a valuable argillaceous deposit, found in a few places in southern Ohio, and in many places in Kentucky a hard flint clay comes into the section. Indeed this clay is one of the two or three strictly firstclass clays of the State. It has been. worked largely at Sciotoville and Portsmouth, and is hence known as the Sciotoville clay. It also occurs near Logan, Hocking County, and there is called the Logan clay. It has been much used for fire brick.

\section{COAL MEASURES.}

These underlie the eastern third of the State, their western border passing through Lawrence, Scioto, Jackson, Vinton, Perry, Licking, Coshocton, Holmes, Wayne, Medina, Summit, Portage, and Trumbull counties.

The lower members are found in the western portion of the area, while the upper members immediately underlie the surface in the middle and eastern parts, toward the Pennsylvania border. 
OHIO.

The best clays in the State are found in the Coal Measures, and beds of clay or shale are very numerous throughout the entire series, from the Conglomerate group up to and including the Barren Measures.

CONGLOMERATE GROUP.

The Conglomerate group includes several gray sandstones and conglomerates, 4 or 5 coal seams, 2 thin limestones, 3 or 4 iron-ore seams, and a half dozen clay beds that are known as fire clays and shales. The following is the section:

\section{Section of Conglomerate group of Ohio Carboniferous.}

Tionesta sandstone.

Tionesta coal.

Tionesta clay and shale.

Upper Mercer ore.

Upper Mercer limestone.

Upper Mercer coal.

Upper Mercer fire clay.

Lower Mercer iron ore.

Lower Mercer limestone.

Lower Mercer fire clay.

Massillon sandstone (lower).

Sharon shales.

Sharon coal.

Sharon clay.

Sharon conglomerate.

The important beds in this section are the Tionesta clay and shale, the Upper Mercer clay, the Lower Mercer clay, the Quakertown clay and shales, and Sharon clay and shales. The lowest coal seam, the Sharon coal, is also known as the Mahoning coal, the Youngstown coal, the Akron coal, the Massillon coal, and the Jackson shaft coal. Under this is a thin deposit with a small amount of clay, which in turn is underlain by the Sharon conglomerate. It is not used.

SHARON SHALES.

The Sharon shales overlie directly the Sharon coal and vary in thickness from 1 to 50 feet. They are usually dark blue, sometimes almost black, with heavy ironore nodules at certain levels. The shales proper have lately become the basis of one of the largest sewer-pipe industries in the United States, at Akron and in its immediate neighborhood. The same deposit is also worked for roofing tile, but the shale is usually high in iron oxide, the amount of this substance ranging between 10 and 15 per cent.

QUAKERTOWN CLAY AND SHALE.

The Quakertown clay and shale occupy a space of 5 to 30 feet between the two divisions of the Massillon sandstones, when such a division occurs. They over-

$9647-$ No. $11-03-13$ 
lie and underlie the Quakertown coal, although the latter may become extremely thin at times. The argillaceous deposits of this age are worked in Summit, Portage, and Stark counties. The Summit deposits furnish stock for the potteries of Springfield, and the Portage bed supplies the Mogadore potteries. The Massillon Fire Brick Company has developed an important deposit at this horizon. It is a streak of hard fire clay 4 to 5 feet thick, immediately underlying the Carboniferous, and representing the Quakertown coal. The bottom of the fire clay is 30 feet above the Sharon coal. This clay resembles the hard No. 1 fire clay of southern Ohio in general appearance. Overlying the coal streak are 10 feet of shale, used for paving blocks.

LOWER MERCER CLAY AND SHALE.

The best-marked horizon of the entire Conglomerate measures is that of the blue or Lower Mercer limestone. Above it there is often a valuable iron ore, while under it is a coal seam of little value. Below the coal the argillaceous deposit is sometimes shale, but generally. clay, which is worked to a great extent. This forms the basis of important manufactures in Stark, Tuscarawas, Muskingum, and Hocking counties, especially in the latter. The Columbus Brick and Terra-Cotta Works, at Union Furnace, use it, and it is also worked at Millersburg, Holmes County. There is considerable range in the quality of this clay throughout the State, and it is nowhere of specially high character. The shale or clay immediately overlying the Lower Mercer limestone is promising.

The following two analyses indicate the composition of this clay as mined at Haydenville:

Analyses of Lower Mercer, or Mingo, fire clay.

[E. M. Reed, analyst.]

\begin{tabular}{|c|c|c|}
\hline . & 1. & 2. \\
\hline Silica..... & 69.92 & 76.24 \\
\hline Alumina......... & 23.46 & 16.87 \\
\hline Ferric oxide $\ldots . . . .$. & .20 & .16 \\
\hline Lime ............. & .48 & .50 \\
\hline Magnesia .............. & .41 & Trace. \\
\hline Alkalies ..................... & 1.43 & 1.09 \\
\hline Water ............................ & 3.84 & 5.14 \\
\hline Total. & 99.74 & 100 \\
\hline
\end{tabular}

1. Outcropping of vein.

2. Hard clay from mine. 
UPPER MERCER CLAY AND SHALE.

The Upper Mercer coal is not of economic importance, but the clay is more persistent than the coal seam. It is a light-colored plastic clay, of widespread occurrence in the State. At Haydenville, Hocking County, it is extensively worked under the name of the Mingo clay, being one of the most valuable clay deposits of the entire series that is included within the Haydenville coal field, the series ranging from the Mercer to the Freeport horizon. The deposit here is 8 to. 10 feet thick.

TIONESTA CLAY.

This ranges from a few feet to 20 feet above the last-named deposits, and there is found at times another valuable clay bed. It is used and highly valued in the Union Furnace Works mentioned above. Above this come the Lower Coal Measures.

LOWER COAL MEASURES.

The principal clay deposits of the Lower Coal Measures are as follows:

Clay deposits of Lower Coal Measures of Ohio.

Upper Freeport clay and shales.

Lower Freeport clay and shales.

Middle Kittanning clay and shales.

Kittanning clay.

Ferriferous limestone clay.

Putnam Hill limestone clay and shales.

Putnam Hill limestone horizon.

PUTNAM HILL OR BROOKVILLE CLAY

The Putnam Hill horizon covers a coal seam called the Brookville coal, and a valuable clay deposit is found in the central Coal Measure counties at this level. It is specially well developed in Muskingum County, and is there largely worked. It continues in good volume and of good character also through Coshocton, Tuscarawas, and Stark counties, where it is largely worked, and it appears promising in Perry, Hocking, and Vinton counties to the south. Like the Lower Mercer clay of the Union Furnace section, it yields on calcination, at least as it is found in the vicinity of Zanesville, a buff or cream-colored brick. This clay is the main basis of the great tile factory at Zanesville. It has also been shipped to North Baltimore, Wood County, for pressed brick. The clay under the Brookville coal is also worked at Greenford, Mahoning County, and New Lexington, Parry County. A red shale, presumably of this age, is also worked here.

In the Zanesville area the clay ranges from 3 to $10^{\circ}$ feet thick, with an average thickness of 6 feet. It is usually divisible into an upper or plastic portion and a 
lower or more siliceous division. It is largely worked at Canton for the manufacture of paving brick. The following analysis of this shale at North Industry, near Canton, shows its character:

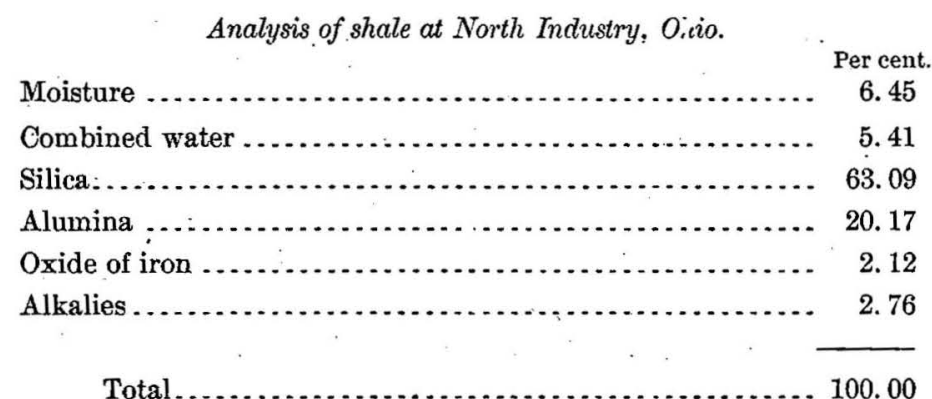

The lower portion of the seam at the same point was analyzed by itself with the following result:

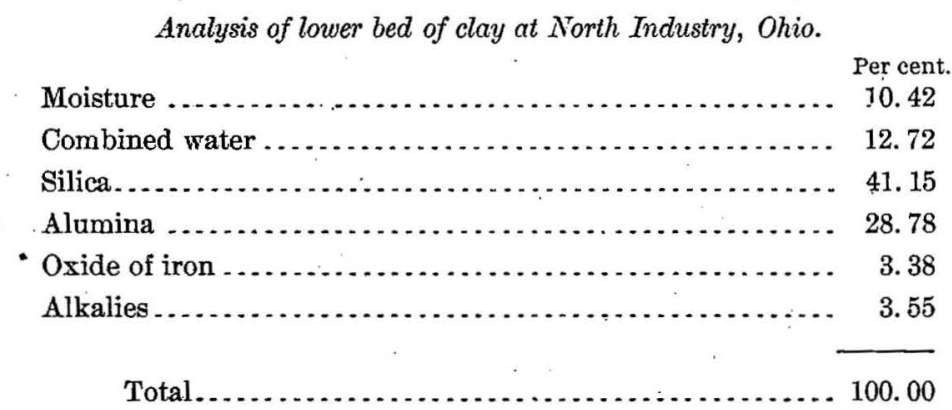

This horizon is looked upon as one of the most valuable in the State: The limestone furnishes a good roof for underground workings. Parts of it are good for fire brick. The Harris fire-brick works, 6 miles above Zanesville, on the west side of the river, uses the lower part of the formation. The section here beginning at the top is as follows:

\section{Section near Zanesville, Ohio.}

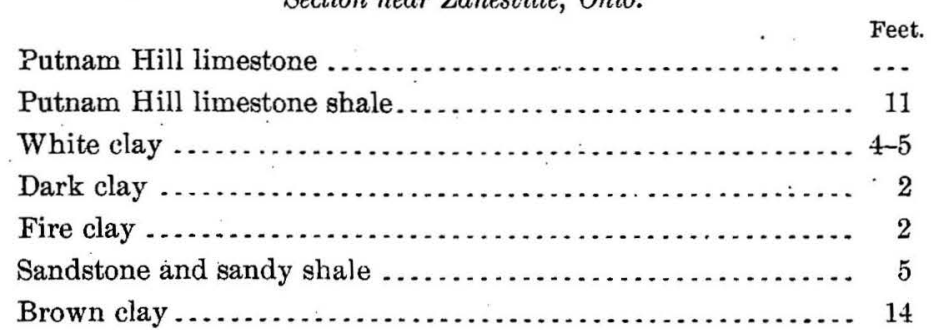

The beds known as fire clay and sandstone and sandy sbale in this section are used for brick making. 
FERRIFEROUS LIMESTONE AND CLAYS

The Ferriferous limestone and clays underlie the limestone coal with a thickness of 2 to 6 feet. It is light-colored, plastic, of fair quality. Prof. E. Orton, jr., states that this forms a very valuable stoneware clay in the district running from Zanesville down to New Lexington on the Cincinnati and Muskingum Valley Railroad. It is also used in southern Ohio, around Scranton, either as a potter's clay or for shipment as a second-grade fire clay. It is not very high grade at this point.

LOWER KITTANNING CLAY AND SHALES.

The Lower Kittanning clay and shales constitute the great clay horizon of the State, being much more important than any other in Obio; indeed, Professor Orton considered it equal in value to all other clay sources of the Coal Measures combined. It belongs between the Ferriferous limestone and Lower Kittanning coal, and often fills in the interval between them. In the more important occurrences its thickness ranges between 8 and 30 feet, and sometimes it is even continuous with the clays above the Lower Kittanning, only the coal seam being between, in which case the combined section is not less than 50 feet. The Kittanning clay horizon proper is best seen where it enters the State from Pennsylvania, and again where it leaves the State in its extension into Kentucky. At both of these localities in the Ohio Valley, namely, in Columbiana and Jefferson counties on the one side and in Lawrence County on the other, it shows great quantities of clay of good quality. In Tuscarawas, Stark, and Muskingum counties also it is scarcely less developed. It is extensively mined at Haydenville, Hocking County, and also at Canton, Stark County. The horizon urually yields a white plastic clay of good quality, and this is the foundation of the great eastern Ohio pottery industries. A second and more valuable bed of the clay is found at a few points in Stark, Tuscarawas, and Carroll counties, where it yields a flint clay which is known as the Mineral Point clay, being largely worked at the village of this name and at Canal Dover. Many analyses are given of the white plastic variety, but it is hard to pick out one which can be called thoroughly representative. The products of this horizon are used in the manufacture of saggers, Rockingham, and yellow ware, as well as stoneware. It is also the main dependence of sewer-pipe factories and is even sometimes employed for ordinary fire brick. It is likewise used in large quantities for paving brick. The following analyses are from different points: 
.. Analyses of Lower Kittanning clays, from Ohio.

\begin{tabular}{|c|c|c|c|c|c|c|}
\hline . & 1. & 2. & 3. & 4. & 5. & 6. . \\
\hline $\mathrm{SiO}_{2}(\mathrm{comb}) \ldots \ldots \ldots \ldots$ & 35.39 & 35.72 & & $57 \quad 15$ & 5580 & \\
\hline $\mathrm{SiO}_{2}($ free $) \ldots \ldots \ldots \ldots$ & 17.13 & 20.65 & 01.00 & .07 .40 & 00.00 & 01.00 \\
\hline $\mathrm{Al}_{2} \mathrm{O}_{3} \ldots \ldots \ldots \ldots \ldots \ldots$ & 31.84 & 29.62 & 26.02 & 21.06 . & 24.34 & 26.02 \\
\hline $\mathrm{H}_{2} \mathrm{O} \ldots \ldots \ldots \ldots$ & 11: 68 & 8.71 & 9.98 & 5.90 & 6.75 & 9.73 \\
\hline $\mathrm{TiO}_{2} \ldots \ldots \ldots \ldots \ldots \ldots$ & 1. 68 & & $\cdots$ & $\therefore \ldots$ & (.......... & $\cdots$ \\
\hline $\mathrm{Fe}_{2} \mathrm{O}_{3} \ldots \ldots \ldots \ldots$ & .67 & 1.14 & .63 & 7.54 & 6.11 & .63 \\
\hline $\mathrm{CaO} \ldots \ldots \ldots \ldots$ & .50 & .45 & .19 & .29 & .43 & 1.26 \\
\hline $\mathrm{MgO} \ldots . .$. & .19 & .14 & 1.26 & 1.22 & .77 & .19 \\
\hline $\mathrm{K}_{2} \mathrm{O} \ldots \ldots \ldots \ldots$ & $.59^{\circ}$ & .79 & .31 & 3.27 & 3.00 & 31 \\
\hline $\mathrm{M}_{2} \mathrm{O} \ldots \ldots \ldots \ldots$ & ....... & .29 & & .39 & .09 & .31 \\
\hline Fluxes...$\ldots \ldots \ldots$ & 1.95 & 2.81 & $\because \ldots$. & 12.71 & 10.40 & 1.76 \\
\hline Moisture .. & .69 & 1.92 & $\cdots$ & 1. 90 . & 2.65 & $\cdots \cdots$ \\
\hline Total $\ldots . .$. & 100. 36 & 99.43 & $100: 25$ & 99.02 & 99.74 & \\
\hline
\end{tabular}

. 1. Flint clay, C. E. Holden, Mineral Point. For refractory wares. Ohio Geol. Survey, Vol. VII, Pt. I, p. 221.

2. Flint clay. Sampled in 1892. Ibid.

3. Flint elay. Sampled in 1892 . Ibid., p. 139.

4. Ohio Paving Brick Company, Darlington, p. 133.

5. Shale and fire-clay mixture. A. O. Jones Co., Zanesville. Ibid.

6. Haydenville.

MIDDLE KITTANNING CLAY.

At one locality, namely, Oak Hill, Jackson County, the Middle Kittanning clay yields a No. 1 or hard fire clay, and there is the basis of fire-brick manufacture. Nodules of iron ore are seen in many of its outcrops, and these interfere with its use. It has no special peculiarities, but it forms a good adjunct to the Lower Kittanning.

LOWER FREEPORT CLAY.

The Lower Freeport clay shows no great development. At one locality, namely, in the vicinity of Moxahala, Perry County, the seam is found in the condition of hard or tlint clay; but of only moderate quality. It contains enough iron to shut it out for use in the highest grades of ware. Usually the clay is of the ordinary type of plastic under clays found in the Coal Measures.

UPPER FREEPORT CLAY AND SHALE.

The Upper Freeport clay and shale is much more important than either of the preceding, for it occurs in great quantity and is more widely distributed than the coal seam from which it gets its name. It assumes a flinty phase at several points. In western Pennsylvania this is known as the Bolivar clay, but in the Muskingum Valley, below Zanesville, it has been worked to a small extent under the name of the Ballou clay. It is not worked at present, except perhaps at Salineville.

LOWER BARREN MEASURES.

The Lower Barren Measures overlie the Lower Coal Measures in order and contain vast deposits of shale, which were just beginning to be used at the time the 
Ohio report ${ }^{a}$ was written. They serve as the basis of paving-brick industry. These shales are distributed through the entire series, but about the middle portion of this division some deposits of peculiar excellence have been developed, particularly in the Sunday Creek Valley, and that part of the series which is bounded by the Cambridge limestone below and the Crinoidal limestone above seems especially well adapted to paving-block manufacture. No true fire clays are known below the summit of the Pittsburg coal. A good fire clay has been noted under this coal at a few points in Athens County, and at one point in eastern Ohio, namely, at Bellaire, a bed of shale 20 feet or more in thickness directly underlies the Pittsburg coal. This deposit gave good results for paving brick and sewer pipe. Professor Orton is of opinion that

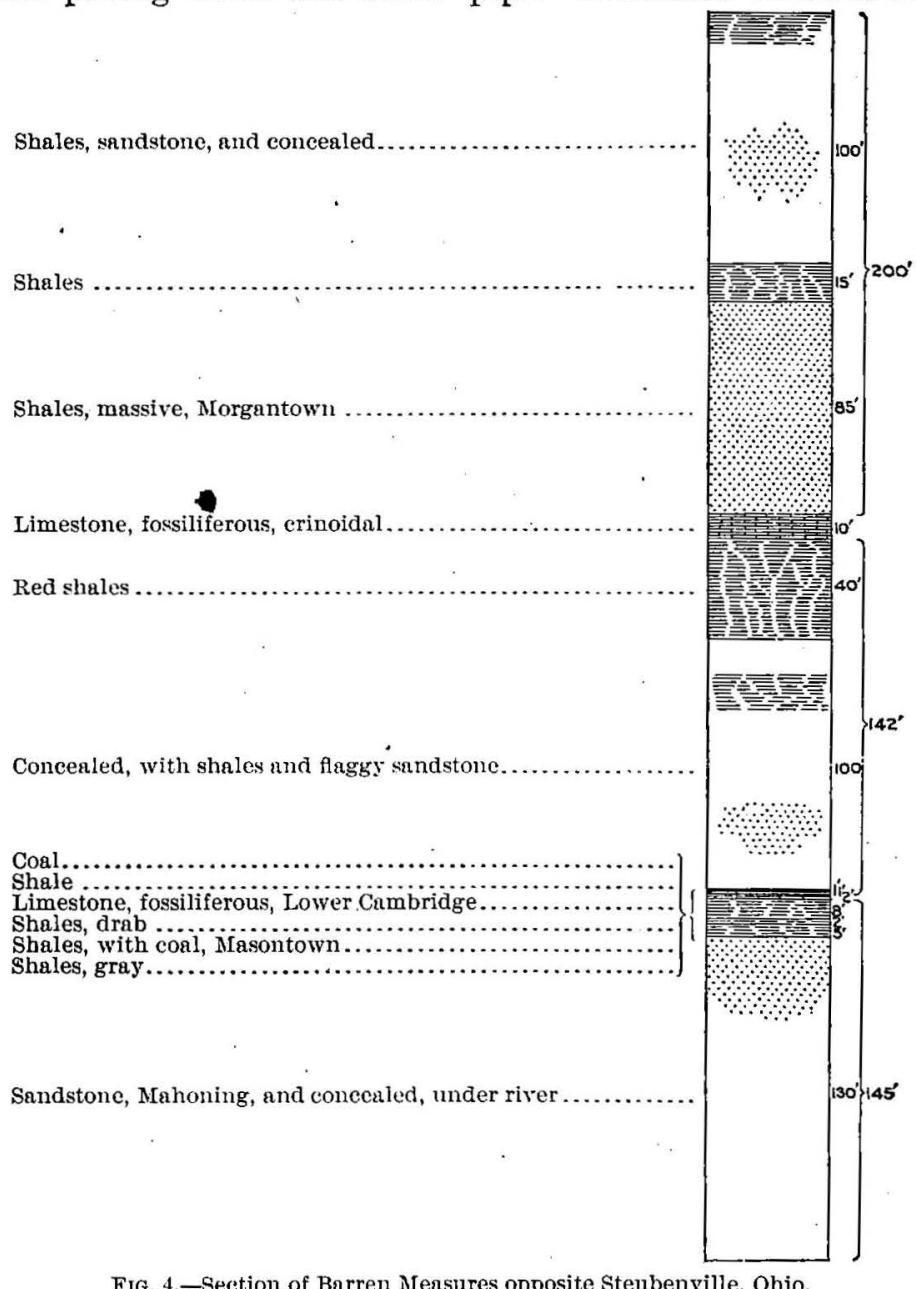

certain deposits of red clay and shale in the Barren Measures will also prove suitable for clay products.

In fig. 4 is given a section ${ }^{b}$ which illustrates the position of these red shales. 
UPPER PRODUCTIVE NIEASURES.

This series of beds extends from the base of the Pittsburg coal up to the Cassville shale. Its thickness in. Ohio is about 200 feet.

The following section, given by I. C. White, from Bellaire, Belmont County, shows the character of the series:

Section near Bellaire, Belmont County, Ohio,

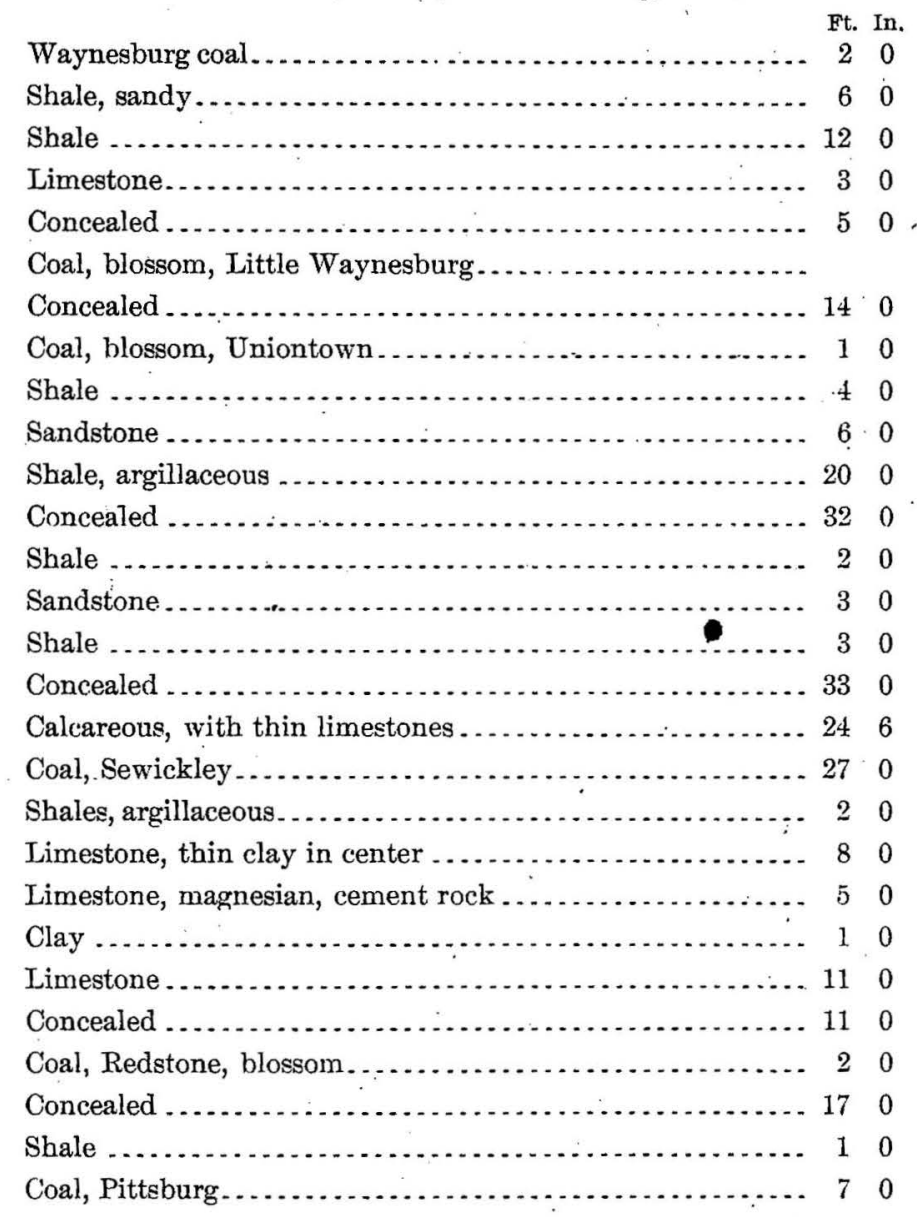

The area of outcrop forms a narrow, sinuous band, extending in a northeasterly direction from Gallipolis to Steubenville, and southward from there to and beyond Bellaire. ${ }^{a}$

UPPER BARREN MEASURES.

In Ohio these form an area extending through the counties of Belmont, Monroe, Washington, Athens, Meigs, and Gallia. 
The following section from Baresville (Hannibal post-office), Monroe County, illustrates well the many shale beds present: ${ }^{b}$

\begin{tabular}{|c|c|c|}
\hline Section at Baresville, Mọnoe County, Ohio. & Feet. & Inch. \\
\hline Cóal blossom.......... & & \\
\hline Concealed...$\ldots \ldots \ldots \ldots \ldots \ldots \ldots \ldots \ldots$ & 145 & 0 \\
\hline Limestone, Nineveh........ & 6 & 0 \\
\hline Shale ....... & 18 & 0 \\
\hline Limestone, sandy ............. & 2 & 0 \\
\hline Red shale............. & 14 & 0 \\
\hline Shale; mostly ................. & 21 & 0 \\
\hline Shale $\ldots \ldots \ldots \ldots \ldots \ldots$ & 20 & 0 \\
\hline 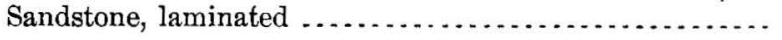 & 36 & 0 \\
\hline Red shale...$\ldots \ldots \ldots \ldots$ & 18 & 0 \\
\hline Sandstone . . . . . . . . . . . . . & 2 & 0 \\
\hline Red shale ...... & 20 & 0 \\
\hline Sandstone ................. & 3 & 0 \\
\hline Shale ................ & $t$ & 0 \\
\hline Sandstone ......................... & 3 & 0 \\
\hline Red shale............ & 13 & 0 \\
\hline Sandstone $\ldots . . . \ldots \ldots \ldots \ldots$ & 11 & 0 \\
\hline Shale $\ldots \ldots \ldots \ldots \ldots \ldots$ & 4 & 0 \\
\hline Sandstone $\ldots \ldots \ldots \ldots \ldots$ & 3 & 0 \\
\hline Shale $\ldots \ldots \ldots \ldots \ldots$ & 3 & 0 \\
\hline 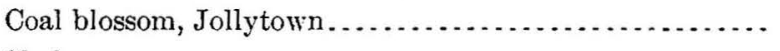 & & \\
\hline 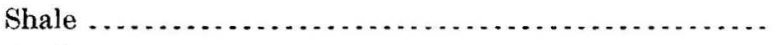 & 3 & 0 \\
\hline Sandstone . . . . . . . . . . . . . . & 4 & 0 \\
\hline Sandy shale $\ldots . . . \ldots \ldots . . . . .$. & 13 & 0 \\
\hline Sandstone .... & 1 & 0 \\
\hline Shale ......... & 12 & 0 . \\
\hline Sandstone . . . . . . . . . . . . . . . . . . . . . . & 6 & 0 \\
\hline Shale ........ & 4 & 0 \\
\hline Sandstone..... & 5 & 0 \\
\hline Shale ........ & $\check{5}$ & 0 \\
\hline 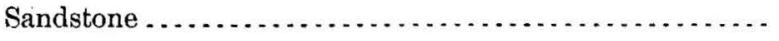 & $t$ & 0 \\
\hline Shale $\ldots . . \ldots \ldots \ldots \ldots \ldots \ldots$ & 23 & 0 \\
\hline$\ldots \ldots \ldots \ldots \ldots \ldots \ldots$ & 12 & 0 \\
\hline Shale ...... & 3 & 0 \\
\hline Sandstone......... & 2 & 0 \\
\hline 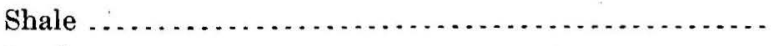 & 28 & 0 \\
\hline n. & 4 & 0 \\
\hline 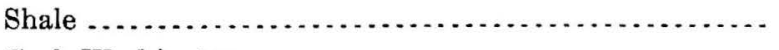 & 20 & 0 \\
\hline 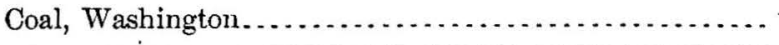 & 3 & 1 \\
\hline
\end{tabular}

b Quoted by I. C. White, Bull. U. S. Geol. Survey No. 65, p. 28, fig. 7, from Ohio Geol. Survey, Vol. II, p. 587, map xiii, sec. No. 11 . 


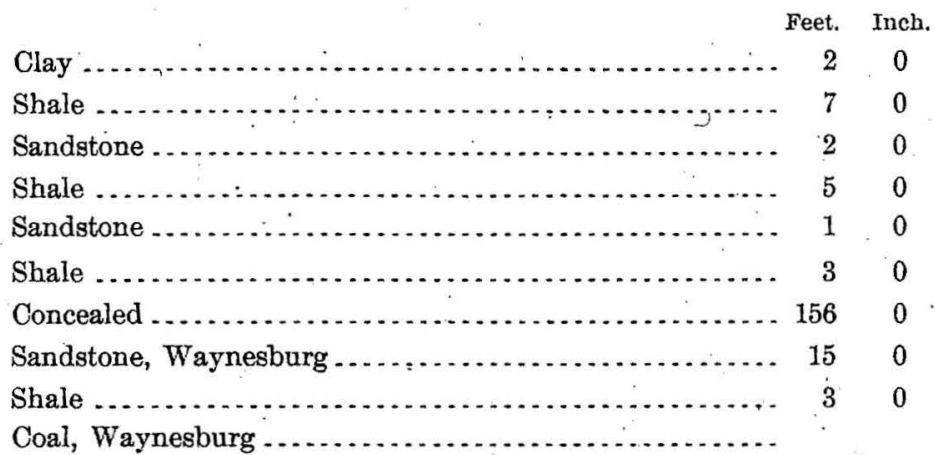

The following analyses give the composition of many of the several important grades of clay worked in Ohio: ${ }^{a}$

Analyses of Ohio stoneware clays.

\begin{tabular}{|c|c|c|c|c|c|c|c|c|c|c|}
\hline Gonstituent. & I: & 2. & 3. & 4. & 5. & 6. & 7 & 8. & 9. & 10. \\
\hline Silica (combined). & 25.60 & 28.61 & 23.88 & 27.68 & .27 .74 & 25.40 & 29.35 & 25.48 & 30.36 & 32.33 \\
\hline Alumina ............ & 19.08 & 23.01 & 19.31 & 22,95 & 23.08 & 21.13 & 23.05 & 20.80 & 24.88 & 26.60 \\
\hline Water (combined) & 5.57 & 8.03 & 5.08 & 6.74 & 6.88 & 6.29 & 7.39 & 5.72 & 6.96 & 7.57 \\
\hline 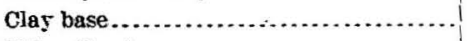 & 50.25 & 59.65 & 48.27 & 57.37 & 57. 70 & 52.82 & 59.79 & 52.00 & 62.20 & 66.50 \\
\hline Silica (free) $\ldots \ldots \ldots \ldots \ldots \ldots$ & 43.73 & 34. 79 & 45.91 & 36.58 & 35.73 & 40.81 & 35.85 & 42.65 & 33.19 & 24.11 \\
\hline Titanic aciđ .... & .29 & .35 & & & .... & .... & .55 & & & \\
\hline Sandy impurities.. & 44.02 & 35.14 & 45.91 & 36.58 & 35.73 & 40.81 & 36.40 & 42.65 & 33.19 & 24.11 \\
\hline Oxide of iron............... & 1.26 & 1.50 & 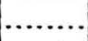 & 1.28 & 1.31 & 1.28 & .99 & 1.20 & 1.17 & 2.00 \\
\hline 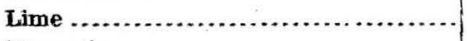 & .60 & .41 & $\cdots \cdots \cdots$ & .45 & .51 & .51 & .58 & .42 & .56 & .47 \\
\hline 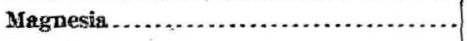 & .63 & .62 & .......... & .37 & .46 & .18 & .58 & .37 & .47 & .63 \\
\hline Potash............. & 2.14 & 1.26 & $\ldots$ & 1.81 & 1.71 & 1.42 & 1.45 & 2.28 & 2.27 & 3.20 \\
\hline Soda.......... & .02 & $\cdots \cdot$ & ....... & .15 & .22 & .38 & $\cdots$ & .27 & ....... & .26 \\
\hline Fluxing impurities...... & 4.65 & $3.81^{\circ}$ & 4.80 & 4.06 & 4.21 & 3.77 & 3.60 & 4.54 & 4.47 & 6.56 \\
\hline 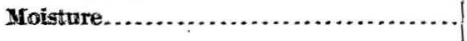 & .94 & 1.97 & 1.02 & $\cdot 2.05$ & 2.18 & 1.65 & 1.11 & 1.00 & 1.38 & 2.48 \\
\hline
\end{tabular}

1. Brumage's stoneware clay, Roseville.

2. Allen's stoneware clay, Roseville.

8. Walker's clay used for cooking wares, Roseville.

4. Zanesville Stoneware Company, clay ground in tracing mill for hand turning.

5. Zanesville Stoneware Company, same clay washed and pressed for use in jollies.

6. Bagley \& Roberts, Zanesville. Clay for cooking ware.

7. Uniontown stoneware clay.

8. Akron stoneware clay. A verage of several samples selected in different plants.

9. New Brighton, Pa. Sample from factory there for comparison.

10. Steubenville. Stoneware clay deficient in fire qualities. 
Analyses of Ohio shale clays used in the manufacture of paving brick and sewer pipe.

\begin{tabular}{|c|c|c|c|c|c|c|c|c|c|c|c|c|c|c|}
\hline Constituent. & 1. & 2. & 3. & 4. & 5. & 6. & 7. & 8. & 9. & 10. & 11. & 12. & 13. & 14. \\
\hline Silica (total) ........... & 57.15 & 58.30 & 57.10 & 49.30 & 57.45 & 55.60 & 58.20 & 58.38 & 57.28 & 57.40 & 53.38 & 56.18 & 52.19 & 56.61 \\
\hline Alumina .............. & 20.26 & 19.67 & 21.29 & 24.00 & 21.06 & 24.34 & 22.47 & 20.89 & 21.13 & 21.20 & 19.36 & 26.70 & 14.61 & 21.63 \\
\hline Water (combined) .... & 5.50 & 5.15 & 6.00 & 9.40 & 5. 90 & 6.75 & 6.15 & 7.53 & 5.22 & 7.75 & & & 5.62 & $\ldots .$. \\
\hline $\begin{array}{l}\text { Clay and sandy im- } \\
\text { purities....................... }\end{array}$ & 82.91 & 83.12 & 84.39 & 82.70 & 84.41 & 86.69 & 86.82 & 86.80 & 83.63 & 86.35 & & & 72.42 & \\
\hline Oxide of iron..... & 7.54 & 7.43 & 7.31 & 8.40 & 7.54 & 6.11 & 5.63 & 5.78 & 8.52 & 6.57 & 14.86 & 7.43 & 10.00 & 7.08 \\
\hline Lime...$\ldots \ldots \ldots \ldots$ & .90 & .84 & .29 & .56 & .29 & .43 & .62 & .44 & 5.79 & 1.00 & 1.48 & .52 & .... & 1.11 \\
\hline Magnesiu.............. & 1.62 & 1.35 & 1.53 & 1.60 & 1.22 & .77 & .98 & 1.57 & 2.13 & 1.40 & 1.06 & 1.12 & & 1.41 \\
\hline Potash....... & 3.05 & 3.04 & 3.44 & 3.91 & 3.27 & 3.00 & 3.08 & 4. 68 & & 4.10 & & & & 3.51 \\
\hline Soda...... & .58 & .73 & .61 & .19 & .39 & .09 & .42 & .34 & & 1.00 & & & ....... & .48 \\
\hline Fluxing impuritíes.... & 13.69 & 13. 39 & 13.18 & 14.63 & 12.71 & 10. 40 & 10.73 & 12. 81 & 16: 44 & 14.07 & & & 4.96 & $\cdots$ \\
\hline Moisture ....... & 2.70 & 2.65 & 1.30 & 1.20 & 1.90 & 2.65 & 1.65 & & & & & & 12.62 & \\
\hline
\end{tabular}

1. Shale used by Bucyrus Brick and Terra Cotta Company; mined at Glouster, on horizon of Cambridge limestone.

2. Same shale, with addition of one-fourth leached drift clay, added to increase plasticity; same place.

3. Shale from Royal Brick Company, Canton; from the horizon of Putnam Hill limestone.

4. Shale from Waynesburgh Brick and Clay Manufacturing Company; from the Middle Kittanning horizon.

5. Shale from the Ohio Paving Company, Columbus; mined at Darlington, from the Lower Kittanning horizon.

6. Shale and fire clay mixture, from the A. O. Jones Company, Zanesville; Kittanning horizon.

7. Shales and fire clays, mixed, from the T. B. Townsend Brick Company, Zanesville; Freeport shales and Kittanning fire clays.

8. Shales from Columbus Sewerpipe Company; Huron shale horizon.

9. Bedford shale; from northern Ohio.

10. Same shale, different sample and another chemist.

11. Shales from Royal Brick Works, Canton; Putnam Hill horizon.

12. Same shales from another opening.

13. Shales from Holloway Paving Brick Company, North Industry; Lower Mercer.

14. Average of first ten analyses. 
Analyses of Ohio fire clays used in paving brick and sewer pipe.

\begin{tabular}{|c|c|c|c|c|c|c|c|c|c|c|c|c|c|c|}
\hline Elements. & 1. & 2. & 3. & 4. & 5. & 6. & 7 & 8. & 9. & 10. & 11. & 12. & 13. & 14. \\
\hline Silica (total) & 54.53 & 51.72 & 51.82 & 62.81 & 57.80 & 64.10 & 70.00 & 57.75 & 59.75 & 65.90 & 77.65 & 59.20 & 58.10 & 56.71 \\
\hline Alumina. & 27.88 & 30.10 & 28.69 & 21.41 & 25.54 & 21.79 & 19.35 & 28.66 & .27 .45 & 24.20 & 12.78 & 26.10 & 29.60 & 33.72 \\
\hline Water ..................... & 8.87 & 9.95 & 9.67 & 6.52 & 8.35 & 6.05 & 5.39 & 8.35 & 5.45 & 4.80 & 4.10 & 8.55 & 8.70 & 6.89 \\
\hline $\begin{array}{c}\text { Clay and sand impuri- } \\
\text { ties ........................... }\end{array}$ & 91.78 & 91.77 & 90.18 & 90.74 & 91.69 & 91.94 & 94.65 & 95.76 & 92.65 & 94.90 & 94.53 & 93.85 & 96.40 & 97.32 \\
\hline Titanic acid . & 1.26 & 1.35 & .72 & 1.26 & & & & & & & & & & ...... \\
\hline Ferric oxid. & 2.41 & 1.94 & 2.77 & 2.65 & 2.51 & 2.51 & 2.22 & 1.94 & & 2.00 & 3.32 & 2.70 & 1.20 & \\
\hline Lime ......... & .42 & .62 & .77 & .58 & .25 & .10 & .15 & .15 & .75 & .80 & .55 & 1.05 & .40 & .29 \\
\hline Magnesia.. & .68 & .53 & 1.41 & .85 & .61 & .58 & .34 & .24 & .65 & .54 & .45 & .75 & .54 & 1.58 \\
\hline Potash..... & 3.31 & 2.74 & 2.57 & 2.89 & 2.51 & 2.62 & 2.90 & 2.55 & 3.58 & 2.30 & 1.30 & 1.53 & 1.75 & 1.01 \\
\hline Soda... & .12 & $\cdots \cdots$ & .25 & .21 & .18 & .03 & & & $\cdots$ & 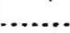 & .... & $\ldots$ & .... & ...... \\
\hline Fluxes . & 6.94 & 5.83 & 7.77 & 7.18 & 6.06 & 5.84 & 5.61 & 4.88 & 4.98 & 5.64 & .5 .62 & 6.03 & 3.89 & 2.88 \\
\hline Moisture . & .76 & 1.05 & 1.72 & 1.47 & 2.25 & 1.10 & & & & & & & & \\
\hline
\end{tabular}

1. N. U. Walkers, sewer-pipe clay, Columbiana County.

2. Freeman's sewer-pipe clay, Jefferson County.

3. Island Siding clay, Jefferson County; fit for sewer pipe.

4. Same clay, another sample.

5. E. Palestine, paving-brick clay, Upper Freeport horizon.

6. Massillon Fire Brick and Stone Company, mixture of fire clay with shale and surface clays used for paving blocks.

7. Toronto sewer-pipe clay, top.

8. Toronto sewer-pipe clay, bottom.

9. Average, top and bottom, Toronto.

10. Empire sewer-pipe clay.

11. Elliottsville sewer-pipe clay.

12. Elliottsville sewer-pipe clay.

13. Croxton Run sewer-pipe clay.

14. N. U. Walker's sewer-pipe clay. 
оніо.

Analyses of fint clays from Ohio.

\begin{tabular}{|c|c|c|c|c|}
\hline & 1. & 2. & 3. & 4. \\
\hline $\mathrm{SiO}_{2}($ combined $) \ldots \ldots \ldots \ldots$ & 35.39 & 35.72 & 44.34 & 59.92 \\
\hline $\mathrm{Al}_{2} \mathrm{O}_{3} \ldots \ldots \ldots \ldots$ & 31.84 & 29.62 & 40.05 & . 27.56 \\
\hline $\mathrm{H}_{2} \mathrm{O} \ldots \ldots \ldots \ldots \ldots$ & 11.68 & 8.71 & 14. 23 & 9.70 \\
\hline $\mathrm{SiO}_{2}$ (free) $\ldots \ldots \ldots \ldots$ & 17.13 & 20.65 & .26 & . \\
\hline $\mathrm{TiO}_{2} \ldots \ldots \ldots \ldots \ldots$ & 1. 68 & 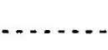 & $\cdots$ & \\
\hline $\mathrm{Fe}_{2} \mathrm{O}_{3} \ldots \ldots \ldots$ & .67 & 1. 14 & .80 & 1.03 \\
\hline $\mathrm{CaO} \ldots \ldots . . . . . . . . . .$. & .50 & .45 & .27 & Trace. \\
\hline $\mathrm{MgO}, \ldots \ldots \ldots \ldots \ldots \ldots \ldots \ldots$ & .19 & .14 & Trace. & Trace. \\
\hline $\mathrm{K}_{2} \mathrm{O} \ldots \ldots$ & .59 & .79 & Trace. & .67 \\
\hline $\mathrm{Na}_{2} \mathrm{O} \ldots \ldots \ldots \ldots$ & ...... & .29 & Trace. & ........... \\
\hline Moist $\ldots \ldots \ldots \ldots$ & .69 & 1.92 & .......... & 1. 12 \\
\hline ........ & 100.06 & 99.43 & 99.95 & 100 \\
\hline Fluxes................ & 1.95 & 2. 81 & 1.07 & 1.70 \\
\hline
\end{tabular}

1. Flint clay from C. E. Holden, Mineral Point, Lower Kittanning, 1883.

2. Same, finely ground and averaged, 1892.

3. Gaylord clay, Scioto County, Ohio, Portsmouth Fire Brick Company.

4. Salineville flint clay, Furnace Fire Brick Company, Salineville, Ohio.

PLEISTOCENE.

Pleistocene clays are found in all parts of the State, but they are used chiefly for common brick and drain tile. The alluvial clays along some of the rivers have been utilized for paving brick.

CLAY-WORKING INDUSTRY.

Ohio is the leading producer of clay products in the United States, producing the largest quantity of paving brick, fancy brick, sewer pipe, tile (other than drain), and all grades of pottery except chinaware, sanitary ware, and electrical supplies. The common brick industry is well developed at many localities, being based specially on the surface or drift clays, which are common in nearly all parts of the State. Yards are located chiefly around the cities of Cleveland and Columbus.

The great abundance of fire clays and red-burning shales form the basis of a flourishing pressed-brick industry, and many are made both by the stiff mud and dry press process. Among the localities at which this class of products is made may be mentioned Columbus, Shawnee, Portsmouth, and Cleveland.

Paving bricks are made in enormous quantities from the Carboniferous shales and fire clays of low grade found in the Coal Measures of the eastern half of the State. In a few cases the surface clays are drawn upon, as in the Ohio Valley, 
where the alluvial river clays are employed. The distribution of the paving-brick plants in this State can be seen from the map, PI. VIII. The Ohio paving bricks, especially those made at Canton and other localities, bear a high reputation.

Terra cotta is manufactured in very small quantities in Ohio notwithstanding. the leading position which she occupies in the line of clay-working States.

Floor tile of plain colors and the encaustic variety form an important item of production, being partly from native shales and fire clays at Zanesville and Hamilton. Roofing tile of the Roman type are produced at Akron, and glazed tile at Hamilton.

In the production of fire brick Ohio stands second to Pennsylvania, but those made from the well-known fire clays occurring at Mineral Point, Portsmouth, Sciotoville, Haydenville, etc., bear a high reputation.

It is in the pottery industry that Ohio becomes especially prominent. Stoneware is made in vast quantities from the shales and impure fire clays of the Coal Measures, factories being located at Steubenville, East Liverpool, Palestine, Zanesville, Mogadore, Massillon, Roseville, and other towns. Rockingham and yellow ware are also produced, though the value is not more than one-quarter that of the stoneware. Yellow and Rociringham are important products, but are not manufactured to the same extent as stoneware, although they are among the earlier forms of ware made in the State. Red earthenware is a product of equal importance. White ware, chiefly of the C. C. and white granite variety, is actively produced at East Liverpool, which is one of the two great potting centers of the United States, the ware made here supplying the western more than the eastern markets. Other whiteware factories are in operation at Tiffin, East Palestine, Akron, Steubenville, Wellsville, Toronto, etc. The Rookwood pottery, made at Cincinnati, and the Weller pottery, manufactured at Zanesville, form a grade of art pottery which is unlike any produced elsewhere.

Some china is produced at East Liverpool, and electrical supplies are manufactured at the same city, but the quantity manufactured is not so large as that molded in New Jersey or New York.

Sewer pipe is turned out in great quantities at Akron, the production being controlled by a few large corporations; in fact, Obio at the present time represents the center of the sewer-pipe industry.

The total value of clay products for the last seven years is given below, together with the itemized produetion for $\mathrm{J} 900$. 
Value of clay products of Ohio from 1894 to 1901.

\begin{tabular}{|c|c|c|c|}
\hline Year. & Value. & Rank. & $\begin{array}{l}\text { Proportion } \\
\text { of United } \\
\text { States. } \\
\text { product. }\end{array}$ \\
\hline $1894 \ldots \ldots \ldots$ & $\$ 10,668,498$ & 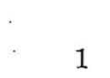 & $\begin{array}{c}\text { Per cent: } \\
16.52\end{array}$ \\
\hline 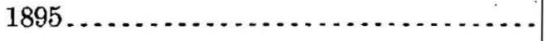 & $10,649,382$ & 1 & 16. 30 \\
\hline $1896 \ldots \ldots \ldots$. & $10,609,571$ & 1 & 15. 96 \\
\hline 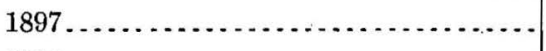 & $11,067,684$ & 1 & 17.75 \\
\hline 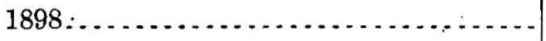 & $12,667,627$ & 1 & 17.34 \\
\hline 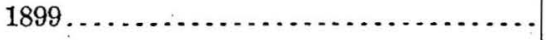 & $16,500,625$ & 1 & 17.22 \\
\hline $1900 \ldots \ldots . . . .$. & $18,304,628$ & 1 & : 19.03 \\
\hline 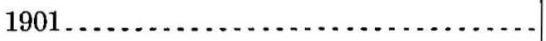 & $21,574,985$ & 1 . & 19.58 \\
\hline
\end{tabular}

Value of clay products of Ohio in 1900 and 1901.

\begin{tabular}{|c|c|c|}
\hline & 1900. & 1901. \\
\hline Common brick.. & $\$ 2,232,090$ & $\$ 2,725,912$ \\
\hline Front brick $\ldots \ldots \ldots \ldots \ldots \ldots \ldots$ & 433,086 & 612,718 \\
\hline Vitrified brick $\ldots \ldots \ldots \ldots \ldots \ldots \ldots$ & $1,118,106$ & $1,443,537$ \\
\hline Fancy brick ............. & 47,155 & 60,908 \\
\hline 'Fire brick ............... & $1,340,775$ & $1,287,059$ \\
\hline Stove linings....... & $(a)$ & $(a)$ \\
\hline Drain tile................ & 715,874 & 707,409 \\
\hline Sewer pipe . . . . . . . . . . . . . . & $2,243,386$ & $2,735,703$ \\
\hline Terra cotta $\ldots \ldots \ldots \ldots$ & 2,857 & $(a)$ \\
\hline Fireproofing $\ldots \ldots \ldots \ldots \ldots \ldots$ & 351,884 & 357,284 \\
\hline Tile (not drain) $\ldots \ldots \ldots \ldots \ldots$ & 690,257 & 996,005 \\
\hline 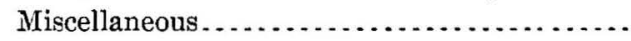 & 491,735 & 599,682 \\
\hline 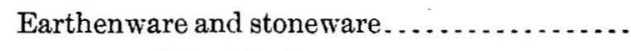 & 949,451 & 952,329 \\
\hline 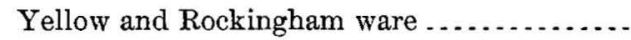 & 175,176 & 206,843 \\
\hline C. C. ware........................ & $1 ; 056,226$ & 726,321 \\
\hline White graniteware...$\ldots \ldots \ldots$. & $2,767,837$ & $2,710,726$ \\
\hline Semivitreous porcelain ware $\ldots . . . \ldots \ldots \ldots$ & $2,251,213$ & $3,520,008$ \\
\hline 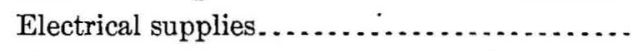 & 247,135 & 325,664 \\
\hline Miscellaneous pottery $\ldots \ldots \ldots \ldots$ & 549,994 & 400,957 \\
\hline Clay, mined $\ldots \ldots \ldots \ldots \ldots \ldots \ldots \ldots \ldots \ldots \ldots$ & 143,547 & 152,785 \\
\hline
\end{tabular}

$a$ Included in miscellaneous. 
PENNSYLVANIA.

The geologic formations of Pennsylvania range from the early pre-Cambrian crystalline rocks to the youngest formations of the Pleistocene.

In the western portion of the State, except the northwestern counties, the rocks are almost all of Carboniferous age. The beds are bent into a series of gentle folds; but often the exposure of the lower or older beds is due partly to the overlying beds having been worn away.

To the east the rocks become highly folded in the central counties of the State, so that the strata often have a very steep dip, and not only the Carboniferous but also the lower-lying Devonian and Silurian formations are exposed, giving rise to bands which extend in a general northeast-southwest direction.

The eastern portion of the State is underlain largely by crystalline rocks and more or less altered Cambrian and Ordovician sediments, which in many cases yield a mantle of residual clay that may be of considerable economic value.

In the extreme eastern portion of the State there is a narrow strip of Coastal Plain formations, but with the exception of the Columbia loams they have little value in Pennsylvania. North of the line of the terminal moraine the drift clays are not uncommon and are found in many of the river valleys.

RESIDUAL CLAYS.

These may occur at almost any locality in the area lying south of the region covered by the glacial drift. The causes governing their formation and distribution have been explained on a previous page. The most important belt of these deposits is probably that found in the Great Valley, all along the line of which, as well as in the South Mountain region, there are great quantities of white and variegated clays. These clays have been derived from the decomposition of hydromica slates, which are interstratified with Ordovician limestones and quartzites, talcose slates, and limestones of Cambrian age. In places the deposits contain iron ores, which have been worked, but the widespread utilization of the clays for the manufacture of clay products is comparatively recent, although mention is made of their former use for making bricks ${ }^{a}$ and in paper manufacture. ${ }^{b}$ 
The composition of such a clay from the Hunter mine, on the Kemp farm, is as follows:

Analysis of clays from Hunter mine, on Kemp farm.

\begin{tabular}{|c|c|}
\hline Silica & 66.17 \\
\hline Alumina .......... & 19.89 \\
\hline Lime............ & .26 \\
\hline Magnesia .................... & 1.902 \\
\hline Iron protoxid..................... & .783 \\
\hline Alkalis and undetermined $\ldots . . . \ldots \ldots \ldots$. & 6. 211 \\
\hline 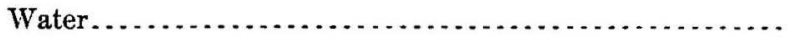 & 4. 784 \\
\hline
\end{tabular}

The clays are referred to in the Pennsylvania reports, ${ }^{a}$ but from the standpoint of the clay worker the most recent important paper is one by T. C. Hopkins, ${ }^{b}$ according to which a kaolin deposit lies $1 \frac{1}{2}$ miles north of Glen Loch station, on the north side of Little Chester Valley. This kaolin is near the contact of the Chester Valley (Ordovician) limestone and the North Valley Hill (probably Cambrian) sandstone. It is said to show great similarity to the South Mountain kaolins of Cumberland, Franklin, Adams, and York counties.

"The most extensive developments have been on the Gettysburg Railway, south of Mount Holly, and on the Hunters Run and State Belt Branch Railway. Although known for a long time, the commercial introduction of these clays is of recent date. The white clay is found in many of the ore mines which were worked in former years, and may either underlie or overlie the ore.

"Another clay-washing plant is working a deposit of clay a mile east of Henry Clay station, the pits being sunk on the mountain side and having a depth of 90 to 100 feet. At Cranes siding, 1 mile above the Hunter Run station, is a deposit of clay which is worked to supply a clay-washing plant also located here. The kaolin comes from the old Crane iron ore mine, where it underlies the ore on the south slope of South Mountain. The mining is done by tunneling, and the clay run out on tram cars. It is used for paper filler and pottery."

Though these clays occur over a large portion of southeastern and central Pennsylvania, the most productive localities are South Mountain, Cumberland County; Mertztown, Berks County; and Ore Hill, near Roaring Springs, in Blair County. Pits have also been opened at the Upper Mill station on the Hanover and Gettysburg Railroad, at Cranes Siding, Henry Clay, and Lowell station on the Hunters Run and State Belt Railroad, at Montello, near Reading (worked for fire brick), north of Glen Loch station, in Little Chester Valley, and north of Conshohocken.

$a$ Notably D 3.

3 The white clays of southeastern Pennsylvania: Eng. Min. Jour. Vol. LXX, p. 131; and article on Kaolin: Min. Indus., Vol. VII, p. 156. Most of the information under this heading, where not credited to the Pennsylrania geological survey, has been obtained from these two papers.

$$
9647 \text {-No. } 11-03-14
$$


Paper clay is obtained from a point one-half mile south of Mertztown, Berks County, and kalsomine clay at Maple Grove, southeast of Mertztown. Other deposits of white clay are seen in many of the old ore pits in Berks and Lehigh counties, notably Ironton; Klines Corners, Friedensville, west of Kutztown, on Neversink Mountain, at Reading. Residual clays are also found in Caln Township, Chester County, having been derived from hydromica schist, which is interbedded with limestone. $^{a}$ In east Caln Township, near Baldwins station, variegated clays occur. ${ }^{b}$ Other localities are in west Whiteland Township, the type of variegated clay being one commonly found in York and Lancaster counties. ${ }^{c}$ Still other deposits occur northwest of Whitehorse, in east Whiteland township, ${ }^{d}$ near Warren Tavern postoffice, ${ }^{e}$ and New Garden township. $f$ Red residuals are known in Penn Township, Chester County..$^{\prime}$ Small deposits of white residual clay have been mentioned as occurring 1 mile from Truemans Mill. ${ }^{h}$ The residual clays found near Hanover have been used for making bricks. ${ }^{i}$

The white clays have been used to some extent for chinaware, but their chief application is in paper manufacture and for kalsomining. They have also been employed in the manufacture of white brick encaustic tiles, stove linings, and fire brick.

"The first use made of the clay was in 1893, when the Penn Tile Works were established at Asper, about the same time that the brick works at Pine Grove began operations. About three years later two clay-washing plants were established on Mountain Creek, between Pine Grove and Mount Holly Springs.

"The works at Pine Grove manufacture ornamental bricks of different kinds. The white clay, together with some colored clay, is used simply as a bond, the body of the material being a slate for reddish colored brick, and a greenish talcose slate for light colored ones. The slate is brought to the works by railway from the slate quarry, 3 miles to the southwest, the talcose rock is hauled from a quarry three-quarters of a mile distant, and the clay is brought by rail from Laurel station, also 3 miles distant."

A second type of white residual clays or kaolin are those of Delaware and Chester counties which have been formed by the weathering of pegmatite veins. These deposits have been worked for a number of years, especially those near Kaolin postoffice, in Chester County, where kaolin has been dug since 1839. The vein here occurs in mica-schists and strikes northeast-southwest, having a width of 120 to 150 feet, with at least one parallel vein. Near the surface the color of the kaolin is buff or yellow, due to the intermixture of soil from neighboring rocks. The clay is mined by means of circular shafts with temporary erib-work linings. These have a depth usually of 80 to 100 feet, but one reached 130 feet. The kaolin is washed and the separated sand is used in part for silica brick and in part is ground and sold to the

a Second Pennsylvania Geol. Survey, Rept. C 4, p. 272.

$b$ Ibid., p. 274 .

c Ibid., p. 275.

albid., p. $2 \pi 7$.

e' Ibid., p. 279. 
potteries as flint. The washed kaolin is shipped to the potteries at East Liverpool, Ohio, and Trenton. N. J.

Other mines occur near Brandywine Summit, in Delaware County, and up to 1895 the kaolin mined at these was washed. Since that time the production of white kaolin has ceased, and one of the two companies located at this locality is engaged in mining feldspar from the pits, while the other is utilizing, for the manufacture of oruamental brick, ${ }^{i}$ the poorer kaolin, which had been thrown on the dump in former years.

At Elam post-office, about 3 miles southeast of the Brandywine Summit kaolin mines, is a white clay which Hopkins considers to be the waste from some kaolin vein. It was worked at one time for the manufacture of fire brick.

Analyses of Pennsylvania white residual clays.

\begin{tabular}{|c|c|c|c|c|c|c|c|c|c|c|}
\hline & 1. & 2. & 3. & 4. & $\tilde{5}$. & 6. & 7. & 8. & 9. & 10. \\
\hline $\mathrm{Al}_{2} \mathrm{O}_{3} \ldots \ldots \ldots \ldots \ldots$ & 9.44 & 17.30 & 17.43 & 31.29 & 26.96 & 26.12 & 20.10 & 31.29 & 36.25 & 20.53 \\
\hline $\mathrm{SiO}_{2} \ldots \ldots \ldots$ & 84.05 & 73.80 & 73.30 & 51.90 & 59.83 & 60.37 & 67.10 & 51.90 & 46.26 & 67.71 \\
\hline $\mathrm{H}_{2} \mathrm{O} \ldots$ & 2. 18 & 4.69 & 4.68 & 8.90 & 9.56 & 5.42 & 5.90 & 8.90 & 13.54 & 3.12 \\
\hline $\mathrm{Fe}_{2} \mathrm{O}_{3} \ldots \ldots \ldots$ & 0.28 & 0.35 & 0.37 & Tr. & 1.98 & 0.69 & 3.90 & $\because$ & 1.64 & 7. 78 \\
\hline $\mathrm{CaO}$. & 0.23 & $\ldots$. & 0.02 & Tr. & 0.11 & 0.05 & 0.10 & Tr. & 0.19 & 0.39 \\
\hline $\mathrm{MgO} \ldots . . .$. & 1.35 & 1. 18 & 1. 28 & 1.52 & $0 . \overline{50}$ & 1.93 & 0.70 & 1.52 & 0.32 & 0.04 \\
\hline $\mathrm{K}_{22} \mathrm{O} \ldots$ & 2.37 & 2.49 & 2.99 & 4.01 & 0.94 & 5. 74 & 2.00 & 4.01 & 1. 69 & .29 \\
\hline $\mathrm{Na}_{2} \mathrm{O} \ldots \ldots$. & 0.28 & 0.20 & 0.17 & 2.99 & 0.24 & 0.29 & & 2.99 & 0.85 & .20 \\
\hline Total . & 100.18 & 100.01 & 100.24 & 100.61 & 100.12 & 100.61 & 99.80 & 100.61 & 100.74 & 99.86 \\
\hline & & & 11. & 12. & & 13. & 14. & 15. & 5. & 16. \\
\hline Sand. & & & 37.17 & 10. & & 51.30 & 45.52 & & 0.16 & 30.46 \\
\hline Feldspar . . . . . . . . & & & 0.54 & 0 . & 19 & 2. 66 & 1. 31 & & 1. 19 & 1.62 \\
\hline Anhydrous clay ..... & 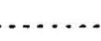 & $\ldots$ & 56.75 & 84. & & 42.16 & 49.77 & & 6.35 & 59.90 \\
\hline Water .............. & & & 5.54 & 4. & 38 & 3.88 & 3.40 & & 2.30 & 8.02 \\
\hline Total ........ & .. & $\therefore$ & 100.00 & 100. & & 100.00 & 100.00 & & 0.00 & 100.00 \\
\hline
\end{tabular}

1. Crude white clay, Upper Mill.

2. Refined white clay, Upper Mill.

3. Mixed white clay, Mount Holly.

4. White land white clay, Chester County.

5. Conshohocken, parti-colored clay.

6. Barren Hill gray clay.

7. Chestnut Hill.

8. Glen Loch.
9. Brandywine Summit.

10. Brandywine Summit.

11. Jno. Allen's white clay, South Mountain.

12. Philadelphia Clay Company, South Mountain.

13. Mr. Hooper, South Mountain.

14. White clay, Latimore.

15. Damourite slate, Latimore.

16. Conshohocken parti-colored clay. 
SILURIAN AND DEVONIAN.

The formations of these series, which contain vast beds of shale, occupy a large area in the eastern and south-central portion of Pennsylvania and should afford an excellent field of exploitation for the clay worker.

The Devonian is found over large areas in the extreme northwestern corner of the State in Erie County, as well as in Tioga, Bradford, Susquehanna, Wayne, and Pike counties. In the eastern counties the beds are apt to be sandy. To the south and southeast the rocks are much folded, and the Devonian and Silurian formations appear as a series of bands in Lackawanna, Luzerne, Carbon, Cumberland, Snyder, Juniata, Perry, and other counties, and the shale beds found in them are worked at several localities for the manufacture of both building and paving brick. Their general distribution is indicated on the map (PI. III), but for more detailed information the map issued with the Final Summary Report of the Pennsylvania Geological Survey for 1893 should be consulted. For locating suitable shale beds in these formations it would be necessary to do more or less field work. The Clinton shales have been dug for brickmaking near Laurelton and Hartleton townships of Union County. ${ }^{a}$ Mr. A. W. Sheafer, of Pottsville, informs me that the shales are worked at Pine Grove, Williamsport, Sandy Run (Mauch Chunk shale), and Reading (Hudson shale).

\section{CARBONIFEROUS.}

The clays and shales derived from the Carboniferous rocks of Pennsylvania are foremost among this type of economic deposits found in the State. They include a wide range of materials, from impure sandy shales, of little value except for the manufacture of common brick, up to the highest grade of refractory clay. It is impossible to enter upon a detailed discussion of these shales in the space which is here available, and unfortunately, but little information regarding them is to be found in the reports of the Pennsylvania Geological Survey, for at the time these were written shales had not come into extensive use for the manufacture of clay products, but the abundance of them is shown by the various published sections given in these reports under the different counties, and also by the sections on page 232 . Of more importance, however, are the fire clays, which often occupy well-marked stratigraphic positions, and in some places form persistent and important beds that are traceable over wide areas.

The Carboniferous rocks cover a large portion of the western half of Pennsylvania, as is shown on the accompanying map (Pl. III), and from what follows it will be seen that the refractory beds of aluminous materials have received much attention in the various geologic publications. The occurrences are taken up in regular order, beginning with the oldest.

$$
\text { CONGLOMERATE GROUP. }
$$

This member of the Carboniferous is composed chiefly of sandy beds, as sandstone and conglomerates, but there are several beds of shale and coal. The latter are often underlain by shale and in some instances by fire clay. 
MERCER OR ALTON FIRE CLAYS

On the Wilmarth coal tract, southwest of Wilmarth station, Elk County, the Alton upper coal is found to be underlain by a fire clay, ranging from 20 to 61 feet thick, the section as exposed at an air shaft being given below. ${ }^{a}$ It is probable that this entire thickness does not represent pure fire clay.

Section southwest of Wilmarth station, Elk County, Pa.

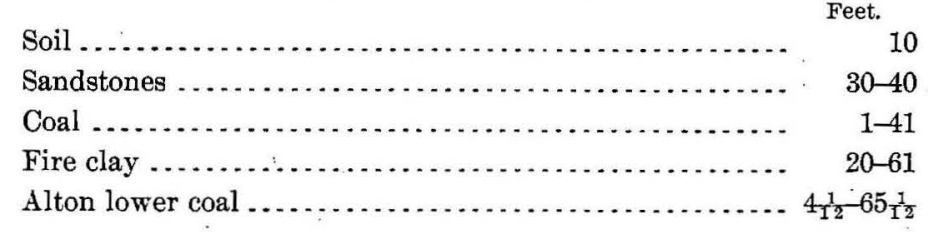

The following analyses, No. 1 by J. M. Stinson and No. 2 by A. S. McCreath, show the composition of this clay:

Analyses of Mercer or Alton fire clay from Pennsylvania.

\begin{tabular}{|c|c|c|}
\hline$\cdot$ & 1. & 2. \\
\hline Silica $\ldots \ldots \ldots \ldots \ldots \ldots \ldots$ & 51.72 & 56.27 \\
\hline Alumina $\ldots \ldots \ldots \ldots \ldots$ & 21.736 & 23.225 \\
\hline Iron protoxide $\ldots \ldots \ldots \ldots \ldots$ & 7.875 & 5.4 \\
\hline Titanic acid. . & .87 & 1. 19 \\
\hline Lime...$\ldots \ldots \ldots \ldots \ldots \ldots$ & .06 & .01 \\
\hline Magnesia . . . . . . . . . . . . . & 2.378 & 2.086 \\
\hline Alkalies .................. & 4.581 & 4.039 \\
\hline Ignition $\ldots \ldots \ldots$ & 10. 78 & 7.78 \\
\hline Total... & 100.00 & 100.00 \\
\hline
\end{tabular}

At Parker Township, in northern Butler County, between Columbia Hill, in Allegheny Township, and Donnelly station, ${ }^{b}$ the following section is shown:

Section in Parker Township, Butler County, Pa.

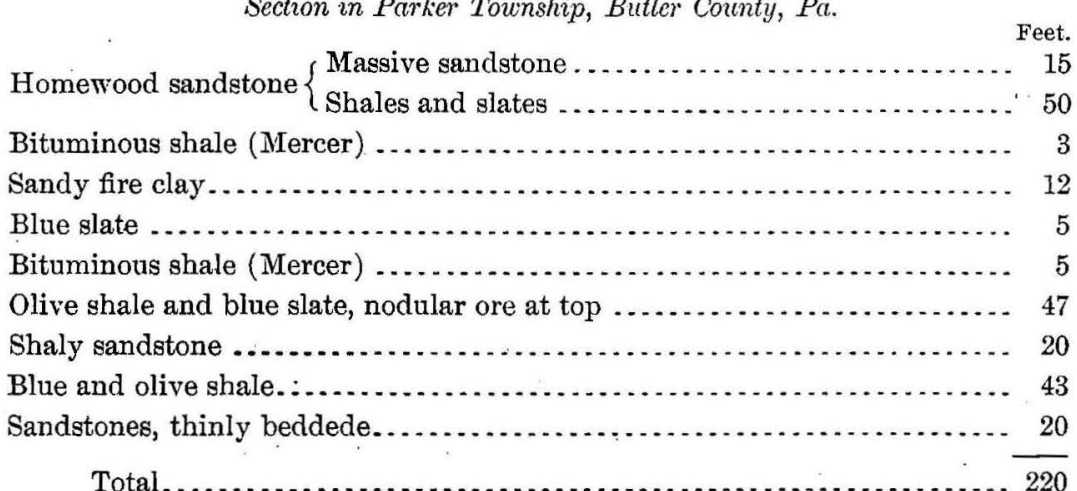

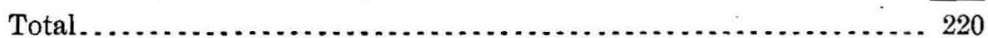

a Second Pennsylvania Geol. Survey, Rept. RR, p. $140 . \quad$ b Idem, Summary Final Rept., Vol. III, Pt. I, p. 1897. 
On Millers Run, in the Broadtop district, the Mercer coal is underlain by 10 . to 15 feet of fire clay, while at Robertsdale, Huntington County, it is said to be only 1 to 2 feet thick.

In Beaver, Lawrence, and Mercer counties ${ }^{a}$ there seems to be several shale beds, but no fire clays. In the columnar sections given in the atlas of Rept. RR., Second Pennsylvania Geological Survey, fire clays are indicated under the Alton coals of the Pottsville conglomerate at Lafayette, Clermont, and on the Butterfield lands, McKean County; at Johnson Run, Norwich, and Benezette, Elk County; and at Cameron, Cameron County.

\section{THE SHARON OR MARSHBURG UPPER COAZ FIRE CLAY.}

In Elk County a bed of fire clay is often found associated with the upper Marshburg coal bed between the Olean conglomerate and the Kinzua Creek sandstone. It is frequently of sufficient thickness and of proper quality to be worth mining. This bed has been worked in western Benezette Township, between Benezette and Rock Hill, Elk County, and again $1 \frac{1}{2}$ miles southwest of Benezette, where it ranges from 4 to 9 feet in thickness, but may be less. ${ }^{b}$ Fig. 5 shows the section at Benezette. At one locality it was 50 feet above the Mauch Chunk red shale. The fire clay also underlies the coal in Spring Creek Township on Laurel Kun. The following analyses indicate the composition of this clay:

Analyses of Sharon or Marshburg Upper Coal fire clay.

\begin{tabular}{|c|c|c|c|}
\hline Elements. & 1. & 2. & 3. \\
\hline Silica. $\ldots \ldots \ldots \ldots \ldots$ & 44.45 & 44.045 & 44.960 \\
\hline Alumina ....... & 38.945 & 39.445 & 38.172 \\
\hline Iron protoxide.... & 2. 135 & .940 & .513 \\
\hline Titanic acid............. & ....... & $\ldots . . . .$. & 1. 240 \\
\hline Lime............ & .173 & .075 & .12 \\
\hline Magnesia .......................... & .155 & .115 & .084 \\
\hline Alkalies . . . . . . . . . . . . . . . & .760 & .720 & .071 \\
\hline Sulphuric acid $\ldots \ldots \ldots \ldots \ldots \ldots$ & Trace. & Trace. & \\
\hline Water and organic matter ........... & 13.287 & & 14.840 \\
\hline Total. & 99.905 & 99.478 & 100.900 \\
\hline
\end{tabular}

1. Jones mine, hard, compact, conchoidal fracture, and pearl gray.

2. Fletcher mine, similar.

3. Barr and Radcliff mine, hard and brittle.

All three analyzed by A. C. McCreath.

In Mercer County the Sharon coal is underlain by fire clay in places. ${ }^{c}$

a H. M. Chance, Second Pennsylvania Geol. Surver, Rept. V, Pt. II, p. 190 et seq.

bIdem, Rept. RR, p. 260

c Idem, Rept. Q3, p. 33. 
SAYAGE MOUNTAIN FIRE CLAY.

In the report on Bedford and Fulton counties it is stated that no good plastic fire clay was seen in the Broadtop region, and that most of the clays contained considerable iron. The Savage Mountain fire clay reaches the. southwest corner of Bedford County in Londonderry Township. No exposures of it are found, but it is mined on the Baltimore and Ohio Railroad in Somerset County, just beyond the line of Bedford County. The deposit in places reaches a thickness of 21 feet. . Much of the clay makes only second-grade products, but at least one-half in the present workings makes bricks of first quality. These clays make excellent coke-oven bricks. Analyses of the clays are given below.

Analyses of Savage Mountain fire clay from Somerset County.

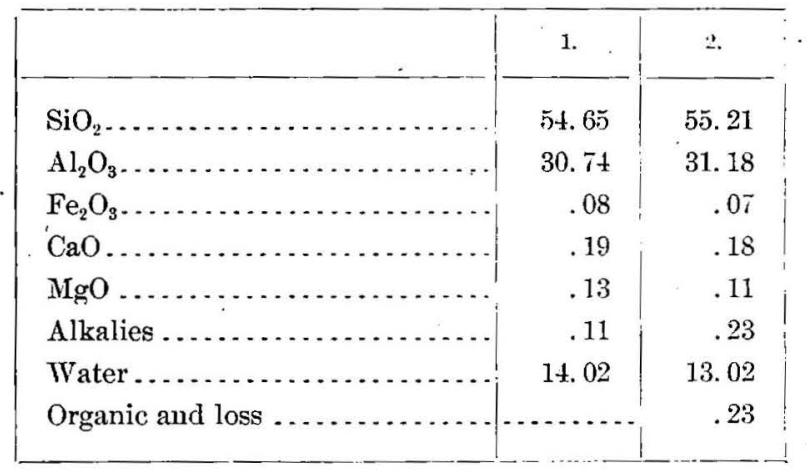

LOWER PRODUCTIVE MEASERES.

These contain a number of important fire-clay beds, as may be seen from the following sections: ${ }^{b}$

Section of Lower Productive Measures in vicinity of Bolivar and Lockport, Pa.

Upper Freeport coal, bed E...................... $8 \begin{gathered}\text { Feet. Ineh } \\ 8\end{gathered}$

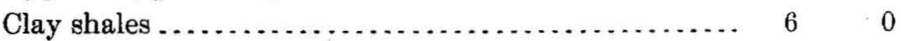

Shales with ore masses ...................... $3 \quad 0$

Sandstone and sandy shales. . . . . . . . . . . . . . . . $10 \quad 0$

Fire clay, worked........................... $3 \quad 0$

Limestone, impure....................... s 8

Thin-bedded sandstones...................... $7 \quad 0$

Clays, slates, and shales ....................... $15{ }^{2} \quad 0$

Lower Freeport coal, bed D................... 2-3 0

Clay, impure.............................. $3 \quad 0_{0}$

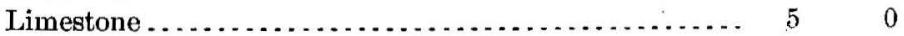

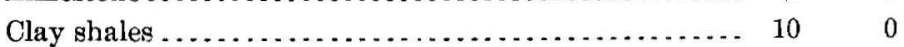

Sandstones ............................... $7 \quad 0$

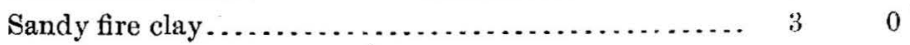

Slates and shales............................ $20 \quad 0$

a Second Pennsylvania Geol. Survey, Rept. TT, p. 336 b Idem, Rept. Hõ, p. 88. 
Section of Lower Productive Measures in vicinity of Bolivar and Lockport, Pa.-Continued.

\begin{tabular}{|c|c|}
\hline Sandstones ......... & $\begin{array}{c}\text { Feet. } \\
10\end{array}$ \\
\hline Gray slates $\ldots \ldots \ldots \ldots \ldots \ldots$. & 6 \\
\hline Coal bed $D \ldots \ldots \ldots \ldots$ & 1 \\
\hline Fire clay, impure $\ldots \ldots \ldots \ldots \ldots \ldots \ldots$ & 6 \\
\hline Limestone, Johnstown cement bed. . . . . . . . & $2-4$ \\
\hline Dark slates and shales $\ldots \ldots \ldots \ldots \ldots \ldots \ldots \ldots \ldots$ & 20 \\
\hline Sandy shales with ore nodules $\ldots \ldots \ldots \ldots \ldots \ldots \ldots$ & 20 \\
\hline Carbonate iron-ore band $\ldots \ldots \ldots \ldots \ldots \ldots \ldots$ & 0 \\
\hline 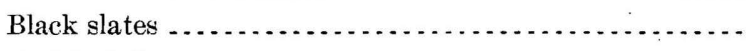 & 10 \\
\hline 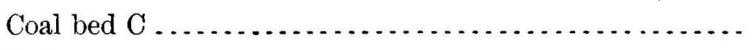 & 1 \\
\hline Slates $\ldots \ldots \ldots \ldots \ldots \ldots \ldots \ldots \ldots \ldots$ & 8 \\
\hline Shales............... & 10 \\
\hline Black slate and shale................. & 30 \\
\hline Coal bed $B . . . \ldots \ldots . . . .$. & 5 \\
\hline Clay $\ldots \ldots \ldots \ldots \ldots \ldots \ldots \ldots \ldots$ & 5 \\
\hline 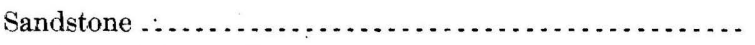 & 10 \\
\hline 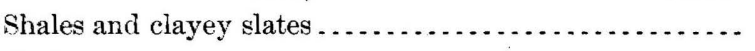 & 13 \\
\hline 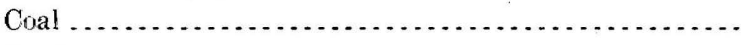 & 7 \\
\hline 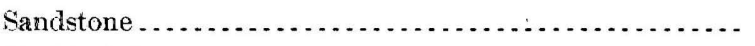 & 5 \\
\hline 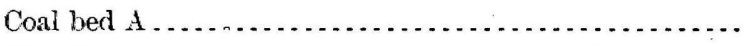 & 1 \\
\hline 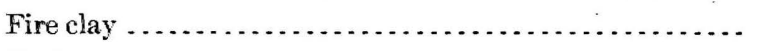 & 2 \\
\hline 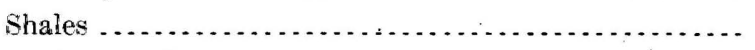 & 10 \\
\hline Sandstones, heavy compact............... & 30 \\
\hline Coal bed $A \ldots \ldots \ldots \ldots \ldots \ldots \ldots \ldots$ & 1 \\
\hline 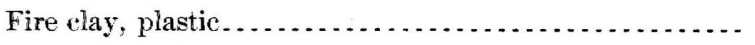 & 4 \\
\hline 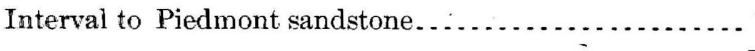 & 15 \\
\hline
\end{tabular}

Section of Lower Coal Measures at Karthaus, Clearfield County, Pa.

[See fig. 6.]

Coal, Upper Freeport

... $6 \quad 6$

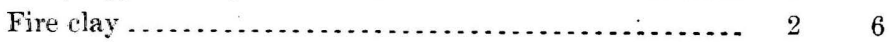

Sandstone, brown ............................. $45 \quad 0$

Coal ......................................... 10

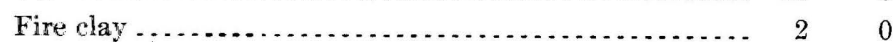

Limestone, silicerous............................... 36

Shale ........................................ 1 . 0

Sandstone, brown............................... $26 \quad 0$

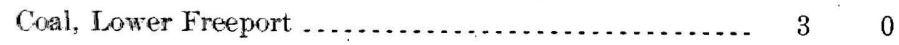

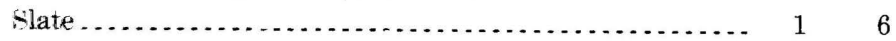

Sandstone, gray, Freeport ..................... $37 \quad 0$

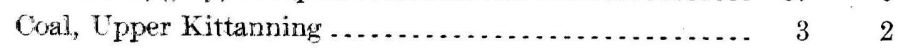

shale, containing irom ore ...................... 110

Coal, Middle Kittanning ........................ 10

Sandstone and slate......................... $21 \quad 0$ 


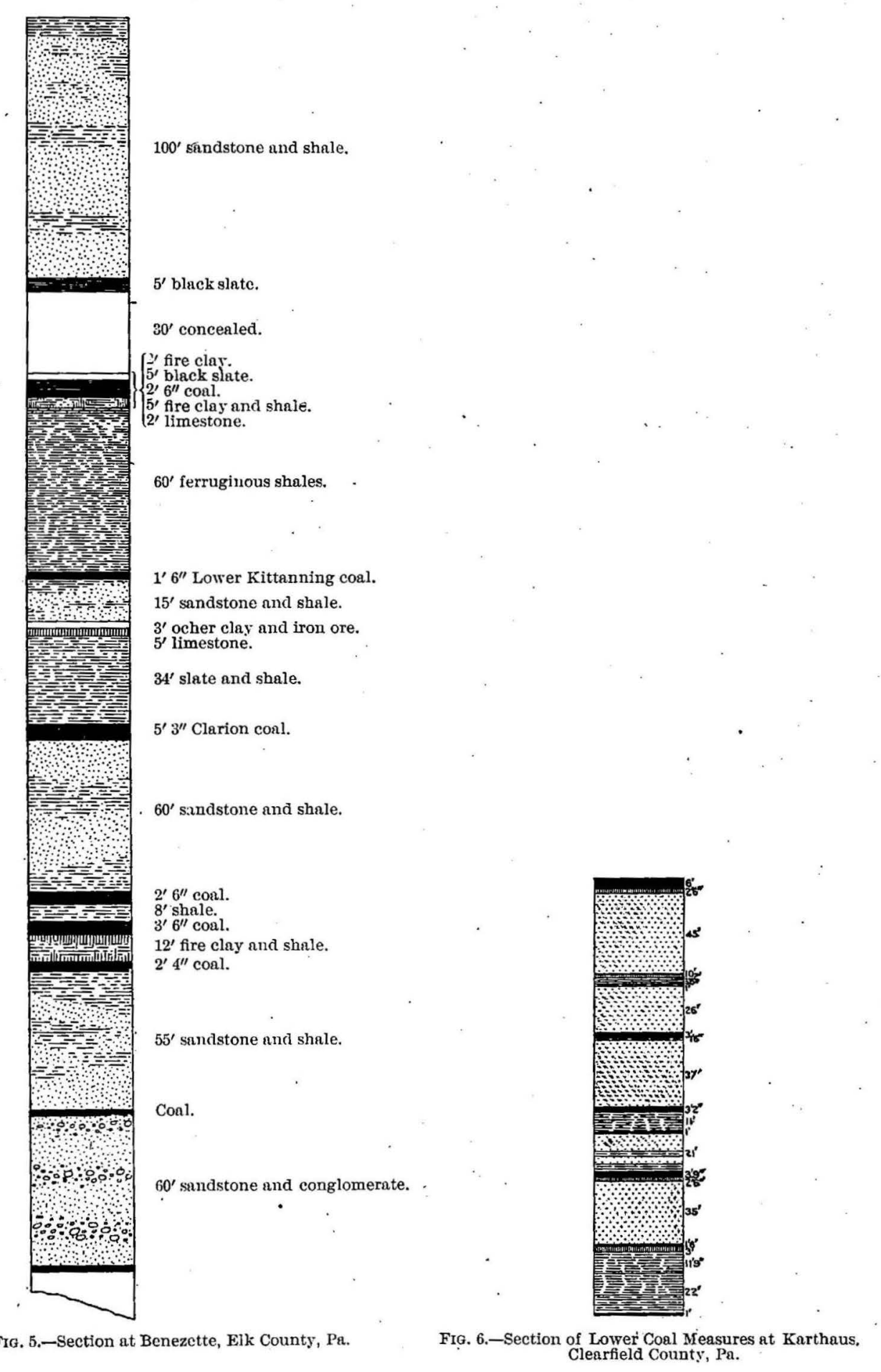




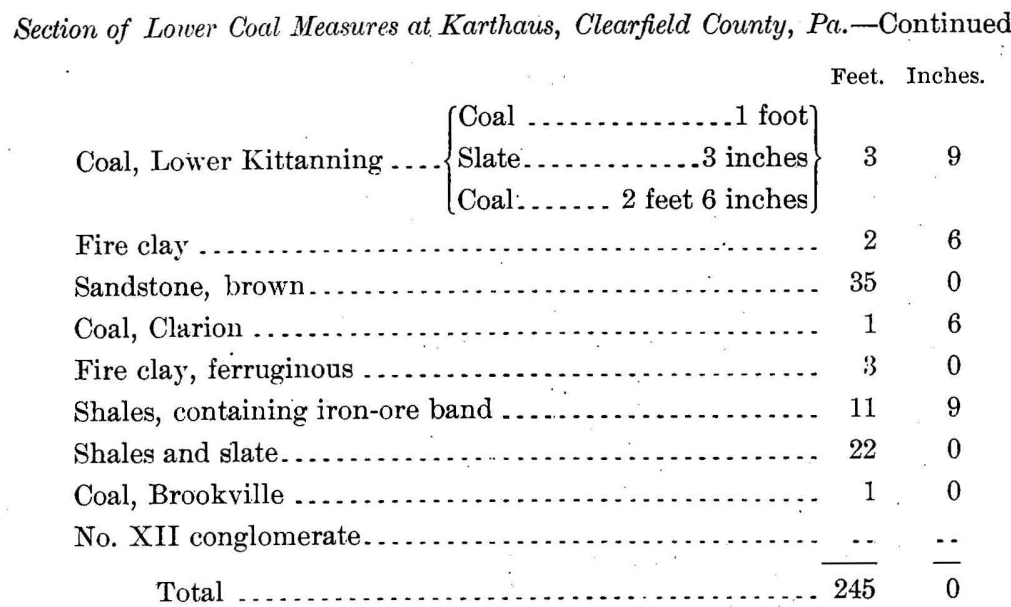

The above sections show an abundance of coal beds, and accompanying them a good development of fire clays; in fact it is the most important source of the Pennsylvania fire clays. The clays are found in greater or less quantity underlying the Brookville and Clarion coal, the Ferriferous limestone, and the Kittanning and Freeport coals.

BROOKVILLE COAL UNDER CLAY.

The Brookville coal bed is underlain by a persistent and widely distributed clay. It is used for making fire brick at Sandy Ridge, Blueball, Woodland, and Hope Station, Clearfield County; Benezette, Elk County; Parkville, Jefferson County; and Queens Run and Farrandsville, Clinton County. It has also been extensively worked at Johnstown, Cambria County, where it is over 4 feet thick, but shows two kinds of clay. ${ }^{a}$ It is often too impure for the manufacture of fire brick.

An analysis of this clay is given in the table below. The same bed is worked by the Burl Firebrick Company at Blacklick, Indiana County, the mine being located on the west slope of Chestnut Ridge, about $1 \frac{1}{2}$ miles east of the village of Blacklick: The clay overlies the Pottsville conglomerate at the base of the Lower Productire Measures, and varies in thickness from 3 to 11 feet, but averages from 7 to 8 feet. It contains many ore balls, and has to be hand picked, but can be mined by open pits. $^{b}$. These mines have been in operation for about thirty-five years.

The Brookville clay as found at Bolivar is plastic, and the same stratum also appears on Blacklick Creek, but there it is somewhat impure. This should not be confounded with the hard fire clay used at the Bells Mills, on Blacklick Creek, the latter being 20 feet lower stratigraphically and not recognizable at Bolivar.

A section from the Upper Freeport down to the Lower Freeport is given on page 65, Rept. H4, Second Pennsylvania Geological Survey.

At a point $2 \frac{1}{2}$ to 3 miles west of Blueball station, on the Tyrone and Clearfield 
branch of the Pennsylvania Railroad, are the following sections, the second being in a shaft. ${ }^{a}$ The mines are near the top of an anticlinal axis, similar to that at Sandy Ridge.

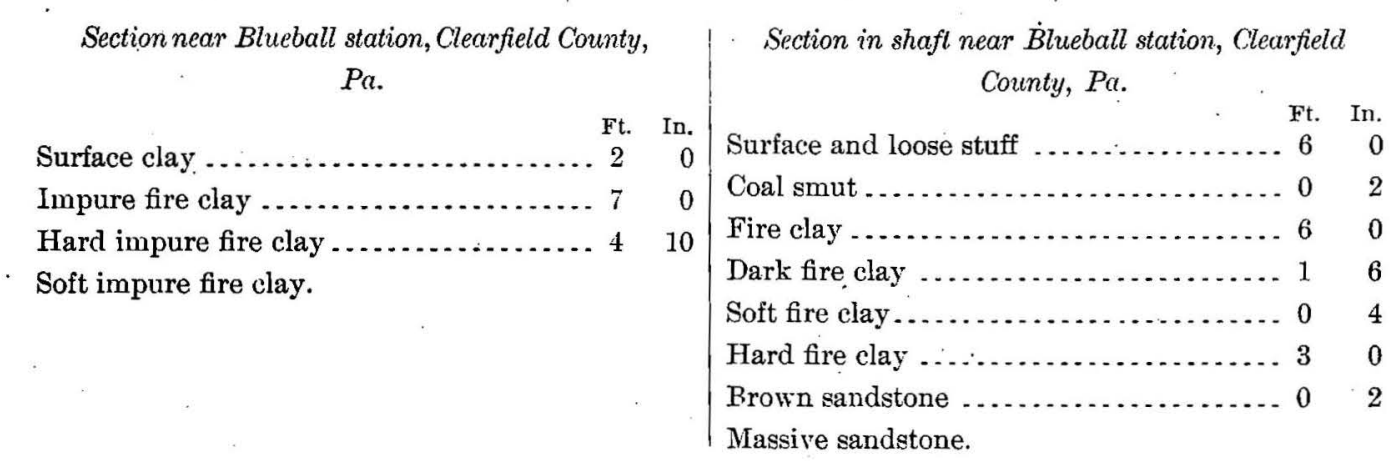

Fire clay also occurs three-fourths of a mile northwest of Woodland station and one-half mile southeast of the Hope mine. At Barrett's station, on the Tyrone and Clearfield branch of the Pennsylvania Railroad, fire clay was opened up, but found to be of uncertain quality. ${ }^{b}$ At Clearfield, east of the railroad station at the north end of the town, the fire clay showed a curious local thickening, but a later examination showed that the bed had so diminished or changed in purity that the mine was abandoned. At Benezette, in the third coal basin, fire clays occur immediately on top of the Pottsville conglomerate, notably from a point one-half mile ąbove Benezette up to Trout Run, a distance of $2 \frac{1}{2}$ miles. It showed from 3 to $T$ feet of hard clay. ${ }^{c}$ Another occurrence was 2 miles west of Benezette.

At Brookville, Jefferson County, the coal is underlain by a bed of fire clay 15 or more feet thick, as shown by the following section from Redbank Creek, south of Brookville. ${ }^{d}$

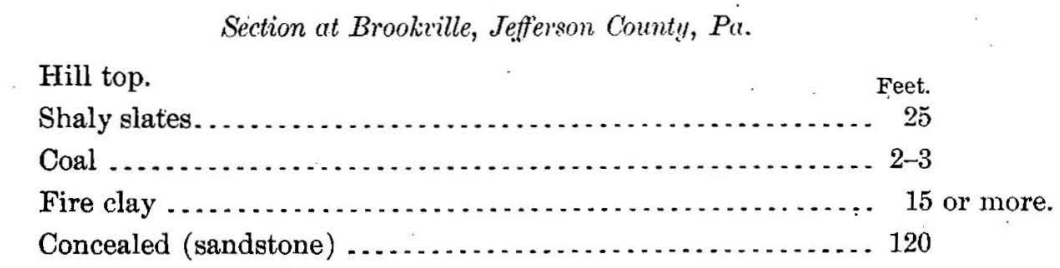

At the time the report referred to was written the upper 6 feet were worked. The composition is shown by Nos. 15,16 , and 17 in the table on page 220 . The clay has been mined at Newsome, and while of the same age probably as the clays at Blueball, Sandyridge, and Woodland, it carries a higher percentage of silica, as a comparison of the analyses will show.

In Mercer County the Brookville coal is underlain at many points by several feet of fire clay.e

a Second Pennsylvania Geol. Survey, Rept. H, pp. 120 and 121.

b Ibid., p. 124.

dIbid., p. 225.

c Ibid., p. 184.

e Idem, Rept. Q3, pp. 27, 81, 111, 134, ete. 
Analyses of Brookville under clays.

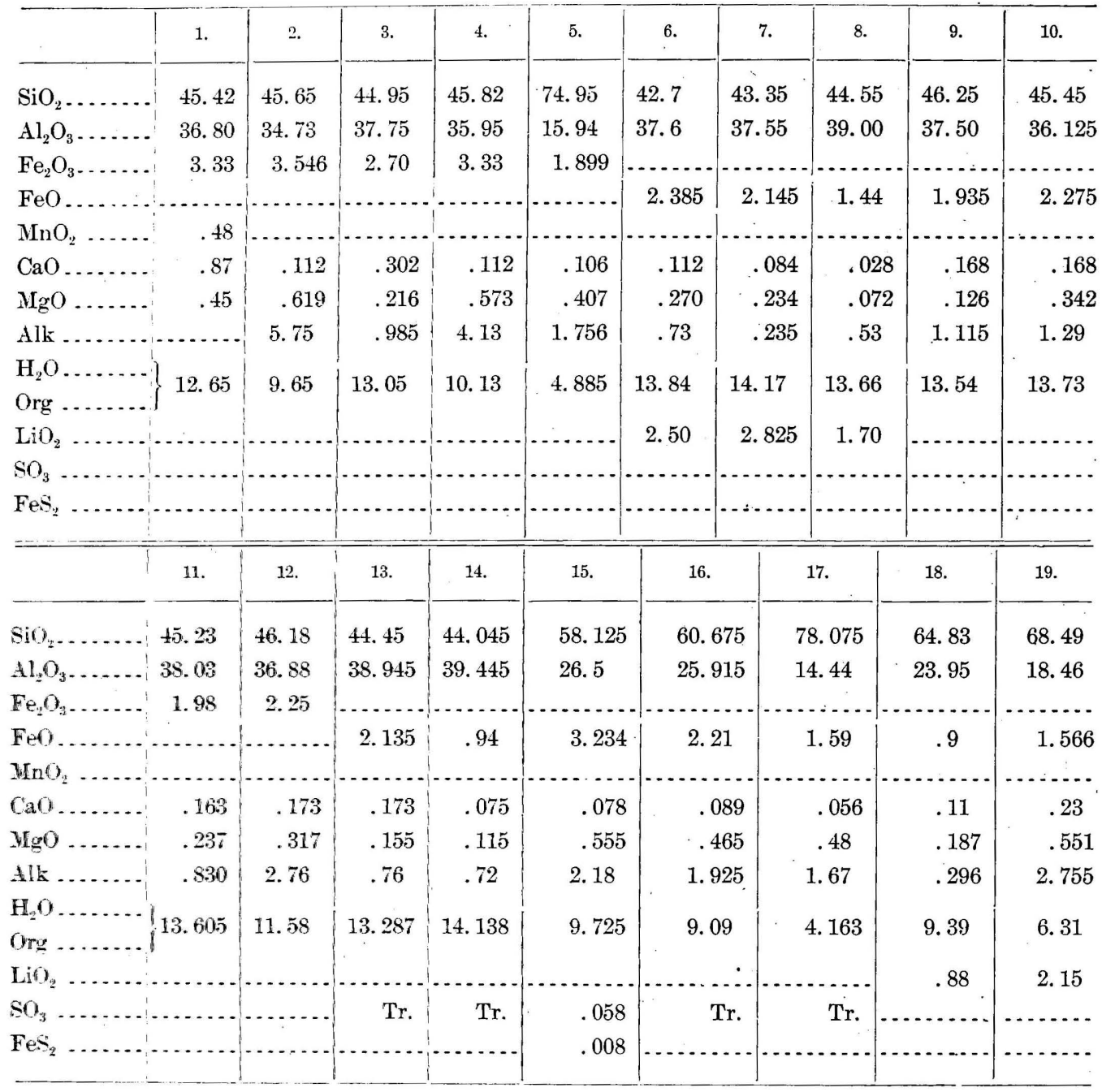

1. Fire clay, Johnstown, Cambria County. Second Pennsylvania Geol. Surv., Rept. HH, p. 147.

2. Fire clay, Sandy ridge, Clearfield County. Top layer used for furnace bottoms.

3. Second layer, same locality. Used for bricks.

4. Third layer, same locality. Used for tiles and inwalls of furnace.

5. Bottom layer, same locality. Sandy and not used; 2 to 5 feet thick. Idem, Rept. H, p. 119.

6. Upper or "Shell clay" from shaft of Harris Firebrick Company, $2 \frac{1}{2}$ miles west of Blueball. Ibid., p. 121.

7. Niddle or Black clay, same place. Ibid.

8. Lower or "Flag clay," same locality; 6 to 8 feet. Ibid.

9. From south side of Roaring Run Brook, near Woodland station. Ibid., p. 123.

10. North side of Roaring Run Brook, three-fourths inile west of Woodland station. Bed 4 to 5 feet hard clay. Ibid., p. 123. 
11. Hard clay, one-half mile southeast of Hope mine. Ibid., p. 124.

12. Soft clay, one-half mile southeast of Hope mine. Ibid.

13. Fire clay from Jones mine, between Benezette and Trout Run, Lycoming County. Ibid., p. 134.

14. Hard fire clay, E. Fletcher \& Brother, 2 miles west of Benezette. Ibid., p. 135.

15.

16. Fire clay, Newsome. Ibid., p. 225.

17.

18. Upper clay
19. Plastic clay Blacklick, Indiana County. Idem, Rept. H4, p. 194.

CLARION COAL UNDER CLAY.

Below the Clarion coal there is a bed of fire clay which seems to be good at nearly all the localities where it is exposed, and which has been used at Bolivar for fire brick. ${ }^{a}$ A large bed of fire clay from 7 to 10 feet thick, the lower part being nonplastic, underlies Clarion coal along Big Beaver. ${ }^{b}$ The Brush Creek coal is underlain by fire clay in several places in Butler County, notably in Cranberry and Adams townships, also Middlesex Township. Again, on the north and east side of the Youghiogheny River, at Ohiopyle, and thence along the road leading to Springfield, the fire clay occurs above the Clarion coal bed.c The Clarion clay has also been mined by the Fallston Pottery Company, Beaver County, on the east side of Bradys $\operatorname{Run}^{d}$, where it is 10 to 12 feet thick. The same clay is also exposed in the bottom of Pine Run near the Enterprise Pottery. ${ }^{e}$

An important deposit of fire clay occurs near top of shales between Brookville and Clarion coal, at a point 1 mile northeast of Kittanning. The clay seems to be of local importance, and not noticeable elsewhere. $f$ It is semiplastic and averages $5 \frac{1}{2}$ feet. A general section is given. Its composition is as follows:

Analysis of fire-clay deposit between Brookille and Clarion coal.

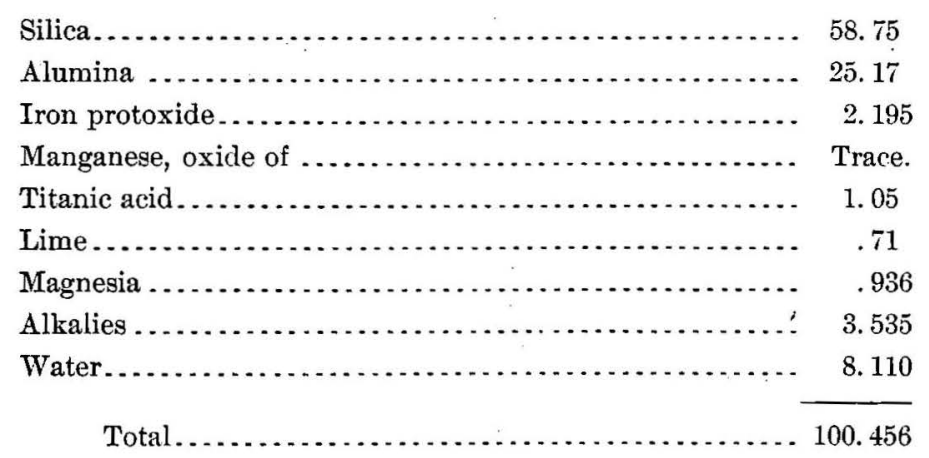

a Second Pennsylvania Geol. Survey, Rept. K3, p. 43

$b$ Idem, Rept. Q, p. 63.

$d$ Hopkins, Clays of Western Pennsylvania, p. 31

$e$ Ibid., p. 32.

$c$ Idem, Rept. K3, p. 94.

$f$ Second Pennsylvania Geol. Survey, Rept. H5, p. 245 . 
The thickness of the Clarion at several localities in Pennsylvania is as follows:

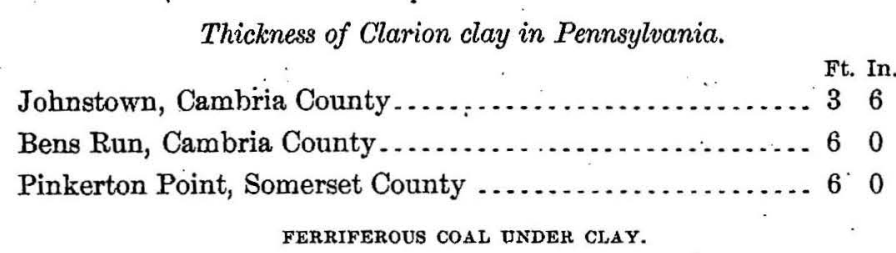

A deposit of fire clay is found between the Ferriferous coal bed and the Buhrstone iron ore in Armstrong County, ${ }^{a}$ and is found in workable quantity near Allegheny Furnace, and also at Kittanning. To the north it seems to be replaced by shale. The clay is both hard and semiplastic. The latter analyzed gives:

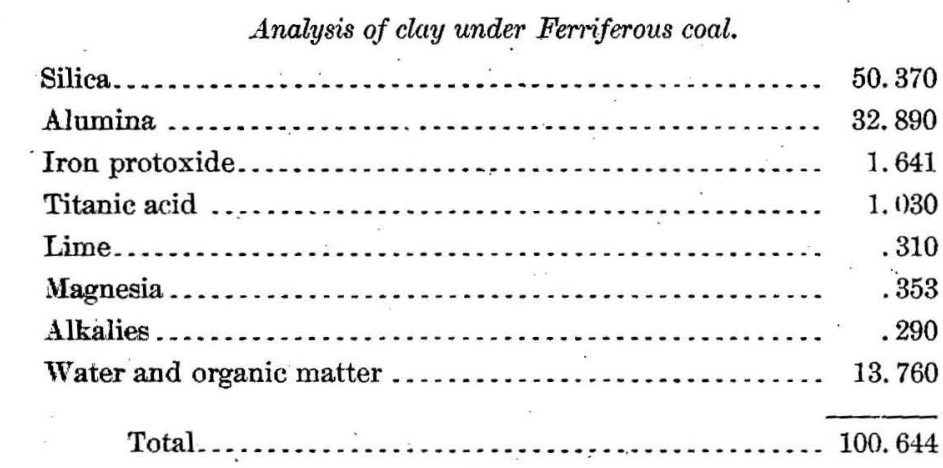

Another deposit has been opened under the Ferriferous coal near. Mineral Spring, at Kittanning: ${ }^{b}$ It is overlain by a considerable thickness of shales, which may at times replace it. The composition of the fire clay is:

Analysis of fire clay near Mineral Spring, at Kittanning, Pa.

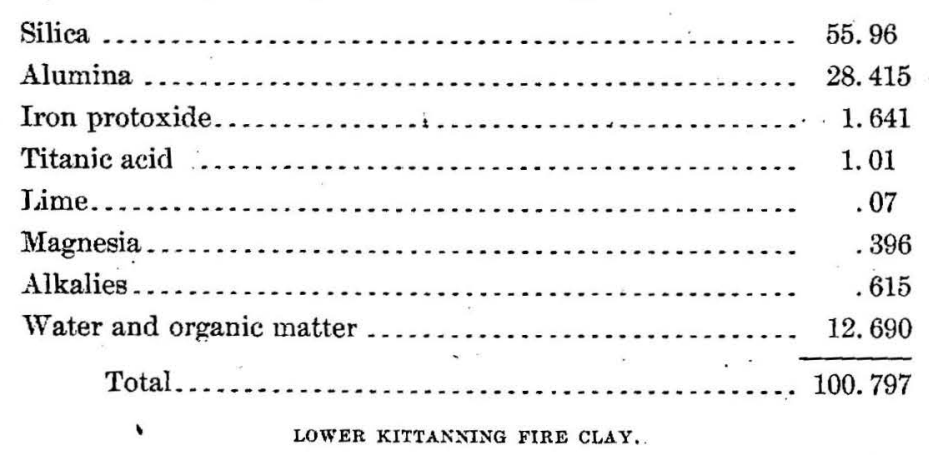

The Kittanning fire clay is one of the most valuable refractory plastic deposits found in Pennsylvania. It occupies a well-marked position under the Lower Kittanning coal, and is sometimes called the New Brighton fire clay ${ }^{c}$ (fig. 7). Folding

a Second Pennsylvania Geol. Survey, Rept. H5, p. 239.

b Ibid., p. 249

c Clays of western Pennsylvania: Ann. Rept. Pennsylvania State College, 1897, p. 53. 
of the rocks and subsequent erosion have exposed it at a number of localities, and outcrops of it are known and worked in Beaver, Armstrong, Fayette, WestmoreClarion, and Jefferson counties. The following notes regarding its occurrence are taken chiefly from the special reports of the Second Pennsylvania Geological Survey.

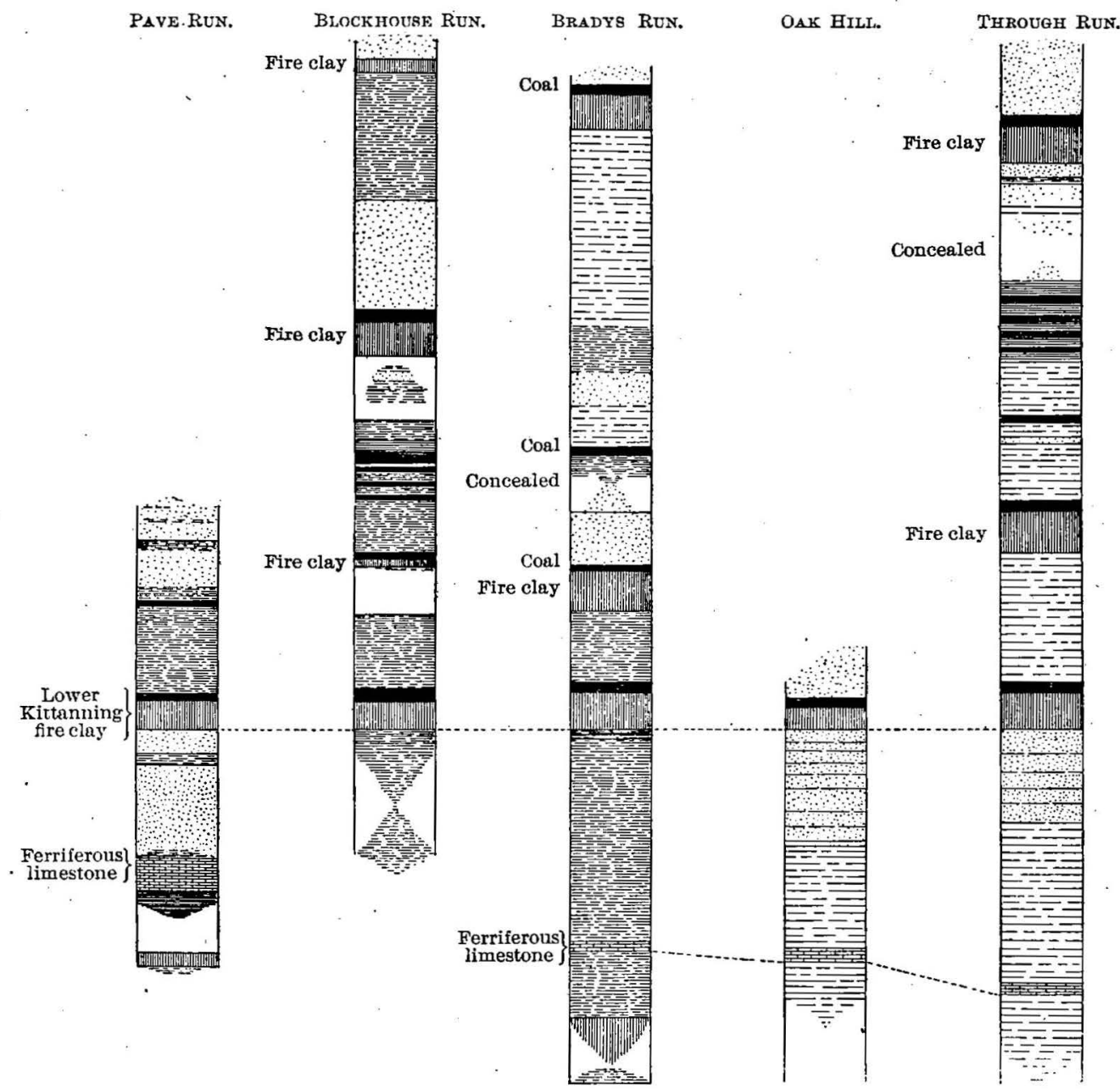

FIG. 7.-Section showing Lower Kittanning fire clay in western Pennsỵlvania (after Hopkins).

At times it does not immediately underlie the coal, but may be found as low as the top of the Ferriferous limestone. It is best developed west of the Allegheny River, ${ }^{\prime}$ attaining its maximum development along the Beaver River and· westward from that stream down the Ohio. 
The thickness of the Lower Kittanning fire clay at several localities in Pennsylvania is as follows:

Thickness of Lover Kittanning fire clay in Pennsylvania.

\begin{tabular}{|c|c|c|}
\hline Locality. & County. & Thickness. \\
\hline & . & Feet. \\
\hline Beaver Run ....... & Westmoreland ..................... & .25 \\
\hline Bennington......... & Blair . . & . \\
\hline Carpenters Station . & Westmoreland . . . . . . . . . . . & 12 \\
\hline Fall Brook . . & Tioga ..... & 3 \\
\hline Kittanning .... & Armstrong........ & 5 \\
\hline Putneyville... & . . . do . . . . . . . . . . & $a_{6}$ \\
\hline Sewickley .... & Allegheny $\ldots . . . \ldots \ldots \ldots$ & 8 \\
\hline
\end{tabular}

Armstrong County.-The Kittanning fire clay is exposed at several points in this county, but at no locality forms a bed of great importance. ${ }^{a}$

Beaver County.-The Kittanning clay is found in nearly every part of the county, and forms the basis of an important fire-brick industry. ${ }^{b}$ The bricks are not of the most refractory character, but are especially adapted to those parts of the furnace where resistance to abrasion is required. The clay is rarely less than 10 feet thick, and may reach 15 feet, but the lower 6 to 7 feet are usually too siliceous. It has been mined in the townships of Ohio, ${ }^{c}$ New Sewickley (Freedom), ${ }^{d}$ Marion, $e$ Pulaski, $f$ and Rochester. ${ }^{g}$

The Lower Kittanning clay is used between Rochester and Brighton by Ingraham \& Co.; also at Conway by G. Dando \& Brother. Here it is 8 feet thick. This clay bed supplies nearly all of the potteries, hollow-ware, fire-brick, and pavingbrick factories at New Brighton and vicinity. In 1897 it was mined at Crows Run, mear Freedom, at Monaca and Vanport, and below Beaver, on the north side of the Ohio River; also opposite Beaver, and on Bennetts Run, above New Brighton. It is probably continuous to Ohio, but west of Vanport dam the drift covering is said to be too heavy to permit its being profitably mined. ${ }^{h}$ The thickness of the clay deposit is rather uniform in the Beaver Valley region, but the thickness of bed worked varies according to the kind of ware to be made from it, some manufacturers being able to use a larger proportion of the sandy layers than others. The thickness worked at several localities is as follows: ${ }^{i}$

d. Setond Pennsylyania Geol. Survey, Rept. H5, Armstrong County. idem, Rept, Q, pp. 58, 59 .

1. Thid. D. 26 .

Itrin.

Thaid., D. 215

$f$ Ibid., p. 195

$g$ Ibid., p. 193.

$h$ Clays of western Pennsylvania: Ann. Rept.

Pennsylvania State College, 1897 , p. 33

$i$ Ibid. 
Thickness of Lover Kittanning clay at various points.

\begin{tabular}{|c|c|}
\hline herwood Bros ............... & $=$ \\
\hline Enterprise Pottery Company... & \\
\hline Sewer-pipe works.... & $6-7$ \\
\hline A. F. Smith \& Sons.... . . . & $6-7$ \\
\hline Ingram \& Co.... . . . . . . . . . . & $7-8$ \\
\hline Welch, Gloniger \& Co., Monaca. . . . . . . . . . . & 6 \\
\hline Bradys Run Fire Brick Company, Monaca............... & 16 \\
\hline Stahl Fire Brick Company, Beaver........ & \\
\hline Park Fire Clay Company, Mahan... & \\
\hline
\end{tabular}

The clay is often weathered before being used.

Fayette County.-In Springhill Township a bed of good fire clay occurs from 15 to 20 feet below the Kittanning coal, and has been used for fire brick. It is usually free from iron, but pockets of ore occur occasionally and may replace the clay for a short distance.

Westmoreland County.-The fire clay usually found is a plastic clay from 5 to $\tau$ feet thick. ${ }^{a}$ It may at times be gritty, as in Cook and Ligonier townships.

\begin{tabular}{|c|c|c|c|c|c|c|c|c|c|}
\hline \multirow{2}{*}{$+\ldots \ldots$} & \multicolumn{6}{|c|}{ Analyses of Kittanning lower coal under clay. } & & $\cdot$ \\
\hline & 1. & 2. & 3. & 4. & 5. & 6. & 7. & s. & 9. \\
\hline $\mathrm{SiO}_{2} \ldots \ldots \ldots$ & 61.970 & 61.750 & 62.890 & 62.260 & 66.610 & 56.670 & 57.670 & 60.190 & 61.980 \\
\hline $\mathrm{Al}_{2} \mathrm{O}_{3} \ldots \ldots \ldots \ldots$ & 22.940 & 23.660 & 21. 490 & 23.890 & 18. 390 & 26.560 & 27.520 & 24.230 & 23.880 \\
\hline $\mathrm{FeO} \ldots$ & 1.818 & 1. 930 & 1. 818 & 1. 408 & 1.964 & 2.106 & 1. 494 & 2.097 & 1.395 \\
\hline $\mathrm{TiO}_{2}$ & 1.975 & 1. 780 & 1.825 & 1. 780 & 2. 810 & 1. 790 & $2.5+0$ & 2. 345 & 1.830 \\
\hline $\mathrm{CaO}$ & 0.440 & 0.455 & 0.380 & 0.470 & 0.490 & 0.260 & 0.380 & 0.850 & 0.040 \\
\hline $\operatorname{MgO} \ldots \ldots \ldots \ldots$. & 0.522 & 0.353 & 0.569 & 0.309 & 0.547 & $0.27 \%$ & 0.122 & 0.036 & 0.281 \\
\hline Alkálies ... & 1. 750 & 2.418 & 2.525 & 1.977 & 1.079 & 3. 790 & 0.619 & 1. 669 & 1. 217 \\
\hline $\mathrm{H}_{2} \mathrm{O}$ (hygroscopic).. & 1. 480 & 0.680 & 1.160 & 7.640 & 7.495 & 8.360 & 9.680 & 9.015 & 1. 460 \\
\hline $\mathrm{H}_{2} \mathrm{O}$ (combined) .... & 7.370 & 7.200 & 7.580 & 1.070 & 1.700 & & 8.000 & & 7.820 \\
\hline Total & 100.265 & 100.226 & 100.237 & 99.734 & 99.385 & 99.813 & 100.025 & 100.432 & 99.903 \\
\hline Sand. & 34.250 & & 35.510 & & & & & & \\
\hline $\mathrm{SiO}_{2}$ in sand $\ldots . . . .$. & 34.180 & & 35.100 & & & & & & \\
\hline
\end{tabular}

1 to 4. From Elverson \& Sherwood's mines, near New Brighton, Beaver County, being, respectively, first, second, and third grades of clay and the raw clay. Second Pennsylvania Geological Survey, Rept. MM, p. 262.

5. Mandon, Hall, and Chamberlain mines, near New Brighton, Beaver County. Ibid.

6. Coale's clay, near New Brighton, Beaver County. Ibid.

7. Couche's clay, New Brighton, Beaver County. Ibid.

8. Severn's clay mines, near Vanporte, on Ohio River, New Brighton township, Beaver County. Ibid.

9. S. Barnes \& Co.'s clay, near Bridgewater, 1 mile north of Rochester, Beaver County. Ibid. 
MIDDLE KITTANNING CLAY.

This may, at times, be underlain by fire clay, as seen in the section at Ore Hill Furnace, Armstrong County, where a bed 2 feet 6 inches thick is found. ${ }^{a}$ The Lower Kittanning is found in the same section.

The thickness of the Middle Kittanning in Pennsylvania is as follows:

Thickness of Middle Kittanning clay in Pennsylvania.

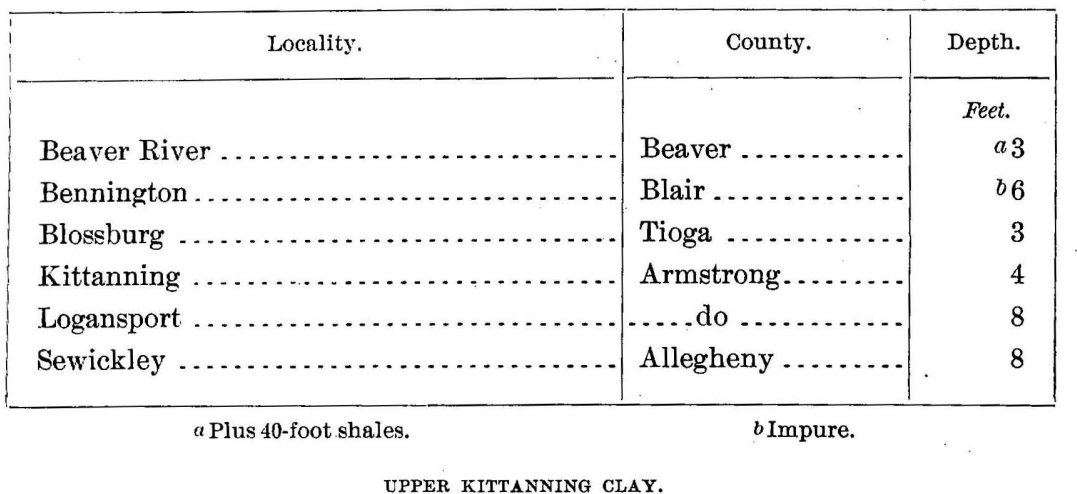

This underlies the Freeport sandstone, a bed of shale lying between. Under it is a fire clay of very good quality. ${ }^{b}$

LOWER FREEPORT CLAY.

This underlies the Lower Freeport coal at several localities at Frostburg, ${ }^{c}$ and is of proper quality for potters' use.

UPPER FREEPORT OR BOLIVAR FIRE CLAY.

This is a bed of nonplastic or flint clay, nad is one of the most valuable of the refractory deposits found in western Pennsylvania, where it is also very extensively worked. It gets its name from the fact that it is best developed at Bolivar, at the eastern end of the Conemaugh Gap through Chestnut Ridge. Stratigraphically it lies near the top of the Lower Productive series, being immediately under the Upper Freeport limestone, but a similar clay, which is sometimes confused with it, appears directly below the Upper Freeport coal bed. ${ }^{d}$

While the Bolivar clay is widely distributed, at the same time it is not found at every one of the localities where its horizon is reached, and its place is sometimes taken by a less refractory'shale. At the type locality at Bolivar it is from 20 to 25 feet thick, according to T. C. Hopkins, but it is said to vary greatly throughout the region of the western slope of Chestnut Ridge and the Ligonier Valley.

a Bull. U. S. Geol. Survey No. 65 , p. 107, fig. 60

$b$ Second Pennsylvania Geol. Survey, Rept. Q, p. 265

c Idem, Rept. H6, p. 16.

a Second Pennsylvania Geol. Survey, Rept. K3, p. 34; and The clays of western Pennsylvania: Ann. Rept. Pennsylvania State College, 1897, p. 53. 
The counties from which occurrences of this clay have been described are Allegheny, Armstrong, Beaver, Butler, Fayette, Indiana, Somerset, and Westmoreland.

The thickness of the Upper Freeport at various localities is given below.

Thickness of Upper Freeport or Bolivar fire clay in Pennsylvania.

\begin{tabular}{|c|c|c|}
\hline Locality. & County. & $\begin{array}{l}\text { Thickness } \\
\text { of fire clay. }\end{array}$ \\
\hline . & & F. $\quad$ In. \\
\hline Bens Creek... & Cambria..... & 60 \\
\hline Carpenters Station ........ & Westmoreland... & $\begin{array}{ll}\dot{a}_{65} & 0\end{array}$ \\
\hline Horton Township . . ....... & Elk $\ldots \ldots \ldots \ldots \ldots \ldots$ & $b_{5} \quad 0$ \\
\hline Near Johnstown ............ & Cambria..... & $c 40 \quad 0$ \\
\hline Karthaus ........... & Clearfield. ........ . & 26 \\
\hline & Clarion........ & $5 \quad 0$ \\
\hline Morrisdale... & Clearfield......... & a $32 \quad 6$ \\
\hline Putneyville ................ & Armstrong.............. & $a_{12} \quad 0$ \\
\hline Sewickley ......................... & Allegheny .............. & 156 \\
\hline
\end{tabular}

Allegheny County:-The Bolivar clay forms a bed 3 feet thick on Gourdhead Kun, Hampton Township, as well as at several other points. ${ }^{c}$

Armstrong County.-The Upper Freeport fire clay is said to be of importance at Salina, but seems to fade out in a westerly direction down the river. It contains occasional small lenses of iron ore. ${ }^{b}$ At Apollo, it is exposed underneath the limestone, and there are said to be 8 feet of it, of somewhat impure character, at Leachburg. ${ }^{c}$ It is also well exposed at the top of the hill south of the rolling mill at Bradys Bend and at Templeton. The clay has also been mined near Manorville, ${ }^{d}$ and may occur in the Cowanshannock region. ${ }^{e}$

Beaver County.-In Big Beaver Township the Freeport clay has been extensively mined and made into fire brick. It ranges in thickness from 2 to 10 feet, but may be replaced at times by limestone and iron ore, as at Adams. $f$

Butler County.-The Freeport upper coal is underlain by 4 feet of excellent fire clay, especially mentioned as occurring in Winfield Township at the Collins bank.

Fayette County.--In Fayette County the Bolivar clay has been reported from the following localities: In Wharton Township, near Wharton furnace, where it is 10 feet thick, with nodules of clay ironstone; in Sterwart Township, forming a bed 8 feet thick along the river hills and containing balls of iron ore; on Indiana Creek, Springhill Township, with a thickness of $t$ feet; 2 miles north of Ohiopyle village.

a Second Pennsylvanin Geol. Survey, Rept. Q, p. 155 .

c Ibid., p. 26.

$e$ Ibid., p. 89. 
At Baylies Point the flint clay is 12 to 15 feet thick and is overlain in places by 2 to 4 feet of plastic clays. Another occurrence is $2 \frac{1}{2}$ miles east of Moir. The Bolivar clay is also mined near Layton station, that quarried 1 mile east of the station being used for the manufacture of glass pots. It is here from 4 to 6 feet thick; the clay is carefully selected by hand, the rejected portions being used for fire brick.

Indiana County.-The clay has been mined at many localities in this county and varies from 3 to 6 feet in thickness. It is said to be usually of good quality and comparatively free from impurities. ${ }^{a}$ A specially large deposit of it is known to occur at Bells Mills. ${ }^{b}$ Professor Stevenson ${ }^{c}$ reports the clay from a number of localities in the Ligonier Valley south of the Conemaugh River, and states that it forms quite a persistent stratum in Fayette County, being traceable across the Youghiogheny into West Virginia.

Analyses of both the hard and soft clay show much $\mathrm{TiO}_{2}$.

Westmoreland County.-The Upper Freeport clay forms the center of an active clay-working industry at Bolivar, but is also worked at several other points.

The following general section at Bolivar is given by Stevenson: ${ }^{d}$

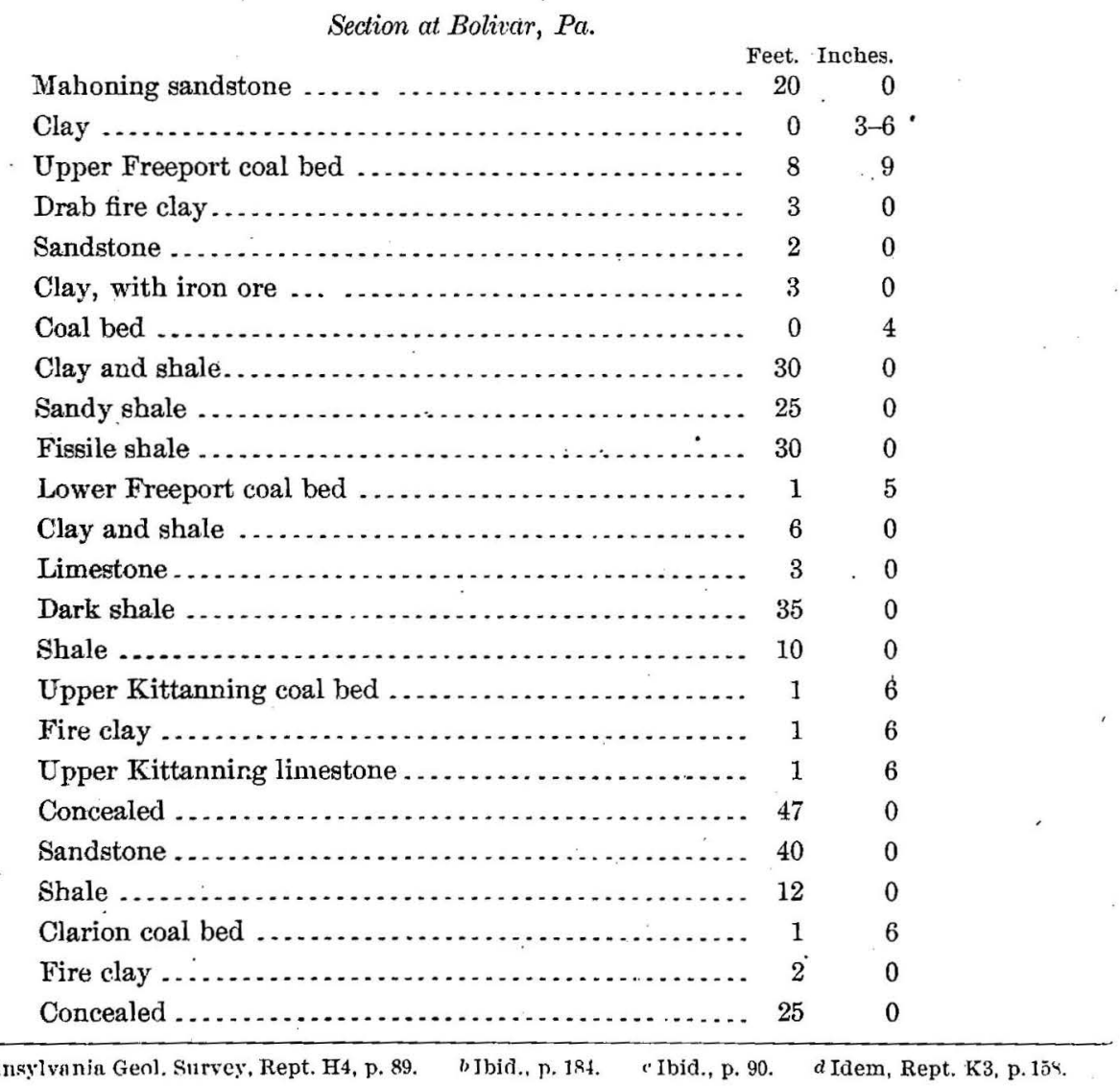

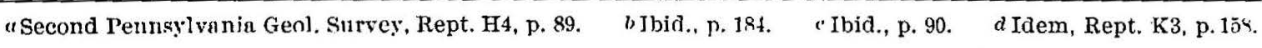




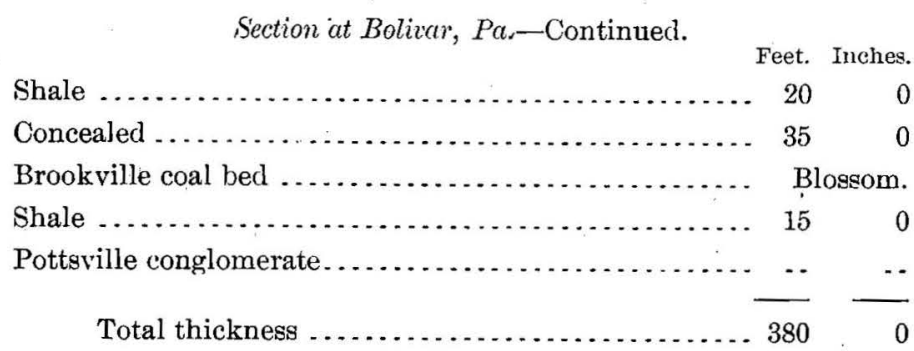

Hopkins ${ }^{a}$ says that while this gives a good idea of the general succession of the beds, still the thicknesses noted do not agree with those observed in the present workings, being in most cases too small. The following statement regarding these fire clays in the vicinity of Bolivar is an abstract of the description in his report:

The Bolivar clay varies greatly in thickness, ranging from 6 to 25 feet at different points in the State. On the south side of the river it has been mined extensively over a large area on the King tract, about half a mile southeast of Bolivar, on the slope east of Tub Mill Creek, near the base of the ridge. The clay here is 18 to 20 feet thick and is worked by open pits. Ore balls are very abundant in certain spots, but seem to'favor the upper layers rather than the lower ones, and in mining they can be, and are, picked out. The Bolivar flint clay is also mined on the property of the Lincoln Company, showing there 18 to 20 feet overlain by 8 feet of shale and soapstone, followed by 6 feet of coal. The upper 6 to 8 feet are often called black clay and are thought to be superior. On the northeast side of the Conemaugh River, in Indiana County, but opposite Bolivar, the upper clay bed has been worked at a number of places, 22 feet of flint clay being exposed at one point. An old flint-clay mine on the northeast side of the river is known as the Garfield flint clay, and is 1 mile east of Bolivar. The flint clay is also worked near the top of the ridge on the south side of Roaring Run. There is said to be a higher bed of flint clay known as the Upper Bolivar flint clay, and found on the hilltops in the form of remnants or pots. It is said to be highly refractory, but is not worked on account of its scareity. Below the Bolivar clay is a bed of plastic fire clay, the interval between the two being 200 feet. It is mined on the south side of the river, near the mouth of Tub Mill Creek, and also on the north side of the river, in the hill below the flint mine No. 3 of Reese, Hammond \& Co. This bed really consists of two beds, known locally as the upper soft clay and the lower clay. In one mine the material between the two layers is sufficiently thin to permit working them together. In the other mines only the upper portion of the clay, from 6 to 8 feet thick and lying above the separating sandstone, is worked. This clay bears an excellent reputation and is rather plastic. Another bed is said to exist between this clay and the flint clay overlying, and one or two beds of plastic clay are also stated to occur at a lower

a Clays of western Pennsylvania: Ann. Rept. Pennsylvania State Colkege, 1897, p. 77. 
horizon; but the test of one of these lower beds bas shown that it is much less refractory.

Where high refractoriness is desired, it is said that some clay is brought to Bolivar from South Fork, Blueball, and Moshannon, in Clearfield County. The Bolivar clay will make a more plastic and porous brick than many other clays of greater refractoriness. ${ }^{a}$

In addition to the workings at Bolivar, the clay is also said to occur northward from Loyalhanna, on the west side of the valley, extending from the southern boundary of Fairfield Township to the Conemaugh Valley. ${ }^{b}$

At Salina the Bolivar clay dips eastward and varies in thickness from 6 to 13 feet, including both the flint clay and the soft plastic fire clay. There is no regularity of distribution of the two, however, in the same bed.

In the following table are given a number of analyses of the Bolivar fire clay:

Analyses of Bolivar or Freeport upper coal under clay.

\begin{tabular}{|c|c|c|c|c|c|c|c|c|c|c|}
\hline & 1. & 2. & 3. & 4. & 5. & 6. & 7. & 8. & 9 & 10. \\
\hline $\mathrm{SiO}_{2} \ldots$ & 59.830 & 51.920 & 47.250 & 40.720 & 60.520 & 55.330 & 55.680 & 56.780 & 65.370 & 52.230 \\
\hline $\mathrm{Al}_{2} \mathrm{O}_{3} \ldots \ldots$ & 24.580 & 31.640 & 34.350 & 37.280 & 24.970 & 27.841 & 29.180 & 26.890 & 24.870 & 31.310 \\
\hline $\mathrm{FeO} \ldots$ & 1. 655 & 1. 134 & 0.693 & 2.448 & 1. 650 & 2.916 & 0.837 & 0.322 & 0.756 & 1.008 \\
\hline $\mathrm{TiO}_{2} \ldots .$. & 1.170 & 1. 160 & 1.990 & 2.280 & 1. 220 & 1.140 & 1. 490 & \multicolumn{2}{|c|}{ Not determined. } & 1. 680 \\
\hline $\mathrm{CaO} \ldots .$. & 0.280 & 0.030 & 0.580 & 0.520 & 0.910 & 0.580 & 0.130 & 0.369 & 0.168 & 0.130 \\
\hline $\mathrm{MgO} \ldots$ & 0.872 & 0.443 & 0.090 & 0.002 & Trace. & 0.756 & 0.180 & 0.987 & 0.234 & 0.165 \\
\hline Alkalies. & 3. 114 & 0.402 & 0.261 & 0.570 & 0.218 & 3.916 & 0.245 & 3.920 & 0.010 & 0.720 \\
\hline Water. & 7.830 & 13.490 & 13.695 & 15.002 & 9.395 & 7.495 & 12.490 & 8.380 & 8. 790 & 13.190 \\
\hline $\mathrm{CO}_{2} \ldots$ & & None. & 0.455 & 0.408 & 0.725 & 0.455 & & & & . \\
\hline Total. . & 99.331 & 100.219 & 99.364 & 99.230 & 99.608 & 100.429 & 100.232 & 100.548 & 100.378 & 100.433 \\
\hline
\end{tabular}

1. E. Robinson's clay deposit in Indiana County. Second Pennsylvania Geol. Survey, Rept. H4, p. 90 .

2. Kier Brothers, Salina, Bell Township, Westmoreland County; flint clay. Idem, Rept. H5, p.14.

3. Kier Brothers' clay, Salina; top stratum, hard and brittle. Ibid.

4. Kier Brothers' clay, Salina; middle stratum, hard and brittle. Ibid.

5. Kier Brothers' clay, Salina; bottom stratum. Ibid.

6. Kier Brothers' clay, Salina; plastic elay. Ibid.

7. R. Hall's, near Laughlinstown, 4 miles east from Ligonier, Westmoreland County. Idem, Rept. K3, p. 249.

8. Furnace clay on Jacobs Creek, 2 miles southeast of Jacobs Creek station. Idem, Rept. L, p. 112.

9. Forge clay un Jacobs Creek, $2 \frac{1}{2}$ miles southeast of Jacobs Creek station. Ibid.

10. George Potter's clay on Meadow Run, south of Ohio Pyle Falls, Fayette County. Idem, Rept. K3, p. 249. 
BARREN MEASURES OR ELK RIVER GROUP.

The Barren Measures or Elk River series consist largely of shales and sandstones, with some limestones, the shales predominating in the upper beds of the section and the sandstones in the lower (fig. 8).

The general character can best be told from a glance at the accompanying section (fig. 8) taken from I. C. White's bulletin ${ }^{a}$ already referred to.

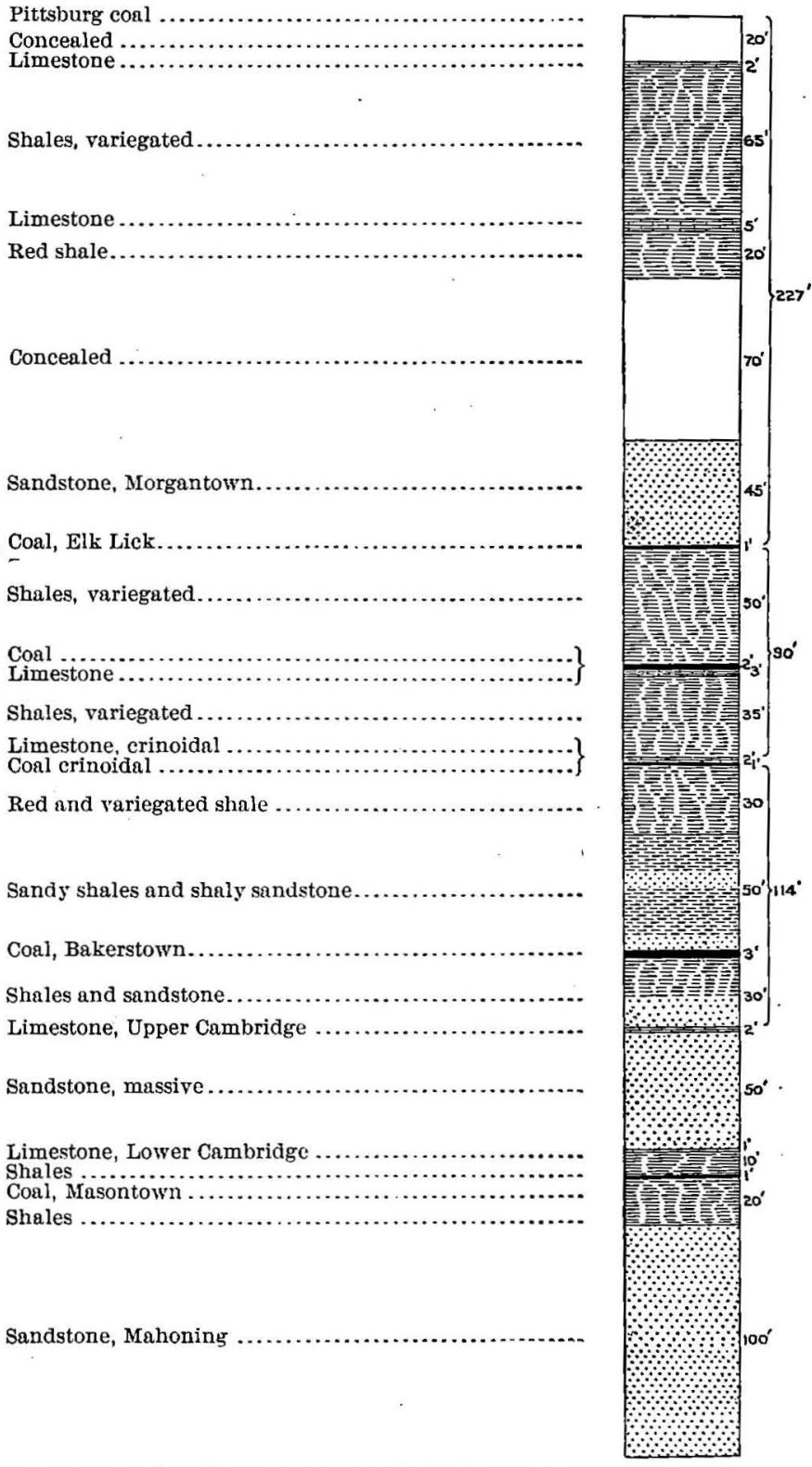

FIG. 8.-Section of Barren Measures in Pittsburg region, Pennsylvania. 
In Allegheny County the Lower Barren Measures constitute the greater part of the surface rocks, all of the northern half of the county, with the exception of small areas of Upper and Lower Productive Measures, and about one-half of the southern part being covered by them. Hopkins gires the following section:

Section of Lower Barren Measures in Allegheny County, Pa.
1. Pittsburg coal bed.
Feet.
2. Fire clay
3
3. Shale
10
4. Limestone
6
5. Coal bed 1
6. Shale. 25
7. Limestone

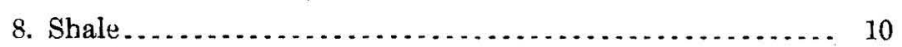
9. Coal bed........................................ 1.5

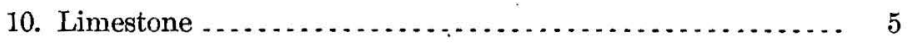
11. Connellsville sandstone .......................... 60
12. Shale...................................... 35

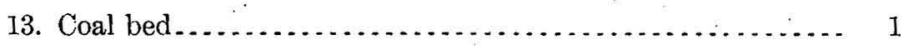

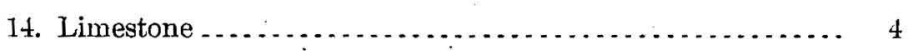
15. Morgantown sandstone ............................. 50
16. Clay . . . . . .
17. Barton coal bed .................................... 1

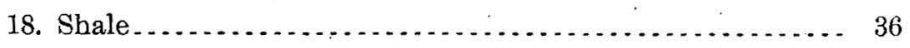

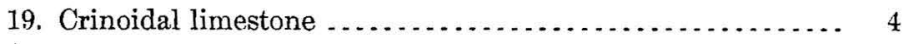

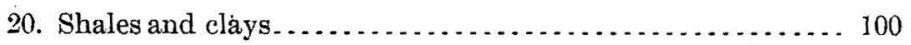

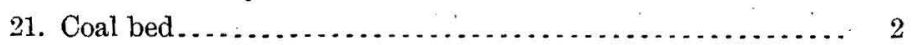

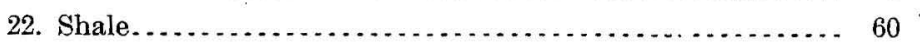
23. Black limestone and shale $\ldots \ldots \ldots \ldots \ldots \ldots \ldots \ldots \ldots . \ldots \ldots$
24. Shale and shaly sandstone $\ldots \ldots \ldots \ldots \ldots \ldots \ldots \ldots \ldots \ldots . \ldots \ldots \ldots$
25. Coal bed.................................... 2
26. Shale......................................... 30
27. Mahoning sandstone.
Total. 491.5

Affelder ${ }^{a}$ states that at Pittsburg, where 320 feet of strata of the Lower Barren Measures are exposed between the level of the Monongahela River and the outcrop of the Pittsburg coal near the hilltop, almost all of the rock is shale. So enormous are the deposits of shale that the manufacture of brick can be carried on for centuries without materially diminishing the amount; but abundant as the shales are, they do not vary greatly in their general characteristics. Nearly all of them, with the exception of the very arenaceous, are well adapted to the manufacture of brick, and they all show evidence of the presence of iron to a greater or less degree. In some the 
prevalent state of the iron is the ferrous, while in others it is the ferric, but the majority are stained with ferric iron, especially after they have been subjected to the action of the atmosphere. By far the most common variety of the shale is the yellowish, slightly arenaceous one, which grades at the surface to a sandy clay, and, as the depth increases, to a more or less impure sandstone. Bluish shales are common in some localities. Some of them are so argillaceous and so distinctly laminated as to look very much like slate, but the majority of them are shelly and readily disintegrate to small flakes. In color they vary from slate to bluish gray. Receatly M. Lanz \& Sons, of Pittsburg, have experimented with a bluish shale which occurs under the shale deposit from which they obtain their material for making red brick, and have succeeded in making a buff brick of good color and quality for building purposes. Greenish shales containing much ferrous iron occur less frequently than the blue, and they are always badly discolored as a result of atmospheric action. Red shales are not very abundant, but where they do occur they have generally disintegrated on the outcrop to a red clay.

Fire clays are not abundant in this county, and even where found they are too impure to be used for making fire brick, although in some localities these clays are used to advantage in making building or paring brick. At Harmarville an excellent reddish-buff repressed brick is made from a 10 -foot vein of such clay. The presence of a small amount of iron prevents uniformity in color, and the brick are adapted only to paving. At Briggston a very hard building brick is made from an impure fire clay mixed with hard shale.

A thriving clay-working industry exists in Allegheny County, and of 57 yards listed in Hopkins's report over two-thirds use shale wholly or in part.

The product consists chiefly of red brick, but some paving and pressed brick also are manufactured.

UPPER COAL MEASURES, OR MONONGAHELA RIVER GROUP.

These have their greatest development in south western Pennsylvania, and while the shale deposits are not so abundant as in West Virginia, still occasional beds of good thickness occur.

An important clay is that found as a persistent parting in the Pittsburg coal, and it is used in the Monongahela Valley. The clay is not more than 6 to 10 inches thick, but has to be removed in mining the coal, hence it is protitable to use it. This bed of clay is said to be wonderfully persistent throughout the entire area of the Pittsburg coal bed, and Hopkins comments on the fact that it has not been used at other places, for there are vast quantities piled up around numerous mines over southwestern Pennsylvania. This clay is used in part for fire brick. The same clayhorseback," or clay parting-is worked at Fayette City. The shale over the coal is 
used for making red brick, the section involved in Dinsmore Brothers' quarry being as follows: ${ }^{a}$

Section at Dinsmore quarry, Fayette City, Pa.

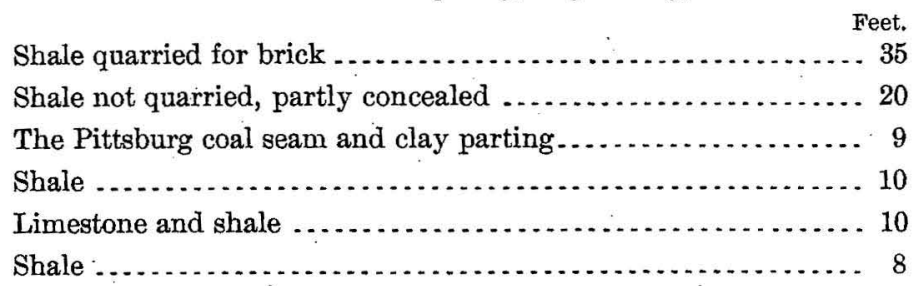

A section of the Upper Productive Measures, after I. C. White, is given in fig. 9.

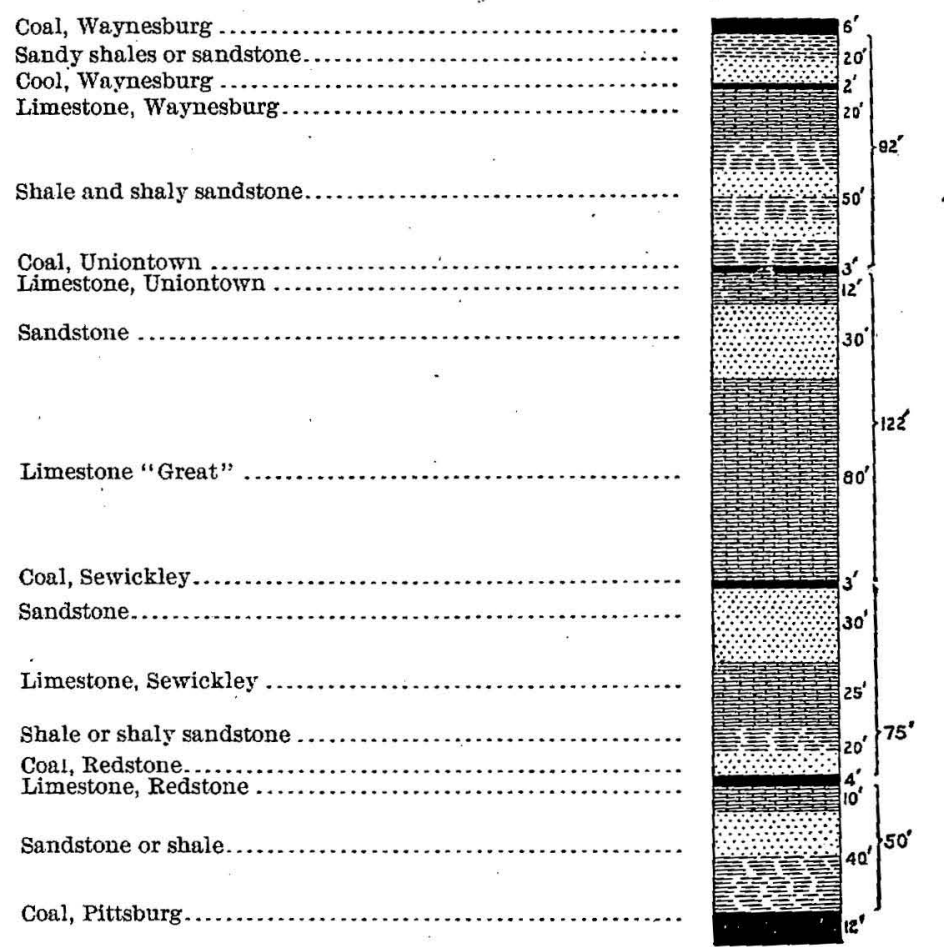

FIG. 9.-Section of Upper Productive Measures in Fayette and Westmoreland Counties, Pa.

At Pittsburg shale of the Upper Coal Measures is used for making common brick at several different yards. The Pittsburg Terra Cotta Lumber Company, at Pittsburg, also uses shale, but mixes it with surface clay. Its composition is given below: 


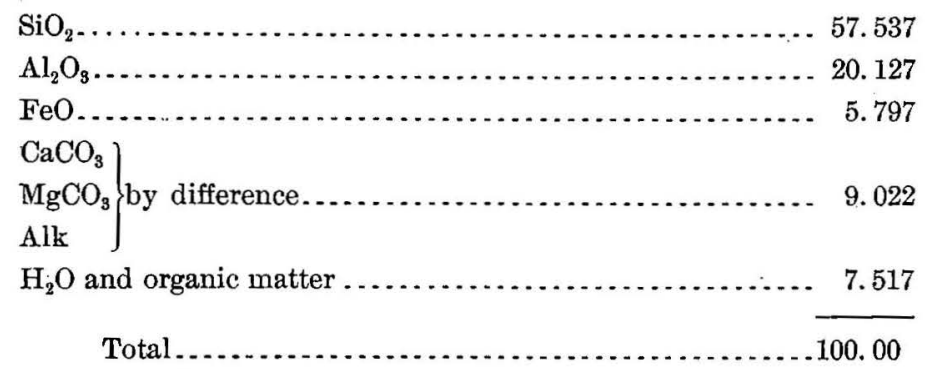

At the quarry of the American Clay Manufacturing Company a section shows: ${ }^{a}$

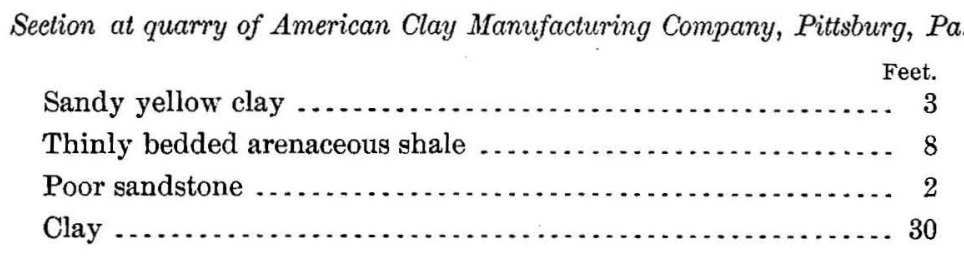

SURFACE, OR PLEISTOCENE CLAYS.

These may occur in all parts of the State, more especially along the larger lines of drainage. They are found existing under several conditions, viz, as terrace deposits, basin deposits, or morainal clays.

The terrace deposits usually underlie the terraces bordering the rivers, and often represent the fine clay and silt deposited during recent or remote periods of high water. The former would be found near the present river level, the latter often many feet above it.

The basin deposits are chiefly to be looked for north of the terminal moraine of the Glacial epoch, and represent the fine clay deposited in valleys whose streams have become dammed up and converted into ponds or lakes.

The morainal deposits are clays of irregular occurrence found at times in the terminal moraine, and may often be stony.

The surface clays are usually impure and frequently sandy, and are consequently chiefly adapted to the manufacture of common brick, although pressed brick and even pottery are made from them in cases where the clays are finer and more homogeneous. In the Carboniferous areas, where shale outcrops are often abundant, the latter are sometimes mixed with the surface clays, producing excellent results. In the western part of the State they are abundant along the Allegheny, Monongahela, Beaver, Ohio, and Youghiogheny. References to these have been made in Hopkins's report on the clays of western Pennsylvania and in the several county reports of the Second Pennsylvania Geological Survey.

a Ann. Rept. Pennsylvania State College, 1897, p. 144. 
The valleys of the Ohio and Beaver rivers are filled with glacial drift, and the terraces bordering them are underlain by clay. ${ }^{a}$ An important deposit has been worked in the fourth terrace at New Brighton. This deposit, which was used for making terra cotta, shows the following composition: ${ }^{b}$

Analyses of terrace clay at New Brighton, Pa.

\begin{tabular}{|c|c|c|}
\hline Constituents. & $\begin{array}{c}\text { Mendenball \& } \\
\text { Chamberlin. }\end{array}$ & $\begin{array}{l}\text { Elverson \& } \\
\text { Sherwood. }\end{array}$ \\
\hline Silica..... & $46: 160$ & 67.780 \\
\hline Alumina.... & 26.976 & 16. 290 \\
\hline Sesquioxide of iron $\ldots \ldots \ldots \ldots$ & 7.214 & 4.570 \\
\hline Titanic acid... & .740 & .780 \\
\hline Lime ....... . & 2.210 & .600 \\
\hline Magnesia .... & 1.520 & .727 \\
\hline . & 3.246 & 2. 001 \\
\hline 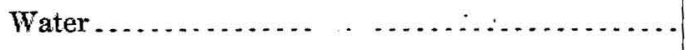 & 11.220 & 6.340 \\
\hline 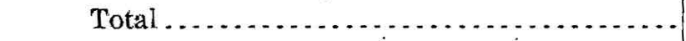 & 99.286 & 99.088 \\
\hline
\end{tabular}

This same clay has also been successfully employed in the manufacture of flower pots.

In Allegheny County the alluvial clays along the rivers are used for making building brick at about 10 per cent of the yards. These clays are obtained from river flats which border on the Ohio, Allegheny, Monongahela, and Youghiogheny rivers. Some of them are said to be flood-plain deposits. Terrace clays are abundant in the vicinity of many rivers, especially in and near Pittsburg. In the Monongahela Valley surface clays are used at several localities for the manufacture of brick, among them Leetsdale, Braddock, and Wilkinsburg. At some of these places the clay is mixed with shale. Surface clays are also worked in the Youghiogheny Valley at Connellsville for building, paving, and pressed brick; ${ }^{c}$ at West Newton, in the same valley, the alluvium is worked to a depth of 8 or 10 feet, or even 15 feet. In the Monongabela Valley many brick are made from surface clays, as at Monongahela City and Charleroi, in Washington County. At this last place the section is as follows:

Section at Charleroi, Washington County, Pa.

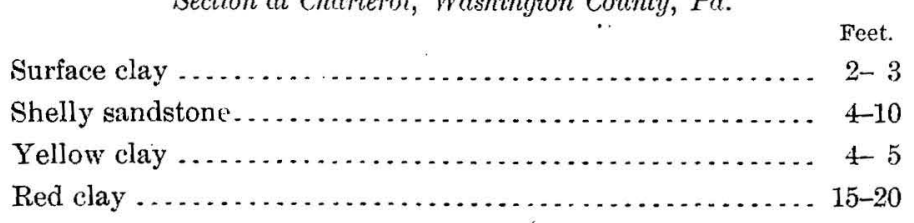

a Second Pennsylvania Geol. Survey, Rept. Q, pp. 10, 11, $12 . \quad{ }^{c}$ Ann. Rept. Pennsylvania State College, 1897, p. 128. bIdem, Rept. MN, p. 257. 
The composition is as follows: ${ }^{a}$

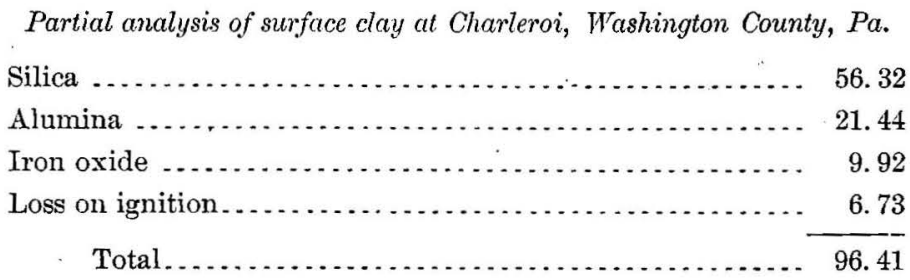

Alluvial clays are also worked for common and pressed brick at Freeport, Armstrong County; Sheridan, Lebanon County; Hyde Park, Ligonier, and Mount Pleasant, Westmoreland County; Uniontown, Dawson, Smithfield, and Fairchance, Fayette County; and California, Washington County.

At Dawson the section involves:

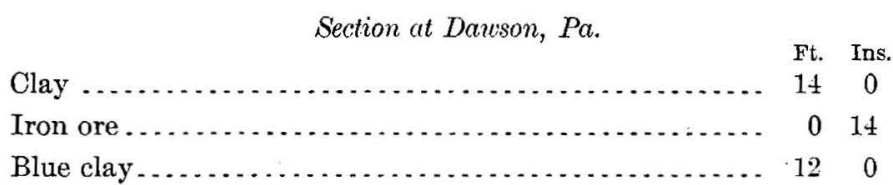

In the Allegheny River Valley several brick yards in the vicinity of Allegheny use the surface clays for mixing with the Carboniferous shales. Most of the swamps in McKean County are said to be underlain by clays which are sometimes refractory in character. ${ }^{b}$ In Perry County common brick clay exists at many points, especially near New Bloomfield, where there is a deposit of alluvial clay of a fine white color. ${ }^{c}$ In Pike and Miner counties surface clay suitable for the manufacture of pottery occurs on the lan'd of T. Bells, $2 \frac{1}{2}$ miles below Ledgedale, on the Old Valley of the Paupack, and has been manufactured into red ware. The section involves: ${ }^{l}$

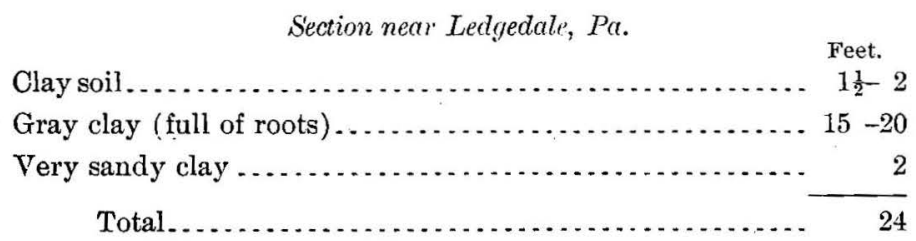

Another deposit occurs on the opposite or Wayne County side of the Paupack, 200 feet above the stream level. It is said to be 200 feet thick.

In Harmony Township, Susquehanna county, ${ }^{e} \mathrm{I}$. C. White states that the old channel of Starrucca Creek has been filled up by 75 feet of impervious reddish-drab clay of glacial origin. It has been used in the manufacture of brick, and 40 feet of it were exposed in a railroad cut. Other deposits of glacial clay occur at Williamsport, Hughesville, and other points in Lycoming County. ${ }^{f}$

a Am. Rept. Pennsylvania State College, 1897, p. 131. $b$ Second Pennsylvania Geol. Survey, Rept. R, p. 28. oIdem, Rept. FF. 208.
dIdem, Rept. G6, p. $\mathbf{1 7 0}$

c Idem, Rept. G5, p. 97

fIdem, Rept. Z, p. 136 
Clays for building brick are found in most of the deeper valleys of McKean County. Those having an outlet through the Allegheny River at the State line, namely, Tuna and Kinzua creeks, have more extensive clay beds than any of the others. They are usually surface deposits of rather limited extent. ${ }^{a}$ Terrace clays are also worked for pottery manufacture at New Geneva and Point Marion, Fayette County; Greensboro, Greene County.

In Delaware County much clay is found at Morton station. Many deposits of loamy clay also occur in Upper and Lower Chichester townships.

Around Philadelphia the Columbia loams form an inexhaustible supply of clay for red brick and have been worked for a long period. ${ }^{b}$

Miscellaneous analyses of Pennsylvania clays.

\begin{tabular}{|c|c|c|}
\hline & 1. & 2. \\
\hline $\mathrm{SiO}_{2} \ldots \ldots \ldots$ & 61.81 & 54.09 \\
\hline $\mathrm{Al}_{2} \mathrm{O}_{3} \ldots \ldots \ldots \ldots$ & 27.18 & 19.95 \\
\hline $\mathrm{Fe}_{2} \mathrm{O}_{3} \ldots \ldots \ldots \ldots$ & 6. 96 & 9.84 \\
\hline $\mathrm{CaO} \ldots \ldots \ldots \ldots$ & 2.00 & .72 \\
\hline $\operatorname{MgO} \ldots \ldots \ldots \ldots$ & 1.50 & 1.55 \\
\hline $\mathrm{Na}_{2} \mathrm{O} \ldots \ldots \ldots \ldots \ldots$ & & 2.20 \\
\hline $\mathrm{K}_{2} \mathrm{O} \ldots \ldots \ldots \ldots$ & & 3.31 \\
\hline $\operatorname{Ign} \ldots \ldots \ldots$ & & 8.98 \\
\hline
\end{tabular}

1. Analysis of brick, Allegheny Brick Company, Limited, Allegheny.

2. Butler Brick and Tile Company, Butler, Pa.

\section{CLAY-WORKING INDUSTRY.}

Pennsylvania ranks second in the list of clay-producing States, Ohio being first, but in certain lines of ware, such as pressed brick, terra cotta, common brick, and fire brick, Pennsylvania outranks Ohio.

Though not the leading State, yet there are probably few others, if, indeed, any, in which the raw materials used by the clay worker are so uniformly distributed. This can be seen by consulting the maps showing the production of paving brick, fire brick, and pottery (PIs. VIII and IX).

Common brick.--This class of ware is manufactured all over the State, although local expansions of the industry are seen around the larger cities, as Philadelphia, Pittsburg, Allentown, Lancaster, Reading, Pottstown, and Scranton. The materials used are commonly surface or alluvial clays, but shales and residual clays are of ien 
found adaptable. In the Allegheny River Valley shales are worked at Harmarville, Sharpsburg, Millvale, Barking, Allegheny, etc.

Pressed brick.-The red Philadelphia pressed brick made from the Columbia loams around Philadelphia have won a high reputation in former years, but are not so much used now as those made from the fire clays in the western part of the State, for the color of the latter is better liked by most architects at the present time. These buff brick are now being turned out in large quantities.

Paving brick.-Pennsylvania again stands second to Ohio in the output of this grade of product, because, while the materials suitable for their manufacture are more widely distributed over the State, still, the great market of the central States being farther off, there is less inducement to build up a paving-brick industry in this State.

The industry in western. Pennsylvania is not so extensive as the fire-brick or building-brick industry. Paving brick are manufactured at many points along with other classes of brick, as at Connellsville, Layton, Kittanning, Fallston, Blacklick, Harmarville, Rochester, Johnstown, Mount Braddock, Hyde Park, Barking, and Bolivar. Most of the companies making them at these points make fire brick their chief product.

The distribution of the plants can be seen by reference to the map (Pl. VIII).

Fire brick.-Pennsylvania produces very nearly half of the fire brick made in the United States. This great yield is due to the location of a great iron and steel industry within the State, which creates a great demand for the refractory wares made. In addition to this, many thousands are also called for in the lining of coke ovens in the bituminous-coa? districts, and for the kilns used in the various branches of the clay-working industry, which is in active operation in western Pennsylvania. In the vicinity of Bolivar the upper Freeport clay is worked to supply the several fire-brick works in that region. In this district fire clay has been mined for more than fifty years. Other fire-brick works are located at Nineveh, Johnstown, and South Fork, in the Conemaugh Valley, and there are also a number of other plants in the Allegheny, Ohio, and Youghiogheny valleys.

In addition to the works in the western part of the State, there are others in the extreme eastern portion which draw on New Jersey for their raw materials. The residual white clays of the South Mountain region are also used.

Glass pots form an important refractory product, and there are several large operators located in the State. This type of ware is made of a mixture of German, Missouri, and Pennsylvania clays.

Pottery.-The established potteries are confined chiefly to the western and eastern ends of the State, and the product includes white earthenware, ordinary and chemical stoneware, and common red earthenware. 
New Brighton is a most important center, for here are three large factories making stoneware, and there is a large white ware works at Beaver Falls, as well as a flower-pot works. The establishment of the pottery industry at this locality dates back to the year 1834, and the conditions have been such that the industry has expanded along several different lines since that time. ${ }^{a}$ The lower grades of ware are made from native clays, but the higher ones are manufactured from materials brought largely from other States. Some white ware is made in Philadelphia, and there has been a chemical stoneware factory in operation at that locality for a number of years. Art tile are made at Beaver Falls, and plain and encaustic floor tile are pressed at Pittsburg, the red burning shales of that vicinity producing a tile of great purity of color and density of body. Terra cotta is made to some extent, the factories being located at Philadelphia and New Brighton. Drain tile are also made at several localities, and the Kittanning clays at New Brighton are well adapted for the manufacture of sewer pipe.

The following table gives the total value of clay products produced in Pennsylvania from 1895 to 1901, and also the output of the individual grades of ware in 1900 and 1901:

Value of clay products of Pennsylvania from 1895 to 1901.

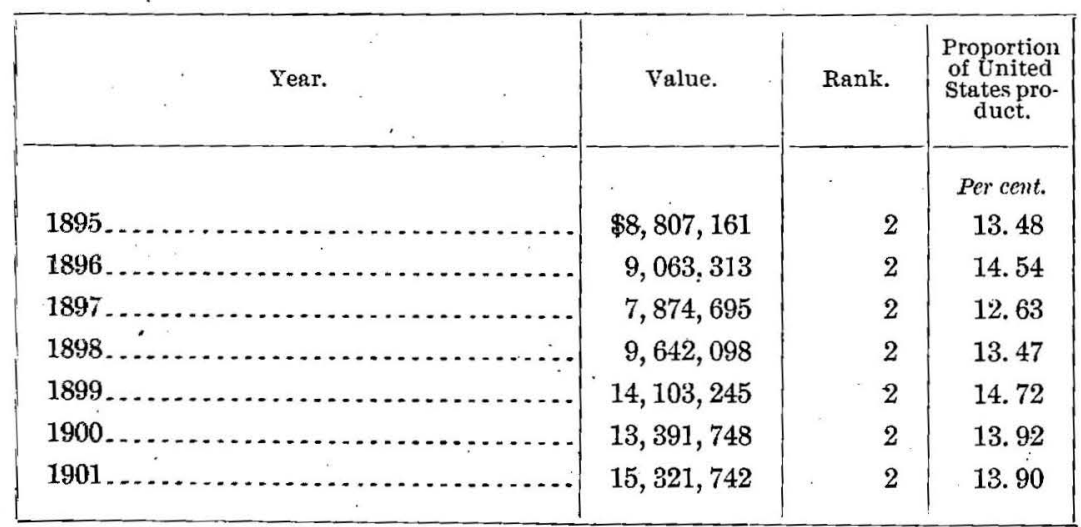

a Clays of western Pennsylvania: Ann. Rept. Pennsylvania State College, 1897, p. 36. 
PENNSYLVANIA-RHODE ISLAND-SOUTH CAROLINA.

Value of clay products of Pennsylrania in 1900 and 1901.

\begin{tabular}{|c|c|c|}
\hline & 1900. & 1901. \\
\hline Common brick $\ldots \ldots \ldots \ldots \ldots \ldots \ldots \ldots$ & $\$ 4,484,590$ & $\$ 5,357,079$ \\
\hline Front brick. . ........ & 596,559 & 844,087 \\
\hline Vitrified brick . . . . . . . . . . . . & 481,670 & 670,081 \\
\hline Fancy brick ..... & 57,279 & 74,726 \\
\hline Fire brick .................. & $4,587,991$ & $4,791,083$ \\
\hline Stove linings. $\ldots \ldots \ldots \ldots \ldots \ldots \ldots \ldots \ldots$ & 90,348 & 86,190 \\
\hline Drain tile................... & 8,420 & 7,409 \\
\hline Server pipe..................... & 522,650 & 438,998 \\
\hline Terra cotta $\ldots \ldots \ldots \ldots \ldots \ldots \ldots \ldots$ & 180,100 & 314,900 \\
\hline Fireproofing $\ldots \ldots \ldots \ldots \ldots \ldots \ldots \ldots \ldots \ldots \ldots \ldots \ldots$ & 95,957 & 101,652 \\
\hline Tile, not drain $\ldots \ldots \ldots \ldots \ldots \ldots \ldots \ldots$ & 191,878 & 188,525 \\
\hline Red earthenware $\ldots \ldots \ldots \ldots \ldots \ldots$ & 88,682 & 431,433 \\
\hline Stoneware.......... & 255,457 & \\
\hline White granite ware $\ldots . . . . . . . . . . . . .$. & 830,000 & 839,903 \\
\hline 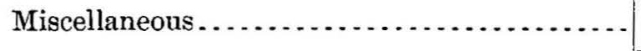 & 920,167 & $1,175,676$ \\
\hline Total $\ldots \ldots \ldots \ldots \ldots \ldots \ldots$ & $13,391,748$ & $15,321,742$ \\
\hline
\end{tabular}

RHODE ISLAND.

The glacial clays of Rhode Island, excluding Block Island, are of limited extent. They occur at a few points around Narragansett Bay, but the principal occurrence is in the town of Barrington. They underlie an area of about 1 by $1 \frac{1}{2}$ miles a ferw feet above tide level. ${ }^{a}$ They are bluish gray, and sandy in their upper portion. Their depth reaches 60 to 65 feet. The production of Rhode Island is included with that of Connecticut. (See p. 79.)

\section{SOUTH CAROLINA.}

There has perhaps been less published regarding the clay resources of this State than those of any other east of the Mississippi except Delaware. The northwestern part of the State is underlain by crystalline rocks, which extend to the edge of the Coastal Plain, the line of division passing a short distance southeast of Chesterfield and Camden, through Columbia and west of Aiken.

\section{RESIDUAL CLAYS.}

These may be looked for throughout the crystalline belt, and are usually impure. No kaolins are reported, but many of the white-burning sedimentary clays found in the Coastal Plain are incorrectly termed such. 


\section{COASTAL PLAIN CLAYS.}

The formations range from the Potomac to the Columbia, and consist of sands, clays, loams, and marls. Of the different formations the Potomac and Columbia are perhaps the most important to the clay worker, though the others might contain local clay deposits of value.

The Potomac outcrops in a belt from 4 to 5 miles wide, reaching from Augusta, Ga., through Aiken, south of Lexington, and through Columbia to Camden and Cheraw. ${ }^{a}$ It contains lenses of white clay which are worked at Aiken, Columbia, Severn, and other points and sold to paper manufacturers. Some of these may be available for pottery or fire brick.

The Columbia loams are found on the lower lands and along rivers, and may be useful for brick manufacture.

Tuomey, in his report on the geology of South Carolina, published in 1848, states $^{\delta}$ that pottery clay is common in the Buhrstone formation (Eocene) and that a good clay occurs north of Hamburg and also near Graniteville and on Congaree Creek.

$=$

CLAY-WORKING INDUSTRY.

Sonth Carolina ranks thirty-first among the clay-producing States, the production since 1895 having been as follows:

Value of clay products of South Carolina from 1895 to 1901.

\begin{tabular}{|c|c|c|c|}
\hline Year. & Value. & Rank. & $\begin{array}{l}\text { Proportion } \\
\text { of United } \\
\text { States } \\
\text { product. }\end{array}$ \\
\hline $1895 \ldots .$. & $\$ 276,918$ & 30 & $\begin{array}{r}\text { Percent. } \\
0.42\end{array}$ \\
\hline $1896 \ldots .$. & 354,275 & 27 & .57 \\
\hline $1897 \ldots$ & 290,497 & 30 & .48 \\
\hline $1898 \ldots . .$. & 259,232 & 35 & .33 \\
\hline $1899 \ldots \ldots \ldots$ & 605,329 & 28 & .63 \\
\hline $1900 \ldots \ldots$ & 711,336 & 27 & .73 \\
\hline $1901 \ldots \ldots \ldots \ldots+\ldots$ & 575,218 & 31 & .52 \\
\hline
\end{tabular}

a Bull. U. S. Geol. Survey No. 138, p. 208.

- $\quad b$ Page 289. 
Value of the clay products of South Carolina in 1900 and 1901.

\begin{tabular}{|c|c|c|}
\hline & 1900. & 1901. \\
\hline Common brick $\ldots \ldots \ldots \ldots \ldots \ldots$ & $\$ 665,998$ & $\$ 546,028$ \\
\hline Front brick $\ldots \ldots \ldots \ldots \ldots$ & 10,784 & 1,188 \\
\hline Fire brick . . . . . . . . . & 14,321 & 14,925 \\
\hline Stove linings. ........ & $\ldots . . .$. & (a) \\
\hline 'Drain tile. $\ldots \ldots \ldots \ldots \ldots \ldots \ldots$ & $\ldots . . .$. & (a) \\
\hline Miscellaneous ........................ & 300 & 250 \\
\hline Pottery $\ldots \ldots \ldots \ldots \ldots$ & 17,633 & 11,872 \\
\hline 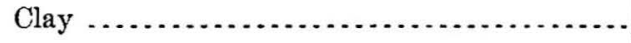 & 79,900 & 143,700 \\
\hline
\end{tabular}

TENNESSEE.

The geologic formations occurring in Tennessee belong to the pre-Cambrian, Cambrian, Ordovician, Silurian, Devonian, Carboniferous, Eocene, and Pleistocene. The pre-Cambrian rocks occur in small areas along the eastern border, while west of them and folded into many narrow belts lie rocks of Cambrian to Silurian age. The Carboniferous reaches from the eastern edge of the Cumberland Plateau westward beyond the Tennessee River. In the central part of the State is a large area of Silurian, and another along the Tennessee River in the southern half of the State. This is followed on the west by a broad belt of Tertiary, which in turn is separated from the Mississippi River by a strip of Pleistocene.

PRE-CAMBRIAN.

No kaolin deposits have been described from the crystalline area of northeast Tennessee, but they may exist, as they are abundant in western North Carolina:

PALEOZOIC RESIDUAL CLAYS.

The rocks of these formations yield residual clays from both limestones and shales, and the latter might also grind up to a plastic mass. In parts of Cumberland, Rhea, Loudon, Meigs, Roane, Grundy, Franklin, Marion, and Sequatchie counties the residual red or blue clays of the Chickamauga limestones are well adapted for making bricks. These clays and some from Cambrian shales are extensively used in adjacent areas for making drain tile. Others are found around Pikeville. ${ }^{a}$ In the region around Knoxville ${ }^{b}$ the calcareous Athens shale also yields a residual brick clay which accumulates in the hollows. These clays are worked at Maysville and Knoxville. ${ }^{c}$ The Knox dolomite also yields a stiff clay, which may

" (Yeologic Atlas U. S., folio 21, Pikeville. $\quad b$ Idem, folio 16, Knoxville. $\quad v$ Idem, folio 59, Bristol. 
at times contain much chert. The Conasauga and upper part.of the Rome formation likewise yield residual clays. ${ }^{a}$ Along the Tennessee-Georgia boundary the residual clays derived from the Bangor and Chickamauga limestones are suited for the manufacture of brick and tile. Some of the highly siliceous residual clays from the Knox dolomite are refractory, ${ }^{b}$ and fire brick are made from them near Cleveland. The Bangor limestone weathers to red and blue residual clays which are worked at many localities in parts of Warren, Dekalb, Grundy, White, and Van Buren counties. Others are found in the region around Pikeville, ${ }^{c}$ Standingstone, ${ }^{d}$ Wartburg, ${ }^{e}$ and Maynardsville. ${ }^{f}$ Near Smithville a white clay derived from the slate in the upper part of the Fort Payne division, is used for pottery. ${ }^{g}$

\section{CARBONIFEROUS.}

J. M. Safford, in his report on the Geology of Tennessee, published in 1869, refers to the following occurrences of clay in the Carboniferous:

Near the Cumberland Iron Works, in Stewart County, is a bed of fire clay of Lower Carboniferous age; ${ }^{h}$ another occurs 4 miles southwest of Cumberland City, in Stewart County; in the valley of Crow Creek, near Anderson station, the Coal Meas. ures at the margin of the table-land show a fire clay 3 feet thick, 163 feet below the top of the cliff; ${ }^{i}$ in Franklin County, near the Grundy County line, and 4 miles northwest of the track of Sewanee road, at the old Logan bank, is a bed of clay 115 feet below the conglomerate; ${ }^{j}$ near the lower end of the Battle Creek Valley, in Marion County, is a bed of fire clay 2 feet thick; 5 miles southeast of Tracy City, and $1 \frac{1}{2}$ miles from Parmley Bank, a bed of clay underlies the main Sewanee coal; ${ }^{k}$ another occurs at the north end of Lookout Mountain, below the Upper Conglomerate. ${ }^{l}$ Many of the under clays of the coal seams, according to Safford, are of

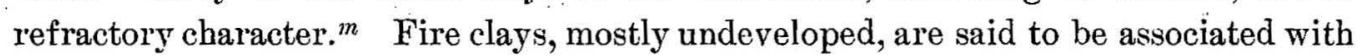
the coals in the areas covered by the following Geologic Atlas folios: Standingstone, No. 53; Wartburg, No. 40 (used for pottery). ${ }^{n}$

In the Kingston region the beds of clay which underlie the coals are, no doubt refractory in many cases, but they are wholly undeveloped. ${ }^{\circ}$

\section{TERTIARY.}

In western Tennessee the plastic clay immediately underlying the Lafayette formation serves as the basis of a rather active stoneware and fire-brick industry.

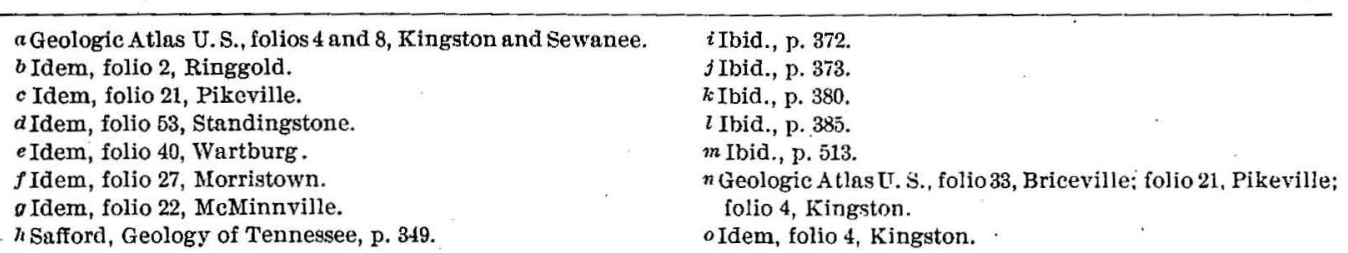


The section ustully seen in the clay pits involves red Lafayette sands, which seem to overlie unconformably the beds of stoneware clay and white sands.

One pottery, located at Grand Junction, used clay from the various pits of the vicinity. The clay varies in quality. In the pits of the Irwin Clay and Sand Company, $1 \frac{1}{4}$ miles east of the station, along the railroad, the section given by E. C. Eckel ${ }^{a}$ is-

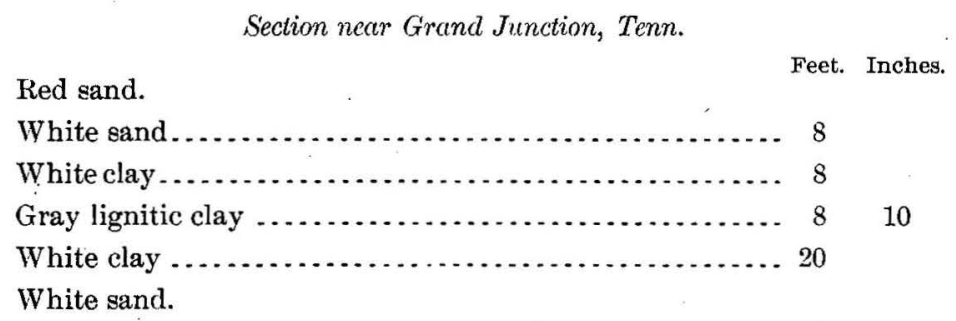

The elay deposits are very irregular, sometimes running together to form overlapping lenses in the white and yellow sand. The Lafayette seems to overlie the section. At Jackson there is another pottery for making stoneware, and the section here is somewhat similar. At Pinson is still another stoneware plant, which also makes fire brick and tiles. There are several around Pinson, all of which show the clay associated with the sands. Some of the clay from Pinson is sent to Jackson for use in the pottery there. The Pinson clay pits are all southwest of the station. Another pottery is at Mackenzie. ${ }^{b}$

The clay at Hico, 3 miles south of Mackenzie, is shipped to the potteries at Akron and East Liverpool, Obio, and Louisville, $\mathrm{Ky}$. The clays from Hollow Rock are shipped to Nashville. There is a large pottery at Toone and one being erected at Henry. Two potteries are also located near Paris.

Three miles east of Currier are the pits of I. Mandle, where an area 60 by 50 feet has been opened up. The section is as follows:

Section at Mandle's clay pits, s miles east of Currier, Tenn.

\begin{tabular}{|l|l|}
\hline \multicolumn{1}{|c|}{ East side. } & \multicolumn{1}{|c|}{ West side. } \\
\hline $\begin{array}{l}2 \text { feet clay. } \\
4 \text { feet clay. }\end{array}$ & Reddish sand. \\
1 foot black clay (lignitic). & 15 feet light-gray clay. \\
5 feet brown clay (ball clay). & 1 foot black clay. \\
\hline
\end{tabular}

The bases of the two sections are at the same level, hence the type beds are very irregular. The light-gray clay is shipped to East Liverpool, Ohio, for saggers. .The ball clay is known as Tennessee ball clay No. 3. Tests of samples of this clay supplied 
by I. Mandle, made by S. Geijesbeek, show that it leaves 10 per cent residue on a 175-mesh sieve. Its rational composition is-

Analysis of clay from Mandle's clay pits, near Paris, Tenn.

Per cent.

Clay substance. . . . . . . . . . . . . . . . . . . . . . 91.35

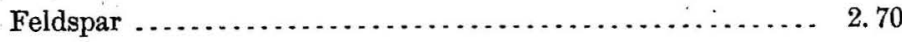

Quartz ....................................... 5.95

It will carry as much as 72 per cent of nonplastic material. The shrinkage at cone 1 is 12.5 per cent; at cone 2,18 per cent. It burns white at cone 1 and gray at cone 8 , being vitrified at that temperature. This is located 5 miles from Paris, and the clay is shipped from Currier, which is 3 miles from the mine.

Tennessee ball clay, No. 1, found in Henry County, shows the following rational analysis:

$$
\text { Analysis of ball clay from Henry County. }
$$

Per cent

Clay substance.

86.20

Feldspar

2. 70

Quartz

11.10

It carries 60 per cent nonplastic material to the mixture. The total fire shrinkage at cone 8 is 15 per cent, and at this temperature it burns to a cream-white color and dense body.

\section{ALLUVIAL CLAYS.}

Alluvial clays are found in many of the river valleys, and in most cases are the wash from the residual clays of surrounding areas. They often underlie the river terraces. These terrace clays are used in the Maynardville area. ${ }^{\alpha}$ Others are common in the region around Morristown, ${ }^{b}$ especially in the low grounds of the Lick Creek, Nolichucky, and French Broad valleys.

The following analyses of Tennessee clays have been gathered from different sources:

Analyses of Tennessee clays.

\begin{tabular}{|c|c|c|c|c|c|c|c|c|c|c|}
\hline Locality. & $\mathrm{SiO}_{2}$ & $\mathrm{Al}_{2} \mathrm{O}_{3}$ & $\mathrm{Fe}_{2} \mathrm{O}_{3}$. & $\mathrm{CaO}$. & MgO. & Alk. & $\mathrm{H}_{2} \mathrm{O}$. & $\begin{array}{l}\text { Moist- } \\
\text { ure. }\end{array}$ & MnO. & Remarks. \\
\hline Loudon.... & 45.06 & 30.03 & a 4:50 & 4.70 & 4.80 & & 10 & 1 & & $\begin{array}{l}\text { Crossley, analyses of } \\
\text { clays. }\end{array}$ \\
\hline Powdes Station... & 68.35 & 12.96 & 6.44 & .23 & 1 & 2.14 & 7 & 8 & 0.9 & J. W. Slocum, analyst. \\
\hline Chattanooga ...... & 68.96 & 20.42 & 1.84 & .16 & .33 & 2.18 & 6.50 & & Tr... & $\begin{array}{l}\text { Tennessee Paying Brick } \\
\text { Co. }\end{array}$ \\
\hline Robbins ............. & 70.57 & 15.19 & 7.97 & .78 & .32 & 2.80 & & & & $\begin{array}{l}\text { Clay Worker, December, } \\
1893 .\end{array}$ \\
\hline
\end{tabular}


CLAY-WORKING INDUSTRY.

Tennessee ranks twenty-fifth among the clay-producing States, the production since 1895 having been as follows:

Value of clay products of Tennessee from 1895 to 1901.

\begin{tabular}{|c|c|c|c|}
\hline Year. & Value. & Rank. & $\begin{array}{l}\text { Proportion } \\
\text { of United } \\
\text { States } \\
\text { product. }\end{array}$ \\
\hline & & & Per cent. \\
\hline $1895 \ldots$ & $\$ 522,534$ & 23 & 0.80 \\
\hline $1896 \ldots \ldots \ldots \ldots$ & 537,325 & 23 & .86 \\
\hline $1897 \ldots \ldots$ & 612,293 & 22 & .98 \\
\hline $1898 \ldots \ldots \ldots$ & 513,738 & 22 & .72 \\
\hline $1899 \ldots \ldots$ & $9 \dot{4} 8,853$ & 22 & .99 \\
\hline $1900 \ldots \ldots$ & 915,578 & 23 & .95 \\
\hline $1901 \ldots \ldots \ldots \ldots \ldots$ & 893,967 & 25 & .81 \\
\hline
\end{tabular}

Value of the clay products of Tennessee in 1900 and 1901.

\begin{tabular}{|c|c|c|}
\hline . & 1900. & 1901. \\
\hline 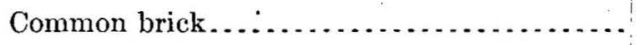 & $\$ 609,994$ & $\$ 610,968$ \\
\hline 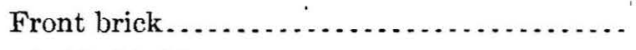 & 59,493 & 32,350 \\
\hline Vitrified brick $\ldots \ldots \ldots \ldots \ldots \ldots \ldots$ & 87,760 & 67,129 \\
\hline Fancy brick $\ldots \ldots \ldots \ldots \ldots \ldots \ldots \ldots \ldots \ldots \ldots \ldots \ldots$ & (a) & (a) \\
\hline Fire brick $\ldots \ldots \ldots \ldots \ldots \ldots$ & 32,573 & 37,100 . \\
\hline Drain tile $\ldots \ldots \ldots \ldots \ldots \ldots \ldots \ldots$ & 18,900 & 15,961 \\
\hline Sewer pipe....... & $(a)$ & (a) \\
\hline Fireproofing .... & (a) & (a) \\
\hline Stoneware .... & 48,325 & 62,093 \\
\hline Fire clay ........ & 2,697 & \\
\hline Stoneware clay ...... & 808 & 32,957 \\
\hline Raw .......... & 3,750 & \\
\hline Total : & 915,578 & 893,967 \\
\hline
\end{tabular}

a Production not given where less than three factories supplied.

\section{VIRGINIA.}

The crystalline rocks, consisting of granites, gneisses, and schists, with some intrusives, cross the State from north to south in a belt of increasing width, whose western boundary follows approximately a line running from Harpers Ferry south- 
westward, passing a few miles east of Front Royal. The eastern edges pass through Alexandria, Fredericksburg, Bothwell, Richmond, and Petersburg.

The Cambro-Silurian rocks form a broad belt lying west of the crystalline belt and extending to the Virginia-West Virginia boundary with the exception of an area of Carboniferous in the extreme southwestern portion.

The Newark group occupies several narrow belts within the crystalline region.

Southeast of the erystalline belt and underlying the Coastal Plain area is a series of mostly unconsolidated sands and clays. The Coastal Plain area lies east of a line running through Alexandria, Fredericksburg, Bothwell, Richmond, Petersburg, and Emporia, and covers 9,800 square miles. The geologic structure is similar to that of eastern Maryland, but the Potomac beds are more sandy. Darton ${ }^{a}$ gives following Coastal Plain formations:

Coastal Plain formations of Virginia.

\begin{tabular}{|c|c|c|}
\hline Formation. & $\therefore \quad$ Character of beds. & Age. \\
\hline Columbia..... & Loams, sands, and gravels in terraces.......... & Pleistocene. \\
\hline Lafayette. & Orange sands, loams, and gravels.......... & Pliocene. \\
\hline Chesapeake. & Clays, sands, infuserial earth, and marl..... & Miocene. \\
\hline Pamunkey. & Clays, marls, and sands......... & Eocene. \\
\hline Potomac.. & 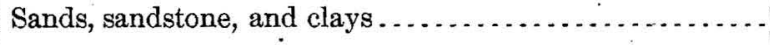 & Early Cretaceous. \\
\hline
\end{tabular}

CRYSTALLINE AREA.

The decomposition of the rocks throughout this area may give rise to residual clays, usually of impure character, which are thicker on the gentler slopes or level surfaces, but the wash from them is often found in the valleys. They are usually adapted to the manufacture of common brick. Prof. J. B. Woodworth informs me that at Clayville, Powhatan County, the gneisses weather to a residual clay, which is used in the manufacture of light-colored brick. The granite along the eastern border of the crystalline belt forms a yellow clay often as much as 20 feet deep.

Kaolin.-This is found in Henry and Patrick counties, and perhaps elsewhere, but the deposits are just being developed. It is also said to occur in Ashe County, on the South Fork of New River, and near Wytheville, Wythe County, as well as in Smyth County. ${ }^{b}$ Kaolin and fire-clay mines are said to have been opened in Nelson County, near the line of the Southern Railway, ${ }^{c}$ but nothing has been published regarding them in recent years. The occurrence of kaolin has also been noted from a locality known as Bon Air, 9 miles from Richmond, ${ }^{l}$ and from the crystalline area of Prince Edward and Cumberland counties, a little east of their court-houses. ${ }^{e}$

a Bull. U. S. Geol. Survey No. 138, p. 162. $a$ Ibid. 
CAMBRO-SILURIAN CLAYS.

The Cambro-Silurian shales and limestones yield an abundance of impure residual clay, which is well adapted to brick manufacture. These clays are likely to be found throughout the region of the Great Valley.

Some of the residual clay found near the zinc deposits in Pulaski County may. contain zinc. It has no special commercial value on this account, however. ${ }^{a}$ Its composition was:

Analysis of residnal clays in Pulaski County, $\mathrm{Y}$ a.

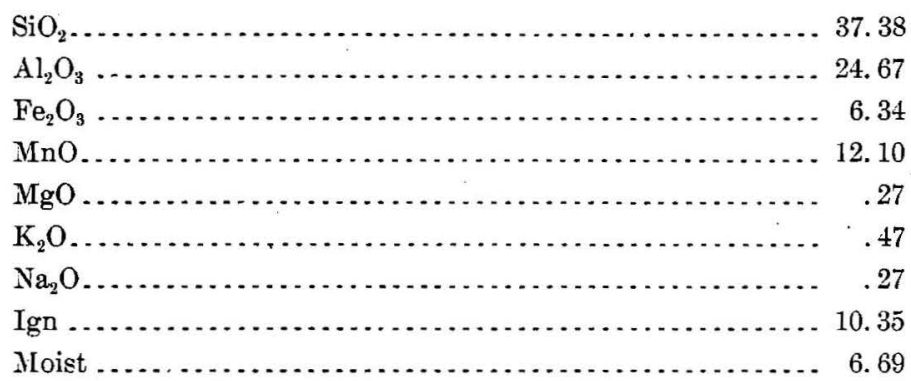

White residual clay is also reported from Black Rock. ${ }^{b}$

CARBONIFEROUS.

Though containing important beds of coal, the clayey members of the formation have received but little notice. ${ }^{c}$

W. B. Rogers ${ }^{l}$ states that on Ryders Creek, in the region west of the Greenbrier River and in the Kanawha Valley, yellow shales are found lying below a heavy szam of coal. They contain occasional lumps of kidney ore, but the shale was thought to be refractory.

At Catawba Furnace, Botetourt County, beds of fire clay are said to occur with the coal. $e^{e}$ The beds dip from $30^{\circ}$ to $50^{\circ}$ away from Catawba Mountain.

TRIASSIC.

No mention is anywhere made of the use of the shales of this formation, but the mellowed outcrops of the more shaly members would no doubt prove serviceable. In the vicinity of Harpers Ferry they yield residual clays suitable for brick manufacture. They also form residual clays along their line of outcrops in the Richmond coal basin.

a Heyward, B. H., On a zinc-bearing clay from the neighborhood of the Bertha zinc mine, Pulaski County, Va.: The Virginias, Vol. III, p. 4.

$b$ The Virginias, Vol, IV,, $5 s$

c For sections see M. R. Campbell, Geology of Big Stone Gap coal field: Bull. U. S. Geol. Survey No. 111, 1893.

a Geology of the Virginias, p. 376

e The Virginias, Vol. IV, p. 161. 
COASTAL PLAIN FORMATIONS.

These contain the most important clay deposits found in the State, but in all publications regarding them their economic value is rarely referred to.

The Potomac group is the basal member of the Cretaceous, and is exposed where the overlying ones have been eroded. These areas are narrow belts in the Nottoway, Appomattox, James, Pamunkey, and Rappahannock depressions, near the western Coastal Plain borders, and from a wide belt from Fredericksburg to Washington. The formation consists of sand, with beds of clay of variable size and shape. The lower beds of the formation dip gently eastward and lie usually on the crystalline rocks, but around Bothwell they rest on the Newark sandstones and shales. Pottery clays are said to be abundant in the Potomac beds around Fredericksburg and also below it.

The Pamankey formation is exposed north of the James River, but does not contain many clays of importance. The clays are referred to by W. B. Rogers, ${ }^{b}$ who states that they usually contain many shell remains. Outcrops are seen at Herring Creek.

The Chesapeake formation can be well seen at many points, since it is cut into by the Rappahannock, Mattaponi, Pamunkey, and James rivers. ${ }^{c}$ It consists chiefly of beds of clay, fuller's earth, shell marl, and fine sand. These clays may attain a great thickness. The Miocene clays may often contain sulphate of iron. ${ }^{d}$ Many of them, however, are suited for pottery and brick manufacture. ${ }^{e}$ Sandy Miocene clays occur in many parts of Hanover, King William, Henrico, and other counties. They are of greenish-gray or brown color and have an astringent taste. $f^{f}$

The Lafayette formation.-This, lying on the surface of ridges between the valleys, is probably of little importance to the clay worker, but occasionally contains beds of brick clay.

The Columbia formation, which caps terraces along the Potomac, Rappahannock, Mattaponi, Pamunkey, York, Chickahominy, James, and Blackwater rivers, and Chesapeake Bay, and which covers all of Norfolk and Princess Anne counties, may often carry brick loams, ${ }^{g}$ so that these Columbia loams and other alluvial clays are found in many parts of the State. They are found in the stream bottoms of the Monterey region, ${ }^{h}$ around Fredericksburg, ${ }^{i}$ around Petersburg, and farther down the South Branch ${ }^{j}$ in the Nomini region. ${ }^{k}$

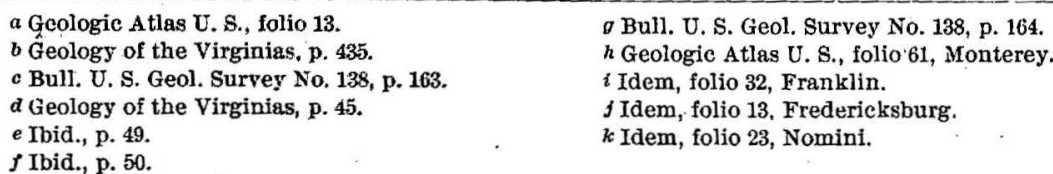


OTHER UNCLASSIFIED OCCURRENCES.

Great beds of blue sandy clay are reported in the section of the Stratford and Chantilly cliffs in Westmoreland County, along the Potomac. ${ }^{a}$ Material termed kaolin is reported from near Sherando, 7 miles southwest of Waynesboro, in the alluvial lands between Back Creek and South Fork of the Shenandoah. The clay, which is said to be 30 feet thick in places, ${ }^{b}$ is involved in the following section:

$$
\text { Section near S'herando, Va. }
$$

Surface of sand, gravel, and cobbles.

Yellowish clay.

White clay.

Analysis of clay from near Sherando, Ta.

Its analysis gave:

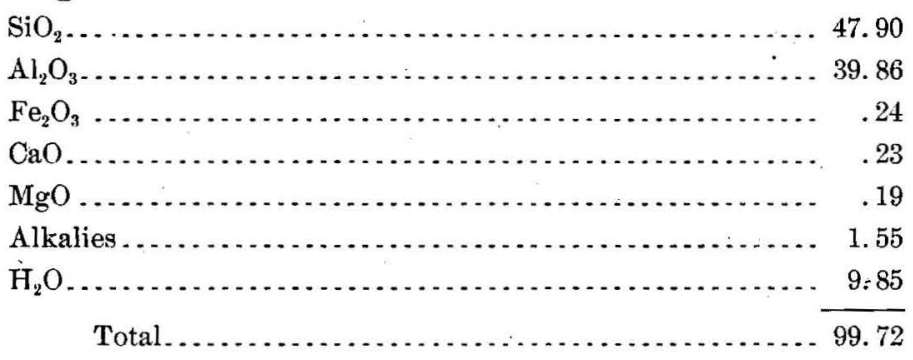

CLAY-WORKING INDUSTRY.

Virginia ranks very low as a producer of clay products. The total production since 1895 has been as follows:

Value of clay products of Virginia from 1895 to 1901.

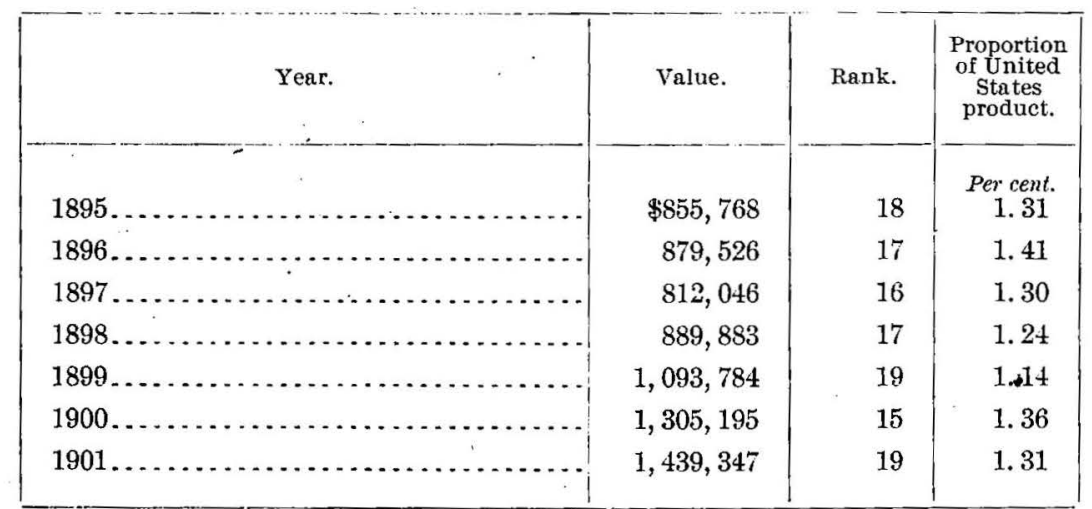

a Geology of the Virginins, p. 428 .

${ }^{b}$ The Virginias, Vol. IV, p. 47 . 
The value of clay products in 1900 and 1901 was as follows:

Value of clay products of Virginia in 1900 and 1901.

\begin{tabular}{|c|c|c|}
\hline . & 1900. & 1901. \\
\hline 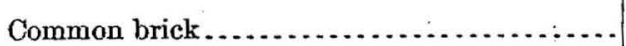 & $\$ 934,185$ & $\$ 1,139,894$ \\
\hline Front brick $\ldots \ldots \ldots \ldots \ldots \ldots$ & 275,847 & 267,028 \\
\hline Vitrified brick $\ldots \ldots \ldots \ldots \ldots \ldots$ & 44,067 & $\ldots . . . . . .$. \\
\hline Fancy brick $\ldots \ldots \ldots \ldots \ldots \ldots \ldots \ldots \ldots \ldots \ldots \ldots \ldots$ & 17,921 & 20,429 \\
\hline Fire brick $\ldots \ldots \ldots \ldots \ldots \ldots \ldots \ldots$ & $26,57.3$ & 3,971 \\
\hline Drain tile $\ldots \ldots \ldots \ldots \ldots \ldots \ldots \ldots$ & 3,285 & 3,978 \\
\hline Sewer pipe............ & $(a)$ & ..... \\
\hline Earthenware $\ldots \ldots \ldots \ldots \ldots \ldots \ldots \ldots \ldots \ldots$ & 425 & $(a)$ \\
\hline Miscellaneous . . . . . . . . . . . . . . & 2,392 & 4,047 \\
\hline
\end{tabular}

a Included in miscellaneous.

WEST VIRGINIA.

The western three-fourths of this State is underlain by rocks of Carboniferous age, while the eastern fourth is covered by Cambro-Silurian rocks, crossing the State in more or less parallel bands, due to their folded structure.

Since there are no pre-Cambrian erystalline rocks found in the State, kaolins of the North Carolina type are not to be looked for, but some white clay may occur in the residual products of the Cambrian and Silurian formations of the eastern part of the State.

\section{CARBONIFEROUS.}

The Carboniferous section of West Virginia is very similar to that of Pennsylrania. The general distribution and character of the clays can best be seen by consulting the map (Pl: III).

POTTSVILLE CONGLOMERATE.

This formation in West Virginia shows many massive sandstone beds, but according to the sections given by I. C. White ${ }^{a}$ fire clay is seen in the sections at several localities. Thus at Piedmont, Mineral County, dark sandy fire clay 12 feet thick is noted under the second coal below the Homewood sandstone and 5 feet thick under the fourth coal. Again, at the mouth of the North Fork of Blackwater, Tucker County, ${ }^{b}$ a bed of fire clay is found between the second and third coals under the Homewood sandstone. Here it is 2 feet thick. The same section also shows numerous shale beds. 
Still another section, taken near the mouth of Sandy Creek, or on Cheat River, Preston County, shows a 7-foot bed of fire clay underlying the coal.

The Mount Savage fire clay of Maryland and Pennsylvania seems to be missing in the West Virginia section.

LOWER COAL MEASURES.

The surface areas of these are again so scattered that the map in Bulletin 65, United States Geological Survey, should be consulted.

These measures may be in place carrying beds of fire clay under the Freeport and Kittanning coals, as in Pennsylvania, but the beds are not as extensive or persistent. The following sections indicate their character:

Section at Newburg, Preston County, W. Va.

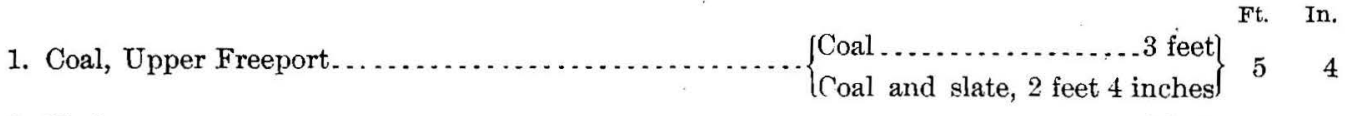

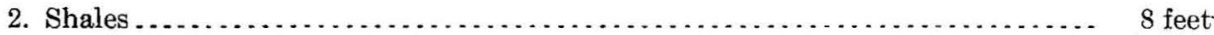

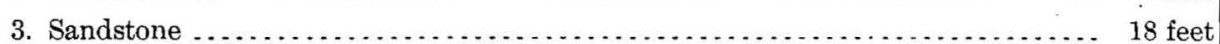

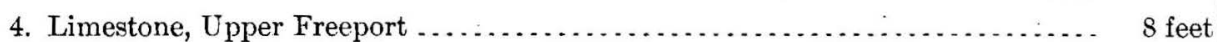

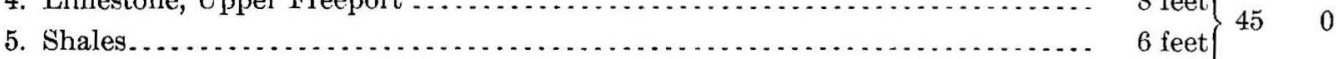

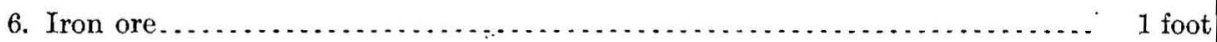

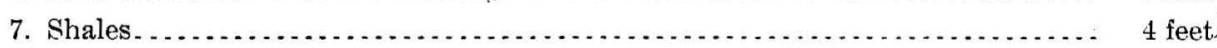

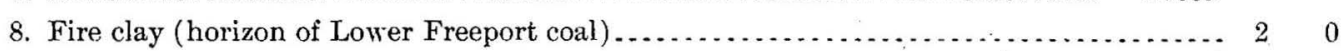

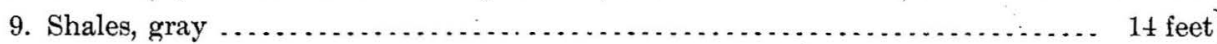

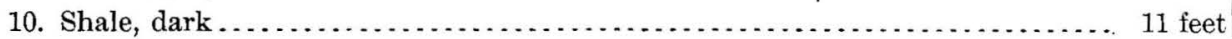

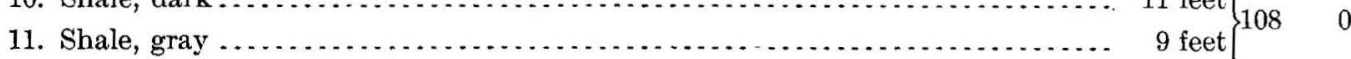

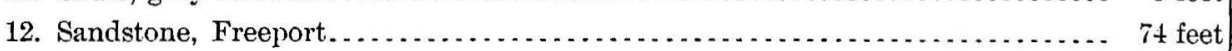

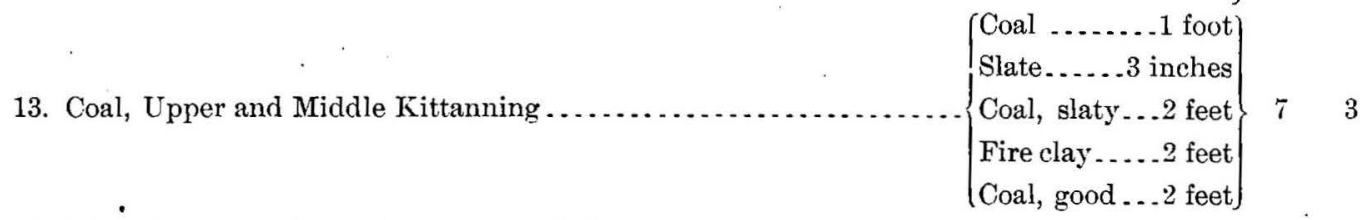

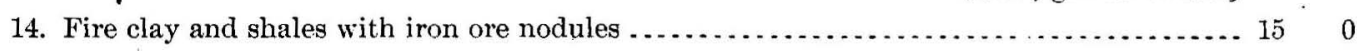

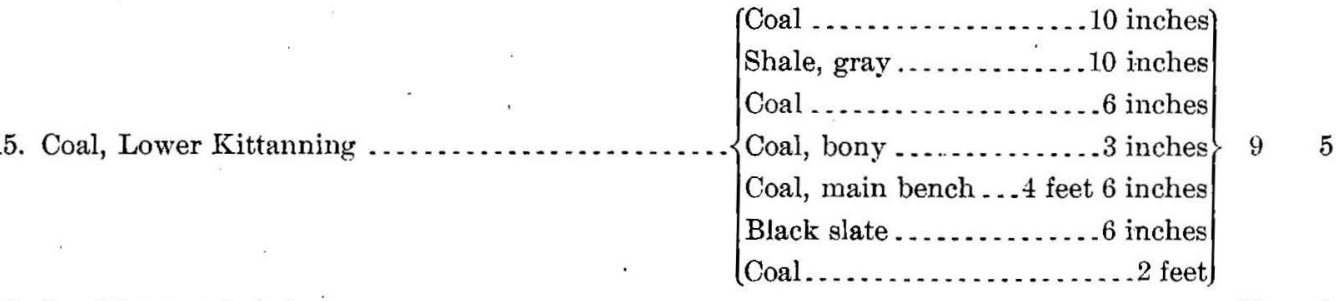

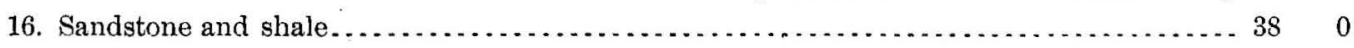

17. Pebbly sandstone, top of No. XII.

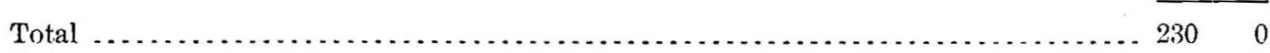


. $\quad$ Coal $\ldots \ldots \ldots \ldots \ldots \ldots \ldots \ldots \ldots \ldots \ldots \ldots \ldots \ldots$ feet

1. Coal, Upper Freeport . ............. Shale and bone. .............

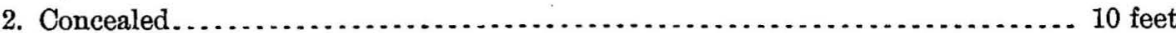

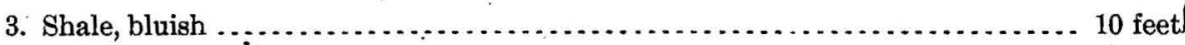

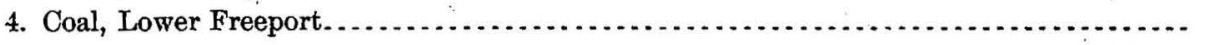

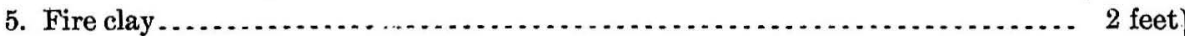

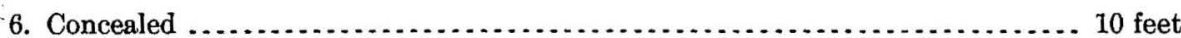

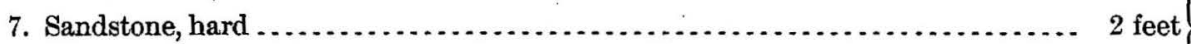

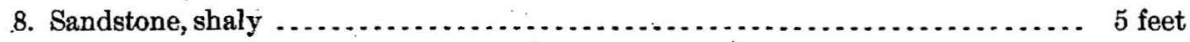

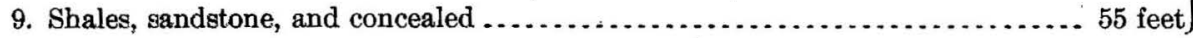

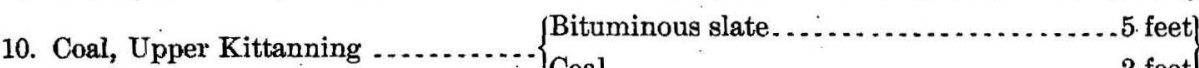

Coal $\ldots \ldots \ldots \ldots \ldots \ldots \ldots \ldots \ldots$ feet

11. Dark shales, and concealed ................................ 10 feet

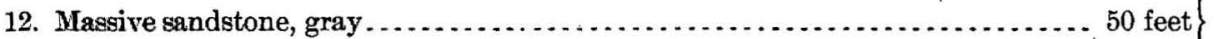

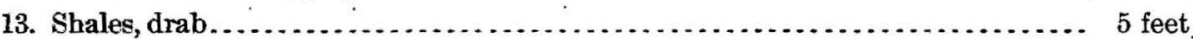

Coal, slaty ......................... 1 foot

14. Coal, Lower Kittanning.

Coal, bony

8 inches

Coal, good..................... foot 4 inches

Slate, hard . . . . . . . . . . . . . . . . . . . . .

Coal, good ..................2 feet 6 inches

15. Fire clay, sandy 3 feet

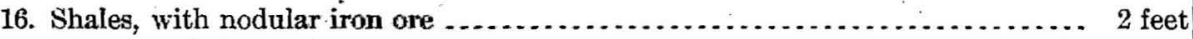

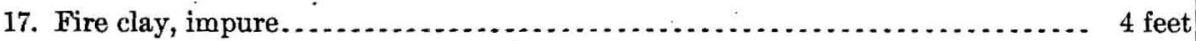

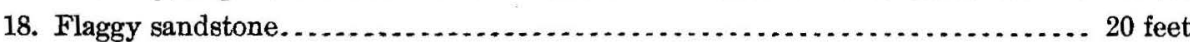

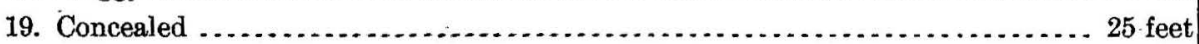

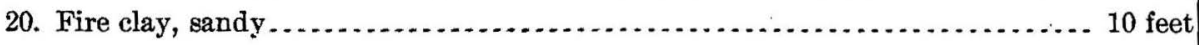

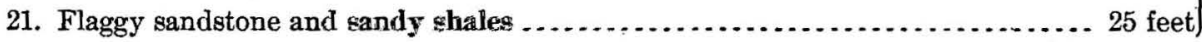

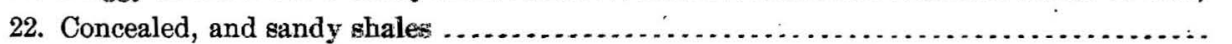

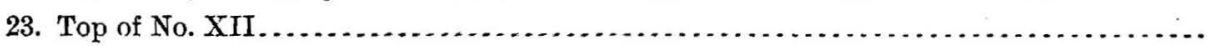

Total.

Section nenr Thomas, Tucker County, W. Va.

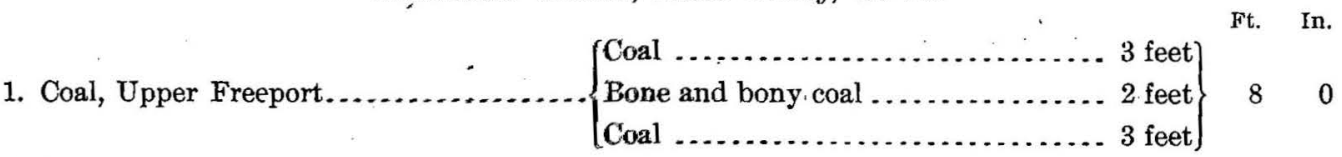

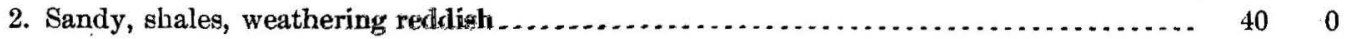

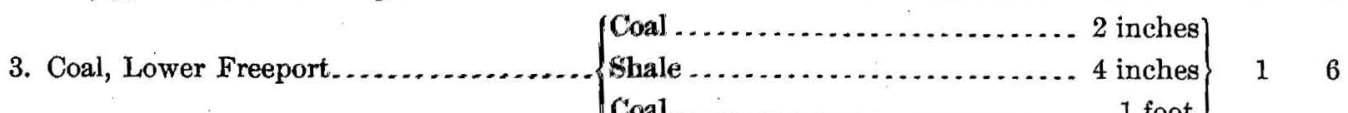

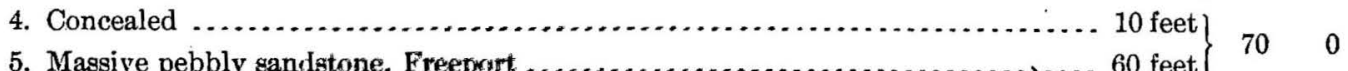

6. Coal, streak, Upper Kittanning 
Section near Thomas, Tucker County, W. Va-Continued.

7. Fire clay and shales

(Coal, good .............. 1 foot 5 inches)

Slate......................... 4 inches

Coal, good ...................... 1 foot

8. Coal, Middle and Lower Kittanning.

Slate ...................... 3 inches $\} 11$

Coal, good................. 3 feet 6 inches

Shale, gray ............... 1 foot 6 inches

Coal, slaty ...................... 3 feet)

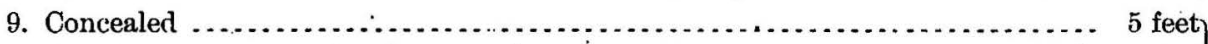

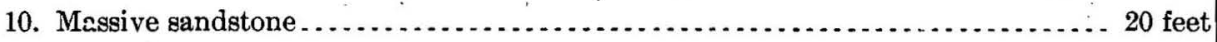

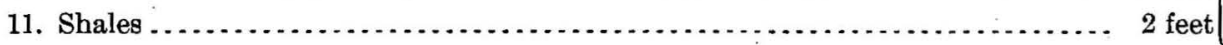

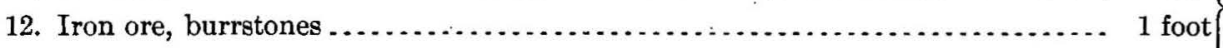

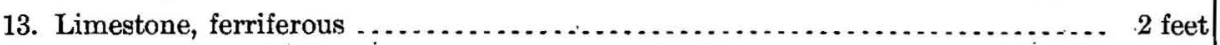

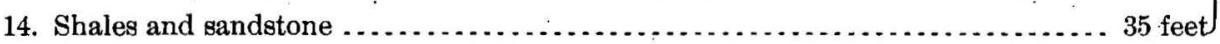

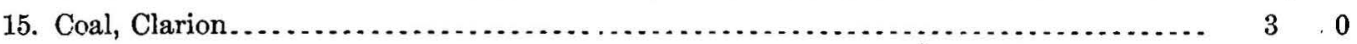

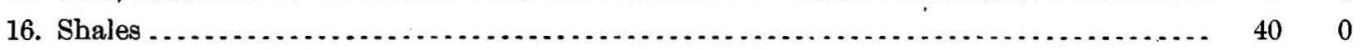

17. Sandstone, top of No. XII.

Total.

In the sections on the North Potomac, at the Maple Swamp water tank on the West Virginia Central Railroad, the clays, if present, are concealed.

Fire clay is noted under the Lower Kittanning coal at Valley Falls, Taylor County, where it is 5 feet thick. It may occur under the Upper Freeport, but in the section was concealed.

Near Nuzums Mills the following section is obtained:

Section at Nuzums Mills (now Hammond), Marion County, W. Va.

1. Coal, Upper Freeport ............... In.

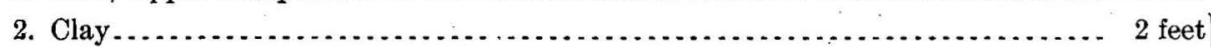

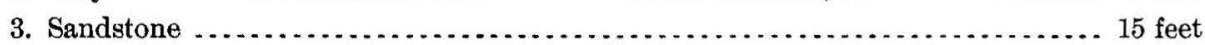

4. Limestone, Upper Freeport ..................................... 3 feet

5. Shales and concealed ............................................. 13 feet

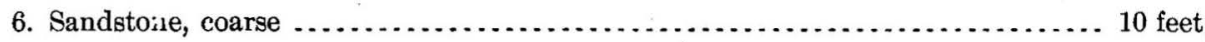

7. Shales, sandy, drab.............................................. 15 feet

8. Coal, Lower Freeport.................................................. 5

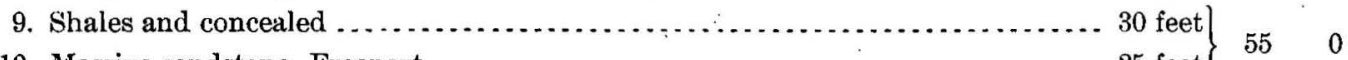

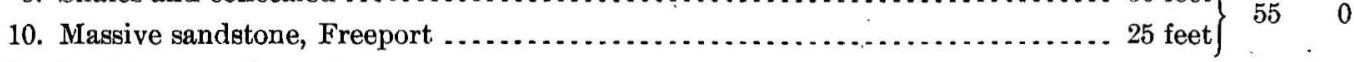

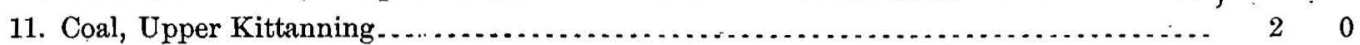

12. Shales, dark, sandy, with limy beds ................................ 40 feet

13. Black slate................................................. 3 feet $\}$

14. Coal, slaty, Middle Kittanning ......................................... 1 
Section at Nuzums Mills (now Hammond), Marion County, W. Va.-Continued.

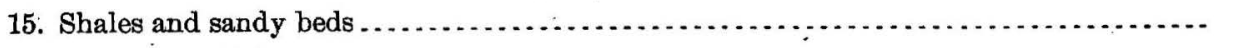

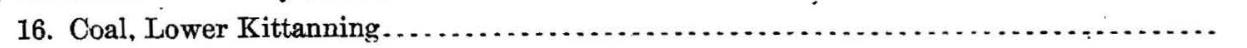

17. Fire clay

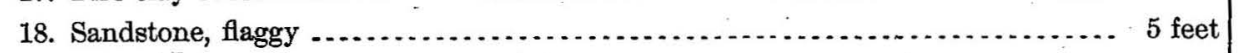

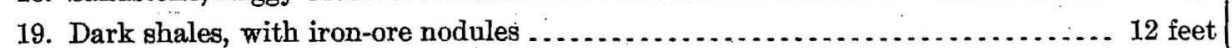

20. Iron ore, Ferriferous limestone horizon......................... 6 inches

21. Dark shales . . . . . . . . . . . . . . . .

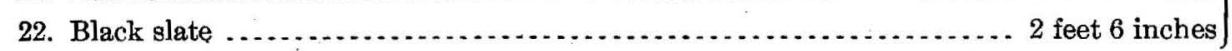

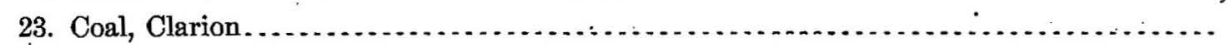

24. Fire clay, sandy ..............

25. Dark shales, with iron-ore nuggets near middle . . . . . . . . . . . . . . . . . . . . 20 feet $33 \quad 0$

26. Flaggy sandstone........

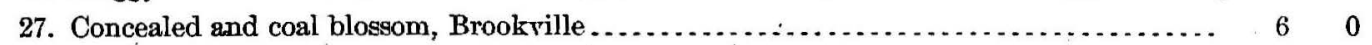

28. No. XII conglomerate.

Total

The Hammond Fire Brick Company, at Hammond, is working 12 feet of Lower Kittaning clay at present (May, 1902), of which the upper half is flint clay and the lower half plastic clay. The composition of the flint clay supplied by the company is given below.

Analysis of flint clay, Hammond, Marion County, W. Ta.

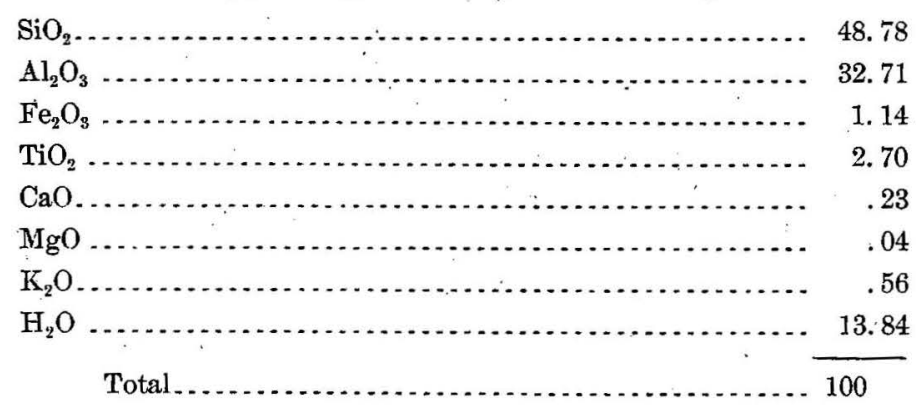

Between cuts Nos. 80 and 81, west of Rowlesburg, on the Baltimore and Obio Railroad, the section, according to I. C. White, ${ }^{a}$ shows 10 feet of impure fire clay about 28 feet under the Upper Freeport limestone. Forty feet below the Upper Kittanning coal is a 10 -foot bed of shales, and 75 feet below the Middle Kittanning or Darlington seam there is a 10-foot fire-clay bed with iron-ore nodules.

Opposite Coalburg, on the Chesapeake and Ohio Railroad, the section shows 5 feet of fire clay below the Cedar Grove coal of the Lower Productive Measures. ${ }^{b}$

The following analyses of Lower Kittanning clay from Spragueville, W. Va., are given by I. C. White: ${ }^{c}$

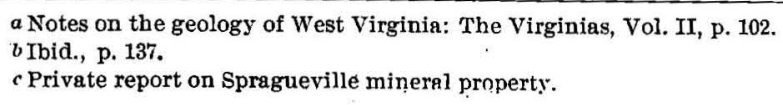


Analyses of clay from Lower Kittanning beds at Spragueville, W. Va.

\begin{tabular}{|c|c|c|}
\hline & 1. & 2. \\
\hline Silica $\ldots \ldots \ldots \ldots \ldots \ldots \ldots \ldots \ldots \ldots$ & 47.880 & 68.315 \\
\hline Alumina $\ldots \ldots \ldots \ldots \ldots \ldots$ & 33.985 & 19.620 \\
\hline Oxide of iron $\ldots \ldots \ldots \ldots \ldots \ldots$ & 1. 368 & 1.575 \\
\hline Titanic acid $\ldots \ldots \ldots \ldots \ldots \ldots \ldots$ & 3.185 & 1. 370 \\
\hline Magnesia $\ldots \ldots \ldots \ldots \ldots \ldots \ldots \ldots$ & .346 & .692 \\
\hline Lime . . . . . . . . . . . . . . . & .360 & .100 \\
\hline Potash $\ldots \ldots \ldots$ & .079 & 2.345 \\
\hline Soda $\ldots \ldots \ldots \ldots \ldots \ldots$ & .402 & .359 \\
\hline Water $\ldots . . . . . . . . . . . . .$. & 12.388 & 5.580 \\
\hline Total $\ldots \ldots \ldots \ldots$ & 99.993. & 99.956 \\
\hline
\end{tabular}

1. "Hard" clay from Spragueville, W. Va., McCreath.

2. "Soft" clay from Spragueville, W. Va., McCreath.

Below are given some additional fire-clay analyses taken from various sources. Analyses of West Virginia fire clays.

\begin{tabular}{|c|c|c|c|c|c|}
\hline & 1. & 2. & 3. & 4. & 5. \\
\hline $\mathrm{SiO}_{2} \ldots \ldots \ldots \ldots$ & 53.100 & 59.008 & 45.86 & 68.16 & 54.27 \\
\hline $\mathrm{Al}_{2} \mathrm{O}_{3} \ldots \ldots \ldots \ldots$ & 32.406 & 23.061 & 44.23 & 24.11 & 33.83 \\
\hline $\mathrm{Fe}_{2} \mathrm{O}_{3} \ldots \ldots \ldots \ldots$ & 1. 256 & 4. 350 & ........... & .01 & .01 \\
\hline $\mathrm{CaO} \ldots \ldots \ldots$ & .210 & .892 & .24 & Trace. & Trace. \\
\hline $\mathrm{MgO} \ldots \ldots \ldots$ & .421 & .976 & .36 & Trace. & .02 \\
\hline Alk .................. & .397 & 2.561 & Trace. & Trace. & Trace. \\
\hline $\mathrm{H}_{2} \mathrm{O} \ldots \ldots \ldots$ & 12.27 & 9.152 & 8.35 & 6. 66 & 10. 86 \\
\hline Moisture .... & $\cdots$ & ............ & .70 & .85 & 1.00 \\
\hline Total... & 100.00 & 100.00 & 99.74 & 99.79 & 99.99 \\
\hline
\end{tabular}

1. Flint clay. Supplied by West Virginia Fire Clay Company, Thornton, W. Va.

2. Plastic clay. Supplied by West Virginia Fire Clay Company, Thornton, W. Va.

3. Marion County. From Report on the Natural Resources of West Virginia, prepared for World's Columbian Exposition by G. W. Summers, 1893.

4. Preston County. From Report on the Natural Resources of West Virginia, prepared for World's Columbian Exposition by G. W. Summers, 1893.

5. Monongalia County. From Report on the Natural Resources of West Virginia, prepared for World's Columbian Exposition by G. W. Summers, 1893.

The Bolivar fire clay, which underlies the Üpper Freeport coal and replaces the Upper Freeport limestone, is of value in only one region in West Virginia, viz, on Deckers Creek, in Preston and Monongalia counties. ${ }^{a}$

$$
\text { 9647-No. 11-03-17 }
$$


The Lower Kittanning clay is said to be rarely of value in West Virginia, ${ }^{a}$ except along the Upper Ohio River, as it is usually too sandy. It has been developed at Hammond, on the Tygart River, where it takes the place of the coal.

The Lower Coal Measures fire clays are also worked in the vicinity of New Cumberland, Hancock County, for making paving brick and other clay products.

BARREN MEASURES.

These attain considerable thickness in West Virginia, being 800 feet near Charleston and about 600 feet near the Pennsylvania border. Important beds of shale occur at many localities, as can be seen by reference to the accompanying section, fig. 10 .

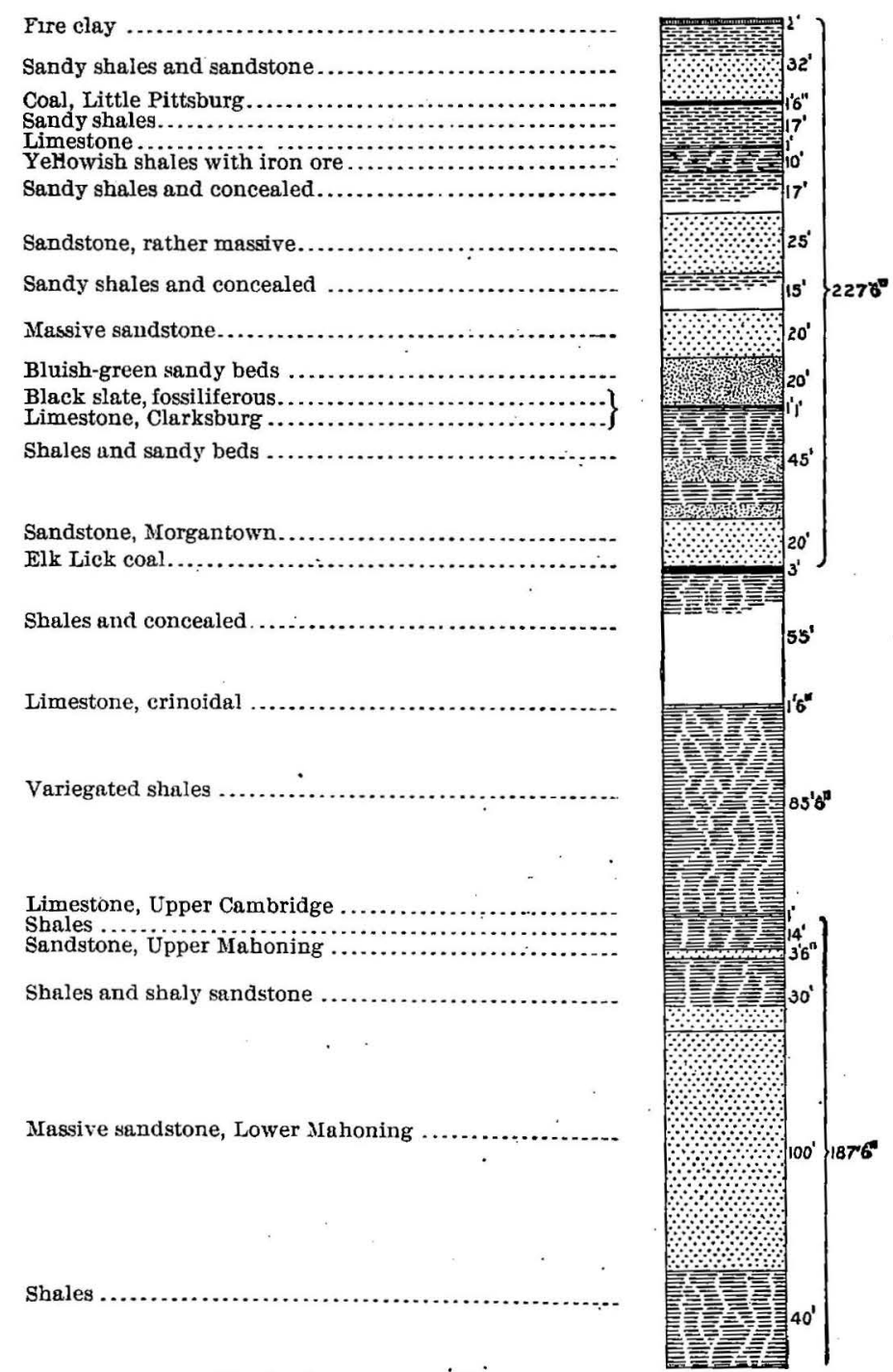

FIG. 10.-Section of Barren Measures in West Virginia.

a Bull. U. S. Geol. Survey No. 65 , p. 172 
The Barren Measure shales are worked at Morgantown, just above the Mahoning sandstone. At Huntington, Cabell County, a red shale from the same measures is worked up into roofing tile. These are also worked at Clarksburg, Fairmont, and Charleston.

Good sections are given by I. C. White at Little Falls, Monongalia County, ${ }^{\prime}$ Newburg, Preston County, ${ }^{b}$ and Fairfax Knob, Tucker County.

The section at Huntington, according to I. C. White, ${ }^{c}$ is as follows:

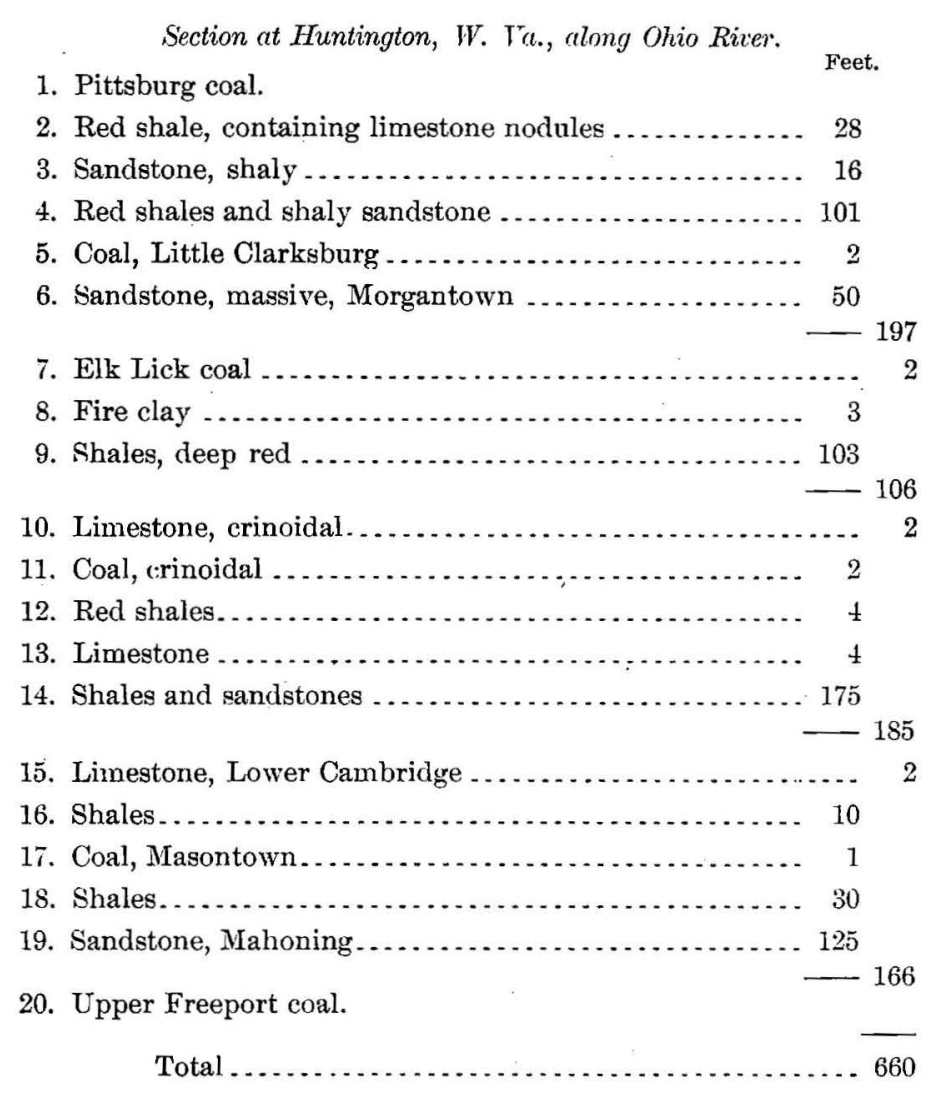

UPPER COAL MEASURES.

These, though of diminished thickness in West Virginia, carry, nevertheless, a great thickness of shale beds, those found immediately over the Pittsburg coal being often well adapted to the manufacture of vitrified brick. Grood sections are exposed at Robinsons Run, Monongalia County (fig. 11), and on Scotts Run, same county; on Buffalo Creek, Marion County, where a $\mathbf{t - f o o t}$ bed of fire clay is represented as occurring under the Uniontown coal. At Moundsville, Marshall County, a 7-foot

a Bull. U. S. Geol. Survey No. 65, p. $80 . \quad$ b Ibid., p. $81 . \quad$ Ibid., p. 84.


bed of fire clay is said to underlie the Redstone coal. Many red shales also outcrop in the bluffs above Hartford, Mason County, and opposite Winfield, Putnam County.
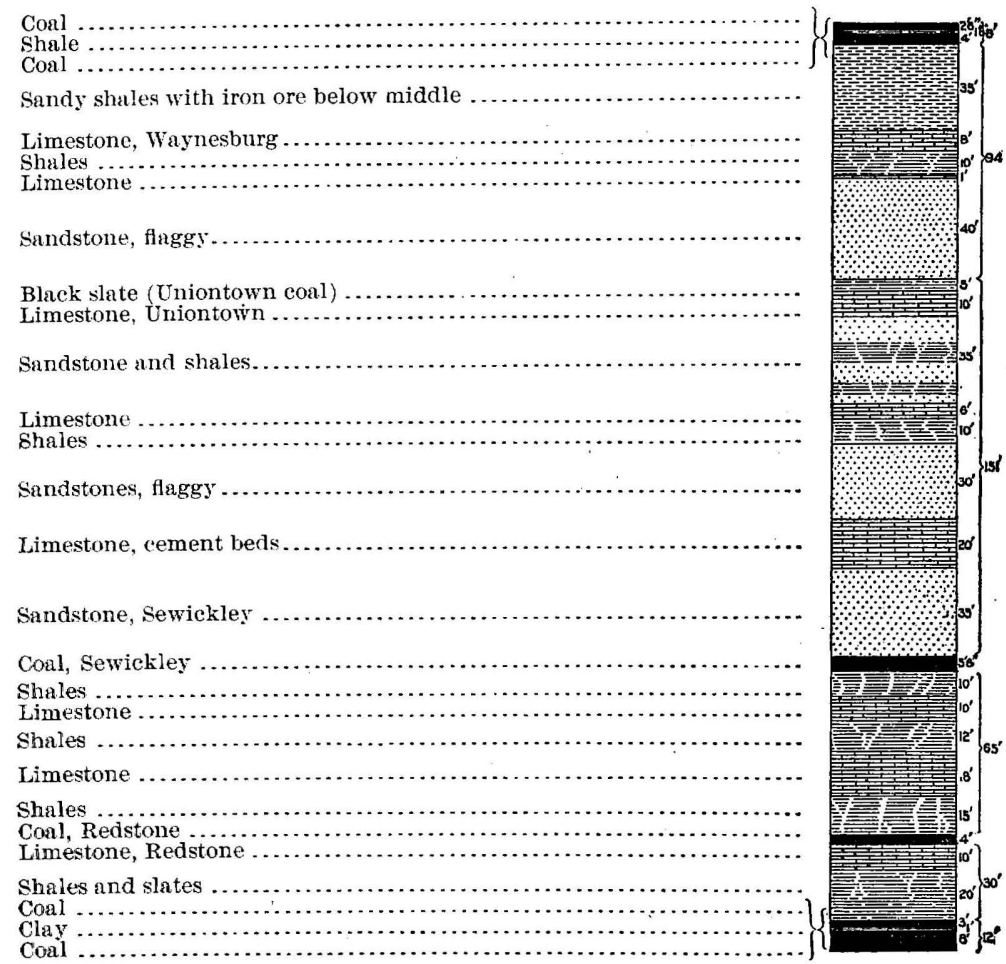

FIG. 11.-Section of Upper Productive Measures on Robinson Run, Monongalia County, W. Va.

In the Buckhannon area ${ }^{a}$ fire clay occurs beneath many of the coal beds. Clay shales are found in both the upper and lower Coal Measures, but are not developed.

UPPER BARREN MEASURES.

According to I. C. White, ${ }^{b}$ the beds of these cover a large area bordering the Ohio River between the Pennsylvania line at the north and the Kanawha River on the south. In West Virginia they carry great beds of red shale, which increase southward, while the limestone beds, so prominent farther north, decrease. These shales will no doubt in time become of great value to the clay worker as the industry of that region develops.

\section{PLEISTOCENE CLAYS}

Two types of surface clays are found in West Virginia, viz, alluvial clays and residual clays.

The alluvial clays are found in the broader or older river valleys and are not infrequently the wash from neighboring hill slopes. Much of this material is found in the ancient channel of the Kanawha River and also in its present valley west of 
Charleston. ${ }^{a}$ In the vicinity of Piedmont, clays are said to occur in the wider stream valleys, especially along the South Branch. In the old Kanawha River valley, known as Teays Valley, there is an abundant deposit of fine laminated clay, sometimes 50 feet thick. ${ }^{b}$

The residual clays are to be looked for in many of the valleys, or on gentle slope especially in areas that are underlain by shales or limestones. Clays of this type a common in the Great Valley.

\section{CLAY-WORKING INDUSTRY.}

The clay products produced in West Virginia from 1895 to 1901 bad the following value:

Total values of clay products of West Virginia from 1895 to 1901.

\begin{tabular}{|c|c|c|c|}
\hline Year. & Y alue. & Rank. & $\begin{array}{c}\text { Proportion } \\
\text { of United } \\
\text { States pro- } \\
\text { duct. }\end{array}$ \\
\hline $1895 \ldots \ldots \ldots \ldots \ldots \ldots$ & $\$ 895,777$ & 17 & $\begin{array}{l}\text { Per cent. } \\
\quad 1.37\end{array}$ \\
\hline $1896 \ldots \ldots \ldots$. & 902,944 & 16 & 1.45 \\
\hline $1897 \ldots \ldots \ldots$ & $1,115,254$ & 13 & 1.79 \\
\hline $1898 \ldots \ldots \ldots \ldots \ldots$ & $1,027,575$ & 13 & 1.44 \\
\hline $1899 \ldots \ldots \ldots \ldots$ & $1,451,539$ & 13 & 1.52 \\
\hline $1900 \ldots \ldots \ldots \ldots \ldots$ & $2,016,765$ & 9 & 2.10 \\
\hline $1901 \ldots \ldots \ldots$ & $1,946,480$ & 9 & 1.77 \\
\hline
\end{tabular}

Value of clay products of West Virginia in 1900 and 1901.

\begin{tabular}{|c|c|c|}
\hline \multirow{2}{*}{ Produet. } & \multicolumn{2}{|c|}{ Value. } \\
\hline & 1900. & 1901. \\
\hline Common brick $\ldots \ldots \ldots \ldots \ldots$ & $\$ 708,861$ & $\$ 348,452$ \\
\hline Front brick $\ldots \ldots \ldots \ldots \ldots \ldots \ldots$ & 16,797 & $(c)$ \\
\hline Vitrified brick ......... & 474,880 & 555,389 \\
\hline Fancy brick . . ............ & ........... & (c) \\
\hline Fire brick ................... & 149,257 & 102,300 \\
\hline Draintile .............. & 1,346 & 1,485 \\
\hline Sewer pipe . ............ & (c) & (c) \\
\hline Tile, not drain ........... & $(c)$ & (c) \\
\hline 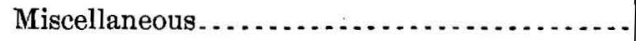 & 655,797 & 505,912 \\
\hline Total plain pottery......... & 222,949 & 297,842 \\
\hline Total decorated pottery $\ldots \ldots \ldots \ldots \ldots \ldots$ & 408,892 & 560,800 \\
\hline Raw clays . . . . . . . . . . . . . & 76,628 & 257,343 \\
\hline
\end{tabular}


WISCONSIN.

The clay deposits of Wisconsin belong to two types, viz, residual and transported. The latter are much the more extensive, as they are closely associated in their origin to the glacial deposits of the State while the former occur only in the driftless area or in places where they have been protected by erosion. ${ }^{a}$

\section{RESIDUAL CLAYS.}

These have been derived from granite and gneisses, greenstones and allied volcanic rocks, limestone and dolomite, sandstone, and shale. Although these may have been abundant in former geologic times, most of the residual deposits were scraped off or carried away by the ice sheet during the Glacial epoch, and those now remaining are found only in the driftless area or in protected situations. The latter type occurs along the contact of pre-Cambrian schists with Potsdam sandstones, where the residual clays have been protected by the sandstone capping. In such cases the clay may extend to a depth of from 10 to 40 feet. Deposits of this nature occur in the vicinity of Grand Rapids, Eau Claire. Black River Falls, Rice Lake, and Stevens Point. $^{b}$ Though iron stained in their crude condition, it is claimed that they can be washed white. At the present time the shale residuals are used for the manufacture of soft mud, stiff mud, and dry press brick. The shales burn to buff or red color.

\section{PLASTIC KAOLINS.}

These are not true kaolins, but white burning sedimentary clays, which bave been derived from the residual products of kaolinic schists and sorted by water action. The layers of clay and sand are interstratified, so that it has to be washed for market. One of these deposits occurs at Hersey, St. Croix County, ${ }^{c}$ and has been worked since 1893. Other deposits occur in the valley of the Eau Claire River. Large quantities of this clay are washed annually and sold to the paper manufacturers of Minnesota and Wisconsin.

$a$ See Bull. Wisconsin Geol. and Nat. Hist. Survey No. 7; Clays and clay industries of Wisconsin, by E. R. Buckley from which the information relating to that State is abstracted.

$b$ Ibid., p. 232.

$c$ Ibid., p. 234. 
WISCONSIN.

The composition of these clays is given below:

Analyses of kaolinic schists or shales of pre-Cambrian rocks.

\begin{tabular}{|c|c|c|c|c|c|c|c|c|c|c|}
\hline & 1. & 2. & 3. & 4. & 5. & 6. & 7. & 8. & 9. & 10. \\
\hline $\mathrm{HO}_{2} \ldots \ldots$ & 70.30 & 59.88 & 50.17 & 72.30 & 55.87 & 65.52 & $67.96^{\circ}$ & 61.22 & 75.66 & 49.86 \\
\hline $\mathrm{Al}_{2} \mathrm{O}_{3}-$ & 18.07 & 18.10 & 17.90 & 16.06 & 19.60 & 16.33 & 17.25 & 13.98 & 12.19 & 27.41 \\
\hline $\mathrm{Fe}_{2} \mathrm{O}_{3}$ & 1.65 & 10.04 & 12.29 & 0.35 & 9.22 & 4.02 & 2.27 & 4.66 & 2.57 & 4.43 \\
\hline $\mathrm{CaO}$. & None. & 0.31 & 0.55 & 0.26 & 1.05 & 1.65 & 0.67 & 3. 76 & 0.82 & 0.48 \\
\hline $\mathrm{MgO}$ & 6.90 & 3.13 & 6.86 & 1.50 & 3.71 & 3.09 & 2.07 & 2.03 & 0.72 & 2.10 \\
\hline $\mathrm{Na}_{2} \mathrm{O}$ & 0.76 & 0.52 & 0.58 & 0.40 & 0.32 & 0.33 & 0.38 & 1. 32 & 1.53 & 0.52 \\
\hline $\mathrm{K}_{2} \mathrm{O}$. & 2.94 & 3. 72 & 3.06 & 5.23 & 3.93 & 3. 94 & 5.81 & 3.44 & 3.00 & 5.30 \\
\hline $\mathrm{TiO}_{2} \ldots$ & None. & - & 0.75 & None. & $\cdots$ & None. & None. & 0.43 & None. & None. \\
\hline $\mathrm{MnO} \ldots$ & .... & Trace. & 0.61 & ... & & $\ldots$ & & & None. & 0.32 \\
\hline $\mathrm{P}_{2} \mathrm{O}_{5}$. & 0.06 & - ..... & $\ldots$ & Trace. & 0.06 & 0.58 & Trace. & & & 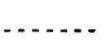 \\
\hline $\mathrm{H}_{2} \mathrm{O}, \mathrm{C} \ldots \ldots$ & 5. 26 & 4.40 & 7.16 & 3.68 & 6.22 & 4.38 & 3.86 & 9.10 & 3. 79 & 9.41 \\
\hline \multirow[t]{2}{*}{ Total. } & 99.94 & 100.10 & 99.93 & 99.78 & 99.98 & 99.84 & 100.28 & 99.94 & 100.34 & 99.83 \\
\hline & 11. & 12. & 13. & 14. & 15. & 16. & 17. & 18. & 19. & 20. \\
\hline $\mathrm{SiO}_{2}$. & 57.33 & 51.53 & 47.00 & 52.52 & 34.44 & 67.50 & 34.29 & 52.60 & 54.47 & 49.29 \\
\hline $\mathrm{Al}_{2} \mathrm{O}_{3} \ldots$ & 21.64 & 20.51 & 35.26 & 14.65 & 17. 26 & 19.23 & 13.53 & 14.42 & 13.68 & 13. 03 \\
\hline $\mathrm{Fe}_{2} \mathrm{O}_{3}$ & 5.57 & 8.10 & 3.03 & 18.07 & 23.80 & 2.60 & 16. 73 & 16.00 & 15.96 & 20.20 \\
\hline $\mathrm{CaO}$. & 0.85 & 0.90 & None. & 0.94 & 0.27 & $\ldots$ & 0.47 & 0.65 & 0.55 & 0.31 \\
\hline $\mathrm{MgO} .$. & 2.67 & 4.02 & 0.28 & 2.40 & 11.21 & 0.83 & 5.66 & 3.15 & 3.17 & 4. 15 \\
\hline $\mathrm{Na}_{2} \mathrm{O}$. & 0.64 & 0.66 & 0.31 & 0.34 & 0.22 & 0.48 & 0.15 & 0.36 & 0.40 & 0.40 \\
\hline $\mathrm{K}_{2} \mathrm{O}$ & 6.06 & 6.86 & 0.64 & 5.52 & 1.94 & 2.50 & 1.32 & 4.90 & 4. 60 & 5.72 \\
\hline $\mathrm{TiO}_{2}$. & None. & 0.25 & 0.25 & 1. 35 & 0.47 & & 1.12 & 0.80 & 1. 10 & 0.85 \\
\hline $\mathrm{MnO}$ & 0.21 & Trace. & & Trace. & 1.55 & $\left.\begin{array}{l}\mathrm{SO}_{3} \\
0.26\end{array}\right\}$ & 1.97 & 0.47 & 0.33 & 0.21 \\
\hline $\mathrm{H}_{2} \mathrm{O}, \mathrm{C}$. & 5. 21 & 7.22 & 3.14 & 4. 69 & 9.10 & 6.47 & $\left\{\begin{array}{c}\mathrm{H}_{2} \mathrm{O} \\
10.53\end{array}\right.$ & 6. 86 & 6.00 & 6.14 \\
\hline Total & 100.18 & 100.00 & 99.91 & 100.48 & 100.26 & 100.27 & 99.63 & 100.23 & 100.26 & 100.30 \\
\hline
\end{tabular}

1. Halcyon Pressed Brick Company, Black River Falls, Jackson County. Wisconsin Geol. Nat. Hist. Survey, Bull. No. 7, p. 222.

2, 3. Halls Creek, Black River Falls, Jackson County. Ibid.

4-8. Halcyon Pressed Brick Company, Black River Falls, Jackson County. Ibid.

9-13. George T. Thompson (undeveloped), Eau Claire, Eau Claire County. Ibid., p. 270

14-16. Scott \& Alexander, Grand Rapids, Wood County. Ibid., p. 271.

17. Graphite Works, Junction City, Portage County. Ibid., p. 272.

18-20. Clay Lumber Company, Ringle, Marathon County. Ibid., p. 273. 
Analyses of "kaolin."

\begin{tabular}{|c|c|c|c|c|c|c|c|}
\hline : & 1. & 2. & 3. & 4. & 5. & 6. & 7. \\
\hline $\mathrm{SiO}_{2}, \ldots \ldots \ldots$ & 61.89 & 73.14 & 65.19 & 58.95 & 64.50 & 52.41 & 58.19 \\
\hline $\mathrm{Al}_{2} \mathrm{O}_{9} \ldots \ldots \ldots \ldots$ & 18.84 & 11. 64 & 25.34 & 29.56 & 26: 20 & 34.10 & 18. 77 \\
\hline $\mathrm{Fe}_{2} \mathrm{O}_{3} \ldots \ldots$ & 6.06 & 5. 00 & 0.21 & 0.43 & 0.07 & 0.15 & 7.90 \\
\hline $\mathrm{CaO}$ & 0.45 & 0.97 & $\ldots . . .$. & $\ldots$. & $\ldots .$. & 0.05 & $0.59^{\circ}$ \\
\hline MgO $\ldots \ldots \ldots$ & 1. 29 & 0.88 & ......... & 0.12 & .. & 0.12 & 3.92 \\
\hline $\mathrm{Na}_{2} \mathrm{O}$ & 1.22 & 1.30 & 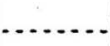 & 0.32 & ...... & 0.18 & 0.10 \\
\hline $\mathrm{K}_{2} \mathrm{O} \ldots \ldots$ & 2.12 & 2.38 & 0.49 & 0.31 & 0.31 & 0.46 & 3.78 \\
\hline $\mathrm{TiO}_{2} \ldots \ldots \ldots$ & 0.63 & 0.45 & ....... & . & & 0.80 & 0.55 \\
\hline $\mathrm{MnO}$ & 0.17 & 0.18 & & Trace. & & & $\left\{\begin{array}{l}\text { Strong } \\
\text { trace. }\end{array}\right.$ \\
\hline $\mathrm{H}_{2} \mathrm{O}, \mathrm{C} \ldots \ldots$ & 7.43 & 4.58 & 8.80 & 10. 23 & 8.90 & 11.89 & 6.18 \\
\hline Total . . . . . & 100.10 & 100.52 & 100.03 & 99.98 & 99.98 & 100.16 & 99.98 \\
\hline
\end{tabular}

1. Undeveloped bed, Baldwin, St. Croix County. Wisconsin Geol. Nat. Hist. Survey, Buil. No. 7, p. 270.

2. Syme, Baldwin \& Ca., Glenwood, St. Croix County. Ibid., p. 271.

3. Undeveloped, Glenwood, St. Croix County. Ibid.

4. Undeveloped, Hersey, St. Croix County. Ibid., p. 272.

5. Superior China Clay Company, Hersey, St. Croix County. Ibid., p. 271.

6. Superior China Clay Company, Hersey, St. Croix County. Ibid., p. 272.

7. Undereloped, Superior, Douglas County. Ibid., p. 274.

\section{CLAYS OF DRIFTLESS AREA.}

These lie in an area in the southeastern portion of the State which has not been modified by glacial action. The elay deposits are chiefly residual, formed by the decomposition of the underlying rock. Such are usually found in the slopes and ridges, while the valleys contain clay beds representing the wash from the residuals. These transported clays are the richest found in the driftless area. They are used at a number of points for the manufacture of common brick, but are not used in large quantities.

\section{POTSDAM SHALES.}

Alternating layers of tough plastic clay and sandstone occur at the base of the Potsdam in places, but in others the two are so mingled as to form a brown shale, which runs from 7 to 10 feet in thickness. This shale or clay is found at a number of points, notably Merrillan, Durand, Black River Falls, Eau Claire, Neillsville, and Fond du Lac. At the present time they are not used for the manufacture of clay products. The chemical composition can be seen from the following analyses: 
Analyses of shales of Potsdam formation.

\begin{tabular}{|c|c|c|}
\hline & 1. & 2. \\
\hline $\mathrm{SiO}_{2} \ldots \ldots \ldots \ldots \ldots \ldots$ & 62.59 & 62.97 \\
\hline $\mathrm{Al}_{2} \mathrm{O}_{8} \ldots \ldots \ldots \ldots \ldots \ldots \ldots$ & 17.42 & 18: 42 \\
\hline $\mathrm{Fe}_{2} \mathrm{O}_{3} \ldots \ldots \ldots \ldots \ldots$ & 5. 88 & 3.36 \\
\hline $\mathrm{CaO} \ldots \ldots \ldots \ldots \ldots \ldots \ldots \ldots$ & None. & None. \\
\hline $\mathrm{MgO} \ldots \ldots . . . .$. & 1. 24 & 1.03 \\
\hline $\mathrm{Na}_{2} \mathrm{O} \ldots \ldots \ldots \ldots$ & 0.52 & 0.56 \\
\hline $\mathrm{K}_{2} \mathrm{O} \ldots \ldots$ & 8.08 & 8. 68 \\
\hline $\mathrm{TiO}_{2} \ldots \ldots$ & 0.30 & 0.35 \\
\hline $\mathrm{SO}_{3} \ldots \ldots \ldots \ldots$ & Trace. & Trace. \\
\hline $\mathrm{H}_{2} \mathrm{O}, \mathrm{C} \ldots \ldots$ & 4.15 & 4.97 \\
\hline Total .. & 100.18 & 100.34 \\
\hline
\end{tabular}

1. Undeveloped, Merrillan, Jackson County. Wisconsin Geol. Nat. Hist. Survey, Bull. No. 7, p. 273.

2. Undeveloped, Merrillan, Jackson County. Ibid.

\section{HUDSON SHAALE.}

The Hudson shale forms a narrow belt in the eastern part of Wisconsin, and lies between the Trenton and Niagara limestone formations. It is a very calcareous shale, with occasional interlaminations of limestone, and the outcrops extend from the southern boundary of Wisconsin to Green Bay. Where exposed to the weather the shale breaks down fast to a powdery mass. On account of its calcareous character (as seen by the analyses below) the clay is not suited to the manufacture of paving brick, but does give very satisfactory results in common brickmaking.

In using this shale, however, it is always necessary to weather it for a season and grind it in dry pans before tempering. An advantage urged for this shale over the calcareous brick clays is that the latter contains lime in pebbles, while the former carries the calcium carbonate in a finely divided condition. Although worked at only two localities, it is molded in stiff mud, soft mud, and dry-press machines. 
Analyses of Hudson shates.'

\begin{tabular}{|c|c|c|}
\hline & 1. & 2. \\
\hline $\mathrm{SiO}_{2} \ldots \ldots \ldots$ & 35.93 & 31.70 \\
\hline $\mathrm{Al}_{2} \mathrm{O}_{3} \ldots \ldots$ & 11.75 & 9.19 \\
\hline $\mathrm{Fe}_{2} \mathrm{O}_{3} \ldots \ldots$ & 4. 08 & 3.76 \\
\hline $\mathrm{CaO}$ & 12.43 & 15.37 \\
\hline $\mathrm{MgO} \ldots \ldots . . . . . . . .$. & 9.92 & 10.90 \\
\hline $\mathrm{Na}_{2} \mathrm{O} \ldots \ldots \ldots$ & 1.24 & 0.68 \\
\hline $\mathrm{K}_{2} \mathrm{O} \ldots \ldots \ldots \ldots$ & 2.46 & 2. 74 \\
\hline $\mathrm{TiO}_{2} \ldots \ldots$ & 0.30 & 0.25 \\
\hline $\mathrm{MnO} \ldots \ldots . . . . . . . . .$. & 0.10 & 0.27 \\
\hline $\mathrm{H}_{2} \mathrm{O}, \mathrm{C} \ldots \ldots \ldots$ & 22.06 & 25.17 \\
\hline Total. & 100.27 & 100.03 \\
\hline
\end{tabular}

1. Frenzel Bros., Oakfield, Fond du Lac County. Wisconsin Geol. Nat. Hist. Survey, Bull. No. 7, p. 273.

2. Frenzel Bros., Oakfield, Fond du Lac County. Ibid.

PLEISTOCENE CLAYS.

The Pleistocene clays of Wisconsin can be grouped as follows: (1) Lacustrine deposits; (2) stream deposits; (3) estuarine deposits; and (4) glacial clays.

LACUSTRINE DEPOSITS.

These represent a very extensive type of deposit, and were laid down during the former inland extension of the Great Lakes, so that they are now often found at some distance from the present lake shore. Thus around Racine they occur 18 miles inland. They are also found at Sheboygan, over all parts of Door County, and in parts of Manitowoc, Calumet, and Fond du Lac counties. Much of Green Lake, Wanshara, and Waupaca counties is underlain by them. To the north they are found as far as Shawano, in the region adjacent to Wolf River, and also at Oconto, the latter locality being 18 miles west of the present shore line.

The lacustrine clays adjoining Lake Michigan on the east and Lake Superior on the north are an important source of cream-colored brick clays. These clays have a maximum thickness along Lake Michigan of 150 feet, and are reported to be thicker along Lake Superior; at Milwaukee borings have shown them to be $100^{\circ}$ or more feet deep. The upper beds of lacustrine clay are usually reddish brown, while the lower ones are commonly dull pinkish. The upper 1 to 5 feet may sometimes burn red, on account of the carbonate of lime having leached out. They are worked for brick and tile at many localities, among them, Green Bay, Depere, Manitowoc, Milwaukee and vicinity, and Racine. The celebrated Milwaukee cream brick are made 
WISCONSIN.

from deposits of this class. No physical tests of these clays have been published, but the following table shows their chemical composition:

Analyses of lacustrine or lake clays of Wisconsin.

\begin{tabular}{|c|c|c|c|c|c|c|c|c|c|}
\hline & 1. & 2. & 3. & 4. & 5. & 6. & 7. & 8. & 9. \\
\hline $\mathrm{SiO}_{2}$ & 29.47 & 29.87 & 46.96 & 49. 79 & 69.30 & 47.02 & 36.57 & 48. 39 & 44.18 \\
\hline $\mathrm{Al}_{2} \mathrm{O}_{3} \ldots$ & 7.11 & 8.01 & 12.79 & 11.92 & 12.89 & 8.51 & 10.15 & 12.50 & 10.83 \\
\hline $\mathrm{Fe}_{2} \mathrm{O}_{3}-$ & 2.58 & 2. 78 & 4.40 & 4.60 & 4.90 & 3. 20 & 4.06 & 5.40 & 3.30 \\
\hline $\mathrm{CaO}$ & 18. 18 & 17.21 & 10.15 & 9.30 & 1.02 & 14.28 & 14.55 & 10.88 & 14.05 \\
\hline $\mathrm{MgO}$ & 12.25 & 12.22 & 6.27 & 5.18 & 1.35 & 6.25 & 9.63 & 4.82 & 5.91 \\
\hline $\mathrm{Na}_{2} \mathrm{O}$. & 0.68 & 0.68 & 0.52 & 0.26 & 1.16 & 0.98 & 0.94 & 0.68 & 0.70 \\
\hline $\mathrm{K}_{2} \mathrm{O} \ldots \ldots$ & 1.76 & 1.82 & 3.64 & 3.32 & 3.62 & 2.69 & 1.82 & 3.90 & 3. 10 \\
\hline $\mathrm{TiO}_{2} \ldots \ldots$. & 0.35 & 0.46 & 0.50 & 0.50 & 0.50 & 0.38 & 0.25 & 0.43 & 0.30 \\
\hline $\mathrm{MnO}$ - & $\ldots$ & $\cdots$ & $\cdots$ & 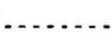 & - & $\therefore .$. & $\cdots$ & Trace. & $\cdots$ \\
\hline $\mathrm{H}_{2} \mathrm{O}, \mathrm{C}$. & 27.85 & 27.03 & 15.19 & 15.40 & 5.53 & 16.57 & 22.29 & 13.02 & 17. 34 \\
\hline \multirow[t]{2}{*}{ Total ......... } & 100.19 & 100.08 & 100.42 & 100.27 & 100.27 & 99.88 & 100.26 & 100.02 & 99.75 \\
\hline & 10. & 11. & 12. & 13. & 14. & 15. & 16. & 17. & 18. \\
\hline $\mathrm{SiO}_{2}$ & 43.42 & 59.98 & 47.66 & 41.63 & 43.84 & 40.17 & 39.11 & 47.30 & 38.54 \\
\hline $\mathrm{Al}_{2} \mathrm{O}_{3}-$ & 10.78 & 16. 33 & 14.98 & 8.51 & 7. 82 & 9.14 & 11.98 & 12.42 & 10.94 \\
\hline $\mathrm{Fe}_{2} \mathrm{O}_{3}$. & 3. 60 & 7.10 & 6.00 & 3.40 & 2.00 & 3.00 & 5.57 & 5.36 & 3.60 \\
\hline $\mathrm{CaO} \ldots$ & 13.68 & 1.02 & 10.27 & 14.39 & 15.16 & 14. 49 & 15.45 & 9.46 & 14.02 \\
\hline $\mathrm{MgQ} \ldots .$. & 5.92 & 1.97 & 4.14 & 8.02 & 8. 03 & 8. 34 & 4.67 & 6.22 & 7.88 \\
\hline $\mathrm{Na}_{2} \mathrm{O}$. & 0.88 & 1.04 & 0.74 & 0.54 & 0.62 & 0.34 & 0.97 & 1.35 & 1.00 \\
\hline $\mathrm{K}_{2} \mathrm{O} \ldots$ & 3.20 & 4.22 & 2. 18 & 2.90 & 2.44 & 3.06 & 3.08 & 3.17 & 2.80 \\
\hline $\mathrm{TiO}_{2}$. & 0.40 & 0.58 & 0.56 & 0.35 & 0.33 & 0.35 & $\cdots$. & .... & 0.40 \\
\hline $\mathrm{MnO}$ & Trace. & ….. & 0.25 & 0.23 & ..... & 0.09 & 0.06 & 0.19 & Trace. \\
\hline $\mathrm{H}_{2} \mathrm{O}, \mathrm{C} .$. & 18.13 & 8.15 & 13.22 & 20.08 & 19.79 & 21.37 & 19.26 & 14.79 & 20.90 \\
\hline \multirow[t]{2}{*}{ Total ......... } & 100.01 & 100.39 & 100.00 & 100.05 & 100.03 & 100.35 & 100.15 & 100.26 & 100.08 \\
\hline & 19. & 20. & , 21. & 22. & 23. & 24. & 25. & 26. & $2 \pi$. \\
\hline $\mathrm{SiO}_{2}-$ & 33.97 & 52.25 & 45. 78 & 43.56 & 36.93 & 38.92 & 37.86 & 36.80 & 43.99 \\
\hline $\mathrm{Al}_{2} \mathrm{O}_{9} \ldots$ & 9.99 & 9.42 & 9.39 & 11. 12 & 8. 76 & 7.50 & 7.12 & 9.43 & 10.06 \\
\hline $\mathrm{Fe}_{2} \mathrm{O}_{3}$ - & 2.80 & 2.50 & 3. 80 & 3.60 & 3.10 & 2. 36 & 3.64 & 3.00 & 3.84 \\
\hline $\mathrm{CaO} .$. & 16.05 & 10.60 & 14.86 & 15. 12 & 16. 73 & 15.92 & 16.42 & 16. 38 & 14.47 \\
\hline $\mathrm{MgO} \ldots . .$. & 7.74 & 6.70 & 5.85 & 5.61 & 8.69 & 9.82 & 9.56 & 8.78 & 5. 72 \\
\hline $\mathrm{Na}_{2} \mathrm{O} \ldots$ & 0.70 & 0.88 & 0.66 & 0.58 & 0.96 & 0.86 & 0.86 & 0.94 & 1.06 \\
\hline $\mathrm{K}_{2} \mathrm{O} \ldots \ldots$ & 2.60 & 2.26 & 3.02 & 3.28 & 2.34 & 2.00 & 1.90 & 2. 36 & 3.18 \\
\hline $\mathrm{TiO}_{2} .$. & 0.28 & 0.28 & 0.40 & 0.40 & 0.30 & 0.25 & 0.20 & 0.23 & 0.33 \\
\hline $\mathrm{MnO} .$. & ...... & Trace. & Trace. & Trace. & ..... & Trace. & Trace. & Trace. & 0.18 \\
\hline $\mathrm{H}_{2} \mathrm{O}, \mathrm{C} \ldots$ & 20.44 & 15.73 & 16. 31 & 17.29 & 22.43 & 22.29 & 22.82 & 21.88 & 17.48 \\
\hline Total . & 100.57 & 100.62 & 100.07 & 100.56 & 100.24 & 99.92 & 100.38 & 99.8 & 100.31 \\
\hline
\end{tabular}


1, 2. William Voigt, Boltonville, Washington County. Wisconsin Geol. Nat. Hist. Survey, Bull. No. 7 , p. 270.

3, 4. Bristol Tile Works, Bristol, Kenosha County. İbid.

5, 6. Duck Creek Brick Company, Duck Creek, Brown County. Ibid., p. 271.

7. Carl Peterson, Fredonia, Ozaukee County. Ibid.

8, 9. Green Bay Brick Company, Green Bay, Brown County. Ibid., p. 271-272.

10, 11. William Finnegan Brick Company, Green Bay, Brown County. Ibid., p. 272.

12. Edward Hartman, Marengo, Ashland County. Ibid., p. 273.

13. Burnham Brothers' West Yard, Milwaukee, Milwaukee County. Ibid.

14. Standard Brick Company, Milwaukee, Milwaukee County. Ibid.

15. Burnham Brothers' Howell Avenue Yard, Milwaukee, Milwaukee County. Ibid.

16, 17. J. W. Schultz, Oshkosh, Winnebago County. Ibid.

18. Gotlieb Gunther \& Sons, Port Washington, Ozaukee County. Ibid.

19, 20. Hilker Brothers Brick Manufacturing Company, Racine, Racine County. Ibid

21, 22. Shawano Brick and Tile Company, Shawano, Shawano County. Ibid.

23. Sheboygan Brick and Tile Company, Sheboygan, Sheboygan County. Ibid., p. 274.

24-26. August Zimbal \& Sons, Sheboygan, Sheboygan County. Ibid.

27. W. D. Jordon, Shiocton, Outagamie County. Ibid.

\section{ESTUARINE CLAYS.}

These inciude all the clays of eastern Wisconsin which are underlain by limestone and have been modified by glacial action. They were formed at the same time and in association with the lake deposits. In fact, they resemble them so.closely that the two can be mapped together. They are, however, more variable in their lime contents than the lacustrine clays. Estuarine deposits are found along the Fox, Wolf, Rock, Wisconsin, Eau Claire, Chippewa, Black, Red, Cedar, and many other rivers in the eastern, western, and southern parts of the State. The clays in these deposits are commonly thinly laminated, and show a maximum thickness of 50 to 150 feet. $^{a}$

Besides the river deposits of this age, much later deposits of clay have formed in the valleys of many of the more important streams of to-day, especially where the tributaries are fed from regions heavily covered with glacial drift, or where they pass through rock which is largely decomposed. At the present time most of the rivers are cutting their channels deeper, and only where the streams laden with silt meander through swamp lands or discharge their loads into a lake or other reservoị are deposits of clay being formed.

The deposits which occur in the river valleys in the southwestern part of the State and those that are found throughout the glaciated region of the eastern part are very caleareous. Those in the west-central part, where limestone is not the predominant rock, are but slightly calcareous. The clays along the rivers in the extreme northern part of the State have been permeated with calcium carbonate 
derived from the limestone and marble which occur farther to the north. Limestone gravel is found abundantly in the very calcareous clays, having been transported from the limestone region either by the glaciers or the waters of the lake, and thus disseminated throughout the body of the clay. The beach deposits which occur within the body of the clay consist largely of sand and limestone gravel.

In Dunn and St. Croix counties, in the western part of the State, there are considerable quantities of pure white kaolin, which is thought to have,been derived from the decomposed igneous rocks that occur northeast of this region. This kaolin is supposed to have been deposited by water prior to the first Glacial epoch. The extent of the deposits has never been accurately determined, although they are known to cover a very large area. They are interbedded with layers of sand and occur underneath a considerable thickness of till or bowlder clay. The level of these kaolin beds is about 200 feet above the estuarine deposits referred to above. It is very certain that these deposits were formed prior to the last Glacial epoch, and there are good reasons for believing that they antedate the first advance of the ice sheet. The reason for believing this is that the deposits are now covered with bowlder clay which is thought to belong to the first Glacial epoch. Further than this, the layers of clay are often crumpled, folded, and broken to a considerable depth below the surface.

The estuarine clays are worked for brick and tile, and among the localities may be mentioned Burlington, Edgerton, Madison, Merrimac, Portage, and Watertown.

The composition of these estuarine clays from different localities is given below.

Analyses of estuarine deposits contiguous to the lacustinine.

\begin{tabular}{|c|c|c|c|c|c|c|c|c|c|c|}
\hline & 1. & 2. & 3. & 4. & 5. & 6. & 7 & s. & 9. & 10. \\
\hline $\mathrm{SiO}_{2} \ldots \ldots$ & 49.39 & 73.36 & 49.26 & 43.68 & 35.81 & 49.57 & 47.57 & 33.48 & 32.66 & 36.65 \\
\hline $\mathrm{Al}_{2} \mathrm{O}_{3} \ldots \ldots$ & 8.99 & 12.83 & 9.25 & 14.37 & 11.19 & 10.84 & 10.49 & 8.95 & $8.73^{\circ}$ & 8.39 \\
\hline $\mathrm{Fe}_{2} \mathrm{O}_{3}$ & 2.10 & 3.50 & 3. 37 & 4. 40 & 3. 60 & 3.60 & 3. 80 & 3. 50 & 3.20 & 3.20 \\
\hline $\mathrm{CaO} \ldots$ & 12.56 & 0.89 & 11.88 & 10.84 & 16.12 & 10.01 & 10.62 & 16.32 & 16.93 & 16. 68 \\
\hline $\mathrm{MgO}$. & 7.48 & 0.52 & 7.47 & 5. 19 & 7.54 & 6.61 & 6.98 & 9.68 & 9.64 & 9.93 \\
\hline $\mathrm{Na}_{2} \mathrm{O} \ldots \ldots$ & 0.74 & 1.04 & 0.84 & 0.36 & 0.44 & 0.82 & 0.72 & 0.76 & 0.86 & 0.60 \\
\hline $\mathrm{K}_{2} \mathrm{O} \ldots$ & 1.90 & 2.30 & 1.52 & 3.76 & 2.64 & 2.50 & 2.44 & 2.08 & 2.30 & 2.61 \\
\hline $\mathrm{TiO}_{2} \ldots$ & 0.30 & 0.50 & 0.33 & 0.40 & 0.33 & 0.35 & 0.35 & 0.27 & 0.30 & 0.44 \\
\hline $\mathrm{MnO} \ldots . . .$. & Trace. & Trace. & Trace. & Trace. & (n) & Trace. & 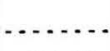 & Trace. & Trace. & $\cdots$ \\
\hline $\mathrm{H}_{2} \mathrm{O}, \mathrm{C} \ldots$ & $17: 03$ & 5.12 & 16. 30 & 17.04 & 22.35 & 16.19 & 17.06 & 24.82 & 25.29 & 21.37 \\
\hline Total. & 100.49 & 100.06 & 100.22 & 100.04 & 100.02 & 100.49 & 100.03 & 99.86 & 99.91 & 99.87 \\
\hline
\end{tabular}


CLAYS OF UNITED STATES EAST OF MISSISSIPPI RIVER.

Analyses of estuarine deposits contiguous to the lacustrine-Continued.

\begin{tabular}{|c|c|c|c|c|c|c|c|c|c|}
\hline & 11. & 12. & 13. & 14. & 15. & 16. & 17. & 18. & 19. \\
\hline $\mathrm{SiO}_{2} \ldots$ & 74.12 & 46.69 & 73.81 & 43. 32 & 38.06 & 70.15 & 75.58 & 31.90 & 44.09 \\
\hline $\mathrm{Al}_{2} \mathrm{O}_{3} \ldots$ & 11.78 & 12.48 & 12.72 & 6.80 & 8.71 & 13.98 & 12.18 & 8.74 & 11.87 \\
\hline $\mathrm{Fe}_{2} \mathrm{O}_{3}$ & 4.50 & 3.60 & 3. 40 & 1. 28 & 1.20 & 4.80 & 3. 30 & 3. 00 & 4.00 \\
\hline $\mathrm{CaO}$. & 0.96 & 10.28 & 0.52 & 15.50 & 16.28 & 1.18 & 1.01 & 17.06 & 10.29 \\
\hline $\mathrm{MgO}$. & 0.85 & 6.57 & 0.81 & 9.62 & 9.96 & 1.03 & 0.84 & 10.63 & 7.15 \\
\hline $\mathrm{Na}_{2} \mathrm{O}$ & 0.44 & 0.41 & 0.76 & 0.98 & 0.72 & 1.34 & 1.08 & 0.82 & 0.86 \\
\hline $\mathrm{K}_{2} \mathrm{O} \ldots$ & 2.62 & 3.01 & 2.22 & 1.64 & 1.56 & 1.94 & 2.04 & 2.20 & 2.74 \\
\hline $\mathrm{TiO}_{2}$ & 0.56 & 0.67 & 0.50 & 0.22 & 0.26 & 0.36 & 0.38 & 0.25 & 0.75 \\
\hline $\mathrm{MnO}$ & ..... & Trace. & Volatile. & & & K. & $\cdots$ & 0.19 & …... \\
\hline $\mathrm{H}_{2} \mathrm{O}, \mathrm{C}$ & 4.60 & 16. 33 & 4.99 & 20.79 & 23.06 & 5.81 & 3.78 & 25.19 & 18. 03 \\
\hline Total & 100.43 & 100.04 & 99.73 & 100.15 & 99.81 & 100.59 & 100.19 & 99.98 & 99.78 \\
\hline
\end{tabular}

1. John Paddock, Baraboo, Sauk County. Wisconsin Geol. Nat. Hist. Survey, Bull. No. 7, p. 270.

2, 3. Beaver Dam Brick Works, Beaver Dam, Dodge County. Ibid.

4, 5. Burlington Brick and Tile Company, Burlington, Racine County. Ibid.

6, 7. Endeavor Brick Yard, Endeavor, Columbia County. Ihid., p. 271.

8, 9. Fort Atkinson Brick Manufacturing Company, Fort Atkinson, Jefferson County. Ibid.

10, 11. J. M. Pluck, Horicon, Dodge County. Ibid., p. 272.

12. Hubbleton, Jefferson County. Ibid.

13. Janesville, Rock County. Ibid.

14, 15. A. P. Drinker, Portage, Columbia County. Ibid., p. 273.

16, 17. Springfield Brick and Tile Company, Springfield, Walworth County. Ibid., p. 274.

18. L. H. Cordes \& Co., Watertown, Jefferson and Dodge counties. Ibid.

19. Wind Lake Brick and Tile Company, Wind Lake, Racine County. Ibid.

$$
\text { gLACIAL CLAYS. }
$$

The glacial clays are distributed over a large part of the northern half of the State, and are all underlain by either pre-Cambrian crystalline rocks or Potsdam sandstone. These clays are of uncertain and variable thickness, but the most valuable are those which are contemporaneous with the last Glacial epoch, and such may be 40 to 50 feet thick. They are worked at several points, including Antigo, Barronnett, Edgár, Menominee, Wausau. 
WISCONSIN.

Analyses of glacial clays from the region not underlain with limestone and outside of the area of lacustrine clays.

\begin{tabular}{|c|c|c|c|c|c|c|c|c|c|c|c|}
\hline . & 1. & 2. & 3. & \multicolumn{2}{|c|}{4.} & 5. & 6. & 7: & 8. & 9. & 10. \\
\hline $\mathrm{SiO}_{2} \ldots \ldots$ & 71.77 & 74.36 & 64.37 & \multicolumn{2}{|c|}{60.29} & 58.94 & 61.02 & 42.50 & 47.52 & 68.74 & 74.16 \\
\hline $\mathrm{Al}_{2} \mathrm{O}_{3} \ldots$ & 13. 74 & 11. 77 & .13 .90 & \multicolumn{2}{|l|}{14} & 12.40 & 15.59 & 12.07 & 14.35 & 10.65 & 11.75 \\
\hline $\mathrm{Fe}_{2} \mathrm{O}_{3}$ & 3.60 & 4. 42 & 5 & \multicolumn{2}{|c|}{ 6. 80} & 9.20 & 5.12 & 3.90 & 5.60 & 3.16 & 2.80 \\
\hline $\mathrm{CaO} \ldots . . .$. & 1.23 & 1. 14 & 2.80 & \multicolumn{2}{|c|}{2.84} & 2.91 & 3.22 & 12.72 & 8.51 & 3.81 & 1. 31 \\
\hline $\mathrm{MgO}$ & 1.17 & 0.69 & 2.15 & \multicolumn{2}{|c|}{2.73} & 3.16 & 2.49 & 7.23 & 5.66 & 2.73 & 1. 17 \\
\hline $\mathrm{Na}_{2} \mathrm{O} \ldots$ & 1. 20 & 1. 22 & 1.46 & \multicolumn{2}{|c|}{ 1. 46} & 1 & 1. 26 & 0.56 & 0.58 & 1.94 & 2.18 \\
\hline $\mathrm{K}_{2} \mathrm{O} \ldots$ & 2.30 & 2. 14 & 2.94 & \multicolumn{2}{|c|}{3.64} & 3.32 & 3.34 & 3.06 & 3.44 & 2.06 & 2.22 \\
\hline $\mathrm{TiO}_{2} \ldots$ & 0.45 & 0.48 & 0.40 & \multicolumn{2}{|c|}{0.57} & 0.55 & 0.52 & 0.38 & 0.45 & 0.43 & 0.50 \\
\hline $\mathrm{MnO} \ldots$ & Trace. & Trace. & Trace. & \multicolumn{2}{|c|}{ Trace. } & 0.22 & Trace. & & & 0.14 & 0.27 \\
\hline $\mathrm{H}_{2} \mathrm{O}, \mathrm{C} \ldots$. & 5 & 3.51 & 7.36 & \multicolumn{2}{|c|}{7.71} & 8.73 & 7.64 & 18 & 13.42 & 6.55 & 3.95 \\
\hline \multirow[t]{2}{*}{ Total. } & 100.46 & 99.73 & 100.38 & \multicolumn{2}{|c|}{100.04} & 100.43 & 100.16 & 100.42 & 99.53 & 100.21 & 100.31 \\
\hline & 11. & 12. & 13. & 14. & 15. & 16. & 17. & 18. & 19. & 20. & 21. \\
\hline $\mathrm{SiO}_{2} \ldots$ & 73.29 & 65.44 & 64.50 & 63.36 & 50.76 & 62.74 & 70.02 & 70.41 & 69.46 & 69.86 & 70.54 \\
\hline $\mathrm{Al}_{2} \mathrm{O}_{3} \ldots$ & 11.98 & 13.51 & 13.11 & 14.01 & 34.05 & 17.01 & 14.77 & 13.64 & 14. 71 & 13.55 & 13. 60 \\
\hline $\mathrm{Fe}_{2} \mathrm{O}_{3} \ldots$ & 3. 32 & 5. 40 & 5.80 & 6.40 & $\cdot 1.14$ & 5.60 & 5 & 5. 20 & $\cdot 4.60$ & 5.46 & 4. 48 \\
\hline $\mathrm{CaO} . . . . . .$. & 1. 34 & 2.95 & 2.69 & 2.63 & 0.60 & 2.38 & 1.02 & 1.54 & 1.21 & 0.71 & 0.70 \\
\hline $\mathrm{MgO}$ & 1.09 & 2.20 & 1. 91 & 2.21 & th & 1.84 & 1.03 & 1.49 & 1.56 & 1. 43 & 1. 41 \\
\hline $\mathrm{Na}_{2} \mathrm{O}$ & 1. 92 & 1. 54 & 1.22 & 1.02 & 0.01 & 0.34 & 0.60 & 1.44 & 1. 26 & 1. 78 & 1. 94 \\
\hline $\mathrm{K}_{2} \mathrm{O} \ldots$ & 2. 10 & 3.44 & 4.12 & 3.48 & 0.24 & 3.18 & 2. 73 & 2.68 & 3 & 2.36 & 2.36 \\
\hline $\mathrm{TiO}_{2}$ & 0.55 & 0.60 & 0.50 & 0.50 & ...... & 0.60 & 0.62 & 0.41 & 0.41 & 0.77 & 1 \\
\hline $\mathrm{MnO}$. & 0.14 & Trace. & T'race. & Trace. & & & 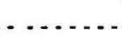 & - Trace. & Trace. & Trace. & $\ldots$ \\
\hline $\mathrm{H}_{2} \mathrm{O}, \mathrm{C} \ldots \ldots$ & 4. 29 & 4. 69 & 6.19 & 6. 79 & 13 & 6.72 & 4.50 & : $\quad 3.37$ & 4.33 & 4.40 & 4. 10 \\
\hline Total. & 100 & 99.77 & 100.04 & 100.39 & 99.80 & 100.41 & 100.29 & 100.18 & 100.50 & 100.32 & 100.13 \\
\hline
\end{tabular}

1,2. J. B. Theriault, Chippewa Falls, Chippewa. County. Wisconsin Geol. Nat. Hist. Survey, Bull. No. 7, p. 270-271.

3-6. East Tramway Brickyard, East Tramway, Dunn County. Ibid., p. 271.

7, 8. Lindaur \& Rhode, Kaukauna, Outagamie County. Ibid, p. 272. .

9-11. Central Wisconsin Pressed Brick Company, Marshfield, Wood County. Ibid.

12-14. Wisconsin Red Pressed Brick Company, Menomonie, Dunn County. Ibid.

15. Rice Lake, Barron County. Ibid., p. $2 \% 3$.

16, 17. River Falls Brick Company, River Falls, Pierce County. Ibid.

18, 19. Tomahawk Brickyard, Tomahawk, Lincoln County. Ibid., p. 274.

20, 21. Langenberg Brick Company, Whittlesey, Taylor County. Ibid.

CLAY-WORKING INDUSTRY.

The most important clay products made in Wisconsin are brick and tile, the latter being turned out chiefly in the southern part of the State. Paving brick or 
sewer pipe are not being made at present in Wisconsin; in fact, on account of the calcareous nature of the clays, attempts to make vitrified wares in this State have been a failure.

The "kaolins" and white-burning so-called "plastic kaolins" which are found are of importance for paper making after they have been washed.

It is suggested by $\mathbf{E}$. R. Buckley that the pure deposits of lacustrine clays could be used for flowerpots, cheap cuspidors, etc.

It seems doubtful, however, whether Wisconsin can ever become an important clay-producing State, partly on account of the character of the raw materials and partly because competition with neighboring States, such as Ohio, would be nearly impossible.

Wisconsin ranks twentieth among the clay-producing States, the production since 1895 having been as follows:

Value of clay products of Wisconsin from 1895 to 1901.

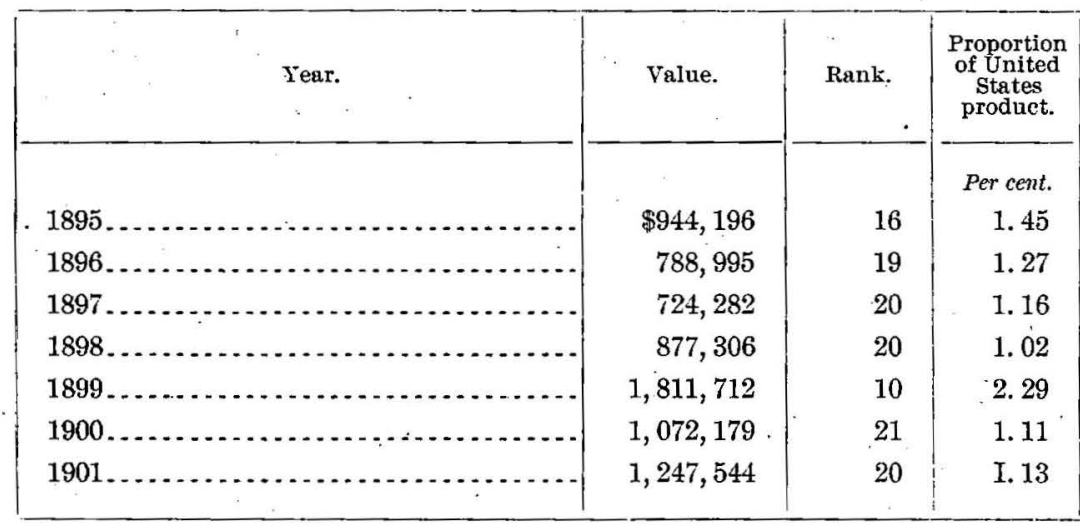

Value of the clay products of Wisconsin in 1900 and 1901.

\begin{tabular}{|c|c|c|}
\hline . & 1900. & 1901. \\
\hline Common brick $\ldots \ldots \ldots \ldots \ldots$ & 963,461 & $1,151,838$ \\
\hline Front brick $\ldots \ldots \ldots \ldots \ldots \ldots$ & 84,601 & 54,379 \\
\hline Vitrified brick...$\ldots \ldots \ldots \ldots \ldots \ldots$ & ................ & $(a)$ \\
\hline Fancy brick $\ldots \ldots \ldots \ldots \ldots$ & 2,272 & 2,105 \\
\hline Fire brick $\ldots \ldots \ldots \ldots \ldots \ldots \ldots \ldots \ldots$ & $(a)$ & $(a)$ \\
\hline Drain tile $\ldots \ldots \ldots \ldots$ & 14,995 & 22,727 \\
\hline Fireproofing $\ldots \ldots \ldots \ldots \ldots$ & $\ldots$ & (a) \\
\hline Tile (not drain) ............. & $(a)$ & $(a)$ \\
\hline Miscellaneous ................... & 1,800 & 1,400 \\
\hline Pottery $\ldots \ldots \ldots \ldots \ldots$ & $\quad(a)$ & 13,400 \\
\hline
\end{tabular}

$a$ Less than three producers. 


\section{RÉSUME OF THE INDUSTRY.}

COMMON BRICK.

Common brick are made in great quantities in all the States of the region covered by this report. Owing to the low price which the product usually brings, but little expense can be incurred in the methods of winning the clay and the manufacture of the brick, and on this account the ordinary surface clays are generally used. The process of manufacture is hurried as much as possible, but little attention being paid to the exact shade of ware produced or to obtaining a very smooth surface. In the Northern States the great spread of drift clays affords everywhere an excellent material for making common brick, while in the South the great mantle of residual clay, which is found throughout the upland region, and the sedimentary clay of the Coastal Plain surface, give opportunity for the establishment of some center of brickmaking wherever there is a market calling for the product. (Pls. III, IV, and VII.) We thus find in the vicinity of almost every one of the larger cities a thriving brickmaking industry developed. On account of their low market value common brick are rarely transported for great distances, except by water. The price per thousand varies with the locality and somewhat also with the quality of the product, but in 1901 it ranged from an average of $\$ 3.78$ per thousand in South Carolina to an average of $\$ 8.13$ in Nevada.

The largest brickmaking region of the Eastern United States, or, indeed in the whole country, is that of the Hudson River Valley in New York State, where nearly a billion brick are made annually and sent mostly to the New York market. Other brickmaking centers in the State are Rochester and Syracuse. In New England many brick are manufactured from the glacial clays around Boston, and in the Connecticut River Valley from the terrace clays of estuarine origin.

In New Jersey a great brickmaking area surrounds Hackensack, Bergen County, where the clays worked are very similar to those found in the Hudson River Valley of New York State. Many common brick are also molded around Sayreville from the Cretaceous clays, and at Trenton from the Columbia loams.

At Philadelphia the Columbia loams have been used for many years for making excellent red brick, while in the western part of the State, around Pittsburg, many shales or mixtures of Carboniferous shales and alluvial clay, have been found suitable for the same purpose.

The Columbia and Potomac clays support an active brickmaking industry in the vicinity of Baltimore and Washington, and the former types of clay are available at many localities farther to the south.

Many common brick are manufactured from calcareous lake clays in States of 9647 -No. $11-03-18$ 
the Mississippi Valley and those of the Great Lake region, as at Cleveland, Ohio, Detroit, Mich., Chicago, Ill., and Milwaukee, Wis. These bricks are usually buff or cream colored, but in some cases are nearly white. Many common brick are made from the drift clays of Ohio, as well as from those of Indiana and Illinois. There are important centers around Brazil, Evansville, Fort Wayne, Indianapolis, South Bend, and Terre Haute, in Indiana, and Chicago, Peoria, Quincy, and Springfield, in Illinois. In Kentucky the more important centers of common brick manufacture are Ashland, Covington, Louisville, and Paducah.

Alabama's chief brickmaking center is Montgomery, but large quantities are also made at Birmingham. In Mississippi the loams of the flood plain of the Mississippi River make an excellent red-burning brick clay and are much used. The great abundance of red residual clay all through the South has, however, interfered somewhat with the establishment of permanent plants, and many local but temporary yards have been built to supply some passing demand.

The processes used in the manufacture of common brick have improved greatly during the last fifteen years. Most yards, indeed all, with the exception of the very small ones, are operated by steam power. The soft-mud process has in many instances given way to the stiff-mud method, which, on account of its greater capacity; has great attractions, but is not adapted to as wide a range of clays. There has been a similar improvement in the drying and burning operations, sun drying having been replaced by drying in tunnels with artificial heat, and the old scove kiln by modern types, among which the continuous. kiln is gaining in favor. Yet in spite of the invention of modern and improved machinery, some of the largest brickmaking regions cling to the old soft-mud process and open-air drying.

The production of common brick in the United States east of the Mississippi from 1895 to 1901 is given below:

Total value of common brick produced in the United States from 1895 to 1901.

\begin{tabular}{|c|c|c|}
\hline Year. & $\begin{array}{c}\text { states east of Mis. } \\
\text { sissippi River. }\end{array}$ & $\begin{array}{c}\text { Total United States } \\
\text { product. }\end{array}$ \\
\hline $1895 \ldots \ldots \ldots \ldots \ldots \ldots$ & $\$ 23,143,772$ & $\$ 31,569,126$ \\
$1896 \ldots \ldots \ldots \ldots \ldots \ldots$ & $24,276,620$ & $29,664,043$ \\
$1897 \ldots \ldots \ldots \ldots \ldots \ldots \ldots$ & $20,429,219$ & $26,430,207$ \\
$1898 \ldots \ldots \ldots \ldots \ldots \ldots$ & $22,881,065$ & $30,980,704$ \\
$1899 \ldots \ldots \ldots \ldots \ldots \ldots$ & $29,868,646$ & $39,887,522$ \\
$1900 \ldots \ldots \ldots \ldots \ldots \ldots \ldots$ & $25,322,478$ & $38,621,514$ \\
$1901 \ldots \ldots \ldots \ldots \ldots \ldots \ldots$ & $35,345,367$ & $45,503,076$ \\
\hline
\end{tabular}


PRESSED BRICK

Since these require a higher grade of raw material, the clays suitable for their manufacture are less widely distributed, and the plants are fewer in number, but the higher price which the product commands permits longer transportation to market. In former years pressed brick were made chiefly from red-burning clays, as in the case of the red Philadelphia brick. Now, however, buff-burning clays, such as No. 2 fire clays, are largely used. The reason for this is that buff is a color much liked, and, furthermore, it makes a good ground with which to mix artificial colors. Many different shades of brick are now put on the market, the color being produced either by the addition of artificial colorants or by manipulation of the kiln fires. Ornamentation is produced by varying the shape and size of the brick.

The most important works for producing pressed brick are located in those States that contain an abundance of fire clays, viz., Pennsylvania, Ohio, and New Jersey, named in the order of their importance.

Pennsylvania leads in the production of pressed brick, three types of material being drawn upon to supply the product. Around Philadelphia the well-known red brick have been made for years from the Columbia loams of that vicinity, and these have met with great favor among the architects of many Eastern cities. In the western part of the State the lower grades of fire clay are much employed for buff and other shades of front brick, and a pressed-brick works has become an adjunct to several of the large fire-brick factories. Works are located at Fallston, Monaca, Vanport, Kittanning, and other places. In the Pittsburg region a mixture of surface clays and Carboniferous shales is often used, and makes an excellent repressed or dry-pressed artiele.

Ohio is second in importance to Pennsylvania, and many pressed brick are made from the Carboniferous under clays at several localities, among them Akron, Shawnee, and Zanesville.

In New Jersey many buff and pressed brick are made from the Cretaceous clays around Woodbridge, Perth Amboy, and Sayreville, and find a ready sale in the markets of New York, Philadelphia, and other Eastern cities. In addition to these, large quantities of hydraulic dry-pressed brick are made from the Pleistocene clays in the vicinity of Winslow Junction, and smaller quantities are made in other parts of the State, among the localities of subordinate importance being Trenton and Belvidere.

Virginia, though of little importance as a clay-working State, produces large quantities of a white or yellowish-white front brick, which is made in large quantities from the residual clays occurring near Richmond. The product is shipped to many of the markets in the Central and Northeastern States and seems to possess 
freedom from discoloration, which is a trouble many pressed-brick manufacturers have to contend with.

Wisconsin has gained some prominence as a producer of pressed brick on account of the cream brick, which have been made for many years from the ealcareous lake clays at Milwankee.

Many pressed brick are made in Illinois from the Carboniferous shales and other clays, as at Belleville and Lasalle. Considerable quantities are also produced in Indiana from Carboniferous shales and fire clays. Additional shades are often produced by mixing these with the surface clays. Among the localities where pressed brick are manufactured are Cayuga, Hillsboro, Terre Haute, Huntingburg, and Evansville.

In New York State considerable quantities of pressed brick are made from the Cretaceous clays on Staten Island, and in the western and southwestern part of the State the Devonian shales lend themselves well to the manufacturer of brick for fronts. In addition, the clays of Long Island are also used for making a dry-pressed product.

Aside from these States there is a scattered production of pressed brick reported annually from others. Many plants keep a repressing machine in order to repress their common brick to supply occasional orders, and to this is due the varying but small and persistent production of pressed brick reported by many States.

Most front brick are now made either by the stiff-mud process and repressed, or by the dry-press method of molding.

- The highest average price of pressed brick in 1900 was $\$ 20$ per thousand in Connecticut, but this average does not represent the highest price received for pressed brick, for those, with a highly ornamented surface, may bring as much as $\$ 40$ or $\$ 50$ per thousand.

The total value of pressed brick (excluding ornamental brick) produced from 1895 to 1901 was as follows:

Total value of pressed brick produced in the United States from 1895 to 1901.

\begin{tabular}{|c|c|c|}
\hline Year. & $\begin{array}{l}\text { States east of Mis- } \\
\text { sissippi River. }\end{array}$ & $\begin{array}{c}\text { Total United States } \\
\text { product. }\end{array}$ \\
\hline 1895 & $\$ 3,458,397$ & $\$ 4,399,367$ \\
\hline $1896 \ldots$ & $2,638.016$ & $3,390,941$ \\
\hline $1897 \ldots$ & $3,194,065$ & $3,855,033$ \\
\hline $1898 \ldots$ & $2,805,073$ & $3,572,385$ \\
\hline $1899 \ldots$ & $3,588,189$ & $4,767,343$ \\
\hline $1900 \ldots \ldots \ldots$ & $3,062,338$ & $3,864,670$ \\
\hline $1901 \ldots \ldots \ldots$ & $3,335,154$ & $4,709,737$ \\
\hline
\end{tabular}


FIREPROOFING.

The active construction of many modern fireproof buildings in all the larger cities at the present time had led to the widespread use of hollow brick or fireproofing for the protection of steel girders and the construction of floor arches and partitions. Some idea of the expansion of this industry may be gained from a statement made in the clay report issued by the New Jersey geological survey in 1878, in which fireproofing is referred to as a new kind of brick which was being experimented with at that time. In 1900 the value of the fireproofing produced in the United States was $\$ 1,820,214$, and most of this came from three or four States. The clays used for fireproofing are either common brick clays or impure fire clays, and consequently the material can be manufactured in almost any State, which accounts for the longlist of producers, although they are by no means all large ones. Certain States, however, as New Jersey, Ohio, and Indiana, produce great quantities of this material to supply the large markets located in their vicinity, and in such States there are. large factories whose output is entirely fireproofing material. More recently these factories have been turning their attention to the manufacture of conduits for electrical subways, since these can be made on the same type of machine and from a similar mixture of clays. These are made in large quantities now by some of the plants in New Jersey.

The total value of the fireproofing produced in the Eastern States from 1895 to 1901 is as follows:

Total vilue of fireproofing produced in the United States from 1894 to 1901.

\begin{tabular}{|c|c|c|}
\hline Year. & $\begin{array}{c}\text { States east of } \\
\text { Mississippi River. }\end{array}$ & $\begin{array}{l}\text { Total United States } \\
\text { product. }\end{array}$ \\
\hline $1894 \ldots$ & $\$ 478,827$ & $\$ 514,637$ \\
\hline $1895 \ldots$ & 660,626 & 741,626 \\
\hline $1896 \ldots$ & $1,378,860$ & $1,706,504$ \\
\hline $1897 \ldots$ & $1,890,565$ & $1,979,259$ \\
\hline $1898 \ldots \ldots$ & $1,571,812$ & $1,900,642$ \\
\hline $1899 .$. & $\quad 1,555,813$ & $1,665,066$ \\
\hline 1900. & $1,610,769$ & $1,820,214$ \\
\hline $1901 \ldots$ & $2,874,290$ & $1,820,269$ \\
\hline
\end{tabular}

ROOFING TILES.

Roofing tiles are made at few localities, but the industry is slowly expanding, although the number of plants is not increasing much. Three styles of tile are made, viz, the Roman, shingle, and interlocking. Each company making roofing tiles usually confines itself to one type, which it most earnestly advocates the use of. 
Two factories are located in New York, two in Illinois, one in Maryland, one in Ohio and one in Georgia. 'The tiles are usually red and are sometimes glazed. Some are vitrified, while others are not.

TERRA COTTA.

The use of terra cotta for exterior decoration and as a substitute for stone has created a great demand for the material, especially in the larger cities, where building operations are active. Factories are located in a number of States, but most of the product comes from New York, New Jersey, and Illinois. The general character of the ware is much the same, consisting usually of a mixture of fire clays, which burn to a strong buff, or sometimes a red, if more ferruginous clays are used. The color of the ware is contained in the slip, which is sprayed over the surface in the form of a thin film. Many shades are made, the çolor applied being frequently put on for the purpose of matching the building stone which is to be used in the same building with the terra cotta. There are a number of firms in New.Jersey manufacturing terra cotta which obtain their supply of material from the neighboring clay pits. The same material is used by some of the New York manufacturers, although those in the southwestern part of the State employ Devonian shales as well.

In Pennsylvania considerable terra cotta is made in the eastern part of the State from New Jersey clays, while a large factory is in operation at Evanston, Ill. Very little is made in Ohio. Other producing States are Maryland, Georgia, Kentucky, and Michigan. The value of the ornamental terra cotta produced in the United States in 1901 was $\$ 3,367,982$, of which $\$ 2,874,290$ was produced east of the Mississippi.

ENAMELED BRICK.

The enameled-brick industry is a young one in the United States and for many years has had to compete with the prejudice that existed in favor of the imported English enameled materials. At the present day it can probably be said, however, that the domestic product is in many cases fully equal to the imported material. Bricks of this type are made in Pennsylvania, New Jersey, Maryland, Illinois, and Georgia.

\section{FLOOR TILES.}

Those made in the United States are of two types, viz, tiles of solid color and encaustic tiles. The tile first named is of the same color throughout, while in the latter the color or design forms only the upper portion of the tile, the remainder of the body being formed of some buff burning clay. The tiles are always made by the dry-press process, and while the solid-color ones are molded in many different forms, the encaustic tiles are usually square. The number of shades and colors produced is so great that artificial methods of coloration have to be resorted to. Clay tiles have gained great favor as a flooring material, and come into active competition with slate 
and marble. They possess the advantage of being harder, more durable, and capable of being worked into a greater number of designs and coloris. Many factories produce both styles of these tiles, and supply not only the domestic demand, but also export their product, which is in some cases shipped as far as Australia.

Floor tiles are manufactured at Trenton, N. J., Pittsburg, Pa., Zanesville, Ohio, Indianapolis, Ind., and other localities. They are commonly made from a mixture of clays and shales, those from the Carboniferous formations being perhaps the most used.

GLAZED TILES.

Glazed tiles for wall decoration are produced in several States. The body of these has to be necessarily much whiter and more porous than that of floor tiles, and they are often made from the higher grades of clay, such as kaolin. The surface is sometimes pressed in relief, and the glaze may be either colorless, colored, or opaque. There is considerable rivalry between the different manufacturers to produce new colors and designs, and the number of them is consequently very great.

Hand-painted tiles and cloissonnée ones are very little made, if at all, in the United States. The distribution of glazed-tile factories bears no relation to the distribution of the raw materials, for these form but a small proportion of the expense of manufacture.

Glazed tiles are made at Chelsea, Mass.; Trenton, N. J.; Morrisville and Beaver Falls, Pa.; Covington, Ky.; Old Bridge and Perth Amboy, N. J.; Tarrytown, N. Y.; and Indianapolis, Ind.

VITRIFLED BRICK.

The production of vitrified brick in the United States is probably not exceeded by that of any other country in the world, and in the Middle States especially it has developed into an industry of vast extent. This is due partly to the absence of other cheap paving materials and to the excellent qualities of brick pavements when subjected to moderate traffic, as well as to the presence in the Central States of suitable raw materials so situated that the product can be turned out rapidly and economically.

The total value of the paving brick produced in the States lying east of the Mississippi from 1895 to 1901 is given below: 
Total value of paiving brick produced in the United States from 1894 to 1901.

\begin{tabular}{|c|c|c|}
\hline Year. & $\begin{array}{c}\text { States east of Missis- } \\
\text { sippi River }\end{array}$ & $\begin{array}{l}\text { Total United States } \\
\text { product. }\end{array}$ \\
\hline 1894 & $\$ 2,739,849$ & $\$ 3,711,073$ \\
\hline $1895 \ldots$ & $2,672,305$ & $3,130,472$ \\
\hline $1896 \ldots$ & $2,442,939$ & $2,794,585$ \\
\hline $1897 .$. & $2,729,583$. & $3,582,037$ \\
\hline $1898 .$. & $2,923,715$ & $4,016,822$ \\
\hline 1899.. & $3,835,955$ & $4,750,424$ \\
\hline $1900 \ldots$ & $3,636,365$ & $4,764,124$ \\
\hline $1901 \ldots$ & $4,321,178$ & $5,484,134$ \\
\hline
\end{tabular}

The output for 1901 was as follows:

Production of paving brick east of Mississippi in 1901.

\begin{tabular}{|c|c|c|c|}
\hline State. & Quantity. & Value. & $\begin{array}{l}\text { Average price } \\
\text { per thousand. }\end{array}$ \\
\hline 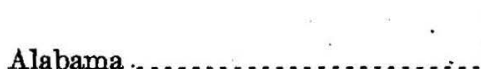 & $\begin{array}{c}\text { Thousands. } \\
\text { (a) }\end{array}$ & (a) & $\$ 11.00$ \\
\hline Georgia ...... & (a) & (a) & 7.69 \\
\hline Illinois .... & 99,572 & 899,454 & 9.03 \\
\hline Indiana ...... & 31,468 & 320,221 & $10: 18$ \\
\hline Kentucky .... & (a) & (a) & 12.71 \\
\hline Maine ...... & (a) & (a) & 20.02 \\
\hline Maryland...... . & (a) & (a) & 15.00 \\
\hline Michigan .... & (a) & $(a)$ & 12.30 \\
\hline New Jersey .... & 2,251 & 22,024 & 9. 78 \\
\hline New York $\ldots . . . \ldots \ldots$ & 29,950 & 343,343 & 11.46 \\
\hline North Carolina & (a) & (a) & 10.00 \\
\hline ohio ................ & 175,757 & $1,443,537$ & 8.21 \\
\hline Pennsylvania . & 73,498 & 670,081 & 9.12 \\
\hline Tennessee ....... & 6,624 & 67,129 & 10.13 \\
\hline West Virginia......... & 62,805 & 555,389 & 8.84 \\
\hline
\end{tabular}

$a$ Where the output is contributed by less than three firms the figures are not given.

Although West Virginia was the cradle of the paving-brick industry, Ohio now leads the States in the production of this class of ware, but large quantities also come from Mlinois, Pennsylvania, West Virginia, New York, and Indiana, named in the order of their importance. The general distribution of paving-brick works is shown on the map (Pl. VWI). Most of the bricks of this class are made from fine-grained ferruginous shales, these being found to yield the best results. In some cases a certain quantity of low-grade fire clay is added-in fact during the early stages of the industry, fire clays alone were considered necessary. The method of manufac- 




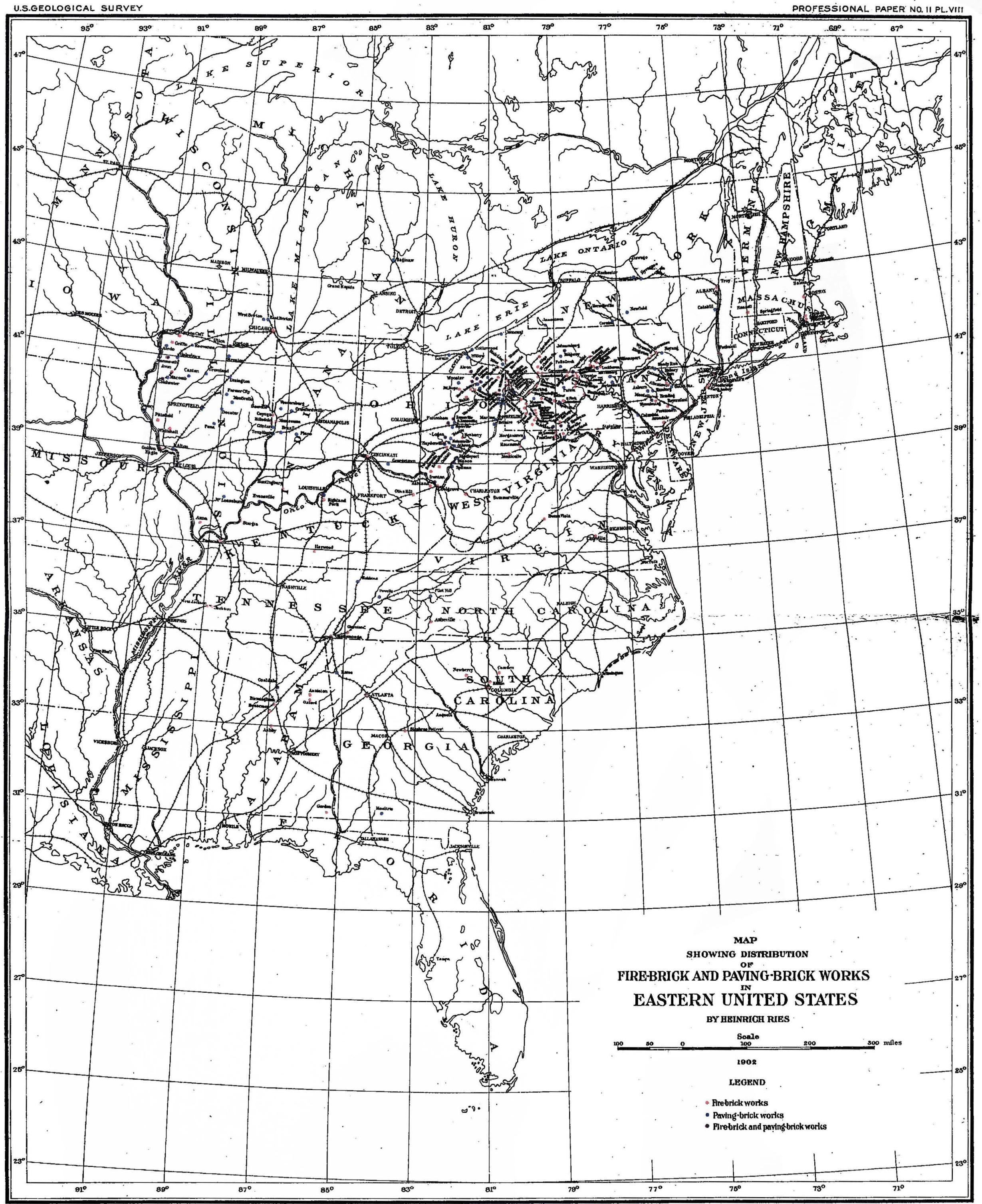



ture has gone through various experimental stages, but the stiff-mud method is now preferred by most paving-brick manufacturers on account of its greater capacity. ${ }^{a}$

Much discussion has taken place in recent years regarding the adoption of a standard method of testing paving brick, and also of the effect of the method of manufacture on the abrasive resistance of the product. This subject has been one of special investigation by a committee appointed by the National Brickmakers' Association, and their report deals with the correct method of making tests so as to insure reliable and uniform results.

\section{DRAIN TILE.}

An examination of the statistics of drain tile production are of interest as showing the agricultural çonditions of the State in which they are made. Since they can be manufactured from ordinary brick clays, they are produced chiefly in response to a local demand. As will be seen from the statistics given annually in the reports of the United States Geological Survey, Ohio, Illinois, Indiana, and Michigan are the most important producers, though large quantities are also made in New Jersey and New York. The variation in the quantity produced by any one State from year to year is due to special and irregular local demands. Any manufacturer making brick by the auger stiff-mud process can, by changing the die, produce tile instead of brick whenever there is a call for the material.

The tile are made of varying diameters, from 2 up to 6 inches, but commonly about 3 or 4 .

Value of drain tile produced from 1894 to 1901.

\begin{tabular}{|c|c|c|}
\hline Year. & $\begin{array}{l}\text { States east of Missis- } \\
\text { sippi River. }\end{array}$ & $\begin{array}{l}\text { Total United States } \\
\text { product. }\end{array}$ \\
\hline 1894. & $\$ 4,898,931$ & $\$ 5,803,162$ \\
\hline $1895 \ldots$ & $3,113,919$ & $3,450,961$ \\
\hline 1896 & $2,326,508$ & $2,613,513$ \\
\hline $1897 \ldots \ldots$ & $2,176,932$ & $2,623,305$ \\
\hline $1898 \ldots$ & $1,936,582$ & $3,115,318$ \\
\hline 1899 & $3,141,607$ & $3,682,394$ \\
\hline 1900 & $2,483,387$ & $2,976,281$ \\
\hline $1901 \ldots$ & $2,465,875$ & $3,143,001$ \\
\hline
\end{tabular}

SEWER PIPE.

Sewer pipe are made from a clay which will yield a vitrified product at moderate temperatures, and shale therefore usually gives the best results. It is consequently not surprising to find Ohio the main producer, leading all the other States by a very large margin. The sewer-pipe factories in that State, especially those near Akron,

$a$ For a discussion of the manufacture of paving brick see pamphlet by $\mathbf{H}$. A. Whecler on Vitrified Paving Briek, Indiamealpolis, 1995. Fror tests of paving brick see Riew, H., The eley-working industry of the United States in 1896: Eighteenth Ann. Rept. U. S. Geol. Survey, Pt. V (eontintued), p. 1111. 
are operated on a gigantic scale, and much of the product is shipped to neighboring: States.

Next to Ohio, Pennsylvania, Indiana, and Illinois produce considerable quantities of sewer pipe, and small amounts come from other States.

The production for 1894-1901 is given below:

Value of sewer pipe produced in the United States from 1894 to 1901.

\begin{tabular}{|c|c|c|}
\hline Year. & $\begin{array}{l}\text { States east of Mis- } \\
\text { sissippi River. }\end{array}$ & $\begin{array}{l}\text { Total United States } \\
\text { product. }\end{array}$ \\
\hline $1894 \ldots$ & $\$ 5,150,497$ & $\$ 5,989,923$ \\
\hline $1895 .$. & $3,573,982$ & $4,482,577$ \\
\hline $1896 \ldots$ & $3,845,436$ & $4,588,503$ \\
\hline $1897 \ldots$ & $3,187,615$ & $4,069,534$ \\
\hline 1898. & $2,209,032$ & $3,791,057$ \\
\hline $1899 .$. & $2,646,599$ & $4,560,334$ \\
\hline $1900 \ldots$ & $3,692,854$ & $5,842,562$ \\
\hline 1901.: & $4,221,018$ & $6,736,969$ \\
\hline
\end{tabular}

FIRE BRICK.

The production of fire briek has shown a phenomenal increase during the last three years, most of the production having come from the States lying east of the Mississippi. This increased output can be seen from the following table, in which the production since 1894 is given:

Value of fire brick produced in the United States from 1894 to 1901.

\begin{tabular}{|c|c|c|}
\hline Year. & $\begin{array}{l}\text { States east of Mis- } \\
\text { sissippi River. }\end{array}$ & $\begin{array}{c}\text { Total United States } \\
\text { product. }\end{array}$ \\
\hline $1894 .$. & $\$ 4,221,665$ & $\$ 4,762,820$ \\
\hline 1895. & $4,587,738$ & $5,279,004$ \\
\hline 1896. & $4,461,785$ & $4,944,723$ \\
\hline $1897 \ldots$ & $3,712,875$ & $4,094,704$ \\
\hline $1898 \ldots$ & $5,039,269$ & $6,093,071$ \\
\hline $1899 \ldots$ & $7,886,866$ & $8,641,882$ \\
\hline 1900. & $8,810,360$ & $9,830,517$ \\
\hline $1901 \ldots$ & $8,523,989$ & $9,870,421$ \\
\hline
\end{tabular}

The important position which the Eastern States occupy as producers of fire brick is due not alone to the presence of refractory clays, but also to the development of metallurgical industries in those areas. In 1900 Pennsylvania alone produced over four and a half million dollars' worth of fire brick, while Ohio and New Jersey each supplied over one million dollars' worth. This great output is occasioned by an active demand, and will no doubt continue as long as the United States ts the leading producer of iron and steel. Many others are consumed by other branches of 
the metallurgical industries. Quantity alone is not called for, however, but in addition the manufacturer has to produce a variety of grades and many different shapes.

A brick can not be produced which will satisfactorily meet all conditions. Some bricks are exposed to high heat alone, others must resist abrasion rather than excessive heat. Again, resistance to corrosion at high temperatures is necessary, and even here it is sometimes an acid, at others a basic, brick that is required.

Comparatively few analyses or tests of refractoriness have been published. Of the former a few are collected here, and such indicate bricks of rather siliceous character:

Analyses of fire brick. $a$

\begin{tabular}{|c|c|c|c|c|c|c|c|c|}
\hline . & 1. & 2. & 3. & 4. & 5. & 6. & 7 . & 8. \\
\hline $\mathrm{SiO}_{2} \ldots$ & 52.87 & 52.48 & 78.08 & 58.97 & 59.98 & 71.55 & 58.75 & 65.24 \\
\hline $\mathrm{Al}_{2} \mathrm{O}_{3} \ldots \ldots \ldots$ & 40.28 & 40.65 & 17.89 & 32.969 & 36.009 & 25.09 & 36.79 & 28.875 \\
\hline $\mathrm{TiO}_{2} \ldots \ldots \ldots$ & 2.44 & 1.67 & .81 & 1.62 & 1. 70 & 1.05 & 1.75 & 1.67 \\
\hline $\mathrm{Fe}_{2} \mathrm{O}_{3} \ldots \ldots$ & 1.32 & 1.99 & .97 & 1.97 & 1. 911 & 1. 28 & 1. 39 & 2.71 \\
\hline $\mathrm{CaO} \ldots \ldots$. & 1. 41 & .26 & .56 & .12 & .10 & .65 & .11 & .09 \\
\hline $\mathrm{MgO} \ldots \ldots$. & .396 & .299 & .35 & .503 & Tr. & .364 & .301 & .338 \\
\hline Alkalies ........ & .98 & 2.79 & 2.115 & 1. 277 & 1. 174 & .384 & .913 & 1. 312 \\
\hline Total & 99.696 & 100.139 & 100.775 & 100.429 & 100.875 & 100.368 & 100.004 & 100.235 \\
\hline
\end{tabular}

a Second Pennsylvania Geol. Survey, Rept. MM., p. 269. For a series of tests see ibid., p. 271 et seq.

1. Clearfield fire brick, Clearfield County, Pa.

2. Queens Run fire brick, Clinton County, Pa.

3. Maxwells, Bradley \& Co., Layton station, Pa.

4. Savage Fire Brick Works, Keystone Junction, Somerset County, Pa.

5. Mount Savage fire brick, Union Mining Company, Mount Savage, Md.

6. Hall \& Sons' No. 1 fire brick, Perth Amboy, N. J.

7. Hyzer \& Lewellen's, made from Woodbridge fire clay.

8. Soisson \& Glover's fire brick, Connellsville.

Silica brick and basic brick constitute special types, which are manufactured to a small extent.

There are many fire-brick works scattered over Pennsylvania, Ohio, and New Jersey, as can be seen from the map on Pl. VIII, and consequently the furnaces in these States rarely send any distance for fire brick. Many furnaces in eastern Pennsylvania, therefore, draw on the New Jersey factories to a large extent.

Fire brick are also manufactured from local clays in West Virginia, Indiana, Illinois, Kentucky, Tennessee, Alabama, Georgia, North Carolina, South Carolina, and Maryland. Those produced in other States, viz, Florida, Wisconsin, Michigan, New Hampshire, Maine, New York, Massachusetts, and Connecticut are made almost entirely from clays obtained from neighboring States. Many brick are shipped by water, and even rail, to Mexico and Canada. 
POTTERY. $a$

The pottery industry of the United States has shown a most phenomenal growth, and the product now embraces a number of grades, including red earthenware, stoneware, porcelain, white earthenware, belleek, majolica, etc. The commoner grades are usually made at. small potteries scattered over the country, and supported by local trade, but the factories making the highest grades of ware are often grouped around a few localities, which have been chosen on account of their being transportation centers. Their distribution is shown on Pl. IX.

The increase in the total value of the product is shown by the following table:

Total value of pottery products from 1896 to 1901.

\begin{tabular}{|c|c|c|}
\hline Year. & $\begin{array}{l}\text { States east of Mis- } \\
\text { Bissippi. }\end{array}$ & $\begin{array}{c}\text { Total United States } \\
\text { product. }\end{array}$ \\
\hline $1896 \ldots$ & $\$ 6 ; 351,240$ & $\$ 7,455,627$ \\
\hline $1897 \ldots$ & $8,880,122$ & $10,309,209$ \\
\hline $1898 \ldots$ & $13,381,750$ & $14,589,251$ \\
\hline 1899 & $16,677,562$ & $17,250,250$ \\
\hline $1900 \ldots$ & 19, 189, 356 & $19,798,670$ \\
\hline $1901 \ldots$ & $21,865,908$ & $22,463,860$ \\
\hline
\end{tabular}

From the above figures it will be seen that most of the pottery produced in this country comes from the region lying east of the Mississippi. This is due partly to a greater demand within this area, and also due to the presence of raw materials and manufacturing facilities.

The rank of the more important States has not changed much during the past six years, as is indicated below.

Rank of States in value of pottery from 1896 to 1901.

\begin{tabular}{|c|c|c|c|c|c|c|}
\hline Rank. & 1896. & 1897. & 1898. & 1899. & 1900. & 1901. \\
\hline 1 & Ohio..... & Ohio.. & Ohio... & Ohio..... & Ohio... & ònio. \\
\hline 2 & New Jersey ....... & New Jersey..... & New.Jersey.. & New Jersey ...... & New Jersey... & New Jersey. \\
\hline 3 & Pennsylvania .. & Pennsylvania & Pennsylvania & Pennsylvania .. & Pennsylvania & Pennsylṿania. \\
\hline 4 & Illinois ..... & nlinois ... & Illinois ..... & Illinois... & New York & New York. \\
\hline 5 & West Virginia ..... & West Virginia & West Virginia ..... & New York... & nllinois ... & West Virginia. \\
\hline 6 & New York ........ & Minnesota.. & New York ......... & West Virginir .... & West Virginia & Illinois. \\
\hline 7 & Massachusetts.... & Maryland ... & Minnesota ... & Maryland .... & Maryland ... & Indiana. \\
\hline 8 & Indiana ... & Massachusetts & Maryland & Indiana. & Indiana... & Maryland. \\
\hline 9 & Kentucky . & Indiana. & Indiana .... & Massachusetts .... & Minnesota... & Minnesota. \\
\hline 10 & Texas .... & New York & Massachusetts .... & Minnesota.. & Massachusetts... & Massachusetts \\
\hline 11 & Missouri........... & Kentucky ........ & Kentucky ......... & Kentucky . & Kentucky .... & Kentucky. \\
\hline 12 & Connecticut. & Connecticut ....... & Connecticut....... & Texas ....... & Texas ........ & Connecticut. \\
\hline
\end{tabular}

a An excellent historic account of the industry is contained in E. A. Barber's Pottery and Porcelain of the United States. See also Ries, H., The pottery industry of the United States: Seventeenth Ann. Rept. U. S. Geol. Surv., Pt. III (conținued), p. 842. 



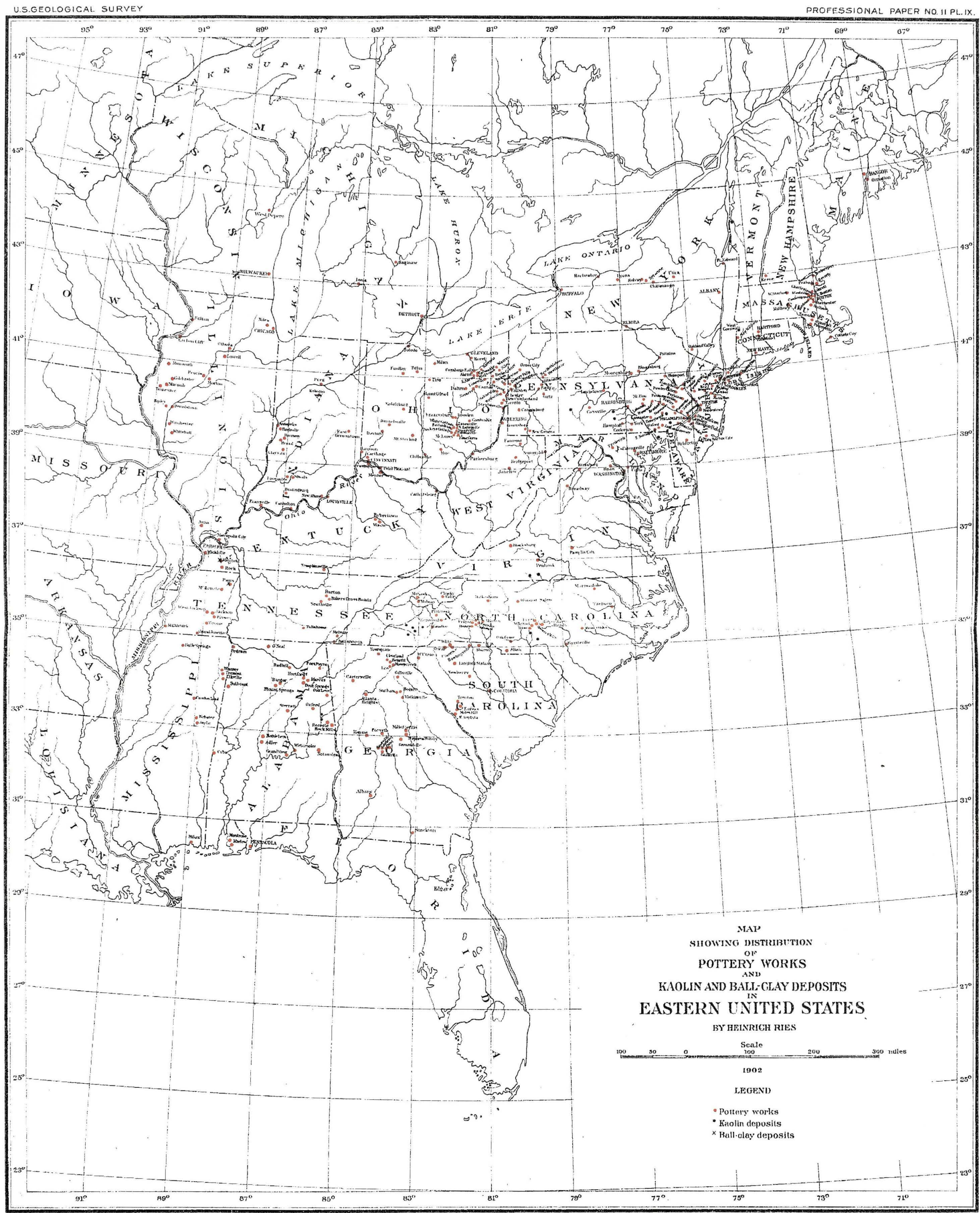


The States ranking first and second in the production of several kinds of ware in 1901 were:

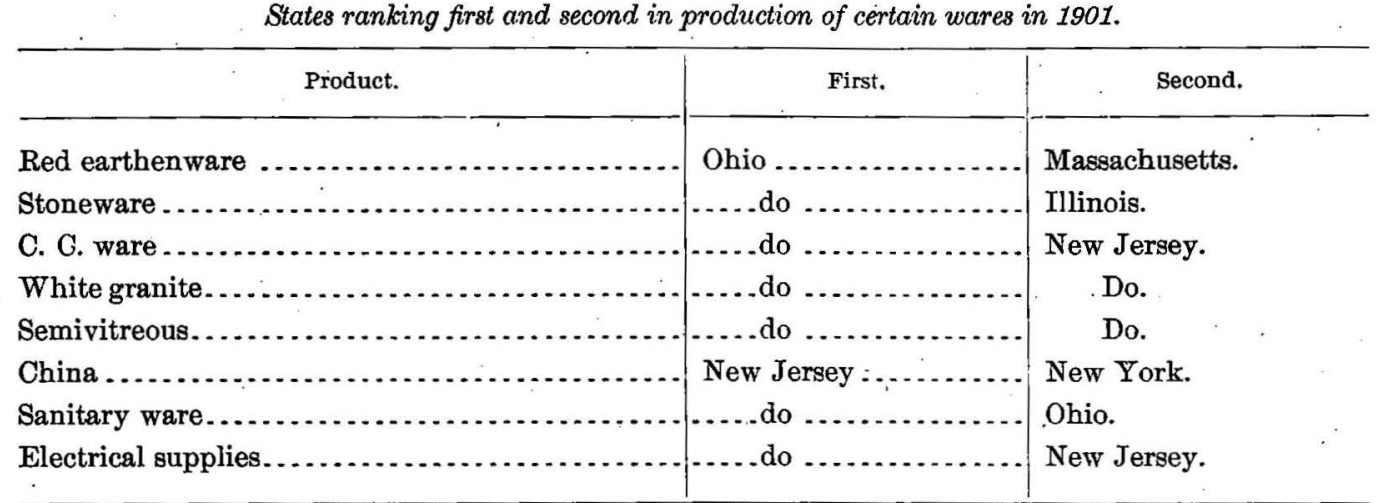

The total value of pottery products produced by the Eastern States in 1900 and 1901 was as follows:

Value of pottery in Eastern States in 1900 and 1901.

\begin{tabular}{|c|c|c|c|c|}
\hline \multirow{2}{*}{ States. } & \multicolumn{2}{|c|}{1900.} & \multicolumn{2}{|c|}{1901.} \\
\hline & Value. & $\begin{array}{l}\text { Per cent of } \\
\text { total United } \\
\text { States } \\
\text { product. }\end{array}$ & Value. & $\begin{array}{l}\text { Per cent of } \\
\text { total United } \\
\text { States } \\
\text { product. }\end{array}$ \\
\hline Ohio ...................... & $\$ 8,573,323$ & 43.30 & $\$ 10,048,561$ & 44.73 \\
\hline New Jersey............. & $5,263,651$ & 26.59 & $5,900,073$ & 26.26 \\
\hline Pennsylvania .............. & $1,390,873$ & 7.03 & $1,665,012$ & 7.41 \\
\hline Illinois $\ldots \ldots \ldots \ldots$ & 776,773 & 3.92 & 682,449 & 3.04 \\
\hline New York.................... & $1,165,325$ & 5.89 & $1,077,360$ & 4.80 \\
\hline West Virginia . . . . . . . . . . & 631,841 & 3.19 & 858,642 & 3.82 \\
\hline Maryland .................... & 436,617 & 2.21 & 333,480 & 1.48 \\
\hline Indiana ................... & 325,900 & 1.65 & 531,371 & 2.37 \\
\hline Massachusetts................ & 238,724 & 1.21 & 281,368 & 1.25 \\
\hline Kentucky ..... & 131,497 & .66 & 139,697 & .62 \\
\hline Connecticut................ & 61,250 & .31 & 91,200 & .41 \\
\hline Tennessee $\ldots . . . . . . . .$. & 49,655 & .25 & 64,093 & .29 \\
\hline Michigan . . . . . . . . . . & 34,317 & .17 & 44,865 & .20 \\
\hline Alabama ............ & 20,296 & $\cdot 10$ & 18,362 & .08 \\
\hline Georgia ................... & 24,383 & .12 & 17,230 & .07 \\
\hline North Carolina............ & 18,863 & .10 & 20,037 & .09 \\
\hline Mississippi ......... & 14,452 & .07 & 4,779 & .02 \\
\hline District of Columbia........ & 10,873 & .06 & 12,879 & .06 \\
\hline South Carolina............ & 17,633 & .09 & 11,872 & .05 \\
\hline Virginia ......... & 13,110 & .02 & 4,047 & .02 \\
\hline Wisconsin ...... & 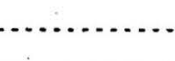 & $\ldots$. & 13,400 & .06 \\
\hline
\end{tabular}

Red earthenware.-Most of the pottery classed under this head represents the lowest form of ware made, such as flower pots. Some decorated earthenware is 
made from common clays, especially in Ohio, the products including jardinières and ornamental objects, often covered with a slip or glaze, and sometimes decorated in relief designs. Red earthenware is manufactured in large quantities in Ohio, Pennsylvania, and Massachusetts, but aside from these the amount produced is usually small and made to supply a local demand.

Stoneware.--In 1900 stoneware was manufactured in most of the States lying east of the Mississippi River, but nearly all of the product was supplied by Ohio, Illinois, and Pennsylvania, for the reason that those States contain materials eminently suited for that class of goods.

The goods made with a stoneware body are intended mostly for domestic use, and consist of crocks, jugs, jars, and various kitchen utensils, which can be placed directly on the stove and used for cooking. Stoneware for chemical purposes forms a special grade of product, since it must resist corrosion by acids and rapid changes of temperature. Several firms have given their attention to the production of this material, which formerly was obtainable only from abroad, and it is now made in Philadelphia, Brooklyn, and to some extent in Ohio; but though the American goods have won a high reputation they do not yet supply the entire demand.

Ornamental goods with stoneware body partake chiefly of the form of jardinières and to some extent vases. They are produced in Ohio. Attempts have been made to introduce the manufacture of Flemish ware, but the industry has not yet gained a strong foothold, and most of the articles of this class are still imported.

White earthernvare and C.C. ware.-These two classes of ware form the greater proportion of pottery goods manufactured in the United States and come into active competition with imported ones, especially with those of English make. Indeed, the industry was probably introduced by English potters.

There is a greater concentration in the case of this branch of the industry than in others, most of the potteries being located at East Liverpool, Ohio, and Trenton, N. J. The importance of these two potting centers was well shown in Mineral Resources for 1900 , where it is pointed out that the value of the product for the two localities in 1900 was as follows:

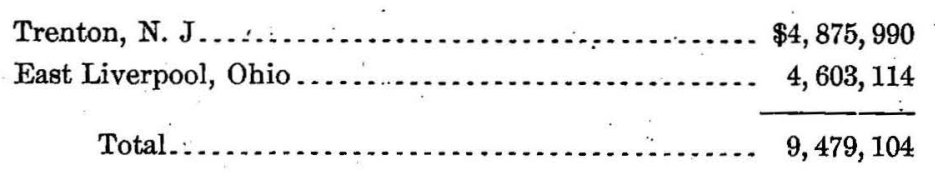

From this it is seen that the output of these two localities above represents 47.88 per cent of the total United States production. Both cities are centrally located, so that the clays, flint, spar, and coal can be easily brought in and the goods shipped over several lines of railroad.

The white ware manufactured is chiefly for table and toilet purposes, and to a smaller extent for ornamental use. The product is chiefly plain white, but some is 
decorated either over or under the glaze by printing. Chromo-lithographic decoration is still but little used in the United States. The wares produced are largely for hotel use, and there is room for improvement in the weight.

Within recent years the manufacture of sanitary ware, begun at Trenton in 1853, has been developed to an extraordinary degree and is fully equal in quality to material formerly much imported.

In addition to the white earthenware centers already mentioned there are a number of other localities whose output is not inconsiderable. These include New York City, N. Y., Baltimore, Md., Wheeling, W. Va., Sebring, Ohio, Kittanning, Pa., and Peoria, Ill.

Semivitreous porcelain.-This includes a grade of white ware which is partially vitrified and manufactured in New York, New Jersey, and Ohio.

China. -The term "china" refers to vitrified white ware, which is manufactured at only a few factories, these being at Syracuse and Greenpoint, N. Y.; Trenton, N. J., and East Liverpool, Ohio. It is translucent and often thinner than white earthenware. Very little hard porcelain is as yet manufactured in the United States, and there is a promising field for development along this line.

Belleek or egg-shell ware is a translucent porcelain with very thin and highly feldspathic body of cream color. The ware is commonly made by "casting" the slip in the molds. The articles made are chiefly of ornamental character, but table articles of smaller sizes are also produced in this manner. Most of the Belleek ware manufactured in the United States comes from Trenton, but smaller quantities are produced in Ohio.

Electrical supplies.-The great development of the electrical industry calls for vast quantities of insulators, and several firms have gone extensively into the manufacture of this class of goods. The conditions of use call for a vitrified body, so that no absorption of moisture can take place. Electrical goods are now made at Trenton, N. J., Syracuse and Victor, N. Y., and East Liverpool, Obio. They include a variety of forms, most of which are made for some special purpose.

Art pottery.-This deserves special mention, because of the uniqueness of the wares produced at several localities. Foremost among the wares of this class stands the Rookwood pottery, manufactured at Cincinnati, Ohio, since 1889. The ware is decorated entirely by hand painting, and shows an intermingling of various rich shades of brown, green, yellow, and other colors. A somewhat similar ware is made in great quantities at Zanesville, Ohio, by the J. B. Owens pottery. The Lonhuda ware, made at Steubenville, Ohio, represents another type.

- The Grueby faience, with its dull enamel surface and greens and yellows, represents still another unique product of the American potters' art. Clock cases are made specially at Baltimore, Md., jardinières at Wheeling, W. Va., and fern dishes and jardinières at Trenton, N. J., and East Livererpool, Ohio. 



\section{N D E X.}

A.

Affelder, W. L., cited on rocks at Pittsburg, P Alabama, brick, vitrifled, in, shales used for

brick works in, location of

clay products of, value of

ys in, characters of, table showing

description of

tensile strength of.

clays, brick, in

clays, Carboniferous, in, anglyses and tests of

clays, Cretaceous, in

analyses and tests of, table showing.

analyses and tests of, table showing $\ldots \ldots \ldots \ldots .74-76$
ays, fire, in.....................................

analyses and tests of

$40,74-76$

geologic horizons of

refractoriness of, table showing ...............

clays, massive, in

clays, mottled, in, analyses and tests of ............ 74-76

clays, paint, in

clays, Pleistocene, in ......................... 76-77

clars, pattery, in, analyses and tests of ...

distribution of $\ldots \ldots \ldots \ldots \ldots \ldots \ldots \ldots \ldots, 68,77-78$

clays, residual, in .............................. 68

analysis of ...

clnys, siliceous, in.

clays, stoneware, in ...

analyses and tests of

physical characters of

clays, terra cotta, in

clays, Tertiary, in .

clays, Tuscaloosa, in

clays, white. in

clay-working industry of

kaolins in, character of

occurrence of ...

limonite beds in

clos-producing States.

rock, Archean and Algonkian, in, clays from...

rocks Cambrian, in, clays from.

rocks, Sllurian, in, clays from

section geologic, near Concord Church

in Elmore County

near Pegram.

Page.
Alabama Geological Survey, analyses and tests by citation from, on Cambrian and Silurian clays.... 68 on Carboniferous clays ................... 69,71 on Cretaceous ciays ................... $71,73,74$

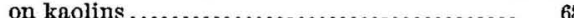

on shales from Coaldale, Ala .................

on Tuscaloosa formation ...................... 72

Alabama Great Southern Railroad, Cretaceous clays along ................................. 72

Algonkian kaolins, clays, paper, from ............. 47 Algonkian rocks, clays from ................. 67-68,134-135 Alkalies, occurrence of, in clays .................... 27-28 Allegany formation, Maryland, clays in ............ 137-138 Alluvial clays, deposits of .................... 104, 205, 246 Alton fire clay, occurrence of ................. 213-214

Amphiboles, hydrous aluminum silicates from ....... 16 Appalachian Mountains, Cambrian and Silurian lime stones along, residual clays from...........

Appalachian region, clays, residual, from, tensile strength of......

Archean rocks in Alabsma, clays from.............. 21

A rundel formation, clays, brick, in.............. 59, 139-141

B.

Ball clays, analyses of, trble showing ............... 39 location of, map showing ....................... $\quad 284$

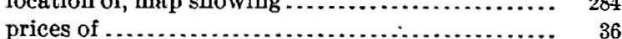

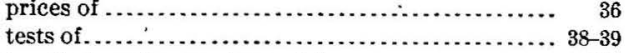
Barber, E. A., reference to work by .................. 284 Barren Measures, character and outcrops of ........ 54,55 clays in ........... 198-199, 200-205, 231-233, 258-259, 260 section of, in Ohio........................... 199 in Pennsylvania ............................. 231 in West Virginin .............................. Barus, Carl, cited on merns of measuring temperature of kiln .................................

Bedford shale, occurrence and character of Belleek ware, manufacture of .................... 287 Blatchley, W. S., cited on clays of Indiana............... 99,110 cited on kaolin outcrops in Indiana............. 107 Bohemia, kaolins from, analyses of ................. 39 Bolivar clay, occurrence of ................. 53,226-230 Booth, J. C., cited on red-clay formation in Delaware. 80 
Brick fire manufacture

ick, paving, clays for, analyses of manufactories of, map showing location of ....... 280 manufacture of, river-terrace deposits used for ... 19 production of..

Brick pressed, elays used for, anolyses of ........ 280 distribution of ..............................62-63 manufacture of, résumé of..................... 275-276 value of product in United States ................ 276 Brick, vitrified, manufacture of, résumé of ......... 279-281 Brick clays, analyses of distribution of $\ldots \ldots \ldots \ldots \ldots \ldots \ldots \ldots \ldots \ldots \ldots \ldots .61-62$ features of

fusibility of.

tensile strength of .

tests of.

th of ................................ 21

Brookville cool, clays fire, under ....... 54,1

Buckley, E. R., cited on clays of Wisconsin........... 262

Burgess, J. T., kaolin-washing plant of, view of ......

Burning, changes during, discussion of

\section{C.}

Calcareous shales, clays, residual, from Calcium carbonate in clays, method of detecting presence of .

Cambrian limestones, clays,

Cambrian rocks, in Alabama, clays from

Cambrian shales, characters of

lime in

occurrence of

Cambro-Silurian rocks, clays in

Campbell, M. R., reference to sections by, in Virginia

Carboniferous rocks, clay-bearing formations in ...... 52-56 clays in ...

$118-124,136-138,192-205,212-235,244,249,252-260$

clays, fire, in, tensile strength of

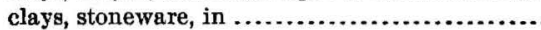

distribution of, in Pennsylvania

in Alabama, clays from .

shales in, carbonate ore in

occurrence of.

tests of

Card, J., analysis of Massachusetts clays by........... 151

Central Railroad of Georgia, clay exposures near line of

Chance, H. M., cited on Pennsylvania shale beds.... 214

Chemical properties of clays, discussion of . ......... 27-30

Chemung formation, shales in .................... 172

Chert, clays, residual, from, analysis of ................ 17-18

Chesapeake formation, clays in ..................... 250

China, manufacture of (......................... 287

China clays, uses of................................ 37-39

Cincinnati shales, use of.......................... 94

Clarion coal, clays, fire, under..................... 54, 222

Clark, W. B., classification of Upper Cretaceous rocks of New Jersey by

Cleansing, methods of ..........................., 32-35

Clinton shale, occurrence and character of......... 51, 171

Coal Measures, clays, fire, in..................... 52, 95

clays, pottery in

clays, stoneware, from

95 98-106, 153-154, 192-205, 233-235, 253-258, 259-260

rocks of, development of ..................... 54-55

section, geologic, of :

Coastal Plain region, clay deposits in, section showing lenticular character of
Coldwater shales, use of $\quad$ Page.

....... 154

Colorado, brick clays from Denver, test of........... 47

Columbia formation, extent and character of ........ 61 clays in ............................ 92-93-143-144, 250

Composition of clay............................... 15

Conemaugh group, character and outcrops of .......... clays in .................................... 138

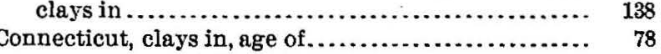

clays in, description of ....................... $78-79$

clay-working industry in ....................... 79

kaolins in, analysis of $\ldots \ldots \ldots \ldots \ldots \ldots \ldots \ldots \ldots . \quad 39$ occurrence of .............................. 48,79

Connecticut and Rhode Island, clay products of, value of

Cook, G. H., cited on plasticity of lean clays...........

Cornwall, England, kgolin from, analysis of ............

Coussac-Bonneval, France, kaolin from, analysis of... 39

Cox, E. T., reference to report on kaolin by.......... 106

Cretaceous rocks, clays in ....................... $71-76,89-92,138-142,159-161,162-166,173-175$

plastic materials in .......................... 56-60 structural characters of ........................... 57-58 Crosby, w. O., cited on kaolin at Blandford, Mass..... 150 $\begin{array}{ll}\text { Crosby, W. O., cited on kaolin at Blandford, Mass...... } & 150 \\ \text { Crossley, }- \text {, analysis by ............................. } & 246\end{array}$ Crystalline rocks, clays derived from.............. 47-50,51 Cuyahoga shale, features of....................... 192

D.

Darton, N. H., cited on brick clay near Washington, D. C...

Definition of clay

Delaware, clay products of, value of

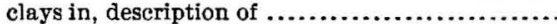

clays, paper, in................................

kaolin in.................................... 48,80

kaolin pit and washing plant at Hockessin, views of ..................

Devonian shale, analysis of.................... 43 occurrence of.............. 20,51-52,117, 136, 191-192, 212 Drift region, clays in, lime in ................... 29 clays in, tensile strength of ........................ 21 Distribution, geologic, of clay ................. 19, 47-61 District of Columbia, clay. products of, value of ....... 81 elays in $\ldots \ldots \ldots \ldots \ldots \ldots \ldots \ldots \ldots \ldots \ldots \ldots, 59,80-81,144$ clays, brick, in ............................... 80-81 Columbia formation in ......................... 61 Drift clays, deposits of....................... 96,110-112 Dunkard group, character of ...

E.

Earthenware, clays used for, requisites of............ $\quad 47$ clays, calcareous, used for...................... 29 red, manufacture of $\ldots \ldots \ldots \ldots \ldots \ldots \ldots \ldots \ldots \ldots . \quad 285$ white, and C. C. ware, manufacture of......... 286-287 Eckel, E. C., cited on Tertiary clays in Tennessee ..... 245 section by, near Grand Junction, Tenn ........... 245 at Holly Springs, Miss .................... 160

Electrical supplies, manufacture of ................. 287

Elk River group, clays in ........................231-233 Engineering and Mining Journal, citation from, on Carboniferous clays and shales in Kentucky.. 118 on Penneylvania clays.

Fngland, boll clay of price of. loolin from; analysis of Poole Poole clay from, analysis of .................... 39 58 Eocene clays in Maryland................... 60,142-143 


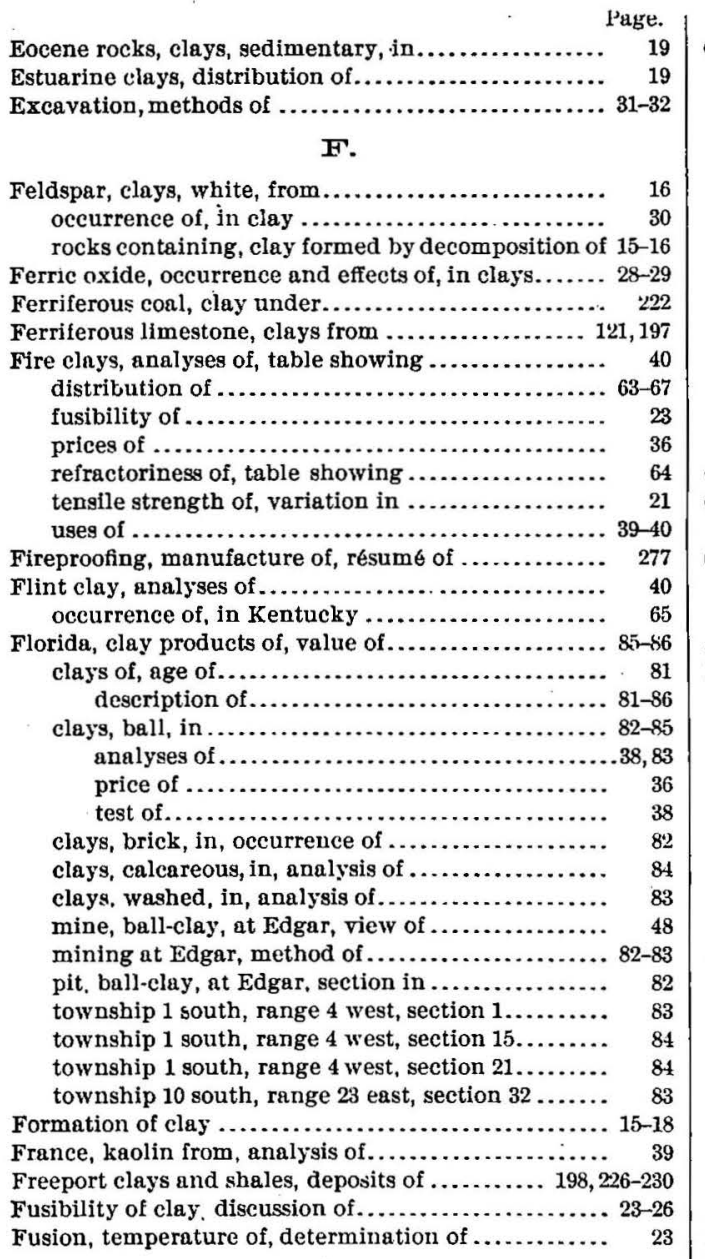

G.

Garnet, occurrence of, in clay.................... 30 Geijesbeek, S., analysis by......................... 246 Geologic distribution of elays ................. 19,47-61 Geologic sections. See under names of States.

Georgin, bauxite beds in, analysis of clay from brick manufoture in, clays used for... clay products of, value of $\ldots \ldots \ldots \ldots \ldots \ldots \ldots \ldots .93-9$. elays of, deseription of.

in Coastal Plain region of, analyses and phys ical characters of table showing........ 90-91 deseription of ......................... $88-98$ clays, alluvial, along Etowah River in, use of..... 92 clays, brick, in, analyses of ..................... clays, Columbia, in Coastal Plain region of, occurrence and characters of.

clays, Cretrceous, in, anglyses of clays, fire, in, distribution of .....................64-65 clays, paper, in

clays, Potomac, in...................... 89, 90,90-91

analyses of

90-91

clays, residual, in, analyses of ................. 17,87

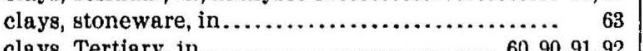

Georgia, clays, Tertiary, analysis of ................ P0, 91 clays, Tertiary, in Coastal Plain region of, outcrops and characters of ... clays, white, in, character of ................... 92

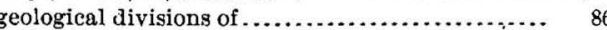
kaolin in, occurrence of ........................... 48 limestone in, residual earth from, composition of. $\quad 87$ rank of, among clay-producing States ............ 93 rocks, Carboniferous, in, section showing ......... 86

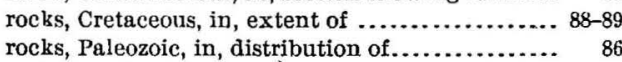
rocks, pre-Cambrian, in, characters of............ 88 rocks, Tertiary, in, distribution of ............... 89 section, geologic, near Climax, in ................ 91 shales, Paleozoic, in, analyses of................. 88 Germany, clays, glass-pot, from ...................... 40 Glass-pot clays, occurrence of........................ 40 requisites of................................ 40 Gumbo clays, strength, tensile, of .................. 21

\section{H.} $\begin{array}{lr}\text { Hall, James, section of Chemung formation by ....... } & 172 \\ \text { Hamilton shale, character and occurrence of ........ } & 51\end{array}$ use of .............................. 155, 171-172, 192 Heyward, B. H., cited on kaolin in Virginia........ 248, 251 on zinc-bearing clay in Virginia Hilgard, Dr., quoted on clays of Tishomingo County, Miss .................................. 159

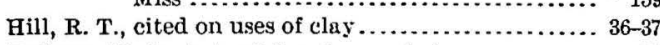
Hofman, H. O., tests of fire clay made by............. 61 Holmes, J. A., cited on sedimentary clays in North Caroling

Hopkins, T. C., cited on Barren Measures in Pennsylvania................................. 232 on Bolivar elay in Pennsylvania.................. 226 on Clarion clay of Pennsylvania ................ 221 on fire clays near Bolivar, $\mathrm{Pa}$................ 229-230 on krolins in Pennsylyanir ...................44, 49, 209 on Kittanning fire clay........................ 222,224 section by, showing Kittanning fire clay in Pennsylvania

Hornblende, occurrence of, in clay .................. 30 Hudson River, Pleistocene clays in valley of, view of. $\quad 176$ Hudson shales, characters of ....................... 50 use of ............................... 163,171, $265-266$

I.

llinois, brick manufacture in .....................

clay materials in, source of.................... 9 clay products of, value of ...................... clays in, deseription of ........................ 94-97 distribution of, map showing ............... 68 clays, brick, in ............................... 62,94 clays, drift, in ............................... 96 clays, fire, in, table showing..................... 95 clays, loess, in .............................. 996 clays, pottery, in .......................... 94, 96 clays, Tertiary, in, occurrence and use of.......... 96 clay-working industry at Chicago .................... Coal Measures in, clays from ..................... 94-95 rank of, as $₫$ clay producer ....................... 96 shale from, test of ........................... 42-43 shale pit near Belleville, view of .................. shales, Carboniferous, in, use of ................. shales, Ordovician, in, use of .................. Ilinois Geological Survey, cited on Cincinnati shales. . 94 


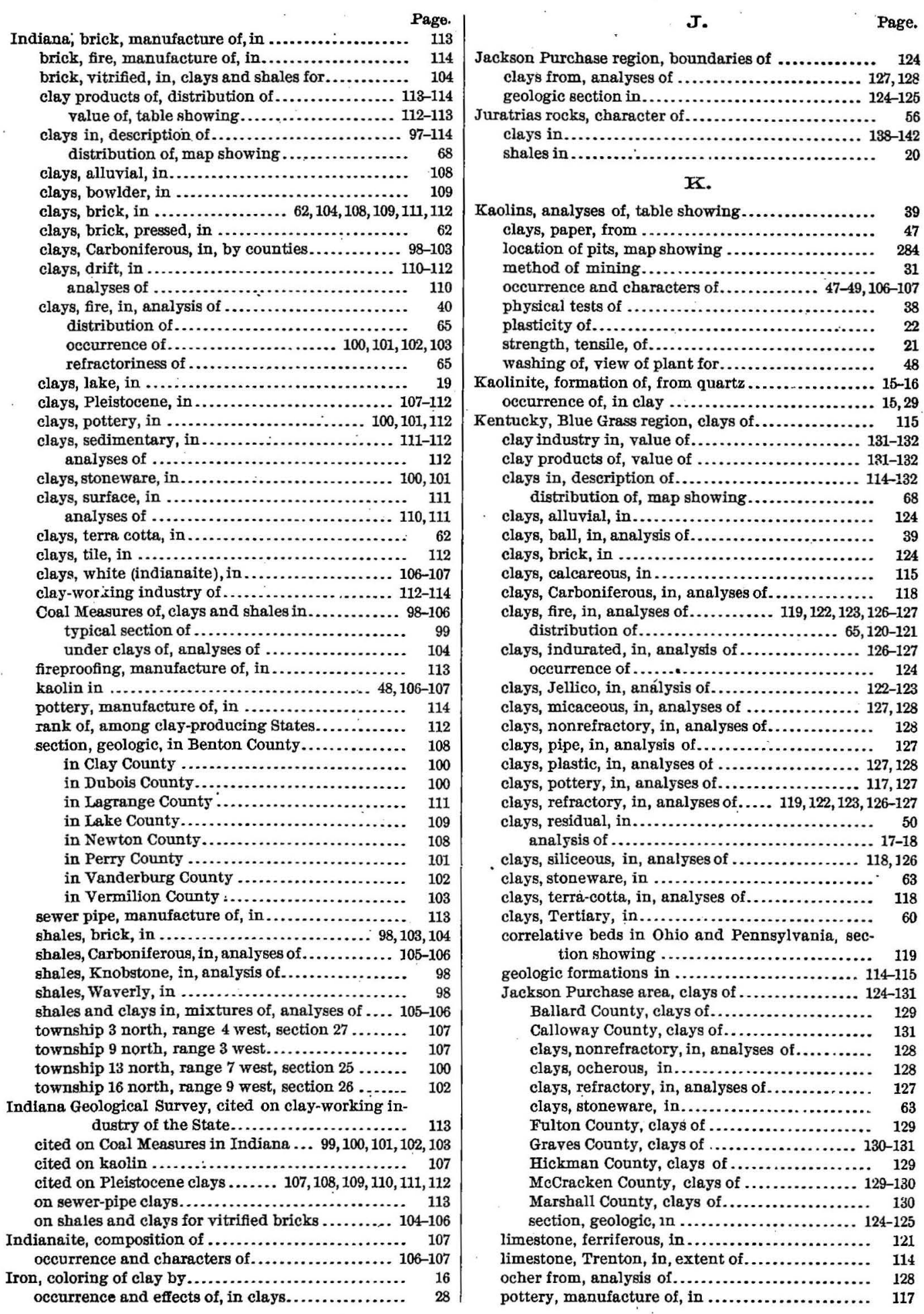


Page.

Kentucy, rocks, Carboniferous, in, clays from... 115,118-124 rocks, Devonian, in, clays from ........ 117 rocks, Ordovician, in, clays and shales from .... 115-116 distribution of............ 11 rocks, Silurian, in, clays and shales from ........ 115-117 rocks, Tertiary, in...

section, geologic, near Amanda

in Ohio County

123 in Rockcastle County....................... 120 shales, Carboniferous, in ........................ 120 analyses of shales, clay, in, analyses of ............. 116, 118, 122-123 shales, Coal Measure, in. shales, Ohio, in, analysis of shales, Ordovician, in shales, Silurian, in, analyses of

Kentucky Geological Survey, analysis by

cited on alluvial clays. cited on Carboniferous clays ........ $65,119,120,121,122$ cited on clays of Jackson Purchase region...........124, $129,130,131$ cited on publications concerning clays and shales 114 cited on Silurian rocks of Kentucky.

Kiln, temperature of, method of measuring. Kittanning beds, clays, stoneware, from ............. 63 Kittanning clays and shales, use of ......... 197-198, 222-226 Kittanning coal, clays, fire, under, occurrence and character of

Knobstone shales in Indiana, clays from

Knox dolomite, kaolins from

Knoxville limestone, clays, residual, from, analysis of 17

\section{L.}

Ladd, G. E., cited on Cretaceous clays of Georgia ..... 89 on Tertiary clays of Georgia. Lafayette formation, clay deposits in ......... $60,143,250$ extent and character of

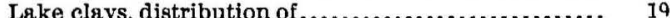
lime in ................................... 29

Langenbeck, Karl, cited on Florida clay ................. 38,83 Leverett, Frank, cited on drift clays of Illinois ....... Lime, occurrence and effects of

\section{IM.}

McCalley, H., cited on Lower Carboniferous clays in

McCreath, A. S., analyses of Pennsylvania fire clay by

MacFarlane, Graham, correlation by

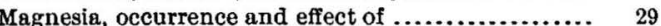
Maine, clay products of, value of.................. 133 Maine, New Hampshire, and Vermont, clays in, description of

Marcellus shales, use of ... Marshall shale, Michigan, plastic clays from..... 52,155 Marshburg upper coal fire clay, deposits of............ 214 Martin, D. S., and Merrill, F. J. H., cited on residual clay in New York.

Maryland, Allegany formation in, shales in ........ 137-138 section of .............................. 137 Arundel formation in, clays in................. 139-141 brick, enameled, made in ..................... 148 brick, fire, made in, analyses of ................ 283 brick, stove, industry in........................ 148 brick, vitrifled, made in clay products of, value of
Maryland, clays in, analyses of, table showing........ Page. clays in, analyses and physical tests of......... 144-147 behavior of, under heat test. 147

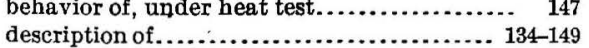

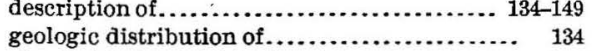
physical tests of, table showing .............. 146 tensile strength of........................ 21, 135 clays, Algonkian, in ....................... 134-135 clays, Cretaceous, in .................... 59,138-142 clays, Eocene, in ........................ 60,142-143 clays, fire, in, distribution of ................. 65, 136-137 clays, Juratrias, in ............................ 138-141 clays, Neocene, in .......................... 143 clays, paper, in .................................. 47 clays, Pleistocene, in ......................... 143-144 clays, pressed-brick, in .......................... 62 clays, residual, in .......................... 134-135 clays, terra-cotta, in ........................... 62 clays, Tertiary, in ............ 142-143 clay-working industry of ..................... 148-149 Conemaugh formation in, shales of .............. 138 Cretaceous beds in ............................. 60 Cretaceous and Juratrias clays in ............. 138-142 kaolin in, occurrence of.................... 48-49, 134 limestones in ............................... 135 Mauch Chunk formation in, clays from ......... 136-137 Patapsco formation in, clays in................ 141 Patuxent formation in, clays in ................ 139 Pottsville formation in, clays from ............. 137 section of ................................ 137 Raritan formation in, clays in.................... 141-142 section, geologic, in Allegany County............. 137, 138 in Anne Arundel Countr.................. 140 in Prince George County.................... 140 of Pottsville formation in............ 137 shales, Carboniferous, in .................... 136-138 shales, Devonian, in........................... 136 shales, Silurian, in ............................... $13 \bar{\jmath}$ Maryland Geological Survey, analyses and physical tests by ............................. 14t-145 cited on Bolivar clay............................. 53 cited on Eocene clays..............................
cited cited on kaolin ............................. 135 cited on shale outcrops....................... 51 reference to map by.......................... 134

Massachusetts, clay products of, value of............. 152-153 clays in, description of.......................... 149-153 clays, Glacial, in, analysis of ..................... 151 clays, Mesozoic, in .............................. 150 clays, Pleistocene, in .......................... 151 clays, pressed-brick, in ........................ 62 clays, red, in, analysis of ......................... 151

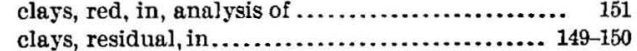
clays, residual, in .......................... 149-150

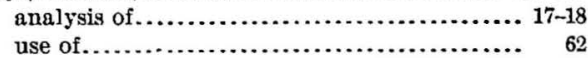

clays, terra-cotta, in

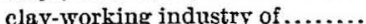
kaolin in, analysis of.......................... 150 occurrence of......................... 49, 149-150 Mauch Chunk formation, Maryland, clays in ....... 136-137 Medina shale, occurrence and character of.......... 51, 171 Mercer clays and shales, occurrence and use of .... 194-195, Merrill, F. J. H., and Martin, D. S., cited on residual clay in New York.....................170-17 Merrill, G. P., cited on hydrous aluminum silicates from amphiboles and pyroxenes .......... 
Mesozoic rocks, clays in

Michigan, clay products of, value of clays in, map showing distribution of . clays, brick, in test of.

clays, lake, in

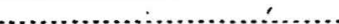
claps, Pleistocene, in ...2. clays, surface, in, analyses and physical tests of... 157 clay-working industry of ....................... 157-158 section from shaft at Saginaw................... 153-15 shales in, physical characters of..

shales, Carboniferous, in test of ....... shales, Coal Measure, in .................. 153-154, 155 shales, Coldwater, in ......................... 154,155 shales, Devonian, in, analyses of ................. shales, Hamilton, in .......................... 52,155 shales, Marshall, in ............................ 155 plastic clays from

52 shales, Michigan, in.......................... 154, 155 shales, Paleozoic, in ......................... 153-156 analyses and physical tests of ............... 155-156

Michigan Geological Survey, cited on clay from Dctroit, Mich.

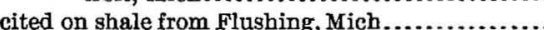

Michigan shales, use of ........................... 154,155

Mining, methods of.

Miocene clays in New Jersey

Mississippi, cloy products of, value of.

lays of description of clays, Cretaceous, in .......................... $72,159-161$ clays, fire, in

clays, pipe, in, analysis of..

in Tishomingo County

clays, pottery, in

section at Holly Springs.

Mississippi River, clays along.

Missouri, clays, ball, used in, test of

clays, brick, from, analyses of.

tests of

clays, glass-pot, from.

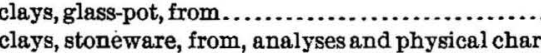
acters of

kaolin used in, physical test of ....................

shales from, analysis of City, Mo

Mohawk River, clays along

of, development of......... 54-55

(233-235

Mount Savage fire clay, Maryland, deposits of ....... 136-137 N.

Neocene rocks, clays, sedimentary, in.... 19,143

Ner Hampshire clay products of, volue of.

New Hampshire, Maine, and Vermont, clays of, de pshire, Maine,

$$
\text { scription of }
$$
Jersey, brick, fire, made in, analyses of....... 169, 28 clay manufactures in........................... 168 clay products of, value of.................... 166-167 lays of description $161-170$ distribution of, map showing. production and value of. tensile strength of .

clays, ball, in, analysis of physical tests of

clays, brick, from, analysis of ..................... clays, brick, pressed, in.........................
. Page.

New Jersey, clays, Cretaceous, in................ 58, 162-166 clays, Cretaceous, in, analysis of.................. 43 at Woodbridge, view of....................... 94 clays, crude, in, price of.......................... clays, fire, in ................................. 66 analyses of ..........................40,164-165 clays, Miocene, in .............................. 60 clays, Pleistocene, in ............................. clays, Pleistocene, in ............................. clays, terra-cotta, in .......................... 62 clays, Tertiary, in............................... 166 clays, washed, in, price of $\ldots \ldots \ldots \ldots \ldots \ldots \ldots \ldots \ldots . \quad 36$ feldspar in, analyses of....................... 165 geologic formations in .......................... 161-162 kaolin of, analyses of........................... 165 Matawan formation in, clays of ............... 165-166 Newark group of ............................ $\quad 162$ rank of, among clay-producing States............: 166 rocks, Cretaceous, in, clays in ................ 162-166 sands, fire, in, analyses of .................... 165 section, geologic, of Lower Cretaceous rocks in.... $\quad 163$ shales, Hudson, in .........................50,162 shales, Marcellus, in ........................... 162

New Jersey Geological Survey, cited on Crosswick clays 166 cited on clays in Matawan formation ............. 166 classification of Upper Cretaceous by ............. 165 reference to report on clays by ............... 162,163

New York, Chemung formation in ................ 172 clay products of, manufacture of.............. 178-179 value of $\ldots \ldots \ldots \ldots \ldots \ldots \ldots \ldots \ldots \ldots \ldots \ldots \ldots \ldots \ldots \ldots$
177, 178 clays of, description of......................... 170-179 distribution of, map showing................ 64 physical tests of ........................ 174-175 clays, brick, in $\ldots \ldots \ldots \ldots \ldots \ldots \ldots .61,62-69$ tests of....................................... 45-46 clays, Cretaceous and Tertiary, in .............. 173-175 analyses of ........................... 174-175 clays, estuarine, in .......................... 176 clays, fire, in ................................. 66

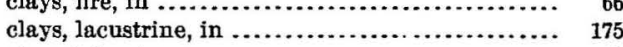

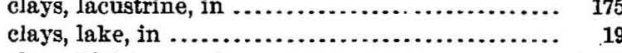
clays, Pleistocene, in ........................ 175-177 analyses of $\ldots \ldots \ldots \ldots \ldots \ldots \ldots \ldots \ldots \ldots \ldots \ldots, 43,177$

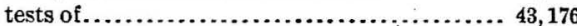

clays, residual, in ............................ 170-171

clays, stoneware, in, analysis and physical characters of ..................................

clays, surface, in, analyses of.................. 177 clays, terra-cotta, in......................... 62-63 clays, Tertiary and Cretaceous, in............. 173-175 analyses of............................. 174-175 geologic distribution of rocks in............... 170 glacial moraine in ............................ 175 krolin deposits in ............................. 170 lake deposits in .............................. 175 I.ong Island, clays on, physical tests of ...... 41, 174-175 clays, fire, on ........................... 66 elays, pressed-brick and terra-cotta, on.......... 62 Portage formation in........................ 172 Salina formation in........................... 171 section, geologic, at Jamestown................ 176 at Rochester................................. 175 shales in, physical tests of ........................ 179 shales, Clinton, in .......................... 171 shales, Devonian, in, analysis of ............... 43 shales, Hamilton, in.......................... 171-172 shales, Hudson, in............................ 171 shales, Medina, in ........................... 171 


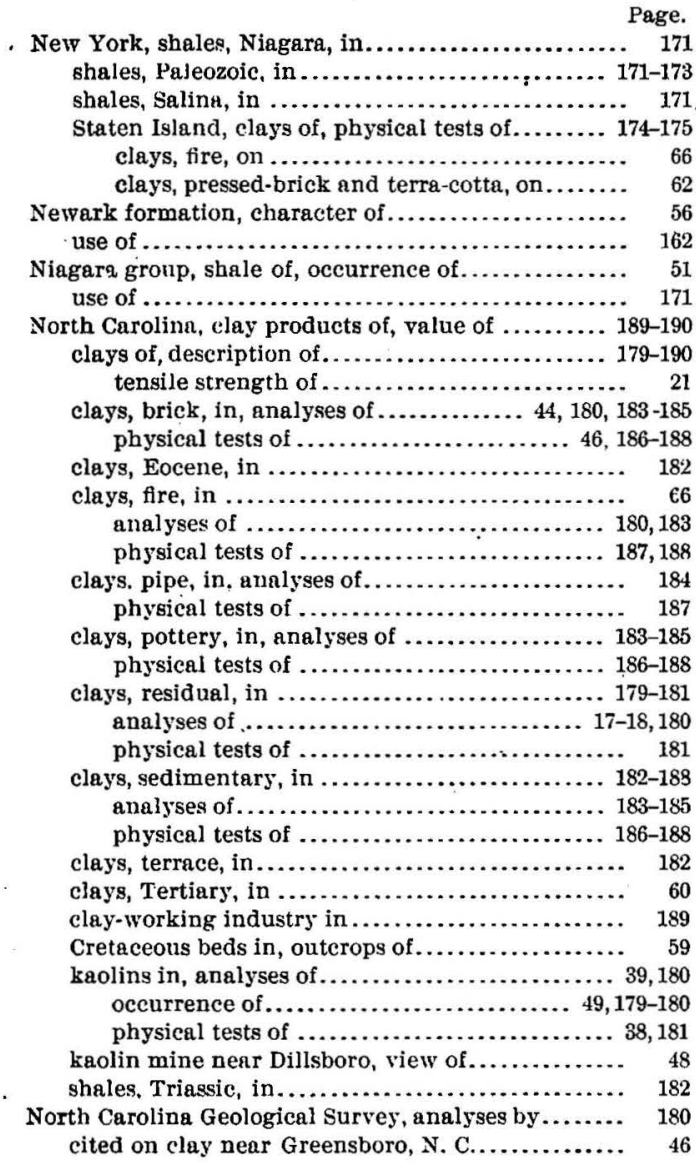

\section{O.}

Ocher, in Kentucky, analysis of.................. 128

Ohio, clay products of, value of ..................... 207 clays in, map showing distribution of. clays, Barren Measures, in ............. 198-199, 200-205 clays, brick, in ............................... 6. clays, brick, paving, annlyses of............ 196, 203-204 clays, Brookville, in......................... 195-196 analyses of .

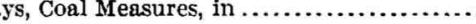

clays, ferriferous, in .......................... 197

clays, fire, in .............................66, 199 analyses of $\ldots \ldots \ldots \ldots \ldots \ldots \ldots \ldots \ldots \ldots \ldots \ldots \ldots \ldots \ldots \ldots, 194,204$ clays, flint, in, analyses of...................... 198, 205 clays, Freeport, in........................... 198 clays, Kittanning, in....................... 197-198 analyses of ............................. 198

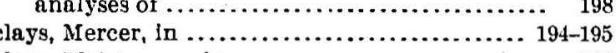
clays, Pleistocene, in .......................... 205 clays, Productive Measures, in .................. 200 clays, Putnam Hill, in........................ 195-196 analyses of.

clays, Quakertown, in......................... 193-19t clays, sewer-pipe, in, analyses of ................ 203-20. clays, shale, in, analyses of .................... 203

clays, stoneware, in analyses of
Ohio, clays, terra cotte in Page.

$\begin{array}{rr}\text { Ohio, clays, terra cotta, in } \ldots \ldots \ldots \ldots \ldots \ldots \ldots \ldots \ldots \ldots \ldots . . & 62 \\ \text { clays, Tionesta, in............................... } & 195\end{array}$

clay-working industry of, discussion of ......... 205-206 correlative beds in Kentucky, Pennsylvania, and, section showing geologic formations of ................... 190-191 limestone, Carboniferous, in, clays from........... limestone, ferriferous, in ....................... 197 rank of, as producer of clay products .......... 205 rocks, Carboniferous, in ...................... 192-205 rocks, Devonian, in ........................... 191-192 rocks, Silurian, in ............................. 19 section, geologic, in, of conglomerate group of Carboniferous .......................... 193 near Bellaire ...........................

in Belmont County ........................... 200 in Monroe County ........................... 201-202

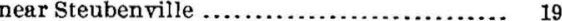

near Zanesville ............................ 196

shales, Bedford, in, use of ...................... 192

shales, Bedford, in, use of $\ldots \ldots \ldots \ldots \ldots \ldots \ldots \ldots \ldots$
shales, brick, paving, in .......................... analysis of ................................... 196 shales, Cuyahoga, in ......................... 192 shales, Hamilton, in, use of .................. 192 shales, Kittanning, in ......................... 197-198 shales, Kittanning, in .......................... 197-198
shales, Mercer, in ......................... 194-195

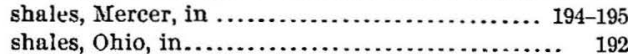

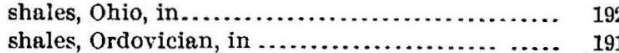
shales, Quakertown, in...................... 193-194 shales, Sharon, in, characters and use of ........... 193 shales, Sharon, in, characters and use of.......... shales, Silurian, in ........................... 191
shales in Lower Barren Measures of............ 198-199 shales in Lower Barren Measures of.............. 198-199
shales in Upper Barren Measures of........... 200-202 shales in Upper Productive Neasures of ....... 200 shales and fire clays in, mixture of, analysis of.... 198 Ohio Geological Survey, analyses of stoneware clays

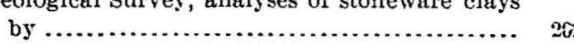
cited on geologic scale of Ohio.................... 190 cited on Niagara shale in Ohio .................. 191 Ohio River, clays along ........................ 19-124 Ohio shale, use of............................. 192 Ordovician formations, clays and shalesin. $50,94,115-116,191$ Organic matter, occurrence and effects of............. 30 Origin of clay.................................... 15-18

Orton, E., jt., cited on clays of Ohio............... 197-199 cited on Cuyahogr shales in Ohio ............... 192 cited on manufacture of glass pots................. 40 cited on occurrence of flint clay................... 54

$$
\text { P. }
$$

Paleozoic rocks, clays and shales from ............ 86-88, 153-156, 171-173, 243-24 aleozoic shales, lime in ......................... 29 occurrence of ................................ 20 Paper clays, prices of ............................ 36 requisites of ............................... 47 Patapsco formation, Maryland, clays from ........ 59,141 Patuxent formation, Maryland, clays in ........... 139 Permo-Carboniferous group, character of ............ Pennsylvania, brick, common, in, manufacture of ... 238-239 brick, fire, made in; unalyses of ................ 283 manufacture of ........................... 239 brick, paving, in, manufacture of ............... 239 brick, pressed, in, manufacture of.............. 239 cla $y$ products of, value of .................... 240-241 clays of, analyses, miscellaneous, of.............. 238 


\begin{tabular}{|c|c|}
\hline & \\
\hline \multirow{5}{*}{ 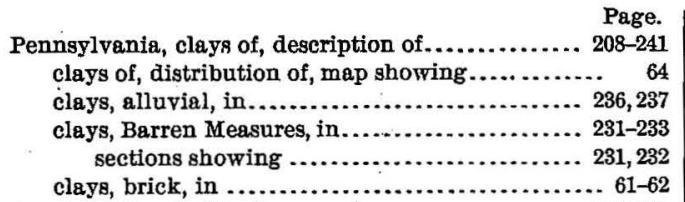 } & \\
\hline & \\
\hline & a Counts \\
\hline & \\
\hline & shales \\
\hline . & $168-169$ \\
\hline $220-221$ & \\
\hline 35 & \\
\hline \multirow{6}{*}{ 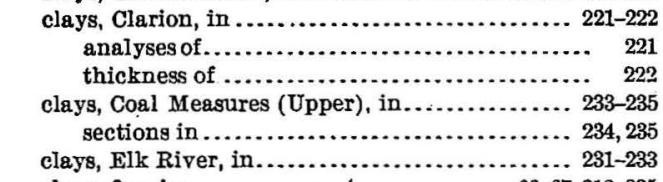 } & 212 \\
\hline & easures \\
\hline & 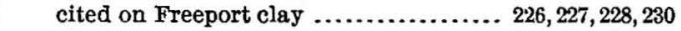 \\
\hline & \\
\hline & \\
\hline & , 237; 238 \\
\hline \multirow{7}{*}{ 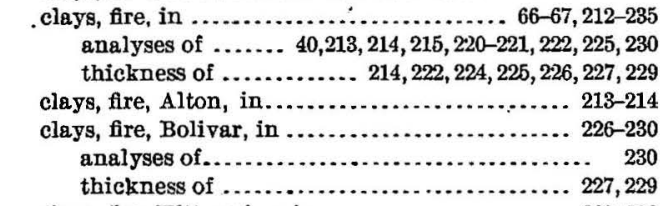 } & $8,210,211$ \\
\hline & 215 \\
\hline & \\
\hline & \\
\hline & \\
\hline & \\
\hline & \\
\hline \multirow{4}{*}{ 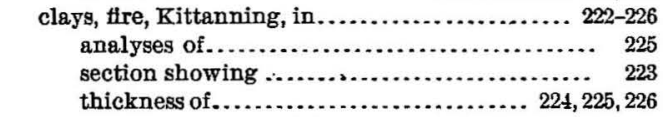 } & .. 226,229 \\
\hline & \\
\hline & \\
\hline & \\
\hline \multirow{4}{*}{ 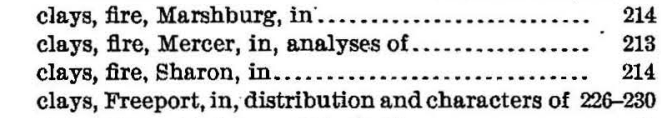 } & \\
\hline & \\
\hline & $0-27$ \\
\hline & ... \\
\hline \multirow{8}{*}{ 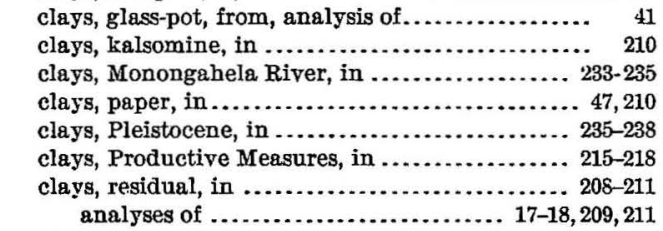 } & -282 \\
\hline & ... \\
\hline & \\
\hline & \\
\hline & \\
\hline & \\
\hline & $\cdots$ \\
\hline & \\
\hline & \\
\hline \multirow{3}{*}{$\begin{array}{r}\text { clays, surface, in } \\
\text { analyses of } \ldots \ldots \ldots \ldots \ldots \ldots \ldots \ldots \ldots \ldots \ldots \ldots \ldots \ldots \\
\text { sections, geologic, in } \ldots \ldots \ldots \ldots \ldots \ldots \ldots \ldots \ldots \ldots \\
236,237\end{array}$} & \\
\hline & \\
\hline & \\
\hline clays, terra-cotta, in ............................... 62 & ........ \\
\hline \multirow{6}{*}{ 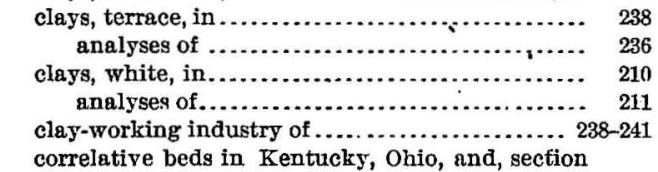 } & $\cdots \cdots \cdot$ \\
\hline & \\
\hline & 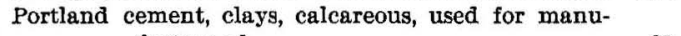 \\
\hline & \\
\hline & \\
\hline & .... 47,250 \\
\hline & 19 \\
\hline $\mathrm{g}$ & \\
\hline $\mathbf{k}$ & \\
\hline & \\
\hline & \\
\hline & \\
\hline $66-67,212-235$ & \\
\hline ...... & of $\ldots \ldots \ldots \ldots$ \\
\hline & \\
\hline & \\
\hline & \\
\hline & \\
\hline & \\
\hline $\begin{array}{ll}\ldots \ldots \ldots & 236\end{array}$ & \\
\hline . $216-218,21$ & \\
\hline & \\
\hline & \\
\hline & \\
\hline & \\
\hline
\end{tabular}


Pyrometer, thermoelectric, use of .

Pyroxenes, hydrous oluminum silicates from .......

Q.

Quakertown clays and shales, use of

Quartz, kaolinite formed from

occurrence and effects of

\section{R.}

Raritan formation, Maryland, clays in .

Raymond pulverizer and separator, action of

Reed, E. M., analysis by .

Residual clays, analyses of

characters and use of

coloring of, by iron.

.... $68,134-135$ $149-150,170-171,179-181,208-211,241,243-244,262$

formation of, section illustrating

lime in

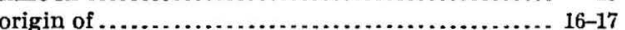

tensile strength of

thickness of

value of..

Résumé of the clay-working industry

Rhode Island, clays, glacial, of

Rhode Island and Connt value of

Ries, H., analyses and tests by, reference to

cited on bricks, paving

cited on clays, brick.

cited on iron in clays, occurrence of ................ 28

cited on Maryland clays....................... 134

cited on Michigan clays.

52,153

eited on New York clays ............. 43,51,171, 173,174

cited on terra cotta, manufacture of

works by, on glass pots, reference to

on pottery, reference to

Rogers, W. B., cited on Virginia clays and shales ....

Russell, I. C., reference to work by

\section{s.}

Safford, J. M., cited on clay in the Carboniferous, in Tennessee ...

Salina group, shale of, occurrence and character of... 51, 171 Savage Mountain fire clay, Pennsylvania, deposits of 215 Sections, geologic. See under names of States.

Sedimentary clays, analysis of

geologic distribution of.

occurrence of, section illustrating.

in North Carolinn

origin of .

plasticity of...

tensile strength of

182-18

A clated on action of quartz in clays

compition and fuing points of table showing $24-20$

use of

hales, geologic distribution of ......................

metamorphism of

mining of .

plasticity 1

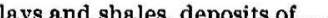

Sheafer, A.W., cited on Pennsylvania shales .......... 2193,214
Silurian rocks, clays from ........... 50,68,115-117, 212 clays, residual, from ............................. 17 shales from .......................... 20,50-51, 135, 191 lime in ................................... 29

Slaking of clay, discussion of.................... 27

Slate, clays, residual, from, analysis of ................. 17-18 geologic distribution of ........................... 20

slocum, J. W., analysis by ............................... 246

Smock, J. C., cited on refractoriness of New Jersey cricks.

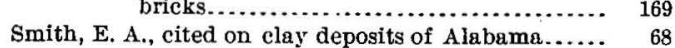

South Carolina, clay products of, value of........... 242-243 clays of, deseription of...................... 241-243 clays, Coastal Plain, in .......................... 242 clays, Cretaceous, in........................... 59 clays, paper, in ............................ 47 clays, residual, in ...............................

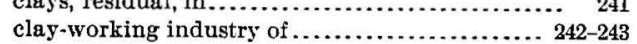
Columbia loams in :............................ 242 rank of, among clay-producing States.......... 242

Spencer, J. W., cited on brick manufacture in northwestern Georgia ......................... cited on earths, residual, in Georgia............... cited on rocks, Paleozoic, of Georgia.............. $86,87,88$ Steam shovel, use of, in mining ................... 31

Stevenson, J. J., section at Bolivar, Pa., by ........ 222-229 Stinson, J. M., analssis of Pennsylvania fire clay by ... 213 Stoneware, manufacture of, résumé of .............. 286 Stoneware clays, distribution of ..................... 63 fusibility of...

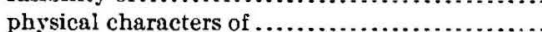

Summers, G. W , gnalyses of West Vinginis clays by .

\section{T.}

Tennessee, clay products of, value of .............. 247 clays of, analyses of ........................... 246 description of ............................... 243-247 clays, alluvial, in........................... 246 clays, Carboniferous, in ........................ .241 clays, fire, in .................................. 67 clays, Paleozoic, in ......................... 243-24t class, residual, in .......................... 243-244 clays, stoneware, in ......................... 63 clays, Tertiary, in ......................60, 244-246 clays, washed, in, price of ...................... 36 geologic formations in....................... 243 rank of, among clay-produciug States.............. 247 $\begin{array}{ll}\text { rank of, among clay-produciug States............ } & 247 \\ \text { section, geologic, near Currier .................... } & 245\end{array}$ section, geologic, near Currier .................... $\quad 245$ near Grand Junction .......... 245

Tennessee River, clays along.

Tensile strength of clays, discussion of .............. 21-22 method of testing .......................... 22

Terra-cotta, manufacture of, calcareousclays used for.. $\quad 29$ manufacture of, discussion of .................. 43-44 résumé of ............................... 278 river-terrace deposits used for ............... $\quad 19$

Terra-cotta clays, analyses of ...................... 43 distribution of................................. $62-63$ Tertiary formations, clays in...................... 60 , $76,92,166,173-175,195,244-246$ clays, pressed brick and terra cotta, in ............ 62 Thermopile, description of ...................... 26 Tile, manufacture of, river-terrace deposits used for.. 15 Tile, drain, manufacture of, calcaręous clays used for. 29 manufacture of, résumé of ..................... 281 


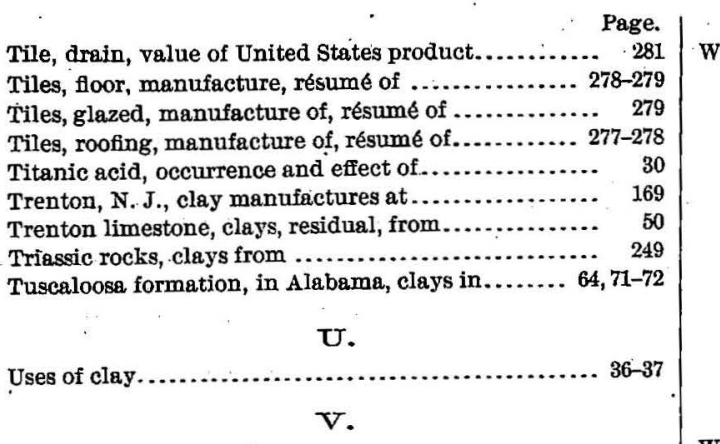

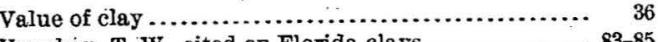

Vaughan, T. W., cited on Florida clays............... 83-85 cited on Georgia clays......................... 91-92

Vermont, clay products of, value of................ 133 clays of, analysis of.............................. 133 clays, residual, in ........................... 133 Vermont Geological Survey, cited on residual clays .. 133 Vermont, Maine, and New Hampshire, clays of, description of

Virginia, clay products of, value of ................ 251 clay workings near Alexandria ................. 247-252

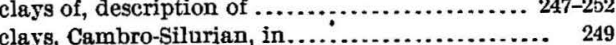
$\begin{array}{ll}\text { clays, Cambro-Silurian, in ...................... } & 249 \\ \text { clays, Carboniferous, in ......................... } & 249\end{array}$ clays, fire, in, occurrence of .................. 67-249

clays, Potomac, in ........................... 250

clays, residual, in ........................... 248,249 $\begin{array}{cc}\text { analysis of ................................. } & 249 \\ \text { Coastal Plain formations of, clays in ............ } & 250\end{array}$ table showing ............................... 248 kaolin in, occurrence of .................. 49, 67, 248, 251

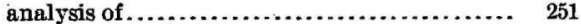
rocks of.................................. 247-248 rocks, crystalline, in ......................... 248 section, geologic, near Sherando............... 250 shales, Triassic, in ............................. 249

Vitrified wares, low grade, clays for ............... $42-43$ W.

Wailes, B. L. C., cited on pottery clay in Mississippi .. 161 Wareham, England, clay from, analyses of........... 39 Washing, methods of, discussion of ............... 33-30 Washington, D. C., terra cotta made near........... 148

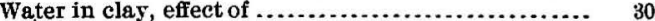
Waverly shales, use of .............................. West Virginia, elay products of, value of ................ $\quad 98$ West Virginia, elay products of, value of .............. 261
clays of description of ........................ $252-261$ clays of, description of ....................... 252-261 distribution of, map showing ................. 64

clays, Barren Measures, in .................. 258-259 clays, Carboniferous, in ..................... 252-260 clays, Coal Measures (Lower), in............... 253-258 clays, Coal Measures (Upper), in .............. $2599-260$ clays, fire, in .............. 67, 252, 253, 255, 258, 259-260 enalyses of .................................... 257 lays, fire, Bolivar, in ........................ 257 clays, flint, in, analyses of..................... 256,257 clays, flint, in, analyses of..................... 256,257
clays, Kittanning, in, analyses of ............. 257 use of.
Page.

est Virginia, clays, plastic, in, analysis of......... 257 clays, Pleistocene, in ........................ 260-261 clays, surface, in ............................. 260-261 Pottsville conglomerate of, clays in ............. 252-25s shales, Barren Measures (Upper), in .............. 260 shales, red, in .................................. 260 section, geologic, of Barren Measures in........... 258

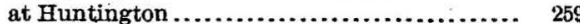
in Marion County ............................ $255-256$ in Mineral County ........................... in Monongalia County ........................ 260 in Preston County ......................... 253

in Tucker County ....................... 254-255 in Upper Productive Measures of .............. 260 Wheeler, H. A., reference to work by ................ 281 White, I. C., analyses by, of West Virginia clay..... 256-257 cited on Barren Measures ..................... 55, 260 eited on estuarine clays ........................ 268 cited on fire clays ............................. 53-54 cited on Corl Measures ............................ 53 cited on Monongahela group................... 54 cited on section in West Virginia ............... 256 section by, at Barnesville, Ohio............... 201-222 section by, of Barren Measures in Pennsylvania .. 231 section by, near Bellaire, Ohio.................. 200

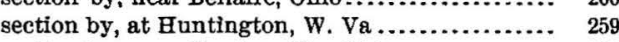
section by, near Steubenville, Ohio................ 199 Whittle, C. L., cited on Massachusetts clays............ 151 Wisconsin, clay products of ................... 271-272 clay products of, value of $\ldots \ldots \ldots \ldots \ldots \ldots \ldots \ldots \ldots .272$ clays of, description of ............................. $262-272$ distribution of, map showing ................. 68 clays, brick, in :................................. 62 clays, estuarine, in ......................... 268-270 analyses of.............................. 269-270 clays, fire, in ................................. 67 clays, Glacial, in ............................. 270-271

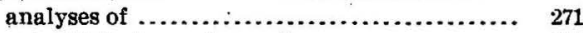

clays, kaolinic, in, analyses of .................. 263

clays, lake, in ............................ 19, 266-268

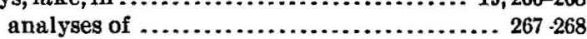
clays, Pleistocene, in ............................ 266-271 clays, residual, in ............................ 262 analysis of $\ldots \ldots \ldots \ldots \ldots \ldots \ldots \ldots \ldots \ldots \ldots \ldots \ldots \ldots \ldots \ldots, 17-18$ driftless area of, clays in ....................... 264 kaolin in ...................................... analyses of ................................. 264 aolins, plastic, in ............................ 262-264 lacustrine deposits of .......................... 266-268 Potsdam formation, shales in ................. 264-265 shales, Hudson, in, analyses of .................. 266 clays in ............................... 265-266 shales, kaolinic, in, analyses of ................ 263 shales, Potsdam, of, clays in ................. 264-265 analyses of

Wisconsin Geological Survey, cited on clay deposits in Wisconsin ........................ 262 Woodworth, J. B., cited on formation of residual clay in Virginia.

Worthen, A. H., cited on Illinois clays............ 94, 95, 96

z.

Zettlitz, Bohemia, kaolin from, analysis of. 


\section{PUBLICATIONS OF UNITED STATES GEOLOGICAL SURVEY. \\ [Professional Paper No. 11.]}

The serial publications of the United States Geological Survey consist of (1) Annual Reports, (2) Monographs, (3) Professional Papers, (4) Bulletins, (5) Mineral Resources, (6) Water-Supply and Irrigation Papers, (7) Topographic Atlas of the United States-folios and separate sheets thereof, (8) Geologic Atlas of the United States-folios thereof. The classes numbered 2, 7, and 8 are sold at cost of publication; the others are distributed free. A circular giving complete lists may be had on application.

The Bulletins, Professional Papers, and Water-Supply Papers treat of a variety of subjects, and the total number issued is large. They have therefore been classified into the following series: A, Economic geology; B, Descriptive geology; C, Systematic geology and paleontology; D, Petrography and mineralogy; E, Chemistry and physics; F, Geography; G, Miscellaneous; H, Forestry; I, Irriga'tion; J, Water storage; K, Pumping water; L, Quality of water; M, General hydrographic investigations; N, Water power; O, Underground waters; $\mathrm{P}$, Hydrographic progress reports. This bulletin is the twenty-first in Series A and the twenty-fourth in Series B, the complete lists of which follow. ( $\mathrm{B}=$ Bulletin, $\mathrm{PP}=$ Professional Paper, WS $=$ Water-Supply Paper. $)$

SERIES A, ECONOMIC GEOLOGY.

B 21. Lignites of Great Sioux Reservation: Report on region between Grand and Moreau rivers, Dakota, by Bailey Willis 1885. $16 \mathrm{pp} ., 5 \mathrm{pls}$.

B 46. Nature and origin of deposits of phosphate of lime, by R. A. F. Penrose, jr., with introduction by N. S. Shaler. 1888. $143 \mathrm{pp}$.

B 65. Stratigraphy of the bituminous coal field of Pennsylvania, Ohio, and West Virginia, by Israel C. White. 1891.212 pp., 11 pls. (Exhausted.)

B 111. Geology of Big Stone Gap coal field of Virginia and Kentucky, by Marius R. Campbell. 1893.106 pp., 6 pls.

B 132. The disseminated lead ores of southeastern Missouri, by Arthur Winslow. 1896. $31 \mathrm{pp}$.

B 138. Artesian-well prospects in Atlantic Coastal Plain region, by N. H. Darton. 1896.228 pp., 19 pls.

B 139. Geology of Castle Mountain mining district, Montana, by W. H. Weed and L. V. Pirsson. $1896.164 \mathrm{pp} ., 17 \mathrm{pls.}$

B 143. Bibliography of clays and the ceramic arts, by John C. Branner. $1896.114 \mathrm{pp}$.

B 164. Reconnaissance on the Rio Grande coal fields of Texas, by Thomas Viayland Vaughan, including a report on igneous rocks from the San Carlos coal field, by E. C. E. Lord. 1900.100 pp., 11 pls. and maps.

B 178. El Paso tin deposits, by Walter Harvey Weed. 1901. $15 \mathrm{pp} ., 1 \mathrm{pl}$.

B 180. Occurrence and distribution of corundum in United States, by J. H. Pratt. $1901.98 \mathrm{pp.}, 14 \mathrm{pls.}$

B 182. A report on the economic geology of the Silverton quadrangle, Colorado, by F. L. Ransome. $1901.266 \mathrm{pp}$., $16 \mathrm{pls}$

$B$ 184. Oil and gas fields of the western Interior and northern Texas Coal Mensures and of the Upper Cretaceous and Tertiary of the western Gulf coast, by George I. Adams. $1901.64 \mathrm{pp} ., 10 \mathrm{pls}$.

B 193. The geological relations and distribution of platinum and associated metals, by J. F. Kemp. $1902.95 \mathrm{pp} ., 6 \mathrm{pls}$ B 198. The Berea grit oil sand in the Cadiz quadrangle, Ohio, by W. T. Griswold. $1902.43 \mathrm{pp} ., 1 \mathrm{pl}$.

PP 1. Preliminary report on the Ketchikan mining district, Alaska, with an introductory sketch of the geology of southeastern Alaska, by Alfred Hulse Brooks. 1902.120 pp., 2 pls.

B 200. Reconnaissance of the borax deposits of Death Valley and Mohave Desert, by M. R. Campbell. $1902.23 \mathrm{pp} ., 1 \mathrm{pl}$.

B 202. Tests for gold and silver in shales from western Kansas, by Waldemar Lindgren. $1902.21 \mathrm{pp}$.

PP 2. Reconnaissance of the northwestern portion of Seward Peninsula, Alaska, by A. J. Collier. 1902.70 pp., 11 pls.

PP 10. Reconnaissance from Fort Hamlin to Kotzebue Sound, Alaska, by way of Dall, Kanuti, Allen, and Kowak rivers, by W. C. Mendenhall. 1902, $68 \mathrm{pp} ., 10 \mathrm{pls}$.

PP 11. Clays of the United states east of the Mississippi River, by Heinrich Ries. 1903. 298 pp., 9 pls. 
SERIES B, DESCRIPTIVE GEOLOGY.

B 23. Observations on the junction between the Eastern sandstone and the Keweenaw series on Keweenaw Point, Lake Superior, by R. D. Irving and T. C. Chamberlin. 1885 . 124 pp., 17 pls.

B 33. Notes on geology of northern California, by J. S. Diller. $1886.23 \mathrm{pp}$.

B 39. The upper beaches and deltas of Glacial Lake Agassiz, by Warren Upham. $1887.84 \mathrm{pp} ., 1 \mathrm{pl}$. $^{\circ}$

B 40. Changes in river courses in Washington Territory due to glaciation, by Bailey Willis. $1887.10 \mathrm{pp} ., 4 \mathrm{pls}$.

B 45. The present condition of knowledge of the geology of Texas, by Robert T. Hill. $1887.94 \mathrm{pp.}$

B 53. The geology of Nantucket, by Nathaniel Southgate Shaler. $1889.55 \mathrm{pp} ., 10 \mathrm{pls.}$

B 57. A geological reconnaissance in southwestern Kansas, by Robert Hay. 1890. 49 pp., 2 pls.

B 58. The glacial boundary in western Pennsylvania, Ohio, Kentucky, Indiana, and Illinois, by George Frederick Wright with introduction by Thomas Chrowder Chamberlin. $1890.112 \mathrm{pp} ., 8 \mathrm{pls}$.

B 67. The relations of the traps of the Newark system in the New Jersey region, by Nelson Horatio Darton. 1890.82 pp.

B 104. Glaciation of the Yellowstone Valley north of the Park, by Walter Harvey Weed. 1893.41 pp., 4 pls.

B 108. A geological reconnaissance in central Washington, by Israel Cook Russell. 1893.108 pp., 12 pls.

B 119. A geological reconnaissance in northwest Wyoming, by George Homans Eldridge. $1894.72 \mathrm{pp} ., 4 \mathrm{pls}$

B 137. The geology of the Fort Riley Military Reservation and vicinity, Kansas, by Robert Hay. 1896.35 pp., 8 pls.

B 144. The moraines of the Missouri Coteau and their attendant deposits, by James Edward Todd. $1896.71 \mathrm{pp} ., 21 \mathrm{pls}$

B 158. The moraines of southeastern South Dakota and their attendant deposits, by J. E. Todd. $1899.171 \mathrm{pp} ., 27 \mathrm{pls}$.

B 159. The geology of eastern Berkshíre County, Massachusetts, by B. K. Emerson. 1899.139 pp., 9 pls.

B 165. Contributions to the geology of Maine, by Henry S. Williams and Herbert E. Gregory. 1900. 212 pp., 14 Fls.

WS 70. Geology and water resources of the Patrick and Goshen Hole quadrangles in eastern. Wyoming and western Nebraska, by George I. Adams.' 1902.50 pp., 11 pls.

B 19y. Geology and water resources of the Snake River Plains of Idaho, by Israel C. Russell. 1902.192 pp., 25 pls.

PP 1. Preliminary report on the Ketchikan mining district, Alaska, with an introductory sketch of the geology of southeastern Alaska, by Alfred Hulse Brooks. 1902.120 pp., 2 pls.

PP 2. Reconnaissance of the northwestern portion of Seward Peninsula, Alaska, by A. J. Collier. 1902.70 pp., 11 pls.

PP 3. Geology and petrography of Crater Lake National Park, by J. S. Diller and H. B. Patton. 1902.167 pp., 19 pls.

PP 10. Reconnaissance from Fort Hamlin to Kotzebue Sound, Alaska, by way of Dall, Kanuti, Allen, and Kowak rivers, by W. C. Mendenhall. 1902.68 pp., 10 pls.

PP 11. Clays of the United States east of the Mississippi River, by Heinrich Ries. 1903. 298 pp., 9 Fls.

Correspondence should be addressed to

The Director,

United States Geological Survey,

APRIL, 1903.

Washington, D. C. 


\section{LIBRARY CATALOGUE SLIPS.}

[Mount each slip upon a separate card, placing the subject at the top of the second slip. The name of the series should not be repeated on the series card, but add the additional numbers, as received, to the first entry.]

\section{Ries, Heinrich.}

... The clays of the United States east of the Mississippi River; by Heinrich Ries. Washington, Gov't print. off., I903.

298, III p. 9 pl. 11 fig. $29 \frac{1}{2} \times 23^{\mathrm{cm}}$. (U. S. Geological survey. Professional paper no. 11.)

Subject series $\left\{\begin{array}{l}\text { A, Economic geology, } 21 . \\ \text { B, Descriptive geology, } 24 .\end{array}\right.$

\section{Ries, Heinrich.}

... The clays of the United States east of the Mississippi River; by Heinrich Ries. Washington, Gov't print. off., I903.

298, III p. 9 pl. 11 fig. $29 \frac{1}{2} \times 23^{\mathrm{cm}}$. (U. S. Geological survey. Professional paper no. 11.)

Subject series $\left\{\begin{array}{l}\text { A, Economic geology, } 21 . \\ \text { B, Descriptive geology, } 24 .\end{array}\right.$

\section{U. S. Geological survey.}

Professional papers.

no. II. Ries, Heinrich. The clays of the United States east of the Mississippi River. I903.

\section{U. S. Dept. of the Interior.}

递 see also

U. S. Geological survey. 






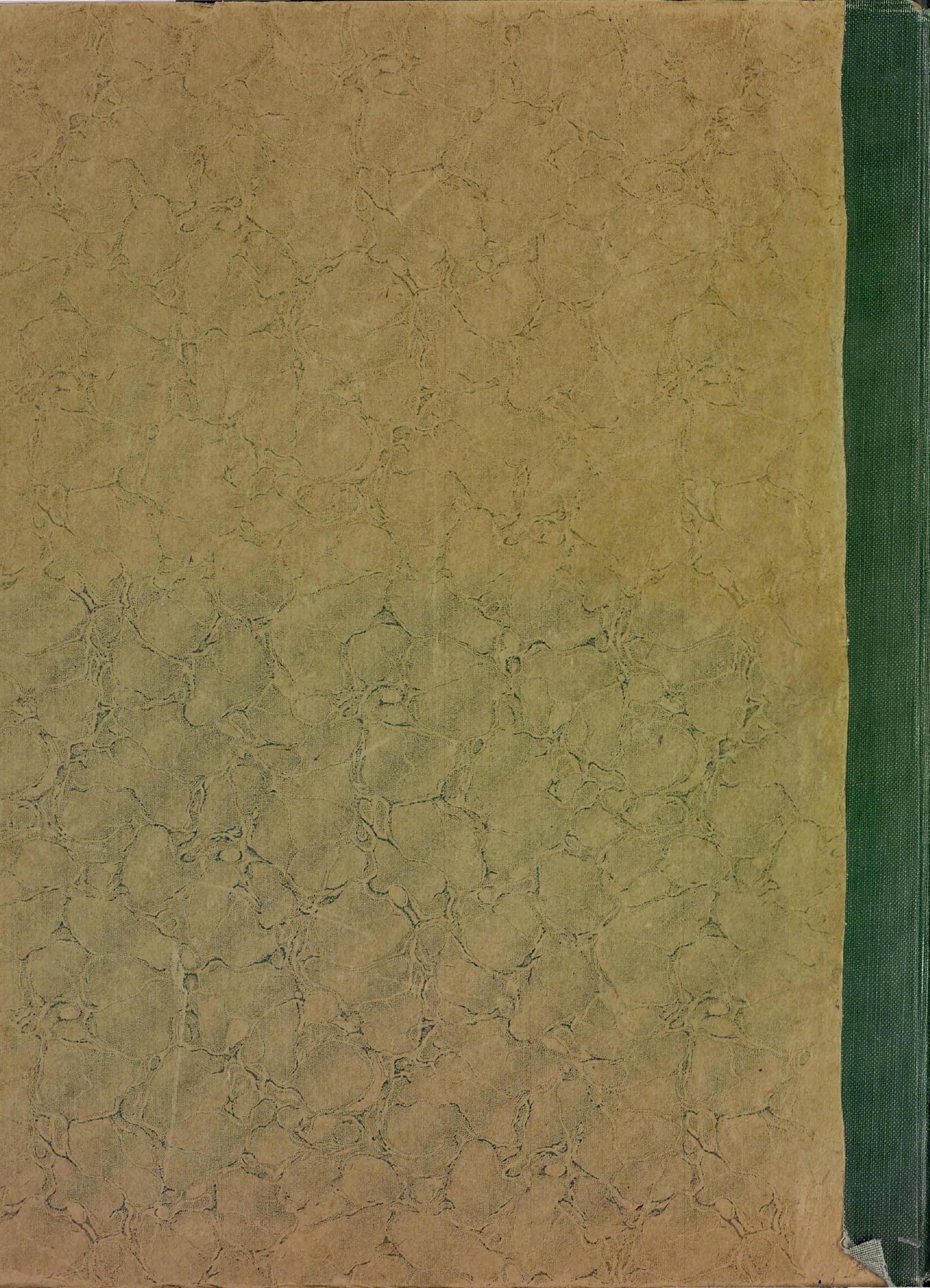

